UNIVERSIDADE DE SÃO PAULO

ESCOLA DE ENGENHARIA DE SÃO CARLOS

ANDRÉ LUIZ ANDREOLI

\title{
Modelagem de Lâmpadas de Descarga: uma Análise de Desempenho Considerando Parâmetros de Qualidade da Energia
}





\section{Modelagem de Lâmpadas de Descarga: uma Análise de Desempenho Considerando Parâmetros de Qualidade da Energia}

Tese apresentada à Escola de Engenharia de São Carlos da Universidade de São Paulo, como parte dos requisitos para obtenção do título de Doutor em Ciências, Programa de Engenharia Elétrica.

Área de Concentração: Sistemas Elétricos de Potência Orientador: Prof. Tit. Denis Vinicius Coury

São Carlos - SP

2011

Trata-se da versão corrigida da tese. A versão original se encontra disponível na EESC/USP que aloja o Programa de Pós-Graduação de Engenharia Elétrica. 
AUTORIZO A REPRODUÇÃO E DIVULGAÇÃO TOTAL OU PARCIAL DESTE TRABALHO, POR QUALQUER MEIO CONVENCIONAL OU ELETRÔNICO, PARA FINS DE ESTUDO E PESQUISA, DESDE QUE CITADA A FONTE.

Ficha catalográfica preparada pela Seção de Tratamento da Informação do Serviço de Biblioteca - EESC/USP

A559m Andreoli, André Luiz
Modelagem de lâmpadas de descarga : uma análise de
desempenho considerando parâmetros de qualidade da
energia / André Luiz Andreoli ; orientador Denis Vinicius
Coury. -- São Carlos, 2011.
Tese (Doutorado-Programa de Pós-Graduação em
Engenharia Elétrica e Área de Concentração em Sistemas
Elétricos de Potência) -- Escola de Engenharia de São
Carlos da Universidade de São Paulo, 2011.
l. Iluminação. 2. Modelos matemáticos. 3. Energia
elétrica - qualidade. 4. Sistemas elétricos - simulações.
I. Título.


Candidato(a): Engenheiro ANDRÉ LUIZ ANDREOLI.

Tese defendida e julgada em 08/04/2011 perante a Comissão Julgaḍora:

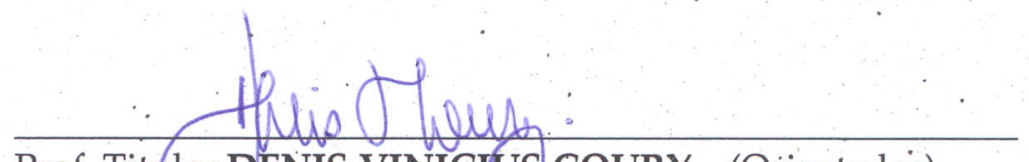

APROVADO

Prof. Titular DENIS VINICIUS COURY - (Orientador)

(Escola de Engenharia de São.Carlos/USP).
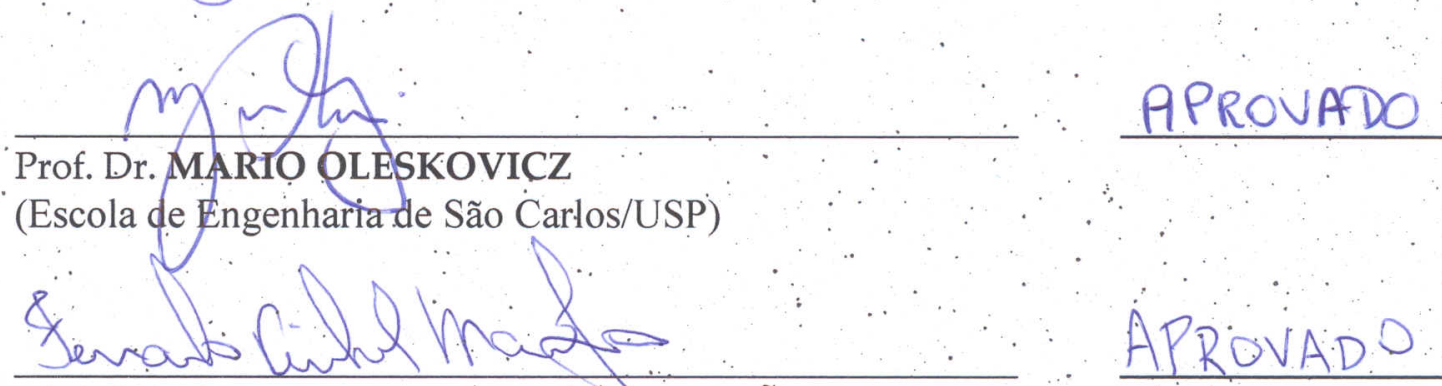

Prof. Dr. FERNANDO PINHABEL MFARAFÃO

(Ủniversidade Estadual Paulista "Júlio de Mesquita Filho"/UNESP/campus de Sorocaba)
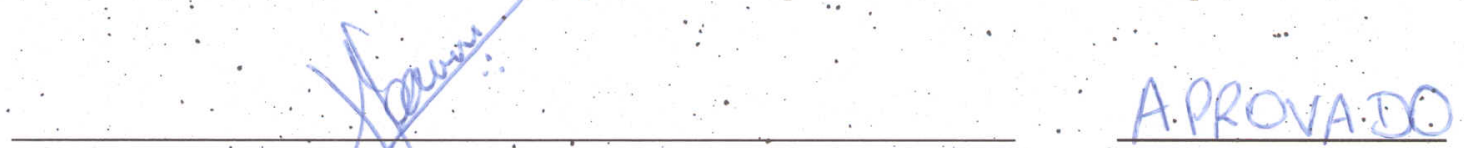

Prof. Dr. PAULO JOSÉ AMARAL SERNI

(Universidade Estadual Paulista "Júlio de Mesquita Filho"/UNESP/campus de Bauru)

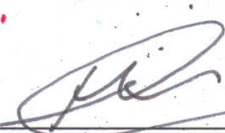

Prof. Dr. MADSON CORTES DE ALMEIDA

Aproveds

(Universidade Estadual de Campinas/UNICAMP)

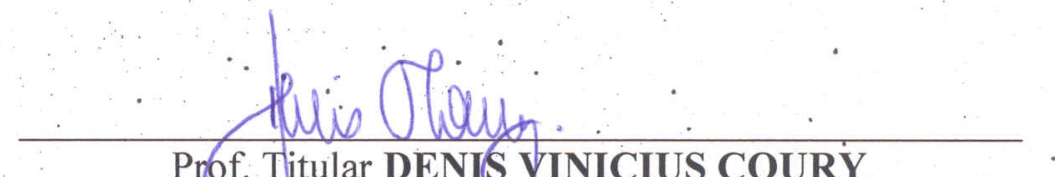

Prof. Titular DENIS YINICIUS COURY.

Coordenador do Programa de Pós-Graduação em

Engenharia Elétrica

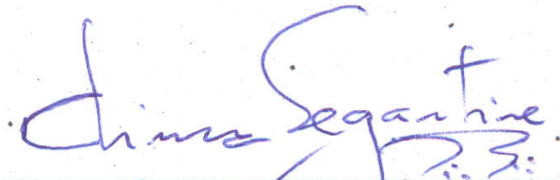

Prof. Associado PAULO CÉṠAR LIMA SEGANTINE

Presidente da Comissão da Pós-Graduação da EESC 

À Minha esposa Marisa, e à minha filha Ana Carolina,

pelas horas que, pacientemente, permaneceram me esperando, dedico este trabalho. 



\section{AGRADECIMENTOS}

A Deus, pela graça recebida.

A Meus Pais, por me proporcionarem as condições primordiais para que atingisse este ponto.

Ao Amigo e Orientador, Professor Titular Denis Vinicius Coury, pela oportunidade concedida e pelo apoio irrestrito nas diversas fases da elaboração deste trabalho, meus sinceros agradecimentos.

Ao inestimável Amigo e Professor, Dr. Paulo José Amaral Serni, por ter me conduzido e me acompanhado fraternalmente durante esta etapa de minha evolução.

Ao grande Amigo e Professor, Dr. José Angelo Cagnon, por todo o apoio e incentivo ao longo de minha jornada pessoal e profissional.

Aos demais amigos e colegas que colaboraram, direta ou indiretamente, na elaboração deste trabalho. 



\section{RESUMO}

ANDREOLI, A. L. Modelagem de Lâmpadas de Descarga: uma Análise de Desempenho Considerando Parâmetros de Qualidade da Energia. 2010. 270 p. Tese (Doutorado) - Escola de Engenharia de São Carlos, Universidade de São Paulo, São Carlos, 2010

Este trabalho apresenta pesquisa relativa à modelagem de lâmpadas de descarga. A metodologia desenvolvida fornece meios de se construir modelos baseados em ferramentas inteligentes, especificamente através de redes neurais artificiais, de forma a representar o dispositivo com características que descrevam seus aspectos operacionais, bem como o comportamento de tais dispositivos diante de eventos relacionados à qualidade da energia elétrica.

Um modelo matemático do conjunto lâmpada-reator, caracterizado como carga não-linear foi implementado inicialmente através da ferramenta SIMULINK ${ }^{\circledR}$, integrante do pacote de software MATLAB ${ }^{\circledR}$, e os resultados de simulações obtidas com este modelo são apresentados e comparados com os dados de operação obtidos experimentalmente, servindo como base de modelo para a lâmpada de descarga estudada e ponto de partida para a modelagem baseada em ferramentas computacionais inteligentes.

Como contribuição, foi proposta a arquitetura de um modelo baseado em um conjunto de redes neurais artificiais destinado a representar a operação do conjunto lâmpada de descarga e reator. Empregando a massa de dados obtida através de ensaios realizados em diversas condições operacionais, e com o auxílio do pacote de software MATLAB $\AA$, realizou-se o treinamento de duas redes neurais artificiais que em conjunto foram capazes de representar com elevado grau de fidelidade o comportamento 
de uma lâmpada de descarga, incluindo as respostas transitórias a eventos relacionados à qualidade da energia elétrica.

Comparado com o modelo matemático, o modelo neural proposto demonstrou maior facilidade de aplicação e boa representação do dispositivo e exigiu esforço computacional consideravelmente menor para simulações envolvendo grandes períodos de tempo e elevado número de dispositivos. Além destas vantagens, a metodologia adotada possibilita a obtenção de modelos de outras famílias de lâmpadas de descarga a partir de dados experimentais apenas, sem necessidade de conhecimento dos dados físicos e construtivos do dispositivo.

O elevado desempenho do modelo obtido permitiu a simulação de conjuntos de lâmpadas de descargas inseridos em um sistema de distribuição em tempos de simulação muito menores que os exigidos pelo modelo matemático, justificando sua aplicação nas representações desta família de cargas inseridas nos sistemas elétricos de potência. A representação do comportamento do dispositivo frente a distúrbios de qualidade da energia também se mostrou como uma ferramenta útil para estudos mais complexos no sistema de distribuição.

Palavras-Chave: Lâmpada de descarga; Modelo matemático; Qualidade da Energia; Simulação de sistemas elétricos 


\section{ABSTRACT}

ANDREOLI, A. L. Discharge Lamps Modeling: a Performance Analysis Considering Power Quality Parameters. 2010. 270 p. Thesis (Ph.D.) - Escola de Engenharia de São Carlos, Universidade de São Paulo, São Carlos, 2010

This work presents research related to the modeling of discharge lamps. This methodology made possible to build models based on intelligent tools, specifically artificial neural networks, to represent the device characteristics concerning operational aspects as well as the behavior of such devices facing power quality events.

The mathematical model of a lamp-reactor, characterized as an non-linear load, was implemented using SIMULINK ${ }^{\circledR}$ toolbox, part of the software MATLAB ${ }^{\circledR}$. The simulation results obtained from this model are compared with data obtained experimentally, serving as a base model for discharge lamps as well as a starting point for the modeling tools based on computational intelligence.

As a contribution, an architecture of a model based on artificial neural networks designed to represent the operation of the discharge lamp and reactor was proposed. Employing the data obtained from tests performed under various operating conditions, and with the aid of the software MATLAB ${ }^{\circledR}$, the training of two neural networks was performed. These networks were able to represent with high fidelity the behavior a discharge lamp, including the response to transient events related to power quality.

Comparing to the mathematical model, the neural model demonstrated greater adaptation and good representation of the device and required a considerably lower computational effort for simulations involving large periods of time and a great number of devices. Besides these advantages, the methodology allows to obtain 
models from other families of discharge lamps from experimental data only, without the knowledge of the physical data of the device.

The high performance of the neural model allowed the simulation of a group of discharge lamps in a distribution system with simulation time much smaller than those required by the mathematical model, justifying its application in electric power systems. The representation of such a device facing power quality disturbances also proved to be a useful tool for more complex studies in a distribution system.

Keywords: Discharge lamps; Mathematical model; Power Quality; Electrical systems simulation. 


\section{LISTA DE EQUAÇÕES}

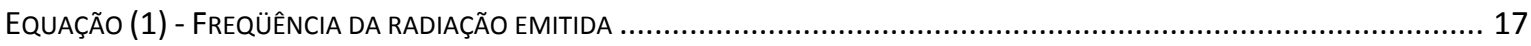

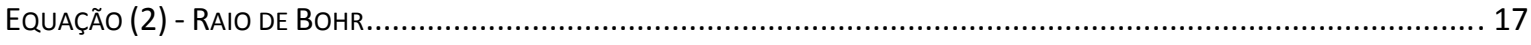

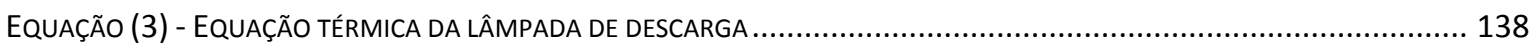

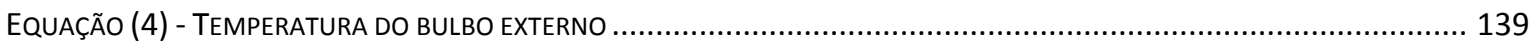

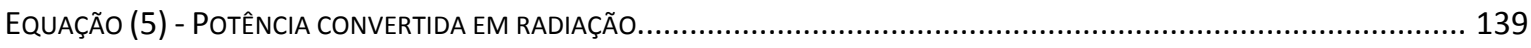

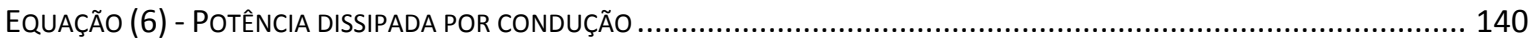

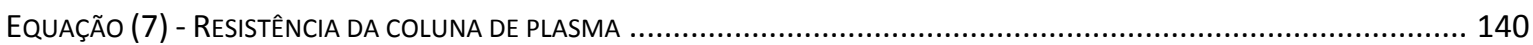

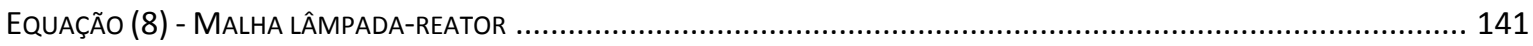




\section{LISTA DE FIGURAS}

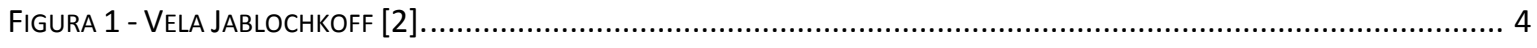

FIGURA 2 - LÂMPADA DE ARCO COM MECANISMO de CONTROLE (COPYRIGHT DA COROA BRITÂNICA) [2] .............................. 5

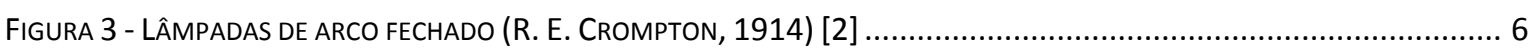

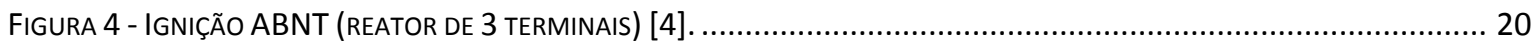

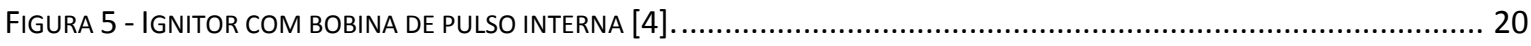

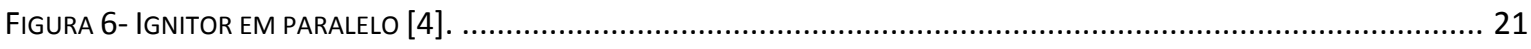

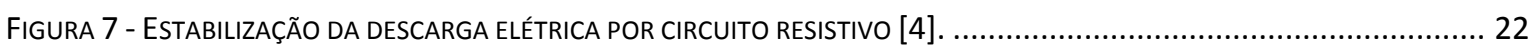

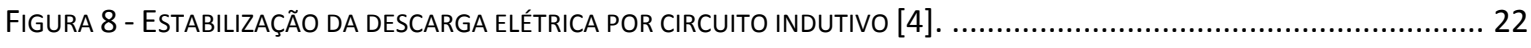

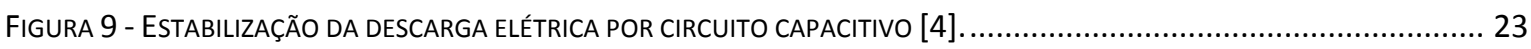

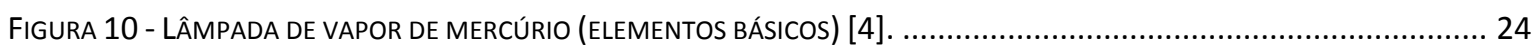

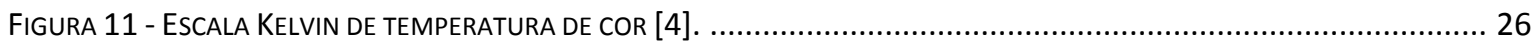

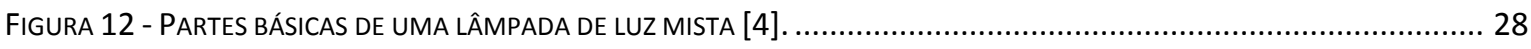

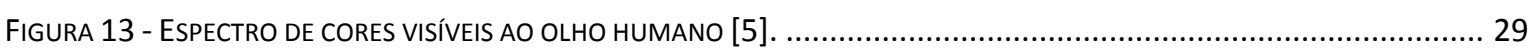

FIGURA 14 - COMPONENTES BÁSICOS DE UMA LÂMPADA DE VAPOR DE SÓDIO DE BAIXA PRESSÃo [4] ................................. 30

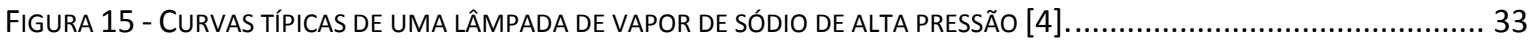

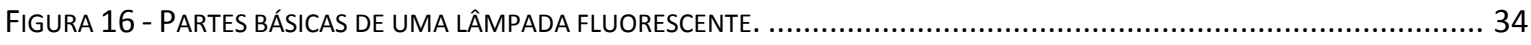

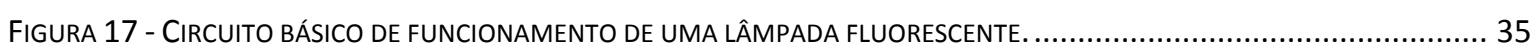

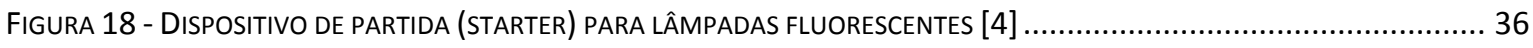

FIGURA 19 - CIRCUITO DE PARTIDA RÁPIDA PARA LÂMPADAS FLUORESCENTES [5] ....................................................... 37

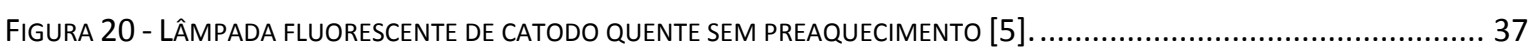

FIGURA 21 - CIRCUITO DE OPERAÇÃo DE UMA LÂMPADA FLUORESCENTE DE CATODO FRIO .............................................. 38

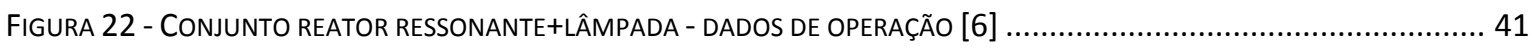

FIGURA 23 - CONJUNTO REATOR RESSONANTE + LÂMPADA - DADOS DE SIMULAÇÃO [6] …....................................... 42

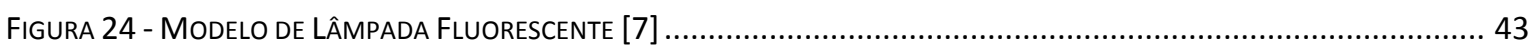

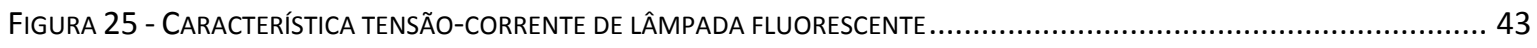

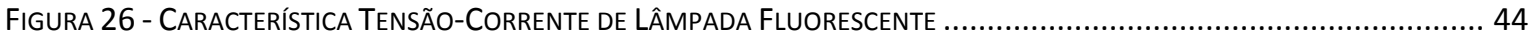


FIGURA 27 - COMPORTAMENTO REAL DA LÂMPADA FLUORESCENTE EM ALTA FREQUÊNCIA [8] 45

FIGURA 28 - RESPOSTA DO MODELO DE LÂMPADA FLUORESCENTE EM ALTA FREQUÊNCIA [8] 45

FIGURA 29 - DADOS DE OPERAÇÃO - LÂMPADA FLUORESCENTE [10] 47

FIGURA 30 - DADOS DE SIMULAÇÃO - LÂMPADA FLUORESCENTE [10] 48

FIGURA 31 - EXPERIMENTO PARA LEVANTAMENTO DE DADOS DE OPERAÇÃO [11] ..................................................... 48

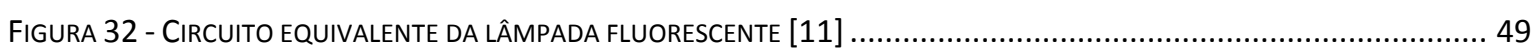

FIGURA 33 - TENSÃO E POTÊNCIA NO ARCO EM FUNÇÃO DA TEMPERATURA [11] ....................................................50

FIGURA 34 - CORRENTE E POTÊNCIA NO ARCO EM FUNÇÃO DA TEMPERATURA [11] ...................................................50

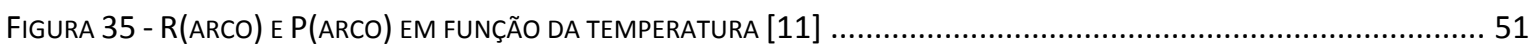

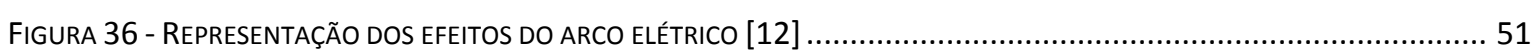

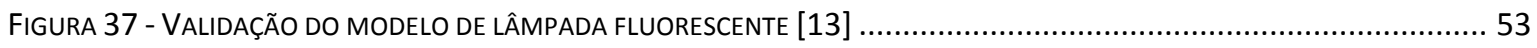

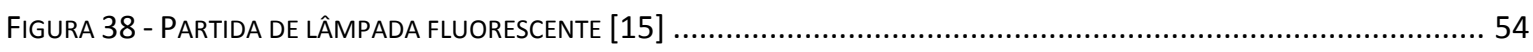

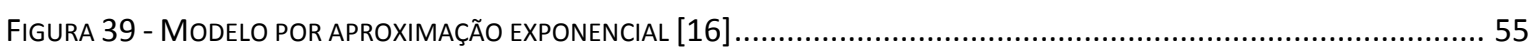

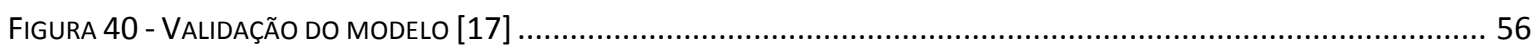

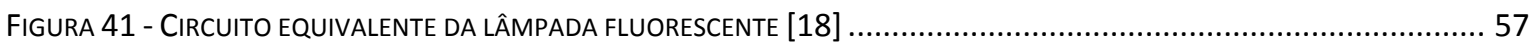

FIGURA 42 - TENSÃO SOBRE O ARCO DA LÂMPADA E RESPOSTA DO MODELO IMPLEMENTADO [20] .................................59

FIGURA 43 - CORRENTE ATRAVÉS DO ARCO DA LÂMPADA E RESPOSTA DO MODELO IMPLEMENTADO [20] .............................59

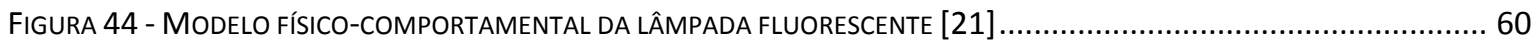

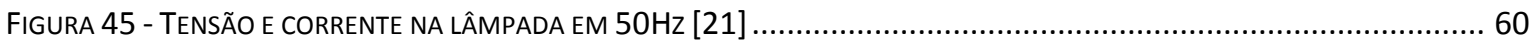

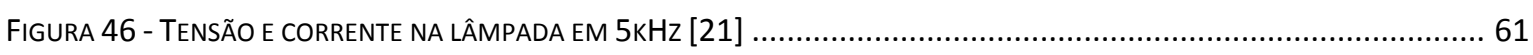

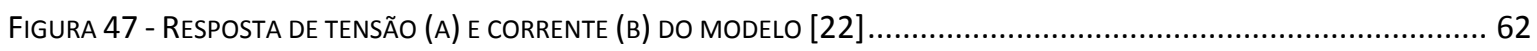

FIGURA 48 - EFEITO dA CORREÇÃo DE FP COM CAPACITORES EM LÂMPADAS DE DESCARGA [24] ..................................6 64

FIGURA 49 - CONTEÚDO HARMÔNICO DA CORRENTE EM LÂMPADAS DE VAPOR DE MERCÚRIO [24] .................................6 65

FIGURA 50 - CONTEÚDO HARMÔNICO DA CORRENTE EM LÂMPADAS DE VAPOR DE SÓDIO [24] ......................................6 66

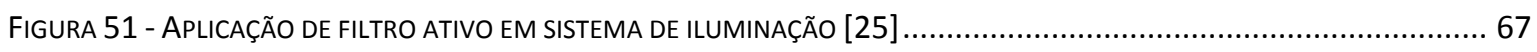

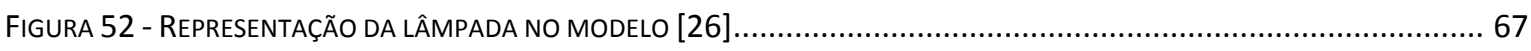

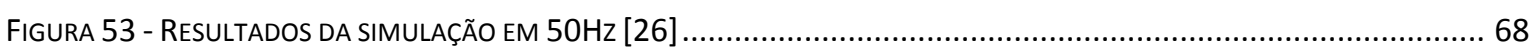

FIGURA 54 - FASE DE AQUECIMENTO DE UMA LÂMPADA HID DE VAPOR DE MERCÚRIO [27] .........................................69 
FIGURA 55 - RESPOSTA DO MODELO DE LÂMPADA HID [28] 69

FIGURA 56 - CURVA V-I EXPERIMENTAL - LÂMPADA VAPOR DE MERCÚRIO 50W OPERANDO EM 50Hz [29].

FIGURA 57 - CURVA V-I DO MODELO - LÂMPADA VAPOR DE MERCÚRIO 50W OPERANDO EM 50Hz [29] 71

FIGURA 58 - CURVAS V-I DA LÂMPADA DE VAPOR DE MERCÚRIO 400W [30].... 71

FigURA 59 - RESPOSTA AO DEGRAU DE TENSÃo - VALORES MEDIDOS [31] 72

FIGURA 60 - RESPOSTA AO DEGRAU DE TENSÃO - SIMULAÇÃO [31]

Figura 61 - Modelagem de LÂMPADA HID DE VAPOR DE SÓDIO [32] 74

FIGURA 62 - DIAGRAMA DE BLOCOS DA MONTAGEM PARA VERIFICAÇÃO DE SENSIBILIDADE AO FLICKER [33] 75

FIGURA 63 - ASPECTO FÍSICO DA MONTAGEM PARA VERIFICAÇÃO DE SENSIBILIDADE AO FLICKER [33] ..... 75

FIGURA 64 - ESTRUTURA DA EQUAÇÃO DE BALANÇO DA ENERGIA [34] 76

Figura 65 - Curvas V-I: (A) CoRrente SEnOIdAL, 60Hz; (B) CORRENTE QUAdRAdA, 40kHz [34]. 77

FIGURA 66 - CORRENTE TRANSITÓRIA IMPULSIVA ORIUNDA DE UMA DESCARGA ATMOSFÉRICA [36] ................................85

FIGURA 67 - TRANSITÓRIO DE ENERGIZAÇÃO DE UM BANCO DE CAPACITORES EM BARRAMENTO DE 34,5KV [36] ..................87

FIGURA 68 - INTERRUPÇÃO MOMENTÂNEA DEVIDO A UM CURTO-CIRCUITO E ATUAÇÃO DA PROTEÇÃO [36]..........................99

FIGURA 69 - AfUNDAMENTO DE TENSÃO CAUSADO POR UMA FALTA FASE-TERRA [36]. ............................................ 91

FIGURA 70 - DECRÉSCIMO DE TENSÃO OCORRIDO PELA PARTIDA DE UM MOTOR [36] ............................................. 92

FIGURA 71 - TOLERÂNCIAS TíPICAS DE TENSÃO PARA COMPUTADORES (CURVA ITIC) [36] ............................................ 93

FIGURA 72 - EleVAÇÃO DE TENSÃO DEVIDO A UMA FALTA FASE-TERRA [36] ......................................................96

FIGURA 73 - VIDA ÚTIL DE UM TRANSFORMADOR EM FUNÇÃO DA DISTORÇÃO HARMÔNICA DE CORRENTE [37]. ................... 105

FIGURA 74 - NOTCHING NA TENSÃO DE ALIMENTAÇÃO DE UM CONVERSOR CA/CC [36] .............................................. 106

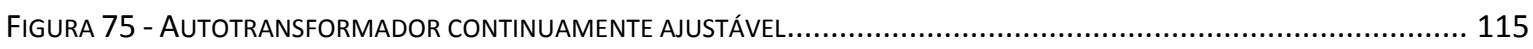

FIGURA 76 - GERAdOR ARBITRÁRIO DE SINAIS CALIFORNIA INSTRUMENTS 5001IX [41] ......................................... 115

FIGURA 77 - INTERFACE GRÁFICA DO USUÁRIO CIGUI CALIFORNIA INSTRUMENTS - TELA PRINCIPAL................................ 116

FiguRA 78 - INTERFACE GRÁfICA do USUÁRIO CIGUI CALIFORNIA INSTRUMENTS - LISTA DE EVENTOS ............................. 117

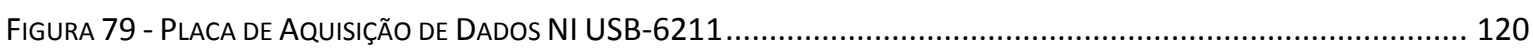

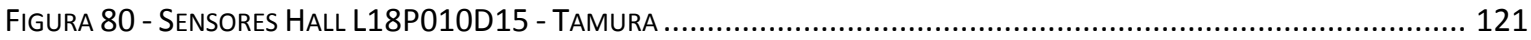

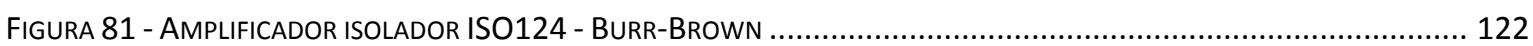

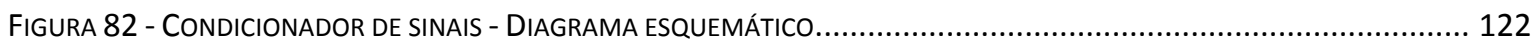


FIGURA 83 - CONDICIONADOR DE SINAIS - ASPECTO FÍSICO DA MONTAGEM.

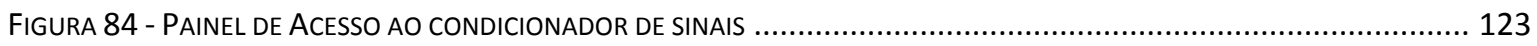

Figura 85 - Transdutor/Controlador de Temperatura CONTEMP Modelo CPM45 ...................................... 124

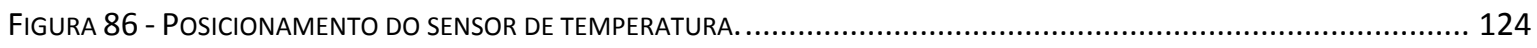

FIGURA 87 - SISTEMA DE AQUISIÇÃO DE DADOS - INTERFACE DE OPERAÇÃO …................................................... 125

FIGURA 88 - SISTEMA DE AQUISIÇÃO DE DADOS - DIAGRAMA DE BLOCOS ....................................................... 127

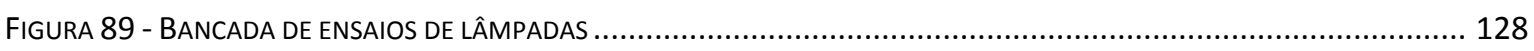

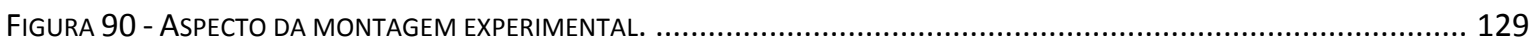

FIGURA 91 - DIAGRAMA DE BLOCOS - MONTAGEM EXPERIMENTAL PARA REGIME PERMANENTE .................................... 130

FIGURA 92 - DIAGRAMA DE BLOCOS - MONTAGEM EXPERIMENTAL PARA REGIME TRANSITÓRIO...................................... 133

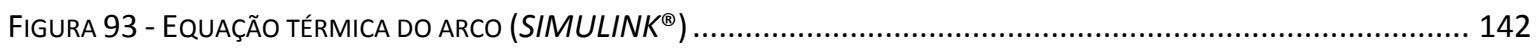

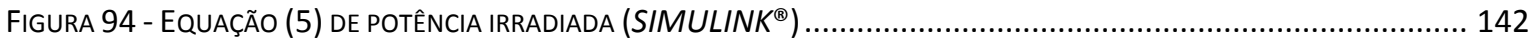

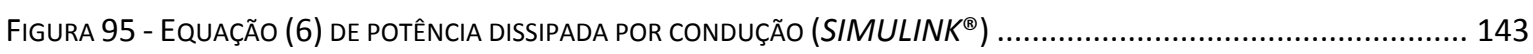

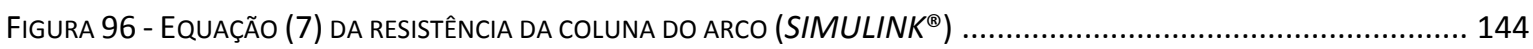

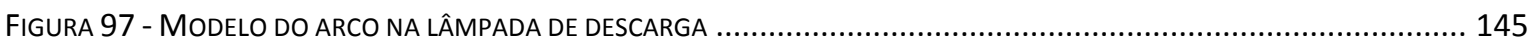

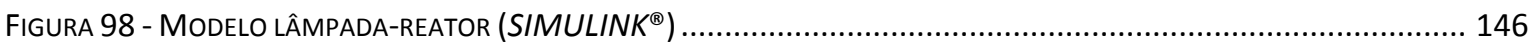

FIGURA 99 - CORRENTE NA LÂMPADA DE DESCARGA - RESPOSTA DO MODELO MATEMÁTICO. ........................................ 148

FIGURA 100 - TENSÃO SOBRE A LÂMPADA DE DESCARGA - RESPOSTA DO MODELO MATEMÁTICO. .................................... 148

FIGURA 101 - COMPARAÇÃO ENTRE VALORES EXPERIMENTAIS (A) E VALORES SIMULADOS (B) ......................................149

FIGURA 102 - TENSÃO NO ARCO - LÂMPADA DE VAPOR DE MERCÚRIO 80W ….......................................................... 150

FIGURA 103 - CORRENTE NO CIRCUITO - LÂMPADA DE VAPOR DE MERCÚRIO 80W .............................................. 150

FIGURA 104 - TEMPERATURA DO BULBO DA LÂMPADA DE VAPOR DE MERCúRIO 80W........................................... 151

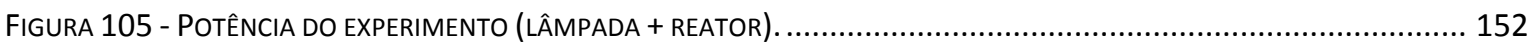

FIGURA 106 - MODELO NEURAL PROPOSTO PARA A LÂMPADA DE DESCARGA. ........................................................ 158

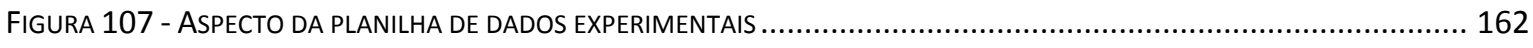

FIGURA 108 - EXEMPLO DE REGRESSÃO DURANTE TREINAMENTO DA RNA 2 PARA CONTEÚDO HARMÔNICO........................164

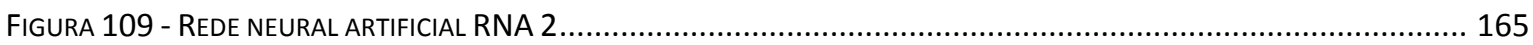

FIGURA 110 - EXEMPLO DE REGRESSÃO DURANTE TREINAMENTO DA RNA 1 PARA DESEMPENHO TERMODINÂMICO.............. 167 
FIGURA 111 - REDE NEURAL ARTIFICIAL RNA1 169

FIGURA 112 - CORRENTE NA LÂMPADA DE DESCARGA - INÍCIO COM A SIMULAÇÃO EM T=100S. 170

FIGURA 113 - COMPONENTES HARMÔNICAS DA CORRENTE - INÍCIO COM A SIMULAÇÃO EM T=100S 170

FIGURA 114 - CORRENTE NA LÂMPADA DE DESCARGA - INÍCIO COM A SIMULAÇÃO EM T=200S. 171

FIGURA 115 - COMPONENTES HARMÔNICAS DA CORRENTE - INÍCIO COM A SIMULAÇÃO EM T=200S. 172

Figura 116 - CoRRENTE NA LÂMPAdA DE DESCARGA - TENSÃo DE 0,8 PU (REGIME PERMANENTE). 173

FIGURA 117 - COMPONENTES HARMÔNICAS DA CORRENTE - TENSÃO DE 0,8 PU. 173

FIGURA 118 - FASE DE AQUECIMENTO DA LÂMPADA DE DESCARGA (EXPERIMENTO). 175

FIGURA 119 - FASE DE AQUECIMENTO DA LÂMPADA DE DESCARGA (RNA 1). 175

Figura 120 - FluXograma - Metodologia para obtenção de MOdelos neURAis. 181

FIGURA 121 - DADOS EXPERIMENTAIS - DEGRAU PERMANENTE DE TENSÃO A 0,95PU EM T=250S 185

FIGURA 122 - RESPOSTA DO MODELO - DEGRAU PERMANENTE DE TENSÃO A 0,95PU EM T=250S. 185

FIGURA 123 - DADOS EXPERIMENTAIS - AFUNDAMENTO A 0,9PU EM T=250s. 187

Figura 124 - RESPOStA do MOdELO - AfUndAMENTO A 0,9PU EM T=250s. 187

FIGURA 125 - DADOS EXPERIMENTAIS DE UMA INTERRUPÇÃO TEMPORÁRIA. 188

FIGURA 126 - RESPOSTA DO MODELO A UMA INTERRUPÇÃO TEMPORÁRIA DE 5 SEGUNDOS. 188

FIGURA 127 - DADOS EXPERIMENTAIS DE UM AFUNDAMENTO TEMPORÁRIO A 0,9 PU EM T=250S. 190

FIGURA 128 - RESPOSTA DO MODELO A UM AFUNDAMENTO TEMPORÁRIO A 0,9PU. 190

FIGURA 129 - DADOS EXPERIMENTAIS - REDUÇÃO DE TENSÃO DE CURTA DURAÇÃO COM EXTINÇÃO DE ARCO 192

FIGURA 130 - RESPOSTA DO MODELO - REDUÇÃO DE TENSÃO DE CURTA DURAÇÃO COM EXTINÇÃO DE ARCO 192

FIGURA 131 - DADOS EXPERIMENTAIS - AFUNDAMENTO TEMPORÁRIO A 0,9 PU DURANTE A PARTIDA. 194

FIGURA 132 - RESPOSTA DO MODELO A UM AFUNDAMENTO TEMPORÁRIO A 0,9 PU DURANTE A PARTIDA. 194

FIGURA 133 - DADOS EXPERIMENTAIS - ELEVAÇÃO TEMPORÁRIA A 1,2 PU DURANTE A PARTIDA 195

FIgURA 134 - RESPOSTA DO MODELO A UMA ELEVAÇÃO TEMPORÁRIA A 1,2PU DURANTE A PARTIDA. 195

FIGURA 135 - DADOS EXPERIMENTAIS - AFUNDAMENTO MOMENTÂNEO A 0,1 PU DURANTE A PARTIDA. 196

FIGURA 136 - RESPOSTA DO MODELO A UM AFUNDAMENTO MOMENTÂNEO DE 0,1PU DURANTE A PARTIDA. 197

FIGURA 137 - DADOS EXPERIMENTAIS - AFUNDAMENTO INSTANTÂNEO A 0,1 PU DURANTE A PARTIDA. 198

FIGURA 138 - RESPOSTA DO MODELO A UMA FUNDAMENTO INSTANTÂNEO A 0,1PU DURANTE A PARTIDA. 198 
FIGURA 139 - DADOS EXPERIMENTAIS - ELEVAÇÃO INSTANTÂNEA A 1,35 PU DURANTE A PARTIDA. 199

FIGURA 140 - RESPOSTA DO MODELO A UMA ELEVAÇÃO INSTANTÂNEA A 1,35PU DURANTE A PARTIDA 200

FIGURA 141 - CORRENTE DE UM CONJUNTO DE TRÊS LÂMPADAS EM PARALELO (ALIMENTAÇÃO MONOFÁSICA). 203

FIGURA 142 - COMPONENTES HARMÔNICAS DA CORRENTE - CONJUNTO DE TRÊS LÂMPADAS EM PARALELO. 203

FIGURA 143 - CONJUNTO DE TRÊS LÂMPADAS EM CONFIGURAÇÃO TRIFÁSICA SIMÉTRICA EM Y $(1+1+1)$. 205

FIGURA 144 - CONTEÚDO HARMÔNICO DA CORRENTE - FASE A - TRÊS LÂMPADAS EM Y. 205

FIGURA 145 - CONTEÚDO HARMÔNICO DA CORRENTE DE NEUTRO - TRÊS LÂMPADAS EM Y. 206

FIGURA 146 - CONJUNTO DE TRÊS LÂMPADAS EM CONFIGURAÇÃo TRIFÁSICA SIMÉTRICA EM $\Delta(1+1+1)$. 207

FIGURA 147 - CONTEÚdo HARMÔNICO dA CORRENTE - FASE A (TRÊS LÂMPADAS EM $\Delta$ ) 208

FIGURA 148 - CONJUNTO DE QUATRO LÂMPADAS EM CONFIGURAÇÃO TRIFÁSICA ASSIMÉTRICA EM Y $(2+1+1)$. 208

FIGURA 149 - CONTEÚDO HARMÔNICO DA CORRENTE DE NEUTRO - QUATRO LÂMPADAS EM Y...... 209

FIGURA 150 - CONJUNTO DE QUATRO LÂMPADAS EM CONFIGURAÇÃO TRIFÁSICA ASSIMÉTRICA EM $\Delta(2+1+1)$. 209

FIGURA 151 - CONTEÚdo HARMÔNICO dA CORRENTE - FASE A (QUATRO LÂMPADAS EM $\Delta$ ). 210

FIgURA 152 - CONJUNTO DE QUARENTA E CINCO LÂMPADAS EM CONFIGURAÇÃO TRIFÁSICA SIMÉTRICA EM Y (15+15+15). .. 211

Figura 153 - CoRRENTE dA FASE A - QUARENTA E CINCO LÂMPADAS EM Y SIMÉTRICO (15+15+15). 212

FIGURA 154 - CONTEÚDO HARMÔNICO DA CORRENTE DE NEUTRO - QUARENTA E CINCO LÂMPADAS EM Y. 212

FiguRA 155 - CONJUNTO DE QUARENTA E CINCO LÂMPADAS EM Y (15+15+15) - ALIMENTAÇÃO EM 0,8 PU. 213

FIGURA 156 - CONTEÚDO HARMÔNICO CORRENTE DE NEUTRO (QUARENTA E CINCO LÂMPADAS EM Y; 0,8PU). 213

FIGURA 157 - CONJUNTO DE QUARENTA LÂMPADAS EM CONFIGURAÇÃO TRIFÁSICA ASSIMÉTRICA EM Y (15+15+10). 214

FIGURA 158 - CONTEÚDO HARMÔNICO CORRENTE DE NEUTRO (QUARENTA LÂMPADAS EM Y). 215

FIGURA 159 - CONJUNTO DE QUARENTA LÂMPADAS EM CONFIGURAÇÃO TRIFÁSICA ASSIMÉTRICA EM $\Delta(15+15+10)$. 216

FiguRA 160 - CONTEÚdo hARMÔNICO dA CORRENTE - FASE A (QUARENTA LÂMPADAS EM $\Delta$ ). 216

FIGURA 161 - CONJUNTO DE SESSENTA LÂMPADAS EM CONFIGURAÇÃO TRIFÁSICA ASSIMÉTRICA EM Y (10+20+30). 217

FiguRA 162 - CORRENTE DE NEUTRO - SESSENTA LÂMPADAS EM Y ASSIMÉTRICO (10+20+30).

FIgURA 163 - CONJUNTO DE SESSENTA LÂMPADAS EM CONFIGURAÇÃO TRIFÁSICA ASSIMÉTRICA EM $\Delta(10+20+30)$. 218

FiguRA 164 - CONTEÚdo HARMÔNICO dA CORRENTE - FASE B (SESSENTA LÂMPADAS EM $\Delta$, ASSIMÉTRICAS). 219

FIGURA 165 - CONJUNTO DE NOVENTA LÂMPADAS EM CONFIGURAÇÃO TRIFÁSICA SIMÉTRICA EM Y (30+30+30). 219

Figura 166 - CoRrENTE dA FASE A - NoVENTA LÂMPADAS EM Y SIMÉTRICO (30+30+30) 
Figura 167 - CoRRENTE de NEUTRO - NoventA LÂMPAdAS EM Y SIMÉTRICO (30+30+30).

FIGURA 168 - CONJUNTO DE NOVENTA LÂMPADAS - CONFIGURAÇÃO TRIFÁSICA SIMÉTRICA; CONEXÃO EM $\Delta$.

FIgURA 169 - CONTEÚdo HARMÔNICO dA CORRENTE - FASE A (NOVENTA LÂMPADAS EM $\Delta$, SIMÉTRICAS).

Figura 170 - CONJUNTO DE DUAS LÂMPADAS EM CONFIGURAÇÃo Y ENTRE DUAS FASE E NEUTRO (A-N E B-N)

Figura 171 - Conteúdo harmônico da CoRrente de NeUtro (DuAS LÂMPAdAS, A-N E B-N).....

Figura 172 - CONJUNTO de dUAS LÂMPADAS EM CONFIGURAÇÃo $\triangle$ ASSIMÉTRICA ENTRE FASES (A-B E A-C).

FigurA 173 - CONTEÚdo HARMÔNICO dA CORRENTE - FASE A (DUAS LÂMPADAS, A-B E A-C)....... 


\section{LISTA DE TABELAS}

TABela 1- Algumas fontes de lUz e temperaturas associadas.

TABELA 2 - COMPORTAMENTO dO ANÁLOGO DAS LÂMPADAS HID [23].

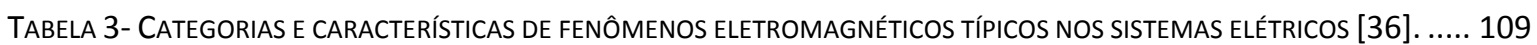

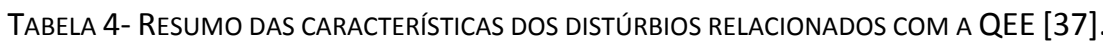
110

TABELA 5- CARACTERÍSTICAS DO SISTEMA DE AQUISIÇÃO DE DADOS.

TABELA 6 - CONSTANTES INICIAIS DO MODELO

TAbela 7 - Registros de Treinamento das Redes Neurais Artificiais.

Tabela 8 - Rede Neural Artificial RNA 2 - Conteúdo Harmônico da Corrente. 165

Tabela 9 - Rede Neural Artificial RNA 1 - Comportamento TermodinÂmico da LÂmpada de Descarga........ 168

TABELA 10 - ENSAIOS PRELIMINARES DE VALIDAÇÃO DO MODELO 174

TABELA 11 - COMPARATIVO DE DESEMPENHO ENTRE MODELO MATEMÁTICO E MODELO NEURAL 178

TABELA 12 - EVENTOS DE QUALIDAdE DA ENERGIA ENSAIAdos 201 


\section{LISTA DE SIGLAS}

$\begin{array}{ll}\text { ABNT } & \text { - Associação Brasileira de Normas Técnicas } \\ \text { CA } & \text { - Corrente Alternada } \\ \text { CC } & \text { - Corrente Contínua } \\ \text { DAQ } & \text { - Data Acquisition (Aquisição de Dados) } \\ \text { DIP } & \text { - Dual in-line package (Encapsulamento em linha duplo) } \\ \text { HID } & \text { - High Intensity Discharge (Alta intensidade de descarga) } \\ \text { IEE } & \text { - Institution of Electrical Engineers } \\ \text { IEEE } & \text { - Institute of Electrical and Electronic Engineering } \\ \text { IET } & \text { - Institution of Engineering and Technology } \\ \text { IRC } & \text { - Índice de Reprodução de Cores } \\ \text { ITIC } & \text { - Information Technology Industry Council } \\ \text { mse } & \text { - Mean Squared Error (Erro quadrático médio) } \\ \text { NI } & \text { - National Instruments }{ }^{\circledR} \\ \text { NTC } & \text { - Negative Thermic Coefficient (Coeficiente térmico negativo) } \\ \text { pu } & \text { - Por Unidade } \\ \text { QE } & \text { - Qualidade da Energia } \\ \text { QEE } & \text { - Qualidade da Energia Elétrica } \\ \text { RNA } & \text { - Rede Neural Artificial } \\ \text { TTL } & \text { - Transistor-Transistor Logic } \\ \text { THD } & \text { - Total Harmonic Distortion (Distorção Harmônica Total) } \\ \text { USB } & \text { - Universal Serial Bus } \\ & \end{array}$




\section{SUMÁRIO}

RESUMO

LISTA DE EQUAÇÕES V

LISTA DE FIGURAS VI

LISTA DE TABELAS XIII

LISTA DE SIGLAS XIV

1 INTRODUÇÃO 1

1.1 A ORIGEM DA LUZ ELÉTRICA

1.2 A ILUMINAÇÃO A ARCO

1.3 As PRIMEIRAS LÂMPADAS DE DESCARGA

1.4 CONTEXTUALIZAÇÃo do tRABALHO

1.5 DESCRIÇão dos CAPÍTULOS

2.1 Produção de RADIAÇões PELA DESCARGa ELÉtRICA

2.2 A IONIZAÇÃo E INÍCIO DA DESCARGA ELÉTRICA EM LÂMPADAS 19

2.3 ESTABILIZAÇÃO DA DESCARGA

2.3.1 ESTABILIZAÇÃO POR CIRCUITO RESISTIVO

2.3.2 ESTABILIZAÇÃO POR CIRCUITO INDUTIVO 
2.4.1 CORREÇÃO DE COR $\quad 24$

2.4.2 Temperatura De COR 25

2.5 LÂMPADAS DE IODETO METÁLICO (VAPORES METÁLICOS) 26

\begin{tabular}{ll}
2.6 & LÂMPADAS DE LUZ MISTA \\
\hline
\end{tabular}

2.7 LÂMPADAS DE VAPOR DE SÓDIO 29

2.7.1 LÂMPADAS DE VAPOR DE SÓDIO DE BAIXA PRESSÃO 29

2.7.2 LÂMPADAS DE VAPOR DE SÓDIO DE ALTA PRESSÃO 31

$\begin{array}{lll}2.8 & \text { LÂMPADAS FLUORESCENTES } & 33\end{array}$

2.8.1 LÂMPADAS FLUORESCENTES DE CATODO QUENTE COM PREAQUECIMENTO 34

2.8.2 LÂMPADAS FLUORESCENTES DE CATODO QUENTE SEM PREAQUECIMENTO 37

2.8.3 LÂMPADAS FLUORESCENTES DE CATODO FRIO 38

$\begin{array}{lll}2.8 .4 & \text { LÂMPADAS FLUORESCENTES MODERNAS } & 39\end{array}$

2.9 CARACTERIZAÇÃo de LÂMPADAS DE DESCARGA DE BAIXA PRESSÃo 40

2.10 CARACTERIZAÇÃo DE LÂMPADAS DE DESCARGA DE ALTA INTENSIDADE 61

$\begin{array}{lll}2.11 & \text { CONSIDERAÇÕES PARCIAIS } & 76\end{array}$

2.12 MODELAGEM MATEMÁTICA DAS LÂMPADAS DE DESCARGA 78

$\begin{array}{lll}\text { 2.12.1 Modelos de RegIME PERMANENTE } & 79\end{array}$

2.12.2 Modelos de REgIME TRANSITÓRIO $\quad 79$

$\begin{array}{lll}2.12 .3 & \text { Modelagem teÓRICA } & 80\end{array}$

$\begin{array}{lll}\text { 2.12.4 MOdelAGEM SEMI-TEÓRICA } & 80\end{array}$

2.12.5 MOdELAGEM BASEADA EM FERRAMENTAS INTELIGENTES 82

$\underline{3}$ FUNDAMENTOS DA QUALIDADE DA ENERGIA ELÉTRICA

3.1 FenÔMENOS ElÉtricos TRANSITÓRIOS RELACIONAdOS COM A QEE 84 
$\begin{array}{lll}3.1 .1 & \text { TRANSITÓRIOS IMPULSIVOS } & 84\end{array}$

3.1.2 TRANSITÓRIOS OSCILATÓRIOS 86

3.2 Variações de Tensão de CuRTa duração Relacionadas com a QEe 88

$\begin{array}{llr}\text { 3.2.1 INTERRUPÇÃOO } & 89\end{array}$

3.2.2 Afundamento de TENSÃo de CURTA DuRAÇÃo 90

3.2.3 EleVAÇÃo de TENSÃo de CURTA DURAÇÃo 95

3.3 VARIAÇõES DE TENSÃo dE LONGA DURAÇÃo 97

$\begin{array}{lll}\text { 3.3.1 INTERRUPÇÕES } & 98\end{array}$

$\begin{array}{lll}\text { 3.3.2 } & \text { Afundamentos de TENSÃo } & 99\end{array}$

$\begin{array}{lll}\text { 3.3.3 EleVAÇÕES DE TENSÃo } & 100\end{array}$

$\begin{array}{ll}\text { 3.4 Desequilíbrios ou Desbalanceamentos } & 101\end{array}$

3.5 DETERIORAÇÕES DA FORMA DE ONDA 102

$\begin{array}{lll}\text { 3.5.1 NÍVEL CC } & 103\end{array}$

$\begin{array}{ll}\text { 3.5.2 DISTORÇÕES HARMÔNICAS } & 103\end{array}$

$\begin{array}{lll}3.5 .3 & \text { INTERHARMÔNICOS } & 104\end{array}$

$\begin{array}{lll}\text { 3.5.4 NOTCHING } & 104\end{array}$

$\begin{array}{lll}\text { 3.5.5 RUÍDOS } & 105\end{array}$

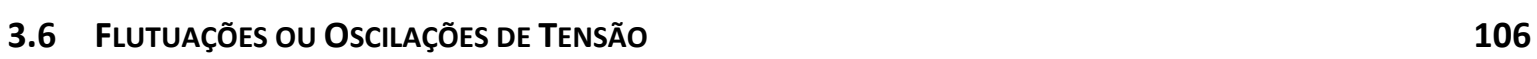

$\begin{array}{ll}\text { 3.6.1 VARIAÇÕES NA FREQUÊNCIA DO SISTEMA ELÉTRICO } & 107\end{array}$

4 AQUISIÇÃO DE DADOS DE OPERAÇ̃̃O DA LÂMPADA DE DESCARGA 111

4.1 OBSERVAÇÃo DA OPERAÇÃo da LÂMPADA DE DESCARGA 111

4.2 OBJetIVOS Gerais DA MONTAGEM LABORATORIAL 113

$\begin{array}{lll}4.3 & \text { DESCRIÇÃO DA MONTAGEM EXPERIMENTAL } & 114\end{array}$

$\begin{array}{lll}\text { 4.3.1 SISTEMA DE ALIMENTAÇÃO } & 114\end{array}$ 
XVIII

$\begin{array}{lll}\text { 4.3.2 SISTEMA DE AQUISIÇÃO DE DADOS } & 117\end{array}$

$\begin{array}{lll}\text { 4.3.3 } & \text { BANCADA DE ENSAIO DAS LÂMPADAS } & 126\end{array}$

$\begin{array}{lll}4.4 & \text { Procedimentos experimentals } & 128\end{array}$

$\begin{array}{lll}\text { 4.4.1 ENSAIOS EM REGIME DE ALIMENTAÇÃo PERMANENTE } & 130\end{array}$

4.4.2 ENSAIOS COM APLICAÇÃO DE DISTÚRBIOS DE QEE 132

$\begin{array}{lll}4.5 & \text { OBSERVAÇÕES OPERACIONAIS } & 135\end{array}$

$\underline{5}$ REPRESENTAÇÃO MATEMÁTICA DAS LÂMPADAS DE DESCARGA 137

5.1 MOdelo teRMOdinÂMICO do ARCO ELÉTRICO 138

5.1.1 MaLha LÂMPADA-REATOR 141

$\begin{array}{ll}5.2 & \text { IMPLEMENTAÇÃO DO MODELO NO SIMULINK } \\ & \end{array}$

5.2.1 Modelo de EQUaÇão (3) E (4) De EQUILíBRIO téRMICO do ARCO 141

5.2.2 IMPLEMENTAÇÃO DA EQUAÇÃO (5) DE POTÊNCIA IRRADIADA 142

5.2.3 IMPLEMENTAÇÃO DA EQUAÇÃO (6) DE POTÊNCIA DISSIPADA POR CONDUÇÃO 143

5.2.4 RESISTÊNCIA DA COLUNA DE ARCO 143

5.2.5 MODELO DE RESISTÊNCIA DO ARCO DA LÂMPADA DE DESCARGA 144

5.2.6 IMPLEMENTAÇÃO DO MODELO DE CIRCUITO ELÉTRICO 145

5.3 Comparação entre MOdelo deSENVOLVIDO E OS ENSAIOS REalizados 146

6 MODELO DA LÂMPADA DE DESCARGA UTILIZANDO REDES NEURAIS ARTIFICIAIS $\quad 155$

$\begin{array}{llr}6.1 & 155\end{array}$

$\begin{array}{ll}\text { 6.2 MOdELO NEURAL PROPOSTO PARA A LÂMPADA DE DESCARGA } & 157\end{array}$

$\begin{array}{lll}\text { 6.2.1 Arquitetura da Rede Neural Artificial empregada } & 158\end{array}$

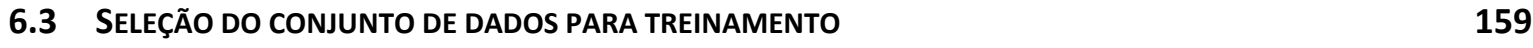

$\begin{array}{ll}\text { 6.4 ESTABELECIMENTO DA BASE DE DADOS PARA TREINAMENTO DAS RNAS } & 160\end{array}$ 
6.5 CONFIGURAÇÃo E TREINAMENTO DAS RNAS 163

6.1 AValiação do Modelo neURal da lâmpada de descarga 168

6.1.1 REPRODUÇÃO DO CONTEÚDO HARMÔNICO 169

$\begin{array}{ll}\text { 6.1.2 REPRODUÇÃO DA CARACTERÍSTICA TERMODINÂMICA } & 174\end{array}$

6.1 COMPARAÇÃO DE DESEMPENHO COMPUTACIONAL 176

6.2 Metodologia para obtenção do modelo neUral 179

6.2.1 IDENTIFICAÇÃO DAS VARIÁVEIS DE OPERAÇÃO 179

6.2.2 DETERMINAÇÃO DOS LIMITES OPERACIONAIS DO DISPOSITIVOS $\quad 179$

$\begin{array}{lll}\text { 6.2.3 } & \text { MONTAgEM EXPERIMENTAL E INSTRUMENTAÇÃO } & 179\end{array}$

$\begin{array}{lll}\text { 6.2.4 EXPERIMENTOS OPERACIONAIS } & 180\end{array}$

6.2.5 Montagem da ARQuitetura e treinamento do MOdelo NeURAL 180

$\begin{array}{ll}\text { 6.2.6 VALIDAÇÃO DO MODELO NEURAL OBTIDO } & 180\end{array}$

\section{$\underline{7}$ ANÁLISE DE DESEMPENHO DO MODELO NEURAL DE LÂMPADA DE DESCARGA}

CONSIDERANDO PARÂMETROS DE QUALIDADE DA ENERGIA $\quad 183$

$\begin{array}{lll}7.1 & \text { INTRODUÇÃO } & 183\end{array}$

$\begin{array}{ll}7.2 & \text { DESEMPENHO DO MODELO EM REGIME PERMANENTE DE OPERAÇÃo } \\ & 184\end{array}$

7.2.1 RESPOSTAS DO MODELO A VARIAÇÕES DE TENSÃO DE LONGA DURAÇÃO 184

$\begin{array}{ll}\text { 7.2.2 RESPOSTA DO MODELO A INTERRUPÇÕES } & 186\end{array}$

$\begin{array}{lll}\text { 7.2.3 } & \text { RESPOSTA A VARIAÇÕES DE TENSÃO DE CURTA DURAÇÃO } & 189\end{array}$

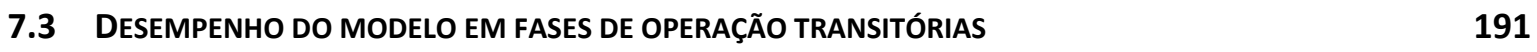

$\begin{array}{lll}\text { 7.3.1 RESPOSTA A AFUNDAMENTOS DURANTE A PARTIDA } & 191\end{array}$

7.4 DESEMPENHO DO MODELO NEURAL DA LÂMPADA DE DESCARGA EM AGRUPAMENTO DE DISPOSITIVOS 201

\begin{tabular}{ll} 
7.4.1 & AGRUPAMENTO EM CONFIGURAÇÃO MONOFÁSICA \\
\hline
\end{tabular}

$\begin{array}{llr}\text { 7.4.2 } & \text { AGRUPAMENTO EM CONFIGURAÇÃO TRIFÁSICA } & 204\end{array}$ 
A.1. Aspectos gerais das Redes NeURAIS ARTIFICIAIS

A.2. O NEURÔNIO ARTIFICIAL

A.3. TOPOLOGIA DE REDES NEURAIS ARTIFICIAIS

A.4. TREINAMENTO DAS REDES NEURAIS ARTIFICIAIS

A.4.2. PROCESSOS DE TREINAMENTO DAS REDES NEURAIS PERCEPTRON MULTICAMADAS 


\section{INTRODUÇÃO}

\subsection{A origem da luz elétrica}

A busca pela obtenção de luz a partir de fenômenos elétricos antecedeu a todas as aplicações da eletricidade atualmente conhecidas pela humanidade. $\mathrm{O}$ primeiro experimento onde está documentada a obtenção de luminosidade elétrica artificial foi realizado no ano de 1672 por Otto von Guericke (1602-1686) em Magdeburgo, e descreve a ocorrência de descargas elétricas acompanhadas de efeitos sonoros e luminosos, a partir de um gerador de eletricidade estática, baseado em uma esfera de enxofre rotativa $[1]$.

Em 1675, o astrônomo Jean Picard (1620-1682) relatou a ocorrência de luminescência na cavidade evacuada de um barômetro de mercúrio, decorrente de trepidações durante seu transporte. O curador de experimentos da Royal Society, Francis Hauksbee (1687-1763), ao tomar conhecimento do "Efeito Picard", construiu um gerador de eletricidade estática similar ao de Guericke, porém substituindo a 
esfera de enxofre original por um globo de vidro. Ao evacuar-se o globo e submetê-lo à eletrificação, seu interior apresentava uma pequena luminescência. Esta montagem experimental, embora sem aplicação prática alguma, pode ser considerada a primeira forma de lâmpada de descarga.

A luz brilhante obtida a partir de arcos de carbono foi provavelmente descoberta por Sir Humphry Davy (1778-1829), durante suas pesquisas em eletroquímica realizadas no Royal Institution of Great Britain entre 1802 e 1810. No entanto, não há evidência de interesse na utilização deste fenômeno como fonte de luz, visto que o arco elétrico era empregado apenas como fonte de calor para as manipulações químicas. Além disso, a aplicação do dispositivo como fonte de luz exigiria a alimentação por meio de geradores em substituição às células eletroquímicas, e a criação de um alimentador automático de eletrodos, que compensasse a queima das barras de carvão durante a produção do arco.

Não se sabe ao certo quem teve a primeira idéia de aquecer condutores até a incandescência através da passagem de corrente elétrica. Grove ${ }^{1}$ (1845 apud [1]) descreve um dispositivo construído por volta de 1840, baseado em um arranjo espiral de fio de platina, capaz de manter a incandescência por várias horas quando percorrido por uma corrente elétrica fornecida por células químicas. Por se mostrar confiável e seguro, o dispositivo foi originalmente sugerido como fonte de luz portátil para mineiros.

\footnotetext{
${ }^{1}$ GROVE, W.R. "On the application of voltaic ignition to lighting mines", Philosophical Magazine, London, 1845 , v. 27. p. 442-446.
} 


\subsection{A iluminação a arco}

Por centenas de anos as grandes cidades têm mostrado preocupação em manter iluminadas suas principais ruas durante a noite. No início, ainda sem o emprego da eletricidade, esta iluminação era realizada de forma individual pela instalação de lanternas e lampiões na fachada das propriedades. Gradualmente, com o objetivo de se uniformizar o serviço e garantir sua continuidade, esta incumbência foi se transferindo para órgãos especializados em associação com as administrações públicas dos municípios.

O surgimento de dispositivos capazes de produzir luz a partir da energia elétrica logo chamou a atenção em relação à iluminação de vias públicas. A iluminação a arco foi demonstrada ao público em Paris e Londres por várias vezes, entre as décadas de 1840 e 1850. A limitação existente à época era a forma de alimentação dos dispositivos, realizada então por meio de células químicas, com limitada autonomia e elevado custo. Deste modo, as demonstrações eram restritas a curtos espaços de tempo, e em número reduzido de equipamentos.

Após a introdução dos geradores eletromecânicos, retomou-se o interesse na aplicação de dispositivos de iluminação a arco. A primeira demonstração bem sucedida de um sistema de iluminação pública se deu no ano de 1878, na França, quando 62 dispositivos denominados "Velas Jablochkoff" iluminaram a Avenue de l'Opera em Paris [2]. Estes dispositivos estão ilustrados na Figura 1.

Cada "vela" era composta por duas finas varetas de carvão, separadas por uma estreita camada de material isolante composto por sulfato de cal e sulfato de barita, e instaladas no interior de uma campânula de material translúcido. O acendimento do dispositivo se dava pela ruptura de uma pequena ponte de carvão colocada no extremo superior dos eletrodos, que se incandescia com a passagem da corrente elétrica 
e dava origem ao arco elétrico. Embora apresentasse a vantagem de dispensar dispositivos de controle do arco e possuir baixo custo, esta "vela" só permitia um único acendimento.

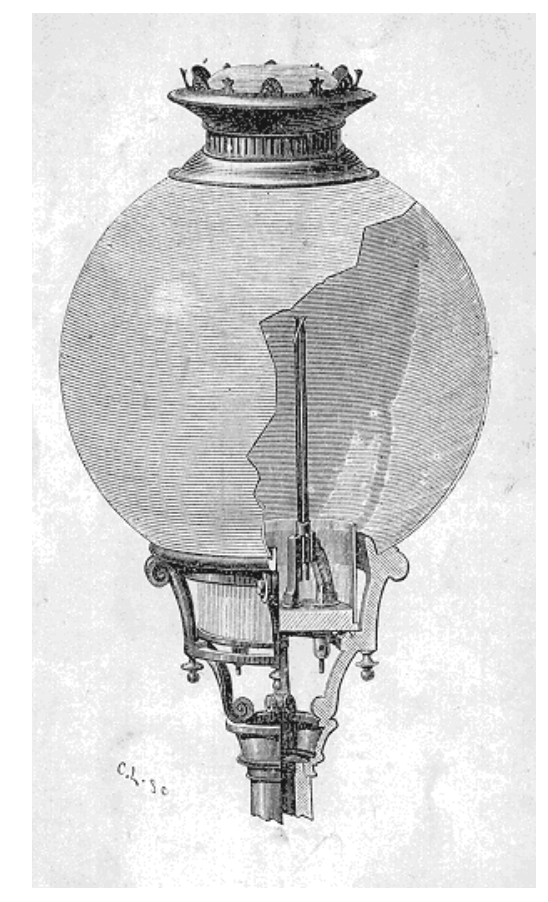

Figura 1 - Vela Jablochkoff [2].

As restritas condições de operação das "Velas Jablochkoff" estimularam o desenvolvimento de dispositivos que apresentassem maior facilidade de aplicação. Nestes quesitos as lâmpadas de arco com controladores automáticos de avanço dos eletrodos, como a ilustrada na Figura 2, mostravam-se superiores, visto que permitiam não só uma operação mais uniforme, como também possibilitavam indefinidos reacendimentos dos arcos.

Estas lâmpadas contavam com mecanismos que proporcionavam o controle da intensidade do arco e a velocidade de avanço dos eletrodos consumíveis, e normalmente incorporavam elementos limitadores de corrente que possibilitavam a operação em paralelo de vários conjuntos, conexão esta impossível na aplicação das lâmpadas baseadas na Vela Jablochkoff. 


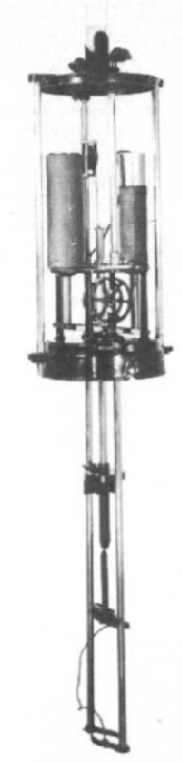

Figura 2 - Lâmpada de arco com mecanismo de controle (Copyright da Coroa Britânica) [2]

O apogeu tecnológico das lâmpadas de arco foi atingido em 1893, com a introdução das lâmpadas de arco fechado ilustradas na Figura 3. Nestes dispositivos, o arco ocorria em uma região protegida por uma campânula de vidro, que limitava consideravelmente a circulação de ar na região do arco, e por consequência elevava em até cinco vezes a vida útil dos eletrodos.

Com o objetivo de se obter maior intensidade luminosa e controlar a cor das emissões, os eletrodos passaram a conter a adição de sais, tais como fluoretos de magnésio, estrôncio, bário e cálcio. Estas adições salinas aos núcleos foram patenteadas em 1889, mas só tiveram seu uso difundido com o aparecimento das lâmpadas de arco fechado.

Apesar do intenso emprego de lâmpadas de arco na iluminação de vias públicas, o progresso das lâmpadas incandescentes demonstrou a necessidade de desenvolvimento de um dispositivo capaz de operar por grandes períodos de tempo sem a 
presença de elementos consumíveis, visando elevar a praticidade de emprego e reduzir os custos operacionais.
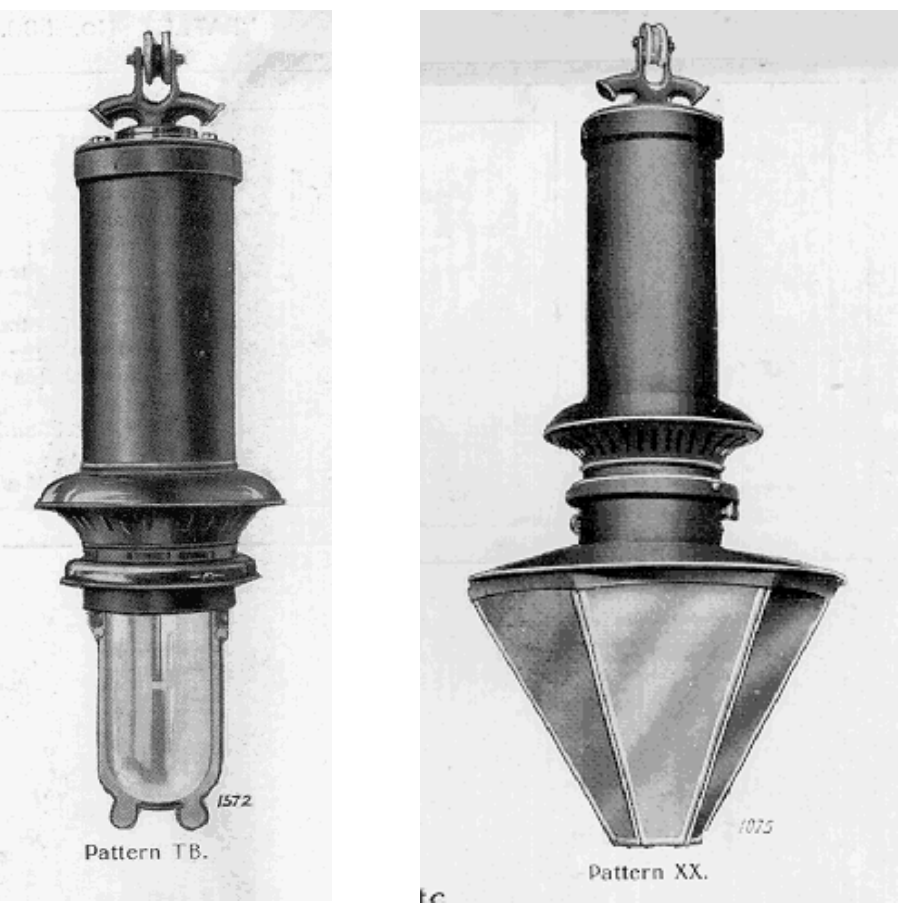

Figura 3 - Lâmpadas de arco fechado (R. E. Crompton, 1914) [2]

\subsection{As primeiras lâmpadas de descarga}

Embora o conhecimento que descargas elétricas produzissem efeitos luminescentes já existisse desde o século XVIII, este fenômeno permaneceu praticamente inexplorado até a proximidade do século XX. O tubo de Moore, criado em 1895, era um tubo de vidro preenchido com dióxido de carbono $\left(\mathrm{CO}_{2}\right)$, com até $60 \mathrm{~m}$ de comprimento, e que emitia luz branca, com uma eficiência de $2 \mathrm{~lm} / \mathrm{W}$, muito baixa para aplicações de iluminação geral [3]. Em 1905, estes tubos foram moldados em formatos de letras, originando assim os tubos luminosos de anúncios comerciais em fachadas.

Notou-se então que era possível controlar a cor da luz emitida através da composição do gás de preenchimento empregado nestes tubos. O emprego de 
Nitrogênio, fornecendo luz rosada, data desta época, e a luz avermelhada do tubo de Neon surgiu em 1910, passando a ser efetivamente utilizado em larga escala a partir de 1920.

A primeira lâmpada de vapor de mercúrio a baixa pressão foi produzida em 1901, por Peter Cooper-Hewitt, e consistia em um tubo de vidro de $1 \mathrm{~m}$ de comprimento e $3 \mathrm{~cm}$ de diâmetro. Uma das extremidades era dilatada, e continha uma cuba de mercúrio que formava um dos eletrodos, e na extremidade oposta do tubo situava-se o outro eletrodo, executado em ferro.

O processo de partida desta lâmpada consistia em se agitar manualmente o tubo, o que posteriormente foi substituído por dispositivos eletromagnéticos que proporcionavam este movimento. Por este inconveniente, somado à pobre reprodução de cor e à eficiência pouco superior às lâmpadas de filamento, que os tubos de Cooper-Hewitt originais não se tornaram comercialmente viáveis.

Os experimentos que resultaram na primeira lâmpada de mercúrio de baixa pressão indicaram que a curva pressão versus eficiência deste dispositivo apresenta um segundo pico de eficiência, muito superior ao primeiro, quando operando em pressões mais elevadas de vapor de mercúrio. Estas novas lâmpadas só se tornaram factíveis em torno de 1930, com o avanço dos materiais que permitiu a obtenção de um bulbo capaz de suportar as extremas condições de temperatura e pressão agora exigidas.

As lâmpadas de vapor de sódio foram desenvolvidas na mesma época que as lâmpadas de vapor de mercúrio. Em razão de o vapor de sódio reagir com vidros comuns, foi necessário desenvolver um tipo especial de vidro inerte para a construção dos bulbos destes dispositivos. De modo a reduzir as perdas por dissipação de calor, os bulbos de vapor de sódio eram montados no interior de bulbos evacuados.

As lâmpadas fluorescentes tiveram seu aparecimento em torno de 1940, empregando um tubo de descarga de vapor de mercúrio em baixa pressão, cuja 
emissão de radiação estava concentrada na faixa do ultravioleta. Para melhorar a eficiência da lâmpada, a parede interna do bulbo recebia o revestimento de "fósforos" capazes de converter a radiação ultravioleta em luz visível.

Esta propriedade dos materiais realizarem a conversão de comprimento de radiação já era conhecida há mais de um século, e vários aperfeiçoamentos nos "fósforos" foram produzidos até o final da década de 1930. O maior avanço ocorreu em 1942, na Inglaterra, com a invenção dos fósforos de halofosfato, que proporcionava rendimentos de conversão entre duas e três vezes superior a qualquer substância anteriormente empregada.

A eficiência atingida por lâmpadas fluorescente produzidas na década de 1940 estava por volta de $23 \mathrm{~lm} / \mathrm{W}$. Atualmente, com o avanço dos fósforos as lâmpadas superam $60 \mathrm{~lm} / \mathrm{W}$ em eficiência de conversão, com grande variedade de espectros de emissão, sem no entanto apresentar significativa alteração em seu conceito inicial.

\subsection{Contextualização do trabalho}

Equipamentos de iluminação, especialmente os dedicados à iluminação de vias públicas, estão presentes desde o início da utilização comercial da energia elétrica, e seu emprego representa um significativo percentual no total de potência instalada no sistema elétrico mundial.

A busca por sistemas de iluminação eficientes sempre conduziu à utilização de lâmpadas de descarga, que apresentam rendimento muito superior às suas equivalentes incandescentes de mesma potência. Estes equipamentos operam por várias décadas em grande parte dos sistemas de iluminação de forma satisfatória, não existindo 
até o presente momento um substituto economicamente viável em termos de eficiência energética e facilidade de manuseio.

Com o crescente aumento na potência instalada e em virtude das limitações existentes em termos de geração e transmissão, uma especial atenção tem sido dada à qualidade da energia elétrica (QEE), em particular aos equipamentos que causam degradações ao sistema. Neste ponto cabe destacar o aspecto não-linear da operação das lâmpadas de descarga, contribuindo com a deterioração da qualidade da energia do sistema onde se encontra instalada, especialmente pelo elevado conteúdo harmônico da corrente solicitada por estes dispositivos.

Do mesmo modo que as lâmpadas de descarga produzem distúrbios na qualidade da energia, os mesmos equipamentos são também afetados por estes distúrbios. Em especial, as lâmpadas de descarga de alta intensidade são bastante sensíveis a afundamentos de tensão, tornando-se inoperantes após variações de tensão de curta duração, e exigindo longos intervalos para o reinício de sua operação. Este aspecto torna-se relevante quando se considera os efeitos sobre a segurança do local iluminado, seja este uma via de tráfego de veículos, uma rua com trânsito de pedestres ou um ambiente industrial.

Do ponto de vista construtivo, a física do plasma envolvida na operação de lâmpadas de descarga apresenta comportamentos aleatórios de difícil descrição matemática, especialmente durante os transitórios de partida, que conduzem a efeitos elétricos indesejáveis, e que embora desapareçam após a entrada em regime do dispositivo, podem afetar diretamente outros elementos do sistema elétrico envolvido, como transformadores, motores e dispositivos de medição e proteção .

Diante dos aspectos apresentados, torna-se interessante a descrição matemática dos fenômenos da operação em regime permanente e transitório de lâmpadas 
de descarga, não apenas considerando o dispositivo isoladamente, mas também estudando os efeitos sofridos por esta carga tão especial quando submetido a distúrbios de qualidade da energia em qualquer uma de suas fases de operação.

Distanciando-se da modelagem físico-matemática clássica, a obtenção de um modelo a partir da avaliação direta da resposta do dispositivo com o emprego de ferramentas computacionais inteligentes pode trazer uma descrição que, embora possa não ser extremamente abrangente, satisfaça aos requisitos de simulações do dispositivo inserido em sistemas elétricos reais e diante de fenômenos relativos à qualidade da energia.

O emprego de simulações no estudo do comportamento do sistema elétrico tem se mostrado de grande utilidade, e seu uso tem se difundido à medida que a capacidade dos sistemas computacionais se eleva. A aplicação destas ferramentas computacionais permite determinar com grande precisão a resposta de um complexo sistema elétrico frente a distúrbios e faltas, com grande facilidade e confiabilidade, e este desempenho se torna mais próximo do comportamento real na proporção em que todos os elementos do sistema analisado possuam modelos computacionais realísticos e confiáveis.

A proposta deste trabalho é, portanto, a obtenção de um modelo de lâmpada de descarga de alta intensidade baseado em suas características de operação e com representação de seu comportamento termodinâmico, operando na frequência de rede e respondendo aos distúrbios de qualidade da energia conforme o dispositivo real.

Duas metodologias de modelagem serão abordadas, e seus desempenhos serão comparados: a modelagem matemática do dispositivo, composta por equacionamento diferencial que descreve o comportamento da coluna de plasma no tubo de descarga da lâmpada, e portanto dependente de parâmetros relacionados às suas características construtivas, e o modelo proposto baseado em aplicações de redes neurais 
artificiais, construído de forma a permitir que métodos de treinamento, realizados a partir de dados experimentais de operação da lâmpada, permitam a caracterização do dispositivo com um elevado grau de representatividade.

Considerando os fatos expostos, é conveniente destacar a relevância desta pesquisa tendo em vista a reduzida quantidade de trabalhos que apresentam a exploração deste tema, sendo praticamente inexistente tal modelo de lâmpadas de descarga baseado em redes neurais artificiais, com aplicação voltada ao estudo dos efeitos da qualidade da energia sobre o dispositivo e seu comportamento elétrico não-linear, caracterizando sua influência como carga potencialmente perturbadora inserida no sistema de distribuição da energia elétrica.

\subsection{Descrição dos capítulos}

O primeiro capítulo deste trabalho aborda uma introdução ao tema desta pesquisa, com uma apresentação histórica da origem e evolução das lâmpadas de descarga, seguida pela contextualização da proposta, sua justificativa e relevância científica.

No segundo capítulo é apresentada a lâmpada de descarga como dispositivo elétrico, abordando seu princípio físico de operação, suas características operacionais e suas diversas famílias. Uma revisão da bibliografia também é apresentada neste capítulo, mostrando os principais e mais recentes trabalhos publicados sobre lâmpadas de descarga e suas diversas formas de caracterização e modelagem.

O terceiro capítulo apresenta os conceitos relacionados à Qualidade da Energia (QE), os efeitos para as cargas e para o sistema de distribuição, assim como as origens dos distúrbios e suas causas. 
O quarto capítulo apresenta os procedimentos adotados no dimensionamento e elaboração da montagem experimental empregada no levantamento das características operacionais da lâmpada de descarga estudada por este trabalho, tratada como carga inserida no sistema elétrico, e a caracterização do seu desempenho frente a fenômenos relacionados a qualidade da energia.

A representação matemática das lâmpadas de descarga é apresentada no quinto capítulo, que mostra o modelo matemático adotado para o dispositivo, baseado em suas características construtivas e parâmetros físicos, sua aplicação em simulações e os resultados obtidos por esta abordagem.

A arquitetura das redes neurais artificiais adotadas na composição do modelo de lâmpada de descarga em conjunto com seu respectivo reator, tratados como carga isolada, e os resultados obtidos a partir dos treinamentos elaborados e testes de validação são apresentados no sexto capítulo deste trabalho. Também são apresentados neste capítulo os resultados comparativos de desempenho entre o modelo neural e o modelo matemático, indicando as vantagens obtidas com a modelagem realizada com base em redes neurais artificiais.

Uma análise de desempenho diante de parâmetros de qualidade da energia para o modelo proposto é o conteúdo do sétimo capítulo deste trabalho, onde o resultado de ensaios e simulações envolvendo conjuntos de lâmpadas é apresentado, confirmando a validação dos procedimentos de elaboração do modelo.

As conclusões apresentadas ao final deste trabalho expõem de forma abrangente os resultados obtidos com a pesquisa elaborada e apresentam um paralelo entre as técnicas de modelagem empregadas, ressaltando a contribuição obtida a partir da abordagem proposta. 
O Apêndice "A" traz uma explanação teórica sobre as redes neurais artificiais, empregadas como ferramenta de inteligência artificial, e que neste trabalho foram aplicadas na caracterização da lâmpada de descarga a partir de dados operacionais obtidos pelo sistema de aquisição de dados. 


\section{LÂMPADAS DE DESCARGA ELÉTRICA: UMA REVISÃO BIBLIOGRÁFICA}

Define-se a lâmpada de descarga como um dispositivo onde o fluxo luminoso é gerado de forma direta ou indireta pela passagem de corrente elétrica através de meio gasoso, seja este confinado ou aberto à atmosfera, sem a presença de meio condutor [4].

As lâmpadas de descarga fabricadas atualmente são constituídas por um tubo (bulbo) contendo gases ou vapores, através dos quais se estabelece um arco elétrico. Os gases mais utilizados são: o Argônio, o Neônio, o Xenônio, o Hélio ou o Criptônio, e os vapores de Mercúrio e Sódio com alguns aditivos.

A pressão do gás ou vapor no interior do bulbo pode variar desde fração de atmosfera (atm) até dezenas de atmosferas. Assim, podemos classificar as lâmpadas de descarga como de baixa, média e alta pressão. As lâmpadas de neônio, utilizadas em anúncios, e as fluorescentes, comumente utilizadas em residências, são 
lâmpadas de baixa pressão. As lâmpadas de vapor de mercúrio, vapor de sódio, iodeto metálico e gás xenônio são de alta pressão.

Entre os metais utilizados na confecção dos eletrodos estão o Níquel (Ni), Tungstênio (W) e Nióbio (Nb), que podem ser recobertos com uma substância de elevado poder emissor de elétrons, geralmente óxidos de Bário (Ba) e Estrôncio ( $\mathrm{Sr}$ ).

Em certos tipos de lâmpadas, os eletrodos são mantidos em baixa temperatura (lâmpadas de catodo frio). Em outros, eles são aquecidos até a incandescência (lâmpadas de catodo quente), e neste último caso, podemos ter catodo com ou sem preaquecimento.

Os catodos com preaquecimento são confeccionados com filamentos de tungstênio, recobertos com óxidos emissores, pelos quais se faz circular uma intensidade de corrente elétrica destinada a aquecê-los enquanto a descarga elétrica se inicia (exemplo, lâmpadas fluorescentes convencionais).

Após o início da descarga plena na lâmpada, o preaquecimento pode ser desativado, mantendo-se os eletrodos na temperatura ótima pela própria descarga elétrica. Os catodos sem preaquecimento são mantidos em temperatura de funcionamento, também pela própria descarga elétrica. Porém, como não há preaquecimento, essas lâmpadas exigem diferenças de potencial elevadas entre seus eletrodos, para que se provoque a ionização do meio interno do bulbo e a descarga se inicie.

Os bulbos das lâmpadas de baixa pressão que funcionam em temperaturas reduzidas, são normalmente confeccionados com vidro. Enquanto as lâmpadas de alta pressão, que funcionam em temperaturas elevadas, exigem bulbos de quartzo, e, em casos especiais, bulbos de cerâmica translúcida.

No caso em que se desejam temperaturas e pressões internas altas no interior do tubo de arco, é comum a utilização de dois bulbos concêntricos entre os 
quais existe vácuo ou gás a baixa pressão, que funciona como isolamento térmico entre ambos. Neste caso, o bulbo interno trabalhará em temperatura bastante superior ao externo.

\subsection{Produção de radiações pela descarga elétrica}

Segundo o modelo de Bohr [5], os elétrons de um átomo giram em órbitas específicas, sem a emissão da energia radiante. Um elétron pode "saltar" de uma órbita interna (com menor valor energético) para uma externa (com maior valor energético), desde que receba energia, isto é, seja excitado. Este estado de excitação, entretanto, é instável e o elétron retorna a sua órbita original (com menor valor energético). Ao retornar, o elétron emite um fóton cuja energia é igual à diferença da energia $\left(E_{1}-E_{2}\right)$ entre os dois estados e cuja frequência ( $f$ ) é dada por:

$$
f=\frac{E_{1}-E_{2}}{h}
$$

onde $h$ é a constante de Planck, cujo valor é $6,63 \times 10^{-34} \mathrm{~J} \cdot \mathrm{s}$.

Nota-se que o estado normal de um átomo é aquele em que a energia é mínima, com os elétrons girando na órbita de menor raio. Para os raios das diferentes órbitas, o modelo de Bohr apresenta a seguinte relação:

$$
r=n^{2} \cdot r_{0}
$$

onde $r_{0}$ é o raio da primeira órbita $\left(0,53 \times 10^{-10} \mathrm{~m}\right)$ e $n$ é o número quântico da órbita.

Caso um elétron excitado "salte" da órbita $n=2$ para $n=1$, a energia radiante (fóton) será emitida em uma frequência diferente da que seria obtida caso o "salto" fosse da $n=3$ para $n=2$. Por isso, a radiação produzida pela descarga elétrica não possui um espectro contínuo, mas as frequências obtidas serão proporcionais às diferenças de níveis energéticos possíveis para um dado gás ou vapor, nas suas condições de pressão e temperatura. 
A descarga elétrica em uma lâmpada faz com que os elétrons emitidos por um eletrodo (catodo) se dirijam ao outro eletrodo (anodo). Ao longo do percurso, eles poderão colidir com um átomo do gás ou vapor contido no bulbo, de forma a retirar-lhe um elétron da órbita interna, passando-o para a órbita mais externa (excitando o átomo) e seu subsequente retorno à órbita original com a emissão de um fóton (energia radiante).

O elétron livre também poderá, na colisão com o átomo do gás ou vapor, retirar um elétron de sua órbita periférica. Neste caso, o elétron "libertado" se encaminhará para o anodo, juntamente com o seu "libertador". Este fenômeno não produzirá energia radiante, mas será responsável pela atmosfera condutora (plasma), que manterá a corrente elétrica no interior do bulbo.

Nas lâmpadas sem o revestimento fluorescente, o fluxo luminoso provém diretamente da energia radiante excitada pela descarga elétrica nos gases ou vapores. Enquanto que nas lâmpadas com revestimentos fluorescentes, a maior parte do fluxo luminoso visível provém dos compostos químicos do revestimento fluorescente, que é excitado pelas radiações ultravioletas $(\lambda=253,7 \mathrm{~nm})$ produzidas pela descarga no vapor de mercúrio.

Essas substâncias fluorescentes (fósforos) agem como conversores de frequência. Quando sobre elas incide uma energia radiante de determinado comprimento de onda, elas absorvem-na e reemitem-na em parte, porém num comprimento de onda diferente. São substâncias cristalinas que contêm traços de impurezas (ativadores), tais como tungstatos, boratos e silicatos de cálcio, magnésio, zinco, berílio e cádmio (a composição química varia conforme a cor da luz desejada)[4]. 


\subsection{A ionização e início da descarga elétrica em lâmpadas}

A descarga elétrica inicia-se quando a diferença de potencial entre os eletrodos é superior a certo valor crítico. Este valor pode ser reduzido se houver um preaquecimento dos eletrodos. Assim que a descarga se inicia, ela poderá ser mantida estável com tensões menores que as de ignição, podendo-se suprimir o aquecimento dos eletrodos, que se manterão na temperatura ideal pela própria descarga elétrica entre eles. Dessa forma, as lâmpadas de catodo frio e as que não possuem preaquecimento exigem sempre tensões mais elevadas para sua partida e para o seu funcionamento em regime permanente.

As lâmpadas de descarga necessitam, pois, de equipamento auxiliar (reatores, transformadores, ignitores), seja para gerar os pulsos de tensão necessários para a partida, para estabilizar o valor da intensidade de corrente na descarga em regime permanente, ou para adaptar as características elétricas da lâmpada aos valores nominais da fonte de alimentação [5].

A função da ignição é superpor um ou mais pulsos de alta tensão sobre a tensão da lâmpada, para que a sua descarga elétrica se inicie. Iniciada a descarga, a ignição se desliga automaticamente.

Existem 3 (três) tipos de construção básica para as ignições:

- Ignição de 3 pontos: utiliza o próprio reator como transformador amplificador dos pulsos produzidos pela ignição (Figura 4). Trata-se do modelo de uso mais comum para lâmpadas de vapor de sódio de alta pressão, e também para lâmpadas de iodeto metálico de alguns fabricantes. Sua tensão de pulso depende do reator utilizado e da posição de sua derivação. 


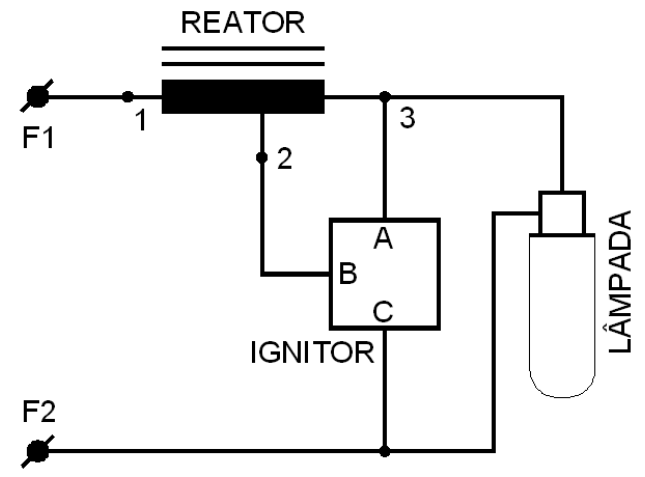

Figura 4 - Ignição ABNT (reator de 3 terminais) [4].

- Ignição com bobina de pulso em série com a lâmpada: é uma ignição mais complexa e cara, pois possui bobina interna de pulso (Figura 5). Sua tensão de pulso independe do reator utilizado, e pode chegar a $50 \mathrm{kV}$ na reignição instantânea de lâmpadas de iodeto metálico de potências elevadas.

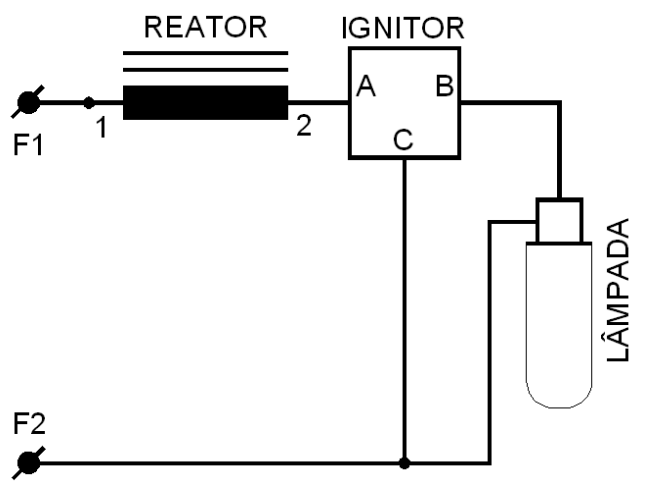

Figura 5 - Ignitor com bobina de pulso interna [4].

- Ignição em paralelo: gera pulso de menor tensão (duas a quatro vezes a tensão de pico da rede de alimentação) sendo utilizadas unicamente em algumas lâmpadas de iodeto metálico e a vapor de mercúrio de baixa pressão (Figura 6). 


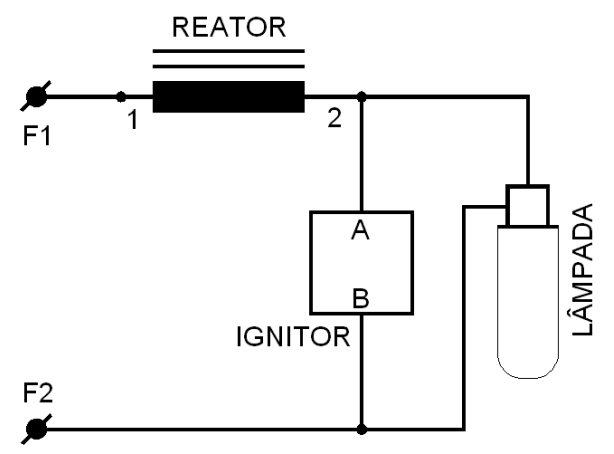

Figura 6- Ignitor em paralelo [4].

\subsection{Estabilização da descarga}

A operação de tubos de descarga com a maioria dos gases apresenta características de resistência negativa, ou seja, a corrente tende a diminuir quando a tensão sobre o dispositivo se torna maior que a necessária para a manutenção da descarga [4]. Deste modo, há a necessidade de se introduzir no circuito, em série com o tubo de arco, uma impedância limitadora, composta normalmente por circuitos reativos (indutivo ou capacitivo) no caso de operação em corrente alternada, ou ainda circuitos resistivos ou elementos eletrônicos com função similar.

\subsubsection{Estabilização por circuito resistivo}

A estabilização por circuito resistivo (Figura 7) é empregada em situações onde se deseja a redução do custo inicial e, também, em alguns circuitos de corrente contínua. Neste caso, tem-se a combinação de uma característica positiva (do resistor) com a característica negativa da lâmpada, resultando em um equilíbrio.

Normalmente, o resistor é um filamento incandescente que, ao emitir radiações, colabora no fluxo luminoso final (lâmpadas de luz mista). A lâmpada, estabilizada por um circuito resistivo, terá fator de potência unitário, mas sua eficiência luminosa global será diminuída devido à baixa eficiência do filamento incandescente como fonte de luz. 

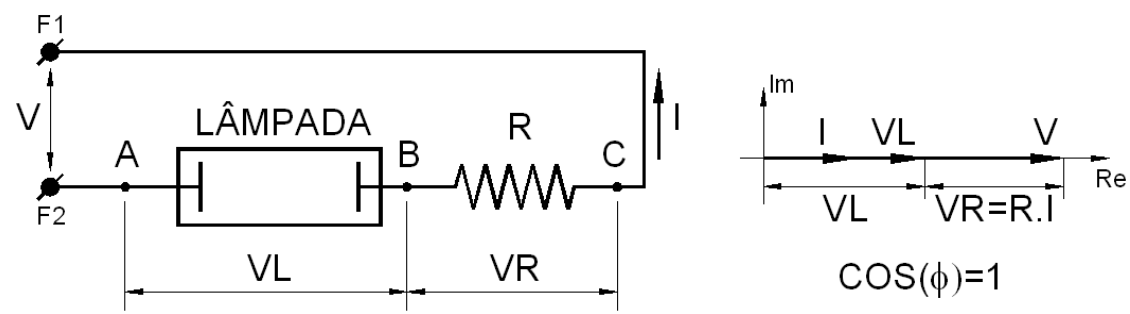

Figura 7 - Estabilização da descarga elétrica por circuito resistivo [4].

\subsubsection{Estabilização por circuito indutivo}

Atualmente, a estabilização por circuito indutivo através de reatores ou transformadores (Figura 8) é a mais empregada. Neste caso, a tensão nas extremidades da lâmpada está em quadratura com a tensão no reator (pois se supõe resistência interna desprezível). O fator de potência é baixo, e a corrente do circuito está atrasada em relação à tensão aplicada.
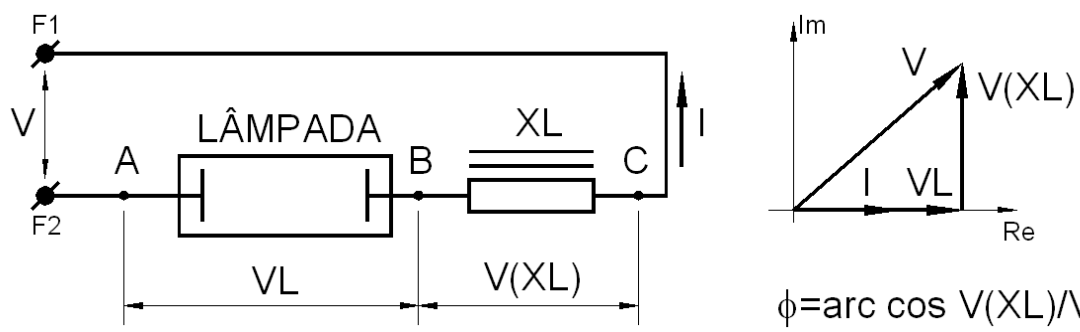

$\phi=\arccos V(X L) / V L$

Figura 8 - Estabilização da descarga elétrica por circuito indutivo [4].

\subsubsection{Estabilização por circuito capacitivo}

No caso da estabilização por capacitância (Figura 9), o fator de potência também é baixo, e a corrente está adiantada em relação à tensão aplicada. É um circuito econômico para aplicações em frequências elevadas, típicas de reatores eletrônicos. 

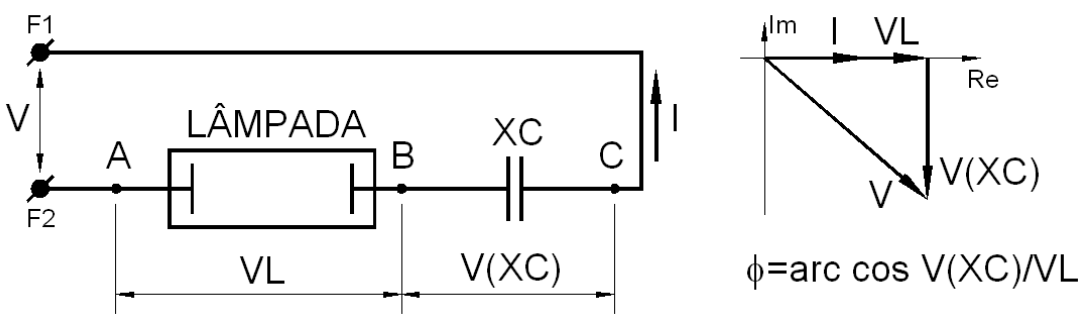

Figura 9 - Estabilização da descarga elétrica por circuito capacitivo [4].

\subsection{Lâmpadas de vapor de mercúrio}

A lâmpada de vapor de mercúrio (Figura 10) apresenta um tubo de descarga construído em quartzo para suportar temperaturas elevadas, e em cada extremidade um eletrodo principal constituído por uma espiral de tungstênio recoberta com material emissor de elétrons. Junto a um dos eletrodos principais existe um eletrodo auxiliar (de partida) ligado em série com um resistor de partida que está externo ao tubo de $\operatorname{arco.}$

O meio interno contém gás inerte (argônio), que facilita a formação da descarga inicial, e gotas de mercúrio, que serão vaporizadas durante o período de aquecimento da lâmpada. Quando uma tensão elétrica, de valor adequado, é aplicada à lâmpada, gera-se um campo elétrico entre o eletrodo auxiliar e principal adjacentes. Assim, gera-se um arco elétrico entre eles, o que provoca o aquecimento dos óxidos emissores, a ionização do gás e a formação do vapor de mercúrio.

Após a ionização do meio interno, a impedância elétrica do circuito principal (entre os eletrodos principais) torna-se reduzida, e como a do circuito de partida é elevada (por causa do seu resistor), este se torna praticamente inativo. Dessa forma, a descarga elétrica passa a ocorrer entre os eletrodos principais. O período de ignição tem a duração de alguns segundos. 


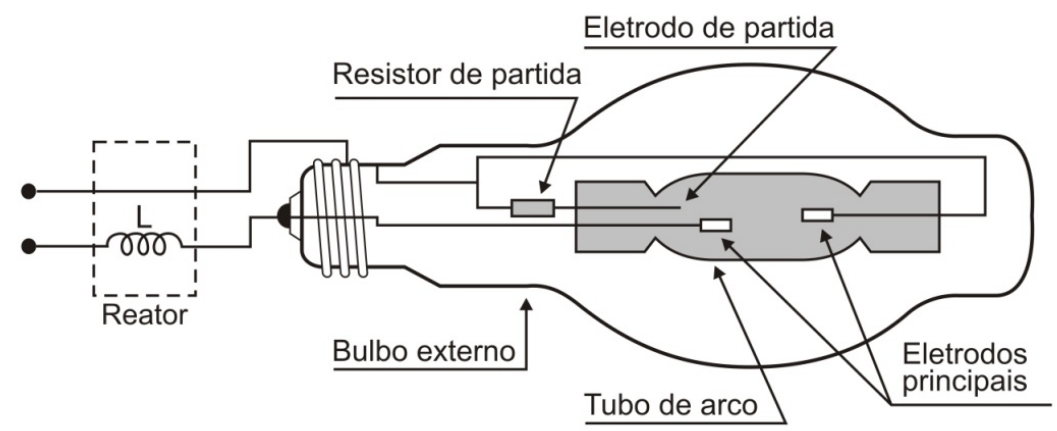

Figura 10 - Lâmpada de vapor de mercúrio (elementos básicos) [4].

À medida que ocorre o aquecimento do meio interno, a pressão dos vapores cresce e consequentemente o fluxo luminoso aumenta. Somente após alguns minutos é que a lâmpada se estabiliza na sua condição normal de operação.

A operação eficiente da lâmpada requer a manutenção de uma alta temperatura no tubo de descarga (ou tubo de arco), o qual é fechado dentro de outro bulbo de vidro, reduzindo-se as perdas de calor para o exterior. Entre os dois bulbos, introduz-se nitrogênio à pressão de 0,5 atm. Se a lâmpada é apagada, o mercúrio não pode ser reionizado, até que a temperatura do arco seja diminuída suficientemente, o que leva de 3 a 10 minutos, dependendo das condições externas e da potência da lâmpada.

A eficiência luminosa das lâmpadas de vapor de mercúrio é de aproximadamente $50 \mathrm{~lm} / \mathrm{W}$, e sua vida útil média da ordem de $18.000 \mathrm{~h}$.

\subsubsection{Correção de cor}

A composição espectral do fluxo luminoso produzido por um tubo de mercúrio de alta pressão é precária, isto é, apresenta luz azulada, pobre em radiações vermelhas; assim, estas lâmpadas distorcem as cores dos objetos iluminados. Para superar esta deficiência, normalmente as lâmpadas de vapor de mercúrio possuem uma camada de fósforo, na face interna do bulbo externo, para a correção de cor. Tal camada transforma as 
radiações ultravioletas (luz negra), produzidas pela descarga, em luz vermelha, que melhorará a composição espectral finnal do fluxo luminoso produzido. São as chamadas lâmpadas de vapor de mercúrio de cor corrigida.

\subsubsection{Temperatura de cor}

Lord Kelvin criou uma escala de temperaturas, à qual deu seu nome e estabeleceu que à temperatura de $1.200 \mathrm{~K}$ o corpo negro se tornaria vermelho. E que quanto mais aquecido, mais sua tonalidade se alterava, correspondendo a temperaturas intermediárias. Assim, a temperatura de cor expressa a aparência de cor da luz emitida pela fonte de luz. A sua unidade de medida é o Kelvin (K). Quanto mais alta a temperatura de cor, mais clara é a tonalidade de cor da luz. A Tabela 1 apresenta algumas fontes de luz e temperaturas associadas.

Tabela 1- Algumas fontes de luz e temperaturas associadas.

\begin{tabular}{c|c}
\hline Temperatura de Cor (K) & Fonte de Luz \\
\hline 1.700 & Luz de vela/candeeiro \\
\hline 2.000 & Lâmpada de vapor de sódio (iluminação pública) \\
\hline 2.680 & Lâmpada incandescente comum (40W) \\
\hline 3.500 & Lâmpada fluorescente do tipo "branca quente" \\
\hline 4.100 & Luz do luar em dia de Lua Cheia \\
\hline 4.500 & Lâmpada fluorescente do tipo "branca fria" \\
\hline 5.000 a 5.500 & Luz do sol ao amanhecer ou entardecer \\
\hline 5.000 a 5.600 & Flash eletrônico \\
\hline 6.000 & Lâmpada de vapor de mercúrio \\
\hline 6.500 & Lâmpada fluorescente do tipo "luz do dia" \\
\hline 6.500 a 7.500 & Céu encoberto \\
\hline 9.000 a 12.000 & Céu azul aberto \\
\hline 25.000 & Céu de dia no Pólo Norte
\end{tabular}

Quando se fala em luz "quente" ou "fria", não se está referindo ao calor físico da lâmpada, mas à tonalidade de cor que ela apresenta ao ambiente, conforme se observa na Figura 11. 


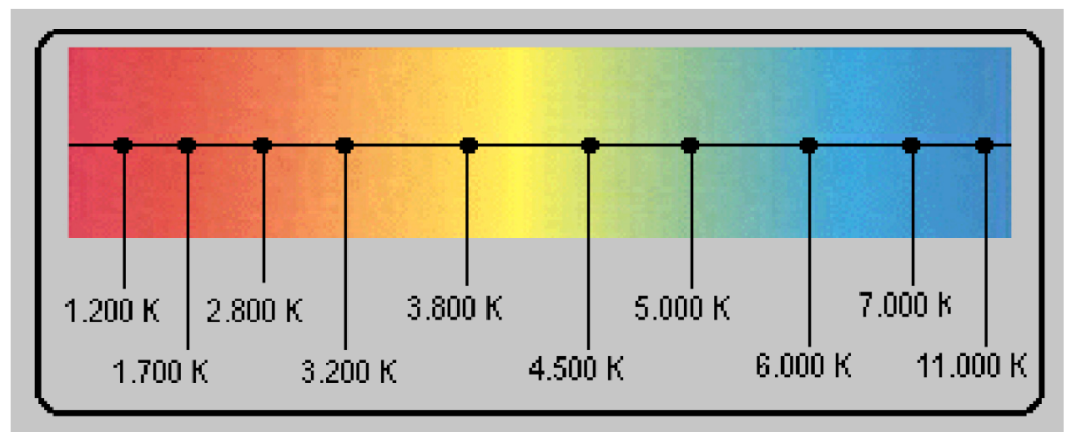

Figura 11 - Escala Kelvin de temperatura de cor [4].

Assim, as cores consideradas "quentes" são cores avermelhadas e cores consideradas 'frias' são cores tendendo para o azul. Esta concepção, como se pode observar, é exatamente o inverso do que mostram as indicações de temperatura associadas às cores. Assim, quando se fala em uma tonalidade "fria", deve-se imaginar altas temperaturas na escala acima, e o inverso para tonalidades "quentes".

\subsection{Lâmpadas de iodeto metálico (vapores metálicos)}

As lâmpadas de iodeto metálico são semelhantes às lâmpadas de vapor de mercúrio, porém, a diferença está na introdução, além de argônio e mercúrio, de outros elementos químicos, de forma que o arco elétrico se realize numa atmosfera mista de vários gases e vapores. Dessa forma, conseguem-se maiores eficiências luminosas (em torno de $95 \mathrm{~lm} / \mathrm{W}$ ) e melhor composição espectral do que nas lâmpadas tradicionais de vapor de mercúrio.

Apresentam luz extremamente branca, com índice de reprodução de cores de até $90 \%$ e temperatura de cor entre $4.000 \mathrm{~K}$ e $6.000 \mathrm{~K}$. Iluminam com intensidade, e valorizam as cores dos ambientes em que é aplicada. Seu tempo de aquecimento é de 5 a 10 minutos e o de nova partida a quente pode chegar a 30 minutos nas lâmpadas de grande potência. 
A tecnologia de fabricação dessas lâmpadas varia bastante entre os diversos fabricantes e suas características foram normatizadas internacionalmente. Há basicamente três diferentes tecnologias de fabricação [4]:

- Tecnologia das 3 cores: utilizam-se vapores de Índio, Sódio e Tálio, responsáveis respectivamente pelas cores azul, vermelha e verde do espectro irradiado. São lâmpadas de vida útil e eficiência luminosa menores, mas com maior manutenção do seu fluxo luminoso.

- Tecnologia do Sódio e Escândio, com presença de Lítio e Tálio. Possui maior eficiência luminosa, boa estabilidade de cor e vida útil maior.

- Tecnologia das terras raras: utilizam-se Tálio, Disprósio e Hólmio. Estes modelos possuem boa eficiência luminosa e estabilidade de cor, além de um elevado índice de reprodução de cores.

Quanto à partida, alguns modelos de menor potência possuem ignitores internos ao bulbo, mas em modelos mais comuns o ignitor é uma peça independente. A Figura 4 mostra em um circuito que emprega equipamentos auxiliares idênticos aos utilizados pelas lâmpadas de vapor de sódio de igual potência, e a Figura 6 apresenta um circuito que utiliza reatores e ignitores específicos para este tipo de lâmpada.

Os modelos de baixa potência (até $150 \mathrm{~W}$ ) são indicados para iluminação interna, tais como shopping centers, lojas, vitrines, hotéis e jardins. As de maior potência são indicadas para iluminação de avenidas, fachadas, monumentos, ginásios, estádios, grandes áreas abertas, estacionamentos e aeroportos.

\subsection{Lâmpadas de luz mista}

As lâmpadas de luz mista (Figura 12) apresentam um tubo de arco de vapor de mercúrio em série com um filamento incandescente de tungstênio que, além de 
produzir fluxo luminoso, funciona como elemento de estabilização da lâmpada. O fluxo luminoso produzido é composto de radiações azuladas (oriundas do arco elétrico), de radiações amareladas (oriundas do filamento incandescente) e de radiações vermelhas (oriundas da eventual camada de correção de cor nas paredes do bulbo).

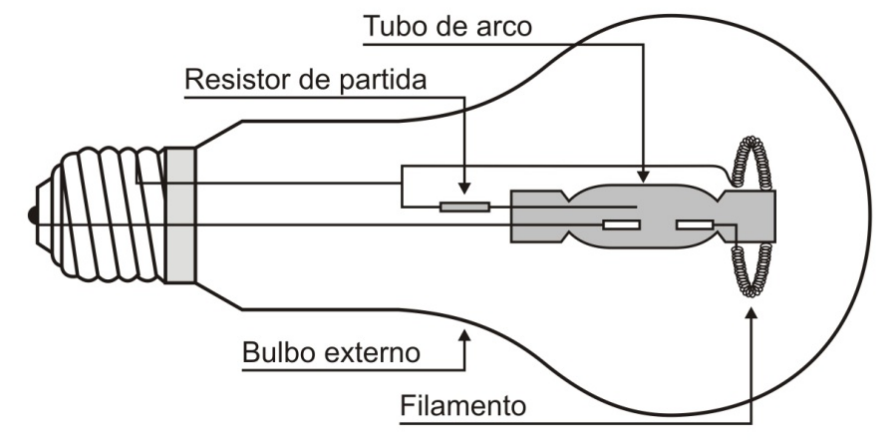

Figura 12 - Partes básicas de uma lâmpada de luz mista [4].

Uma vez que o filamento, além de produzir luz, limita a corrente de funcionamento do tubo de arco, as lâmpadas de luz mista dispensam o equipamento auxiliar (reator), o que permite serem ligadas diretamente aos terminais da rede elétrica, na tensão para qual foram projetadas. Esta tensão normalmente é de $230 \mathrm{~V}$, pois tensões menores não são suficientes para a ionização do tubo de arco. As lâmpadas de luz mista apresentam eficiência luminosa de 25 a $35 \mathrm{~lm} / \mathrm{W}$, metade das de vapor de mercúrio, devido à baixa eficiência do filamento. Sua vida útil também fica limitada a do filamento, sendo em torno de $6.000 \mathrm{~h}$.

As únicas vantagens da lâmpada de luz mista, quando comparadas com as de vapor de mercúrio, seriam um menor custo inicial de instalação (por não exigirem reator) e o fator de potência unitário. É também uma alternativa precária para a substituição de lâmpadas incandescentes em pequenas instalações. 


\subsection{Lâmpadas de vapor de sódio}

\subsubsection{Lâmpadas de vapor de sódio de baixa pressão}

A energia radiante emitida pelas lâmpadas de vapor de sódio concentra-se, na maior parte, em duas linhas próximas de ressonância, com comprimentos de onda de 589,0 e 589,6 nm. Estes comprimentos de onda são próximos daquele para o qual a visão humana apresenta máxima acuidade visual (diurna: 555nm, próximo ao amarelo esverdeado; noturna: $510 \mathrm{~nm}$, próximo ao verde azulado), o que permite uma grande eficiência luminosa. Cabe salientar que a faixa de comprimento de onda visível ao olho humano está entre 380nm e 780nm [5], conforme mostra a Figura 13.

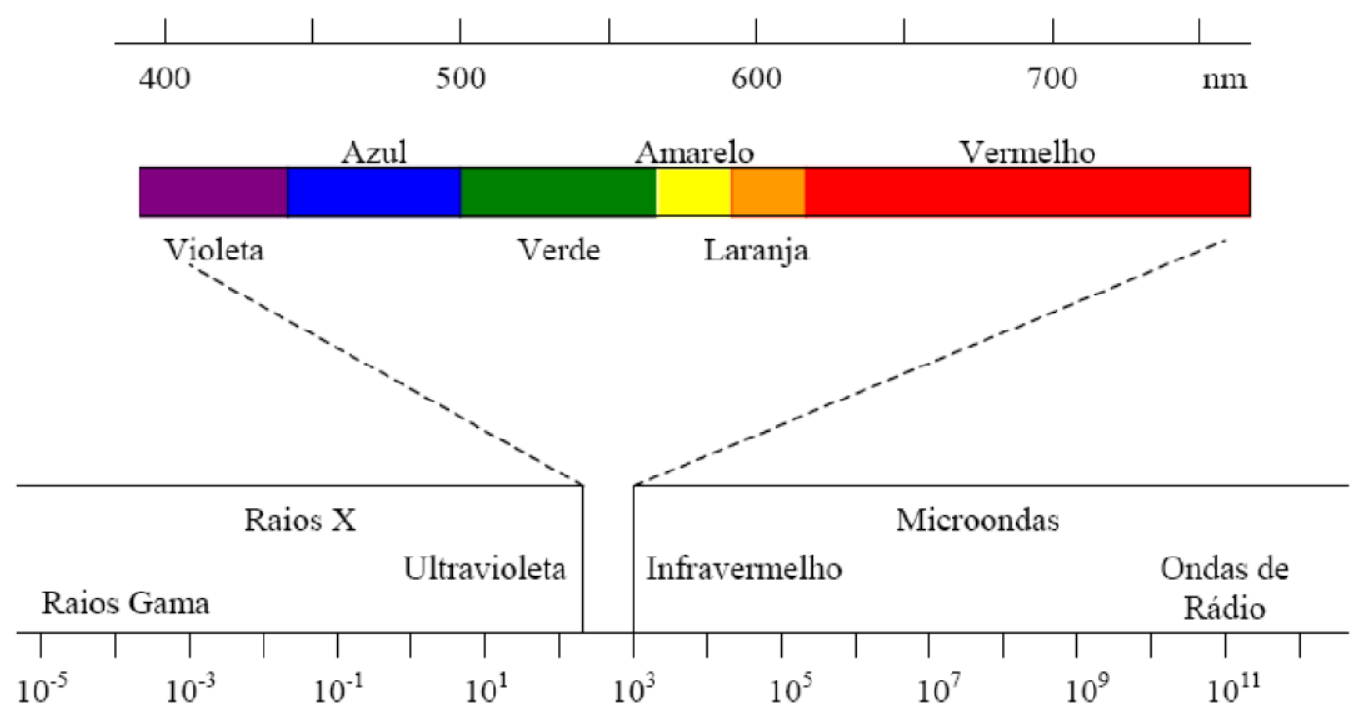

Figura 13 - Espectro de cores visíveis ao olho humano [5].

A pressão do vapor no interior do tubo de descarga desempenha um papel importante. Quando a pressão é muito baixa haverá poucos átomos de sódio para excitação na descarga; enquanto que para pressões demasiadamente elevadas, grande parte da radiação de ressonância do átomo se perde por auto-absorção na própria descarga.

Dessa forma, a pressão ideal é de aproximadamente $0,67 \mathrm{~Pa}$ $\left(6,61 \times 10^{-6} \mathrm{~atm}\right)$, e se obtém com uma temperatura de $260^{\circ} \mathrm{C}$ no tubo de descarga. Sua 
composição espectral, quase monocromática (luz amarela), distorce as cores, o que impede seu uso em iluminação interior. Devido a sua alta eficiência luminosa, são aplicáveis na iluminação de ruas, túneis e auto-estradas.

Tais lâmpadas apresentam um tubo de descarga interno, em forma de U, como apresentado na Figura 14, que contém gás neônio e $0,5 \%$ de argônio à baixa pressão, para facilitar a partida da lâmpada, e certa quantidade de sódio metálico, que é vaporizado durante o funcionamento. Nas extremidades encontram-se os eletrodos recobertos com óxidos emissores de elétrons. Com o intuito de se evitar a variação do fluxo luminoso com a variação da temperatura ambiente, o tubo de descarga é fechado dentro de uma camisa externa, na qual há vácuo.

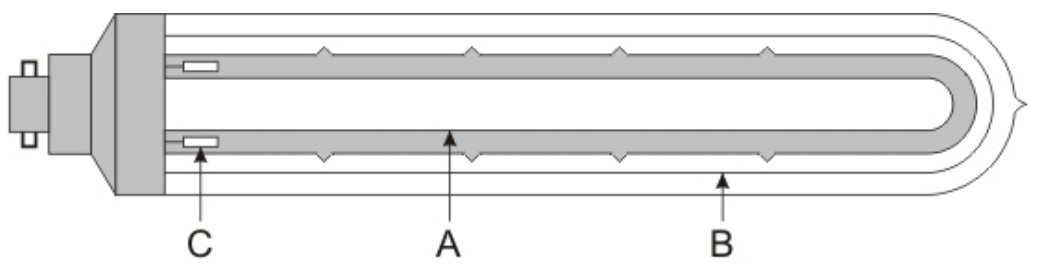
A) Tubo de Descarga
B) Camisa de Vácuo Externa
C) Eletrodos

Figura 14 - Componentes básicos de uma lâmpada de vapor de sódio de baixa pressão [4].

Durante a partida, a descarga elétrica inicia-se no gás neônio, que provoca a produção de um pequeno fluxo luminoso de cor rosa e uma elevação da temperatura, que progressivamente causa uma vaporização do sódio metálico. Em torno de 15 minutos, a lâmpada adquire uma condição normal de funcionamento e produz um fluxo luminoso amarelo, característico da descarga no vapor de sódio. A eficiência luminosa das lâmpadas de vapor de sódio de baixa pressão, do tipo tradicional, é da ordem de $100 \mathrm{~lm} / \mathrm{W}$ e sua vida útil média é de $6.000 \mathrm{~h}$.

Nos últimos anos, os fabricantes europeus de lâmpadas elétricas têm lançado no mercado novas linhas de lâmpadas de vapor de sódio com elevadas eficiências luminosas (180 lm/W para uma lâmpada de 180W) e vida útil bem mais longa 
(18.000h). Alcançou-se este aumento de eficiência por usar uma camada refletora infravermelha de óxido de índio, na face interior da camisa de vácuo, a qual reflete a radiação infravermelha produzida na descarga (comprimento de onda de $5.000 \mathrm{~nm}$ ) novamente sobre o bulbo interno. Este artifício permite manter uma temperatura ideal $\left(\sim 260^{\circ} \mathrm{C}\right)$ no interior do tubo de arco, porém com intensidades menores de correntes no arco elétrico.

\subsubsection{Lâmpadas de vapor de sódio de alta pressão}

As lâmpadas de vapor de sódio de alta pressão trabalham com pressão mais elevada. A denominação "alta pressão" não tem um sentido estrito, mas relativo, em comparação com as lâmpadas de vapor de sódio de baixa pressão.

Quando se aumenta a pressão numa lâmpada de vapor de sódio de baixa pressão, a eficiência luminosa diminui devido à auto-absorção da radiação de ressonância na parte exterior dos átomos de sódio. À medida que se continuar aumentar a pressão interna, outras raias do espectro começam a ser geradas. $\mathrm{Na}$ pressão de aproximadamente $26,7 \mathrm{kPa}(0,2635 \mathrm{~atm})$, o espectro torna-se contínuo nas regiões do verde e do azul. Pelo fato de ainda existir a auto-absorção da raia amarela, consegue-se uma cor mais agradável e uma melhor reprodução de cores. A luz produzida tem cor branca dourada, com índice de reprodução de cor (IRC) igual a 20.

O IRC indica a capacidade que uma fonte luminosa tem de reproduzir fielmente a cor do objeto por ela iluminado, variando de 0 a 100. Quanto maior esse índice, maior será a fidelidade das cores.

Nas condições nominais de operação, a temperatura do tubo de arco chega a aproximadamente $1.000^{\circ} \mathrm{C}$, em atmosfera agressiva, não sendo possível a utilização do vidro duro e do quartzo na fabricação da ampola interna. Assim, é utilizado, 
na fabricação da ampola interna o óxido de alumínio sinterizado, material cerâmico com ponto de fusão de $2.050^{\circ} \mathrm{C}$, translúcido (transmitância de $90 \%$ ), quimicamente à prova de vapor de sódio em elevadas temperaturas.

Tais lâmpadas são compostas por um tubo de descarga de óxido de alumínio translúcido, dentro do qual temos os eletrodos de nióbio e o meio interno preenchido com xenônio, mercúrio e sódio metálico. A função do gás é facilitar a partida da lâmpada.

O tubo de descarga é localizado dentro do bulbo externo (fabricado com vidro duro). O vácuo existente entre os dois bulbos permite diminuir a perda de calor para o exterior e aumenta a pressão no tubo de arco e a eficiência luminosa da lâmpada. A vida útil média destas lâmpadas é da ordem de $24.000 \mathrm{~h}$, e sua eficiência extremamente elevada (em torno de 130 lm/W para lâmpadas de maior potência).

As lâmpadas de vapor de sódio, como outras lâmpadas de descargas, necessitam de um reator para limitação da intensidade de corrente no tubo de arco e que forneça as tensões de ignição da ordem de $2 \mathrm{kV}$ a $5 \mathrm{kV}$. Elas apresentam duas particularidades que as diferem das demais lâmpadas de descarga:

- a tensão no tubo de descarga sobe de valor a razão de $1 \mathrm{~V}$ a $2 \mathrm{~V}$ para cada $1.000 \mathrm{~h}$ de operação, até que a tensão instantânea necessária para o seu reacendimento aproxime-se do valor instantâneo da tensão da rede. A partir de então não existirá mais estabilidade do arco elétrico e a lâmpada não se mantém em operação.

- Possuem uma tensão de arco positiva, então, para cada aumento de corrente no arco teremos o correspondente aumento na sua tensão e na sua potência.

As lâmpadas devem funcionar de maneira estável dentro de limites de potência e de tensão de arco, representados por um trapézio (conforme mostrado na Figura 15), mantendo sua curva característica próxima do seu ponto ótimo de operação. 
Os limites extremos indicados pelas linhas de tensão máxima e mínima delimitam a máxima variação de tensão admitida pela lâmpada durante sua vida útil.

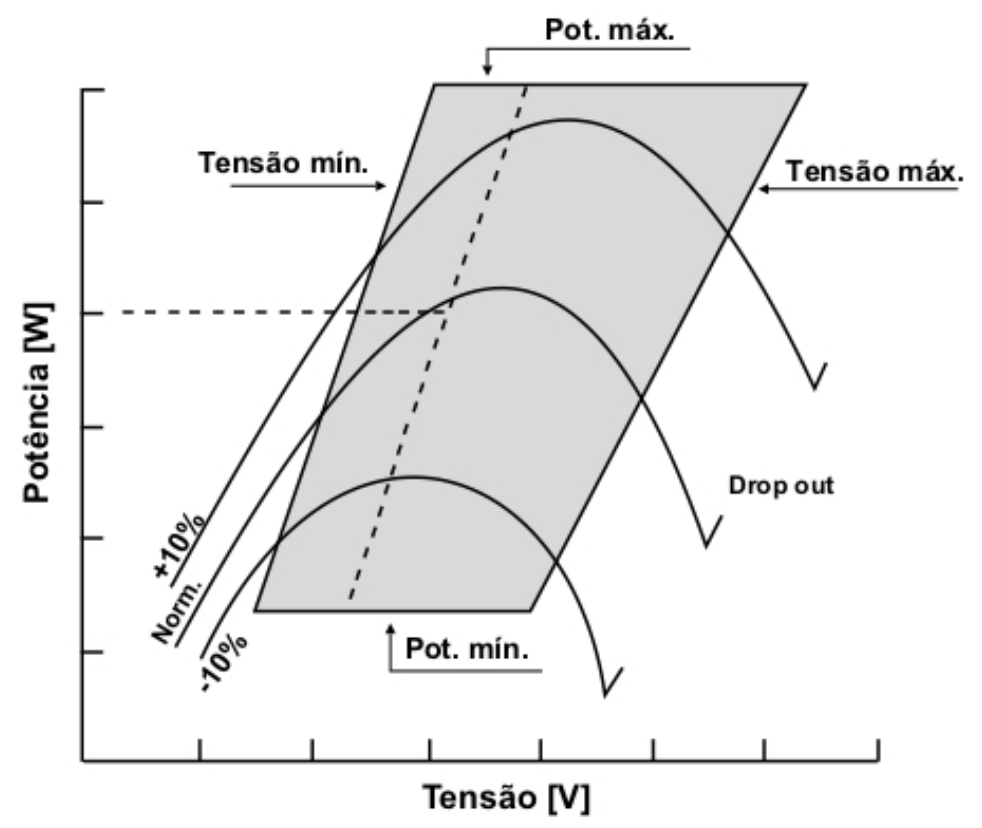

Figura 15 - Curvas típicas de uma lâmpada de vapor de sódio de alta pressão [4].

O valor de potência máxima é definido pelo fabricante para proporcionar uma vida de depreciação razoável. Já o valor da potência mínima é definido como o menor valor justificável de potência a ser dissipada pela lâmpada.

Pequenas variações na tensão de alimentação podem levar a um aumento ou diminuição significativos na potência dissipada. Assim, variações maiores na tensão de alimentação sugerem a necessidade do uso de reatores estabilizadores, para que a potência nas lâmpadas não se torne excessiva e reduza sua vida útil.

\subsection{Lâmpadas fluorescentes}

As lâmpadas fluorescentes são lâmpadas de descarga a baixa pressão, podendo ter catodos quentes (com ou sem preaquecimento) ou catodos frios. Enquanto nas lâmpadas de vapor de mercúrio a temperatura e a pressão internas são 
reguladas de modo que a descarga elétrica produza diretamente a máxima emissão luminosa, nas lâmpadas fluorescentes procura-se obter o máximo de radiações ultravioleta $(253,7 \mathrm{~nm})$, que serão transformadas em luz visível pela camada fluorescente que recobre a parte interna do bulbo. A pressão ótima do vapor de mercúrio para essa aplicação é de aproximadamente $0,666 \mathrm{~Pa}\left(6,61 \times 10^{-6} \mathrm{~atm}\right)$, que se obtém com uma temperatura de $40^{\circ} \mathrm{C}$ no bulbo.

\subsubsection{Lâmpadas fluorescentes de catodo quente com preaquecimento}

Tais lâmpadas apresentam um longo tubo de vidro, em cujas extremidades localizam-se os eletrodos de tungstênio triplamente espiralados, recobertos com uma camada de óxidos emissores de elétrons (Figura 16). Durante o funcionamento, a temperatura dos filamentos atinge $950^{\circ} \mathrm{C}$, o que possibilita a correta emissão eletrônica. A composição espectral do fluxo luminoso depende da natureza da camada fluorescente da parte interna do bulbo. O meio interno é uma atmosfera de gás argônio com uma pequena quantidade de mercúrio que será vaporizada no momento da partida. A intensidade da corrente de arco também deve ser estabilizada por um reator.

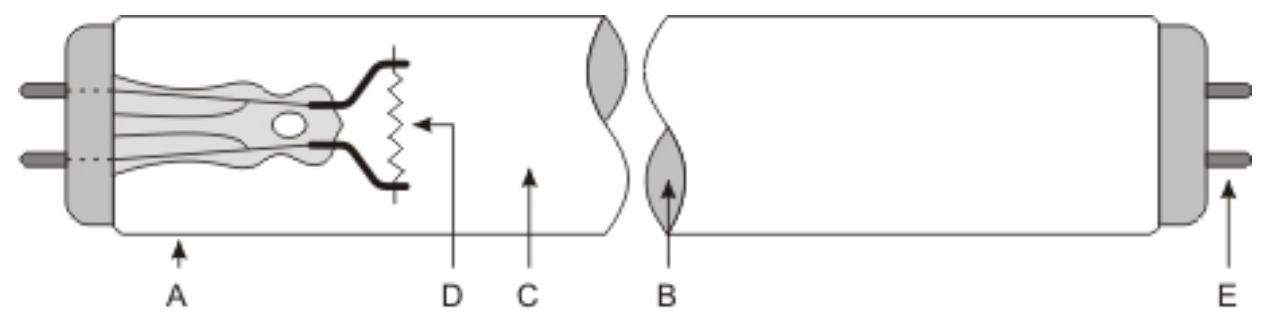

Figura 16 - Partes básicas de uma lâmpada fluorescente.

$A$ : tubo de vidro; $B$ : camada fluorescente; $C$ : meio interno; $D$ : filamento de tungstênio recoberto com óxidos emissores de elétrons; $E$ : terminais externos [5]

Há basicamente dois circuitos de funcionamento para uma lâmpada fluorescente: o circuito convencional e o circuito de partida rápida. O circuito convencional está representado na Figura 17. Ele é composto essencialmente de lâmpada, reator e dispositivo de partida. 


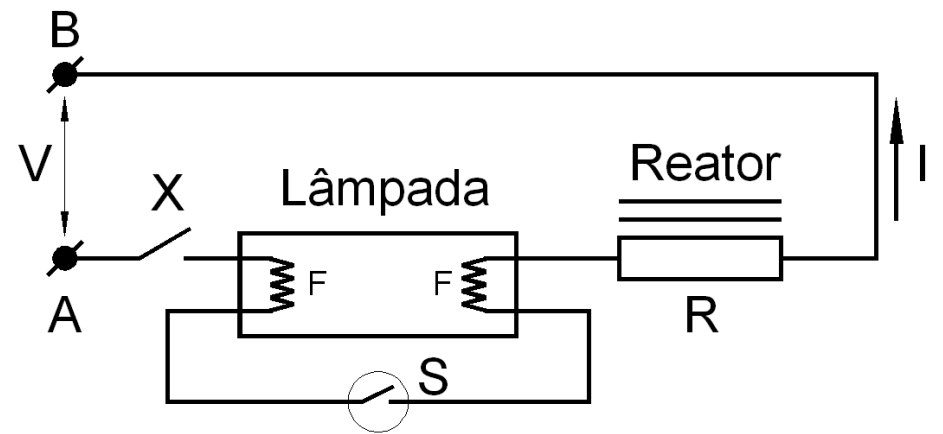

Figura 17 - Circuito básico de funcionamento de uma lâmpada fluorescente.

$A, B$ : Rede elétrica; F: Filamentos; R: Reator fluorescente; S: Starter; X: Interruptor [5]

Quando se fecha o circuito ao acionar o interruptor $(X)$ e o dispositivo de partida $(S)$ passa a funcionar, a corrente elétrica fluirá através do circuito, aquecendo os eletrodos que emitirão elétrons. Se o dispositivo de partida é desligado, produz-se uma variação de corrente elétrica que será responsável pela geração de uma tensão elevada de auto-indução na indutância do reator, o que provocará a formação de um arco elétrico entre os eletrodos. A partir deste instante, o reator continuará a funcionar como um estabilizador da intensidade da corrente na lâmpada, em valores projetados.

Normalmente utiliza-se um dispositivo de partida $(S)$ de funcionamento automático, comumente denominado starter. O tipo mais comum (Figura 18) consiste em um pequeno bulbo de vidro em cujo interior há gás argônio ou neônio e dois eletrodos, sendo um fixo e o outro uma lâmina bimetálica recurvada. O bulbo é envolto por uma capa cilíndrica de proteção e ligado a dois terminais externos. 

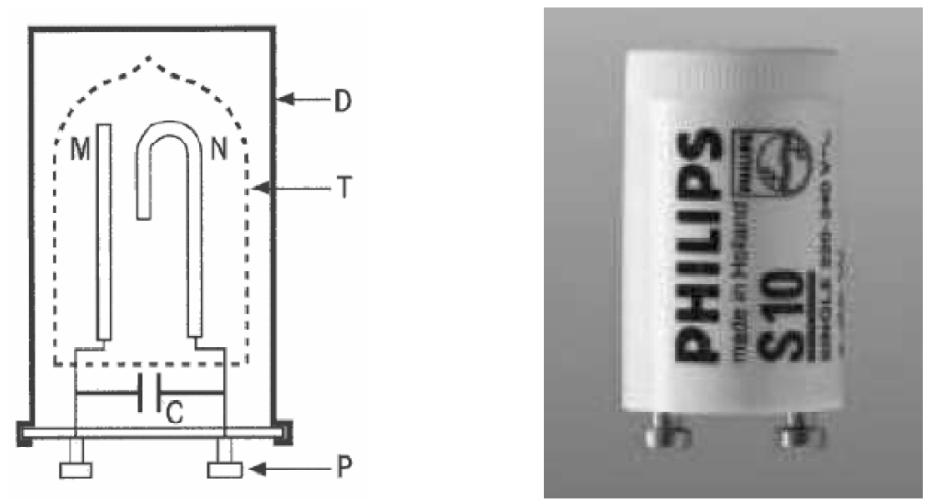

Figura 18 - Dispositivo de partida (starter) para lâmpadas fluorescentes [4] $C$ : Capacitor; $D$ : Capa cilíndrica de proteção; $M$ : Eletrodo fixo; $N$ : Lâmina bimetálica recurvada; $P$ : Terminais; $T$ : Bulbo de vidro.

Quando se aciona o interruptor $(X)$, da Figura 17, a tensão da rede elétrica de alimentação é suficiente para produzir um arco elétrico entre os dois eletrodos $(M$ e $N)$ do starter. O calor gerado nesta descarga faz a lâmina bimetálica distender e, assim, estabelece-se um contato elétrico entre $M$ e $N$, fechando o circuito, que fornece a corrente de preaquecimento dos catodos $(F)$ da lâmpada.

Como, neste momento, não há arco elétrico entre os eletrodos $M \mathrm{e}$ $N$ do dispositivo de partida, a lâmina bimetálica se resfria e volta a posição original, interrompendo a corrente elétrica no circuito de partida, o que provoca aquela tensão na indutância do reator, mencionada anteriormente. Este surto de tensão é suficiente para a partida da lâmpada, o que é facilitado pela anterior emissão eletrônica entre os eletrodos (F) durante o período de preaquecimento.

Na operação em regime permanente, a corrente flui através do tubo de descarga da lâmpada e não há tensão suficiente entre os eletrodos $M$ e $N$ para ionizar o starter, que permanecerá inativo. O capacitor $(C)$, na Figura 18, tem a finalidade de diminuir a interferência da lâmpada sobre os aparelhos eletrônicos nas proximidades durante o instante da partida. 
O circuito de partida rápida (Figura 19) apresenta as seguintes diferenças fundamentais em relação ao circuito anterior: não possui starter e necessita de um reator com desenho especial. Este tipo de circuito exige que o reator funcione no período de partida (em torno de 2s) como um autotransformador que eleva a tensão da rede elétrica aos valores necessários para iniciar um arco elétrico no interior do bulbo. Além disso, fornece aos catodos da lâmpada sua corrente de preaquecimento.

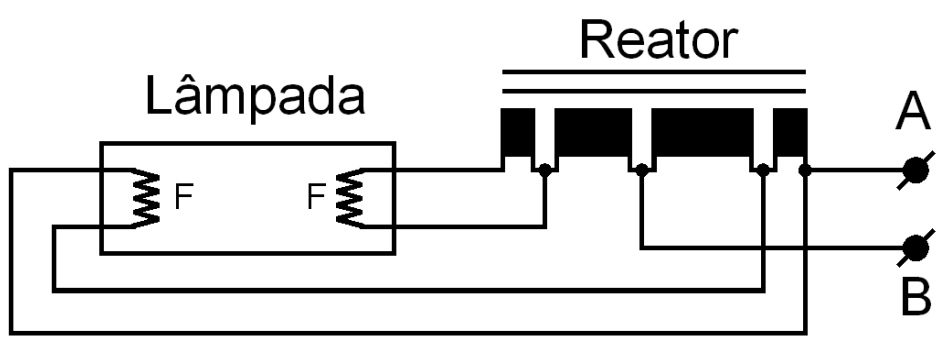

Figura 19 - Circuito de partida rápida para lâmpadas fluorescentes [5].

\subsubsection{Lâmpadas fluorescentes de catodo quente sem preaquecimento}

As lâmpadas fluorescentes de catodo quente sem preaquecimento diferem, construtivamente, das com preaquecimento unicamente pela construção dos catodos (Figura 20). Dispensam o uso de dispositivos de partida, ao utilizar reatores especiais capazes de gerar uma elevada tensão transitória de partida, para dar início à emissão eletrônica sem preaquecimento. Como não há circuito de preaquecimento, a partida é instantânea e sua base é uma conexão de um único pino.
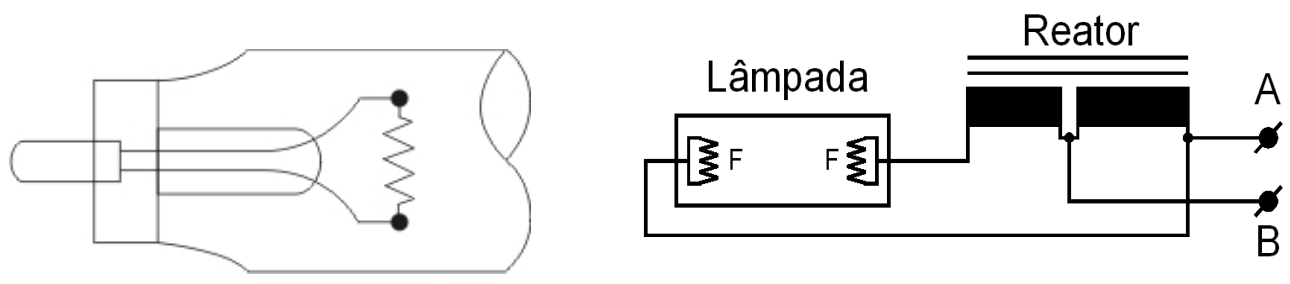

Figura 20 - Lâmpada fluorescente de catodo quente sem preaquecimento [5].

Como a tensão de partida é elevada (em torno de 3 vezes a tensão nominal da rede para lâmpadas de $40 \mathrm{~W}$ ), geralmente os tubos continuam a trabalhar, 
mesmo depois de seus catodos estarem com seu material emissor de elétrons esgotado (fim da vida normal da lâmpada). Neste caso, observam-se um forte comportamento em espiral do arco elétrico interno, flashes amarelados no tubo e enegrecimento de uma ou de ambas as extremidades.

\subsubsection{Lâmpadas fluorescentes de catodo frio}

O catodo das lâmpadas fluorescentes de catodo frio consiste de um cilindro de ferro ( $C$, na Figura 21$)$ de amplas dimensões, o que proporciona longa vida às lâmpadas. A temperatura de operação deste eletrodo é em torno de $150^{\circ} \mathrm{C}$.
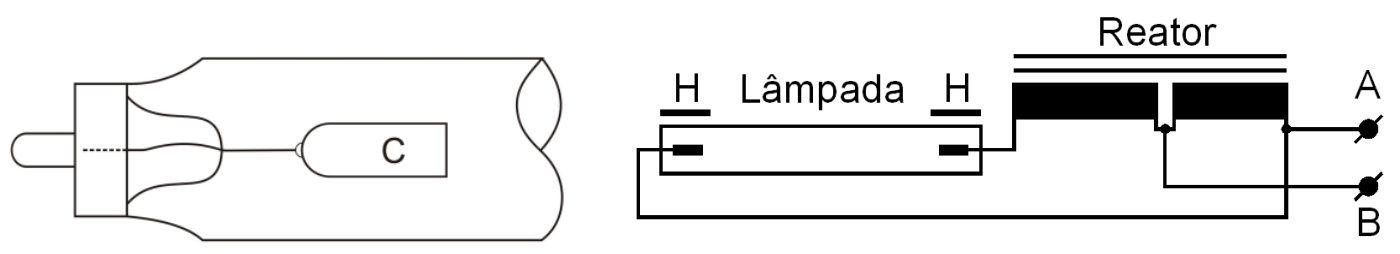

Figura 21 - Circuito de operação de uma lâmpada fluorescente de catodo frio $C$ : Catodo; $H$ : Anteparo de cobertura para os catodos [5].

Por apresentarem eletrodos com maiores dimensões, elas têm um comprimento de bulbo não-produtor de luz e, por isso, estas lâmpadas possuem, por motivo estético, um anteparo $(H)$ que recobre suas extremidades. A tensão necessária para partida, que se dá por diferença de campo elétrico, é da ordem de cinco vezes a de operação em regime permanente, o que obriga o uso de reatores de alta indutância (baixo fator de potência) e um ótimo isolamento dos componentes elétricos do circuito.

Sua emitância luminosa $\left(\mathrm{lm} / \mathrm{m}^{2}\right)$ é aproximadamente a metade das de catodo quente, e por isso apresentam aproximadamente o dobro do comprimento das de catodo quente, o que obriga o uso de luminárias maiores e mais caras.

Suas grandes vantagens são: longa vida útil (em torno de 25.000h) e a partida instantânea. Por essas razões são dispositivos indicados para aplicações em locais de difícil acesso e manutenção. 


\subsubsection{Lâmpadas fluorescentes modernas}

Por vários anos, as lâmpadas fluorescente de catodo quente de 15 , 20, 30, 40, 65 e 110W, nas tonalidades "luz do dia" e "branca fria", diâmetros T10 (33mm) e T12 (38mm), eram praticamente as únicas utilizadas no Brasil.

A grande revolução das lâmpadas fluorescentes ao longo dos anos ficou por conta da redução do seu diâmetro para T8 $(26 \mathrm{~mm})$ e T5 (16mm), que se deu com a maior possibilidade de desenvolvimento ótico dos refletores de alumínio de alto brilho das luminárias, e do aperfeiçoamento dos sais fluorescentes (trifósforos de elevada eficiência na transformação da luz ultravioleta em luz visível).

Atualmente, o desenvolvimento das lâmpadas fluorescentes está focado na compactação, no aumento da eficiência energética (chegando até $100 \mathrm{~lm} / \mathrm{W}$ ), na melhoria do índice de reprodução das cores e na possibilidade de uso intensivo de reatores eletrônicos de alta frequência (com baixas perdas, sem ruído e efeito estroboscópico nulo).

Toda a evolução teve duas finalidades básicas:

- produzir lâmpadas de alta eficiência para substituir as fluorescentes tradicionais.

- produzir lâmpadas fluorescentes, de baixa potência (de 7 a 25W), para substituir as lâmpadas incandescentes de até $150 \mathrm{~W}$.

Estas novas lâmpadas fluorescentes possuem bulbos T5 com diâmetro de $16 \mathrm{~mm}$ dobrados várias vezes para torná-las compactas. O starter está embutido em suas bases e várias delas possuem reatores eletrônicos incorporados, o que possibilita uma substituição direta das incandescentes.

Como são fabricadas com trifósforos de diferentes temperaturas de cor (em torno de $5.000 \mathrm{~K}, 4.000 \mathrm{~K}$ e $2.800 \mathrm{~K}$ ), permitem sua correta integração às cores dos ambientes. Com sua utilização, além da grande economia da energia elétrica (da ordem de 
50 a $80 \%$ ), consegue-se minimizar a manutenção, pois sua vida é de aproximadamente 10 vezes superior a das lâmpadas incandescentes em geral.

\subsection{Caracterização de lâmpadas de descarga de baixa pressão}

$\mathrm{O}$ estudo de dispositivos baseados em arcos elétricos remonta às primeiras aplicações comerciais da energia elétrica, uma vez que as primeiras experiências em distribuição da energia visavam justamente fornecer energia aos sistemas de iluminação de vias públicas.

O foco destes estudos, todavia, tem sofrido alterações ao longo da história, em decorrência da crescente preocupação com a qualidade da energia. Nos primórdios o conjunto lâmpada-reator era representado apenas por sua característica resistivo-indutiva. A preocupação maior nestes tempos era o baixo fator de potência do conjunto, que limitava a potência disponível e introduzia um significativo aumento nas perdas do sistema elétrico.

Atualmente a preocupação com a preservação da qualidade da energia tornou relevante o distúrbio que a não-linearidade das lâmpadas de descarga introduz no sistema elétrico, tanto em regime permanente quanto durante os transitórios.

Um modelo geral de lâmpadas fluorescentes foi proposto por Mäder e Horn [6], baseado na característica de resistência com coeficiente negativo de temperatura (Negative Thermic Coefficient - NTC) apresentado pela coluna de plasma existente na operação em regime permanente. Neste trabalho é destacada a diferença fundamental entre um resistor tipo NTC e o arco sustentado pela lâmpada fluorescente, que consiste basicamente nas constantes de tempo envolvidas.

Foram abordados os modelos de arco com resistência linear e o modelo cúbico de resistência de arco, com parametrização obtida por análise de operação 
da lâmpada fluorescente. A implementação dos modelos foi realizada no software PSpice através do conjunto de equações que reproduziam as curvas V-I do dispositivo, operando em regime permanente e considerando várias condições de tensão e frequência de alimentação.

A Figura 22 apresenta um conjunto de curvas utilizado como parâmetro de operação de um conjunto reator ressonante-lâmpada fluorescente HO de $80 \mathrm{~W}$, alimentada em rede de $220 \mathrm{~V} / 60 \mathrm{~Hz}$.

Através do modelo cúbico proposto, o autor obteve o conjunto de curvas apresentado na Figura 23, que mostrou grande similaridade com os dados de operação coletados. Neste caso, as simulações obtidas no PSpice demonstraram também que a reprodução do conteúdo harmônico em muito se assemelhava à característica real de operação da lâmpada.

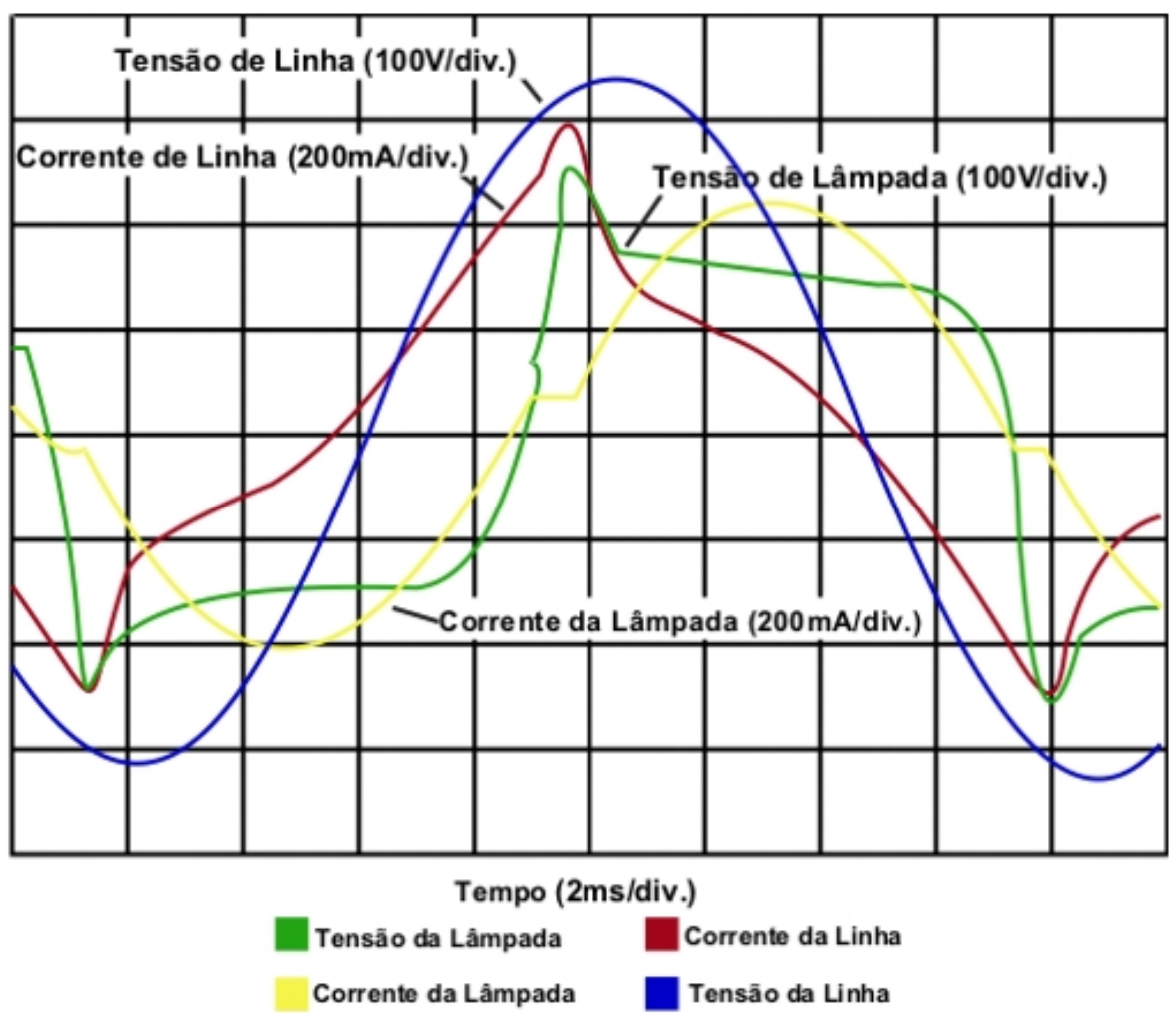

Figura 22 - Conjunto reator ressonante+lâmpada - dados de operação [6] 


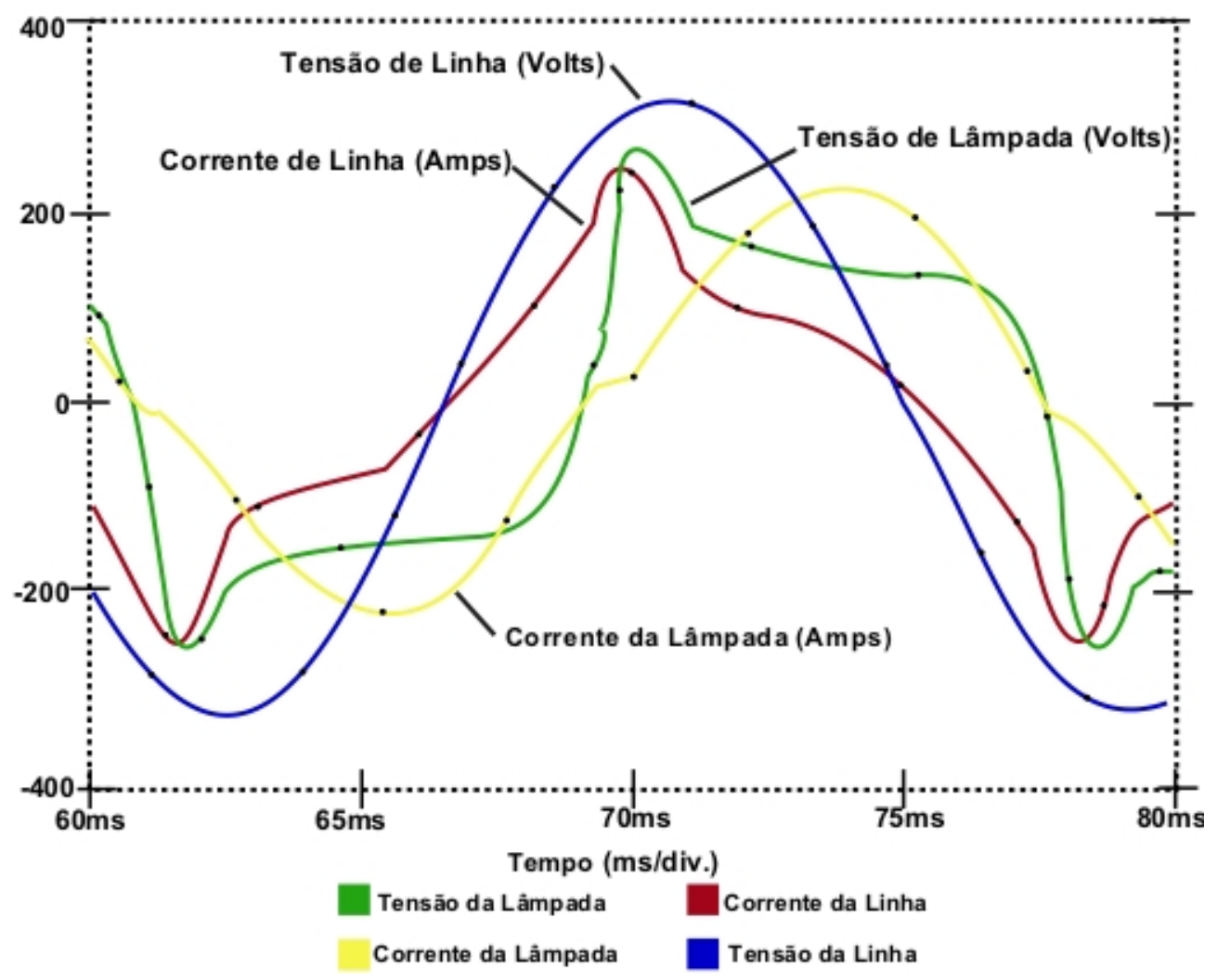

Figura 23 - Conjunto reator ressonante + lâmpada - dados de simulação [6]

O comportamento geral do modelo obtido também demonstra sua utilidade como descritor do elemento inserido em circuitos elétricos e no desenvolvimento de reatores operando em frequências fixas. Destaca o autor, no entanto, que várias melhorias devem ser inseridas no modelo, como a caracterização de respostas dinâmicas da operação em uma ampla faixa de frequências.

Com o objetivo de caracterizar a operação de lâmpadas fluorescentes em altas frequências, Hu, Hung e Yu desenvolveram um aperfeiçoamento do modelo de resistência do arco capaz de representar a região de resistência negativa de operação em alta frequência [7]. As curvas características foram obtidas através dos dados de tensão e corrente no dispositivo real operando em diversas potências.

O dispositivo foi representado através do software PSpice pelo modelo mostrado na Figura 24, composto por um arranjo de fontes dependentes e 
resistências cuja resposta em regime permanente se aproxima à de uma coluna de plasma de uma lâmpada fluorescente operando em altas frequências.

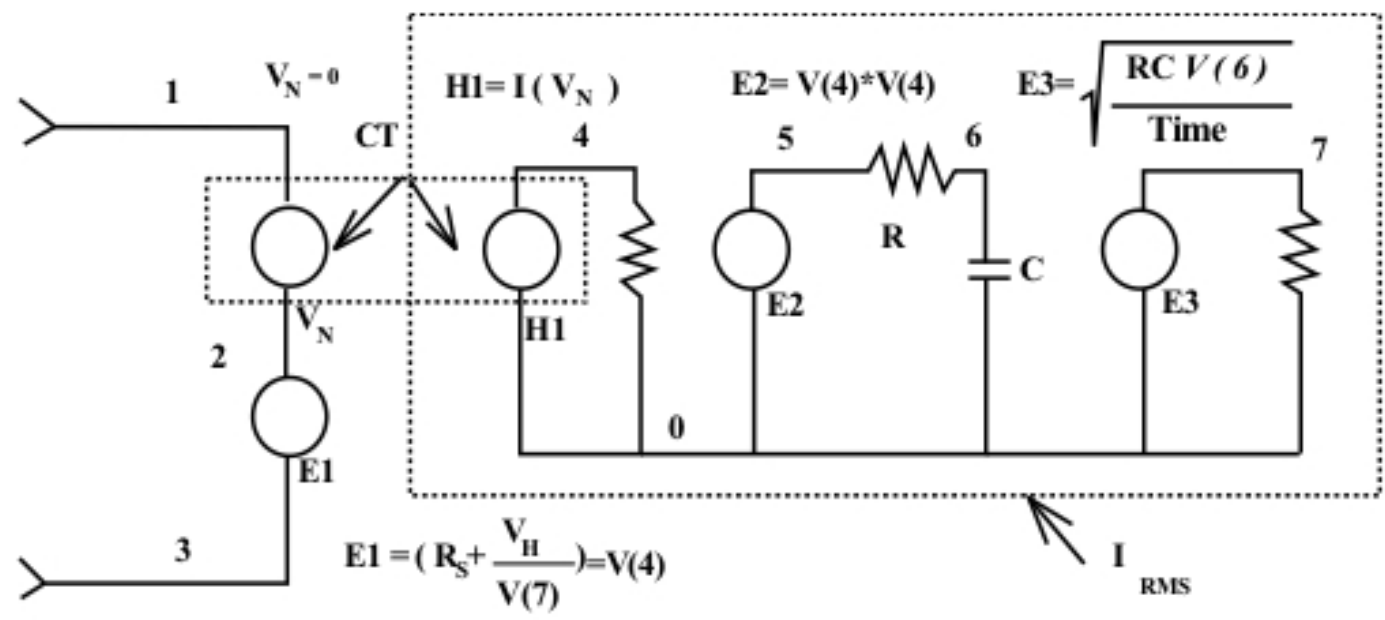

Figura 24 - Modelo de Lâmpada Fluorescente [7]

As curvas de operação de uma lâmpada fluorescente OSRAM modelo FO 32W/741K TS em diversos pontos de operação, utilizadas no levantamento dos coeficientes empregados no modelo, estão representadas na Figura 25. Após o ajuste de coeficientes, o modelo forneceu como resposta o conjunto de curvas representado na Figura 26, demonstrando similaridade entre os comportamentos simulado e real.

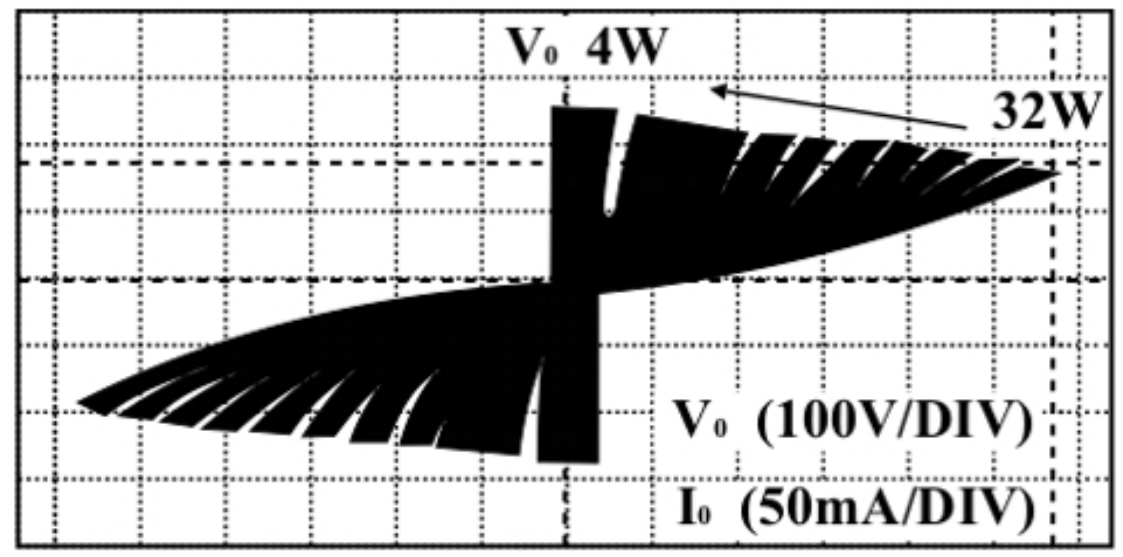

Figura 25 - Característica tensão-corrente de lâmpada fluorescente para várias potências de operação - valores medidos [7] 


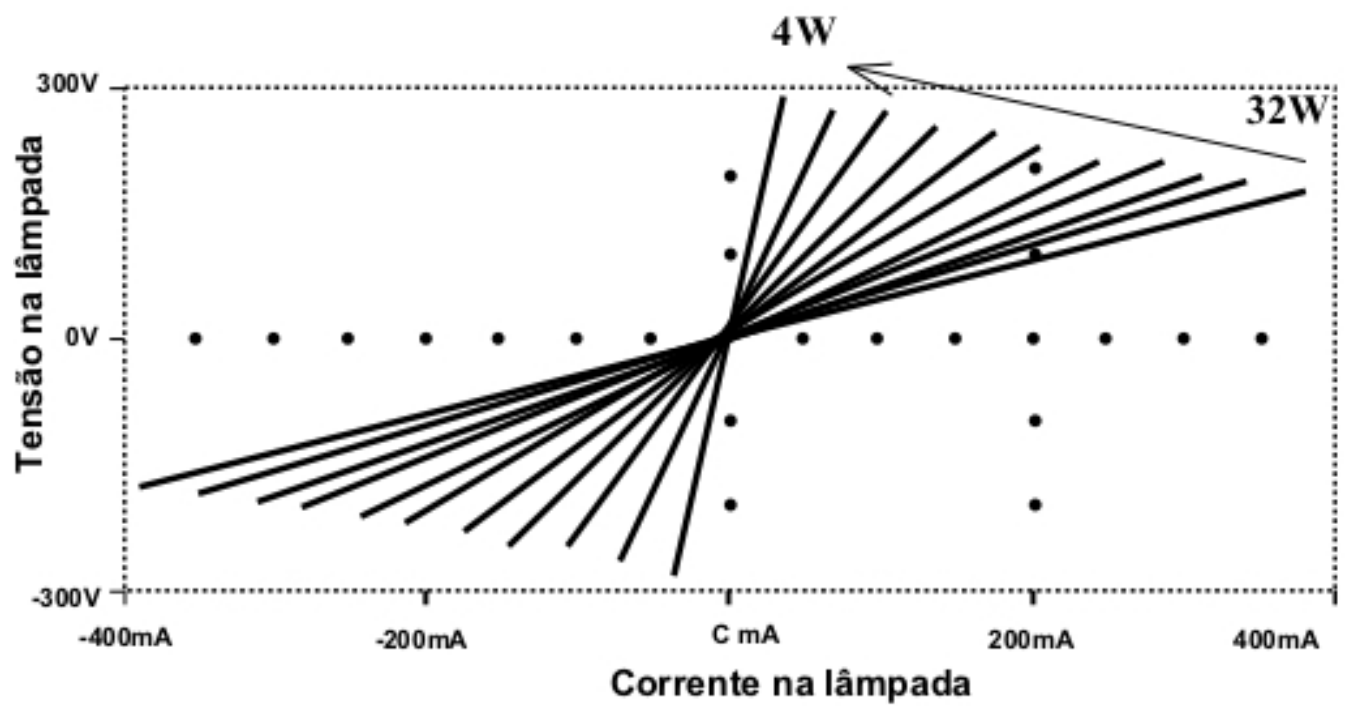

Figura 26 - Característica Tensão-Corrente de Lâmpada Fluorescente para várias Potências de Operação - Valores Simulados [7]

Conforme os autores, este modelo, quando empregado em simulações de reatores eletrônicos em sua fase de desenvolvimento, apresentou resposta satisfatória na representação do dispositivo.

Através de incrementos nos algoritmos para aproximação cúbica da curva de operação propostos em [6], Sun e Hesterman obtiveram um modelo particularizado de lâmpadas fluorescentes operando em altas frequências empregando o PSpice, partindo das curvas experimentais V-I da lâmpada em várias potências de operação [8]. Uma vez determinado o modelo, os resultados mostraram uma excelente aproximação entre os parâmetros operacionais e o comportamento simulado.

A Figura 27 exibe o comportamento de corrente e tensão da lâmpada operando sob alimentação de um reator eletrônico de alta frequência. Comparadas com as curvas da Figura 28, nota-se a grande proximidade entre os valores reais e os valores obtidos a partir do modelo. 


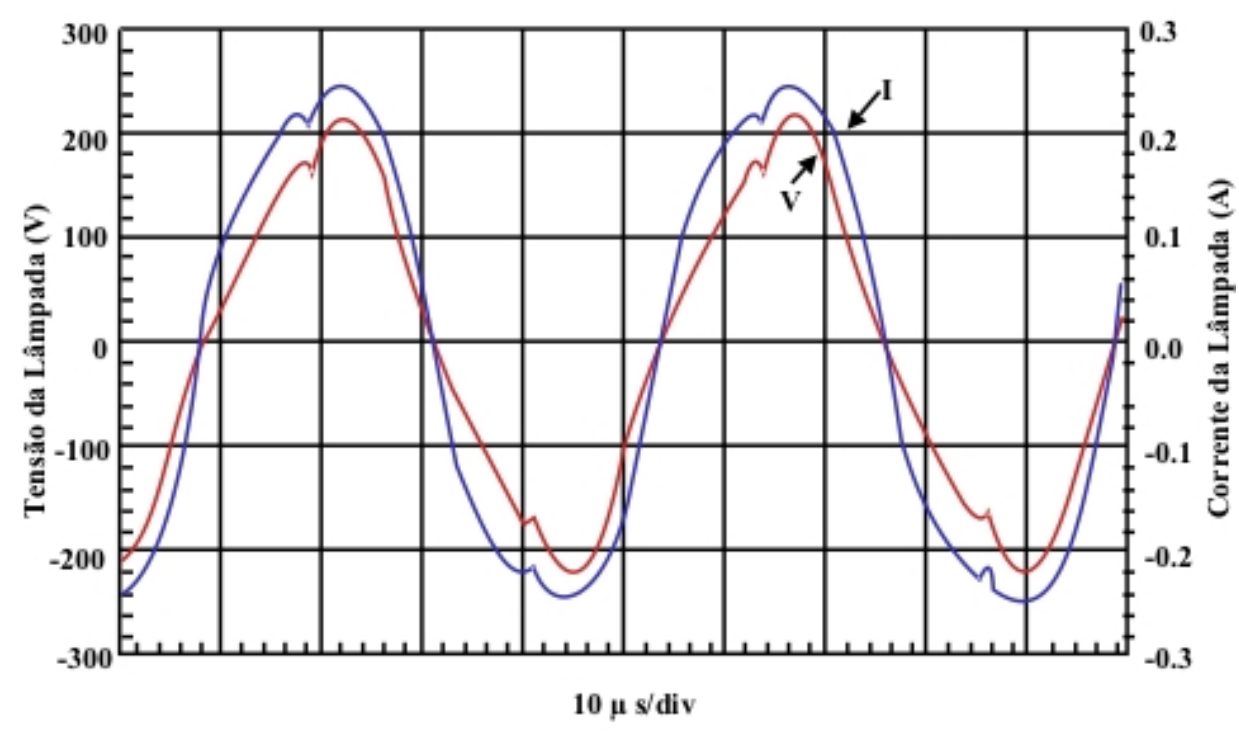

Figura 27 - Comportamento real da lâmpada fluorescente em alta frequência [8]

Com o objetivo de se obter um modelo bastante simplificado de lâmpada fluorescente, especificamente destinado ao desenvolvimento de reatores eletrônicos de alta frequência, Ribarich e Ribarich propuseram a aproximação da curva de operação do tubo de descarga através de uma equação quadrática [9].

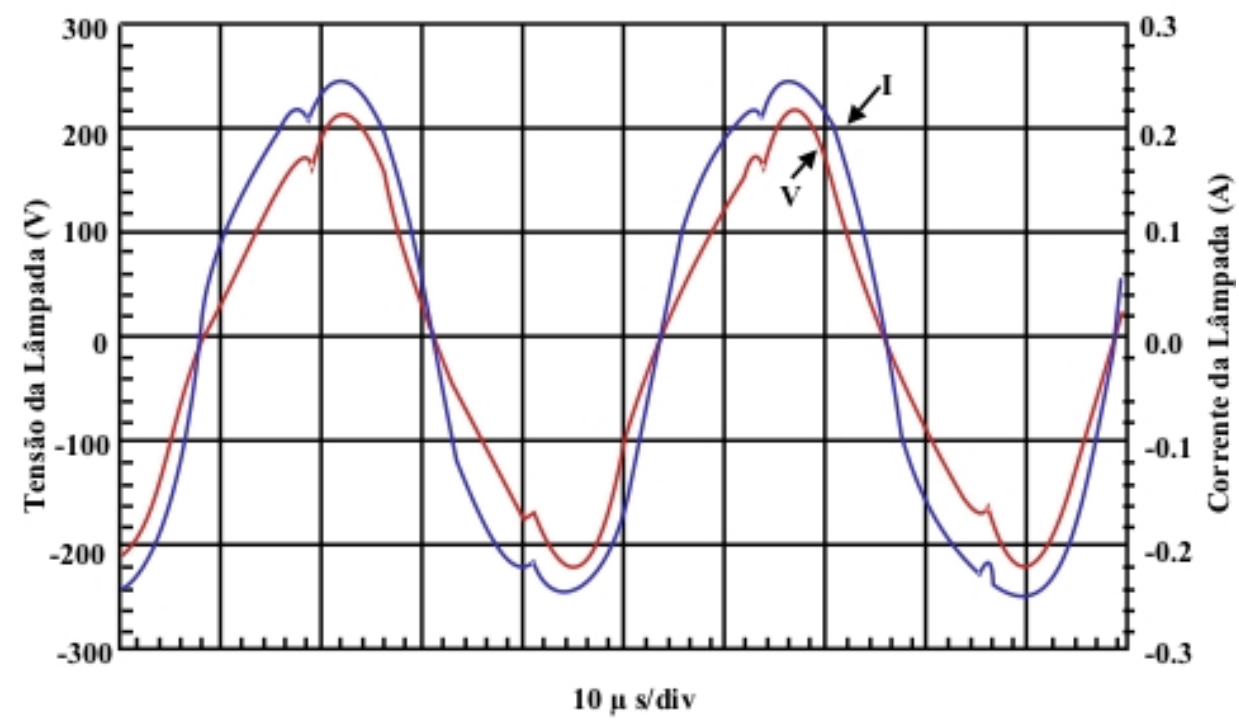

Figura 28 - Resposta do modelo de lâmpada fluorescente em alta frequência [8] 
Desta pesquisa resultou o modelo parabólico da lâmpada fluorescente, extremamente simplificado, porém com limitações que restringiam sua aplicação às operações em altas frequências, em regime permanente. A principal vantagem do modelo obtido foi justamente a facilidade de sua implementação em ferramentas computacionais destinadas ao projeto dos reatores eletrônicos.

O aparecimento de ferramentas computacionais alternativas para simulação de sistemas elétricos sempre despertou o interesse em pesquisadores no desenvolvimento de modelos para diversos dispositivos, criando por vezes bibliotecas que tornam populares os novos softwares.

Seguindo esta linha, Wuang e Kuo desenvolveram um modelo de lâmpada fluorescente derivado do modelo cúbico, com o objetivo de servir como ferramenta auxiliar no projeto de reatores eletrônicos de alta frequência, empregando para tal a ferramenta computacional EMTP (ElectroMagnetic Transient Program), combinada com os módulos TACS (Transient Analysis of Control Systems) e a linguagem de simulação MODELS [10].

Caracterizou-se o dispositivo inicialmente para operação com altas frequências, mas posteriormente foi possível comprovar que a resposta em frequência de rede também se mostrou satisfatória.

A comparação entre os gráficos da Figura 29, contendo os dados de operação, e os gráficos da Figura 30, mostrando os valores obtidos por simulação, indicam a validade do modelo implementado com a nova ferramenta, demonstrando esta ser uma alternativa viável ao uso do software PSpice. 


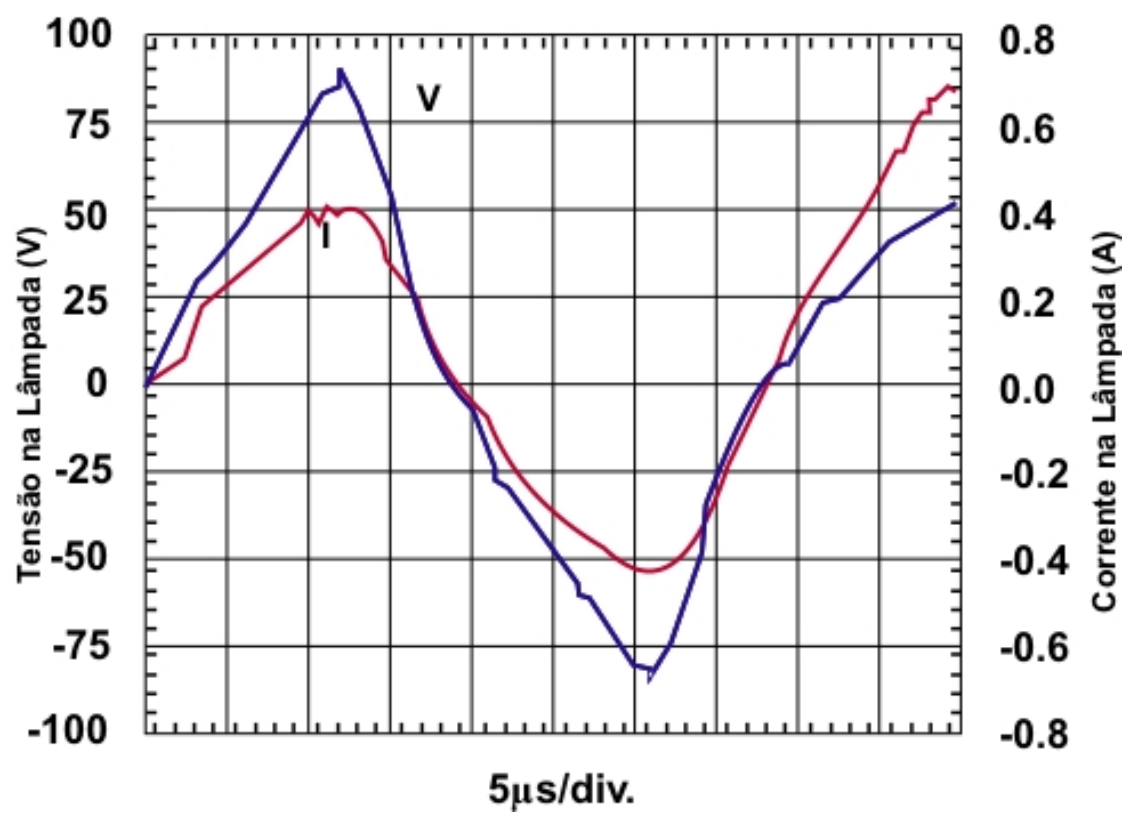

Figura 29 - Dados de operação - lâmpada fluorescente [10]

Os modelos até então apresentados consideravam em seu equacionamento os parâmetros elétricos do dispositivo, sem inserir nas formulações os efeitos termodinâmicos da operação da lâmpada de descarga. Em [11], Moo et al. apresentam o desenvolvimento de um modelo de lâmpada de descarga de baixa pressão baseado na variação da resistência equivalente do componente, inserindo o efeito da temperatura ambiente no equacionamento como forma de descrever os efeitos da variação de pressão no interior do tubo de descarga sobre a resistência da coluna de plasma.

Com uma montagem experimental apresentada na Figura 31, onde a lâmpada fluorescente ensaiada era mantida em ambiente com temperatura controlada, e mediante o emprego de um sistema de alimentação com tensão e frequência controlada, levantou-se as diversas curvas V-I necessárias à caracterização do dispositivo em toda a faixa de temperaturas de operação prevista. Neste experimento, foram monitoradas a corrente do reator da lâmpada $i_{r}$ e a tensão sobre a lâmpada $\mathrm{V}$. O valor $i_{f}$ indicado no diagrama representa a corrente de filamento presente no instante de acendimento do dispositivo. 


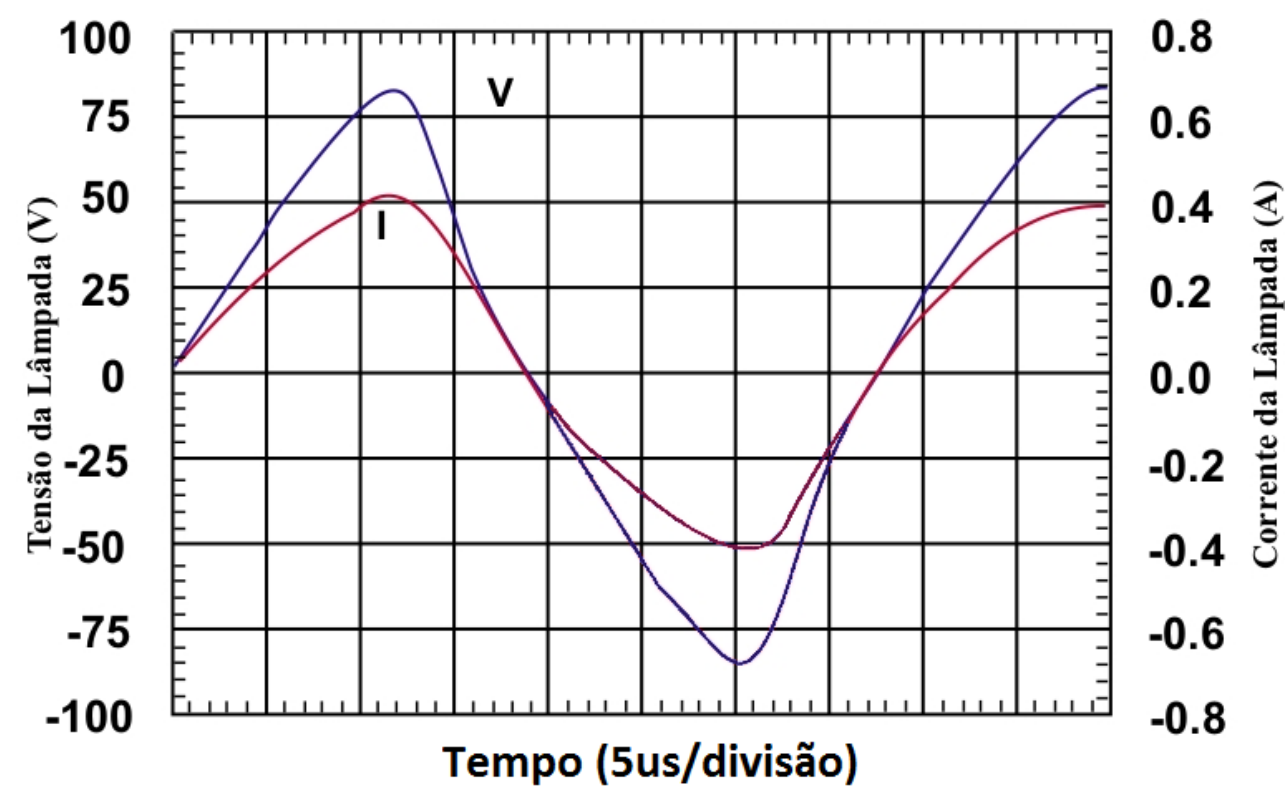

Figura 30 - Dados de simulação - lâmpada fluorescente [10]

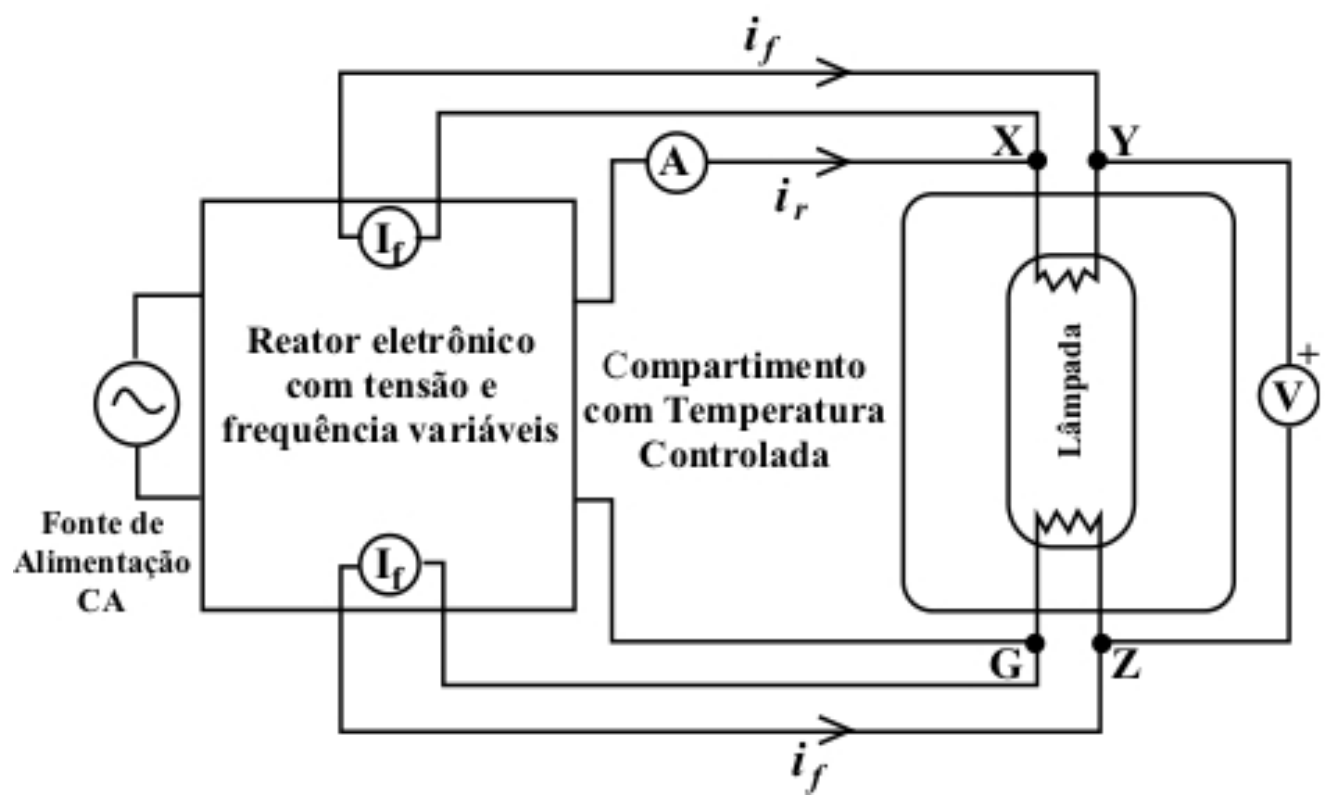

Figura 31 - Experimento para levantamento de dados de operação [11]

O circuito equivalente da lâmpada fluorescente empregado na construção do modelo é mostrado na Figura 32. Neste circuito, otimizado para a operação em altas frequências, o arco é caracterizado por uma resistência inserida entre os eletrodos 
da lâmpada, representados por suas resistências de filamento $r_{f}$. A capacitância $C_{f}$ presente em operações em elevadas frequências também é representada no modelo.

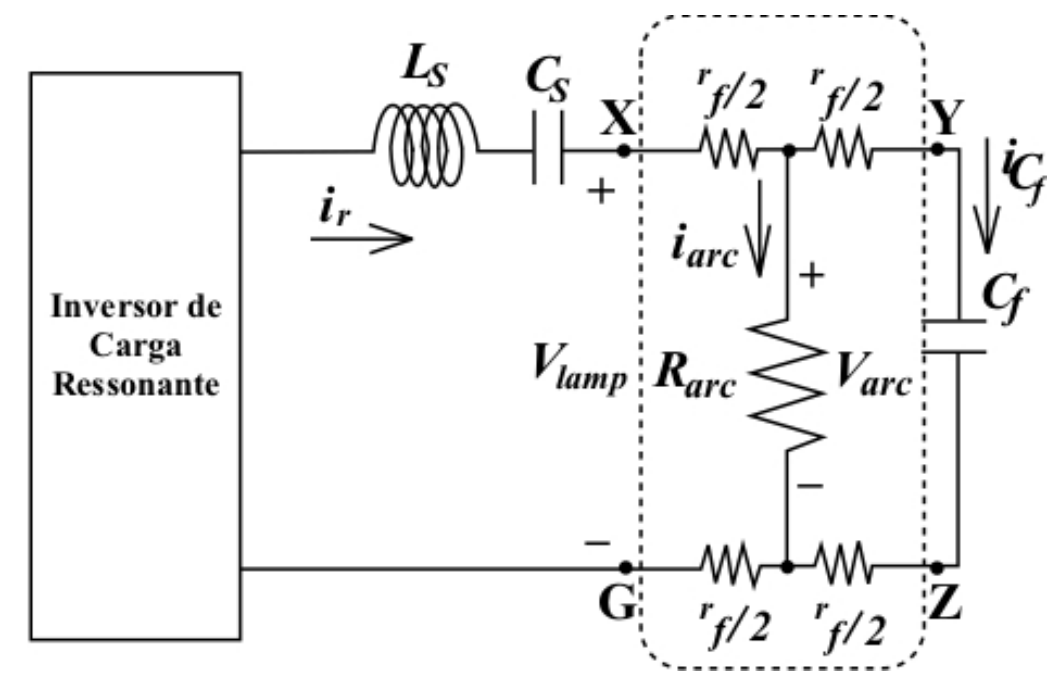

Figura 32 - Circuito equivalente da lâmpada fluorescente [11]

Os componentes $L_{s}$ e $C_{s}$ representam respectivamente a indutância série e a capacitância série equivalentes do circuito limitador de corrente empregado em conjunto com a lâmpada fluorescente. A corrente fornecida pelo reator é representada por $i_{r}$, a corrente através do arco é indicada no diagrama por $i_{a r c}$ e a corrente através do efeito de capacitância de alta frequência está representada por $i_{C f}$.

A coleta de dados permitiu a construção dos planos de operação da lâmpada em função da temperatura ambiente (Figura 33, Figura 34 e Figura 35). Torna-se nítida a influência da temperatura sobre a tensão no arco, resultante do aumento no valor da resistência da coluna de plasma com pico próximo à temperatura de $40^{\circ} \mathrm{C}$, como apresentado na Figura 33. Do mesmo modo, as operações com potência reduzida resultam em valores elevados de resistência de arco, proporcionando considerável crescimento na tensão do arco, que em situações extremas pode levar à extinção do mesmo. 


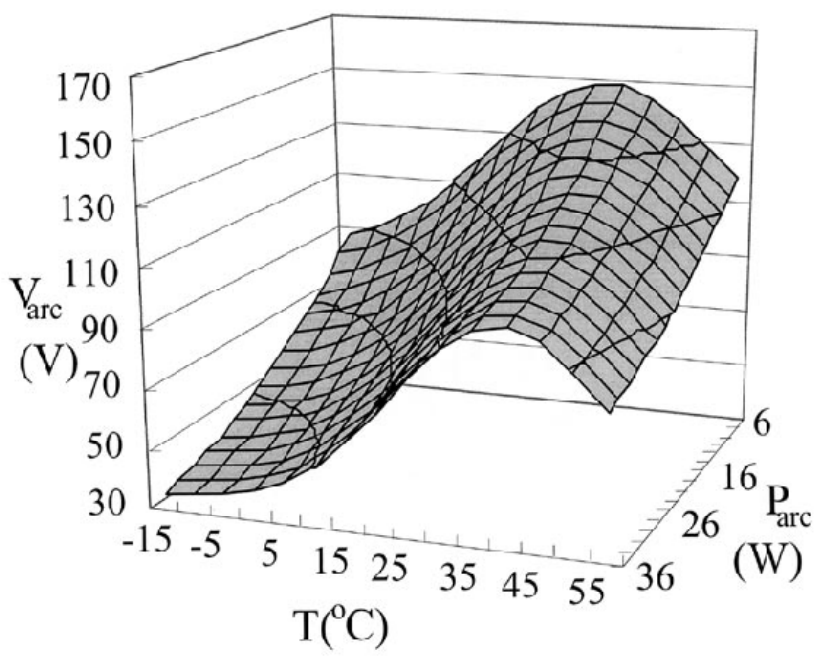

Figura 33 - Tensão e potência no arco em função da temperatura [11]

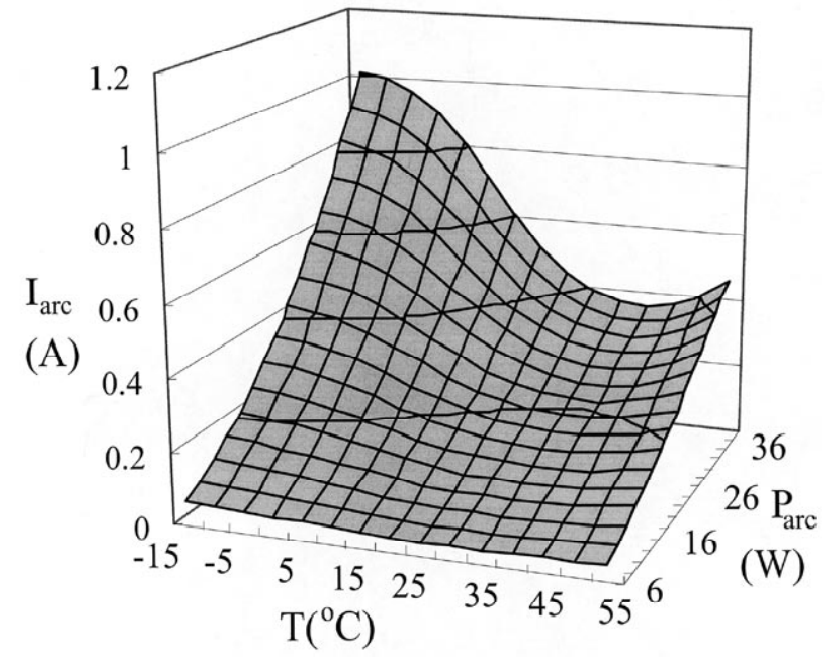

Figura 34 - Corrente e potência no arco em função da temperatura [11]

A obtenção dos mesmos perfis através do modelo demonstrou comportamento bastante próximo dos valores experimentais, comprovando a eficácia do método utilizado na caracterização do dispositivo.

A caracterização de lâmpadas de descarga se assemelha em muitos aspectos aos primitivos dispositivos baseados em arcos elétricos abertos (Figura 36), e por esta razão o equacionamento clássico estabelecido para estes fenômenos pode ser empregado. 


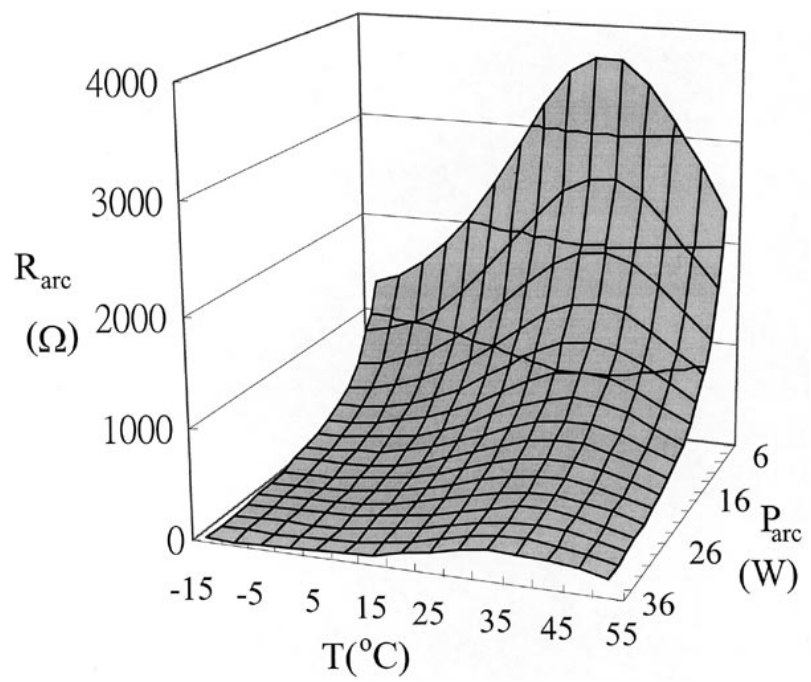

Figura 35 - R(arco) e P(arco) em função da temperatura [11]

Neste sentido, Emanuel e Orr realizaram um estudo sobre a caracterização do conteúdo harmônico presente em arcos elétricos de forma genérica, ressaltando a não-linearidade deste tipo de carga [12].
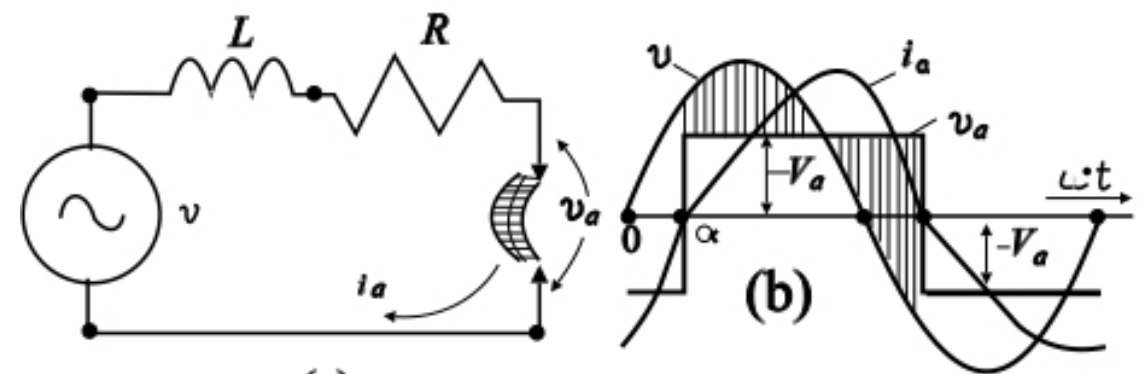

(a)

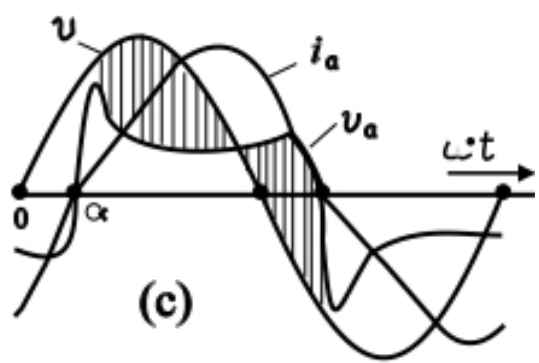

(a) Circuito equivalente (b) Efeito na corrente (c) Efeito na tensão Figura 36 - Representação dos efeitos do arco elétrico [12] 
Baseados no modelo estabelecido por $\mathrm{Mayr}^{2}$ (1943 apud [12]), os autores comparam a resposta do modelo com a idealização do arco elétrico, representado por um dispositivo limitador de tensão análogo a um diodo Zener ideal. A ferramenta empregada nas simulações foi o software PSpice.

A análise mostrou significativa diferença entre o conteúdo harmônico obtido pelo modelo de Mayr e pelo modelo com componentes ideais. O trabalho ainda indica que para os arcos operando na frequência da rede a distorção harmônica total mostrou-se mais proeminente que a obtida através do modelo ideal, tornando-se menor com o aumento na frequência do arco.

O projeto de reatores eletrônicos para lâmpadas fluorescentes operando em elevadas frequências levaram Cervi et al. ao desenvolvimento de um modelo de dispositivo para o software PSpice empregando métodos de aproximação tangencial para o ajuste dos coeficientes [13].

A validação do modelo demonstrou que sua resposta atendia aos principais requisitos de projeto de reatores, com grande facilidade de implementação matemática. A Figura 37 apresenta o comparativo entre as curvas experimentais (a) e as curvas obtidas pelo modelo implementado (b).

Em outra abordagem, Cervi et al. apresentam um novo estudo estabelecendo um modelo para a lâmpada baseado na aproximação exponencial da variação da resistência equivalente da coluna de plasma [14]. Destinado à modelagem de reatores eletrônicos utilizando o PSpice, este modelo apresentou consistência em operações na faixa de $50 \mathrm{kHz}$ em situações controladas de temperatura e potência desenvolvida no bulbo.

\footnotetext{
2 Mayr O. Contribution to the Theory of Static and Dynamic Electric Arc, Arch. fur Elektrotech, vo1.37, 1943, p.588-609.
} 


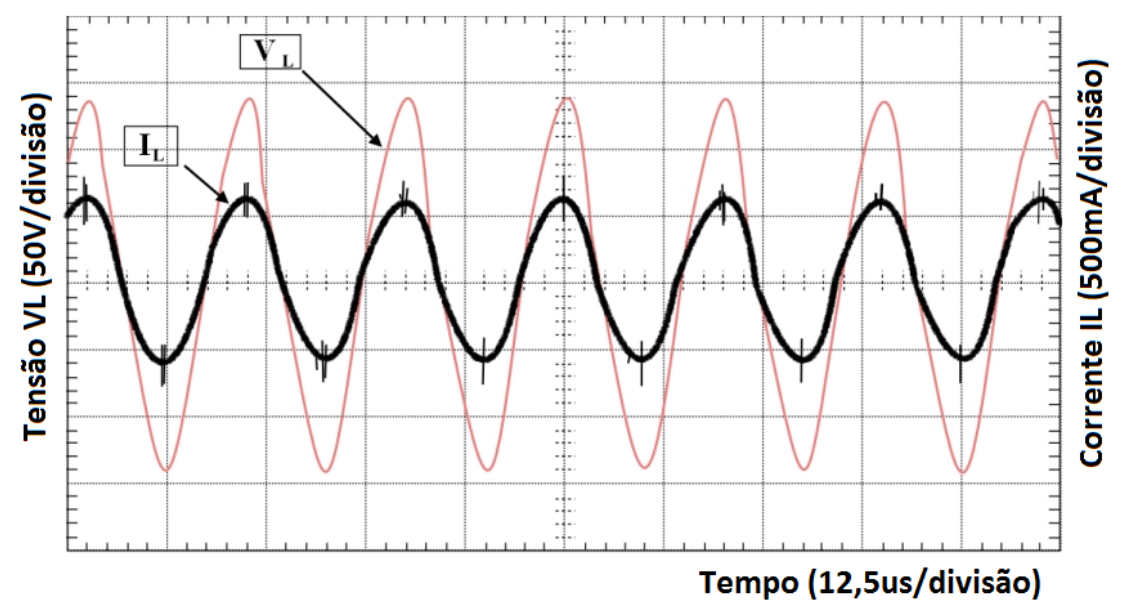

(a) Medição

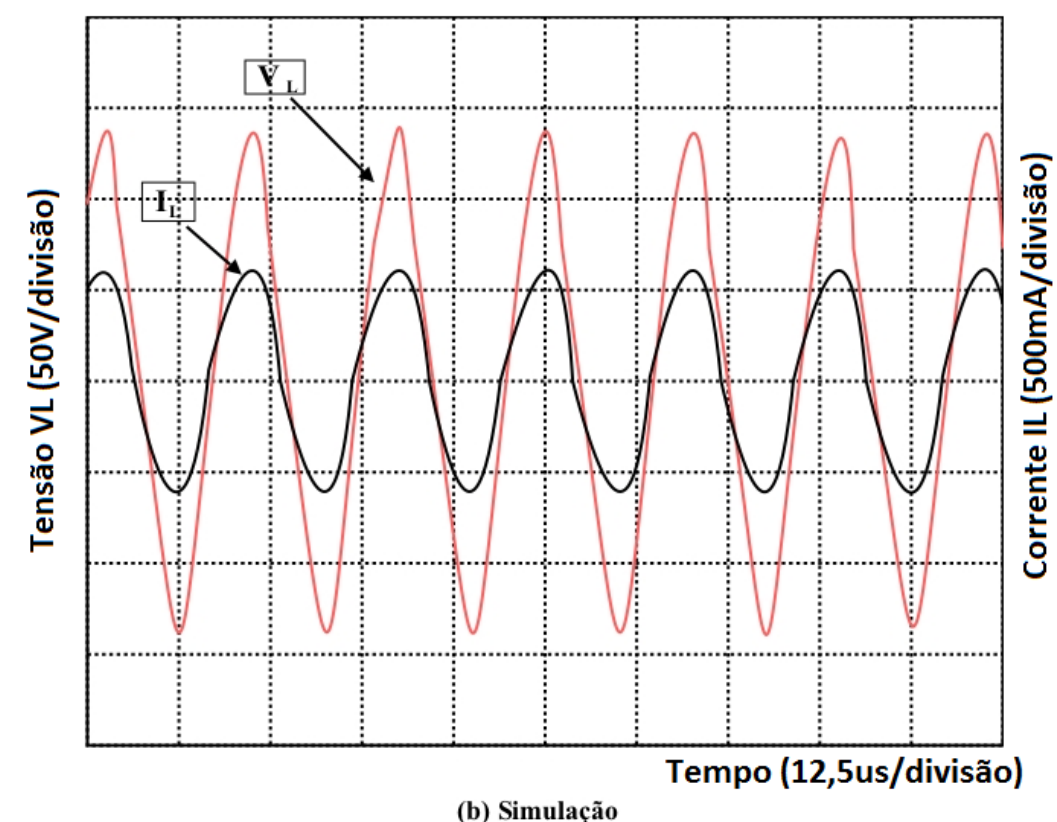

Figura 37 - Validação do modelo de lâmpada fluorescente [13]

Um modelo capaz de contemplar a fase de partida da lâmpada fluorescente operando em altas frequências foi descrito por Chen e Qian em [15]. Baseado na simplificação da curva V-I, o modelo foi construído e validado empregando-se a ferramenta $S A B E R$ e a linguagem $M A S T$ em sua descrição computacional.

A fase de partida obtida por este modelo está representada pela Figura 38. Nota-se a elevada tensão sobre o bulbo antes do estabelecimento do arco, que ocorre tão logo o gás se torna ionizado, nos primeiros ciclos de operação do dispositivo. 


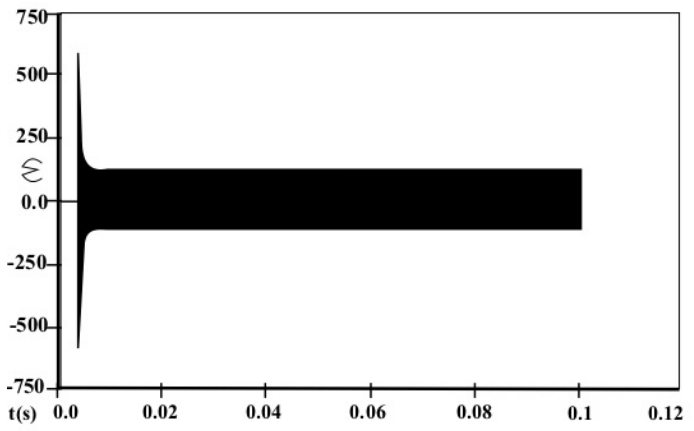

(a) Simulação

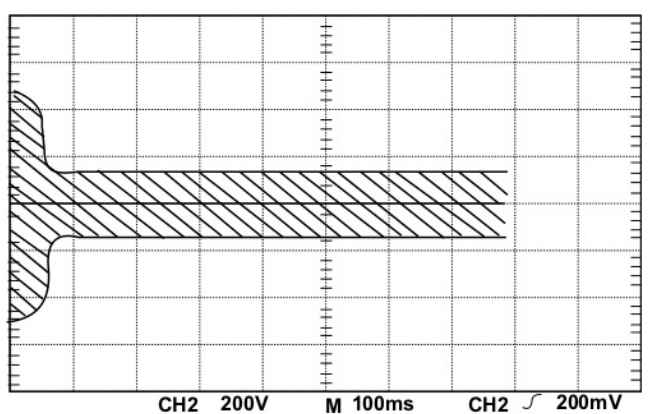

(b) Experimento

Figura 38 - Partida de lâmpada fluorescente [15]

Para a operação em regime de potência variável, através de aplicação de reatores controláveis de alta frequência, o modelo apresentado por Cardoso, Marques e Braga em [16] mostrou robustez e facilidade de implementação no software PSpice.

Os coeficientes do modelo foram obtidos por aproximações com curvas reais levantadas durante a operação da lâmpada em condições específicas de alimentação, e o resultado apresentou-se satisfatório na simulação de reatores eletrônicos controláveis. O diagrama do modelo implementado é mostrado na Figura 39.

Para demonstrar as variações que ocorrem no comportamento V-I do arco elétrico em função da variação na frequência, Perdigão e Saraiva propuseram um modelo resistivo de lâmpada de descarga de baixa pressão [17], baseado no modelo descrito em [6].

A construção deste modelo foi realizada no ambiente $M A T L A B \circledR$ SIMULINK®, e teve como principal objetivo a simulação de reatores eletrônicos com sistema incorporado de controle de intensidade da lâmpada.

Os resultados das simulações em altas e baixas frequências demonstraram um boa representação do dispositivo, como o exemplo da Figura 40, que apresenta a validação do modelo para operação em $50 \mathrm{~Hz}$. 
Wakabayashi et al. apresentam um modelo da lâmpada fluorescente baseado em resistências equivalentes [18], considerando os efeitos de operação com controle de potência, para aplicação no projeto e simulação de reatores eletrônicos controláveis. Com base no circuito equivalente apresentado na Figura 41, empregou-se técnicas de regressão linear para a determinação dos coeficientes do modelo, que foi implementado com o auxílio da ferramenta de simulação WAVESTAR®.
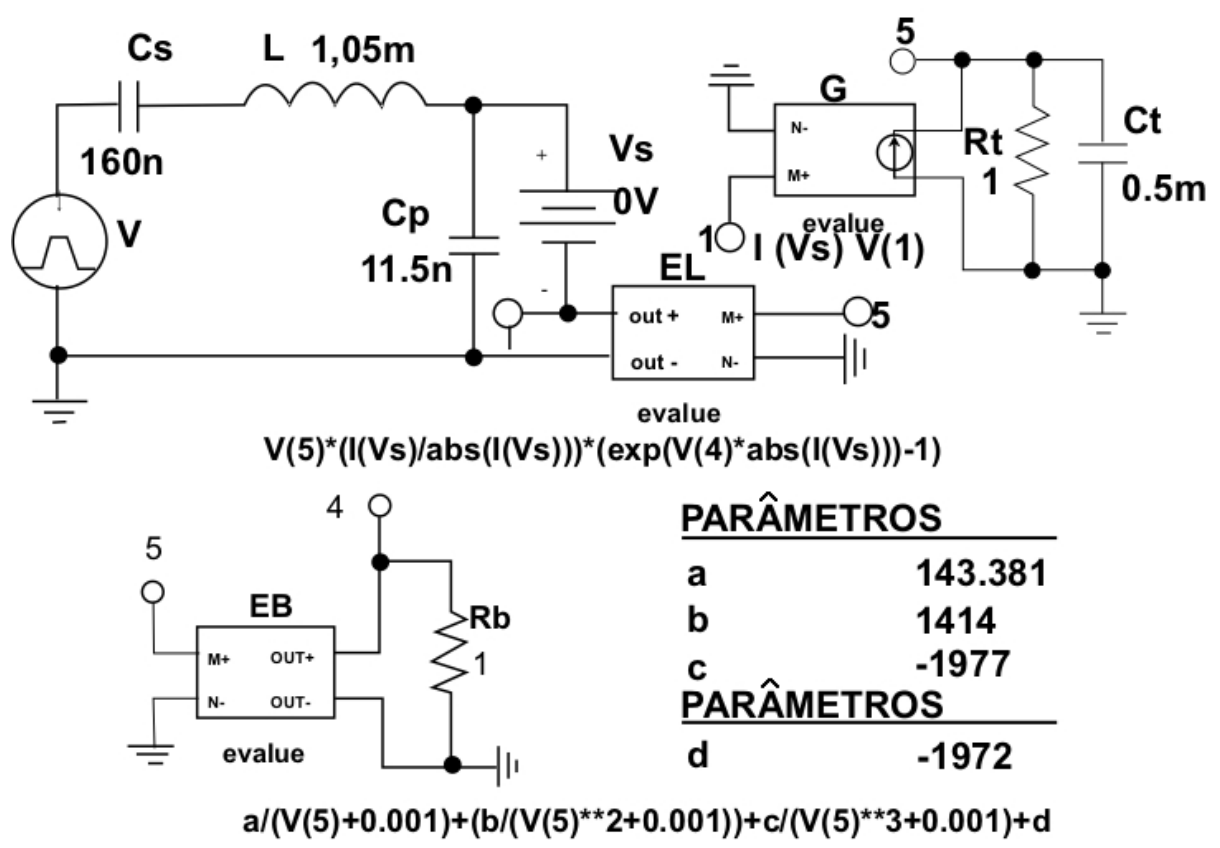

Figura 39 - Modelo por aproximação exponencial [16]

A simulação de reatores eletrônicos também foi o objetivo do trabalho descrito por Loo et al. em [19]. Empregando uma abordagem voltada aos aspectos físicos do dispositivo, implementou-se, com o auxílio das ferramentas de simulação SPICE, SABER e SIMULINK®, um modelo da lâmpada fluorescente baseado na condutância dinâmica do arco. 


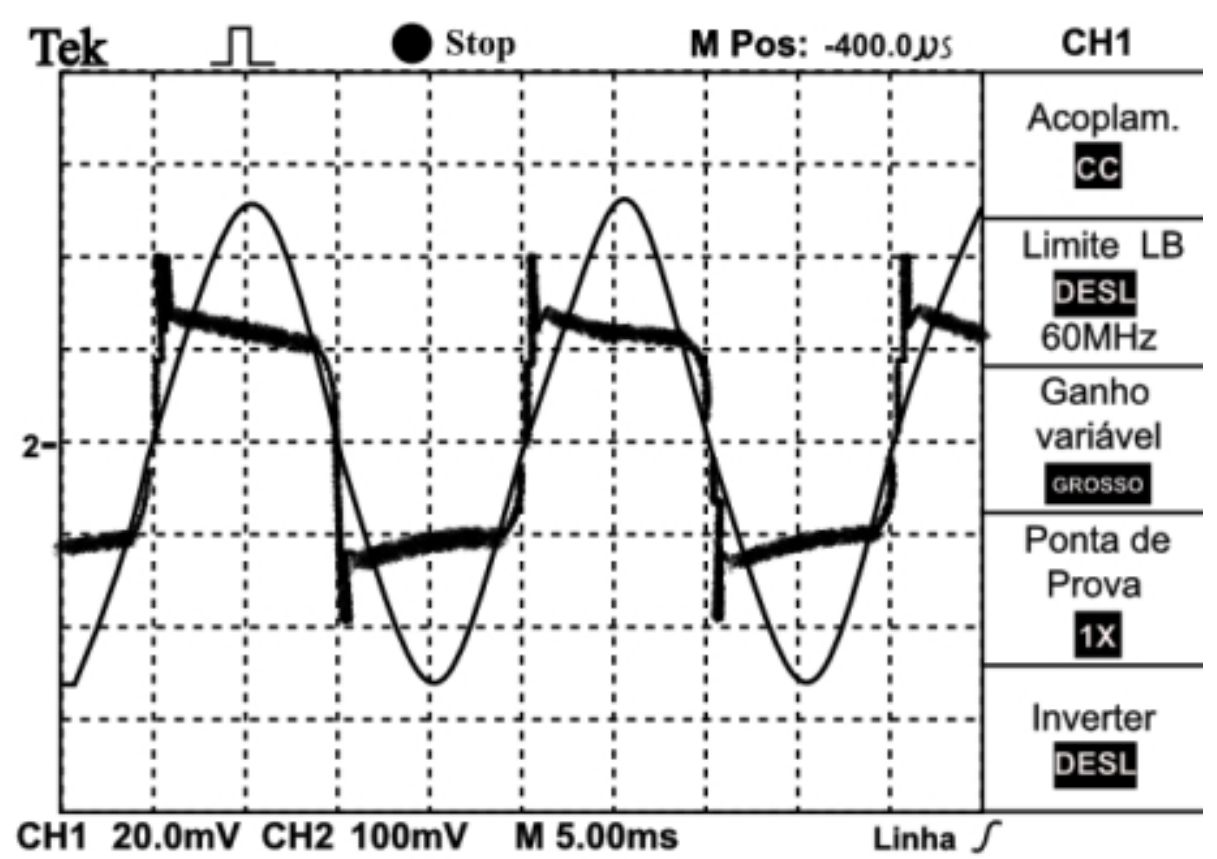

(a) Dados Experimentais

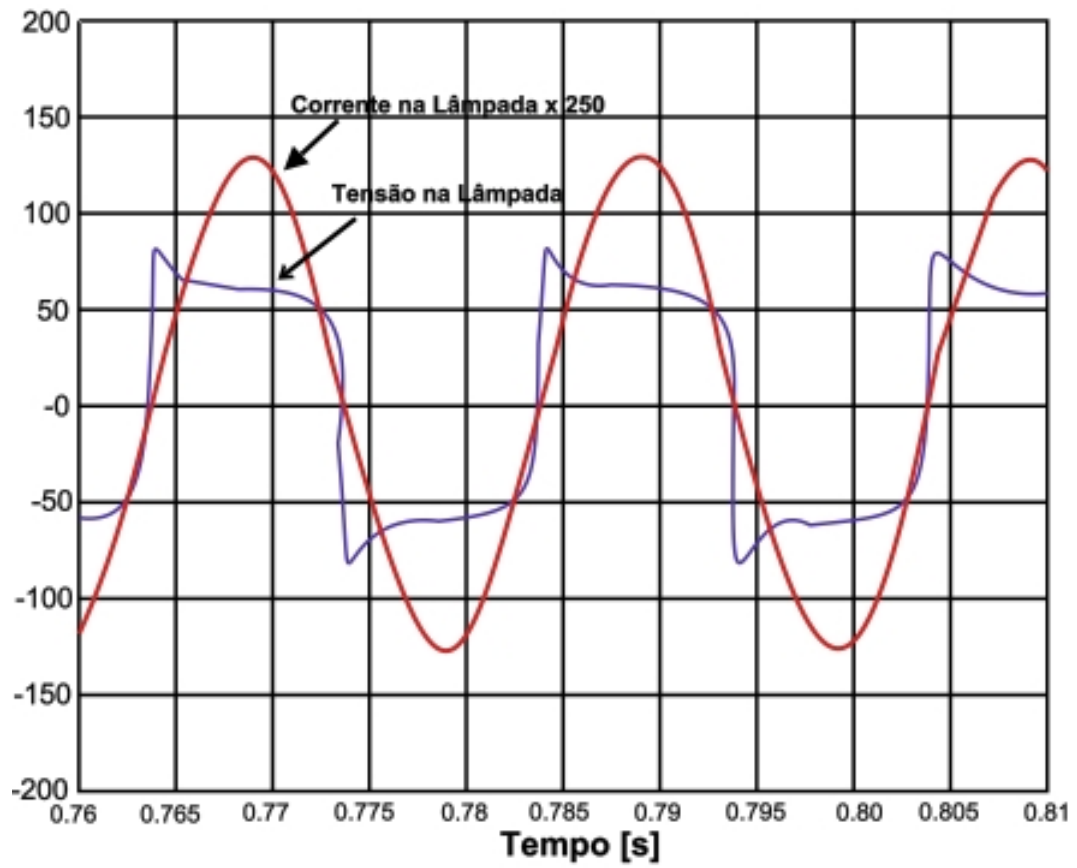

(b) Simulação

Figura 40 - Validação do modelo [17] 
O equacionamento considerou o balanço termodinâmico da ionização do plasma, tornando o modelo desta forma válido para toda a faixa de frequências de operação, e suportando a análise em condições transitórias restritas.
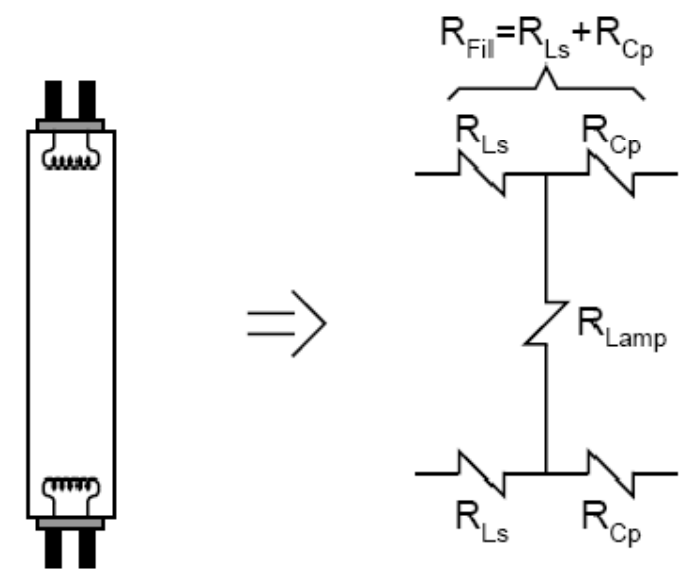

Figura 41 - Circuito equivalente da lâmpada fluorescente [18]

Como parâmetros, este modelo considera a geometria da lâmpada, a pressão parcial do Argônio contido no tubo de descarga e a temperatura dos eletrodos.

O uso de ferramentas inteligentes foi abordado por Tam e Hui [20], onde os autores apresentam um modelo semi-teórico para a lâmpada fluorescente desenvolvido a partir de características físicas da coluna de plasma, ajustada através de algoritmos genéticos.

As construções do modelo proposto nos ambientes PSpice e SIMULINK ${ }^{\circledR}$ apresentaram resultados satisfatórios para operação em regime transitório e permanente, servindo como ferramenta auxiliar no projeto de reatores eletromagnéticos e eletrônicos. A Figura 42 mostra uma comparação entre as curvas de tensão sobre o arco da lâmpada e a resposta apresentada pelo modelo implementado, e a Figura 43 mostra o gráfico comparativo entre a corrente real através do arco e a curva simulada para operação em $50 \mathrm{~Hz}$, indicando a boa aproximação entre os dados experimentais e os valores obtidos na simulação. 
A criação de um modelo híbrido para a lâmpada fluorescente, empregando em seu equacionamento uma aproximação físico-comportamental simplificada, é o objeto de estudo de Holloway, Stone e Tozer [21]. A principal utilidade deste modelo é como ferramenta auxiliar no projeto e simulação de reatores eletrônicos e eletromagnéticos.

A implementação do modelo Físico-Comportamental simplificado na plataforma SIMULINK® é apresentada na Figura 44.

Os aspectos operacionais considerados o tornam válido para toda a faixa de frequências de operação, e requer como dados de entrada a geometria da lâmpada, a pressão do argônio e a temperatura do gás no interior do bulbo.

As respostas do modelo operando em $50 \mathrm{~Hz}$ (Figura 45) e em $5 \mathrm{kHz}$ (Figura 46) demonstram a similaridade entre as curvas, comprovando a boa caracterização do dispositivo obtida pela modelagem.

A obtenção de um modelo semi-teórico para lâmpada fluorescente ultravioleta foi proposta do trabalho de Erenturker [22]. Empregando os dados de operação como base, os parâmetros do modelo foram ajustados por meio de regressão não-linear, de forma a caracterizar a operação do dispositivo em regime permanente para uma ampla faixa de frequências de trabalho.

A Figura 47 apresenta as respostas de tensão e corrente obtidas por simulação através do modelo proposto, comparadas com os dados de operação da lâmpada em $50 \mathrm{~Hz}$.

De um modo geral, nota-se que os trabalhos realizados envolvendo modelagem de lâmpadas fluorescentes são construídos para complementar o estudo, projeto e construção de reatores eletrônicos para estas lâmpadas. 


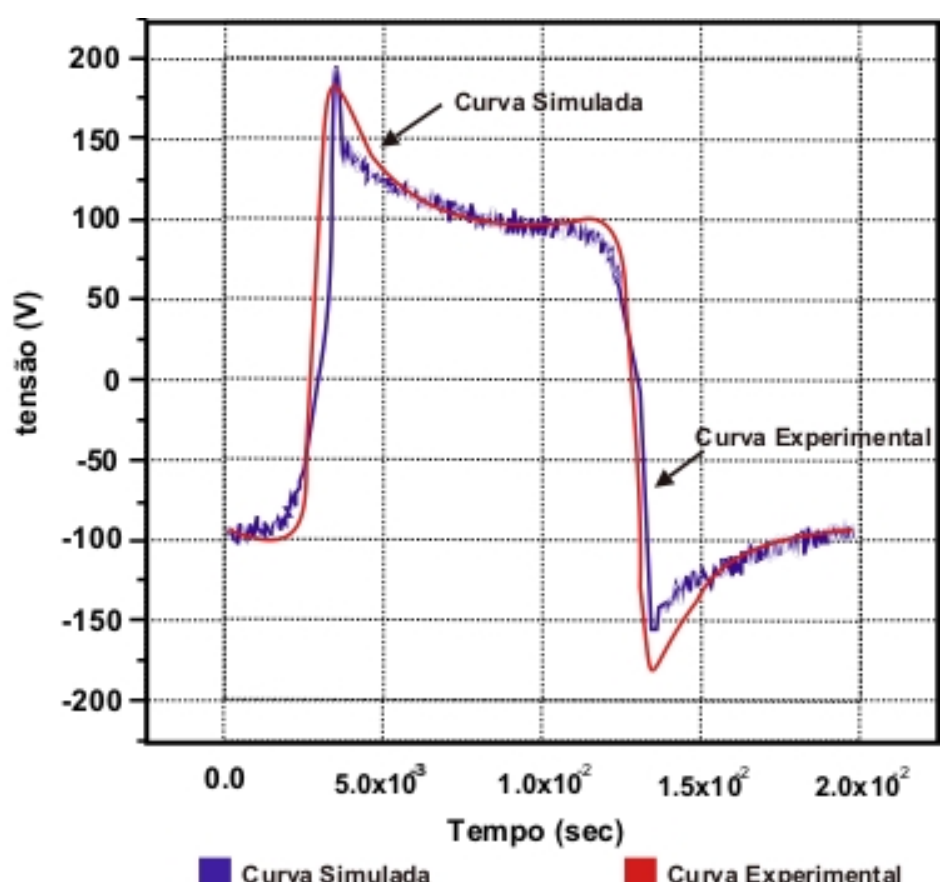

Figura 42 - Tensão sobre o arco da lâmpada e resposta do modelo implementado [20]

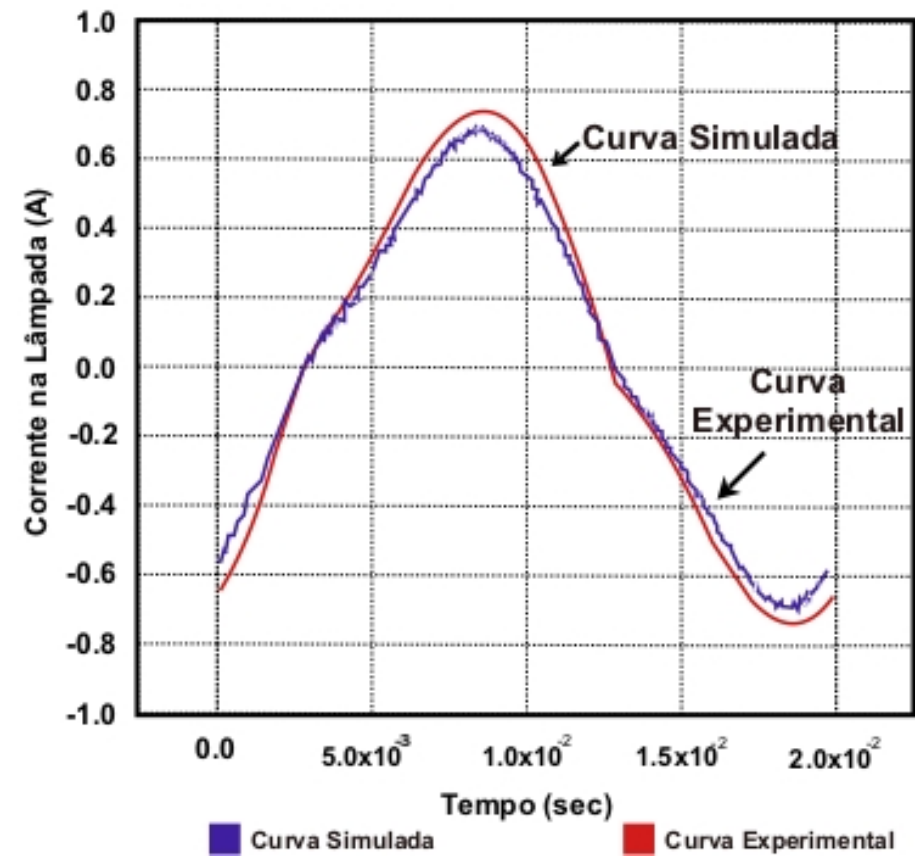

Figura 43 - Corrente através do arco da lâmpada e resposta do modelo implementado [20] 


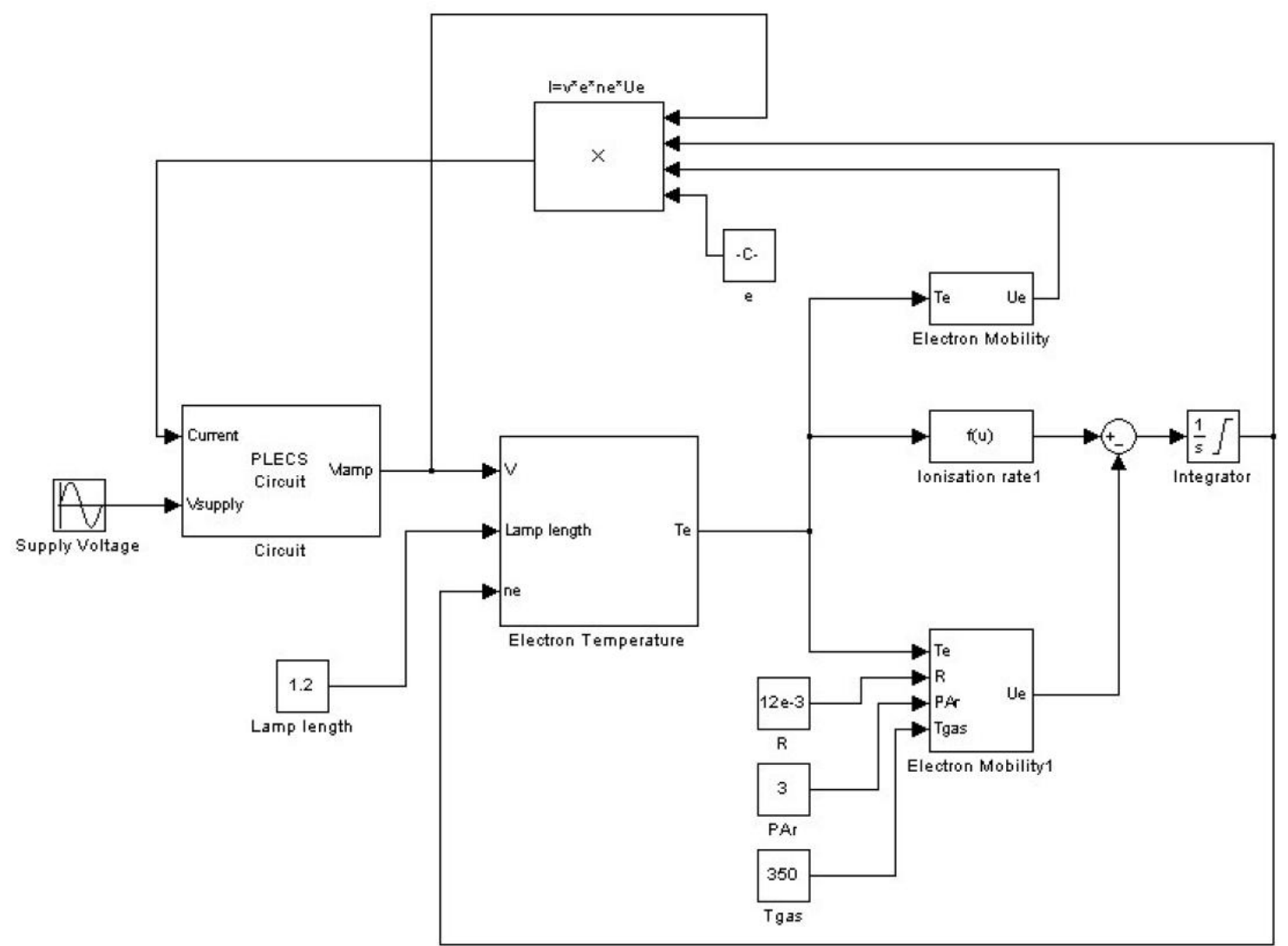

Figura 44 - Modelo físico-comportamental da lâmpada fluorescente [21]

\section{Tensão $50 \mathrm{hz}$}

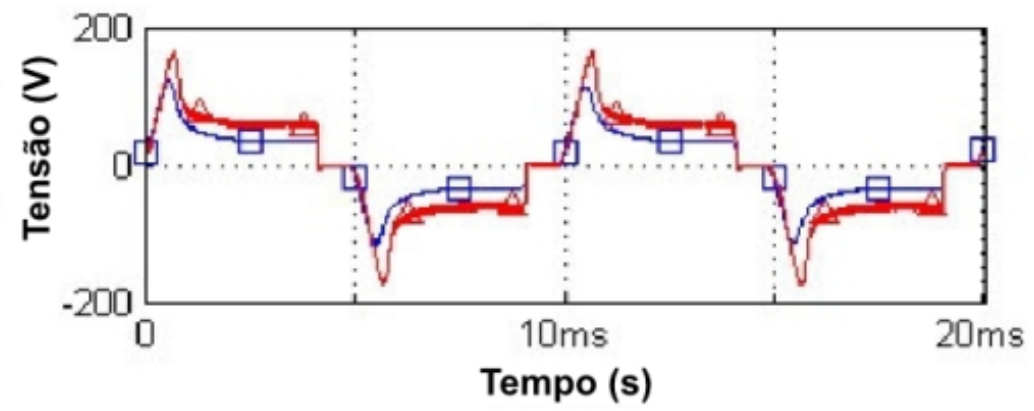

Corrente $\mathbf{5 0 h z}$

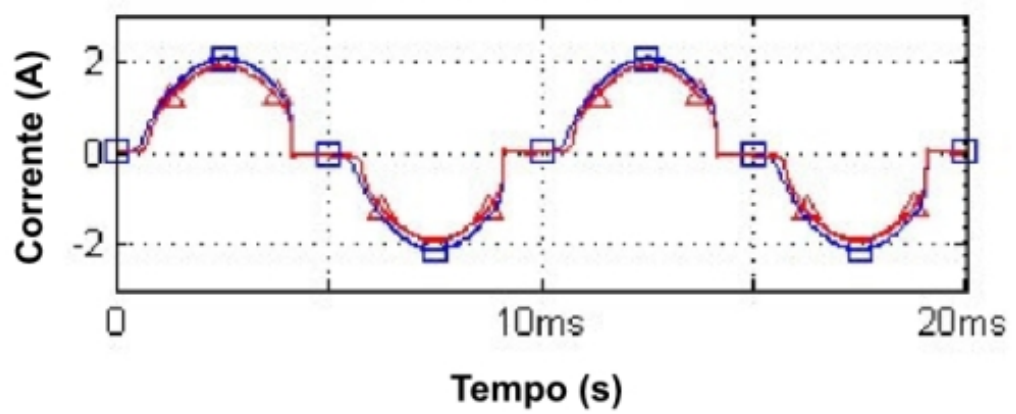

Figura 45 - Tensão e corrente na lâmpada em 50Hz [21] 


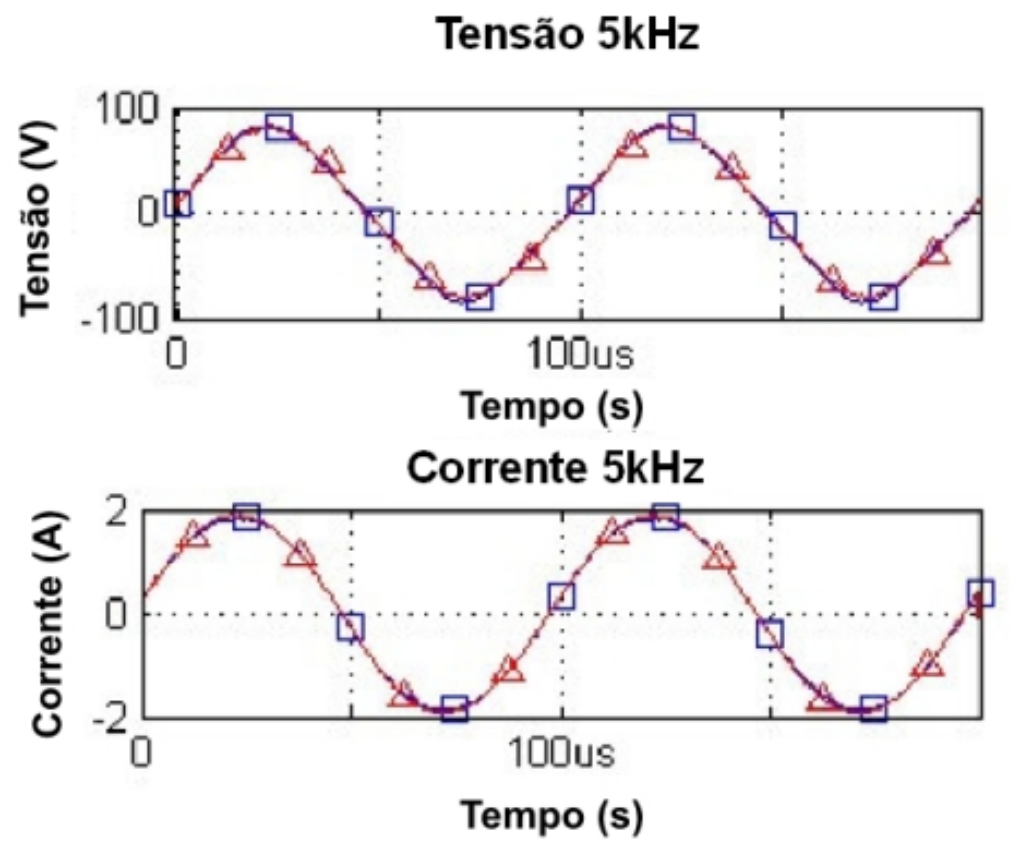

Figura 46 - Tensão e corrente na lâmpada em $5 \mathrm{kHz}$ [21]

A maioria dos modelos apresentados considera a operação em regime permanente e a lâmpada alimentada em alta frequência, sem contemplar a fase de acendimento e as respostas aos transitórios. Cabe notar que as pesquisas não fazem abordagens relevantes em relação aos efeitos da qualidade da energia sobre a operação das lâmpadas de descarga de baixa pressão.

\subsection{Caracterização de lâmpadas de descarga de alta intensidade}

Uma das primeiras caracterizações para lâmpadas de descarga de alta intensidade (HID- High Intensity Discharge) operando em várias condições fora da frequência industrial foi proposta por Herrick [23]. A abordagem empregada foi a criação de um análogo para a lâmpada através de equações diferenciais não-lineares, cujo comportamento correspondia a um primitivo modelo para lâmpadas HID.

Ensaios realizados com lâmpadas de vapor de mercúrio de $400 \mathrm{~W}$ e vapor de sódio de alta pressão de $400 \mathrm{~W}$ forneceram dados operacionais que foram 
comparados com as respostas apresentadas pelo análogo matemático. Os resultados das comparações estão na Tabela 2.

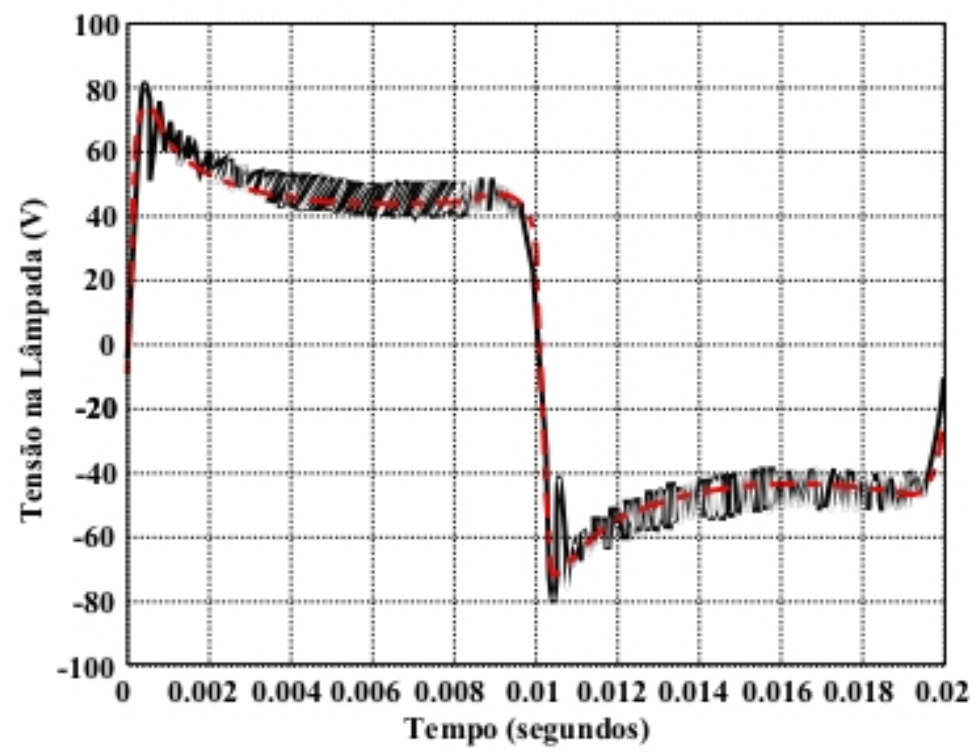

(a)

$\frown$ - Experimento $\quad \because, \quad$ - Modelo

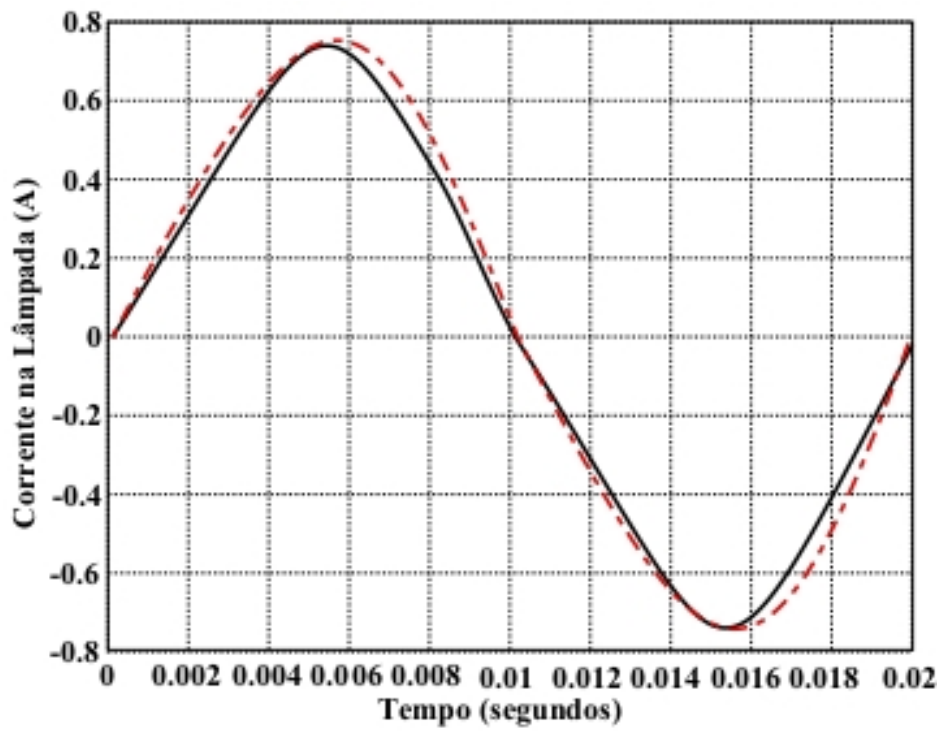

(b)

$\frown$ - Experimento $\quad \because \%$ - Modelo

Figura 47 - Resposta de tensão (a) e corrente (b) do modelo [22] 
O efeito da não-linearidade das lâmpadas de descarga de alta intensidade é frequentemente abordado por pesquisadores que trabalham em linhas que englobam a qualidade da energia. Os pesquisadores Ríos, Castañeda e Veas citam uma avaliação relativa à distorção harmônica e fator de potência de lâmpadas de descarga empregadas na iluminação pública, demonstrando a influência da correção do fator de potência com capacitores no conteúdo harmônico da corrente [24].

Tabela 2 - Comportamento do análogo das lâmpadas HID [23]

\begin{tabular}{|c|c|c|c|c|c|c|c|c|}
\hline \multicolumn{9}{|c|}{ Lâmpada de Vapor de Mercúrio } \\
\hline \multirow{2}{*}{ Reator } & \multirow{2}{*}{$\begin{array}{l}\text { Freq. } \\
(\mathrm{Hz})\end{array}$} & \multirow{2}{*}{$\begin{array}{l}\text { Tensão } \\
\text { de linha }\end{array}$} & \multicolumn{3}{|c|}{ Lâmpada Real } & \multicolumn{3}{|c|}{ Modelo Análogo } \\
\hline & & & $\begin{array}{l}\text { Tensão } \\
\text { (Volts) }\end{array}$ & $\begin{array}{c}\text { Corrente } \\
\text { (Ampéres) }\end{array}$ & $\begin{array}{c}\text { Potência } \\
\text { (Watts) }\end{array}$ & $\begin{array}{l}\begin{array}{l}\text { Tensão } \\
\text { (Volts) }\end{array} \\
\end{array}$ & $\begin{array}{c}\text { Corrente } \\
\text { (Ampéres) }\end{array}$ & $\begin{array}{c}\text { Potência } \\
\text { (Watts) }\end{array}$ \\
\hline Indutivo & 60 & 240 & 136 & 3,13 & 399 & 138 & 3,11 & 394 \\
\hline Capacitivo & 60 & 240 & 140 & 4,20 & 545 & 141 & 4,23 & 541 \\
\hline Resistivo & 60 & 242 & 140 & 3,50 & 394 & 141 & 3,55 & 396 \\
\hline Resistivo & 60 & 238 & 137 & 3,34 & 395 & 140 & 3,33 & 387 \\
\hline Resistivo & 220 & 235 & 132 & 3,15 & 403 & 137 & 3,12 & 396 \\
\hline Resistivo & 610 & 246 & 132 & 3,36 & 448 & 137 & 3,35 & 447 \\
\hline \multicolumn{9}{|c|}{ Lâmpada de Vapor de Sódio de Alta Pressão } \\
\hline \multirow[b]{2}{*}{ Reator } & \multirow{2}{*}{$\begin{array}{c}\text { Freq. } \\
(\mathrm{Hz})\end{array}$} & \multirow{2}{*}{$\begin{array}{l}\text { Tensão } \\
\text { de linha }\end{array}$} & \multicolumn{3}{|c|}{ Lâmpada Real } & \multicolumn{3}{|c|}{ Modelo Análogo } \\
\hline & & & $\begin{array}{c}\text { Tensão } \\
\text { (Volts) }\end{array}$ & $\begin{array}{c}\text { Corrente } \\
\text { (Ampéres) }\end{array}$ & $\begin{array}{c}\text { Potência } \\
\text { (Watts) }\end{array}$ & $\begin{array}{l}\text { Tensão } \\
\text { (Volts) }\end{array}$ & $\begin{array}{c}\text { Corrente } \\
\text { (Ampéres) }\end{array}$ & $\begin{array}{c}\text { Potência } \\
\text { (Watts) }\end{array}$ \\
\hline Indutivo & 60 & 270 & 100 & 4,65 & 400 & 101 & 4,60 & 393 \\
\hline Resistivo & 220 & 220 & 107 & 4,70 & 423 & 105 & 4,70 & 408 \\
\hline Resistivo & 600 & 224 & 103 & 4,60 & 428 & 103 & 4,60 & 429 \\
\hline
\end{tabular}

Nota-se que a característica não-linear da lâmpada de descarga intensifica o conteúdo harmônico da corrente destes dispositivos quando se emprega a correção de fator de potência através de capacitores, como mostrado na Figura 48.

O estudo ainda demonstra a sensibilidade apresentada por tipos diferentes de lâmpadas ao efeito da aplicação dos capacitores. A Figura 49 apresenta a diferença entre o conteúdo harmônico do conjunto lâmpada-reator sem a correção capacitiva e o resultado obtido quando da aplicação de capacitores para a compensação da 
potência reativa, para lâmpadas de vapor de mercúrio. O mesmo estudo para as lâmpadas de vapor de sódio é mostrado na Figura 50, evidenciando as diferenças de resposta para os diferentes tipos de lâmpada.

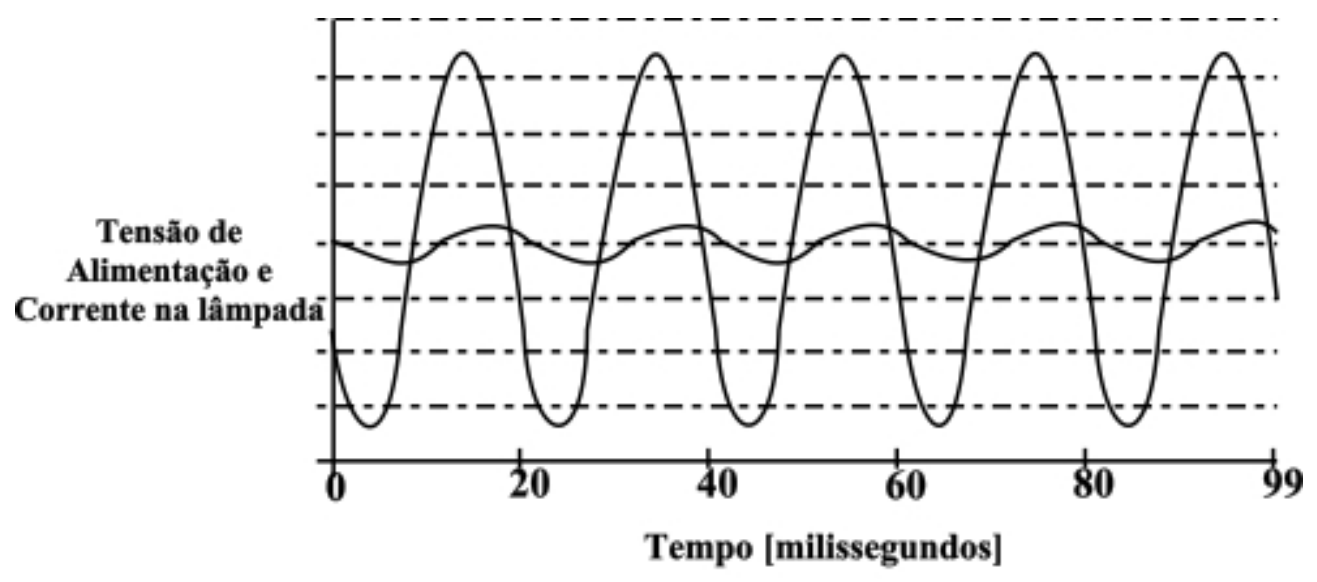

(a) Sem capacitores

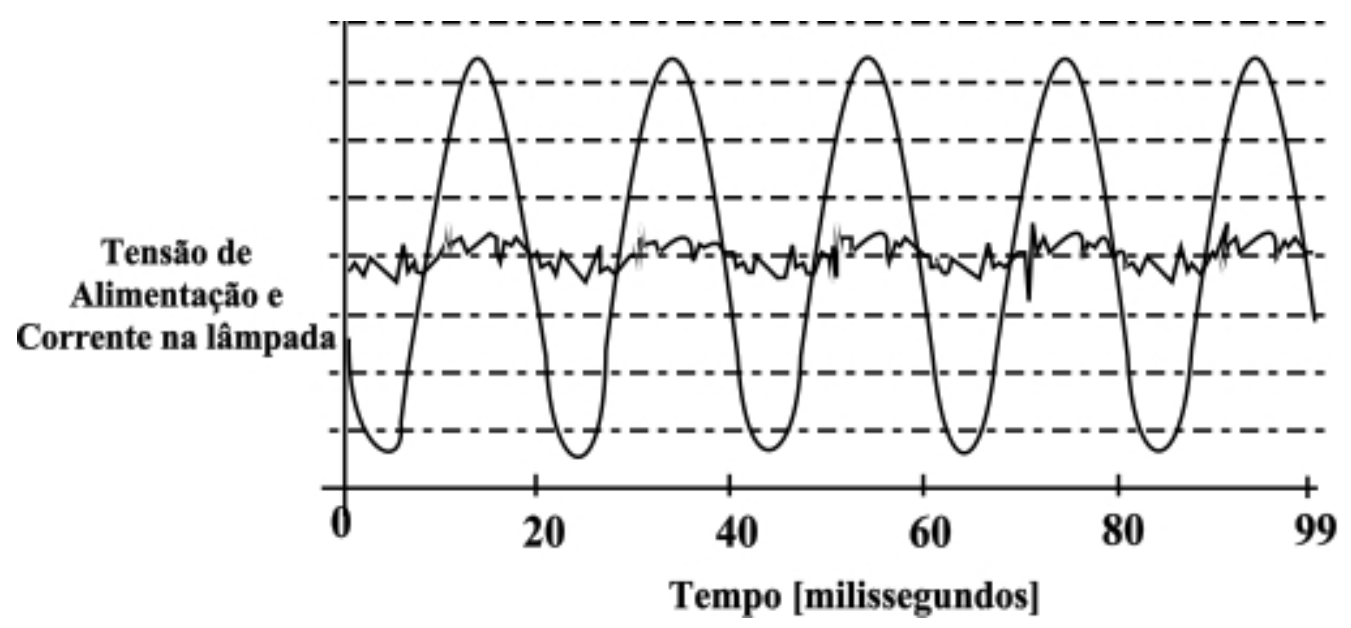

(b) Com capacitores

Figura 48 - Efeito da correção de FP com capacitores em lâmpadas de descarga [24]

Com a crescente preocupação com a qualidade da energia,

Milczarski, Szczepanik e Lawrance mostram uma proposta para a redução das correntes harmônicas produzidas em sistemas compostos por lâmpadas de descarga [25].

Através da construção de um filtro ativo, buscou-se a significativa redução das correntes harmônicas fluindo através do neutro. Este efeito torna-se significativo à medida que vários dispositivos encontram-se associados em um mesmo 
sistema. Por esta razão, o trabalho apresenta uma solução que atenda não apenas aos equipamentos de forma individual, mas representa uma solução aplicável a instalações reais. A montagem experimental utilizada na validação dos experimentos é esquematizada na Figura 51.

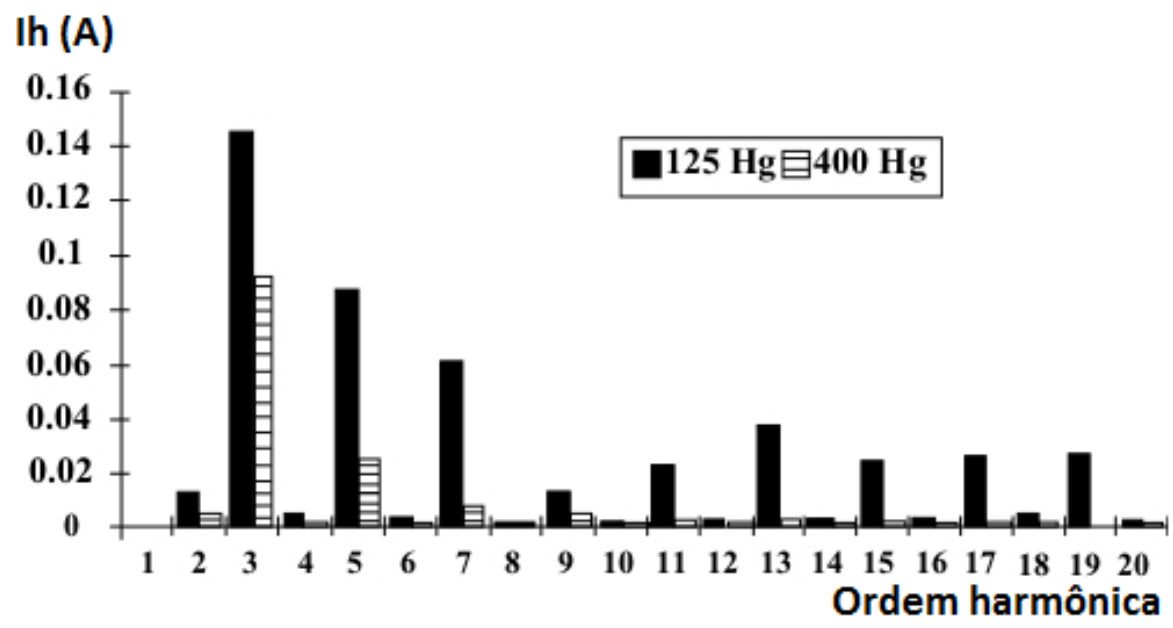

(a) Sem capacitores

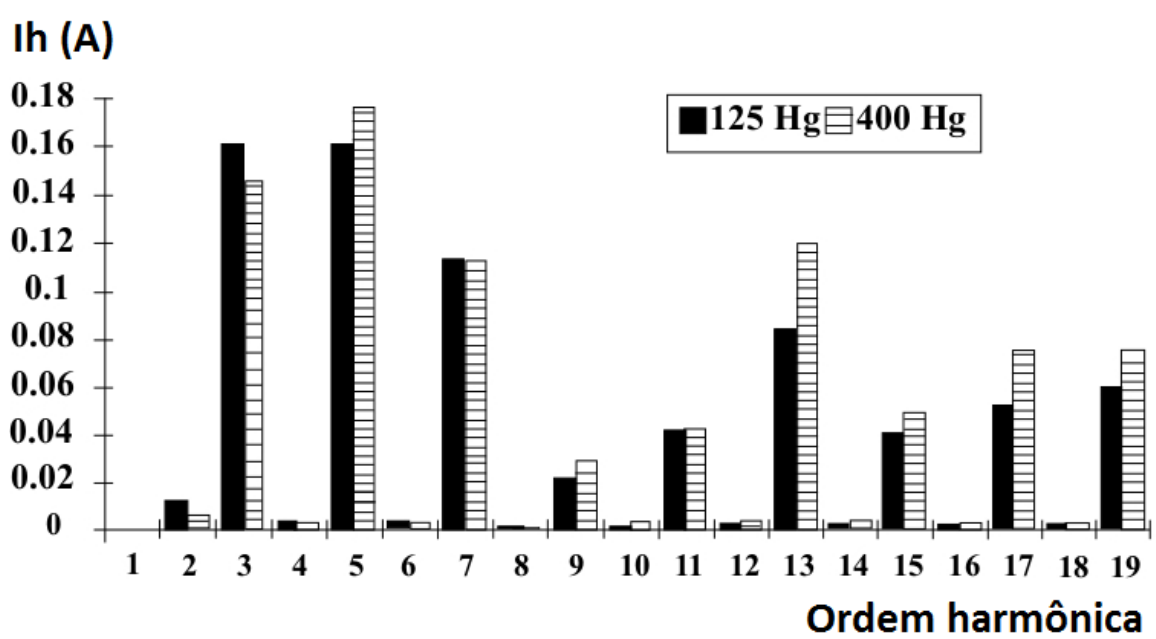

(b) Com capacitores

Figura 49 - Conteúdo harmônico da corrente em lâmpadas de vapor de mercúrio [24]

A caracterização da lâmpada de descarga como dispositivo inserido no sistema elétrico é realizada por Shvartzas e Yaakov, através da implementação de um modelo de lâmpada HID de Vapor de Sódio no ambiente de simulação SPICE [26]. 
Baseado no modelo termodinâmico do arco elétrico, o modelo simula a operação da lâmpada em regime transitório e permanente, na faixa de frequências de ensaio compreendida entre $50 \mathrm{~Hz}$ e $30 \mathrm{kHz}$, representando para isto o arco como uma fonte de corrente dependente dos parâmetros de tensão e corrente sobre o bulbo de descarga, como mostrado na Figura 52. Os resultados obtidos com este modelo demonstraram uma boa aproximação do comportamento real do dispositivo, como apresentado na Figura 53.

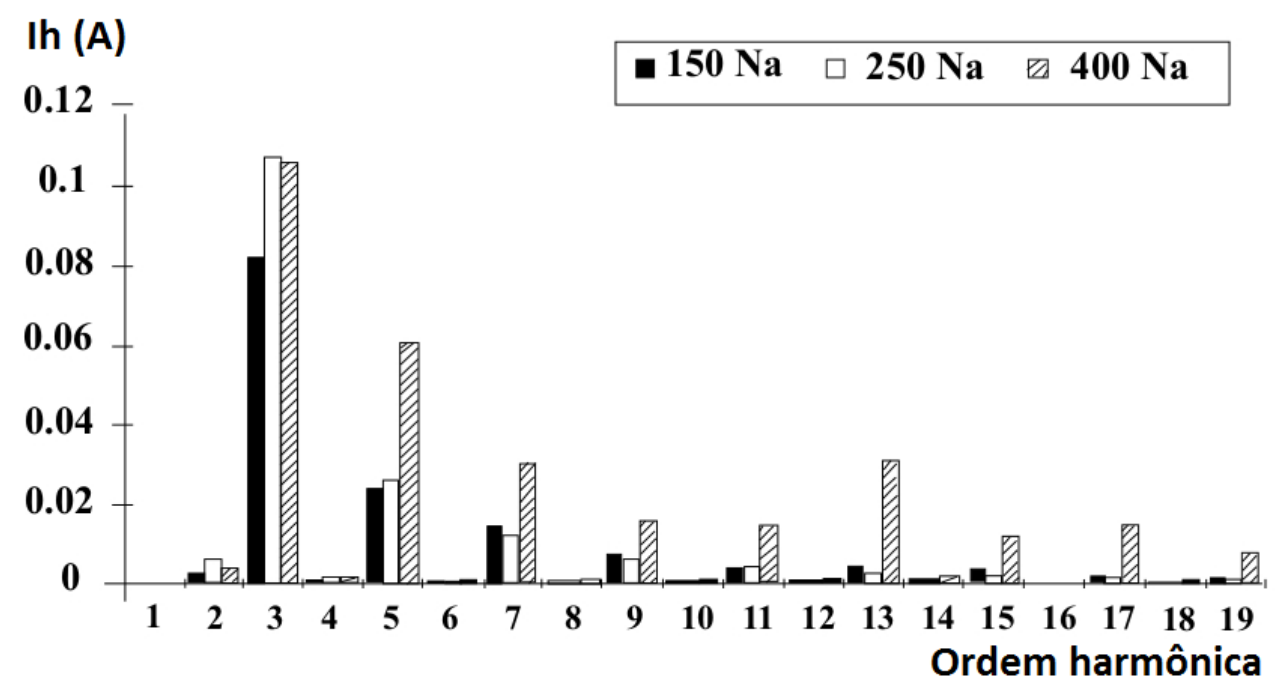

(a) Sem capacitores

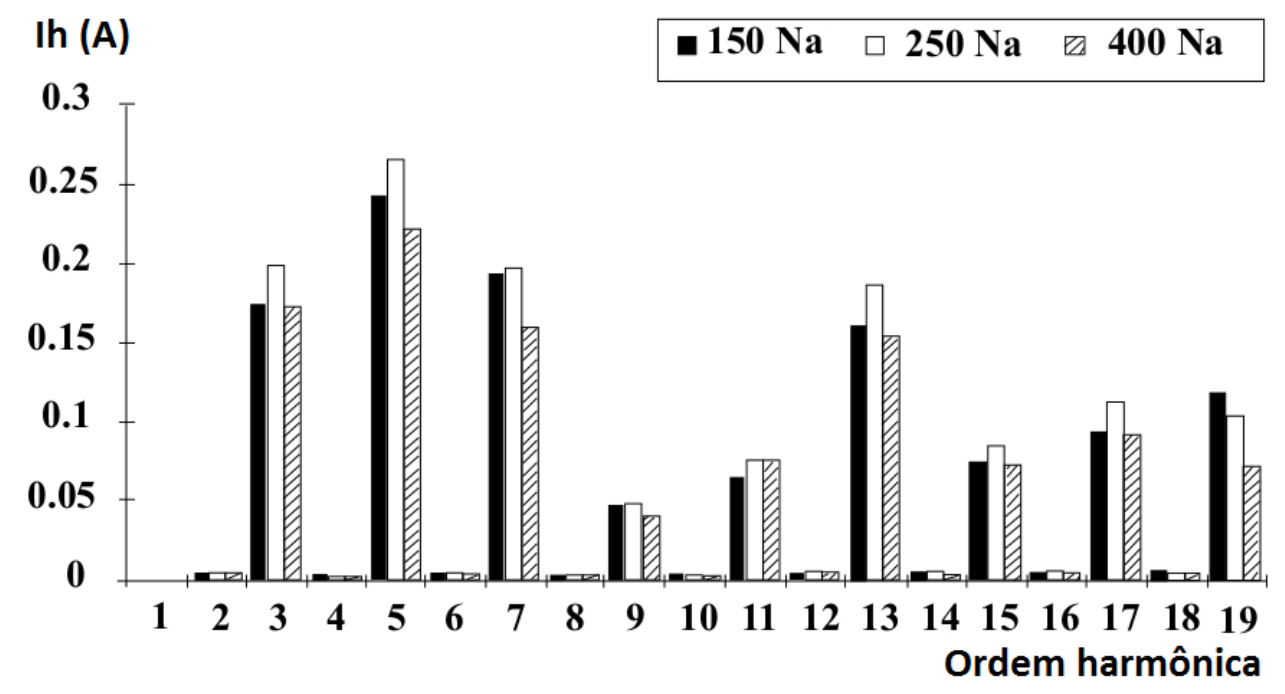

(b) Com capacitores

Figura 50 - Conteúdo harmônico da corrente em lâmpadas de vapor de sódio [24] 


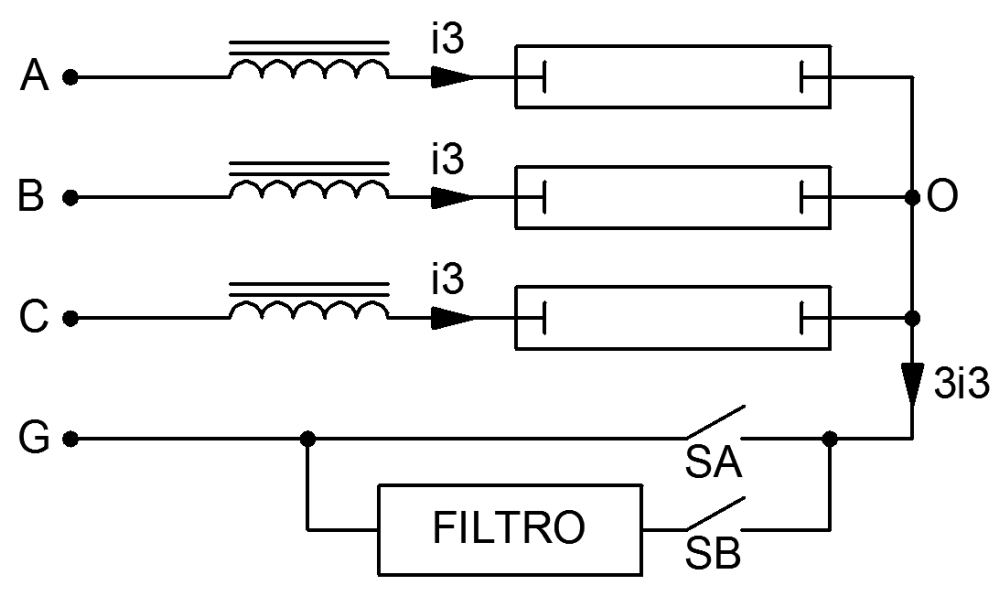

Figura 51 - Aplicação de filtro ativo em sistema de iluminação [25]

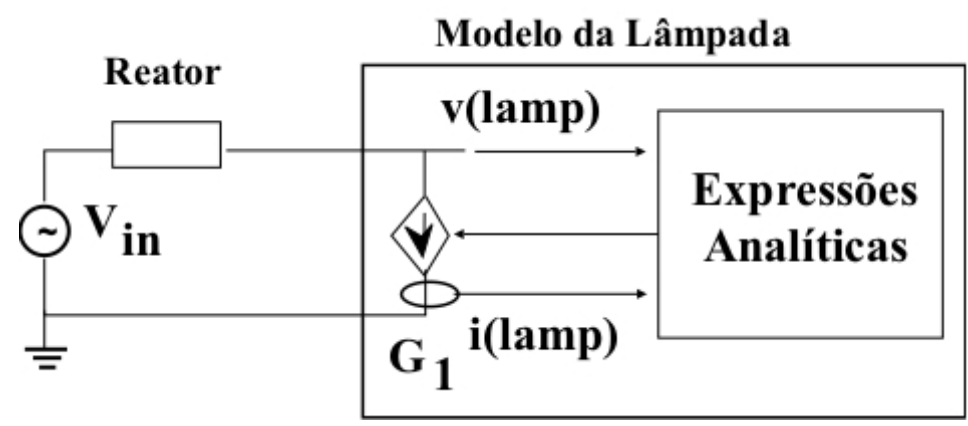

Figura 52 - Representação da lâmpada no modelo [26]

Particularizando uma condição de operação, a pesquisa realizada por Stambouli et al. propõe a modelagem da fase de aquecimento de uma lâmpada HID de Vapor de Mercúrio [27], com base no comportamento termodinâmico do arco elétrico, cuja resposta é apresentada na Figura 54. A caracterização considera operação em frequência industrial, e demonstrou uma boa aproximação dos perfis de tensão e corrente do dispositivo nesta fase de operação.

Através do emprego de algoritmos genéticos, um modelo de lâmpada HID destinado a simular o dispositivo inserido no sistema elétrico foi construído por Yan et al. [28]. Esta pesquisa tomou como base os valores obtidos através de medição em dispositivos reais em operação, caracterizando desta forma o aspecto comportamental do modelo. 


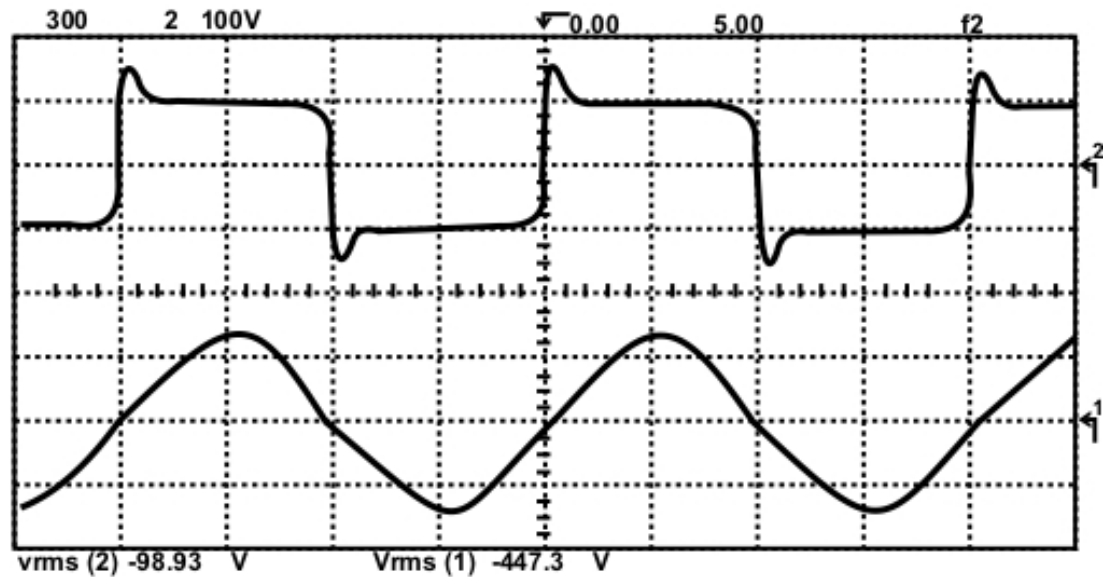

(a) Medição
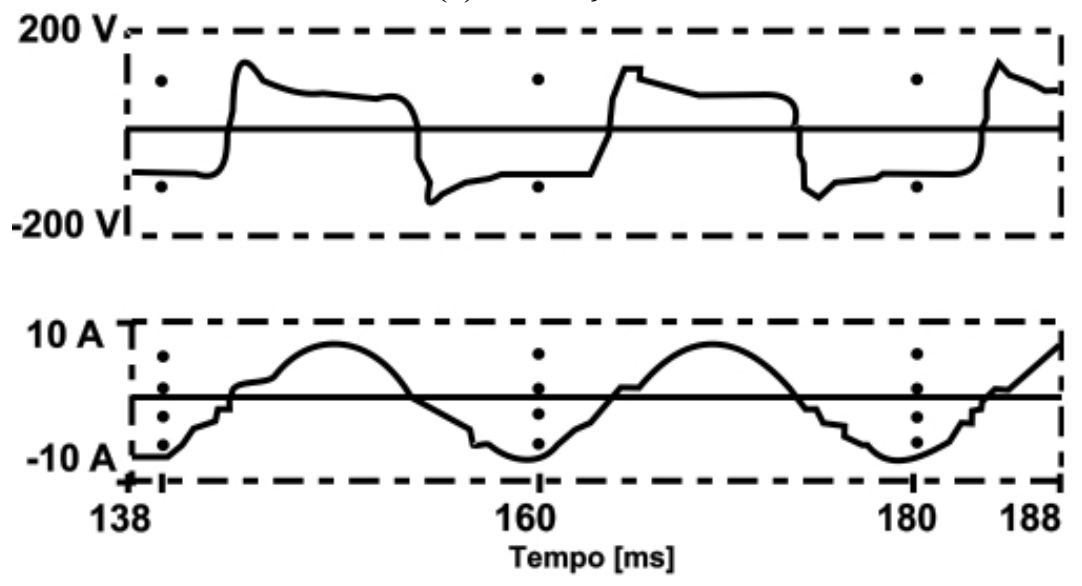

(b) Simulação

Figura 53 - Resultados da simulação em 50Hz [26]

A resposta obtida mostra que o modelo foi capaz de representar o comportamento do dispositivo modelado operando em baixa e alta frequência. A Figura 55 mostra um segmento da simulação do dispositivo operando em $50 \mathrm{~Hz}$, comparado com valores medidos durante a operação real.

Yan e Hui apresentam outro emprego de algoritmos genéticos, agora como ferramenta para ajuste de parâmetros de um modelo universal de lâmpada HID implementado no ambiente SPICE [29]. Este modelo teve por base o equacionamento da descarga de plasma, e empregou uma lâmpada de vapor de mercúrio de $50 \mathrm{~W}$ como 
elemento real. A Figura 56 mostra a operação do dispositivo real em $50 \mathrm{~Hz}$, e os resultados obtidos através do modelo são apresentados na Figura 57.

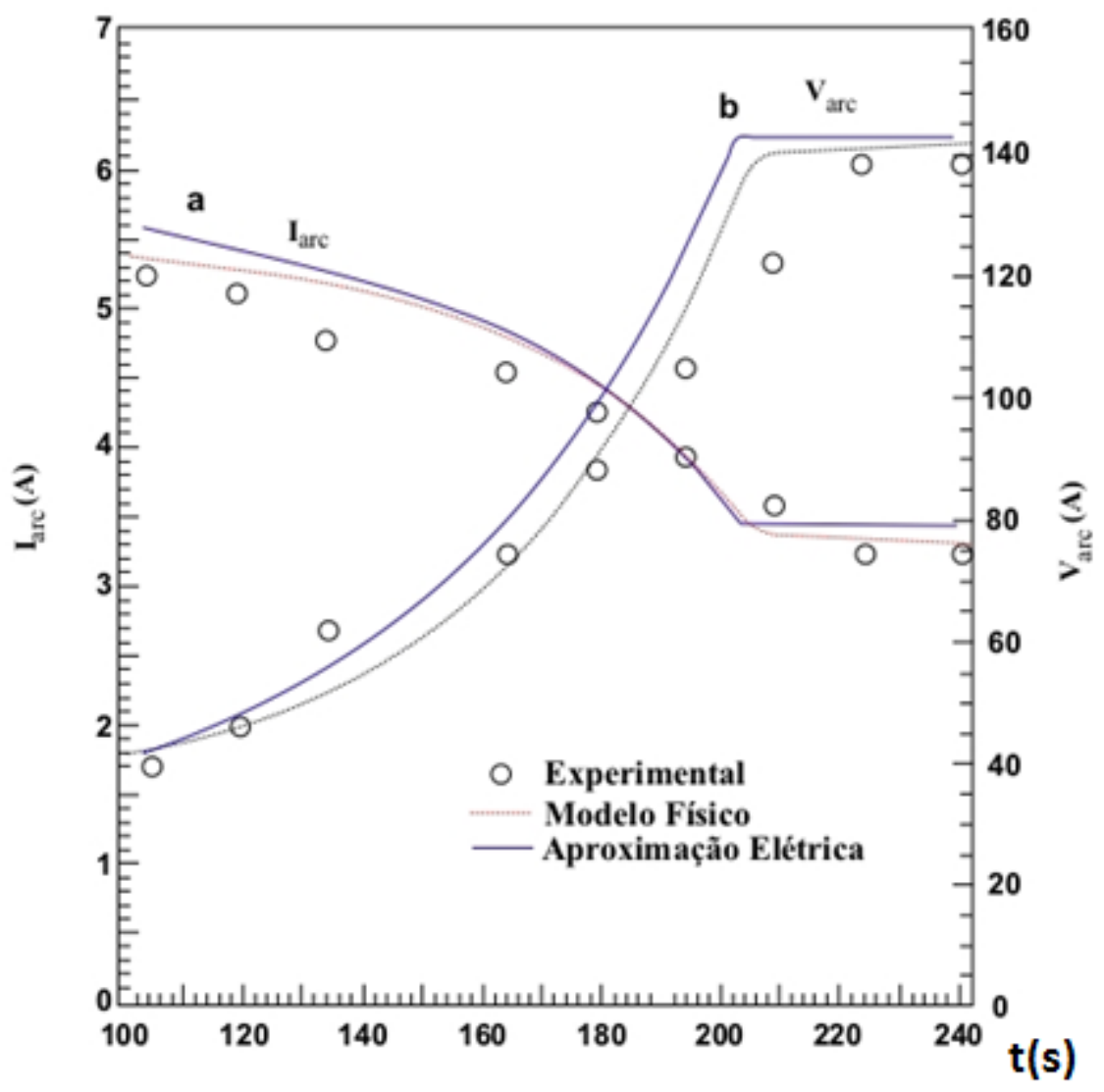

Figura 54 - Fase de aquecimento de uma lâmpada HID de vapor de mercúrio [27]
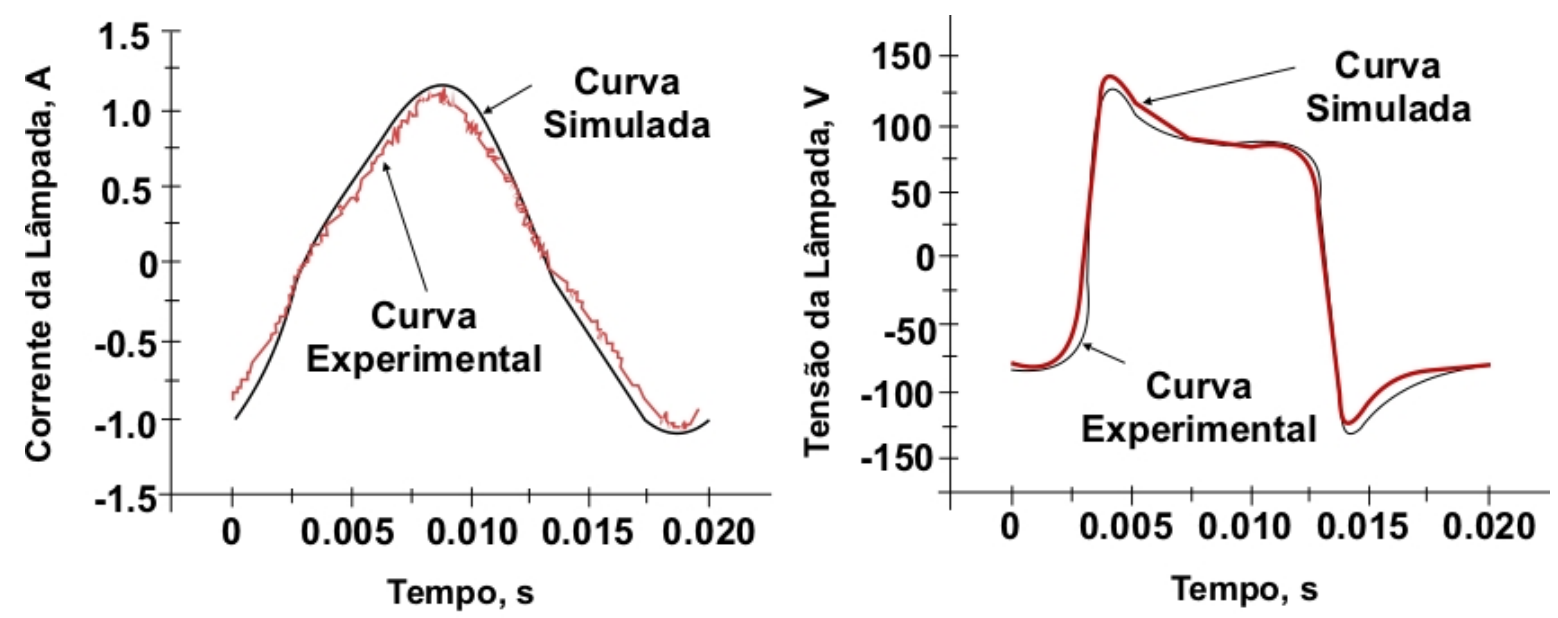

Figura 55 - Resposta do modelo de lâmpada HID [28] 
O trabalho apresentado por Zouidi et al. mostra o desenvolvimento de um modelo não-linear de tempo contínuo da lâmpada HID de vapor de mercúrio, válido para operação em frequência industrial de $50 \mathrm{~Hz}$ [30].

Baseado no modelo não-linear comportamental proposto por Herrick, empregou-se uma rede neural artificial tipo feed-forward back-propagation como elemento de determinação de parâmetros. Os resultados mostraram grande precisão na representação do dispositivo, como mostrado na curva V-I apresentada na Figura 58.

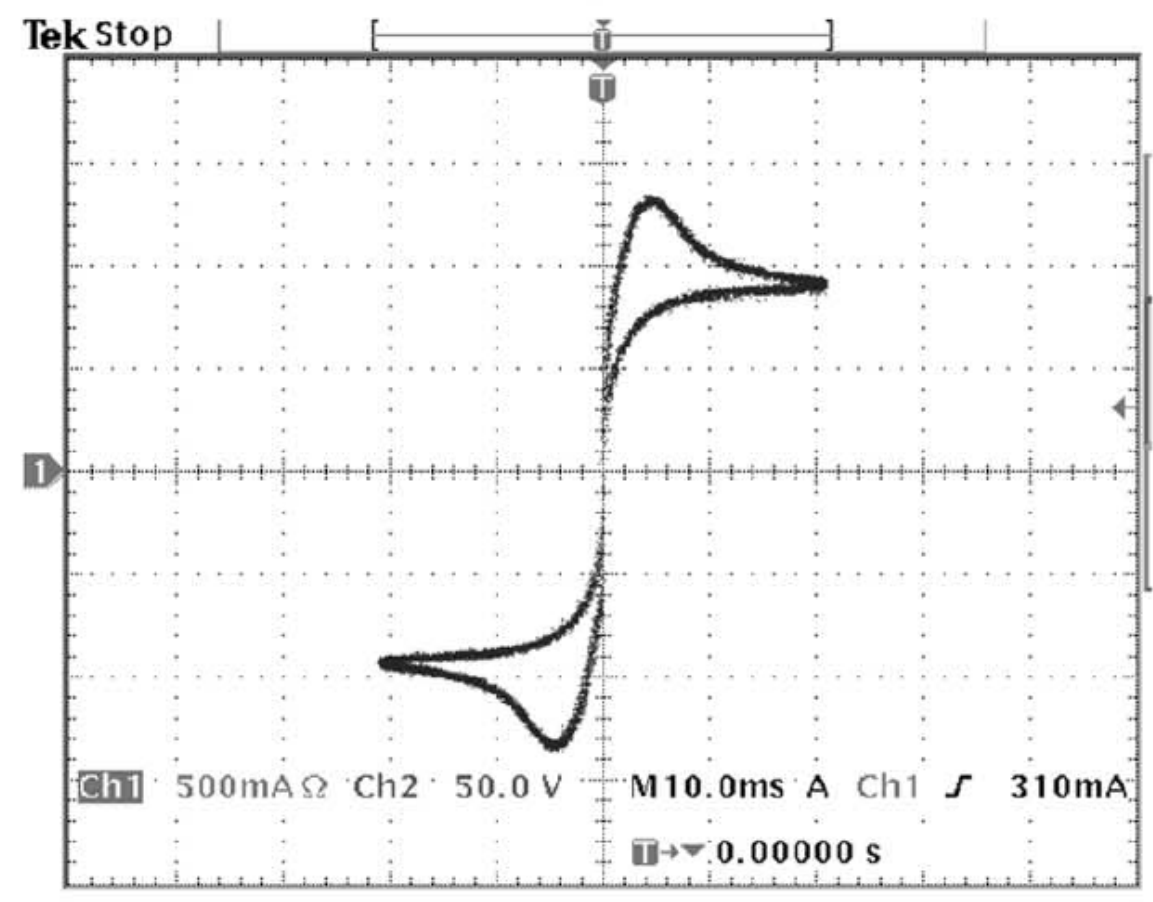

Figura 56 - Curva V-I experimental - lâmpada vapor de mercúrio 50W operando em 50Hz [29]

Visando o desenvolvimento de reatores eletrônicos para lâmpadas de descarga de alta intensidade, Alonso et al. apresentam um modelo de lâmpada HID de vapor metálico de baixa potência implementado no SIMULINK ${ }^{\circledR}$, com abordagem diversa às anteriormente apresentadas [31]. 


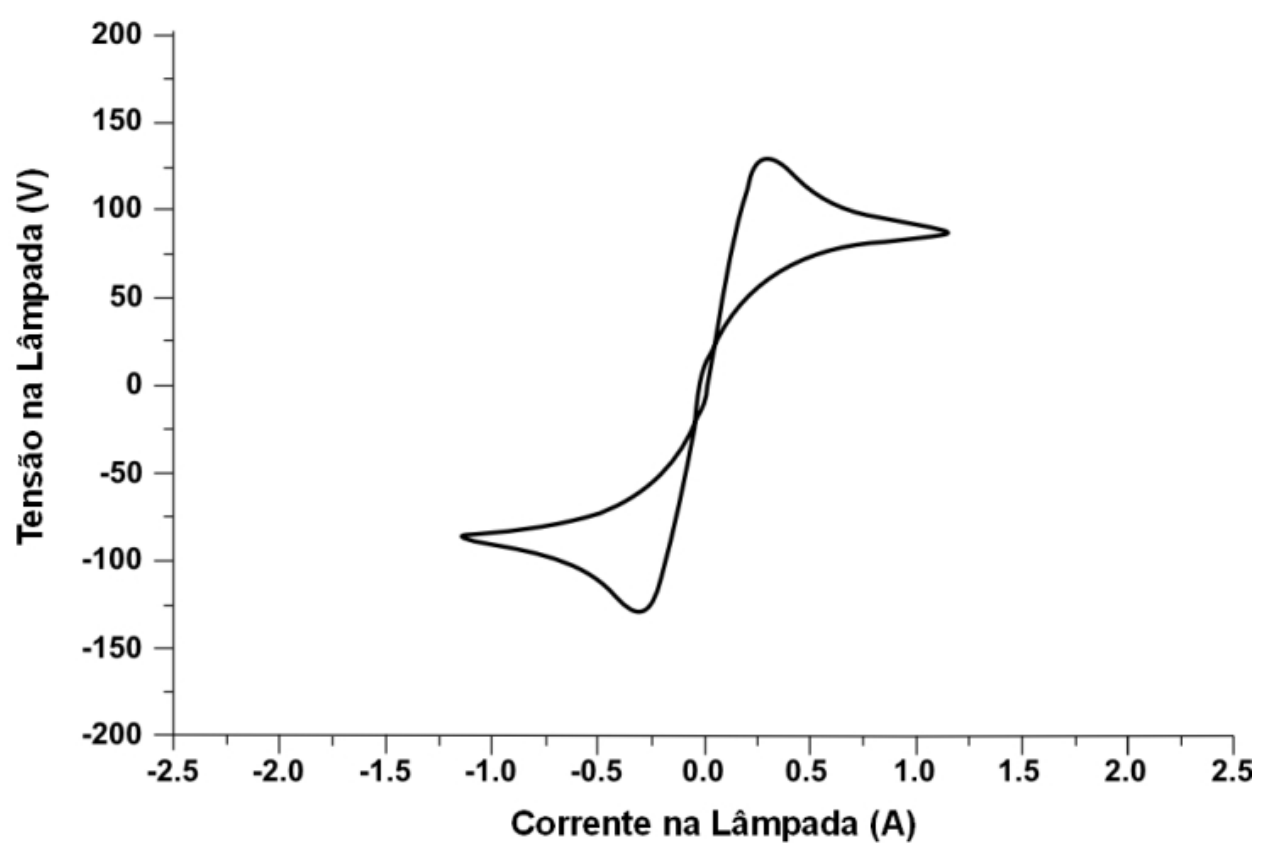

Figura 57 - Curva V-I do modelo - lâmpada vapor de mercúrio 50W operando em 50Hz [29]

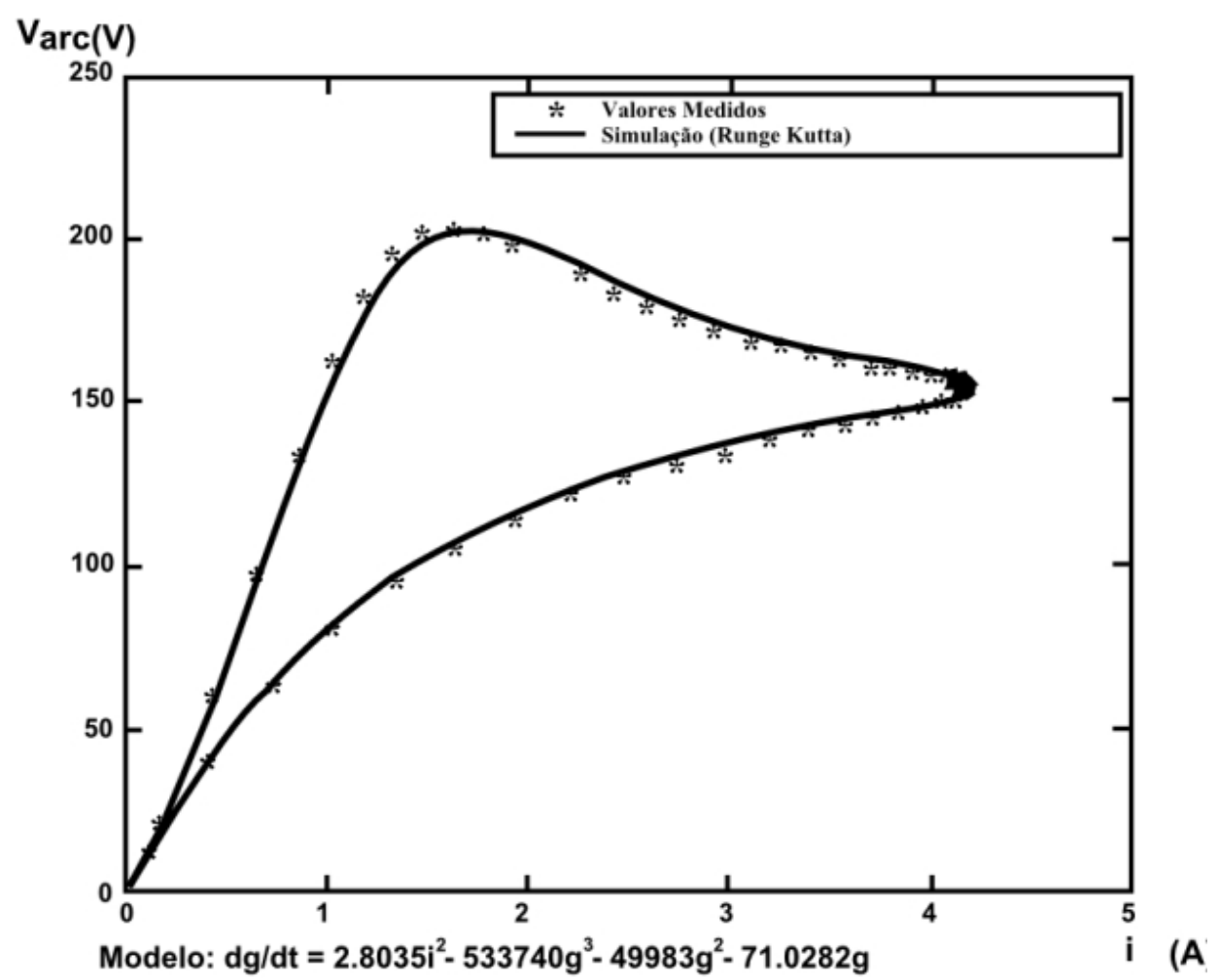

Figura 58 - Curvas V-I da lâmpada de vapor de mercúrio 400W [30]

Os coeficientes do modelo foram obtidos com base na resposta do dispositivo no domínio da frequência a um degrau de tensão, partindo de uma condição 
estável de operação. Os valores obtidos por medição realizada no experimento estão apresentados na Figura 59, e os resultados obtidos através da simulação com base no modelo construído são mostrados na Figura 60.

Baseado na condutância dinâmica do tubo de descarga, Blanco et al. descrevem um modelo de lâmpada HID de vapor de sódio [32]. Contando com implementação no ambiente matemático SIMULINK ${ }^{\circledR}$, o modelo apresentou resposta satisfatória na faixa de frequências de ensaio compreendida entre $50 \mathrm{~Hz}$ e $100 \mathrm{kHz}$. Parte dos resultados expostos no trabalho para o conjunto operando em $50 \mathrm{~Hz}$ estão apresentados na Figura 61.

Em trabalho publicado em 2007, Mañana et al. demonstram mais um efeito da precariedade da qualidade da energia sobre os equipamentos de iluminação, através da comparação da sensibilidade ao flicker entre lâmpadas de vapor de sódio de alta pressão [33].

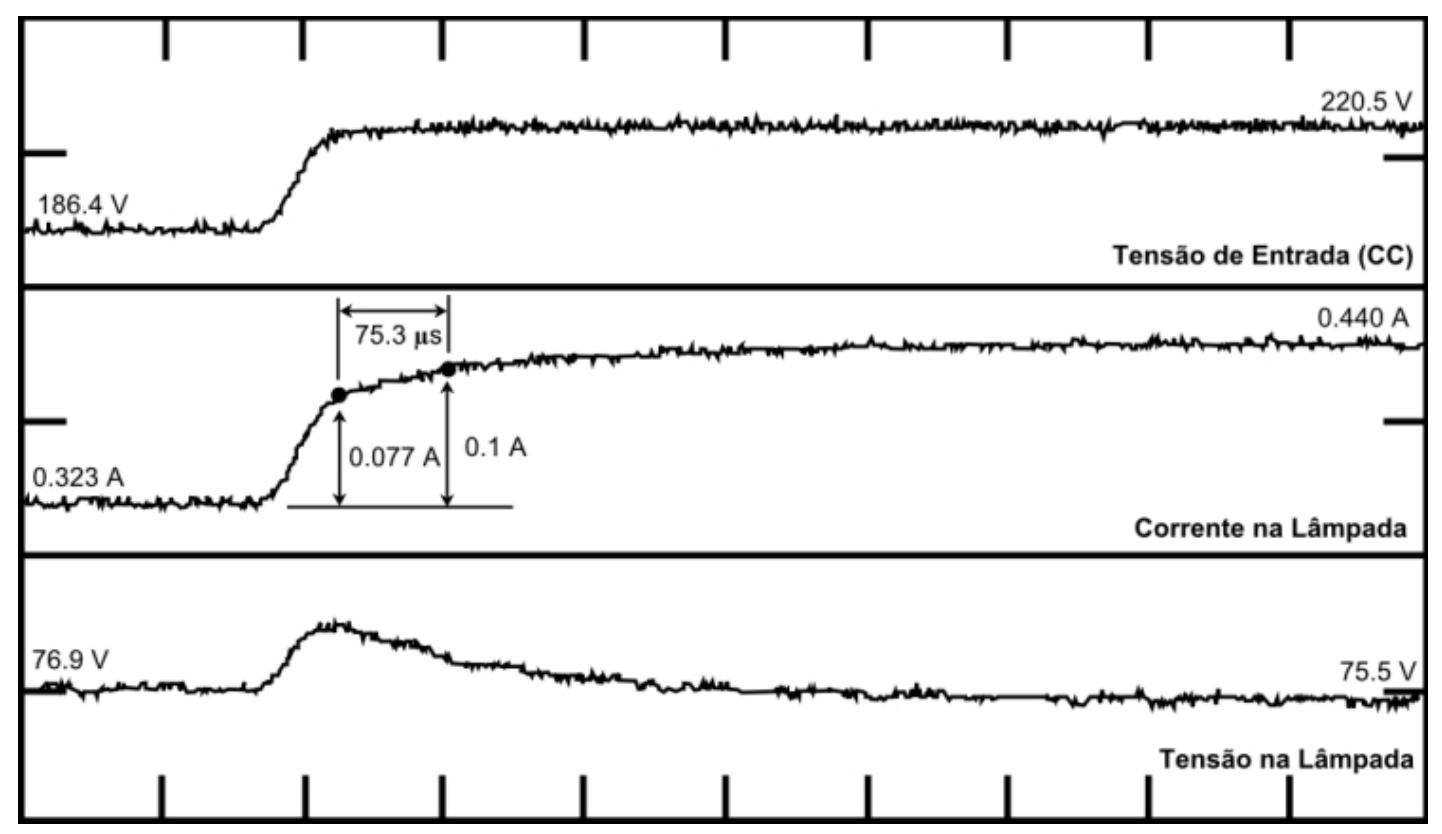

Figura 59 - Resposta ao degrau de tensão - valores medidos [31] 

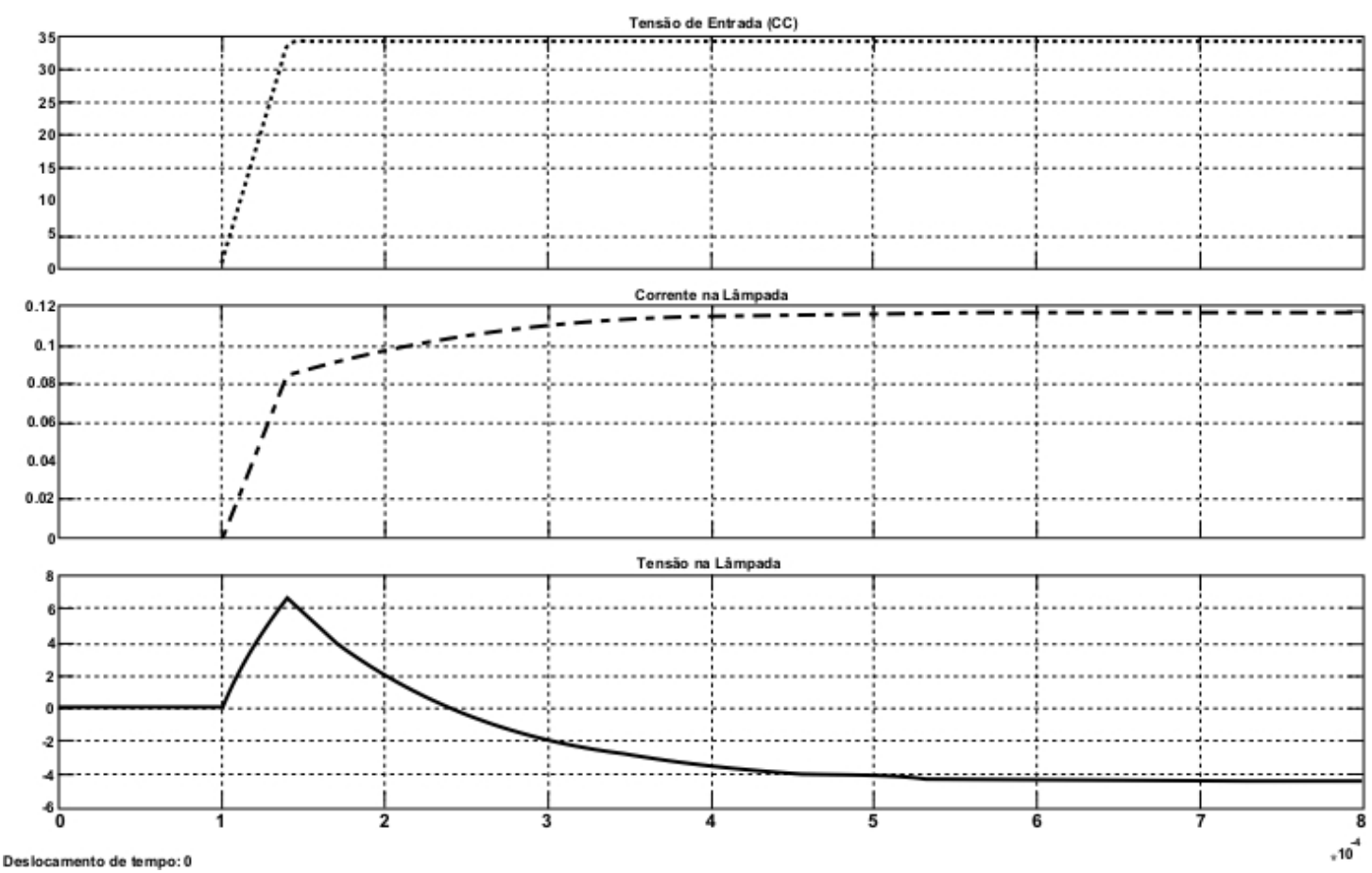

Figura 60 - Resposta ao degrau de tensão - simulação [31]

Nesta pesquisa estão relacionados os efeitos visuais e a variações introduzidas na alimentação da lâmpada, que resultam na degradação das características operacionais do dispositivo, comparados a um padrão de referência estabelecido por uma lâmpada incandescente.

Para tal avaliação, os pesquisadores empregaram a montagem esquematizada na Figura 62, com modulações em 1Hz, $10 \mathrm{~Hz}$ e $20 \mathrm{~Hz}$ e amplitudes de tensão de alimentação variando entre 5\% e 10\% sobre os valores nominais, aplicados a diferentes tipos de reatores. $\mathrm{O}$ aspecto da montagem experimental realizada para a pesquisa apresentada é mostrado na Figura 63.

Uma caracterização de lâmpada de vapor de sódio de alta pressão baseada na equação de balanço da energia, mostrada na Figura 64, foi proposta por Fabela et al. [34]. Através de uma implementação no ambiente SIMULINK®, obteve-se um modelo capaz de descrever o dispositivo em regime permanente operando entre $60 \mathrm{~Hz}$ e 40kHz com uma boa aproximação dos valores reais, como apresentado pela Figura 65. 


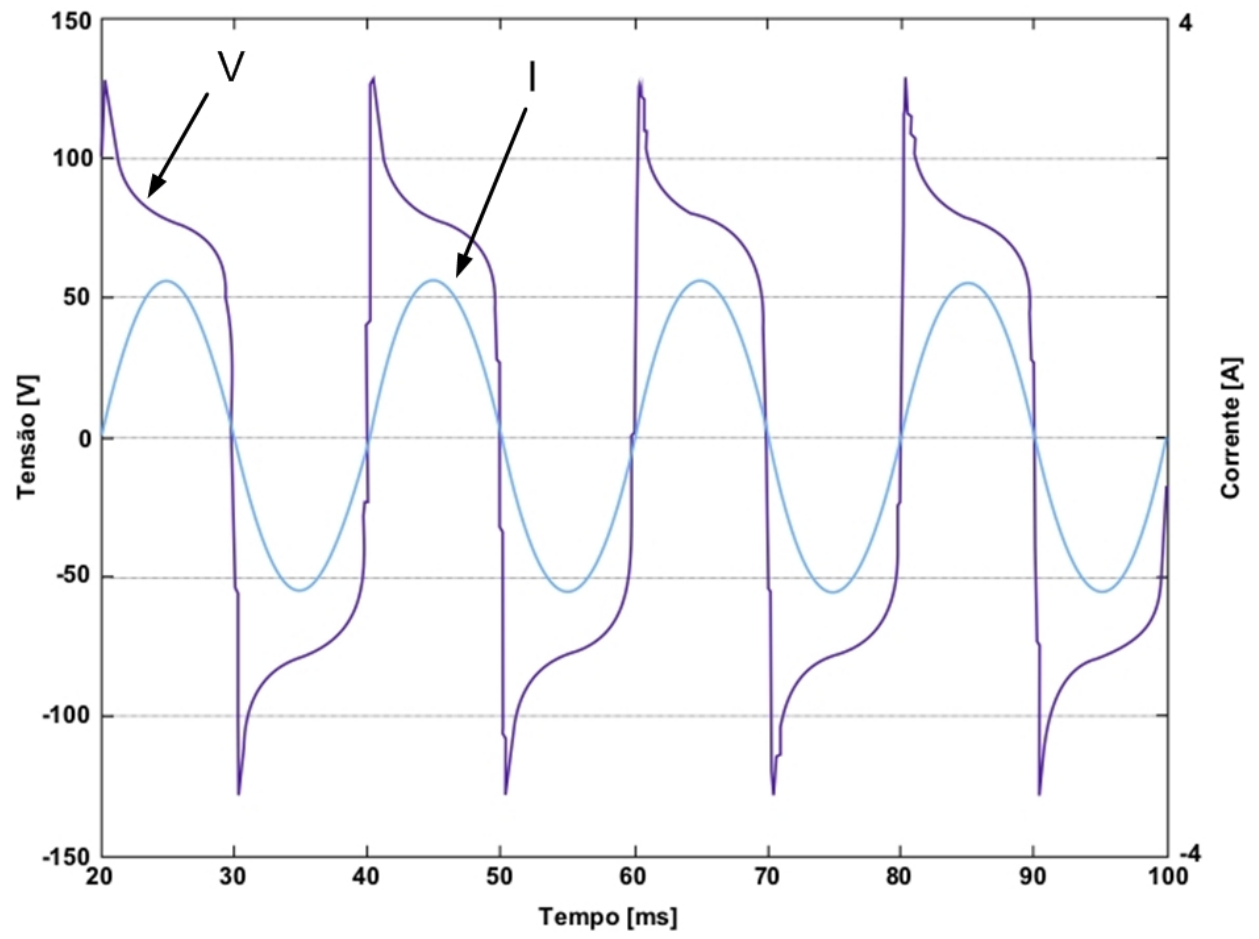

(a) Valores Medidos $(50 \mathrm{~Hz})$

(a) Tensão e corrente na lâmpada - dados experimentais $(50 \mathrm{~Hz})$

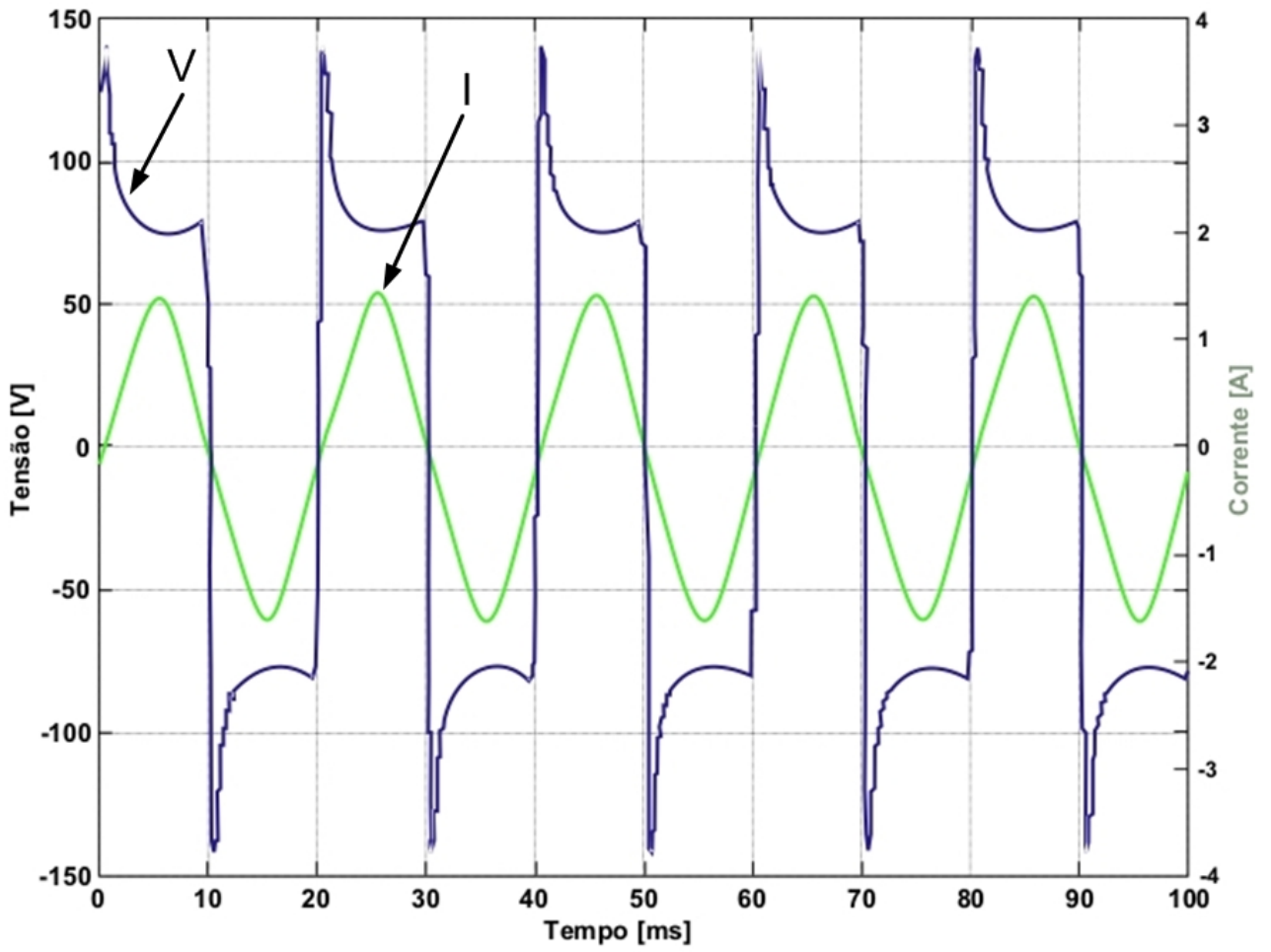

(b) Valores Simulados $(50 \mathrm{~Hz})$

(b) Tensão e corrente na lâmpada - simulação $(50 \mathrm{~Hz})$

Figura 61 - Modelagem de lâmpada HID de vapor de sódio [32] 


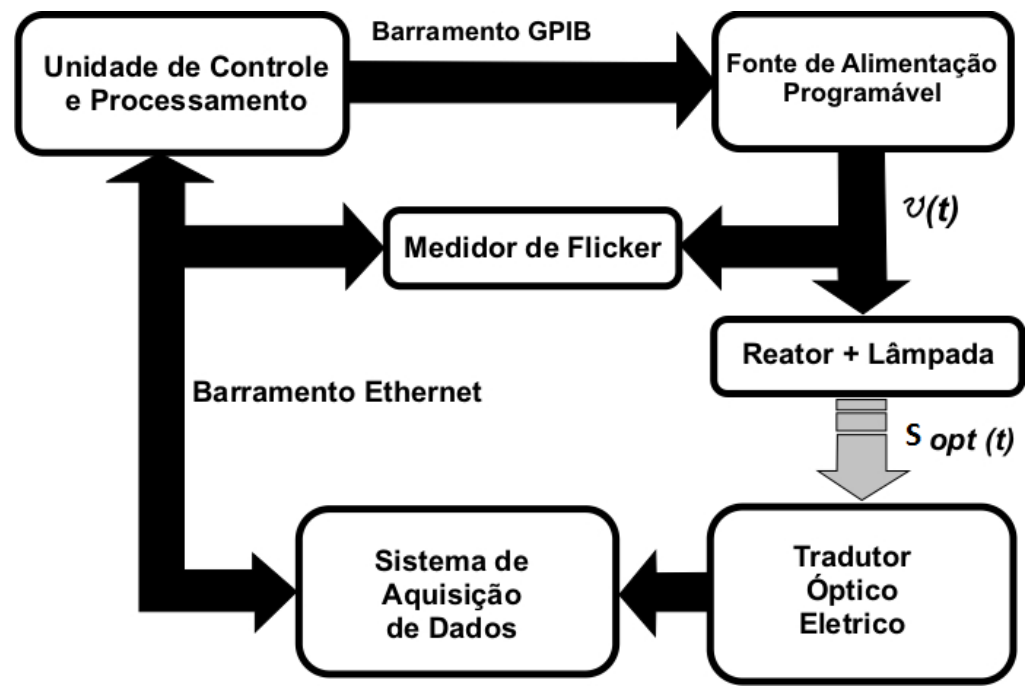

Figura 62 - Diagrama de blocos da montagem para verificação de sensibilidade ao flicker [33]

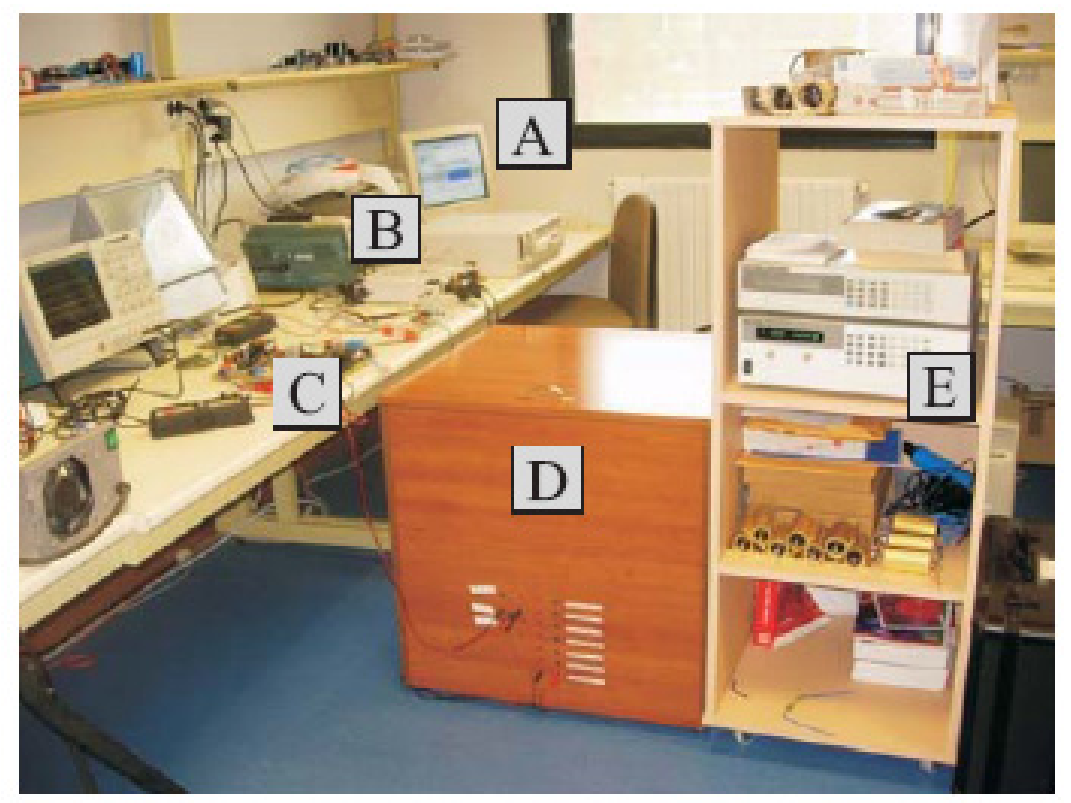

Figura 63 - Aspecto físico da montagem para verificação de sensibilidade ao flicker [33]

(A) Unidade de controle; (B) Medidor de flicker; (C) Reator; (D) Câmara escura com lâmpadas; (E) Fonte programável

El-Gawad apresenta em sua pesquisa o estudo dos efeitos de conteúdo harmônico e do fator de potência para diversas famílias de equipamentos de iluminação operando de forma individual e em conjunto [35], evidenciando assim o efeito cumulativo destas cargas presentes dentro de um mesmo sistema. 


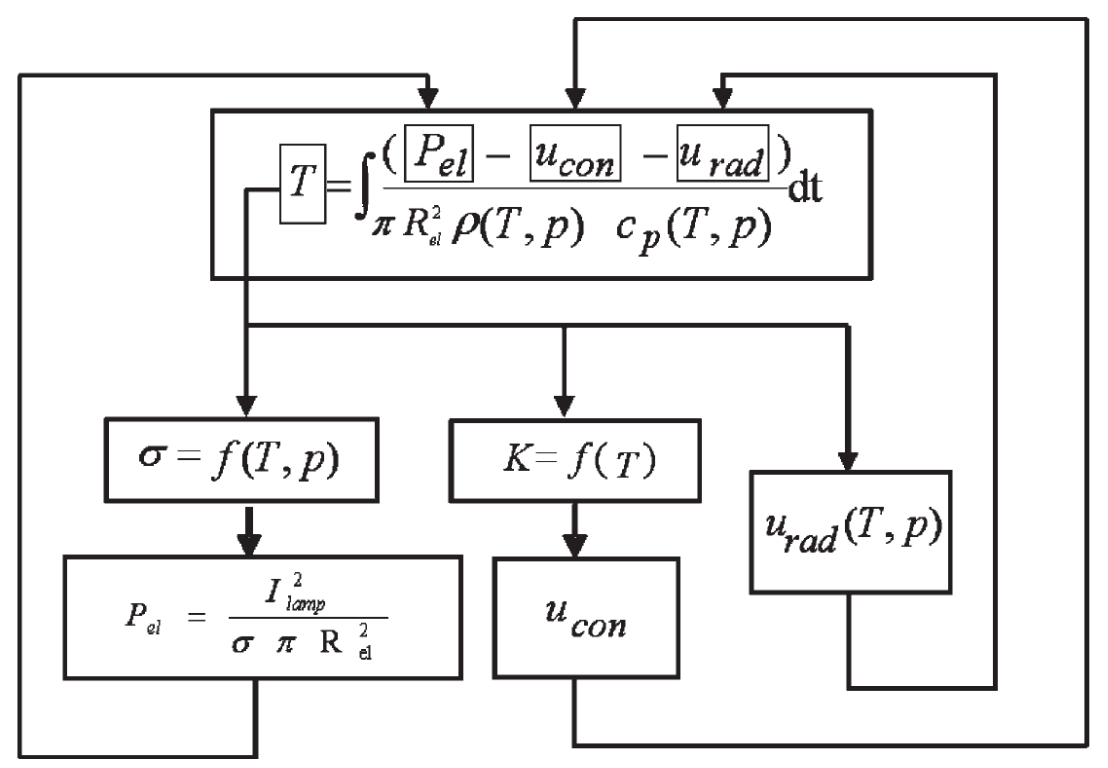

Figura 64 - Estrutura da equação de balanço da energia [34]

Os dados foram coletados por intermédio de um sistema de aquisição de dados (DAQ), e permitiram a comparação de vários tipos de lâmpadas, de descarga e de filamento, pelo ponto de vista da qualidade da energia elétrica.

Os resultados deste trabalho apresentam também a influência negativa que o emprego de capacitores para correção de fator de potência em equipamentos de iluminação exerce no conteúdo harmônico da corrente destes equipamentos.

\subsection{Considerações parciais}

Para as pesquisas envolvendo o desenvolvimento de modelos de lâmpadas de alta intensidade de descarga, nota-se a preocupação em caracterizar o dispositivo não apenas como componente isolado, mas sim inserido no contexto do sistema elétrico como carga não-linear. 
A precisão e o detalhamento dos modelos de lâmpadas de descarga obtidos tem se mostrado evidente com a evolução dos sistemas computacionais disponíveis, e em estudos mais recentes as chamadas ferramentas inteligentes têm mostrado aplicação na obtenção de parâmetros que tornam os modelos mais próximos do componente real.

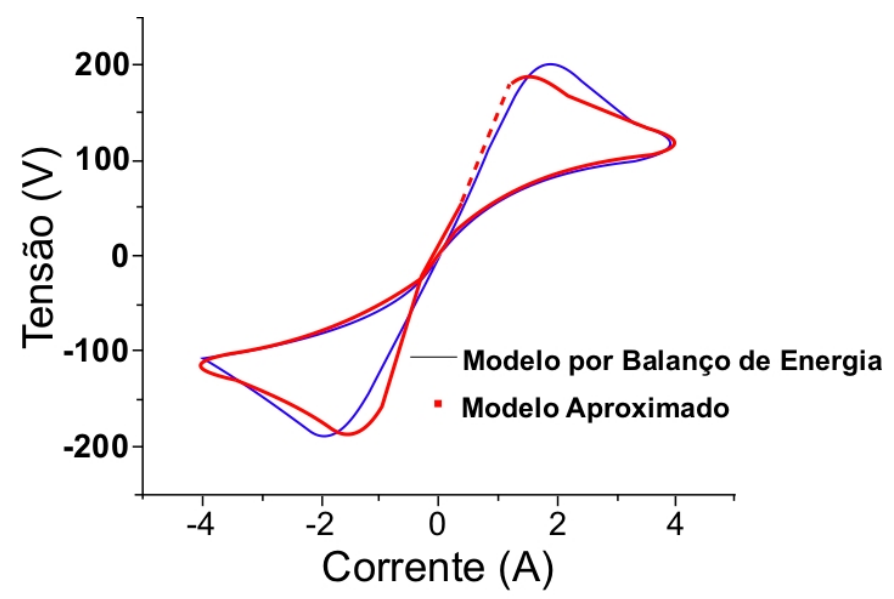

(a) Corrente senoidal, $60 \mathrm{~Hz}$

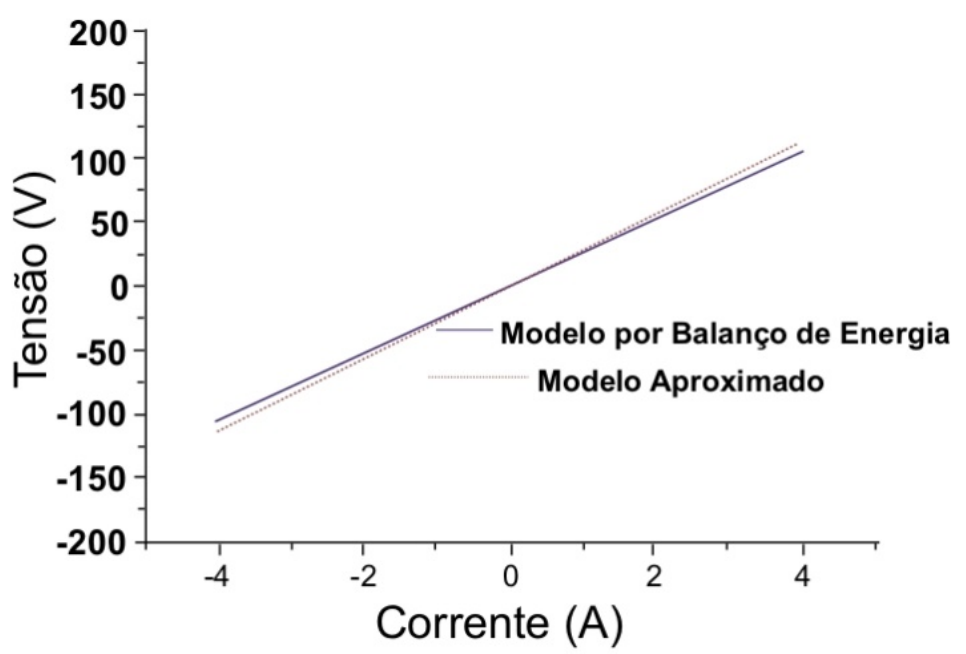

(b) Corrente quadrada, $40 \mathrm{kHz}$

Figura 65 - Curvas V-I: (a) Corrente senoidal, 60Hz; (b) Corrente quadrada, 40kHz [34]

Embora vários trabalhos publicados utilizem a geometria e os princípios físicos do dispositivo na construção de seu modelo, nota-se que grande parte das pesquisas adota como parâmetros de modelagem o próprio comportamento da lâmpada, 
obtido através de medições operacionais por meio de sistemas de aquisição digital de sinais.

Os distúrbios de qualidade da energia decorrentes do uso intenso deste tipo de carga têm motivado também um grande número de pesquisas, considerando especialmente efeito das harmônicas no sistema de distribuição.

Tornou-se evidente através desta revisão bibliográfica a lacuna existente em relação a modelos baseados no conteúdo harmônico de lâmpadas de descarga que caracterizem especificamente as regiões transitórias de operação.

Os desenvolvimentos apresentados também não citam ou quantificam os efeitos produzidos por variações transitórias na tensão de alimentação sobre sistemas de iluminação com lâmpadas de descarga de alta intensidade.

\subsection{Modelagem matemática das lâmpadas de descarga}

Como exposto pela revisão bibliográfica apresentada, grande parte dos modelos matemáticos desenvolvidos para os dispositivos baseados em arcos elétricos descreve as características de tensão e corrente do dispositivo em determinada condição de operação.

Estes modelos são, em muitos casos, simplificados para aplicações limitadas, ou pouco abrangentes, como por exemplo, o desenvolvimento dos dispositivos de limitação de corrente $[7,8,9,10,13,16,20,21,31]$, o estudo termodinâmico do dispositivo $[11,12,26,27,29]$, e mais recentemente a preocupação com seu comportamento inserido no sistema elétrico e a avaliação dos distúrbios de qualidade da energia oriundos de sua característica não-linear [24, 25, 26, 28, 33, 35]. 


\subsubsection{Modelos de regime permanente}

Os modelos em regime permanente oferecem a representação das condições operacionais do dispositivo em regiões livres de fenômenos transitórios [6, 9, $10,12,22,34]$. Permitem desta forma a avaliação de suas características operacionais com detalhamento suficiente para a determinação dos níveis de distorção harmônica, estabelecimento do equilíbrio termodinâmico e a obtenção dos índices de desempenho da lâmpada após atingir as condições nominais de operação.

Estes modelos podem, em alguns casos, contemplar as regiões limites de operação das lâmpadas de descarga, através da inserção dos pontos de instabilidade operacional relativos à partida e extinção do arco, além do processo de reignição, mas sem a garantia de reprodução fidedigna dos efeitos elétricos experimentados pelo sistema de alimentação durante estas fases transitórias.

\subsubsection{Modelos de regime transitório}

O desenvolvimento de modelos para operação em regime transitório permite a representação do dispositivo em determinadas condições de operação não contempladas por modelos de regime permanente, como por exemplo os transitórios de partida das lâmpadas de descarga ou a resposta às variações na tensão de alimentação $[11,15,18,20]$.

Embora mais completos que os modelos de regime permanente, estes modelos apresentam maior complexidade computacional, inviabilizando em alguns casos a simulação do dispositivo em conjunto com outros elementos do sistema elétrico. A busca por modelos simplificados de lâmpadas de descarga operando em regime transitório tem por objetivo, desta forma, a redução do esforço computacional envolvido em simulações de sistema elétricos de relativa complexidade. 


\subsubsection{Modelagem teórica}

Entende-se por modelo teórico aquele desenvolvido a partir de dados construtivos, considerando a geometria e os materiais empregados, bem como os aspectos físicos do fenômeno, resultante na sustentação de uma coluna de plasma capaz de emitir radiação dentro de um espectro de frequências adequado a uma eficiente conversão para o espectro das radiações visíveis.

A representação obtida a partir destes modelos é bastante detalhada, permitindo a caracterização do dispositivo em todas as suas regiões de operação com grande precisão, atendendo aos aspectos elétricos, térmicos e físicos do elemento modelado [9, 10, 12, 13, 17, 23, 32].

A contrapartida ao uso frequente deste tipo de modelagem é a complexidade na obtenção dos parâmetros construtivos, que na maioria dos casos constituem dados de divulgação restrita, tornando complexa sua aplicação em sistemas onde se encontram dispositivos de fabricantes e características diversas.

A própria complexidade computacional do modelo obtido deve ser considerada, visto que todos os aspectos físicos do dispositivo e do meio onde este se encontra instalado devem ser cuidadosamente determinados para que a resposta do modelo apresente um índice de fidelidade satisfatório.

\subsubsection{Modelagem semi-teórica}

Uma alternativa viável à modelagem teórica é a modelagem obtida através da analise de determinados parâmetros de interesse do dispositivo, baseada no comportamento operacional do elemento em análise. Este tipo de modelagem, conhecida como semi-teórica, explora os pontos relevantes do modelo teórico e introduz 
simplificações no modelo matemático clássico que tornam sua aplicação menos complexa $[6,7,11,21,28,35]$.

Embora a representação do dispositivo seja relativamente empobrecida quando comparado com a formalidade obtida no modelo teórico, os resultados de simulações empregando estes modelos mostram-se capazes de representar os principais traços característicos dos elementos modelados, com a vantagem de serem facilmente obtidos e exigirem menor esforço computacional nas ferramentas de simulação.

A obtenção de modelos semi-teóricos pode ser subdividida entre as seguintes etapas:

1-Delimitação da abrangência do modelo

2-Ensaio do dispositivo nas condições definidas anteriormente

3-Levantamento das curvas de operação estáticas e dinâmicas

4-Identificação dos principais aspectos operacionais

5-Obtenção do equacionamento das curvas obtidas

6-Análise dos resultados para outras condições de operação

No caso específico das lâmpadas de descarga, os modos usuais de obtenção do equacionamento destes modelos a partir de dados operacionais estão: a decomposição dos valores de tensão e corrente do dispositivo em suas n-ésimas componentes harmônicas, o emprego de redes neurais artificiais e o uso de algoritmos genéticos.

Através destas ferramentas torna-se possível a aproximação matemática do comportamento do dispositivo com precisão aceitável sem, no entanto haver necessidade de se conhecer os parâmetros construtivos do referido elemento. 


\subsubsection{Modelagem baseada em ferramentas inteligentes}

Com base em pesquisas realizadas na literatura especializada, foi possível notar o reduzido número de trabalhos envolvendo a modelagem de lâmpadas de descarga a partir de ferramentas computacionais de inteligência artificial. Dentre os trabalhos citados na revisão apresentada, as pesquisas desenvolvidas em $[20,28]$ empregaram algoritmos genéticos e o trabalho mostrado em [30] aplicou redes neurais artificiais na determinação de parâmetros.

Não foi observada na literatura a citação de trabalhos envolvendo a construção de modelos empregando redes neurais artificiais na caracterização direta de lâmpadas de descarga de alta intensidade, como proposto neste trabalho. Por este motivo, novamente pode-se afirmar a relevância da pesquisa proposta no preenchimento de uma lacuna presente na aplicação de redes neurais artificiais na modelagem deste tipo de dispositivo. 


\section{FUNDAMENTOS DA QUALIDADE DA ENERGIA ELÉTRICA}

A aplicação de lâmpadas de descarga em um sistema elétrico remete à sensibilidade destes dispositivos a distúrbios na tensão de alimentação [4], e também o efeito que estes dispositivos produzem em decorrência de sua não-linearidade [36]. Este capítulo apresenta a definição de alguns dos fenômenos elétricos relacionados com a Qualidade da Energia Elétrica (QEE), de modo a contextualizar este estudo das lâmpadas de descarga.

Os fenômenos elétricos relacionados à degradação da qualidade da energia elétrica podem ser classificados em categorias de acordo com o seu tempo de duração, seu conteúdo espectral e a amplitude típica que atingem no sistema. Considerando estes princípios, serão apresentados ao longo deste capítulo os diferentes distúrbios, subdivididos em transitórios, variações de tensão de curta duração, variações de tensão de 
longa duração, desequilíbrio de tensão, distorções na forma de onda, flutuação de tensão e variações da frequência do sistema.

\subsection{Fenômenos Elétricos Transitórios Relacionados com a QEE}

Entende-se por transitórios eletromagnéticos as manifestações ou respostas elétricas locais ou nas adjacências, oriundas de alterações súbitas nas condições operacionais de um sistema de energia elétrica. Geralmente, a duração de um transitório é muito pequena, mas de grande importância, uma vez que os equipamentos presentes nos sistemas elétricos estarão submetidos a grandes solicitações de tensão e/ou corrente [36].

Os fenômenos transitórios podem ser classificados em dois grupos: os chamados transitórios impulsivos, causados por descargas atmosféricas, e os transitórios oscilatórios, causados por chaveamentos.

\subsubsection{Transitórios Impulsivos}

Normalmente causado por descargas atmosféricas, um transitório impulsivo pode ser definido como uma alteração repentina nas condições de regime permanente da tensão, corrente ou ambas, caracterizando-se por apresentar impulsos unidirecionais em polaridade (positivo ou negativo) e nível de frequência bastante diferenciado com relação à frequência da rede elétrica [36]. A Figura 66 ilustra uma corrente típica de um transitório impulsivo, oriundo de uma descarga atmosférica.

Os transitórios impulsivos geralmente são definidos por um tempo de subida e outro de descida do impulso, os quais, também, podem ser expressos pelo seu conteúdo espectral. Para exemplificar, um impulso transitório tendo como parâmetros 1,2 $\times$ $50 \mu$ s e $2000 \mathrm{~V}$, o que significa que o mesmo atinge seu valor máximo de $2000 \mathrm{~V}$ em um tempo de $1,2 \mu$ s e, posteriormente, decai até a metade de seu valor máximo no tempo de 50 $\mu \mathrm{s}$. 


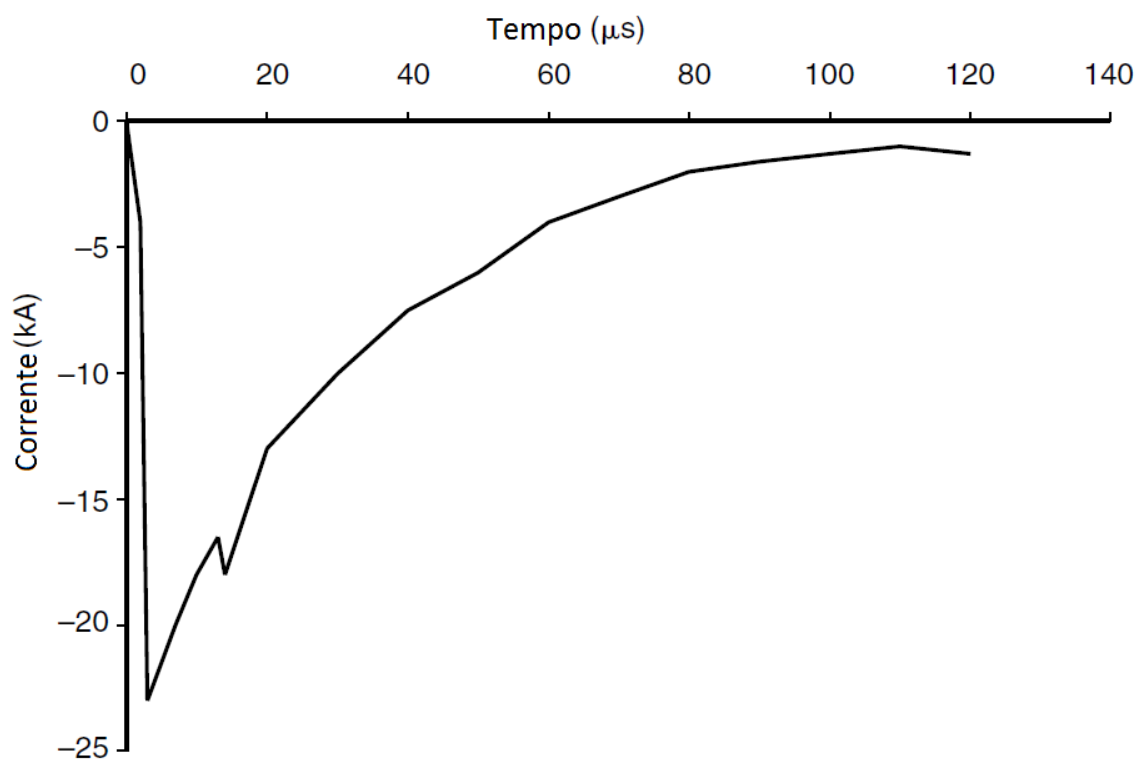

Figura 66 - Corrente transitória impulsiva oriunda de uma descarga atmosférica [36]

Por se tratarem de transitórios causados por descargas atmosféricas, é de fundamental importância observar qual o nível da tensão no ponto de ocorrência da descarga. Em sistemas de distribuição o caminho mais provável para as descargas atmosféricas é através de um condutor fase, no primário ou no secundário, causando altas sobretensões no sistema.

Uma descarga diretamente na fase geralmente causa alta sobretensão na linha próxima ao ponto de incidência e pode gerar não somente um transitório impulsivo, mas também uma falta acompanhada de afundamentos de tensão de curta duração e interrupções.

Altas sobretensões transitórias podem também ser geradas por descargas que fluem ao longo do condutor terra. Existem numerosos caminhos através dos quais as correntes de descarga podem penetrar no sistema de aterramento, tais como o terra do primário ou do secundário de um transformador e as estruturas do sistema de distribuição. Os principais problemas relacionados com a QEE causados por estas correntes no sistema de aterramento são os seguintes: 
-Considerável elevação do potencial do terra local em relação a outros terras. Equipamentos eletrônicos sensíveis que são conectados entre duas referências de terra, tal como um computador conectado ao telefone através de um modem, podem falhar quando submetidos a altos níveis de tensão.

-Indução de altas tensões nos condutores fase, quando as correntes passam pelos cabos a caminho do terra.

No caso de descargas incidentes em pontos de extra alta tensão, o surto se propaga ao longo da linha em direção aos seus terminais, podendo atingir os equipamentos instalados em subestações de manobra ou estações abaixadoras.

Esta onda de tensão, ao percorrer a linha desde o ponto de incidência até as subestações abaixadoras para a tensão de distribuição, tem a sua crista atenuada consideravelmente, atenuando ou eliminando os efeitos advindos de descargas atmosféricas ocorridas em nível de transmissão para os consumidores ligados em nível de média e baixa tensão. Os consumidores atendidos em tensão de transmissão, e portanto localizados eletricamente mais próximos ao ponto de descarga, estarão sujeitos a tais efeitos, podendo ocorrer danos a equipamentos em suas instalações [37].

\subsubsection{Transitórios Oscilatórios}

Um transitório oscilatório é caracterizado por uma alteração repentina nas condições de regime permanente da tensão e/ou corrente possuindo valores de polaridade positiva e negativa. Os tipos de transitórios oscilatórios podem ser definidos em função do conteúdo espectral, duração e magnitude da tensão, e são decorrentes da energização de linhas, corte de corrente indutiva, eliminação de faltas, chaveamento de bancos de capacitores e transformadores, e outras manobras no sistema elétrico.

Os transitórios oscilatórios de baixa frequência frequentemente encontrados em sistemas de subtransmissão e distribuição têm origem em vários tipos de 
eventos. O mais frequente destes é a energização de bancos de capacitores, o qual geralmente resulta em oscilações de tensão com frequência entre 300 e $900 \mathrm{~Hz}$, com magnitude máxima próxima a 2,0 pu, sendo valores típicos de 1,3 a 1,5 pu com uma duração entre 0,5 e 3 ciclos dependendo das características de amortecimento do sistema [36]. A Figura 67 ilustra o resultado da simulação da energização de um banco no instante da conexão a um barramento de $34,5 \mathrm{kV}$.

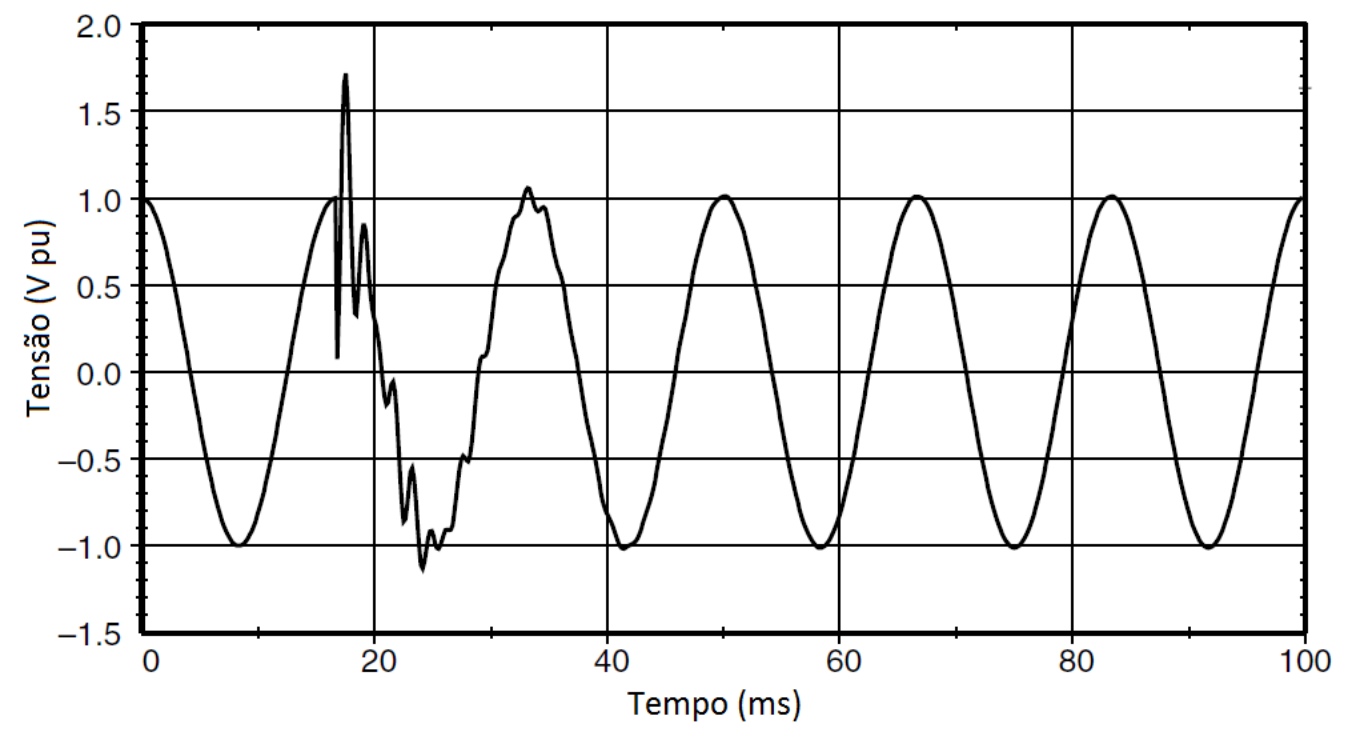

Figura 67 - Transitório de energização de um banco de capacitores em barramento de 34,5kV [36]

Considerando o crescente emprego de capacitores pelas concessionárias para a manutenção dos níveis de tensão, e pelas indústrias com vistas à correção do fator de potência, surge uma questão especial relativa à possibilidade de se estabelecer uma condição de ressonância. Tal condição pode ser satisfeita devido às oscilações de altas frequências, entre o sistema da concessionária e a indústria, e assim ocorrer uma amplificação das tensões transitórias, bem superiores às citadas anteriormente, podendo alcançar níveis de tensão entre 3 e 4 pu.

Transitórios oscilatórios com frequências menores do que $300 \mathrm{~Hz}$ podem também ser encontrados nos sistemas de distribuição, e estão geralmente associados aos fenômenos de ferrorressonância e energização de transformadores. 
Os transitórios oscilatórios de alta frequência são geralmente o resultado de uma resposta do sistema a um transitório impulsivo, isto é, podem ser causados por descargas atmosféricas ou por chaveamento de circuitos indutivos [36].

A desenergização de cargas indutivas pode gerar impulsos de alta frequência. Apesar de serem de curta duração, estes transitórios podem interferir na operação de cargas eletrônicas. Filtros de alta-frequência e transformadores isoladores podem ser usados para proteger as cargas contra este tipo de transitório.

Conforme apresentado, existem diferentes meios causadores de oscilações transitórias e algumas técnicas podem ser utilizadas na tentativa de se reduzir os níveis dos transitórios causados, seja por chaveamentos ou por descargas atmosféricas. Como por exemplo os transitórios oriundos de surtos de chaveamento em redes de distribuição, podem ter seu grau de incidência e magnitudes reduzidas através de uma reavaliação das filosofias de proteção e investimentos para melhorias nas redes. Esta medida visa o aumento da capacidade da rede evitando que bancos de capacitores venham a ser exigidos [37].

\subsection{Variações de Tensão de Curta Duração Relacionadas com a QEE}

As variações de tensão de curta duração podem ser caracterizadas por alterações instantâneas, momentâneas ou temporárias, dependendo da duração. Tais variações de tensão são, geralmente, causadas por condições de falta, energização de grandes cargas as quais requerem altas correntes de partida ou por intermitentes falhas nas conexões de cabos do sistema. Dependendo do local da falta e das condições do sistema, a falta pode causar tanto um afundamento de tensão temporário, como uma elevação de tensão, ou ainda uma interrupção completa do sistema elétrico [36]. 


\subsubsection{Interrupção}

Uma interrupção de curta duração ocorre quando a tensão de suprimento decresce para um valor menor que $0,1 \mathrm{pu}$ por um período de tempo não superior a 1 minuto [38].

Este tipo de interrupção pode ser causado por faltas no sistema de energia, falhas de equipamentos e mal funcionamento de sistemas de controle. A duração de uma interrupção, devido a uma falta no sistema da concessionária, é determinada pelo tempo de operação dos dispositivos de proteção. Religadores programados para operar instantaneamente, geralmente limitam a interrupção a tempos inferiores a 30 ciclos. Religadores temporizados podem originar interrupções momentâneas ou temporárias, dependendo da escolha das curvas de operação do equipamento [37].

Algumas interrupções podem ser precedidas por um afundamento de tensão quando estas são devidas a faltas no sistema supridor. O afundamento de tensão ocorre no período de tempo entre o início de uma falta e a operação do dispositivo de proteção do sistema. A Figura 68 exemplifica uma interrupção momentânea sendo precedida por um afundamento de tensão. Observa-se que a tensão cai para um valor de 20\%, com duração de 3 ciclos e, logo após, ocorre a perda total do suprimento.

Os afundamentos de tensão de curta duração são caracterizados por uma redução no valor eficaz da tensão, entre 0,1 e 0,9 pu, na frequência fundamental, com duração entre 0,5 ciclo e 1 minuto [38]. Detalhes mais aprofundados para os afundamentos de tensão podem ser encontrados na referência [39].

Afundamentos de tensão com período inferior a 10ms e abaixo de 10\% não são levados em consideração. Isto se explica pelo fato de que os distúrbios com período de duração abaixo de $10 \mathrm{~ms}$ e tensão residual menor que $10 \%$ são considerados como transitórios, e são toleradas pela maioria dos equipamentos elétricos. 


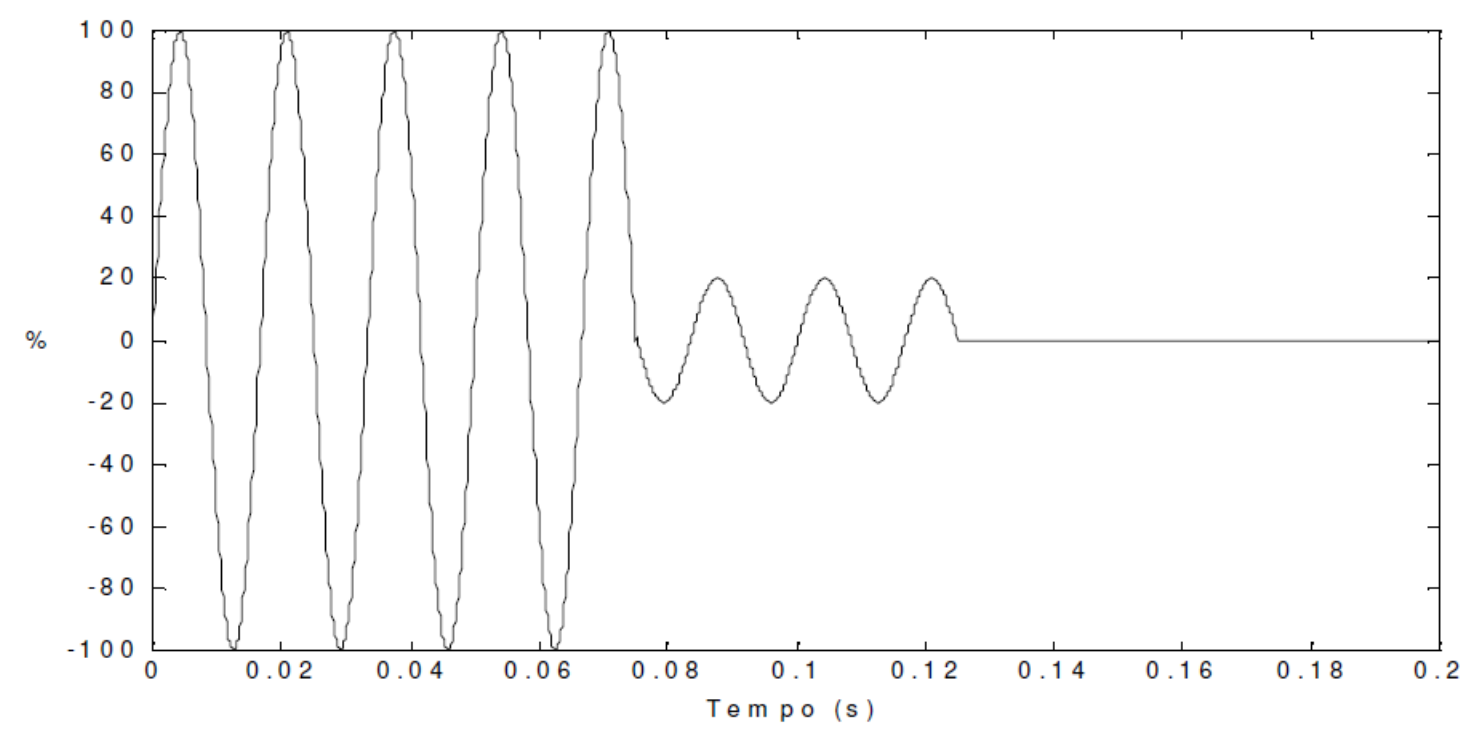

Figura 68 - Interrupção momentânea devido a um curto-circuito e atuação da proteção [36].

\subsubsection{Afundamento de tensão de Curta Duração}

Este tipo de distúrbio está associado, principalmente, a curtoscircuitos ocorridos nas redes de distribuição. Mas pode também ser causado pela energização de grandes cargas, partida de grandes motores e pela corrente inrush de um transformador [37].

A Figura 69 ilustra um afundamento de tensão de curta duração típico, causada por uma falta fase-terra [36]. Observa-se um decréscimo para $80 \%$ na tensão por um período de aproximadamente 3 ciclos, até que o equipamento de proteção da subestação opere e elimine a corrente de falta. Neste caso o afundamento de tensão é dito ser de caráter instantâneo. Entretanto, as características do afundamento de tensão diante de uma determinada falta depende de vários fatores como: a natureza da falta, sua posição relativa a outros consumidores ligados na rede e o tipo de filosofia de proteção adotada no sistema. 
Para ilustrar o afundamento de tensão causado pela partida de um motor de indução tem-se a Figura 70 [36], que apresenta o decréscimo no valor eficaz da tensão.

Durante a partida de um motor de indução, este absorve uma corrente de 6 a 10 vezes a corrente nominal, resultando em uma queda significativa na tensão de suprimento. Observa-se neste caso, que a tensão, apresentada em seu valor eficaz, cai rapidamente para 0,8 pu e, num período de aproximadamente 3 segundos, retorna ao seu valor nominal [36].

\section{Tensão (\%)}

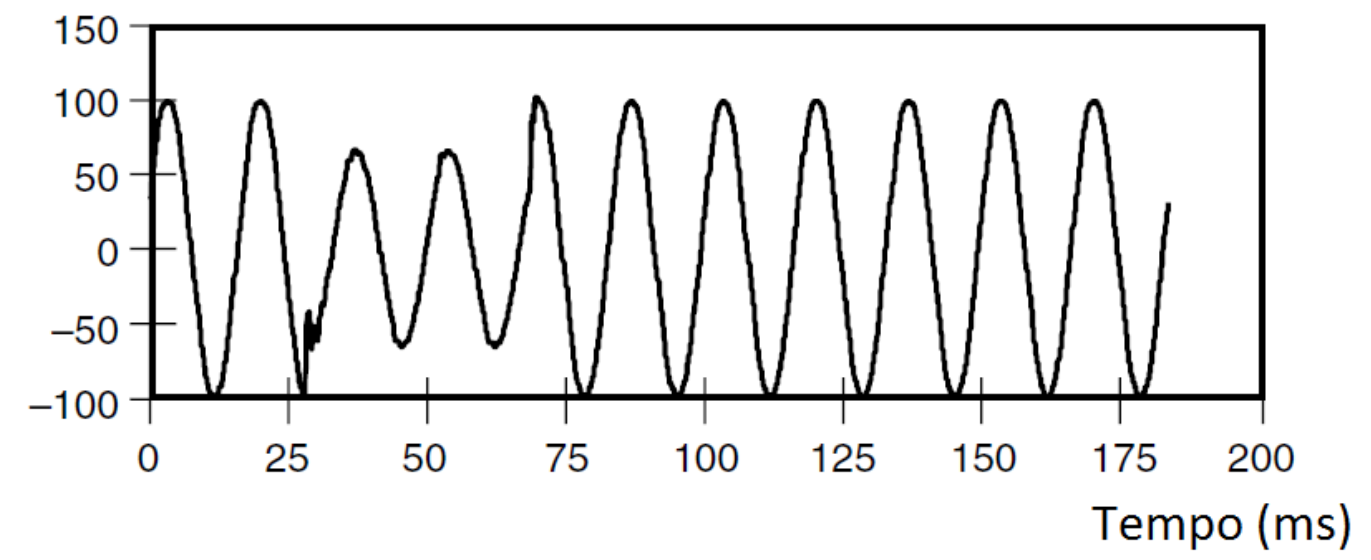

Figura 69 - Afundamento de tensão causado por uma falta fase-terra [36].

Como efeito deste distúrbio tem-se principalmente a má operação de equipamentos eletrônicos, em especial os sistemas computadorizados, que tem sido alvo de preocupações de órgãos de pesquisa em QEE. Entretanto, determinar os níveis de sensibilidade de tais equipamentos torna-se uma tarefa difícil, devido ao grande número de medições necessárias para a coleta de dados, além das dificuldades de se ter equipamentos de medição em condições reais de campo.

Sendo os computadores uma fonte de preocupação no que se refere aos afundamentos de tensão, uma vez que os dados armazenados na memória podem ser 
totalmente perdidos em condições de subtensões indesejáveis, foi estabelecido pela ANSI/IEEE (American National Standards Institute/Institute of Electrical and Electronic Engineering), e pelo ITIC (Information Technology Industry Council) limites de tolerância relativos a distúrbios no sistema elétrico.

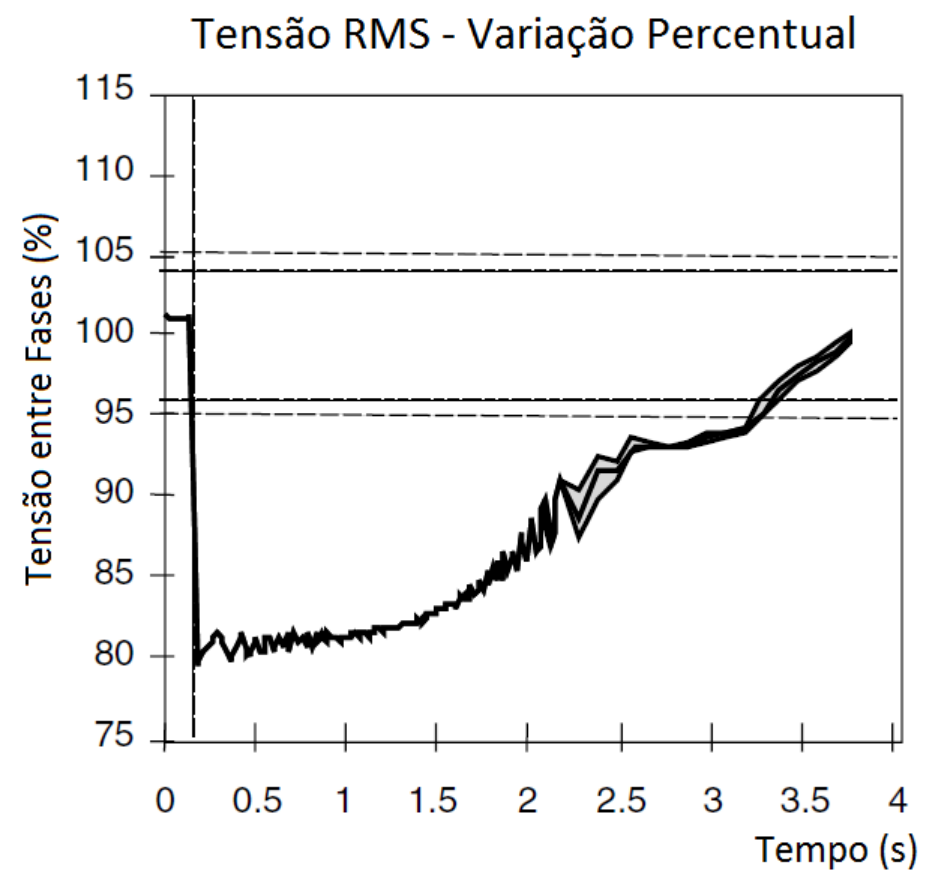

Figura 70 - Decréscimo de tensão ocorrido pela partida de um motor [36].

Estes trabalhos conduziram à elaboração de um gráfico contendo as curvas de tolerância, representadas pela curva de suportabilidade (superior) e de sensibilidade (inferior) a eventos de tensão, cujo aspecto é mostrado na Figura 71, e onde os níveis de tensão, abaixo ou acima do valor nominal, conjugados aos respectivos tempos de ocorrência, representam os limites dentro dos quais um computador típico pode resistir a distúrbios de afundamentos ou elevações de tensão sem apresentar falhas. Nota-se que a sensibilidade e a suportabilidade a eventos de tensão de um computador é dependente do período de duração do distúrbio.

Existem várias medidas que podem ser tomadas por parte de consumidores, concessionárias e fabricantes de equipamentos no sentido de diminuir o 
número e a severidade dos afundamentos de tensão de curta duração. Algumas destas medidas são [36]:

-Utilização de transformadores ferrorressonantes, conhecidos também como CVT's (Constant Voltage Transformers).

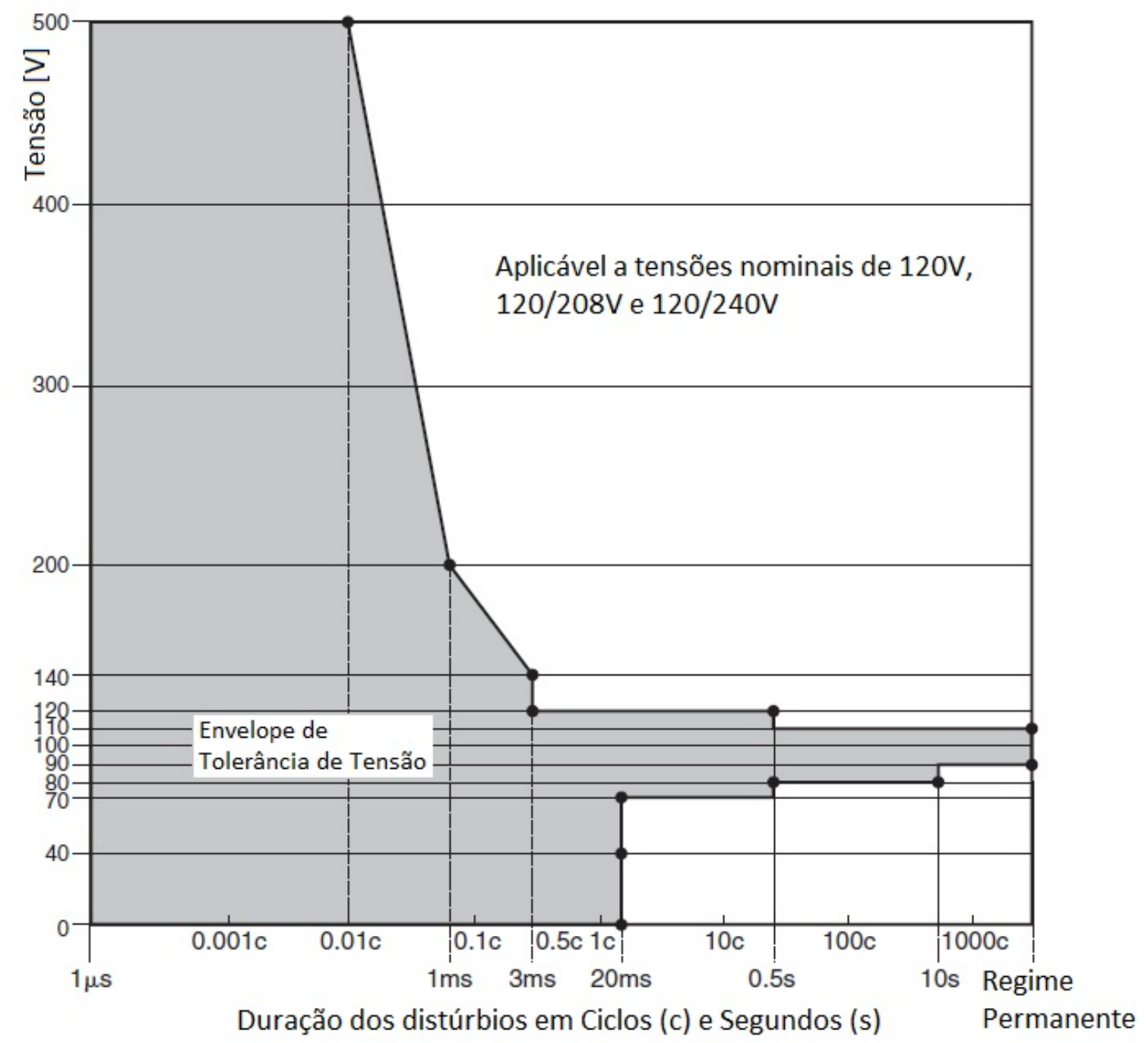

Figura 71 - Tolerâncias típicas de tensão para computadores (curva ITIC) [36].

Este equipamento pode controlar a maioria das condições de afundamento de tensão. São utilizados especialmente para cargas com potências constantes e de pequenos valores. Transformadores ferrorressonantes são basicamente transformadores de relação de transformação 1:1, altamente excitados em suas curvas de 
saturação, fornecendo assim uma tensão de saída que não é significativamente afetada pelas variações da tensão de entrada.

- Utilização de UPS's (Uninterruptible Power Supply).

Os tipos básicos de UPS's fundamentam-se nas operações on-line e standby. Estes dispositivos podem ser usados para períodos de interrupção superiores a 15 minutos de duração. A UPS híbrida, que corresponde a uma variação da UPS standby, também pode ser usada para interrupções de longa duração.

- Utilização de conjuntos motor-gerador (M-G).

Estes conjuntos existem em uma grande variedade de potências e configurações, sendo capazes de suprir uma saída constante. A inércia do volante acoplado mecanicamente ao conjunto faz com que o rotor do gerador mantenha a rotação caso ocorra a falta de energia.

- Utilização de um dispositivo magnético supercondutor de armazenamento de energia.

Este dispositivo utiliza um magneto supercondutor para armazenar energia da mesma forma que uma UPS utiliza baterias. Os projetos na faixa de 1 a $5 \mathrm{MJ}$ são chamados de micro-SMES (Superconducting magnetic energy storage). A principal vantagem deles é a grande redução do espaço físico necessário ao magneto, quando esta solução é comparada ao espaço para as baterias. Os projetos iniciais dos micro-SMES estão sendo testados em vários locais nos EUA com resultados favoráveis [37].

- Utilização de métodos de partida de motores.

Dentre os mais utilizados pode-se citar os seguintes métodos de

partida:

- Partida suave (Soft Starter);

- Partida por meio de autotransformadores; 
- Partida por meio de resistência e reatância;

- Partida por meio de enrolamento parcial;

- Partida pelo método estrela-triângulo.

- Melhorar as práticas para o restabelecimento do sistema da concessionária em caso de faltas.

Isto implica em adicionar religadores de linha, eliminar as operações rápidas de religadores e/ou disjuntores, adicionar sistemas do tipo Network e melhorar o projeto do alimentador. Estas práticas podem reduzir o número e/ou a duração de interrupções momentâneas e afundamentos de tensão, mas não podem garantir por completo a eliminação das faltas nos sistemas das concessionárias.

- Adotar medidas de prevenção contra faltas no sistema da concessionária.

Estas medidas incluem atividades como poda de árvores, colocar pára-raios de linha, manutenção dos isoladores, blindagem de cabos, modificar o espaçamento entre condutores e melhorar o sistema de aterramento.

\subsubsection{Elevação de tensão de Curta Duração}

Uma elevação de tensão de curta duração é definida como um aumento entre 1,1 e 1,8 pu na tensão eficaz, considerando-se a frequência do sistema, com duração entre 0,5 ciclo a 1 minuto [36].

Assim como os afundamentos de tensão, as elevações de tensão estão geralmente associadas com as condições de falta no sistema, principalmente no que diz respeito ao curto-circuito fase-terra, visto que nestas condições as fases não defeituosas experimentam uma elevação de tensão. Esta elevação de tensão pode atingir num sistema a 4 fios multi-aterrado, valores próximos a 1,25 pu [5]. Este fenômeno pode também estar associado à saída de grandes blocos de cargas ou à energização de grandes bancos de 
capacitores, porém, com uma incidência pequena se comparada com as sobretensões provenientes de faltas fase-terra nas redes de transmissão e distribuição [36]. A Figura 72 ilustra uma elevação de tensão típica, que poderia ser causada por uma falta fase-terra.

A severidade de uma elevação de tensão durante uma condição de falta é função do local da falta, da impedância do sistema e do aterramento. A duração da elevação de tensão está intimamente ligada aos ajustes dos dispositivos de proteção, à natureza da falta (permanente ou temporária) e à sua localização na rede elétrica.

Em situações de elevação de tensão oriundas de saídas de grandes cargas ou energização de grandes bancos de capacitores, o tempo de duração das elevações depende da resposta dos dispositivos reguladores de tensão das unidades geradoras, do tempo de resposta dos transformadores de tap variável e da atuação dos dispositivos compensadores que porventura existam no sistema [36].

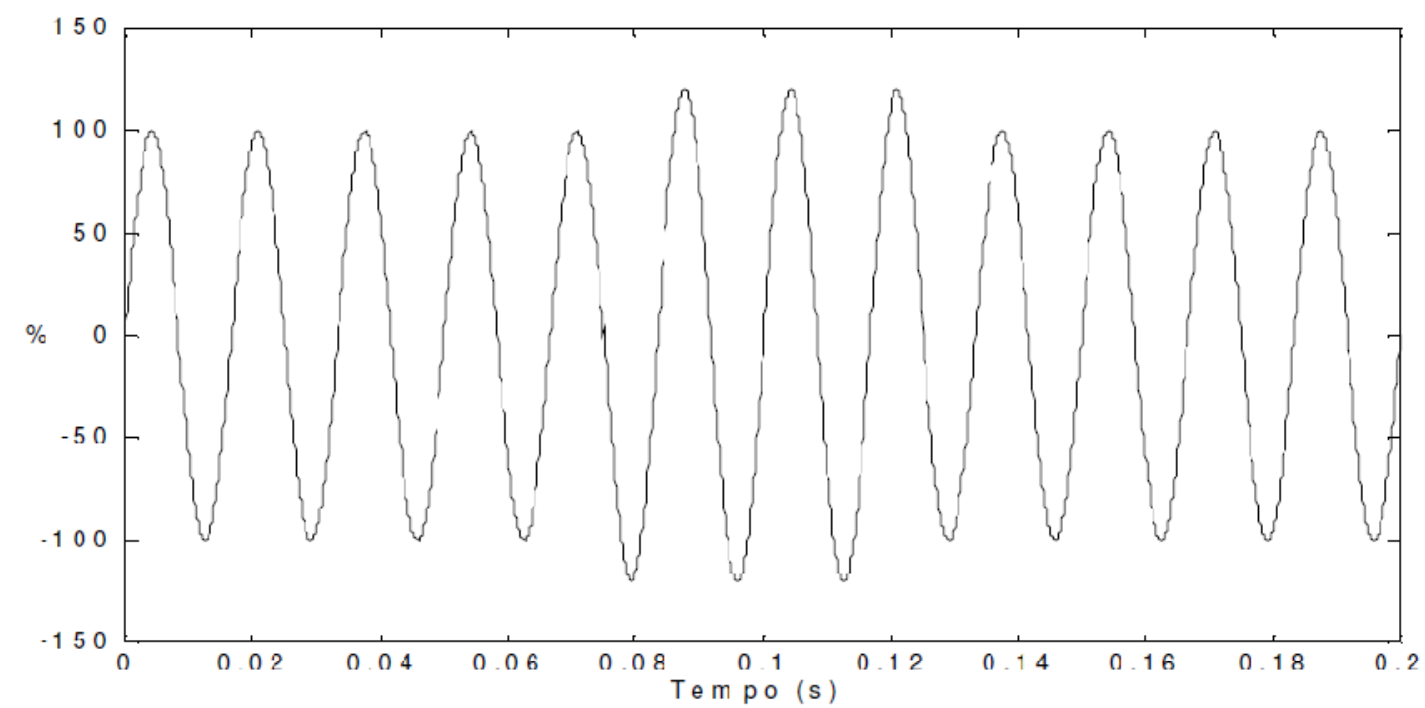

Figura 72 - Elevação de tensão devido a uma falta fase-terra [36].

Dependendo da frequência de ocorrência do distúrbio pode-se ter como consequência das elevações de tensão de curta duração em equipamentos, falhas dos componentes. Dispositivos eletrônicos incluindo computadores e controladores eletrônicos, podem apresentar falhas imediatas durante uma condição de elevação de tensão. Já os 
transformadores, cabos, barramentos, dispositivos de chaveamento, Transformadores de Potencial (TP's), Transformadores de Correntes (TC's) e máquinas rotativas podem ter sua vida útil reduzida. Um aumento na tensão em um período de curta duração em alguns relés pode resultar em má operação dos mesmos, enquanto outros podem não ser afetados. Uma elevação de tensão em um banco de capacitores pode causar danos ao equipamento. Aparelhos de iluminação podem ter um aumento da luminosidade e dispositivos de proteção contra surto, podem ser destruídos quando submetidos a elevações de tensão que excedam suas taxas de MCOV (Maximum Continuous Overvoltage) [36].

Dentro do exposto, a preocupação principal recai sobre os equipamentos eletrônicos, uma vez que estas elevações de tensão podem danificar os componentes internos destes equipamentos, conduzindo-os à má operação, ou em casos extremos, à completa inutilização. Vale ressaltar mais uma vez que, a susceptibilidade a distúrbios de um equipamento não depende apenas da magnitude da elevação de tensão, mas também do seu período de duração, conforme ilustra a Figura 71, a qual mostra a tolerância de microcomputadores às variações de tensão.

Diante de tais problemas causados por elevações de tensão de curta duração, este distúrbio sugere que seja mantida uma atenção por parte de consumidores, fabricantes e concessionárias, no intuito de eliminar ou reduzir as consequências oriundas deste fenômeno.

\subsection{Variações de Tensão de Longa Duração}

As variações de tensão de longa duração podem ser caracterizadas como desvios que ocorrem no valor eficaz da tensão, na frequência do sistema, com duração superior a 1 minuto [36]. 
Atualmente, índices que caracterizam variações de tensão de longa duração encontram-se definidos nos Procedimentos de Distribuição de Energia Elétrica no Sistema Elétrico Nacional - PRODIST da ANEEL, no módulo referente à qualidade da energia elétrica [40].

Estas variações de tensão podem se dar como subtensões, sobretensões ou interrupções. Todas elas são geralmente causadas por variações de carga e operações de chaveamento no sistema [39].

\subsubsection{Interrupções}

Quando a tensão de suprimento permanece em zero por um período de tempo superior a 1 minuto, a variação de tensão de longa duração é considerada uma interrupção sustentada. Interrupções de tensão por um tempo superior a 1 minuto são em sua maioria permanentes, e requerem a intervenção da concessionária para reparar o sistema e restaurar o fornecimento de energia [36].

As interrupções sustentadas podem ocorrer devido à manutenção programada ou não. A maioria delas ocorrem de forma não programada e as principais causas são falhas nos disjuntores, queima de fusíveis, falha de componentes de circuito alimentador, etc.. Já o outro caso de interrupção sustentada, ocorre geralmente para executar a manutenção da rede, ou seja, serviços como troca de cabos e postes, mudança do tap do transformador, alteração dos ajustes de equipamentos de proteção, entre outros.

Seja a interrupção de natureza sustentada ou inesperada, o sistema elétrico deve ser projetado e operado de forma a garantir que:

- O número de interrupções seja mínimo;

- Uma interrupção dure o mínimo possível e

- O número de consumidores afetados seja pequeno. 
A consequência de uma interrupção sustentada é o desligamento dos equipamentos, exceto para aquelas cargas protegidas por sistemas no-breaks ou por outras formas de armazenamento de energia.

\subsubsection{Afundamentos de Tensão}

Um afundamento de tensão é caracterizado por um decréscimo no valor eficaz da tensão a valores menores que $0,9 \mathrm{pu}$, considerando-se a frequência do sistema, e com período de duração maior que 1 minuto [40].

Os afundamentos de tensão são decorrentes principalmente do carregamento excessivo dos circuitos alimentadores, os quais são submetidos a determinados níveis de corrente que, interagindo com a impedância da rede, dão origem a quedas de tensão acentuadas. Outros fatores que contribuem para as subtensões são: a conexão de cargas à rede elétrica, o desligamento de bancos de capacitores e, consequentemente, o excesso de reativo transportado pelos circuitos de distribuição, o que limita a capacidade do sistema no fornecimento de potência ativa e ao mesmo tempo eleva a queda de tensão.

Dentre os problemas causados por afundamentos de tensão de longa duração, destacam-se [36]:

$\rightarrow$ Redução da potência reativa fornecida por bancos de capacitores ao sistema;

$\rightarrow$ Possível interrupção da operação de equipamentos eletrônicos, tais como computadores e controladores eletrônicos;

$\rightarrow$ Redução de índice de iluminamento para os circuitos de iluminação incandescente.

$\rightarrow$ Elevação do tempo de partida das máquinas de indução, o que contribui para a elevação de temperatura dos enrolamentos; e 
$\rightarrow$ Aumento nos valores das correntes do estator de um motor de indução quando alimentado por uma tensão inferior à nominal. Desta forma tem-se um sobreaquecimento da máquina, o que certamente reduzirá a expectativa de vida útil da mesma.

As opções para melhorar a regulação de tensão são [36]:

$\rightarrow$ Instalar reguladores de tensão para elevar o nível da tensão;

$\rightarrow$ Instalar capacitores shunt para reduzir a corrente do circuito;

$\rightarrow$ Instalar capacitores série para cancelar a queda de tensão indutiva;

$\rightarrow$ Instalar cabos com bitolas maiores para reduzir a impedância da linha;

$\rightarrow$ Mudar o transformador de serviço para um com maior capacidade, reduzindo assim a impedância da linha e

$\rightarrow$ Instalar compensadores estáticos de reativos, os quais tem os mesmos objetivos que os capacitores, para mudanças bruscas de cargas.

\subsubsection{Elevações de Tensão}

Uma elevação de tensão sustentada é caracterizada por um aumento no valor eficaz da tensão acima de 1,1 pu (valores típicos entre 1,1 e 1,2 pu) por um período de duração maior que 1 minuto [40].

As sobretensões de longa duração podem ser o resultado do desligamento de grandes cargas ou da energização de um banco de capacitores. Transformadores cujos taps são conectados erroneamente também podem causar elevações de tensão [36].

Geralmente, são instalados bancos de capacitores fixos nos sistemas de distribuição das concessionárias, com vistas a suprir energia reativa e, portanto, melhorar o perfil de tensão. Ao mesmo tempo são instalados nas indústrias bancos de capacitores, normalmente fixos, para correção do fator de potência ou mesmo 
para elevação da tensão nos circuitos internos da instalação. Nos horários de ponta, quando há grandes solicitações de carga, a potência reativa fornecida por estes bancos auxilia a atuação do sistema. Entretanto, no horário fora de ponta, principalmente no período noturno, tem-se um excesso de reativo injetado no sistema, o qual se manifesta por uma elevação da tensão.

A principal consequência das sobretensões é a falha dos equipamentos. Dispositivos eletrônicos podem sofrer danos durante condições de sobretensões, embora transformadores, cabos, disjuntores, TC's, TP's e máquinas rotativas, geralmente não apresentam falhas imediatas. Entretanto, estes equipamentos quando submetidos a sobretensões poderão ter as suas vidas úteis reduzidas.

Relés de proteção também poderão apresentar falhas de operação durante as elevações de tensão. A potência reativa fornecida pelos bancos de capacitores aumentará com o quadrado da tensão durante uma condição de sobretensão, enquanto que a iluminação poderá também ser aumentada em tal condição.

Dentre algumas opções para a solução de tais problemas, destaca-se a troca de bancos de capacitores fixos por bancos automáticos, tanto em sistemas de concessionárias como em sistemas industriais e a instalação de compensadores estáticos de reativos, possibilitando um controle maior do nível da tensão [36].

\subsection{Desequilíbrios ou Desbalanceamentos}

Os desequilíbrios podem ser caracterizados usando-se diagramas de sequências pela relação entre o componente de sequência negativa e o componente de sequência positiva dos sinais referenciados [36].

As origens destes desequilíbrios estão geralmente nos sistemas de distribuição, os quais possuem cargas monofásicas distribuídas inadequadamente, 
causando o surgimento de tensões de sequência negativa. Este problema se agrava quando consumidores alimentados de forma trifásica possuem uma má distribuição de carga em seus circuitos internos, impondo correntes desequilibradas no circuito da concessionária. Tensões desequilibradas podem também ser o resultado da queima de fusíveis em uma fase de um banco de capacitores trifásicos.

Tais fatores prejudicam a qualidade no fornecimento de energia idealizada pela concessionária, e desta forma, alguns consumidores encontram na sua alimentação um desequilíbrio de tensão, a qual pode se manifestar sob três formas distintas:

$\rightarrow$ Assimetria de amplitudes;

$\rightarrow$ Assimetria angular entre fases e

$\rightarrow$ Assimetria conjunta de amplitudes e fases.

Destas, apenas a primeira é frequentemente evidenciada no sistema elétrico.

\subsection{Deteriorações da Forma de Onda}

A deterioração da forma de onda é definida como um desvio, em regime permanente, da forma de onda senoidal, na frequência fundamental, e é caracterizada principalmente pelo seu conteúdo espectral.

Existem cinco tipos principais de deteriorações da forma de onda [36]:

$\rightarrow$ Nível de Corrente Contínua (CC);

$\rightarrow$ Distorções harmônicas;

$\rightarrow$ Inter-harmônicos;

$\rightarrow$ Notching; 
$\rightarrow$ Ruídos.

\subsubsection{Nível CC}

A presença de tensão ou corrente $\mathrm{CC}$ em um sistema elétrico $\mathrm{CA}$ pode ocorrer como o resultado da operação ideal de retificadores de meia-onda. O nível $\mathrm{CC}$ em redes de corrente alternada pode levar à saturação de transformadores, resultando em perdas adicionais e redução da vida útil do equipamento. Pode também causar corrosão eletrolítica dos eletrodos de aterramento e de outros conectores [36].

\subsubsection{Distorções Harmônicas}

Componentes harmônicos são tensões ou correntes senoidais de frequências múltiplas inteiras da frequência fundamental na qual opera o sistema de energia elétrica. A presença destes componentes harmônicos distorcem as formas de onda da tensão e corrente, e são oriundos de equipamentos e cargas com características nãolineares instalados no sistema de energia [36].

A distorção harmônica vem contra os objetivos da qualidade do suprimento promovido por uma concessionária de energia elétrica, a qual deve fornecer aos seus consumidores uma tensão puramente senoidal, com amplitude e frequência constantes. Entretanto, o fornecimento de energia a determinados consumidores que causam deformações no sistema supridor, prejudicam não apenas o consumidor responsável pelo distúrbio, mas também outros conectados à mesma rede elétrica.

Nos períodos anteriores à década de 80 não existiam maiores preocupações com distorções harmônicas. Cargas com características não lineares eram pouco utilizadas e os equipamentos eram mais resistentes aos efeitos provocados por distorções harmônicas. Entretanto, nos últimos anos, com o rápido desenvolvimento da eletrônica de potência e a utilização de métodos que buscam o uso mais racional da energia 
elétrica, o conteúdo harmônico presente nos sistemas tem se elevado, causando uma série de efeitos indesejáveis em diversos equipamentos ou dispositivos, comprometendo a qualidade e o próprio uso racional da energia elétrica. O problema é ainda agravado com a utilização de equipamentos e cargas mais sensíveis à QEE.

Como ilustração, a Figura 73 mostra um perfil da vida útil de um transformador de corrente que se estabelece através de seus enrolamentos. Os resultados consideram que as componentes harmônicas, para cada situação, são superpostas a uma corrente fundamental igual à nominal do equipamento.

\subsubsection{Interharmônicos}

Interharmônicos são componentes de frequência, em tensão ou corrente, que não são múltiplos inteiros da frequência fundamental do sistema supridor (50 ou $60 \mathrm{~Hz}$ ). Estes podem aparecer como frequências discretas ou como uma larga faixa espectral. Os interharmônicos podem ser encontrados em redes de diferentes classes de tensão. As suas principais fontes são conversores estáticos de potência, cicloconversores, motores de indução e equipamentos a arco. Sinais carrier (sinal superposto ao sinal de tensão utilizado para transmissão de informações) em linhas de potência também podem ser considerados como interharmônicos [36].

\subsubsection{Notching}

Notching é um distúrbio de tensão causado pela operação normal de equipamentos de eletrônica de potência quando a corrente é comutada de uma fase para outra. Este fenômeno pode ser detectado através do conteúdo harmônico da tensão afetada. As componentes de frequência associadas com os notchings são de alto valor e, desta forma, não podem ser medidas pelos equipamentos normalmente utilizados para análise harmônica. A Figura 74 mostra a forma com que o notching se manifesta [36]. 


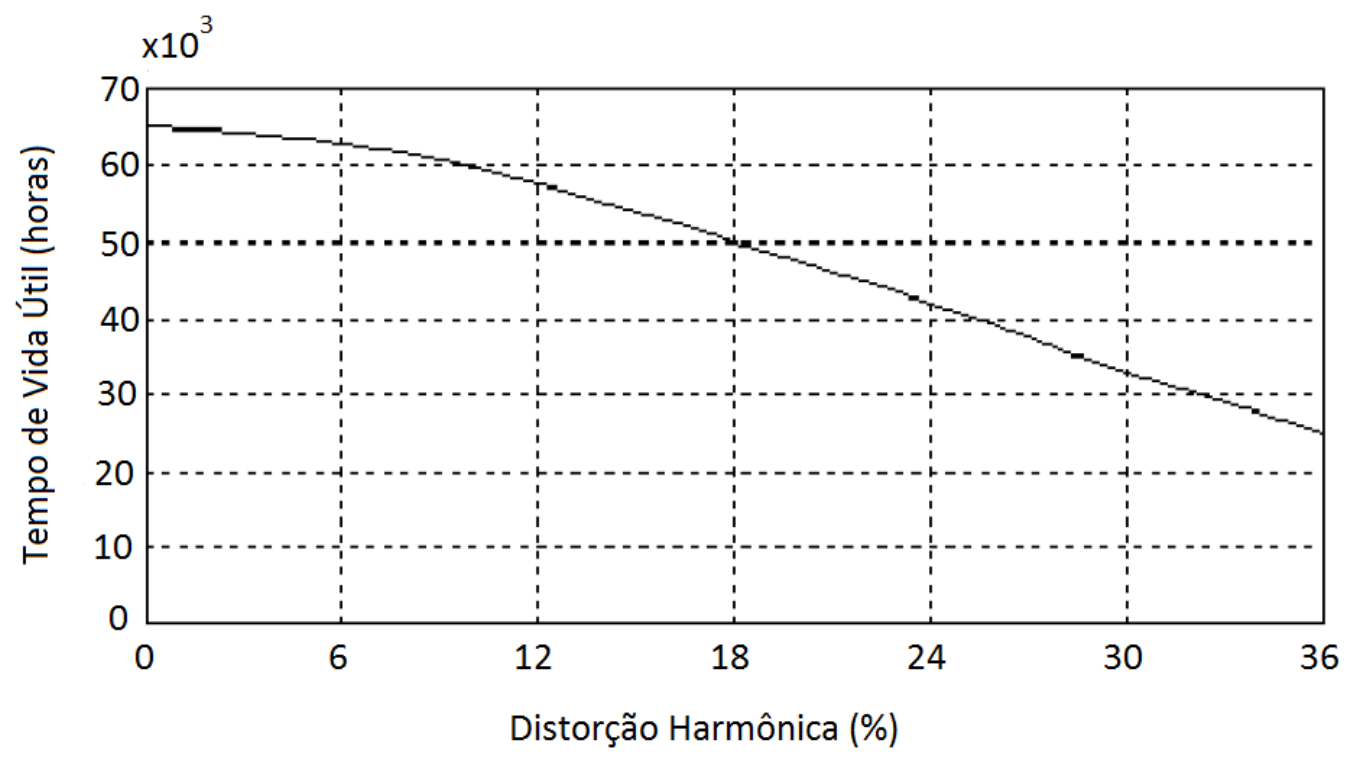

Figura 73 - Vida útil de um transformador em função da distorção harmônica de corrente [37].

\subsubsection{Ruídos}

Ruído é definido como um sinal elétrico indesejado, contendo uma larga faixa espectral com frequências menores que $200 \mathrm{kHz}$, as quais são superpostas às tensões ou correntes de fase, ou encontradas em condutores de neutro.

Os ruídos em sistemas de potência podem ser causados por equipamentos de eletrônica de potência, circuitos de controle, equipamentos a arco, retificadores a estado sólido e fontes chaveadas e, via de regra, estão relacionados com aterramentos impróprios. Basicamente, os ruídos consistem de uma distorção indesejada no sinal elétrico que não pode ser classificado como distorção harmônica ou transitório.

A faixa de frequência e o nível da amplitude depende da fonte que produz o ruído e das características do sistema. A amplitude típica é menor que $1 \%$ da tensão fundamental, e os mesmos podem causar distúrbios em equipamentos eletrônicos tais como microcomputadores e controladores programáveis. O problema pode ser minimizado utilizando-se filtros e transformadores isoladores, entre outros [36] 


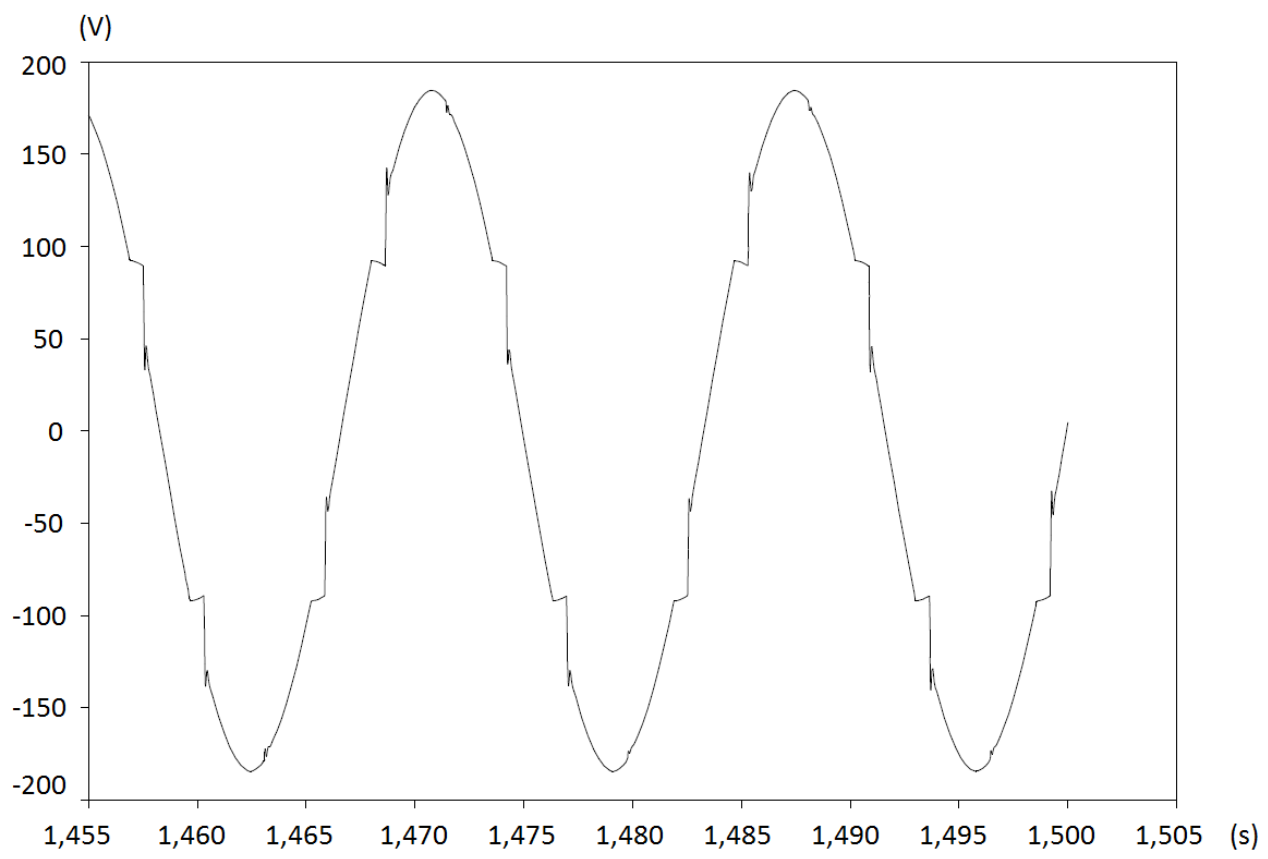

Figura 74 - Notching na tensão de alimentação de um conversor CA/CC [36].

\subsection{Flutuações ou Oscilações de Tensão}

As flutuações de tensão correspondem a variações sistemáticas no valor eficaz da tensão de suprimento dentro da faixa compreendida entre 0,95 e 1,05 pu. Tais flutuações são geralmente causadas por cargas industriais e manifestam-se de diferentes formas, a destacar:

\section{•Flutuações Aleatórias}

A principal fonte destas flutuações são os fornos a arco, onde as amplitudes das oscilações dependem do estado de fusão do material, bem como do nível de curto-circuito da instalação.

- Flutuações Repetitivas

Dentre as principais fontes geradoras de flutuações desta natureza tem-se:

$\rightarrow$ Máquinas de solda;

$\rightarrow$ Laminadores; 
$\rightarrow$ Elevadores de minas e

$\rightarrow$ Ferrovias.

\section{- Flutuações Esporádicas}

A principal fonte causadora destas oscilações é a partida direta de

grandes motores.

Os principais efeitos nos sistemas elétricos, resultados das oscilações causadas pelos equipamentos mencionados anteriormente são:

$\rightarrow$ Oscilações de potência e torque das máquinas elétricas;

$\rightarrow$ Queda de rendimento dos equipamentos elétricos;

$\rightarrow$ Interferência nos sistemas de proteção e

$\rightarrow$ Flicker (cintilação luminosa).

O flicker ou cintilação luminosa consiste no efeito mais comum provocado pelas oscilações de tensão. Este tema merece especial atenção, uma vez que o desconforto visual associado à perceptibilidade do olho humano às variações da intensidade luminosa é, em toda sua extensão, indesejável.

\subsubsection{Variações na Frequência do Sistema Elétrico}

Variações na frequência de um sistema elétrico são definidas como sendo desvios no valor da frequência fundamental deste sistema $(50 \mathrm{ou} 60 \mathrm{~Hz})$. A frequência do sistema de potência está diretamente associada à velocidade de rotação dos geradores que suprem o sistema. Pequenas variações de frequência podem ser observadas como resultado do balanço dinâmico entre carga e geração no caso de alguma alteração (variações na faixa de $60 \pm 0,5 \mathrm{~Hz}$ ). A amplitude da variação e sua duração dependem das características da carga e da resposta do regulador de velocidade instalado no sistema de geração. 
Variações de frequência que ultrapassam os limites para operação normal em regime permanente podem ser causadas por faltas em sistemas de transmissão, saída de um grande bloco de carga ou pela saída de operação de uma grande fonte de geração.

Em sistemas isolados, entretanto, como é o caso da geração própria nas indústrias, na eventualidade de um distúrbio, a magnitude e o tempo de permanência das máquinas operando fora da velocidade, resultam em desvios da frequência em proporções mais significativas. A Tabela 3, extraída da referência [36], traz um resumo dos diferentes distúrbios, mostrando as categorias e as características típicas dos fenômenos que contribuem para a perda da qualidade de um suprimento elétrico.

A Tabela 4, extraída da referência [37], mostra de forma resumida, os fenômenos que se relacionam com a QEE com as suas respectivas causas, efeitos e propõe algumas soluções para mitigar tais fenômenos, os quais foram apresentados ao longo deste capítulo. 
Tabela 3- Categorias e características de fenômenos eletromagnéticos típicos nos sistemas elétricos [36].

\begin{tabular}{|c|c|c|c|}
\hline Categoria & $\begin{array}{c}\text { Conteúdo Espectral } \\
\text { Típico }\end{array}$ & Duração Típica & $\begin{array}{c}\text { Amplitude de Tensão } \\
\text { Típica }\end{array}$ \\
\hline \multicolumn{4}{|l|}{ 1-Transitórios } \\
\hline \multicolumn{4}{|l|}{ 1.1-Impulsivos } \\
\hline 1.1.1-Nanossegundos & $5 \mathrm{~ns}$ & $<50 \mathrm{~ns}$ & \\
\hline 1.1.2-Microssegundos & $1 \mu \mathrm{s}$ & $50 \mathrm{~ns}-1 \mathrm{~ms}$ & \\
\hline 1.1.3-Milissegundos & $0,1 \mathrm{~ms}$ & $>1 \mathrm{~ms}$ & \\
\hline \multicolumn{4}{|l|}{ 1.2-Oscilatórios } \\
\hline 1.2.1-Baixa Frequência & $<5 \mathrm{kHz}$ & $3-50 \mathrm{~ms}$ & $0,4 \mathrm{pu}$ \\
\hline 1.2.2-Média Frequência & $5-500 \mathrm{kHz}$ & $20 \mu \mathrm{s}$ & $0,4 \mathrm{pu}$ \\
\hline 1.2.3-Alta Frequência & $0,5-5 \mathrm{MHz}$ & $5 \mu \mathrm{s}$ & $0,4 \mathrm{pu}$ \\
\hline \multicolumn{4}{|l|}{$\begin{array}{l}\text { 2-Variações de Tensão de Curta } \\
\text { Duração }\end{array}$} \\
\hline \multicolumn{4}{|l|}{ 2.1-Instantânea } \\
\hline 2.1.1-Afundamento de Tensão & & $0,5-30$ ciclos & $0,1-0,9 \mathrm{pu}$ \\
\hline 2.1.2-Elevação de Tensão & & $0,5-30$ ciclos & $1,1-1,8 \mathrm{pu}$ \\
\hline \multicolumn{4}{|l|}{ 2.2-Momentânea } \\
\hline 2.2.1-Interrupção & & 0,5 ciclos $-3 \mathrm{~s}$ & $<0,1 \mathrm{pu}$ \\
\hline 2.2.2-Afundamento de Tensão & & 30 ciclos $-3 \mathrm{~s}$ & $0,1-0,9 \mathrm{pu}$ \\
\hline 2.2.3-Elevação de Tensão & & 30 ciclos $-3 s$ & $1,1-1,4 \mathrm{pu}$ \\
\hline \multicolumn{4}{|l|}{ 2.3-Temporária } \\
\hline 2.3.1-Interrupção & & $3 \mathrm{~s}-1$ minuto & $<0,1 \mathrm{pu}$ \\
\hline 2.3.2-Afundamento de Tensão & & $3 \mathrm{~s}-1$ minuto & $0,1-0,9 \mathrm{pu}$ \\
\hline 2.3.3-Elevação de Tensão & & $3 \mathrm{~s}-1$ minuto & $1,1-1,2 \mathrm{pu}$ \\
\hline \multicolumn{4}{|l|}{$\begin{array}{l}\text { 3-Variações de Tensão de } \\
\text { Longa Duração }\end{array}$} \\
\hline 3.1-Interrupção Sustentada & & $>1$ minuto & $0,0 \mathrm{pu}$ \\
\hline 3.2-Subtensão Sustentada & & $>1$ minuto & $0,8-0,9 \mathrm{pu}$ \\
\hline 3.3-Sobretensão Sustentada & & $>1$ minuto & $1,1-1,2 \mathrm{pu}$ \\
\hline 4-Desequilíbrio de Tensão & & Regime permanente & $0,5 \%-2 \%$ \\
\hline \multicolumn{4}{|l|}{ 5-Distorção de Forma de Onda } \\
\hline 5.1-Nível CC & & Regime permanente & $0-0,1 \%$ \\
\hline 5.2-Harmônicos & da ordem $0-100$ & Regime permanente & $0-20 \%$ \\
\hline 5.3-Interharmônicos & $0-6 \mathrm{kHz}$ & Regime permanente & $0-2 \%$ \\
\hline 5.4-Notching & & Regime permanente & \\
\hline 5.5-Ruído & Faixa ampla & Regime permanente & $0-1 \%$ \\
\hline 6-Flutuação de Tensão & $<25 \mathrm{~Hz}$ & Intermitente & $0,1 \%-7 \%$ \\
\hline $\begin{array}{l}\text { 7-Variação de Frequência do } \\
\text { Sistema }\end{array}$ & & $<10 \mathrm{~s}$ & \\
\hline
\end{tabular}


Tabela 4- Resumo das características dos distúrbios relacionados com a QEE [37].

\begin{tabular}{|c|c|c|c|}
\hline $\begin{array}{c}\text { Tipos de } \\
\text { Distúrbios }\end{array}$ & Causas & Efeitos & Soluções \\
\hline $\begin{array}{l}\text { Transitórios } \\
\text { impulsivos }\end{array}$ & $\begin{array}{l}\text {-Descargas atmosféricas; } \\
\text {-Chaveamentos de } \\
\text { cargas }\end{array}$ & $\begin{array}{l}\text {-Excitação de circuitos ressonantes; } \\
\text {-Redução da vida útil de motores, } \\
\text { geradores, transformadores, etc. }\end{array}$ & $\begin{array}{l}\text {-Filtros; } \\
\text {-Supressores de surto; } \\
\text {-Transformadores } \\
\text { isoladores. }\end{array}$ \\
\hline $\begin{array}{l}\text { Oscilações } \\
\text { transitórias }\end{array}$ & $\begin{array}{l}\text {-Descargas atmosféricas; } \\
\text {-Chaveamentos de: } \\
\text { capacitores, linhas, cabos, } \\
\text { cargas e transformadores. }\end{array}$ & $\begin{array}{l}\text {-Mau funcionamento de equipamentos } \\
\text { controlados eletronicamente, } \\
\text { conversores de potência, etc.; } \\
\text {-Redução da vida útil de motores, } \\
\text { geradores, transformadores, etc. }\end{array}$ & $\begin{array}{l}\text {-Filtros; } \\
\text {-Supressores de surto; } \\
\text {-Transformadores } \\
\text { isoladores. }\end{array}$ \\
\hline $\begin{array}{c}\text { Sub e } \\
\text { sobretensões }\end{array}$ & $\begin{array}{l}\text {-Partidas de motores; } \\
\text {-Variações de cargas; } \\
\text {-Chaveamento de banco de } \\
\text { capacitores. }\end{array}$ & $\begin{array}{l}\text {-Pequena redução na velocidade dos } \\
\text { motores de indução e no reativo dos } \\
\text { bancos de capacitores; } \\
\text {-Falhas em equipamentos eletrônicos; } \\
\text {-Redução da vida útil de máquinas } \\
\text { rotativas, transformadores, cabos, } \\
\text { disjuntores, TP's e TC's; } \\
\text {-Operação indevida de relés de } \\
\text { proteção. }\end{array}$ & $\begin{array}{l}\text {-Reguladores de tensão; } \\
\text {-Fontes de energia de } \\
\text { reserva; } \\
\text {-Chaves estáticas; } \\
\text {-Geradores de energia. }\end{array}$ \\
\hline Interrupções & $\begin{array}{l}\text {-Curto-circuito; } \\
\text {-Operação de disjuntores; } \\
\text {-Manutenção. }\end{array}$ & $\begin{array}{l}\text {-Falha de equipamentos eletrônicos e de } \\
\text { iluminação; } \\
\text {-Desligamento de equipamentos; } \\
\text {-Interrupção do processo produtivo } \\
\text { (altos custos); }\end{array}$ & $\begin{array}{l}\text {-Fontes de energia } \\
\text { sobressalentes; } \\
\text {-Sistemas no-break } \\
\text {-Geradores de energia. }\end{array}$ \\
\hline Desequilíbrios & $\begin{array}{l}\text {-Fornos a arco; } \\
\text {-Cargas monofásicas e } \\
\text { bifásicas; } \\
\text {-Assimetrias entre as } \\
\text { impedâncias. }\end{array}$ & $\begin{array}{l}\text {-Redução da vida útil de motores de } \\
\text { indução e máquinas síncronas; } \\
\text {-Geração, pelos retificadores, de } 3^{\circ} \\
\text { harmônico e seus múltiplos. }\end{array}$ & $\begin{array}{l}\text {-Operação simétrica; } \\
\text {-Dispositivos de } \\
\text { compensação. }\end{array}$ \\
\hline Nível CC & $\begin{array}{l}\text {-Operação ideal de } \\
\text { retificadores de meia onda, } \\
\text { etc. }\end{array}$ & $\begin{array}{l}\text {-Saturação de transformadores; } \\
\text {-Corrosão eletrolítica de eletrodos de } \\
\text { aterramento e de outros conectores. }\end{array}$ & \\
\hline Harmônicos & -Cargas não-lineares. & $\begin{array}{l}\text {-Sobreaquecimento de cabos, } \\
\text { transformadores e motores de indução; } \\
\text {-Danificação de capacitores, etc. }\end{array}$ & $\begin{array}{l}\text {-Filtros; } \\
\text {-Transformadores } \\
\text { isoladores. }\end{array}$ \\
\hline Interharmônicos & $\begin{array}{l}\text {-Conversores estáticos de } \\
\text { potência; } \\
\text {-Cicloconversores; } \\
\text {-Motores de indução; } \\
\text {-Equipamentos a arco, etc. }\end{array}$ & $\begin{array}{l}\text {-Interferência na transmissão de sinais } \\
\text { carrier; } \\
\text {-Indução de flicker visual no display de } \\
\text { equipamentos. }\end{array}$ & \\
\hline Notching & $\begin{array}{l}\text {-Equipamentos de } \\
\text { eletrônica de potência. }\end{array}$ & & \\
\hline Ruídos & $\begin{array}{l}\text {-Chaveamento de equip. } \\
\text { eletrônicos de potência; } \\
\text {-Radiações } \\
\text { eletromagnéticas. }\end{array}$ & $\begin{array}{l}\text {-Distúrbios em equipamentos } \\
\text { eletrônicos (computadores e } \\
\text { controladores programáveis). }\end{array}$ & $\begin{array}{l}\text {-Aterramento das } \\
\text { instalações; } \\
\text {-Filtros. }\end{array}$ \\
\hline $\begin{array}{l}\text { Oscilações de } \\
\text { tensão }\end{array}$ & $\begin{array}{l}\text {-Cargas intermitentes; } \\
\text {-Fornos a arco; } \\
\text {-Partidas de motores. }\end{array}$ & $\begin{array}{l}\text {-Flicker; } \\
\text {-Oscilação de potência e torque nas } \\
\text { máquinas elétricas; } \\
\text {-Queda de rendimento de equipamentos } \\
\text { elétricos; } \\
\text {-Interferência nos sistemas de proteção. }\end{array}$ & $\begin{array}{l}\text {-Sistemas estáticos de } \\
\text { compensação de } \\
\text { reativos; } \\
\text {-Capacitores série. }\end{array}$ \\
\hline $\begin{array}{c}\text { Variações na } \\
\text { frequência do } \\
\text { sistema elétrico }\end{array}$ & $\begin{array}{l}\text {-Perda de geração, perda de } \\
\text { linhas de transmissão, etc. }\end{array}$ & $\begin{array}{l}\text {-Pode causar danos severos nos } \\
\text { geradores e nas palhetas das turbinas, } \\
\text { etc. }\end{array}$ & \\
\hline
\end{tabular}




\section{AQUISIÇÃO DE DADOS DE OPERAÇÃO DA LÂMPADA DE DESCARGA}

\subsection{Observação da operação da lâmpada de descarga}

As lâmpadas de descarga são dispositivos elétricos que operam em sua grande maioria associadas a elementos auxiliares que possuem como função básica permitir a ignição e manutenção da coluna de plasma em seu interior de forma estável, dentro de limites de alimentação compatíveis com as características de um sistema de distribuição de energia, em especial no que se refere às variações de tensão em torno de um valor nominal.

Por se tratar de elementos que apresentam fases distintas de operação, desde o estabelecimento do arco que origina a coluna de plasma até o ponto estável de operação, e que o comportamento da evolução entre estas fases está relacionado à temperatura do dispositivo, pode-se admitir que o comportamento elétrico da lâmpada dependente de dois parâmetros: a tensão de alimentação e sua temperatura. 
Em lâmpadas de descarga de baixa intensidade, como por exemplo as lâmpadas fluorescentes tubulares, a temperatura do dispositivo apresenta ao longo de sua operação uma discreta elevação em relação à temperatura ambiente, e pelo fato de apresentar grande área de contato com o ar, após desligada rapidamente retorna à situação de equilíbrio térmico com o ambiente onde se encontra instalada, retornando as condições do gás em seu interior favoráveis a uma ionização imediata. Por esta razão, lâmpadas fluorescentes tubulares e dispositivos similares podem ser acionados a qualquer instante, sem necessidade de se aguardar períodos de resfriamento.

As lâmpadas de descarga de alta intensidade, no entanto, apresentam considerável elevação de temperatura de seu tubo de descarga durante a fase de aquecimento. Por esta razão, estes dispositivos não permitem uma ionização instantânea do gás no interior do tubo de descarga após um desligamento que venha a ocorrer durante sua operação estável, já aquecida, exigindo um período de resfriamento que propicie o retorno de condições de pressão e temperatura favoráveis a uma nova ionização.

Este período de resfriamento é, portanto, consideravelmente superior ao experimentado por lâmpadas tubulares, não apenas pela diferença entre a temperatura do tubo e a temperatura ambiente, mas também pela elevada resistência térmica entre o tubo de descarga e o ambiente, resultante do isolamento proporcionado pelo bulbo externo e pelo gás inerte que preenche seu interior, como pode ser observado na representação da Figura 10.

Para permitir a modelagem da lâmpada de descarga de alta intensidade proposta por este trabalho, torna-se necessária a comparação entre os comportamentos do modelo e do dispositivo real, obtido através da observação da variáveis de operação da lâmpada ao longo do tempo, estando esta submetida a condições controladas de alimentação. 
Os equipamentos empregados nesta montagem devem portanto possibilitar a coleta e armazenagem das informações referentes ao funcionamento da lâmpada de descarga que se deseja modelar, para posterior treinamento e validação dos modelos construídos.

\subsection{Objetivos gerais da montagem laboratorial}

A montagem experimental proposta destinada ao acompanhamento do experimento tem por objetivo geral o registro das variáveis de operação de uma lâmpada de descarga de alta intensidade, operando em condições controladas de alimentação, permitindo o armazenamento dos dados coletados em arquivos para posterior processamento e avaliação, permitindo:

a)Verificar a eficácia dos modelos propostos, por comparação entre valores simulados e dados experimentais, e

b)Verificar o comportamento prático de lâmpadas individuais e conjuntos de lâmpadas frente a fenômenos de qualidade da energia elétrica, através de análise dos comportamentos do modelo e do experimento.

A montagem experimental será alimentada na frequência da rede de distribuição, em virtude de empregar reatores construídos para esta condição de operação, e tensão com amplitude estabelecida conforme a situação de operação a ser analisada. Serão monitorados continuamente a tensão e a corrente no conjunto lâmpada/reator e a temperatura externa do bulbo da lâmpada, de forma a caracterizar as fases de operação do dispositivo.

Os equipamentos empregados na montagem experimental e a metodologia utilizada na coleta dos dados de operação da lâmpada de descarga serão detalhados no decorrer deste capítulo. 


\subsection{Descrição da montagem experimental}

Os equipamentos que compõem a montagem experimental desta pesquisa podem ser divididos em três subsistemas:

•O sistema de alimentação;

-O sistema de aquisição de dados; e

- A lâmpada de descarga analisada.

\subsubsection{Sistema de alimentação}

Na pesquisa, adotou-se duas possibilidades de alimentação para o experimento, empregadas exclusivamente de acordo com o perfil de operação a ser estudado.

Para as analises do dispositivo operando em regime permanente com valores estáveis de alimentação foi empregado como fonte um autotransformador continuamente ajustável, com as seguintes características:

-Tensão de Entrada: 220V

-Tensão de Saída: 0-250V

•Potência Nominal: 2.000VA

O aspecto físico do dispositivo empregado no experimento é apresentado na Figura 75.

A avaliação de características transitórias da lâmpada de descarga exige o emprego de uma fonte de alimentação programável capaz de simular com precisão alguns distúrbios relacionados a qualidade da energia elétrica. Para estes ensaios utilizouse um gerador arbitrário de sinais modelo 5001ix, fabricado pela California Instruments (Figura 76). 
Com potência nominal de 5.000VA, o equipamento oferece tensão de saída entre 0 e 300V (RMS), totalmente programável em relação à amplitude e forma de onda, e com frequência de saída entre $16 \mathrm{~Hz}$ e $500 \mathrm{~Hz}$ no modo CA ou tensão contínua o modo CC.

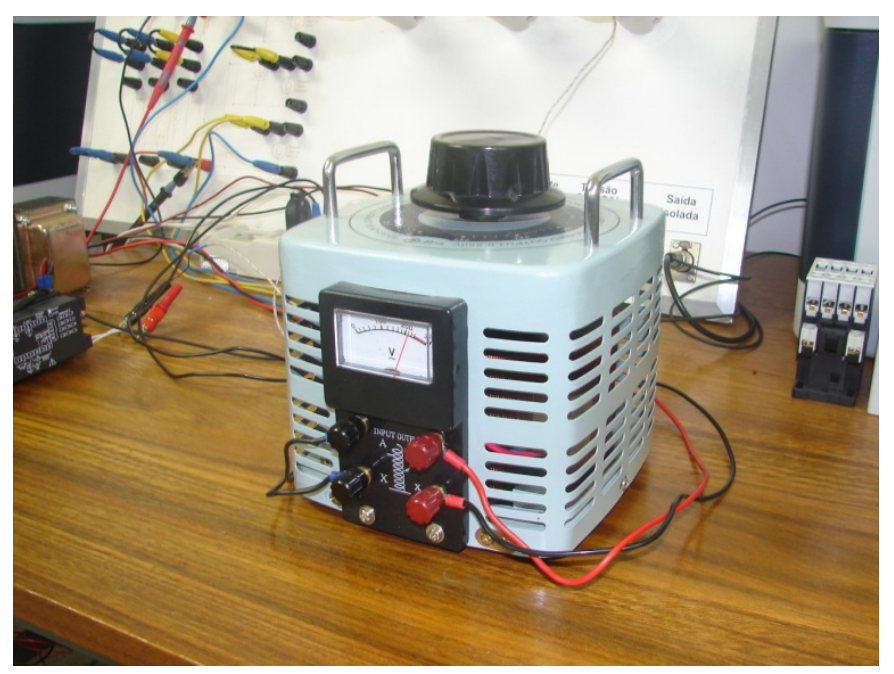

Figura 75 - Autotransformador continuamente ajustável

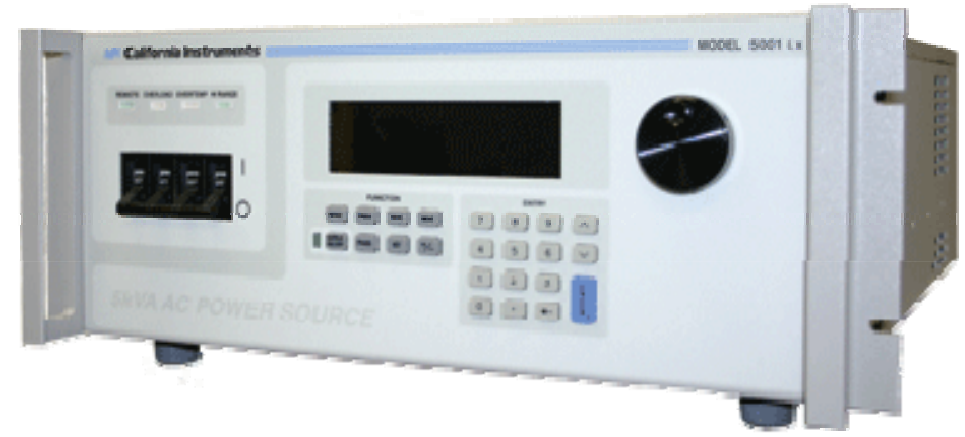

Figura 76 - Gerador arbitrário de sinais California Instruments 5001ix [41]

\subsubsection{Interface de operação do gerador arbitrário}

O gerador arbitrário de sinais é operado através de um programa de interface gráfica denominado CIGUI (California Instruments Graphic User Interface), cuja tela principal é apresentada na Figura 77. Através desta interface é possível o completo controle do equipamento em sua operação e o ajuste de seus parâmetros de programação. 


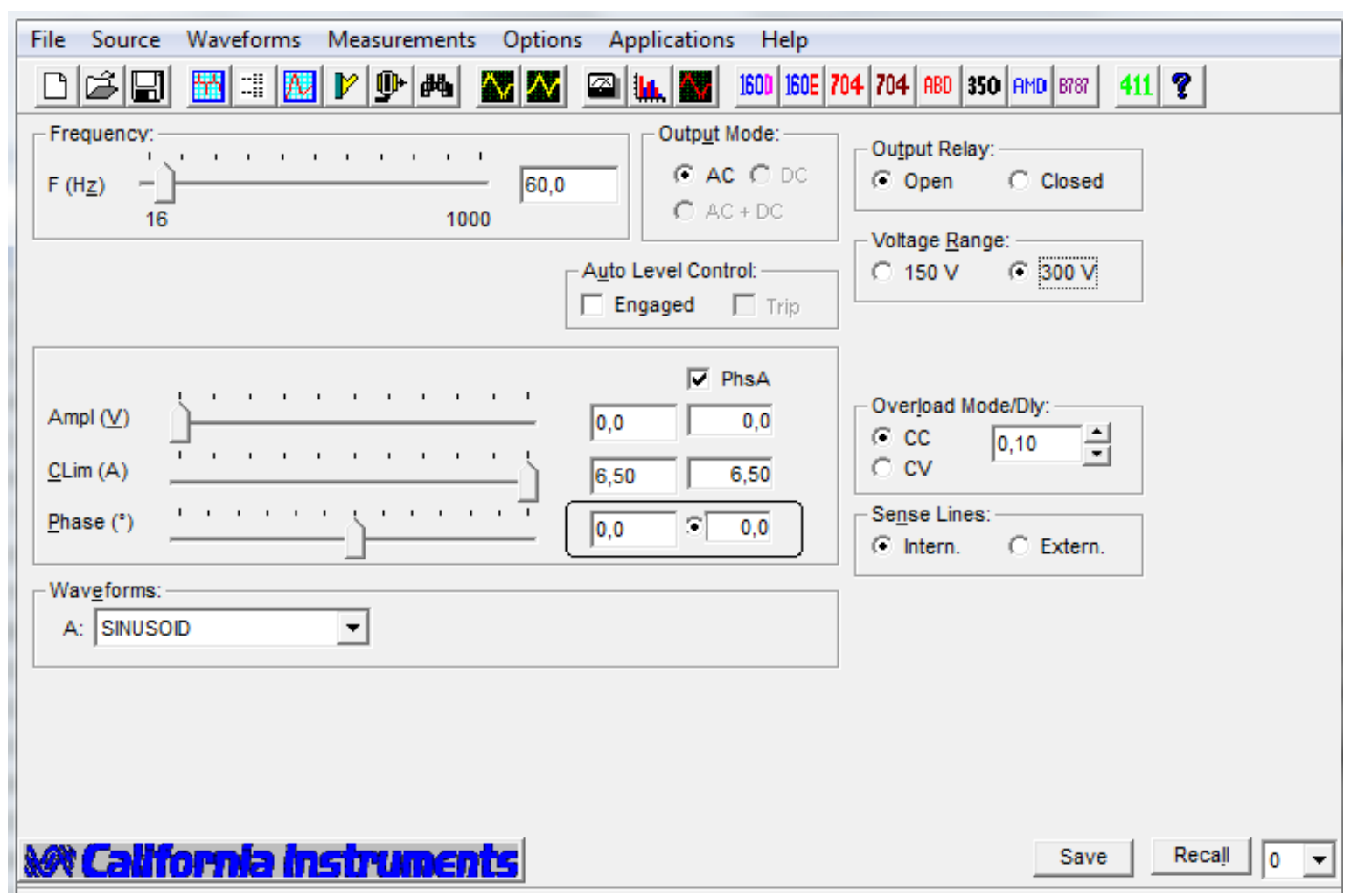

Figura 77 - Interface gráfica do usuário CIGUI California Instruments - tela principal

O gerador arbitrário de sinais permite a programação total de seus parâmetros de saída, incluindo a tensão, a frequência, a impedância apresentada pela fonte, a forma de onda de saída e a característica de transitórios em sua saída quando desejado.

Os eventos são aplicados à carga conforme uma listagem estabelecida por programação. Esta listagem define o tipo de evento, o tipo de gatilho para o evento, sua intensidade, sua duração, o ângulo de fase de incidência do evento, a forma de onda presente na saída da fonte durante o evento e a quantidade de repetições desejada. A Figura 78 mostra uma lista de eventos, representando a forma de programação destes eventos no gerador arbitrário de sinais.

Após definida a lista e a forma de aplicação, é possível o início do processo de aplicação dos distúrbios na carga sob análise, que passa a receber alimentação conforme o perfil programado. 


\subsubsection{Sistema de aquisição de dados}

Para que as medições realizadas no experimento pudessem ser posteriormente utilizadas no processo de validação dos modelos propostos, foi construído um sistema de instrumentação para o experimento destinado à aquisição dos dados de operação da lâmpada de descarga a ser modelada.

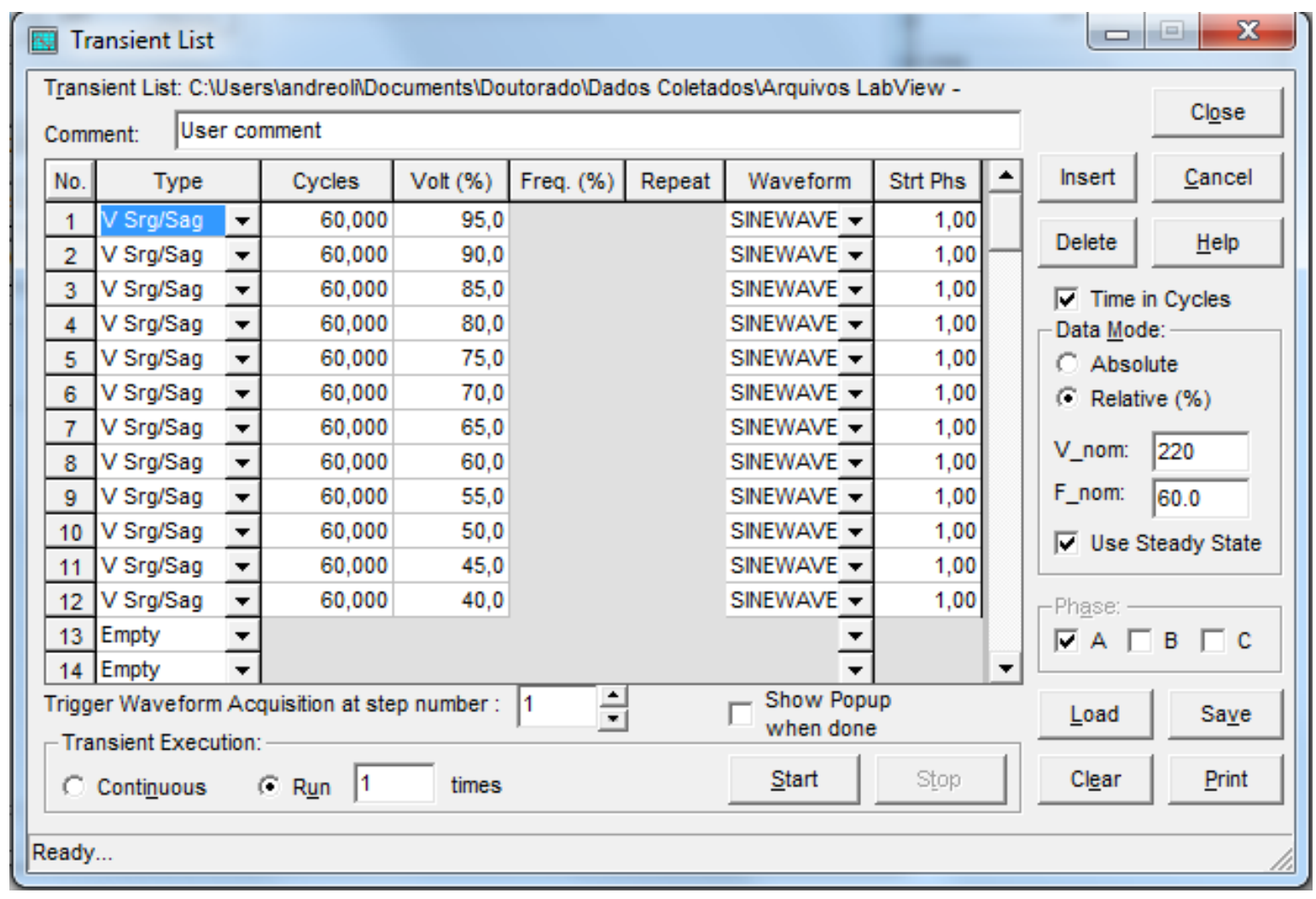

Figura 78 - Interface Gráfica do Usuário CIGUI California Instruments - Lista de Eventos

As variáveis monitoradas diretamente no experimento foram:

-A corrente de operação do sistema;

-A tensão de alimentação do conjunto lâmpada/reator; e

- A temperatura do bulbo externo da lâmpada ensaiada.

Para se definir os limites operacionais do sistema de aquisição de dados, foram adotados os parâmetros de base correspondentes a uma lâmpada de vapor de 
mercúrio de $80 \mathrm{~W}$, associada a um reator eletromagnético convencional, alimentada em $220 \mathrm{~V}$ e frequência de $60 \mathrm{~Hz}$. Os valores nominais de operação para este dispositivo são:

$\rightarrow$ Tensão nominal: 220V (RMS)

$\rightarrow$ Corrente nominal: $0,60 \mathrm{~A}(\mathrm{RMS})^{*}$

$\rightarrow$ Temperatura de operação: $190^{\circ} \mathrm{C}^{* *}$

*Sem correção de fator de potência.

**Medido após 10 minutos de operação, por observação experimental; Temperatura ambiente de $25^{\circ} \mathrm{C}$.

O sistema de aquisição de dados da montagem experimental foi concebido considerando três aspectos operacionais:

1)Possibilitar o monitoramento das variáveis elétricas em limites superiores aos requeridos pelo dispositivo ensaiado, assim como o ensaio de um conjunto de dispositivos associados. Adotou-se como base o monitoramento de cinco lâmpadas conectadas em paralelo.

2)Permitir a analise de conteúdo harmônico das variáveis elétricas com detalhamento até a $60^{\mathrm{a}}$ harmônica, superando assim os requisitos estabelecidos em normas pertinentes. Baseado no teorema de Nyquist, para uma frequência de $60 \mathrm{~Hz}$ isto corresponde a uma taxa de amostragem de $7,2 \mathrm{kHz}$.

3)Proporcionar isolamento galvânico entre os pontos de medição e o sistema computacional a ser empregado na aquisição de dados, tornando o experimento independente do referencial de potencial adotado.

Partindo destas considerações, foram estabelecidas as seguintes características nominais desejáveis para o sistema de aquisição de dados, mostradas na Tabela 5.

O sistema de aquisição de dados assim dimensionado pode ser subdividido em quatro subsistemas: 
-Placa de aquisição de dados;

-Condicionador de sinais analógicos;

-Transdutor de temperatura; e

-Supervisor do sistema de aquisição de dados.

Tabela 5- Características do sistema de aquisição de dados.

\begin{tabular}{c|c}
\hline \multicolumn{2}{c}{ Sistema de Aquisição de Dados - Características Nominais } \\
\hline Tensão de Entrada & $0-500 \mathrm{~V}(\mathrm{RMS})$ \\
\hline Corrente de Entrada & $0-5 \mathrm{~A}(\mathrm{RMS})$ \\
\hline Temperatura de operação & $0-400^{\circ} \mathrm{C}$ \\
\hline Frequência de aquisição de dados & $7,2 \mathrm{kHz}$ \\
\hline
\end{tabular}

\subsubsection{Placa de aquisição de dados}

A aquisição computacional dos dados do experimento foi realizada através de uma placa de aquisição produzida pela National Instruments ${ }^{\circledR}(\mathrm{NI})$, modelo NI USB-6211, que tem seu aspecto físico mostrado na Figura 79. A placa utilizada possui as seguintes características construtivas e operacionais:

$\bullet 16$ Entradas analógicas;

-Conversor analógico-digital de 16 bits;

-Taxa máxima de amostragem de 250kS/segundo;

-2 Saídas analógicas 16 bits;

•4 Entradas digitais e 4 saídas digitais, em nível TTL; e

- Comunicação e alimentação através de interface USB.

As entradas analógicas da placa de aquisição de dados admitem sinais com amplitude de $\pm 10 \mathrm{~V}$, e podem ser configuradas no modo referenciado ao terra analógico ou em modo diferencial, sendo que nesta última configuração são empregadas duas entradas analógicas por canal. No experimento, as entradas serão utilizadas no modo referenciado ao terra analógico. 
O gerenciamento da placa de aquisição pode ser realizado diretamente através do software LabView ${ }^{\circledR}$, da National Instruments ${ }^{\circledR}$, ou através de outro aplicativo que acesse a biblioteca dinâmica do dispositivo diretamente através do sistema operacional.

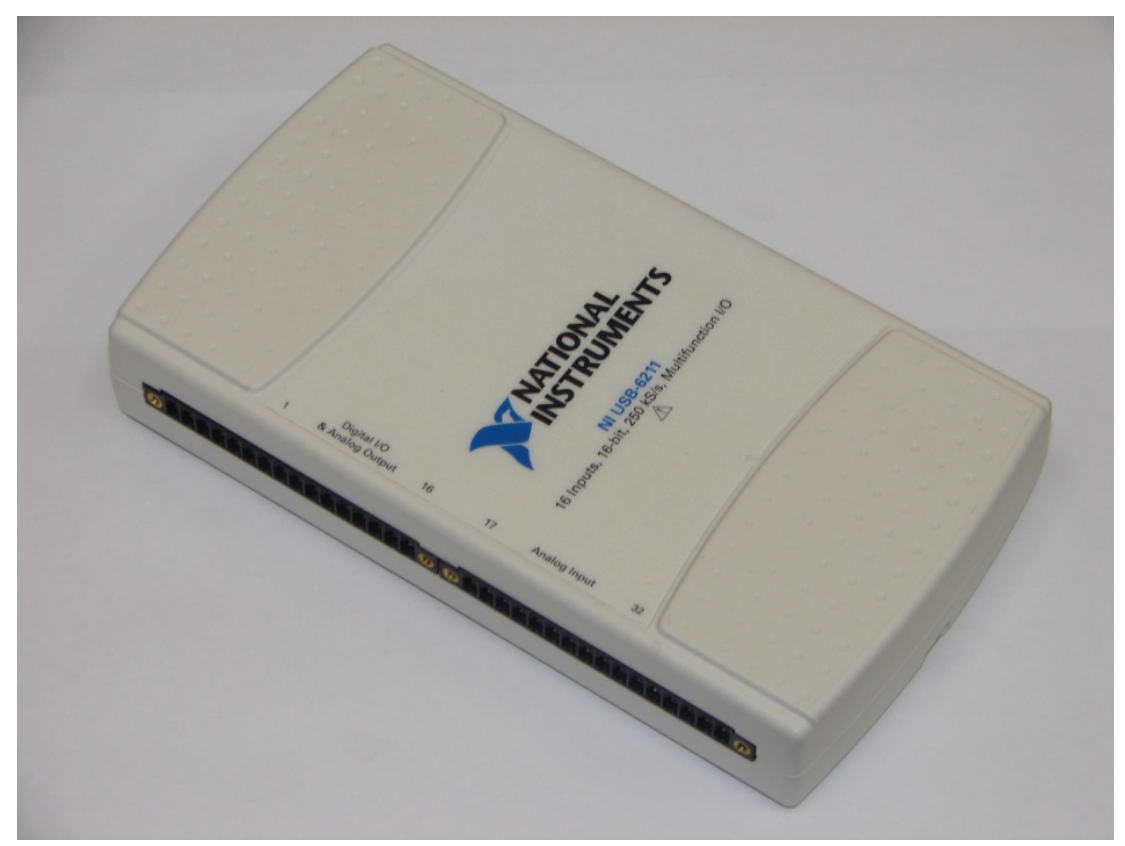

Figura 79 - Placa de Aquisição de Dados NI USB-6211

\subsubsection{Condicionador de sinais analógicos}

De modo a compatibilizar os níveis de tensão e corrente medidos no experimento aos limites admissíveis pela placa de aquisição de dados utilizada, torna-se necessário o emprego de um condicionador de sinais analógicos.

O sistema de condicionamento de sinais construído para o experimento conta com dois canais independentes de medição, sendo um destinado à medição de corrente e o outro para medição de tensão. Ambos apresentam isolação galvânica entre os sinais de entrada e saída, conferindo desta forma grande flexibilidade de aplicação durante os ensaios, com relação aos referenciais de potencial. 
Construtivamente, o condicionador de sinais tem seu bloco de medição de corrente baseado em um sensor tipo Hall produzido pela TAMURA, código L18P010D15 (Figura 80), com corrente nominal de entrada de \pm 10 A e saída com excursão entre $\pm 4 \mathrm{~V}$, quando alimentado por fonte simétrica de $\pm 15 \mathrm{Vcc}$.

Para medição de tensão foi utilizado um amplificador isolado produzido pela Burr-Brown sob o código ISO124, fornecido em encapsulamento DIP (Figura 81), que garante ganho unitário constante para sinais na faixa de frequência entre CC e $50 \mathrm{KHz}$. O diagrama esquemático do condicionador de sinais é mostrado na Figura 82.
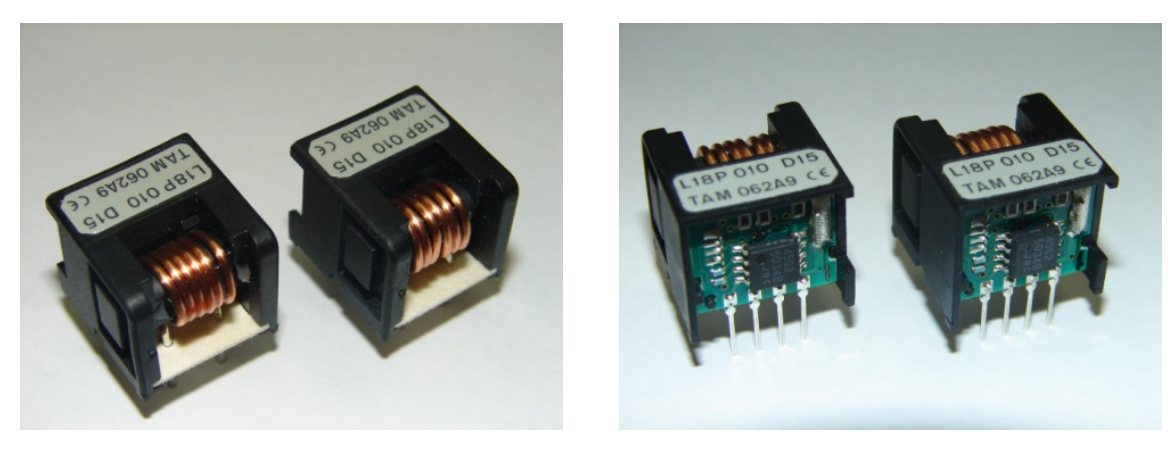

Figura 80 - Sensores Hall L18P010D15 - Tamura

A montagem do condicionador de sinais foi realizada em circuito impresso de face simples, e seu aspecto físico é mostrado na Figura 83.

O painel de acesso ao condicionador de sinais, ilustrado na Figura 84, disponibiliza para conexão à placa de aquisição de dados, através de suas saídas isoladas galvanicamente, os valores de corrente do experimento com fundo de escala de $5 \mathrm{~A}$ RMS, em tensão contínua ou alternada, convertidos para 2V RMS (Relação de 2,5 A/V), e de tensão de entrada com fundo de escala de 500V RMS, em tensão contínua ou alternada, convertidos em 5V RMS (escala 100:1), com banda passante de $50 \mathrm{KHz}$ e precisão da faixa de $\pm 1 \%$ sobre o fundo de escala. 


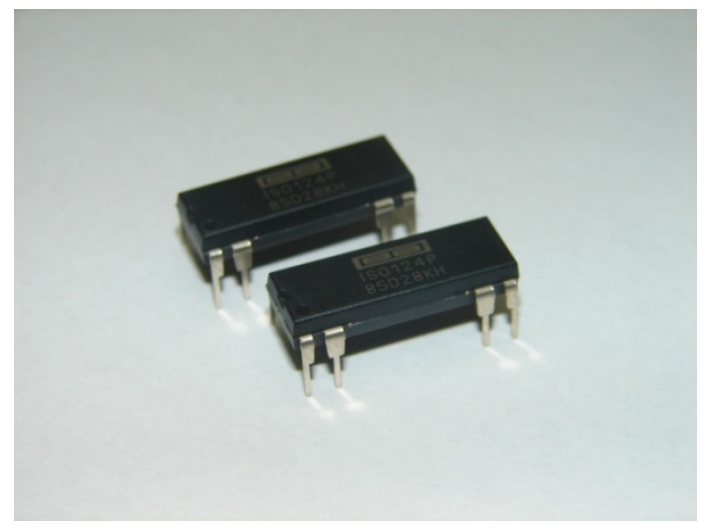

Figura 81 - Amplificador isolador ISO124 - Burr-Brown

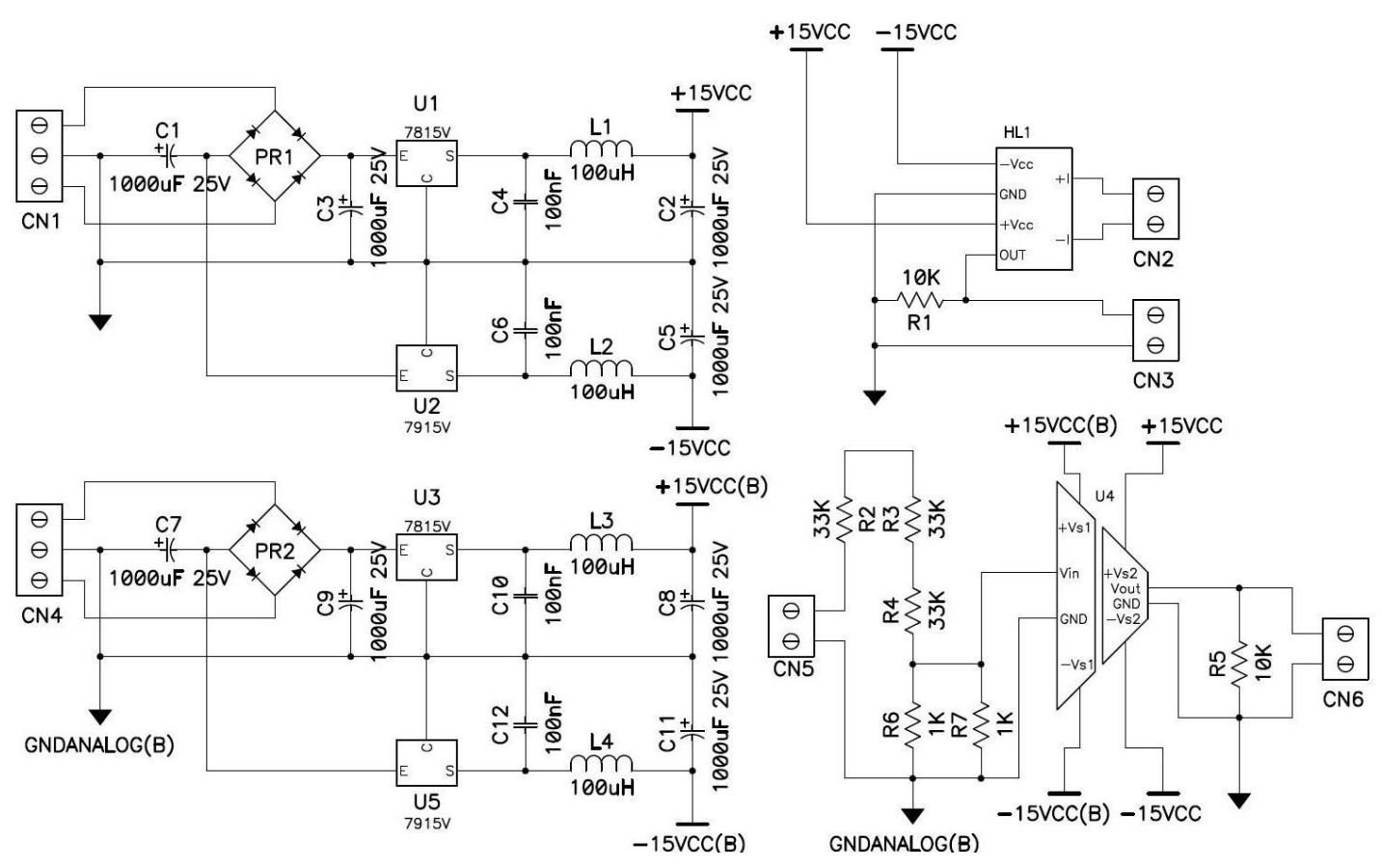

Figura 82 - Condicionador de sinais - Diagrama esquemático

\subsubsection{Transdutor de Temperatura}

Como forma de acompanhar o desempenho térmico do dispositivo a ser modelado, fez-se necessário o uso de um equipamento para transdução de nível do sinal de temperatura de operação em tensão compatível com o dispositivo de conversão analógico-digital empregado. Para esta função, foi empregado um equipamento comercial produzido pela CONTEMP, modelo CPM45, que apresenta função de controlador de 
temperatura e transdutor temperatura-tensão. $\mathrm{O}$ aspecto físico do transdutor/controlador CONTEMP CPM-45 é mostrado na Figura 85.

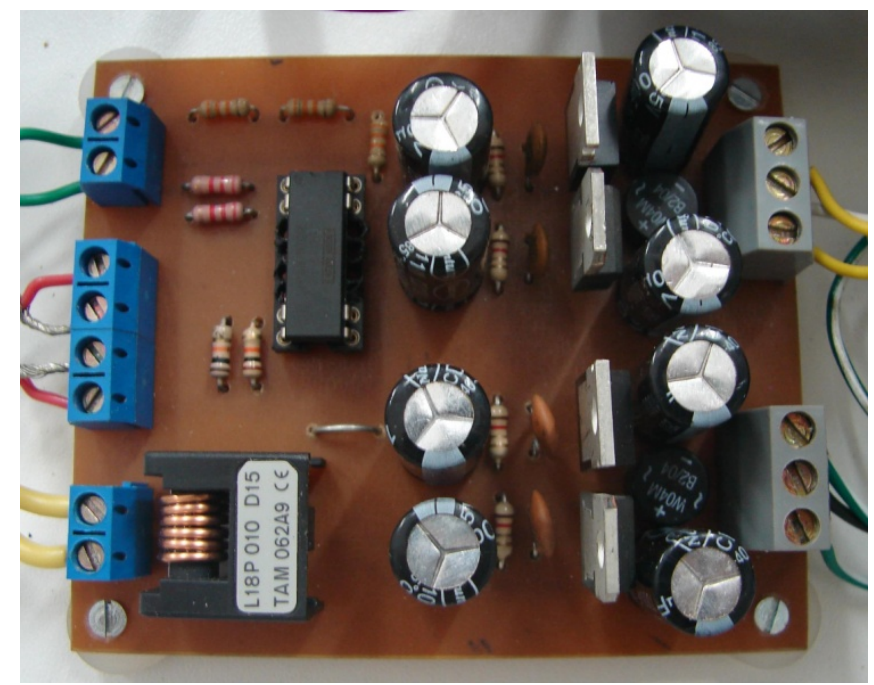

Figura 83 - Condicionador de sinais - Aspecto físico da montagem

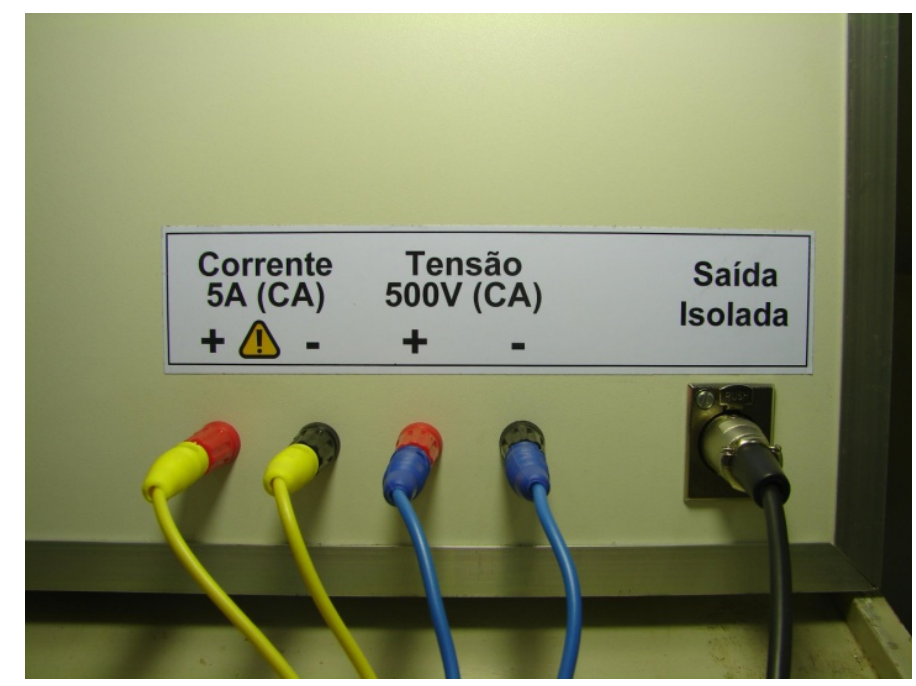

Figura 84 - Painel de Acesso ao condicionador de sinais

O dispositivo foi configurado para transdução de sinais de temperatura na faixa de $0^{\circ} \mathrm{C}$ a $400^{\circ} \mathrm{C}$, a partir de termopares tipo $\mathrm{K}$, para valores de tensão de $0 \mathrm{~V}$ a $10 \mathrm{~V}$ (razão de conversão de $40^{\circ} \mathrm{C} / \mathrm{V}$ ), compatíveis com os limites de entrada da placa de aquisição de dados utilizada e com o elemento sensor utilizado. 


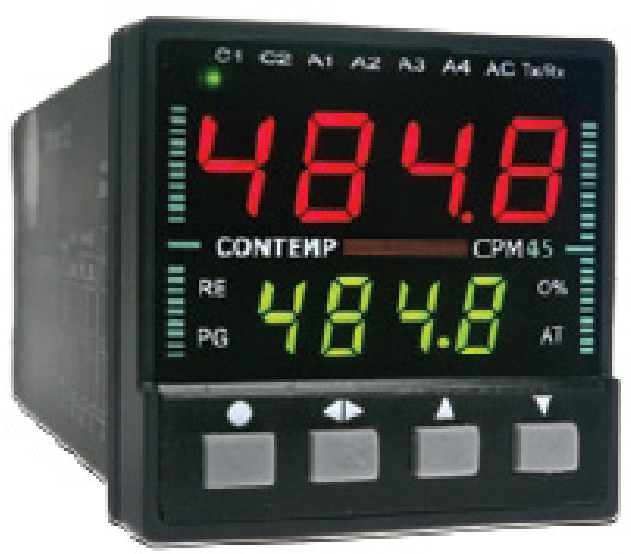

Figura 85 - Transdutor/Controlador de Temperatura CONTEMP Modelo CPM45

Para a faixa de temperatura considerada no experimento foi adotado como elemento sensor um termopar tipo K (Junção Cromel-Alumel) com capacidade de medição na faixa de $-20^{\circ} \mathrm{C}$ a $400^{\circ} \mathrm{C}$. O sensor de temperatura foi posicionado no ponto de maior circunferência da lâmpada, e afixado através de pasta condutora térmica, de forma a transmitir a temperatura do bulbo ao transdutor. $\mathrm{O}$ posicionamento do sensor de temperatura no experimento pode ser visto na Figura 86 .

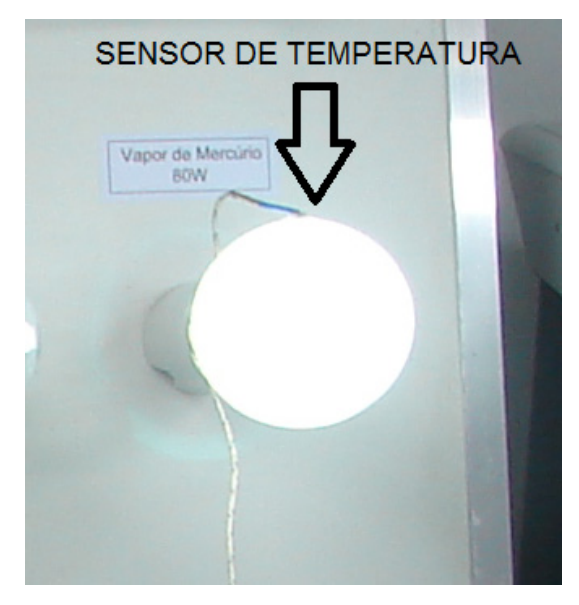

Figura 86 - Posicionamento do sensor de temperatura.

\subsubsection{Supervisor do sistema de aquisição de dados}

Para o controle do processo de aquisição de dados do experimento, foi desenvolvido um programa supervisor baseado na plataforma NI 
LabView ${ }^{\circledR}$. Este supervisor incorpora funcionalidades que permitem o contínuo monitoramento da montagem experimental através de uma interface gráfica, representando o painel de controle do sistema de aquisição de dados.

O sistema de supervisão, cuja interface de operação está mostrada na Figura 87, gerencia a aquisição de dados e a criação dos arquivos contendo os valores tabulados das variáveis monitoradas no experimento.

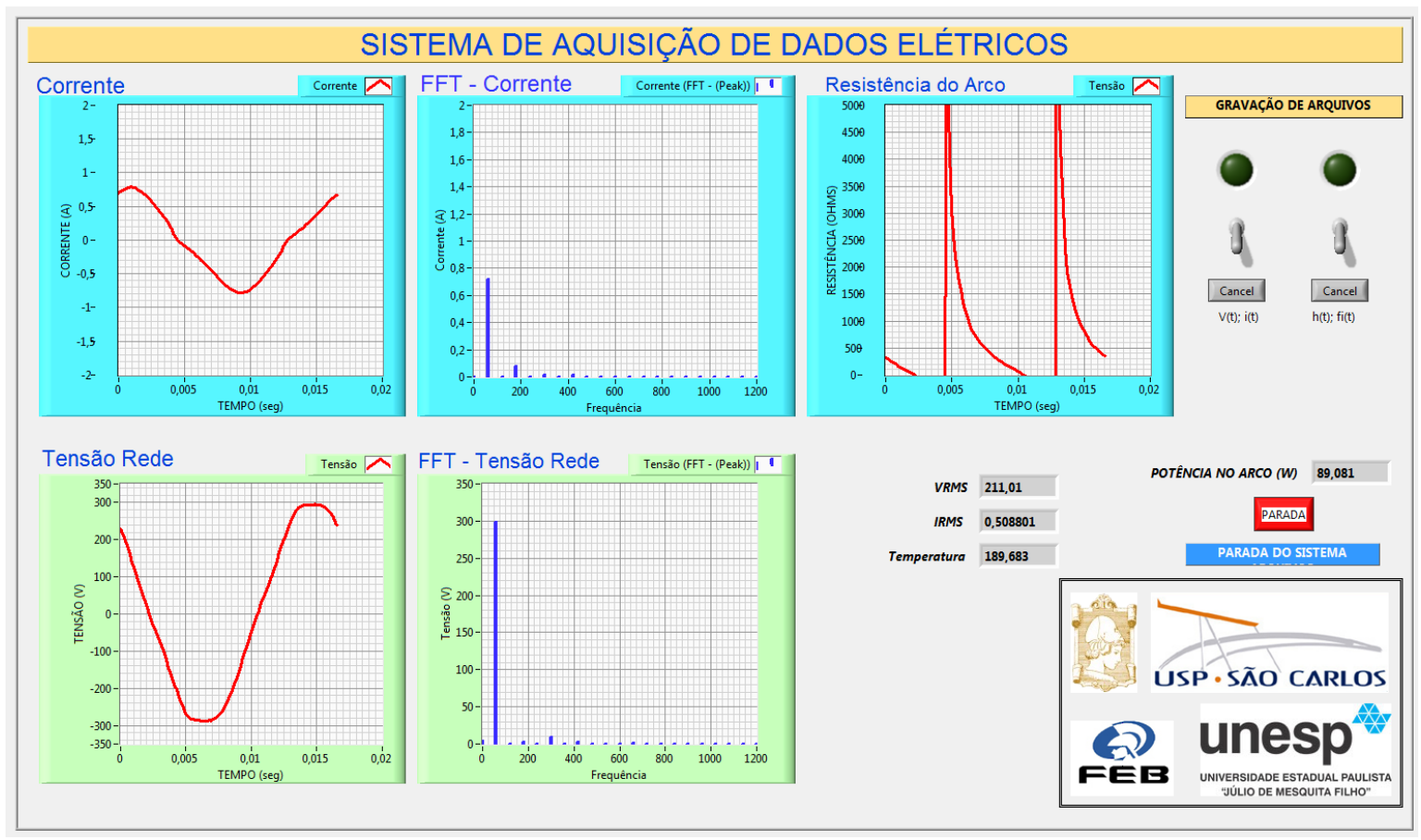

Figura 87 - Sistema de aquisição de dados - interface de operação

$\mathrm{Na}$ tela de operação do programa supervisor são exibidos simultaneamente os gráficos de tensão, corrente e os seus respectivos conteúdos harmônicos, permitindo ao operador acompanhar a evolução dos parâmetros elétricos do experimento em tempo real. Um quinto gráfico mostrando o desempenho da resistência do arco em função do tempo também é exibido, e os valores de tensão RMS, corrente RMS, potência no arco e temperatura do bulbo são apresentados continuamente no painel do aplicativo de gerenciamento da aquisição de dados. 
Ao operador do sistema supervisor de aquisição de dados é permitido o controle sobre o início e término de gravação de dois tipos de arquivos: um contendo os valores de tensão e corrente associados ao tempo, e outro tendo como conteúdo a decomposição harmônica dos sinais de tensão e corrente, valores RMS de tensão e corrente, temperatura, potência e estado da lâmpada.

Cada arquivo criado recebe numeração sequencial, incrementada por novo evento de gravação após cancelamento ou parada do sistema de aquisição de dados durante sua execução normal. Desta forma, além de permitir o ordenamento cronológico dos experimentos, evita-se a superposição acidental de dados gravados em etapas anteriores do experimento.

O tamanho dos arquivos obtidos é função direta do tempo de aquisição e da taxa de amostragem empregada no sistema de aquisição de dados. Para análise de conteúdo harmônico e da temperatura do experimento foi adotada uma taxa de atualização de $4 \mathrm{~Hz}$, correspondente a leituras efetuadas a cada $250 \mathrm{~ms}$, que mostrou-se suficiente devido a elevada inércia térmica do conjunto ensaiado.

A estrutura dos blocos funcionais empregados na composição do sistema supervisor de aquisição de dados, desenvolvido na plataforma de programação LabView ${ }^{\circledR}$, é ilustrado pela Figura 88 .

\subsubsection{Bancada de ensaio das lâmpadas}

Composta por um conjunto de lâmpadas de descarga de vários tipos, esta bancada foi construída de forma a permitir a instrumentação dos dispositivos de forma individual. Em sua composição, apresentam-se instalados os seguintes dispositivos:

1) 03 Lâmpadas fluorescentes de $20 \mathrm{~W}$

2) 01 Lâmpada de vapor de sódio de $70 \mathrm{~W}$

3) 01 Lâmpada de vapor metálico de $70 \mathrm{~W}$ 
4) 01 Lâmpada de vapor de mercúrio de $80 \mathrm{~W}$

5) Reatores eletromagnéticos convencionais, $220 \mathrm{~V}$

6) Ignitores para as lâmpadas de vapor de sódio e vapor metálico

7) 03 Starters para as lâmpadas fluorescentes

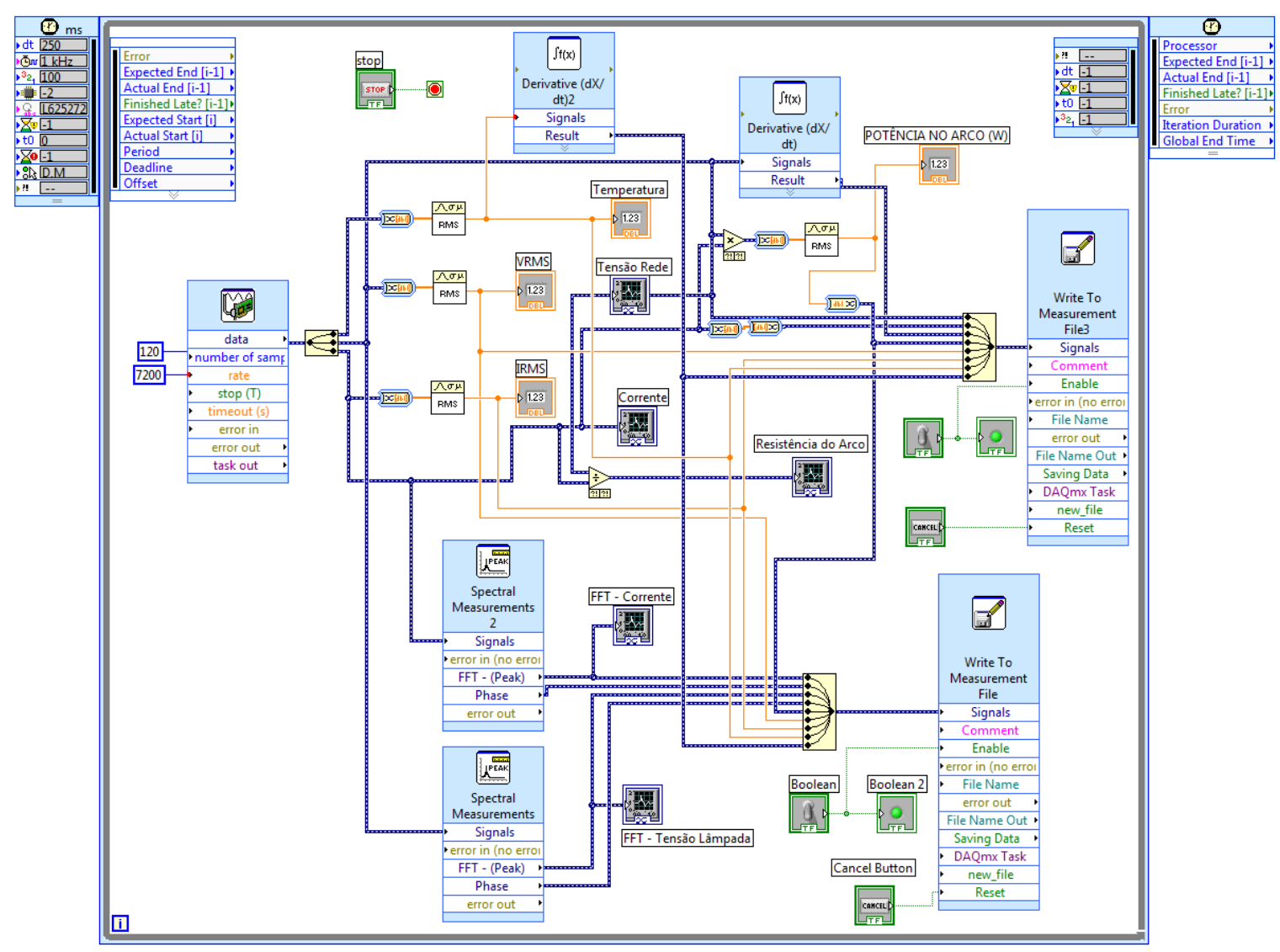

Figura 88 - Sistema de aquisição de dados - diagrama de blocos

As conexões dos diversos dispositivos estão acessíveis para as medições por meio de bornes, situados junto aos respectivos elementos. Através de conexões adequadas, são possíveis as medições de tensão e corrente individuais em cada um dos dispositivos presentes na bancada. O aspecto da bancada de ensaios é mostrado na Figura 89. 
$\mathrm{Na}$ pesquisa realizada, o elemento da bancada de lâmpadas utilizado durante o processo experimental de aquisição de dados para posterior modelagem foi a lâmpada de vapor de mercúrio de $80 \mathrm{~W}$ associada a seu reator eletromagnético.

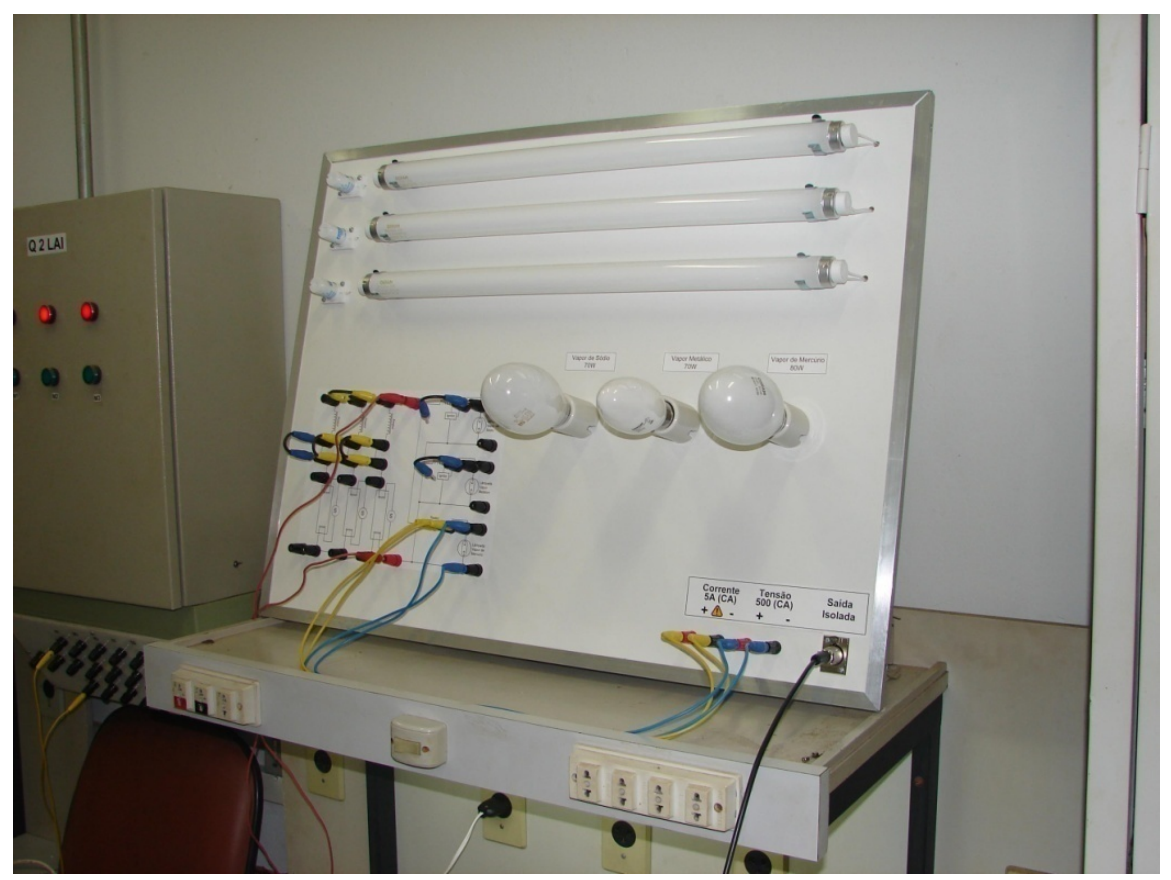

Figura 89 - Bancada de ensaios de lâmpadas

\subsection{Procedimentos experimentais}

A avaliação do comportamento prático das lâmpadas de descarga que permita atestar a eficácia de modelos propostos requer a analise do dispositivo para a maior quantidade de condições operacionais permitidas, e para todas as suas fases de operação. Para tornar isto possível, estabeleceu-se uma série de levantamentos das características operacionais da lâmpada de descarga a ser modelada, com o auxílio da montagem experimental proposta, de forma a compor uma base de dados bastante abrangente, aplicável na comprovação de desempenho dos modelos desenvolvidos. Um aspecto da montagem experimental com os componentes anteriormente descritos, utilizada na avaliação do comportamento da lâmpada de descarga, pode ser visto na Figura 90. 
Os ensaios foram divididos em dois conjuntos, cada qual destinado a caracterizar o dispositivo em determinadas condições operacionais. O primeiro conjunto de ensaios foi realizado com o objetivo de se estudar o comportamento da lâmpada diante de uma situação de alimentação estável, para aquisição dos parâmetros elétricos e termodinâmicos do dispositivo em regime de alimentação permanente. O segundo conjunto de ensaios teve por objetivo introduzir distúrbios na alimentação do dispositivo, caracterizando assim seu comportamento diante de eventos relacionados à qualidade da energia elétrica.

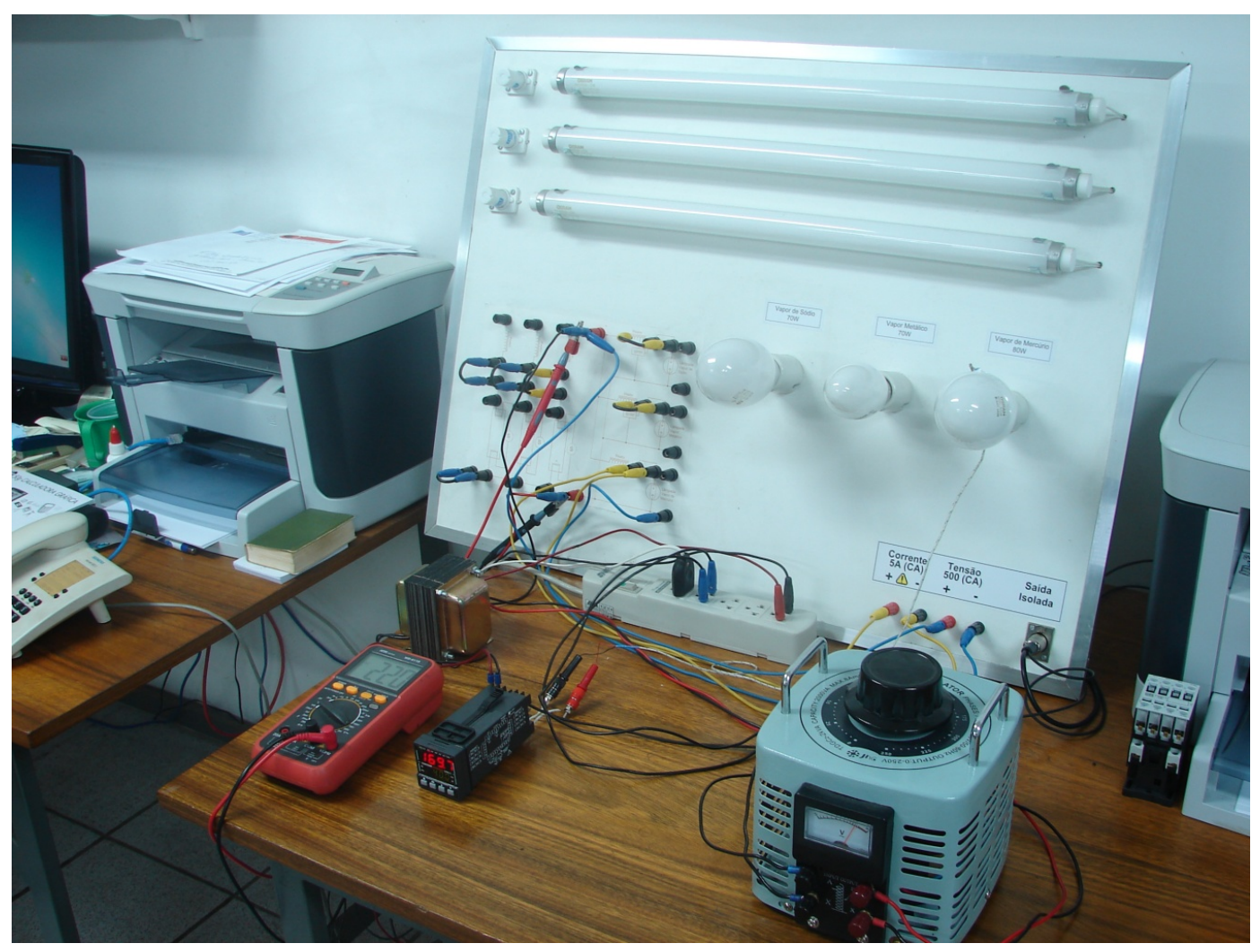

Figura 90 - Aspecto da montagem experimental.

Uma descrição detalhada dos dois conjuntos de ensaios realizados para a caracterização da lâmpada de descarga é apresentada a seguir. 


\subsubsection{Ensaios em regime de alimentação permanente}

Os ensaios destinados a avaliação do comportamento do dispositivo em condições de regime permanente de alimentação empregaram como fonte de alimentação um autotransformador continuamente ajustável (Variac), destinado a estabelecer o ponto de alimentação desejado para o ensaio. Nestes ensaios foi possível coletar dados referentes ao processo de partida e estabilização da lâmpada, acompanhando a evolução dos parâmetros através do sistema de aquisição de dados. $\mathrm{O}$ arranjo esquemático do experimento para estas situações é mostrado na Figura 91.

Deve ser observado que neste arranjo experimental o conjunto lâmpada/reator é alimentado por uma valor fixo de tensão, previamente estabelecido por ajuste no autotransformador (Variac), que deve ser realizado em um instante anterior ao início da aquisição dos dados de operação do experimento.

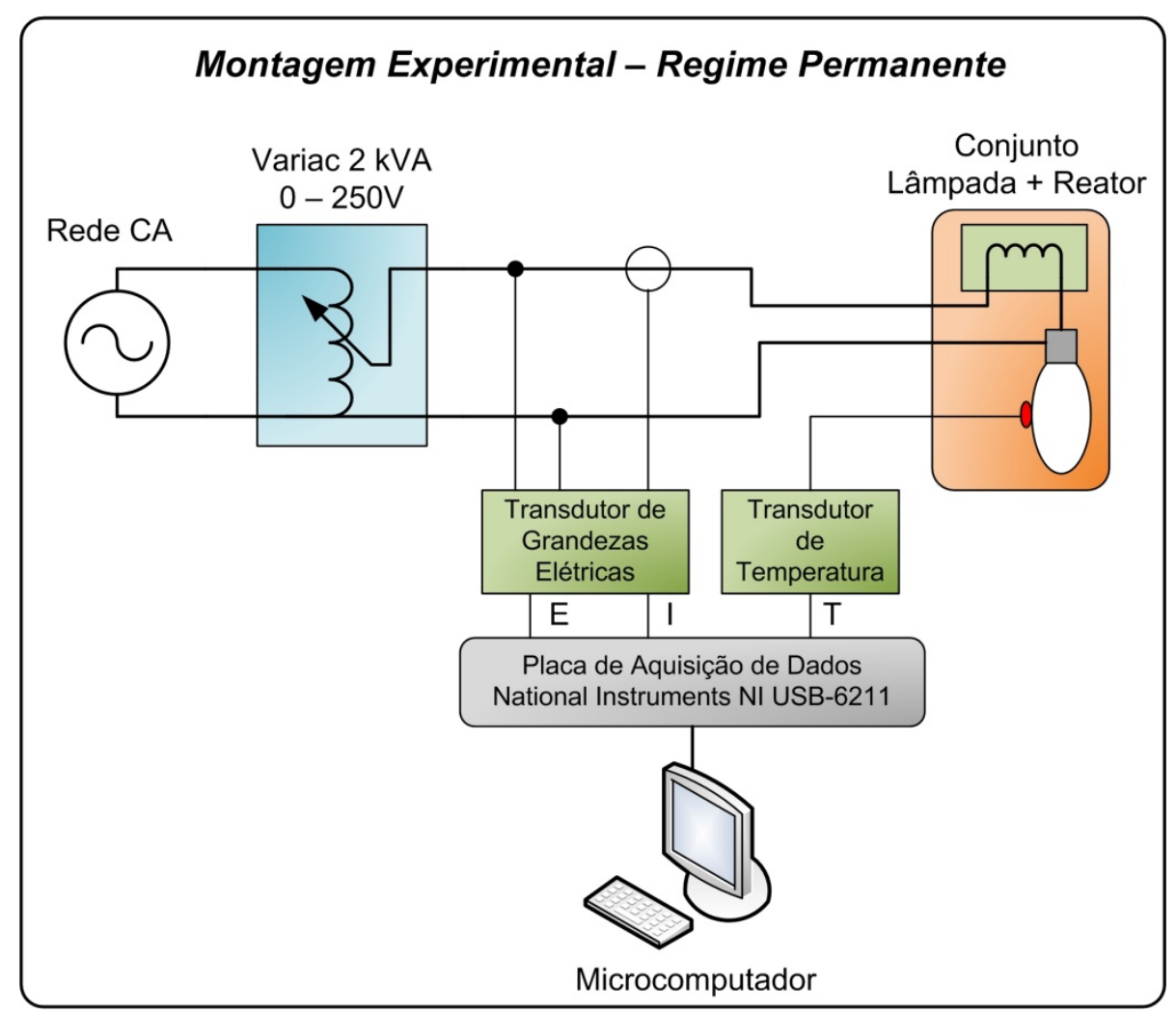

Figura 91 - Diagrama de blocos - montagem experimental para regime permanente 
Por meio do sistema de aquisição de dados, gerenciado pelo programa supervisor, realizou-se o registro de operação dos ciclos completos de operação do dispositivo, com amostragem dos dados realizada a cada $250 \mathrm{~ms}$, seguindo o procedimento abaixo descrito.

Com o experimento em condição de equilíbrio térmico com o ambiente, efetuou-se a partida da lâmpada, utilizando o valor de tensão de alimentação desejado já ajustado no Variac, e com o programa supervisor habilitado para a captura e registro dos dados de tensão, corrente no circuito e temperatura. Deste modo, obteve-se o comportamento elétrico e térmico da lâmpada durante a fase de aquecimento

Após a entrada em regime, caracterizada pela estabilização dos valores de temperatura e corrente observadas através do painel de controle do sistema aquisição de dados desenvolvido, a alimentação é interrompida por 3 segundos, de forma a permitir o registro dos valores nulos de corrente e potência do experimento. Após este período, a tensão é restabelecida em seu valor original, e a coleta de dados permanece até a lâmpada iniciar novamente sua operação, permitindo assim o registro do comportamento térmico da lâmpada em sua fase de resfriamento.

Os valores de tensão de alimentação empregados foram: $120 \mathrm{~V}$, $130 \mathrm{~V}, 140 \mathrm{~V}, 150 \mathrm{~V}, 160 \mathrm{~V}, 170 \mathrm{~V}, 180 \mathrm{~V}, 190 \mathrm{~V}, 200 \mathrm{~V}, 210 \mathrm{~V}, 220 \mathrm{~V}, 230 \mathrm{~V}$ e $240 \mathrm{~V}$.

Valores de tensão de alimentação abaixo de $120 \mathrm{~V}$ foram descartados por produzirem ignição precária e resultarem em um arco com instabilidade de operação. Valores de tensão acima de $240 \mathrm{~V}$ ultrapassam o limite de corrente permitido para o reator utilizado e, quando utilizados por longos períodos, produzem seu aquecimento excessivo, além de elevar consideravelmente a temperatura de operação da lâmpada ensaiada, reduzindo sua vida útil. 
Cada ensaio foi realizado por três vezes, de forma a se obter os comportamentos médios do dispositivo. Para cada ciclo de operação foi gerado um arquivo, e estes arquivos foram posteriormente combinados conforme as condições do ensaio realizado para a caracterização de um único tipo de experimento.

Com os ensaios desta fase foi possível a obtenção de um banco de dados com informações referentes ao conteúdo harmônico de tensão e corrente de operação, associado à curva de comportamento termodinâmico do dispositivo, em sua fase de aquecimento, operação estável e resfriamento até atingir novamente condições de ionização. Os dados assim obtidos são suficientes para as definições necessárias às comparações de desempenho do modelo matemático de lâmpada de descarga e dos parâmetros de treinamento do modelo proposto baseado em redes neurais artificiais, com relação ao comportamento em regime de alimentação estável.

\subsubsection{Ensaios com aplicação de distúrbios de QEE}

O conjunto de ensaios destinado a caracterizar o comportamento da lâmpada de descarga frente a distúrbios de qualidade da energia foi realizado utilizando como fonte de alimentação o gerador arbitrário de sinais fabricado pela California Instruments, modelo 5001ix, anteriormente descrito.

Na caracterização da lâmpada submetida a eventos de alimentação, o uso do gerador arbitrário de sinais como fonte de alimentação permitiu a aplicação controlada de distúrbios relacionados à qualidade da energia em diversos instantes de operação do dispositivo, e assim complementar o banco de dados de comportamentos do dispositivo com relação à qualidade da energia do sistema de alimentação.

O arranjo empregado nestes experimentos é apresentado na Figura 92. Nesta configuração, o conjunto lâmpada/reator é alimentado através do gerador arbitrário de sinais, previamente programado para aplicar um distúrbio na alimentação do 
experimento no instante conveniente, e assim permitir ao sistema de aquisição de dados registrar o comportamento da lâmpada frente ao distúrbio aplicado.

Deve ser observado que os experimentos realizados com este arranjo foram inicialmente estabilizados, isto é, a lâmpada de descarga foi alimentada pelo gerador arbitrário de sinais em uma condição inicial estável, com nível de tensão adequado ao experimento conduzido, e sua operação atingiu um ponto estável de operação antes da aplicação do distúrbio a ser estudado. Exceção se faz aos casos onde o distúrbio em interesse foi aplicado nas fases transitórias de operação da lâmpada, como por exemplo os afundamentos e interrupções que incidiram durante a fase de aquecimento do dispositivo.

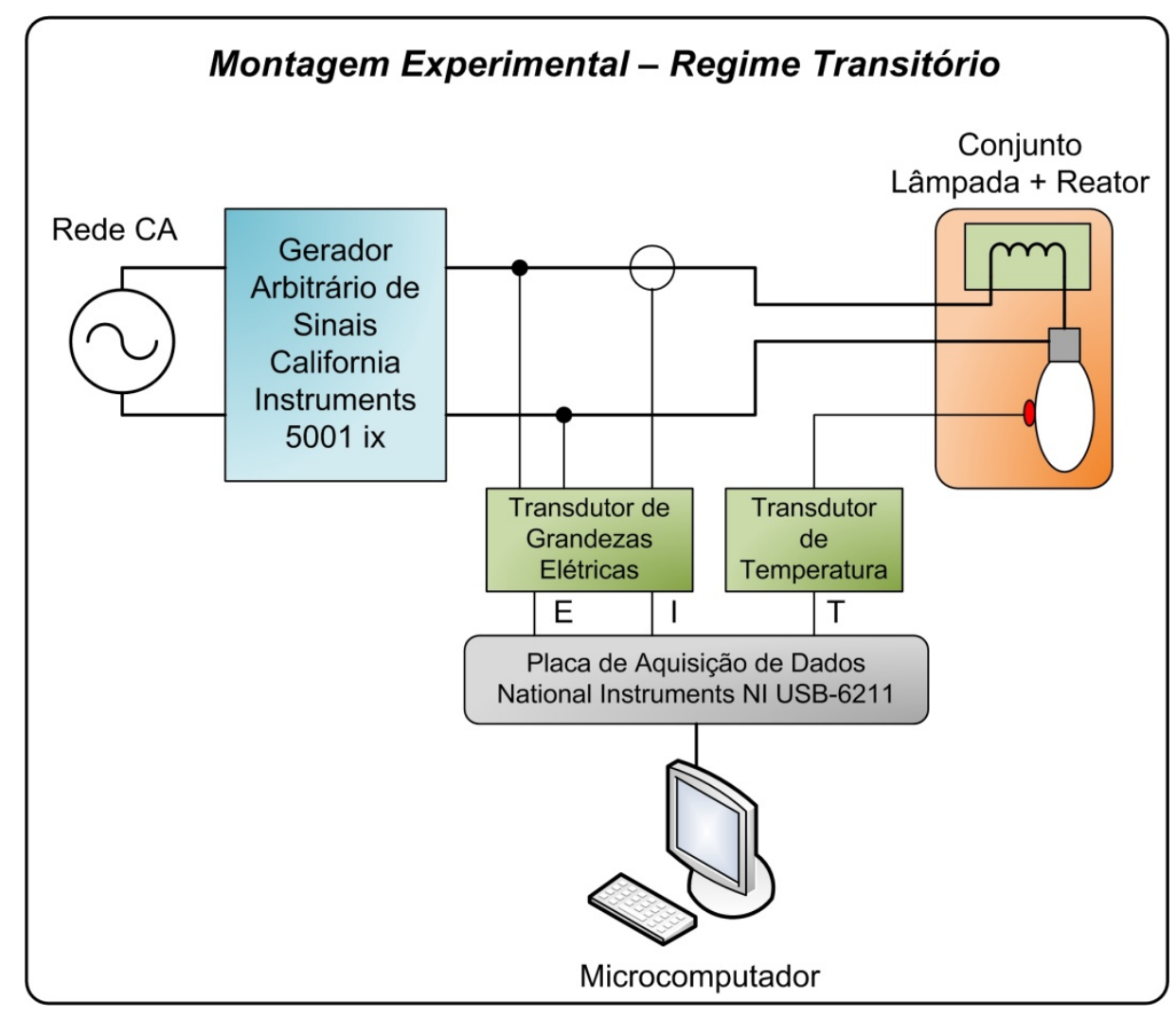

Figura 92 - Diagrama de blocos - montagem experimental para regime transitório

Cada experimento desta série teve seu perfil programado através de uma lista de distúrbios inserida no gerador arbitrário de sinais, conforme procedimentos já 
abordados neste capítulo, e os distúrbios programados foram aplicados no instante em que o experimento se encontrava na situação adequada.

Os seguintes distúrbios de alimentação relacionados à qualidade de energia foram experimentados:

$\rightarrow$ Elevações de tensão instantâneas (1,1 pu, 1,2 pu e 1,3 pu) com a lâmpada em regime e durante a fase de aquecimento

$\rightarrow$ Elevações de tensão momentâneas (1,1 pu, 1,2 pu e 1,3 pu) com a lâmpada em regime e durante a fase de aquecimento

$\rightarrow$ Afundamentos instantâneos ( $0,9 \mathrm{pu}, 0,8 \mathrm{pu}, 0,7 \mathrm{pu}, 0,6 \mathrm{pu}$ e $0,5 \mathrm{pu})$ com a lâmpada em regime e durante a fase de aquecimento

$\rightarrow$ Afundamentos momentâneos ( $(0,9$ pu, 0,8 pu, 0,7 pu, 0,6 pu e 0,5 pu) com a lâmpada em regime e durante a fase de aquecimento

$\rightarrow$ Aplicação de degraus de tensão $(0,70$ pu, 0,75 pu , 0,80 pu, 0,85 pu, 0,90 pu, $0,95 \mathrm{pu}, 1,05 \mathrm{pu}, 1,10 \mathrm{pu}, 1,15 \mathrm{pu}, 1,20 \mathrm{pu}, 1,25 \mathrm{pu}$ e 1,30 pu), a partir de valores de alimentação estáveis de $160 \mathrm{~V}, 170 \mathrm{~V}, 180 \mathrm{~V}, 190 \mathrm{~V}, 200 \mathrm{~V}, 210 \mathrm{~V}, 220 \mathrm{~V}, 230 \mathrm{~V}$ e $240 \mathrm{~V}$, caracterizando assim variações de tensão de longa duração (VTLD).

Cada sequência de eventos foi repetida por três vezes, a partir das mesmas condições iniciais, de forma a representar o comportamento médio do dispositivo. Os resultados foram agrupados conforme a natureza do experimento realizado, compondo assim uma base de dados para o treinamento e validação dos modelos a serem desenvolvidos.

Com os ensaios desta fase foi possível a obtenção de um banco de dados com informações referentes ao comportamento da lâmpada de descarga quando submetida a distúrbios de alimentação relacionados à qualidade da energia. Os dados deste modo obtidos contribuem para as comparações de desempenho de modelos de lâmpada de 
descarga, com relação ao comportamento do dispositivo recebendo distúrbios de alimentação, em fases de estabilidade ou em períodos transitórios de operação.

\subsection{Observações operacionais}

A observação qualitativa da operação do conjunto durante variações permanentes na amplitude da tensão de alimentação permitiu a observação dos seguintes aspectos:

1) A ocorrência de afundamentos durante a partida a frio do conjunto permite o acendimento, mesmo em significativas reduções na tensão. Nestas condições, o conteúdo harmônico da corrente é significativamente reduzido. Isto se deve ao fato do arco apresentar baixa resistência por efeito da temperatura relativamente baixa do tubo de descarga, e em conjunto com a reatância indutiva do reator, compor uma impedância praticamente linear.

2) Os afundamentos durante a fase de aquecimento produzem a limitação na potência da lâmpada, sem contudo provocar seu apagamento. Novamente o efeito da temperatura do tubo de descarga é evidenciado, impedindo a extinção do arco.

3) Após a fase de aquecimento, a sensibilidade a afundamentos do conjunto se pronuncia, levando inclusive à extinção do arco. Isto se deve às elevadas temperaturas e pressões presentes no interior do tubo de descarga após o aquecimento do dispositivo, que tornam mais difícil a ionização do gás em seu interior.

4) A presença de elevações de tensão de alimentação durante a partida a frio da lâmpada produz elevação da corrente de partida, com consequente aceleração no aquecimento da lâmpada; neste caso o conteúdo harmônico da corrente se eleva devido às distorções introduzidas principalmente pela saturação do núcleo do reator 
5) Após a fase de aquecimento, as elevações de tensão levam ao aumento da temperatura no arco, que por consequência produz elevação na potência irradiada pelo tubo de descarga. Nota-se novamente a elevação do conteúdo harmônico da corrente, causada pela saturação do reator.

A massa de dados obtida com o conjunto de experimentos realizados abrange um conjunto de situações operacionais da lâmpada de descarga que permite sua caracterização em diversas condições de alimentação e representa seu comportamento prático diante de distúrbios de alimentação relacionados à qualidade da energia. Espera-se, deste modo, que os modelos validados a partir desta massa de dados possibilitem a reprodução do dispositivo modelado com elevado grau de semelhança entre comportamentos. 


\section{REPRESENTAÇÃO MATEMÁTICA DAS LÂMPADAS DE DESCARGA}

As lâmpadas de descarga são dispositivos baseados na sustentação de uma coluna de plasma de forma estável, capazes de converter eficientemente energia elétrica em radiação eletromagnética. O comportamento elétrico desta coluna e a eficiência do dispositivo são dependentes da geometria e da natureza dos materiais empregados na constituição física da lâmpada.

Desta forma, a representação matemática da operação destes dispositivos pode ser realizada por algumas metodologias, entre elas:

a) Considerando os aspectos físicos e geométricos do dispositivo em relação ao comportamento da coluna de plasma, e por consequência seus aspectos elétricos;

b) Através do equacionamento termodinâmico de balanço de energia no dispositivo e sua relação com a conversão de energia realizada durante a operação do mesmo; e 
c) Por meio do levantamento das características elétricas operacionais do dispositivo e construção de um modelo que reproduza matematicamente seu comportamento, baseado nos dados coletados.

Como já exposto, este trabalho tem por objetivo desenvolver um modelo derivado do equacionamento termodinâmico da lâmpada de descarga com características adicionais que permitam a representação da operação do dispositivo na presença de distúrbios da qualidade da energia elétrica presentes em sua alimentação, possibilitando assim uma caracterização desta família de cargas inseridas em um sistema elétrico real.

Para que tal representação seja validada, torna-se interessante estabelecer um parâmetro de comparação com o método de modelagem convencional, baseado em um equacionamento matemático que descreva o dispositivo. Embora existam outros modelos matemáticos, com vocações diversas no que se refere ao grau de fidelidade de reprodução, o modelo apresentado a seguir é o que melhor se aplica na representação da lâmpada de descarga como elemento inserido no sistema elétrico.

\subsection{Modelo termodinâmico do arco elétrico}

Conforme apresentado no levantamento bibliográfico, as lâmpadas de descarga podem ser matematicamente representadas por um conjunto de equações que definem o comportamento termodinâmico do dispositivo, ou seja, o balanço térmico que ocorre durante a operação do tubo de descarga enquanto sustenta a coluna de plasma em seu interior [20]. A base deste equacionamento é mostrada na seguinte equação:

$$
\frac{d T}{d t}=a_{1}\left(i^{2} R-P_{c o n}-P_{r a d}\right)
$$

Onde:

dT/dt: Taxa de Variação da Temperatura do Bulbo 
$\mathrm{a}_{1}$ :Constante de variação térmica do dispositivo

$i^{2} R$ :Potência Elétrica gerada no Bulbo

$\mathrm{P}_{\text {con:Potência dissipada por condução }}$

$P_{\text {rad }}$ Potência irradiada

Esta equação, que representa o balanço térmico, mostra a razão de variação da temperatura dependente de três termos: a potência elétrica desenvolvida pelo arco, representando a fonte de calor, a potência dissipada por condução e a potência convertida em radiação, que efetivamente é aproveitada na geração de fluxo luminoso.

A temperatura do bulbo externo da lâmpada, considerando a resistência térmica entre o bulbo interno e o bulbo externo, será dada pelo valor médio quadrático proporcional à temperatura do bulbo interno, dada por:

$$
T_{\text {bulbo }}=\frac{T_{R M S}}{R_{T h}}
$$

Onde:

$\mathrm{T}_{\text {bulbo: }}$ Temperatura do bulbo externo da lâmpada

$\mathrm{T}_{\mathrm{RMS}}$ : Valor médio quadrático da temperatura do bulbo interno

$\mathrm{R}_{\mathrm{Th}}$ : Resistência térmica entre o bulbo interno e bulbo externo

A potência irradiada é representada pela seguinte equação [20]:

$$
P_{r a d}=a_{2} \cdot \exp \left(\frac{-e \cdot a_{3}}{k \cdot T}\right)
$$

Onde:

$\mathrm{P}_{\text {rad }}$ :Potência irradiada

$a_{2}, a_{3}$ :Constantes de ajuste do modelo de irradiação

e: Carga do elétron

$\mathrm{k}$ :Constante de Boltzmann

$\mathrm{T}:$ Temperatura do plasma, em Kelvin

Pela equação nota-se a dependência direta existente entre a potência irradiada e a temperatura da coluna de plasma. O limite prático para a eficiência 
destes dispositivos encontra-se, desta forma, na resistência a operações em altas temperaturas oferecida pelos materiais empregados na construção do tubo de descarga.

Além da energia convertida em radiação, parte do calor gerado pelo dispositivo é dissipado por condução, principalmente através dos elementos condutores e de sustentação do tubo de descarga. Considerando a condução térmica como uma função linear, podemos quantificar seu efeito através da equação [20]:

$$
P_{\text {con }}=a_{4} \cdot\left(T-T_{0}\right)
$$

Onde:

$\mathrm{P}_{\text {con }}$ :Potência dissipada por condução

$\mathrm{a}_{4}$ :Constante de condutividade Térmica do meio

$\mathrm{T}$ :Temperatura do plasma, em $\mathrm{K}$

$\mathrm{T}_{0}$ :Temperatura externa ao bulbo, em $\mathrm{K}$

A resistência apresentada pela coluna de plasma, após sua ionização, tem relação inversa com a temperatura no interior do tubo de descarga, além de depender das características geométricas da construção do dispositivo. O comportamento da resistência elétrica do tubo de descarga é descrito pela seguinte equação [20]:

$$
R=a_{5} \cdot T^{-\frac{3}{4}} \cdot \exp \left(\frac{e \cdot a_{6}}{2 \cdot k \cdot T}\right)
$$

Onde:

R:Resistência da coluna de plasma, em Ohms

$\mathrm{a}_{5}, \mathrm{a}_{6}$ :Constantes de ajuste do modelo de resistência

e: Carga do elétron

$\mathrm{k}$ :Constante de Boltzmann

$\mathrm{T}$ :Temperatura do plasma, em $\mathrm{K}$

As constantes presentes nas equações são dependentes da forma construtiva de cada dispositivo, e referem-se a condições estáveis de operação. Para uma melhor representação das descontinuidades existentes na operação dos tubos de descarga, especialmente em regime transitório, pode ser desejável a substituição de algumas 
constantes por funções que ajustem o modelo dinamicamente às condições mais próximas da operação real da lâmpada.

\subsubsection{Malha lâmpada-reator}

A representação do circuito elétrico composto pela conexão em série entre fonte de alimentação, reator e lâmpada de descarga pode ser feita através da seguinte equação de malha [20]:

$$
V=L \cdot \frac{d i}{d t}+i \cdot(R+r)+v_{e l e}
$$

Onde:

$\mathrm{V}$ :Tensão da fonte

L:Indutância do reator

R:Resistência ôhmica do arco de plasma

$r$ :Resistência ôhmica do reator

$\mathrm{V}_{\text {ele: }}$ Queda de tensão nos eletrodos da lâmpada

Durante a fase de partida, a assimetria no aquecimento dos eletrodos pode introduzir um caráter retificador na lâmpada de descarga. Neste caso, o termo $\boldsymbol{v}_{\text {ele }}$ assume valor médio diferente de zero e variável no tempo.

\subsection{Implementação do modelo no SIMULINK®}

O modelo do sistema fonte-lâmpada-reator foi implementado inicialmente no ambiente SIMULINK® ${ }^{\circledR}$, para validação do modelo em regime permanente com base nos valores obtidos através dos experimentos descritos no capítulo quatro deste trabalho. Cada equação implementada está descrita a seguir, e a conexão entre os diversos blocos é apresentada ao final deste tópico.

\subsubsection{Modelo de equação (3) e (4) de equilíbrio térmico do arco}

A representação da equação (3) que descreve o equilíbrio térmico da lâmpada de descarga é mostrada na Figura 93. 
$\mathrm{Na}$ implementação da equação de equilíbrio térmico é possível observar as entradas, correspondentes à resistência do arco (R), a corrente na lâmpada (i), os valores de potência dissipada por condução (Pcon) e potência convertida em irradiação (Prad), além da constante do modelo $\boldsymbol{a} \mathbf{1}$ e da resistência térmica entre o tubo de descarga e o bulbo externo (Rth), conforme a equação (4). As saídas desta equação mostram a temperatura instantânea do plasma e a temperatura média quadrática do bulbo da lâmpada.

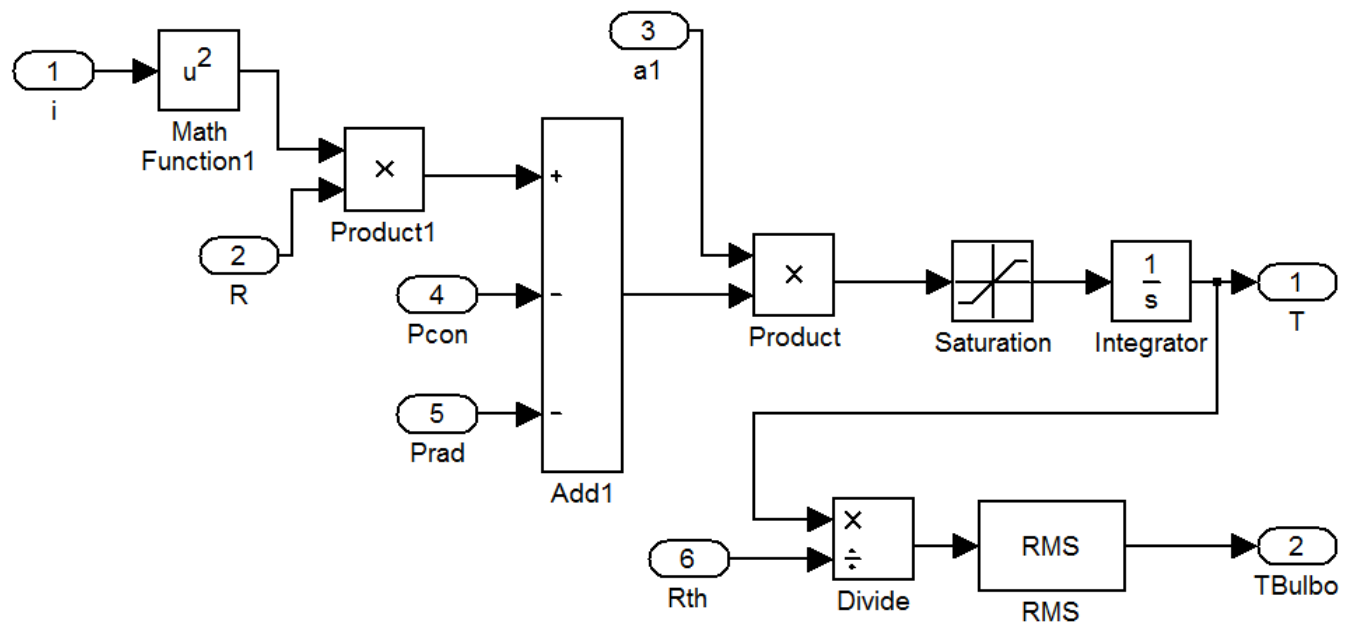

Figura 93 - Equação térmica do arco (SIMULINK®)

\subsubsection{Implementação da equação (5) de potência irradiada}

A implementação da equação (5), que representa a potência irradiada pelo tubo de descarga, é representada por blocos no SIMULINK® conforme a Figura 94.

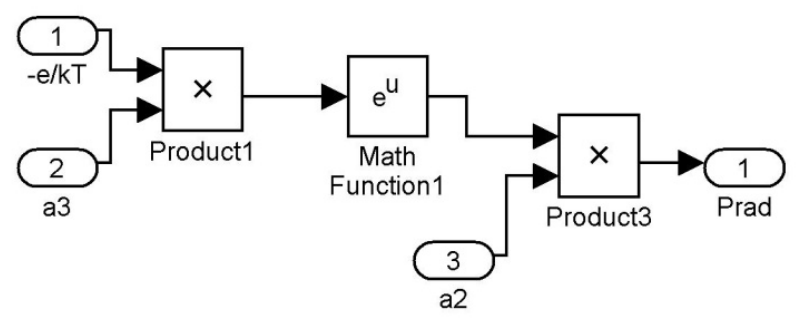

Figura 94 - Equação (5) de potência irradiada (SIMULINK®) 
Esta implementação tem como entradas as constantes $\boldsymbol{a} \mathbf{2}$ e $\boldsymbol{a} \mathbf{3}$ do modelo, e o resultado de uma função dependente da temperatura do plasma $(\boldsymbol{- e} / \boldsymbol{k T})$. A saída da equação é o valor de potência convertida em radiação Prad.

\subsubsection{Implementação da equação (6) de potência dissipada por condução}

A Figura 95 mostra a equação (6), que representa a potência dissipada por condução em sua adaptação à linguagem de blocos do SIMULINK®. Nesta equação, as entradas são os valores de temperatura instantânea do plasma $\mathrm{T}$ e a temperatura de referência T0, além da constante do modelo a4. A saída da equação é o valor de potência dissipada por condução Pcon.

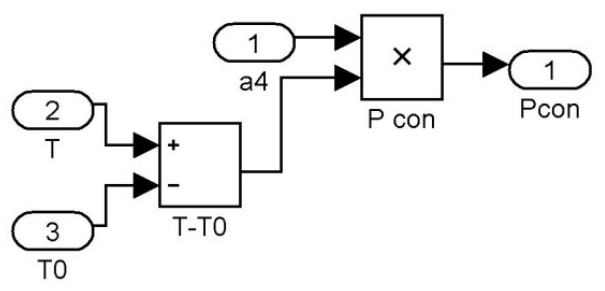

Figura 95 - Equação (6) de potência dissipada por condução (SIMULINK®)

\subsubsection{Resistência da coluna de arco}

A resistência elétrica apresentada pela coluna de plasma após a ionização, definida pela equação (7), é descrita através do conjunto de blocos matemáticos do SIMULINK® arranjados conforme a Figura 96. 


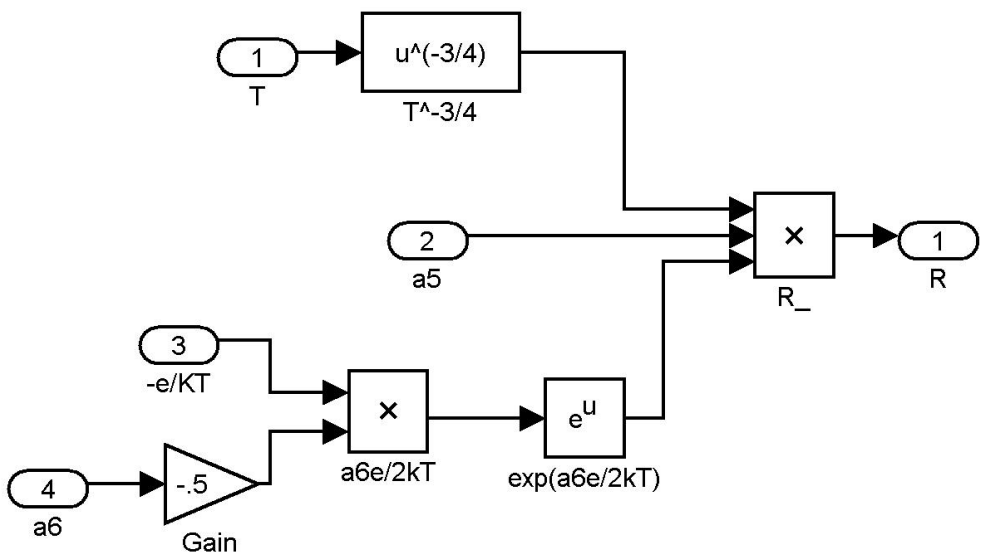

Figura 96 - Equação (7) da resistência da coluna do arco (SIMULINK®)

As entradas da equação implementada são as constantes do modelo a5 e a6, o valor de temperatura instantâneo $\mathrm{T}$ e o resultado da função dependente da temperatura -e/kT. A saída da equação é o valor de resistência instantânea da coluna de plasma.

\subsubsection{Modelo de resistência do arco da lâmpada de descarga}

A Figura 97 apresenta o conjunto de blocos anteriormente descritos conectados de forma a compor o modelo de resistência do arco da lâmpada de descarga. Deve ser observado que, como entradas, o modelo recebe as constantes de ajuste, a temperatura externa e a corrente de operação. Destes valores obtém-se a resposta, representada pelo valor de resistência ôhmica da coluna de plasma, além dos valores de temperatura do plasma e temperatura do bulbo da lâmpada. 


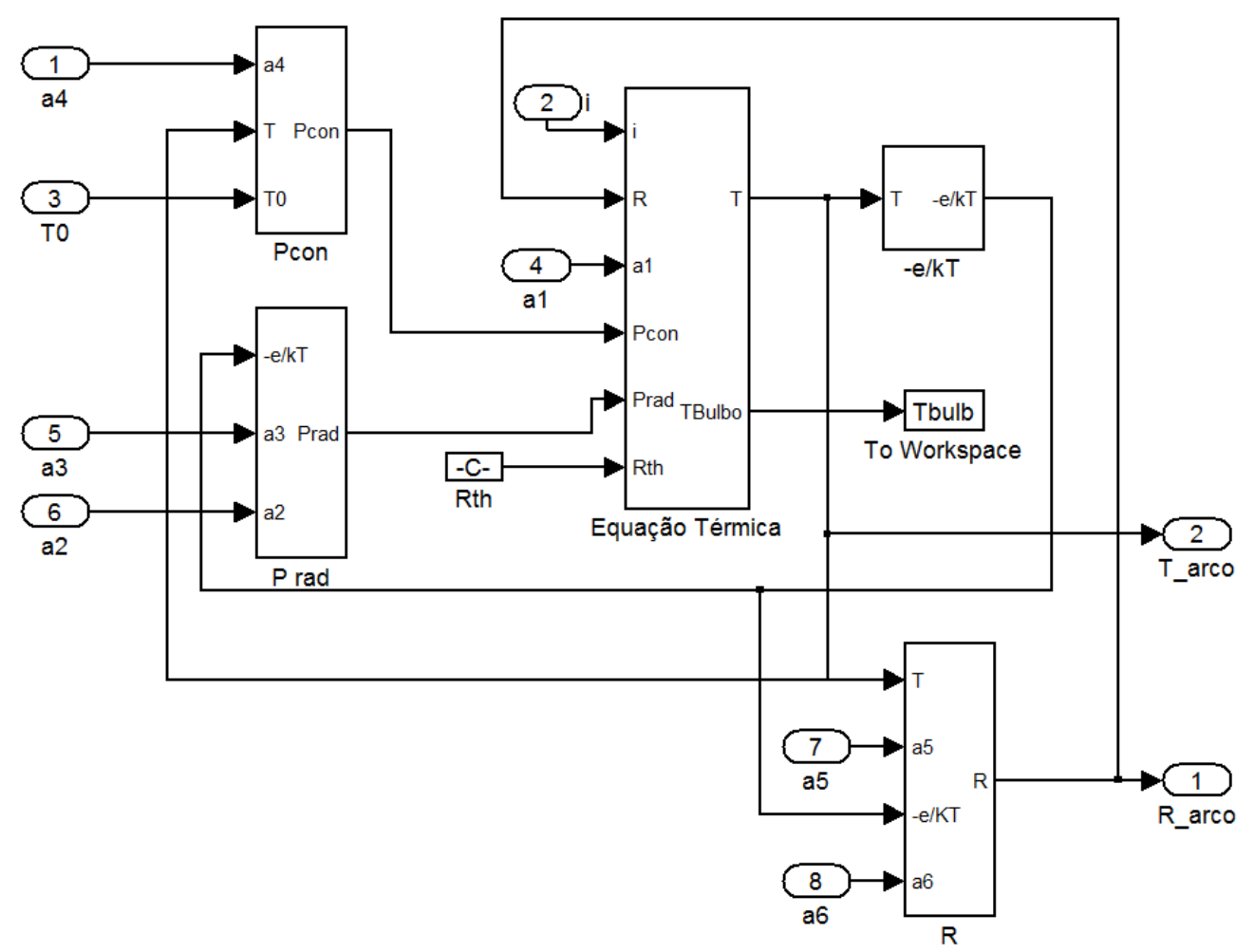

Figura 97 - Modelo do arco na lâmpada de descarga

\subsubsection{Implementação do modelo de circuito elétrico}

O circuito composto pela fonte, reator e lâmpada é apresentado pelo diagrama de blocos da Figura 98. Nesta implementação do modelo é possível verificar a representação da lâmpada como uma fonte de tensão dependente, associada em série com o circuito do reator. A queda de tensão sobre a lâmpada é função da resistência da coluna de plasma, definida pelos valores das constantes de ajuste do modelo e da temperatura instantânea do plasma.

O ponto de operação da lâmpada neste modelo pode ser definido através do valor de sua temperatura inicial (T0). As variáveis de saída da simulação, correspondentes à resposta do modelo implementado, são disponibilizadas na forma de variáveis alocadas na área de trabalho do ambiente $M A T L A B \circledR$, permitindo desta forma o armazenamento dos resultados das simulações para analises posteriores. 


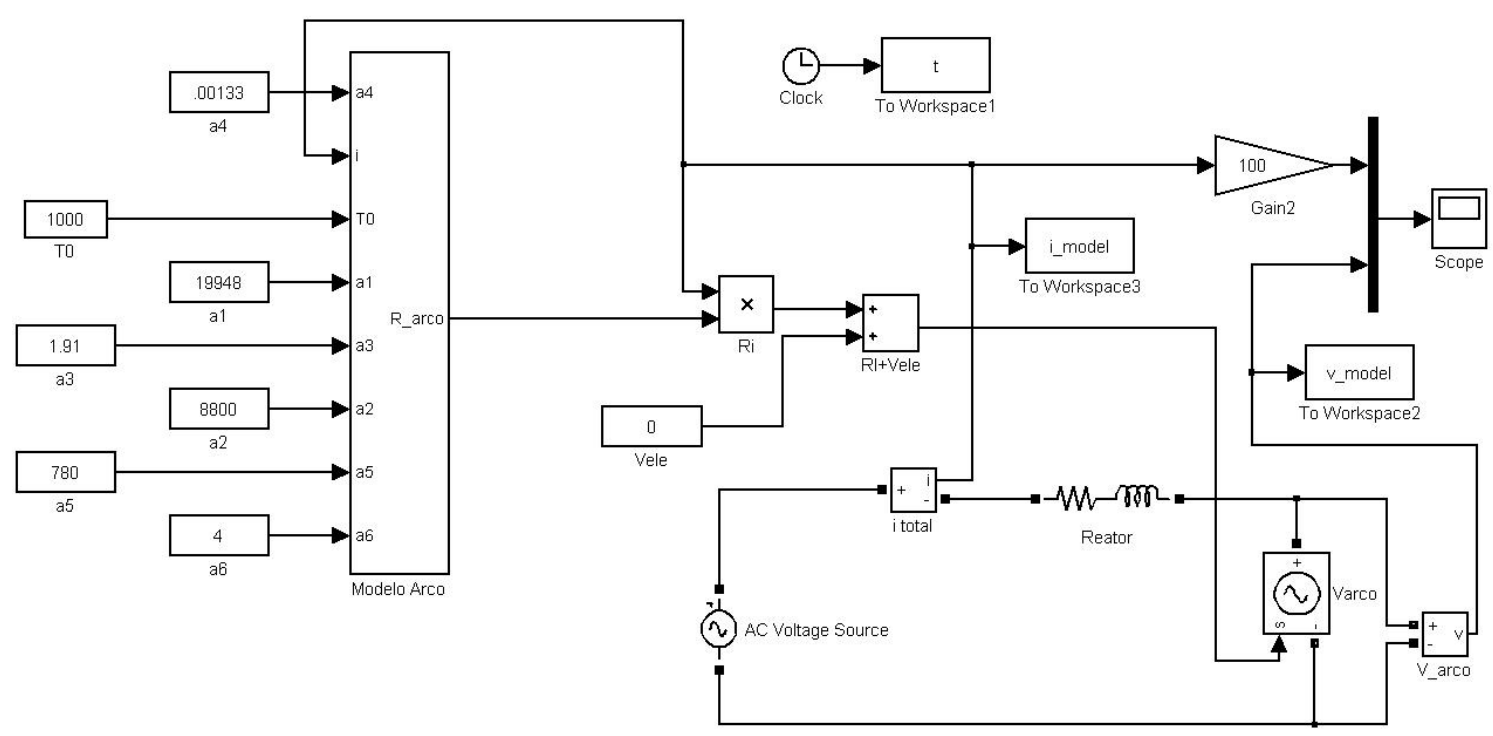

Figura 98 - Modelo lâmpada-reator (SIMULINK®)

Entre os pontos notáveis apresentados por este modelo, observamos a reprodução da natureza resistiva do arco elétrico, com dependência direta da temperatura do plasma. Isto explica a não-linearidade na resposta de tensão sobre o arco das lâmpadas de descarga acionadas em frequência industrial, onde a variação relativamente lenta no valor instantâneo da corrente produz ondulações na temperatura do bulbo que refletem em variações de resistência da coluna de plasma.

O modelo não limita os níveis de tensão de operação da lâmpada, desconsiderando, portanto, as condições para ignição e manutenção do arco. Este aspecto pode ser acrescentado ao modelo mediante análise do comportamento do dispositivo real e ajuste dos coeficientes por funções apropriadas, como proposto por este trabalho.

\subsection{Comparação entre modelo desenvolvido e os ensaios realizados}

A coleta de dados foi empregada como base para a definição dos parâmetros de operação do modelo em regime permanente, em uma primeira etapa. A partir de parâmetros indicados na literatura [20], os valores das constantes foram ajustados 
manualmente, a partir de observações de comportamento do modelo, de modo a permitir uma caracterização muito próxima dos valores experimentais obtidos. Deste modo, o conjunto de constantes que melhor representou o dispositivo está exposto na Tabela 6:

Tabela 6 - Constantes iniciais do modelo

\begin{tabular}{c|c}
\hline Constante & Valor \\
\hline $\mathrm{a}_{1}$ & 19.948 \\
\hline $\mathrm{a}_{2}$ & 8.800 \\
\hline $\mathrm{a}_{3}$ & 1,91 \\
\hline $\mathrm{a}_{4}$ & 0,003 \\
\hline $\mathrm{a}_{5}$ & 780 \\
\hline $\mathrm{a}_{6}$ & 4 \\
\hline $\mathrm{T}_{0}$ & 300 \\
\hline
\end{tabular}

O modelo matemático para a lâmpada operando em regime permanente, utilizando os parâmetros mostrados anteriormente, apresenta um comportamento na corrente mostrado no gráfico da Figura 99.

A reprodução realizada pelo modelo matemático da tensão sobre o arco de plasma da lâmpada de descarga é apresentado no gráfico da Figura 100. A condição apresentada refere-se ao dispositivo em regime permanente de operação com alimentação em tensão nominal (220V) em frequência de $60 \mathrm{~Hz}$.

Em análise de amostras de tempo menores é possível observar a forma de onda referente à corrente simulada. Os resultados da simulação, comparados diretamente com os valores obtidos pela montagem experimental, estão mostrados na Figura 101, onde é possível observar a grande similaridade entre os valores simulados e os dados experimentais. 


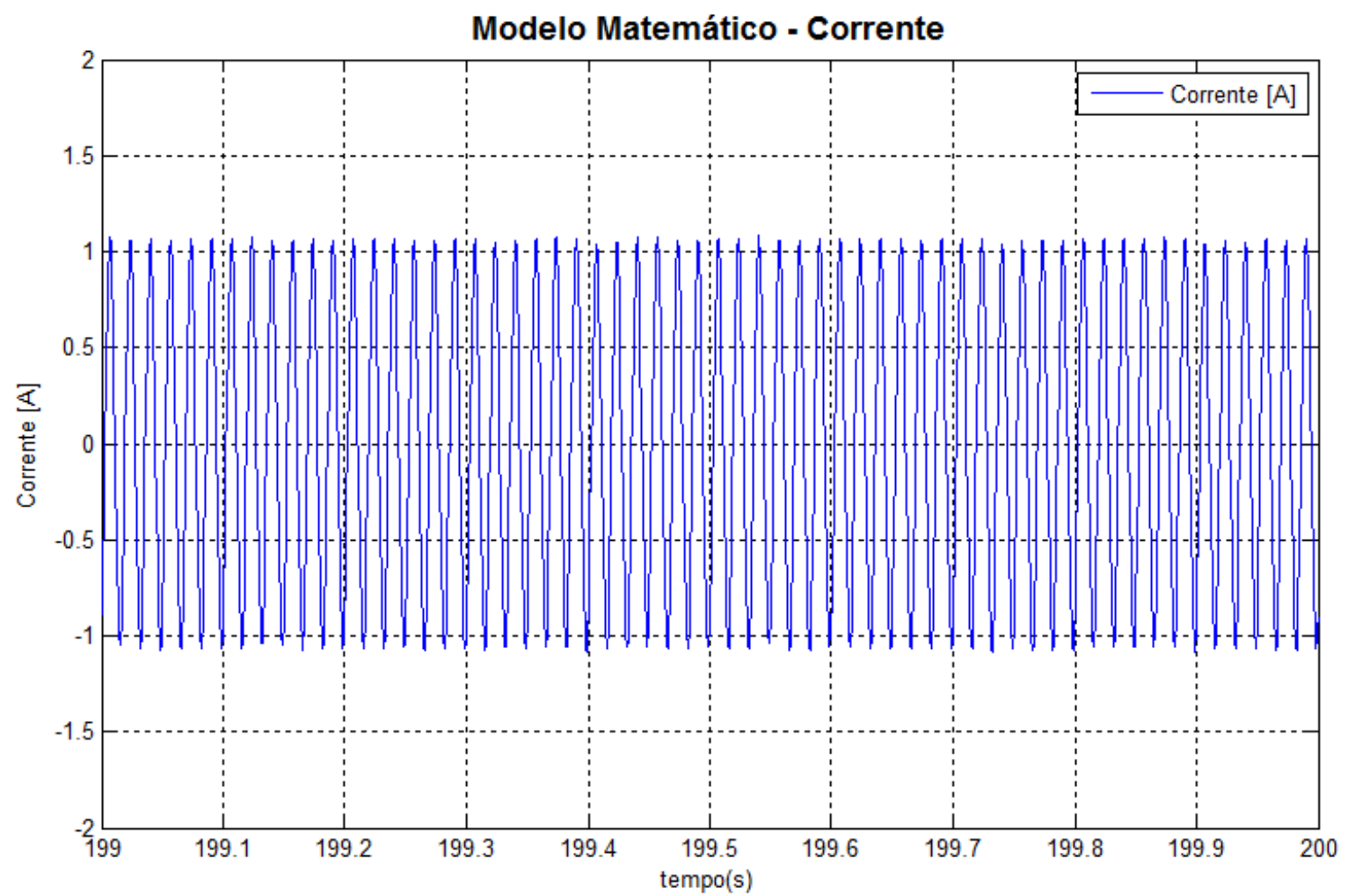

Figura 99 - Corrente na lâmpada de descarga - resposta do modelo matemático.

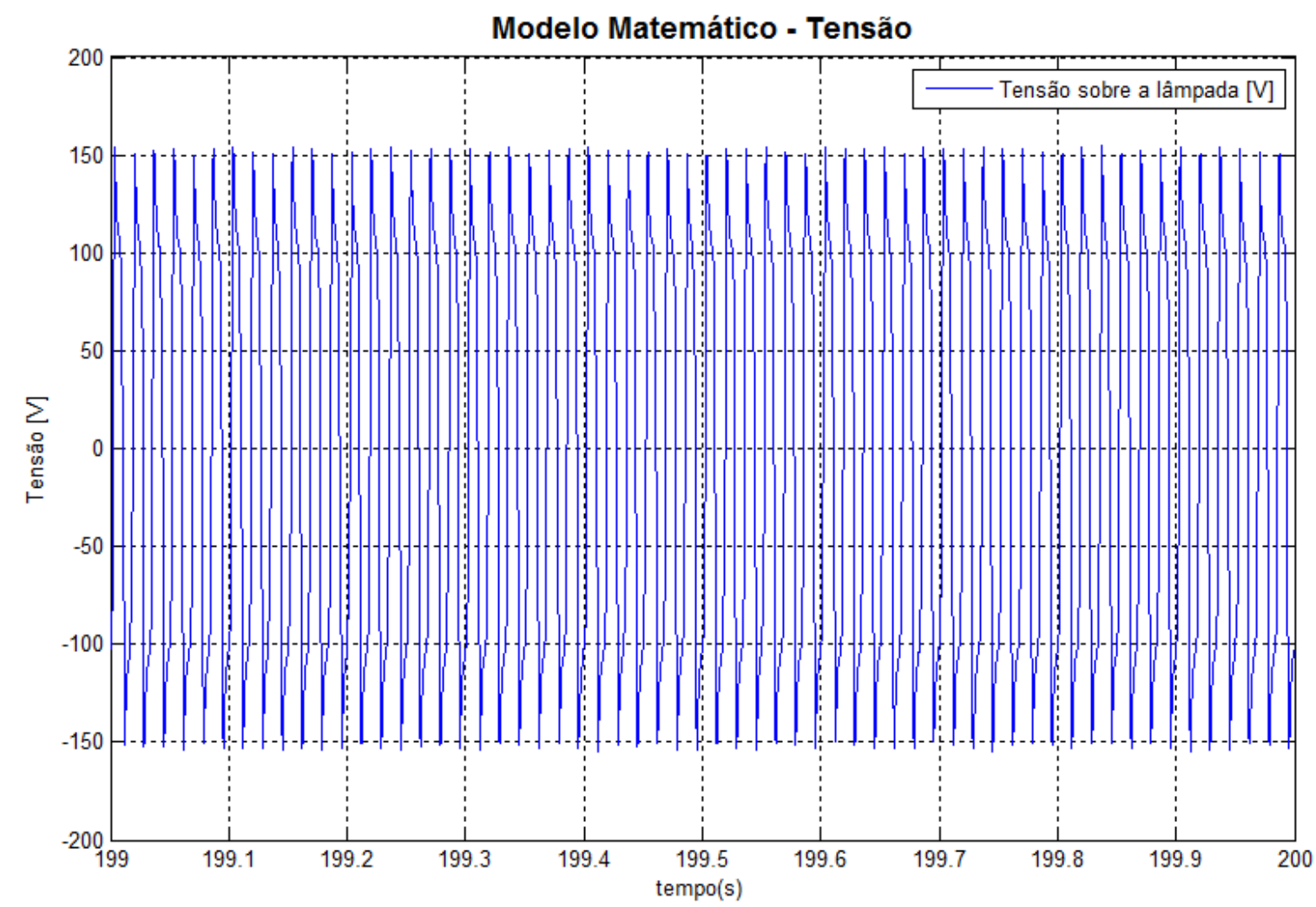

Figura 100 - Tensão sobre a lâmpada de descarga - resposta do modelo matemático. 

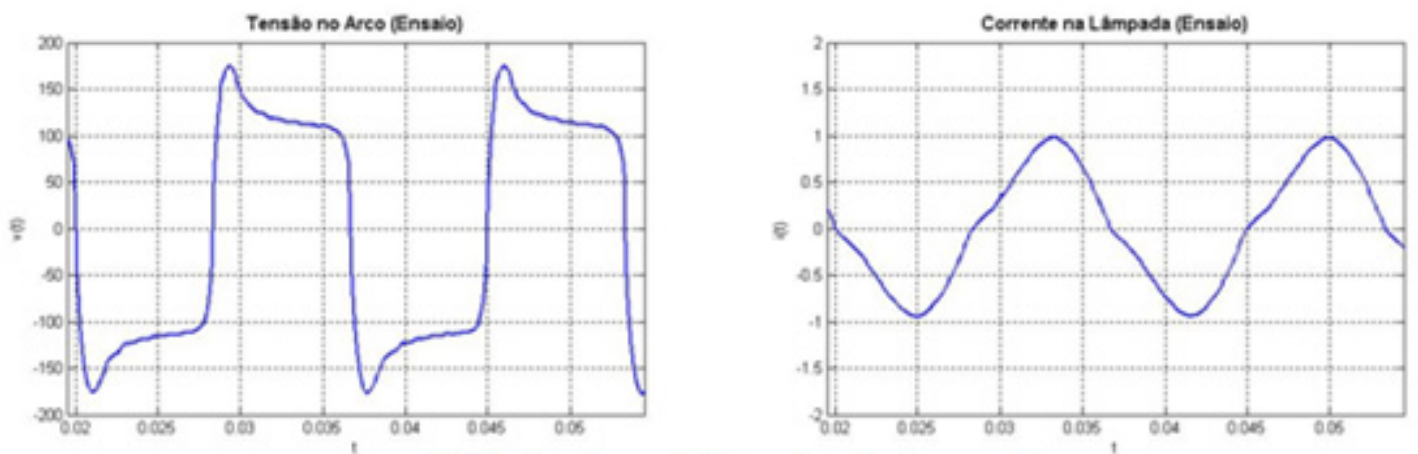

(a) Parâmetros obtidos através do ensaio
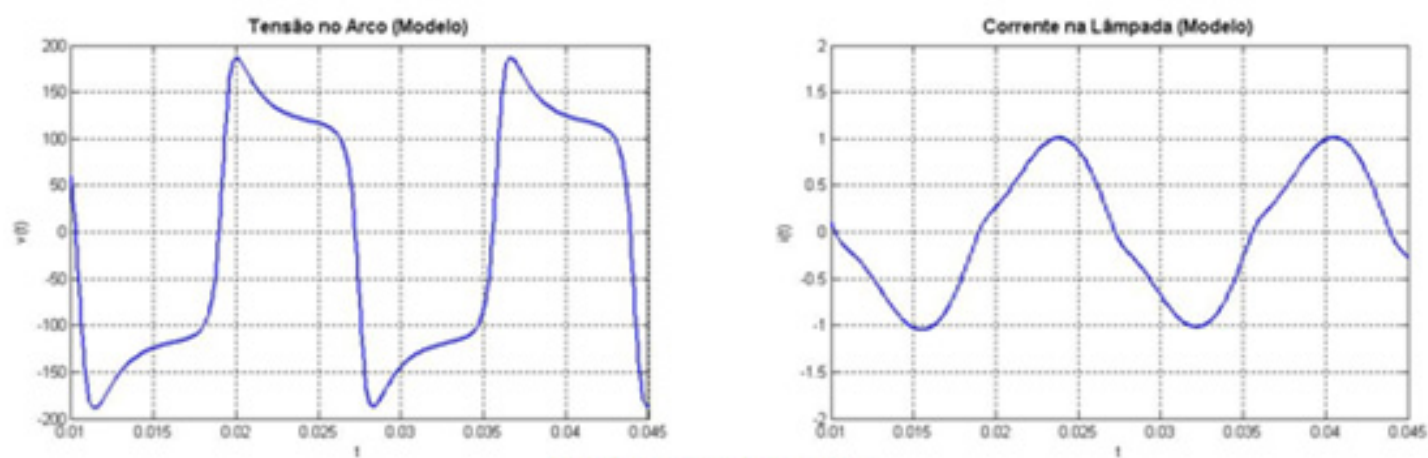

(b) Valores simulados

Figura 101 - Comparação entre valores experimentais (a) e valores simulados (b)

Para permitir a comparação direta entre os resultados fornecidos pela simulação, os dados adquiridos através do sistema de aquisição de dados construído descrito no capítulo quatro deste trabalho receberam tratamento de forma a se tornarem compatíveis com o ambiente $M A T L A B{ }^{\circledR}$, no sentido de ajuste da estampa de tempo e do sincronismo de fase entre os dados analisados. Deste modo, foi possível realizar a superposição das curvas geradas pelo modelo e dos gráficos obtidos por medição experimental.

O resultado obtido com a superposição dos gráficos de tensão sobre o arco é mostrado na Figura 102. Observar que o comportamento da simulação se aproxima do resultado experimental, mas não reproduz perfeitamente o comportamento do dispositivo. A superposição dos gráficos de corrente é mostrada no gráfico da Figura 103, 
onde novamente é possível observar grande semelhança entre os resultados, sem contudo podermos afirmar que a representação proporcionada pelo modelo esteja perfeita.

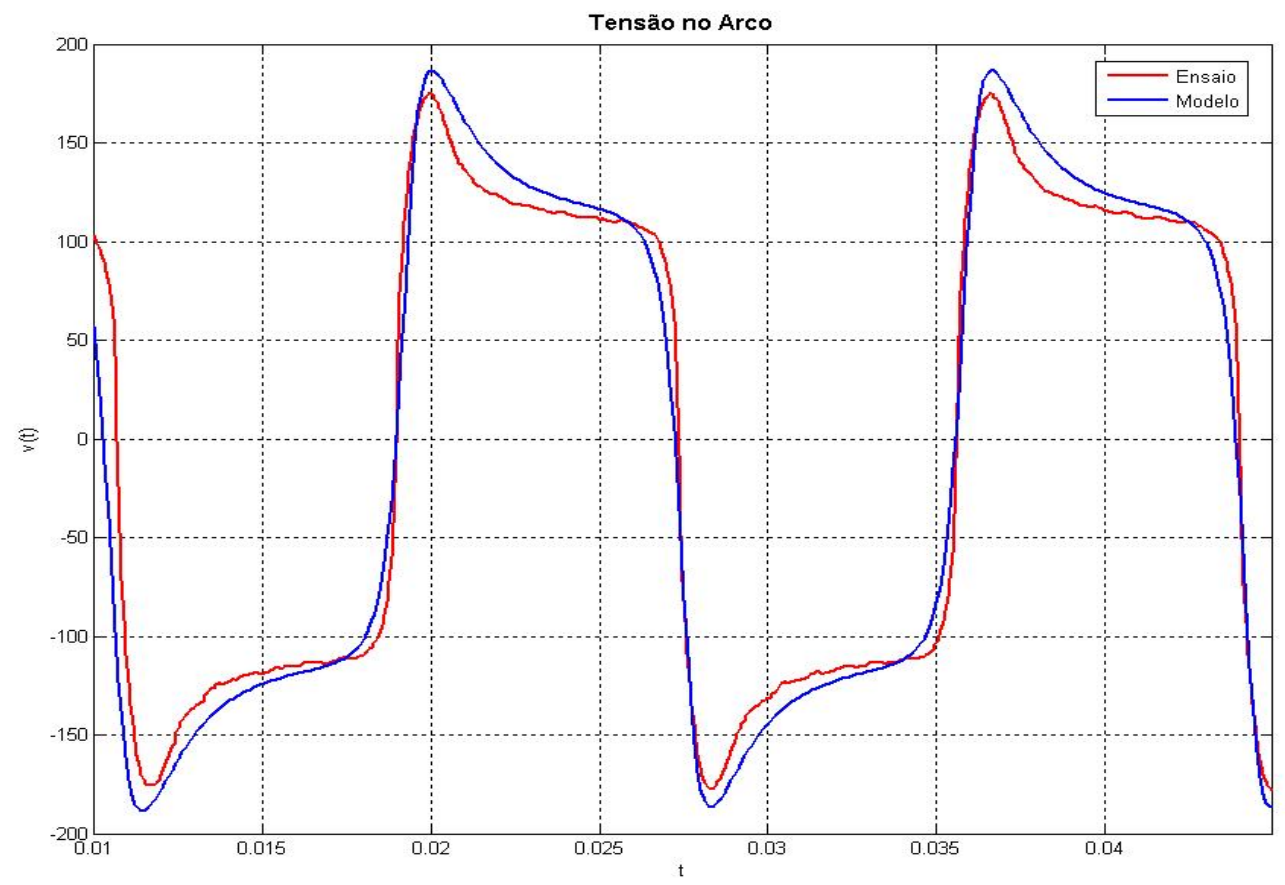

Figura 102 - Tensão no arco - lâmpada de vapor de mercúrio 80W

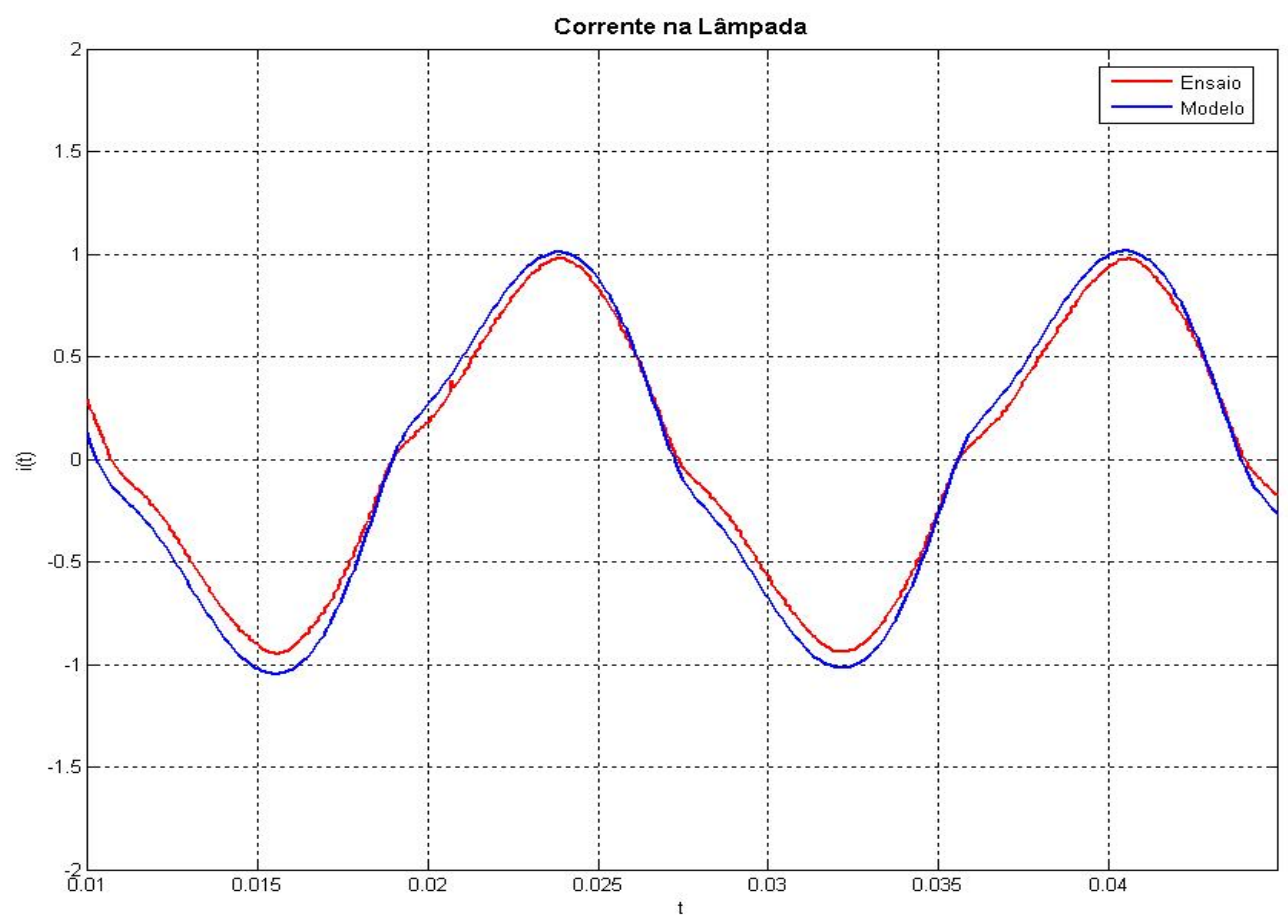

Figura 103 - Corrente no circuito - lâmpada de vapor de mercúrio 80W 
O resultado da comparação entre valores medidos e valores simulados de temperatura na superfície do bulbo do dispositivo estão ilustrados no gráfico apresentado na Figura 104. O aquecimento da lâmpada obtido através do modelo matemático mostra diferenças em relação ao experimento devido às simplificações no modelamento térmico do dispositivo, que consideram a transmissão de calor entre plasma e bulbo externo com uma interface simplificada.

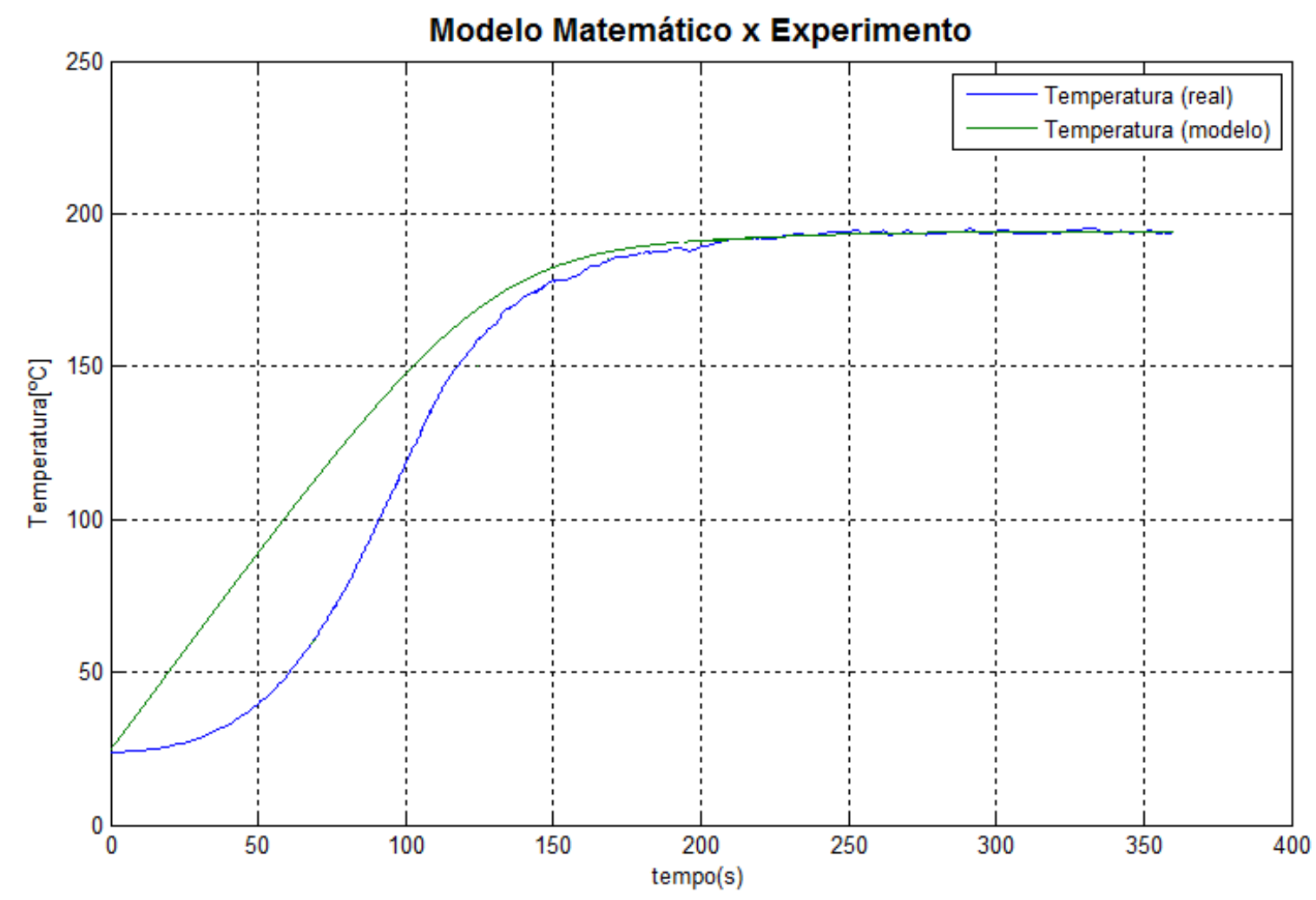

Figura 104 - Temperatura do bulbo da lâmpada de vapor de mercúrio 80W

A evolução das características de potência no experimento em função do tempo, em comparação com o modelo matemático, está apresentada no gráfico da Figura 105. Notar a diferença entre o valor simulado e o valor experimental, resultante de aproximações efetuadas no modelo matemático nas fases transitórias de operação.

Para representação do conjunto composto por lâmpada e reator como carga presente no sistema elétrico mostra-se suficiente a modelagem da corrente do 
dispositivo frente a uma determinada tensão de alimentação. Os gráficos apresentados referentes à tensão sobre a lâmpada podem ser obtidos indiretamente através do perfil de corrente e da modelagem do reator utilizado em conjunto com a lâmpada, através de cálculos instantâneos de tensões na malha composta pela associação em série entre fonte, lâmpada e reator.

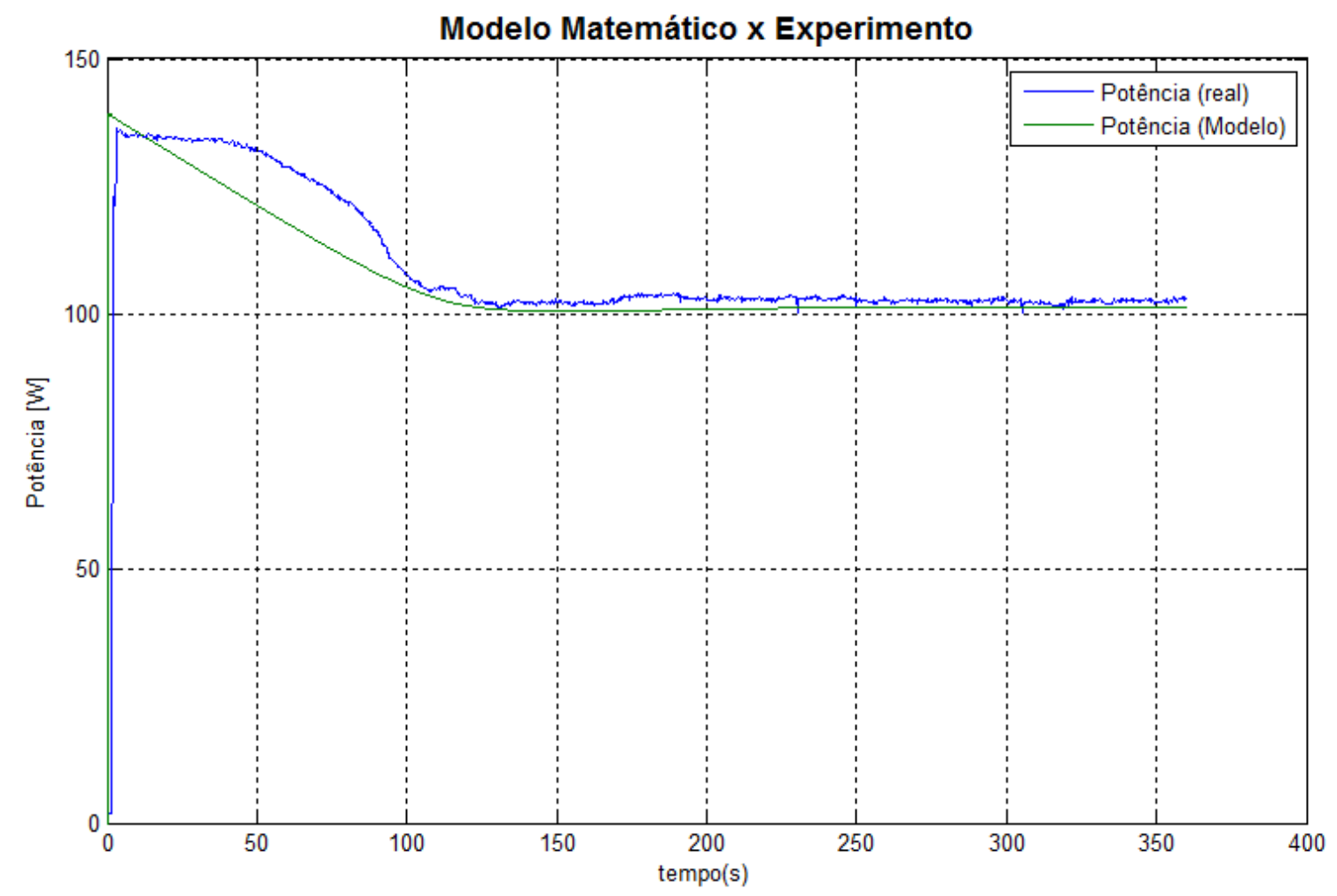

Figura 105 - Potência do experimento (lâmpada + reator).

Os resultados apresentados mostram que o modelo matemático implementado reproduz com relativa fidelidade o comportamento da lâmpada de descarga modelada em regime permanente de operação, fato que pode ser constatado pela semelhança entre as formas de onda de corrente e tensão sobre o dispositivo e os valores finais de temperatura e potência do dispositivo após a fase inicial de operação. 
O mesmo modelo, porém, não apresenta grande fidelidade na representação da fase transitória, por não incorporar uma boa representação dos fenômenos termodinâmicos ocorridos durante a fase de aquecimento do dispositivo.

Apesar desta deficiência na representação, o modelo pode ser considerado satisfatório pelo aspecto que permite uma avaliação qualitativa do comportamento da lâmpada de descarga em regime permanente, podendo ser empregado em situações onde a precisão na representação não seja um fator limitante. 


\section{MODELO DA LÂMPADA DE DESCARGA UTILIZANDO REDES NEURAIS}

\section{ARTIFICIAIS}

\subsection{Introdução}

O emprego de redes neurais artificiais (RNAs) na modelagem de dispositivos elétricos tem se mostrado uma ferramenta de extrema eficácia, especialmente quando o dispositivo modelado apresenta um certo nível de complexidade em sua descrição físico-matemática [42].

Esta ferramenta encontra especial aplicação em situações onde não se mostra possível identificar todas as variáveis relativas ao processo de modelagem [43]. No caso específico das lâmpadas de descarga, encontramos um dispositivo elétrico que possui diferentes características operacionais conforme a fase de operação em que se encontra. 
Estas diferenças surgem não apenas na forma com que o dispositivo emite maior radiação conforme aproxima-se de sua temperatura nominal de operação, mas também no modo como se torna mais susceptível a variações de tensão de alimentação, denotando curvas de sensibilidade e susceptibilidade dependentes do ponto de operação do dispositivo.

A descrição matemática dos efeitos que resultam na variação da curva de susceptibilidade tornam a modelagem complexa, uma vez que os parâmetros da modelagem clássica deveriam ser ajustados para diversas condições operacionais, e em alguns casos serem substituídos por funções que permitam a melhor descrição matemática das condições operacionais do dispositivo.

A utilização de uma ferramenta que proporcione certo grau de aprendizado com base em medições efetuadas no dispositivo real em operação permite reduzir, e até mesmo eliminar, o processo de ajuste de um modelo matemático de um dispositivo com complexidade de descrição [44,45], como é o caso de lâmpadas de descarga.

Conforme indicado na literatura $[46,47,48]$, os modelos obtidos a partir de redes neurais artificiais para diversos dispositivos apresentam desempenhos compatíveis com as necessidades de representação destes elementos modelados, exigindo um custo computacional menor quando comparado aos métodos de modelagem matemática.

O modelo neural proposto por este trabalho corresponde a um sistema computacional baseado em redes neurais artificiais capaz de representar os aspectos harmônicos da corrente da lâmpada de descarga modelada quando submetida a variadas condições de alimentação, trazendo consigo os aspectos de susceptibilidade a distúrbios relacionados à qualidade da energia elétrica, de forma a permitir a simulação 
destes elementos inseridos em um sistema de distribuição a um custo computacional menor que o exigido por uma simulação baseada em modelos matemáticos.

Não será objeto deste modelo a representação direta da tensão presente sobre o arco da lâmpada de descarga, visto que este dado pode ser obtido indiretamente através de cálculos de tensões de malha a partir do modelo do reator empregado, e também pela razão de não se empregar a lâmpada sem a associação de seu reator compatível como elemento limitador de corrente. Deste modo, o modelo passa a considerar apenas os efeitos do conjunto composto pela lâmpada associada a seu reator.

Maiores informações sobre a teoria de redes neurais artificiais podem ser encontradas no Apêndice A deste documento.

\subsection{Modelo neural proposto para a lâmpada de descarga}

O modelo neural proposto para o conjunto lâmpada/reator é composto por duas redes neurais artificiais independentes alimentadas com as variáveis de operação do conjunto, e tem sua arquitetura mostrada na Figura 106. Apresenta como entradas a tensão de alimentação do conjunto e a temperatura ambiente (ou ponto inicial de simulação, se desejado), e retorna como saídas a corrente representada por seu conteúdo harmônico, a potência média quadrática do conjunto, a temperatura do bulbo da lâmpada e o estado do dispositivo.

A rede neural artificial RNA 1, que representa o comportamento termodinâmico do dispositivo, deve ser treinada a partir dos dados obtidos experimentalmente conforme procedimentos descritos no capítulo quatro deste documento, e durante a execução das simulações apresenta em sua saída a taxa de variação de temperatura do dispositivo, decorrente da condição operacional, reproduzindo seu comportamento diante de eventos relacionados à qualidade da energia elétrica. 
Para a reprodução do conteúdo harmônico de corrente da carga, a rede neural artificial RNA 2 recebe como entradas os valores de tensão de alimentação decomposta em seu conteúdo harmônico, a potência desenvolvida pelo dispositivo e a temperatura de operação, fornecendo como saída o espectro de correntes harmônicas solicitado pelo dispositivo durante sua operação.

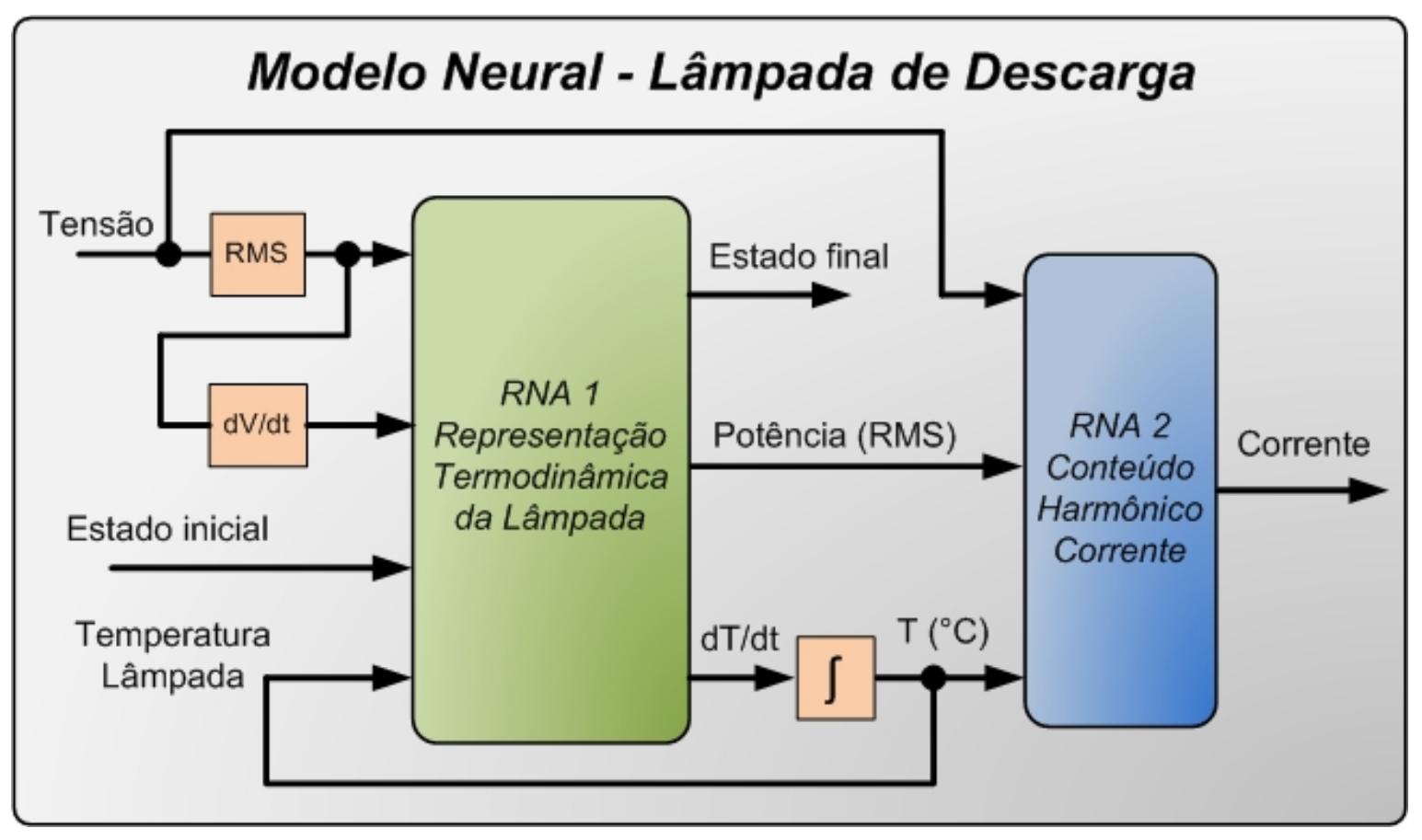

Figura 106 - Modelo neural proposto para a lâmpada de descarga.

\subsubsection{Arquitetura da Rede Neural Artificial empregada}

Para tornar possível a caracterização do dispositivo, adotou-se um conjunto de duas redes neurais artificiais Perceptron Multicamadas, sendo uma destinada a representar o comportamento termodinâmico do dispositivo e reproduzir a curva de sensibilidade para diversas condições operacionais da lâmpada de descarga (RNA 1) e outra destinada a modelar o conjunto de características harmônicas da corrente do dispositivo em função do ponto de operação (RNA 2).

Para construção do modelo neural foi empregado o pacote de programas MATLAB ${ }^{\circledR}$ em sua versão 7.7.0.471 (R2008b), e seu conjunto de ferramentas 
Neural Network Toolbox TM, que permite a rápida estruturação, treinamento e avaliação de redes neurais artificiais, para posterior utilização como elemento de simulação.

A rede neural artificial RNA 1, que modela o comportamento termodinâmico opera em sua entrada com os valores RMS de tensão de alimentação do experimento, de temperatura instantânea do bulbo externo da lâmpada em ensaio, taxa de variação de tensão de alimentação do experimento (dV/dt) e estado inicial da lâmpada, representado por uma variável booleana (ligada ou desligada). Como saída, esta rede reproduz o estado booleano final da lâmpada, a potência RMS do experimento e a taxa de variação de temperatura do bulbo externo da lâmpada.

A rede neural artificial RNA 2, destinada a reproduzir o conteúdo harmônico de corrente, foi composta de forma a receber em suas entradas os valores do conteúdo harmônico (amplitude e fase) da tensão de alimentação, a potência RMS e o valor de temperatura de operação do dispositivo. Como saída desta rede, temos o conteúdo harmônico (amplitude e fase) da corrente de operação do dispositivo.

\subsection{Seleção do conjunto de dados para treinamento}

O conjunto dos dados empregados para treinamento das RNAs foi formado a partir de amostras dos arquivos obtidos pelo sistema de aquisição de dados experimentais, em situações operacionais de regime permanente e de regime transitório, conforme procedimentos descritos no capítulo quatro deste documento. $\mathrm{O}$ universo de dados assim obtido representa o comportamento da lâmpada da forma mais abrangente possível, respeitando os limites operacionais do dispositivo.

Como já descrito no capítulo quatro, as seguintes amostragens foram contempladas na composição do conjunto de treinamento: 
1)Operação do dispositivo em regime permanente para diversos níveis de tensão de alimentação;

2)Operação do dispositivo em regime transitório de acendimento, com diversos níveis de tensão de alimentação;

3)Operação do dispositivo em condição de reignição para diversos níveis de tensão de alimentação;

4)Aplicação de variações de tensão no dispositivo provocando deslocamento do ponto operacional, a partir de diversos valores de tensão de alimentação;

5)Aplicação de variações de tensão de curta duração com o auxílio do gerador arbitrário de sinais, conduzindo o dispositivo aos limites de susceptibilidade.

A quantidade de amostras apresentadas para treinamento em cada situação específica foi limitada, como medida para se otimizar o treinamento das RNAs e evitando-se assim um condicionamento indesejado no comportamento das redes, que se obtém quando o treinamento ocorre com grande quantidade de pontos similares.

\subsection{Estabelecimento da base de dados para treinamento das RNAs}

A base de dados composta conforme explanação anterior gerou uma planilha de dados no formato Microsoft ${ }^{\circledR}$ Excel ${ }^{\circledR}$, tabulada em registros $\boldsymbol{R}$ distribuídos em 12 colunas e 60 linhas cada, contendo as informações apontadas na Tabela 7. $\mathrm{O}$ aspecto de uma planilha mostrando parcialmente um registro é apresentado na Figura 107, onde é possível verificar a distribuição dos dados referentes ao conteúdo harmônico, divididos por frequência, e os valores médios quadráticos do experimento apresentados no início do registro.

Considerando características obtidas através do sistema de aquisição de dados descrito no capítulo quatro, foi possível observar que a partir da $15^{\mathrm{a}}$ 
harmônica as amplitudes de corrente na carga tornam-se insignificantes. A partir desta observação, optou-se pela limitação de abrangência de conteúdo harmônico até a $15^{\mathrm{a}}$ harmônica, correspondente à frequência de $900 \mathrm{~Hz}$ em um sistema de alimentação em $60 \mathrm{~Hz}$

Tabela 7 - Registros de Treinamento das Redes Neurais Artificiais

\begin{tabular}{|c|c|c|}
\hline Coluna & Linha & Conteúdo \\
\hline 1 & $1^{\mathrm{a}}$ a $60^{\mathrm{a}}$ & Frequência da amostra (em decomposição harmônica) \\
\hline 2 & $1^{\mathrm{a}}$ a $60^{\mathrm{a}}$ & Amplitude de corrente harmônica de ordem $\mathrm{h}(\mathrm{h}=1 . .60)$ \\
\hline 3 & $1^{\mathrm{a}}$ a $60^{\mathrm{a}}$ & Fase de corrente harmônica de ordem $\mathrm{h}(\mathrm{h}=1 . .60)$ \\
\hline 4 & $1^{\mathrm{a}}$ a $60^{\mathrm{a}}$ & Amplitude de tensão harmônica de ordem $\mathrm{h}(\mathrm{h}=1 . .60)$ \\
\hline 5 & $1^{\mathrm{a}}$ a $60^{\mathrm{a}}$ & Fase de tensão harmônica de ordem $\mathrm{h}(\mathrm{h}=1 . .60)$ \\
\hline 6 & $1^{\mathrm{a}}$ & Potência RMS do experimento \\
\hline 7 & $1^{\mathrm{a}}$ & Tensão RMS de alimentação do experimento \\
\hline 8 & $1^{\mathrm{a}}$ & Corrente RMS do experimento \\
\hline 9 & $1^{\mathrm{a}}$ & Temperatura do bulbo externo da lâmpada em Graus Celsius \\
\hline 10 & $1^{\mathrm{a}}$ & $\mathrm{dT} / \mathrm{dt}$ do bulbo da lâmpada \\
\hline 11 & $1^{\mathrm{a}}$ & $\mathrm{dV} / \mathrm{dt}$ de alimentação do experimento \\
\hline 12 & $1^{\mathrm{a}}$ & Estado da lâmpada (Booleano; 1=Ligada; 0=Desligada) \\
\hline
\end{tabular}

Esta limitação aplicou-se apenas à rotina de treinamento da RNA, visto que a massa de dados brutos disponibilizada traz o conteúdo harmônico até a $60^{\mathrm{a}}$ ordem para a tensão e corrente, levantadas durante os experimentos na fase de aquisição de dados.

Partindo destas considerações, estes dados foram então tratados pelo MATLAB ${ }^{\circledR}$ de forma a limitar a massa de treinamento à $15^{\mathrm{a}}$ harmônica, correspondente a frequência de $900 \mathrm{~Hz}$ para um sistema com frequência fundamental de 60Hz. O conjunto assim obtido foi dividido em dois subgrupos através do algoritmo randômico (dividerand) do pacote de ferramentas de redes neurais artificiais, na proporção de $75 \%$ dos dados para treinamento e $25 \%$ dos dados para validação. Nos casos onde foram realizados testes após o treinamento, a massa total de dados foi separada em três 
subgrupos através do algoritmo randômico, empregando as proporções de $60 \%$ para

treinamento, $20 \%$ para validação e $20 \%$ para testes na divisão da massa de dados.

\begin{tabular}{|c|c|c|c|c|c|c|c|c|c|c|c|c|c|}
\hline 4 & A & B & C & D & $\mathrm{E}$ & $\mathrm{F}$ & G & $\mathrm{H}$ & I & J & K & L & M \\
\hline 48658 & 3420,96 & $9,23 \mathrm{E}-05$ & 1,07503 & 0,08001 & 1,1626 & & & & & & & & \\
\hline 48659 & 3480,97 & 0,00012 & $-0,36084$ & 0,08628 & $-0,29988$ & & & & & & & & \\
\hline 48660 & 3540,99 & 0,00031 & 0,24791 & 0,0269 & $-1,55303$ & & & & & & & & \\
\hline 48661 & 0 & 0,03144 & 3,14159 & 4,53904 & 0 & 104,587 & 222,852 & 0,57191 & 186,67 & 0,01122 & 0,01146 & 1 & \\
\hline 48662 & 60,0168 & 0,80332 & 3,12042 & 315 & $-2,13637$ & & & & & & & & \\
\hline 48663 & 120,034 & 0,00653 & 2,63446 & 0,26724 & $-2,00278$ & & & & & & & & \\
\hline 48664 & 180,05 & 0,08629 & 2,44145 & 3,77262 & $-0,5535$ & & & & & & & & \\
\hline 48665 & 240,067 & 0,00098 & $-2,90788$ & 0,09147 & $-2,89236$ & & & & & & & & \\
\hline 48666 & 300,084 & 0,01329 & $-1,97817$ & 7,46173 & $-1,37737$ & & & & & & & & \\
\hline 48667 & 360,101 & 0,00173 & 2,698 & 0,06082 & $-0,36054$ & & & & & & & & \\
\hline 48668 & 420,118 & 0,01223 & 2,15077 & 3,05683 & 1,55239 & & & & & & & & \\
\hline 48669 & 480,134 & 0,00061 & 0,48824 & 0,09696 & $-1,76372$ & & & & & & & & \\
\hline 48670 & 540,151 & 0,00294 & $-0,58231$ & 0,39053 & 1,33876 & & & & & & & & \\
\hline 48671 & 600,168 & 0,00016 & $-2,91795$ & 0,06996 & 2,3904 & & & & & & & & \\
\hline 48672 & 660,185 & 0,00226 & 2,56789 & 0,3079 & $-2,84521$ & & & & & & & & \\
\hline 48673 & 720,202 & 0,00026 & $-2,48728$ & 0,08424 & $-1,658$ & & & & & & & & \\
\hline 48674 & 780,218 & 0,00206 & 0,16978 & 0,08761 & 2,23112 & & & & & & & & \\
\hline 48675 & 840,235 & 0,00056 & 2,40844 & 0,1395 & 2,81898 & & & & & & & & \\
\hline 48676 & 900,252 & 0,00167 & 2,78646 & 0,22131 & 1,92104 & & & & & & & & \\
\hline 48677 & 960,269 & 0,0002 & 0,14017 & 0,15085 & 2,62842 & & & & & & & & \\
\hline 48678 & 1020,29 & 0,0008 & $-0,08239$ & 0,28228 & $-1,27303$ & & & & & & & & \\
\hline 48679 & 1080,3 & 0,00039 & $-0,70099$ & 0,0376 & 0,95617 & & & & & & & & \\
\hline 48680 & 1140,32 & 0,00037 & $-1,36759$ & 0,20886 & $-2,08953$ & & & & & & & & \\
\hline 48681 & 1200,34 & 0,00035 & 1,46834 & 0,0972 & 2,53815 & & & & & & & & \\
\hline 48682 & 1260,35 & 0,00074 & 1,508 & 0,14087 & 0,23373 & & & & & & & & \\
\hline 48683 & 1320,37 & 0,00038 & $-0,72152$ & 0,04504 & 0,49718 & & & & & & & & \\
\hline 48684 & 1380,39 & 0,00072 & $-2,44811$ & 0,15915 & $-0,89647$ & & & & & & & & \\
\hline 48685 & 1440,4 & 0,00058 & 2,65289 & 0,07021 & $-1,2716$ & & & & & & & & \\
\hline 48686 & 1500,42 & 0,00027 & 1,12277 & 0,18277 & 1,42913 & & & & & & & & \\
\hline 48687 & 1560,44 & 0,00035 & 2,72202 & 0,06135 & $-2,4145$ & & & & & & & & \\
\hline 48688 & 1620,45 & 0,00083 & $-0,48736$ & 0,01931 & $-2,84769$ & & & & & & & & \\
\hline 48689 & 1680,47 & 0,00049 & $-0,84327$ & 0,0349 & $-2,77603$ & & & & & & & & \\
\hline 48690 & 1740,49 & 0,00052 & 2,70088 & 0,10793 & $-2,24969$ & & & & & & & & \\
\hline 48691 & 1800,5 & 0,00051 & $-0,03225$ & 0,01266 & 0,82538 & & & & & & & & \\
\hline 48692 & 1860,52 & 0,00068 & $-0,28279$ & 0,14334 & $-1,6696$ & & & & & & & & \\
\hline 48693 & 1920,54 & 0,00061 & 2,88414 & 0,05406 & 2,78099 & & & & & & & & \\
\hline 48694 & 1980,55 & 0,00044 & 3,06218 & 0,08786 & $-0,07407$ & & & & & & & & \\
\hline 48695 & 2040,57 & 0,0008 & $-0,46548$ & 0,10199 & 3,00162 & & & & & & & & \\
\hline 48696 & 2100,59 & 0,00059 & $-2,01314$ & 0,02785 & $-2,90296$ & & & & & & & & \\
\hline 48697 & 2160,6 & 0,0002 & 0,16928 & 0,02635 & $-1,67732$ & & & & & & & & \\
\hline 48698 & 2220,62 & 0,00085 & 2,96141 & 0,08728 & 1,82963 & & & & & & & & \\
\hline 48699 & 2280,64 & 0,00044 & 0,73066 & 0,1175 & $-2,16398$ & & & & & & & & \\
\hline 48700 & 2340,66 & 0,0005 & $-0,35957$ & 0,17956 & $-2,2609$ & & & & & & & & \\
\hline 48701 & 2400,67 & 0,00048 & $-0,4608$ & 0,10299 & $-2,20696$ & & & & & & & & \\
\hline 48702 & 2460,69 & 0,00061 & 1,93491 & 0,17101 & 3,02179 & & & & & & & & \\
\hline 48703 & 2520,71 & 0,00086 & 0,99475 & 0,48172 & $-2,14392$ & & & & & & & & \\
\hline 48704 & 2580,72 & 0,00053 & 1,77126 & 0,20252 & 0,42522 & & & & & & & & \\
\hline 48705 & 2640,74 & 0,00042 & 2,70973 & 0,17394 & 0,84638 & & & & & & & & \\
\hline 48706 & 2700,76 & 0,0004 & $-2,86435$ & 0,1025 & 0,34522 & & & & & & & & \\
\hline 48707 & 2760,77 & 0,00039 & $-2,38045$ & 0,09312 & $-0,14841$ & & & & & & & & \\
\hline
\end{tabular}

Figura 107 - Aspecto da planilha de dados experimentais 


\subsection{Configuração e treinamento das RNAs}

Com a utilização do conjunto de dados de treinamento, as RNAs que compõem o modelo foram configuradas e treinadas para ajuste de seus pesos sinápticos, de forma a melhor representar o dispositivo.

Inicialmente treinou-se a rede RNA 2, construída e configurada para a representação do conteúdo harmônico da corrente do dispositivo, realizando-se experimentos em relação à estrutura da RNA 2. Foram testadas diversas configurações com relação ao número de camadas escondidas, quantidades de neurônios e funções de ativação, e a configuração que apresentou melhor desempenho em termos de regressão e representação dos resultados foi adotada como definitiva.

A rede neural artificial RNA 2 foi treinada a partir do algoritmo de Levenberg-Marquardt (ver Apêndice A), definido no pacote de ferramentas como trainlm, e seu desempenho foi avaliado através do algoritmo do erro médio quadrático, apresentado como algoritmo mse (Mean Squared Error). Os critérios de parada adotados para o processo de treinamento da rede neural artificial foram os seguintes:

• Número máximo de épocas: 10.000

- Erro médio quadrático desejado: $10^{-9}$

-Gradiente mínimo: $10^{-15}$

-Valor máximo de $\mathrm{Mu}: 10^{10}$

O tempo máximo de simulação não foi adotado como critério de parada, sendo definido como infinito na determinação dos parâmetros de treinamento da RNA 2.

$\mathrm{O}$ resultado de uma das regressões obtida durante o treinamento desta rede é apresentado na Figura 108. Nesta figura é possível observar a correlação obtida no processo de treinamento, através do gráfico superior à esquerda, e o resultado das 
validações mostrado no gráfico superior à direita. O gráfico inferior à esquerda mostra a superposição dos dois conjuntos de dados.

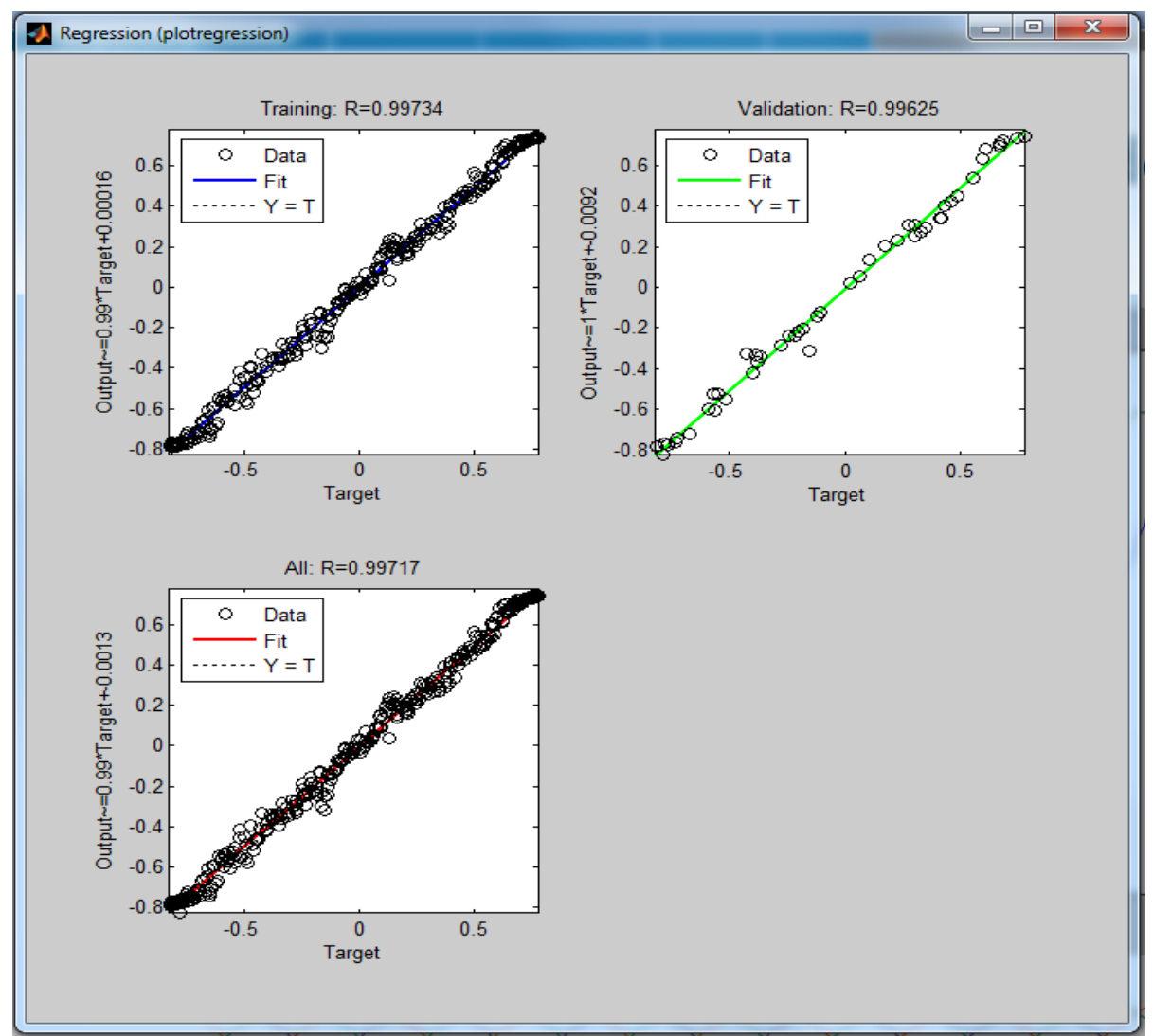

Figura 108 - Exemplo de regressão durante treinamento da RNA 2 para conteúdo harmônico.

A configuração final adotada para a rede neural artificial RNA 2 utilizada na representação do conteúdo harmônico da lâmpada de descarga apresenta as características mostradas na Tabela 8. Esta arquitetura foi escolhida em função de experimentações com a massa de dados de treinamento, e corresponde à configuração que apresentou melhor desempenho de resposta após o treinamento.

Um diagrama de blocos da rede neural artificial RNA 2 é mostrado na Figura 109, onde são apresentadas suas entradas, saídas e sua organização interna.

Outras arquiteturas foram ensaiadas, no que se refere à quantidade de neurônios em camadas escondidas, número de camadas escondidas e tipos de função de 
ativação, sem, no entanto, apresentarem resultados equivalentes à configuração acima descrita.

Tabela 8 - Rede Neural Artificial RNA 2 - Conteúdo Harmônico da Corrente

\begin{tabular}{|c|c|}
\hline \multicolumn{2}{|c|}{ Rede Neural Artificial RNA 2 - Modelagem de Conteúdo Harmônico de Corrente } \\
\hline Tipo de RNA & Perceptron Multicamadas \\
\hline Tipo de Realimentação & Feed-Forward Backpropagation \\
\hline Número de camadas escondidas & 2 \\
\hline Número de neurônios na camada de entrada & 32 \\
\hline Número de neurônios da primeira camada escondida & 15 \\
\hline Função de ativação da primeira camada escondida & Tangente Sigmoidal \\
\hline Número de neurônios da segunda camada escondida & 7 \\
\hline Função de ativação da segunda camada escondida & Tangente Sigmoidal \\
\hline Número de neurônios da camada de saída & 30 \\
\hline Função de ativação da camada de saída & Linear \\
\hline Algoritmo de treinamento & Levenberg-Marquardt \\
\hline
\end{tabular}

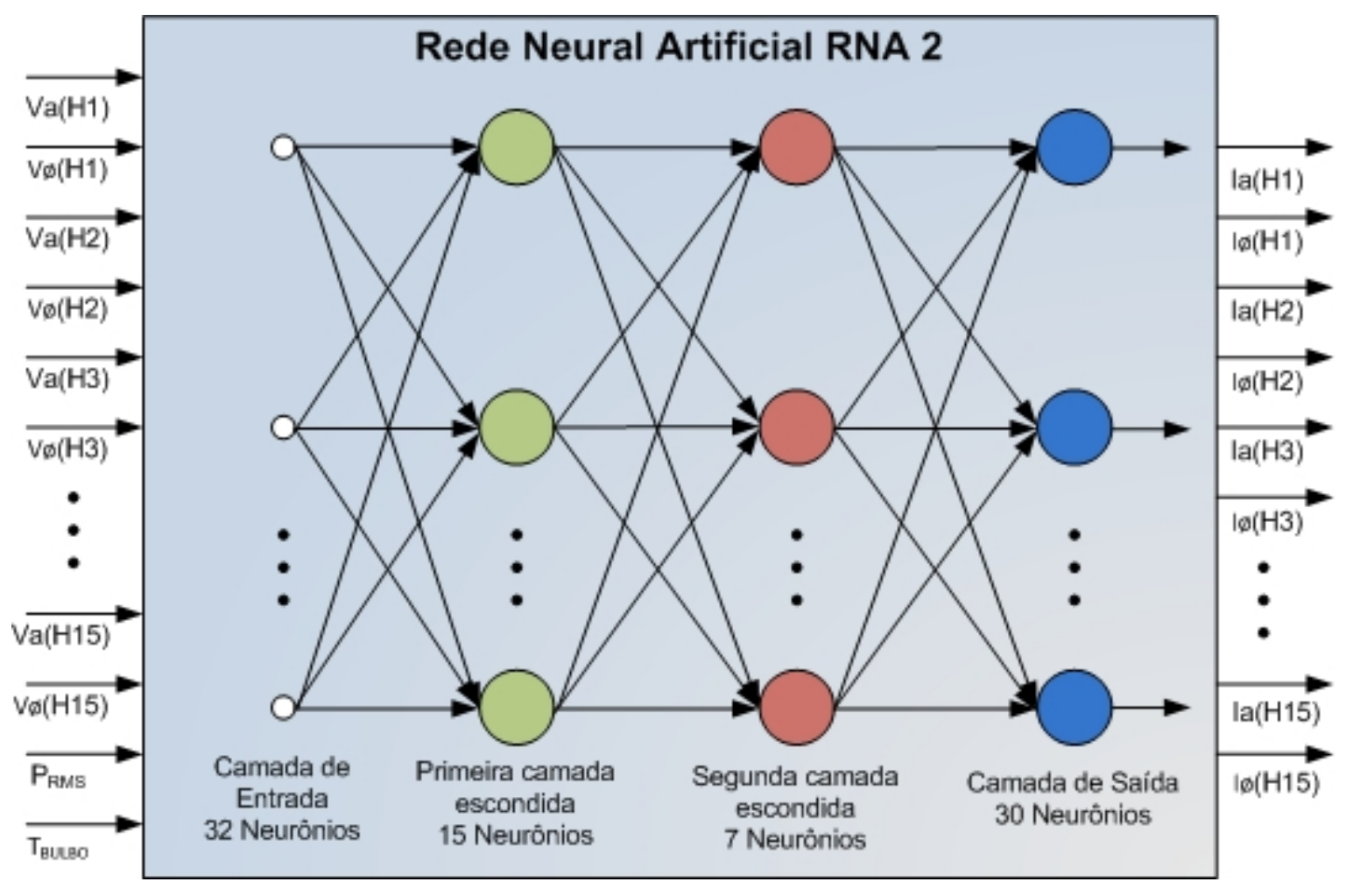

Figura 109 - Rede neural artificial RNA 2

A recomposição do conteúdo harmônico de corrente, obtido na saída da RNA 2, permite reproduzir a forma de onda de corrente correspondente ao 
comportamento da lâmpada de descarga, no que se refere à distorção harmônica por ele produzida quando em operação.

O treinamento da rede neural artificial RNA 1, que modela o comportamento termodinâmico foi efetuado empregando a mesma massa de dados empregada no treinamento da RNA 2, que caracteriza o conteúdo harmônico, obtida através dos procedimentos experimentais descritos no capítulo quatro. Diversas configurações de rede foram testadas, no que se refere ao número de camadas escondidas, quantidades de neurônios nas camadas escondidas e funções de ativação. Adotou-se como definitiva a configuração que apresentou melhor desempenho em termos de regressão e representação dos resultados.

Novamente foi utilizado o algoritmo de Levenberg-Marquardt no treinamento da RNA 1, tendo seu desempenho avaliado através do algoritmo de erros quadráticos médios mse (Mean Squared Error). Os critérios de parada adotados para o processo de treinamento desta rede neural artificial foram os seguintes:

•Número máximo de épocas: 10.000

-Erro quadrático médio desejado: $10^{-9}$

-Gradiente mínimo: $10^{-15}$

-Valor máximo de $\mathrm{Mu}: 10^{10}$

De modo análogo à rede anterior, o tempo máximo de simulação não foi estabelecido como critério de parada, sendo este definido como infinito na determinação dos parâmetros de treinamento da RNA 1.

Um dos inúmeros resultados de treinamentos efetuados nesta fase está apresentado na Figura 110. Nesta figura é possível a observação dos gráficos referentes ao treinamento (superior esquerdo), validação (superior direito), teste (inferior esquerdo) e a superposição dos efeitos no gráfico inferior à direita. 
Os vazios nos conjuntos de dados de saída representam os pontos referentes às potências onde a lâmpada nunca opera, por encontrar-se apagada e sem condição de acendimento.

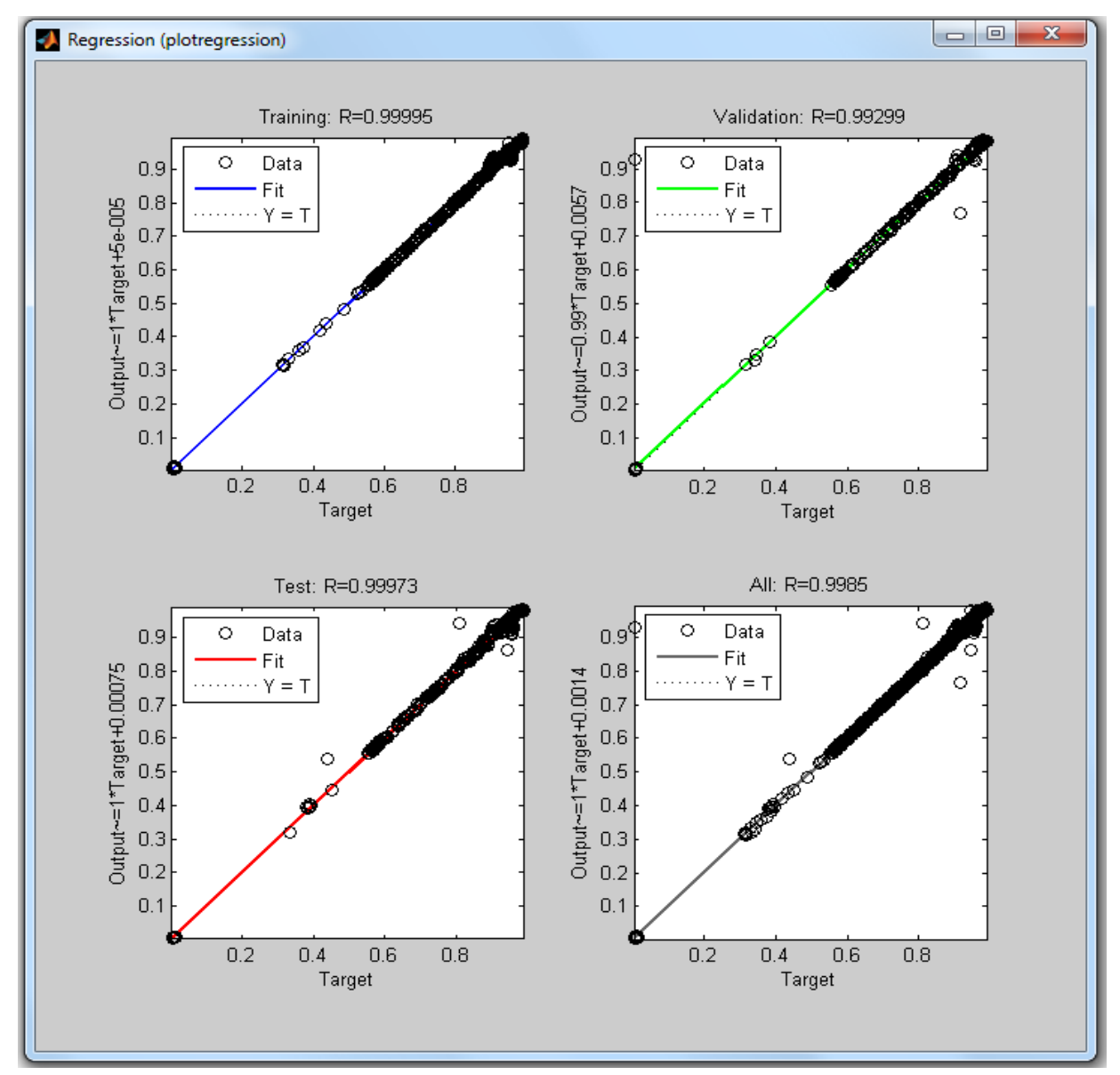

Figura 110 - Exemplo de regressão durante treinamento da RNA 1 para desempenho termodinâmico.

A Tabela 9 apresenta a composição da rede neural artificial RNA 1 empregada na modelagem termodinâmica da lâmpada de descarga. Optou-se por uma rede de características semelhantes à rede que representa o conteúdo harmônico, alterando-se apenas o número de entradas e saídas e a quantidade de neurônios nas camadas escondidas.

Um diagrama de blocos da rede neural artificial RNA 1 é apresentado na Figura 111, onde são apresentadas suas entradas, saídas e organização interna. 


\subsection{Avaliação do modelo neural da lâmpada de descarga}

A avaliação de desempenho do modelo é realizada a partir de um conjunto de situações operacionais distintas das empregadas no treinamento das RNAs, e os resultados das simulações são comparados diretamente com os dados obtidos através do sistema de aquisição de dados, com o experimento ajustado para a condição operacional pretendida.

Tabela 9 - Rede Neural Artificial RNA 1 - Comportamento Termodinâmico da Lâmpada de Descarga

\begin{tabular}{|c|c|}
\hline $\begin{array}{c}\text { Rede Neural Artificial RNA 1 - Modelagem do Comportamento Termodinâmico da } \\
\text { Lâmpada de Descarga }\end{array}$ \\
\hline Tipo de RNA & Perceptron Multicamadas \\
\hline Tipo de Realimentação & Feed-Forward Backpropagation \\
\hline Número de camadas escondidas & 2 \\
\hline Número de neurônios na camada de entrada & 4 \\
\hline Número de neurônios da primeira camada escondida & Tangente Sigmoidal \\
\hline Função de ativação da primeira camada escondida & 17 \\
\hline Número de neurônios da segunda camada escondida & Tangente Sigmoidal \\
\hline Função de ativação da segunda camada escondida & 3 \\
\hline Número de neurônios da camada de saída & Linear \\
\hline Função de ativação da camada de saída & Levenberg-Marquardt \\
\hline Algoritmo de treinamento &
\end{tabular}

O desempenho do modelo pode ser avaliado por dois aspectos:

a)Reprodução da forma de onda de corrente e respectivo conteúdo harmônico para diversas fases de operação, guardando relação com a distorção harmônica relacionada à Qualidade da Energia

b)Reprodução do comportamento térmico operacional do dispositivo, remetendo à sensibilidade a eventos de qualidade de energia apresentada pelo componente em suas diversas fases operacionais. 


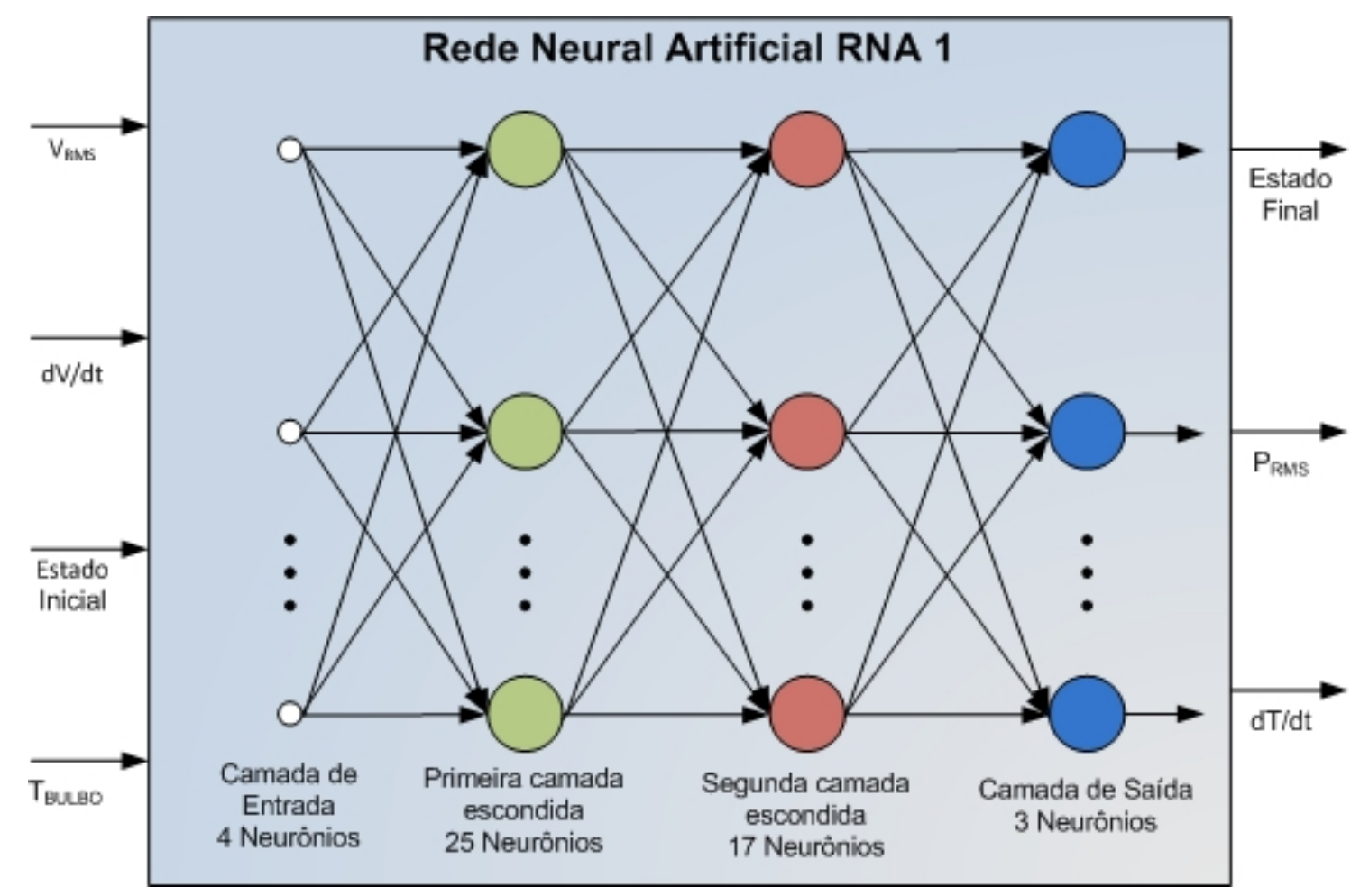

Figura 111 - Rede neural artificial RNA1

\subsubsection{Reprodução do conteúdo harmônico}

A simulação da lâmpada de descarga com base no modelo neural de conteúdo harmônico permite representar o comportamento da corrente do dispositivo a partir do ponto de operação em que este se encontra, com base na tensão aplicada, na temperatura do bulbo da lâmpada e no estado de operação da mesma.

A Figura 112 representa a corrente da lâmpada no instante de tempo $\mathrm{t}=100 \mathrm{~s}$ após a partida, após a fase inicial de aquecimento. Os componentes harmônicos da corrente para a situação apresentada são mostrados na Figura 113, onde é possível verificar a resposta satisfatória do modelo na representação do dispositivo. 


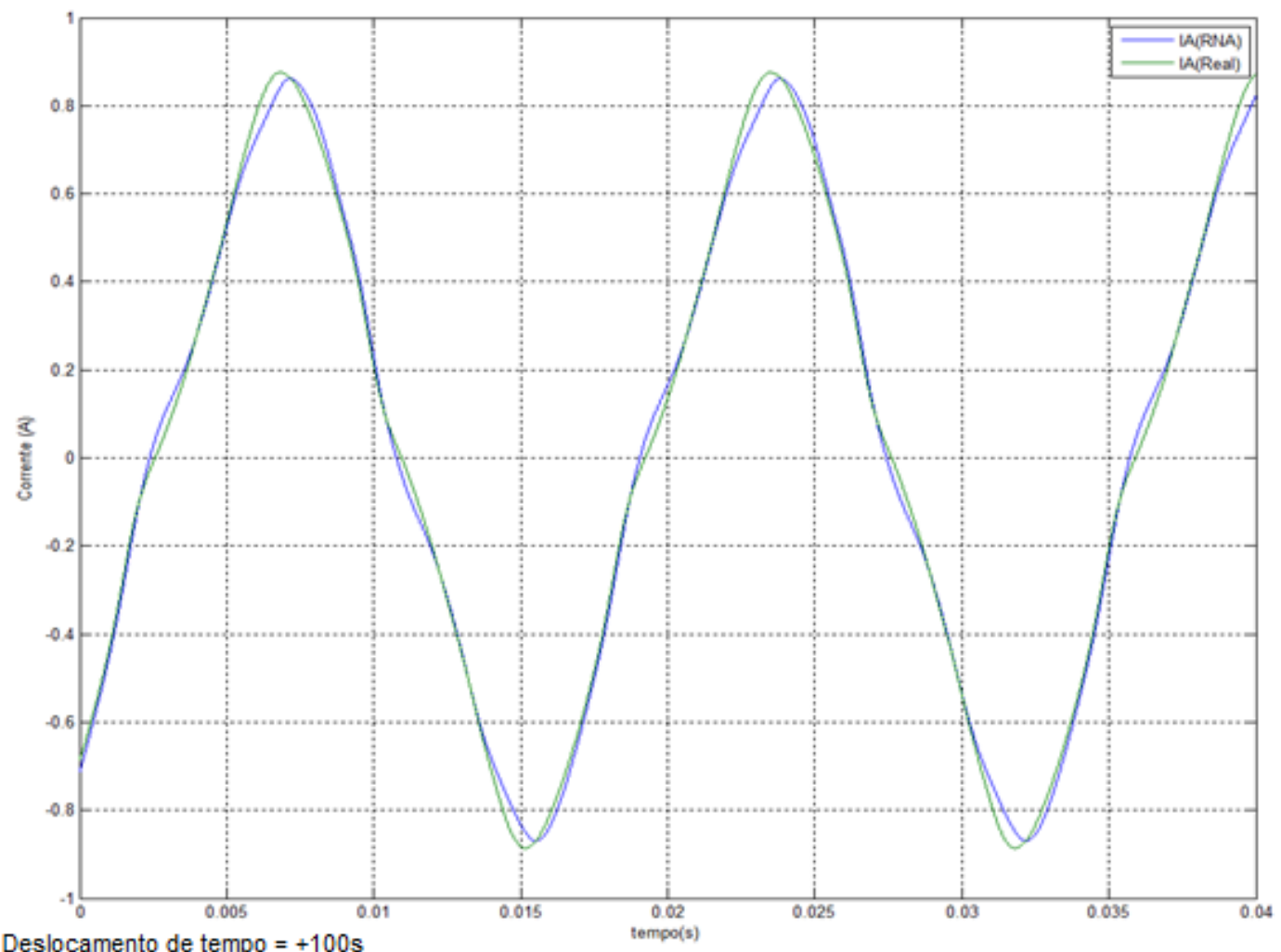

Figura 112 - Corrente na lâmpada de descarga - início com a simulação em t=100s.

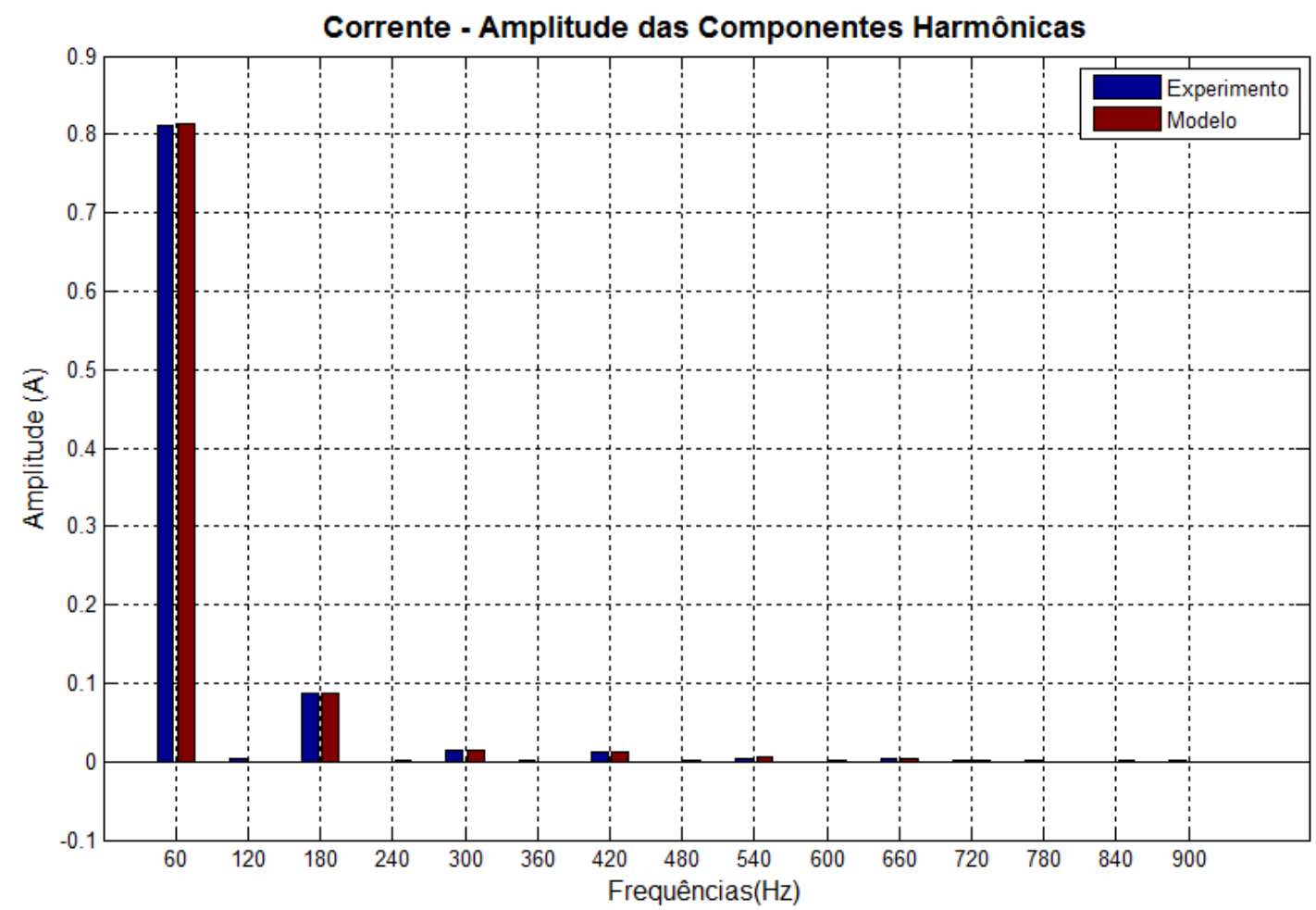

Figura 113 - Componentes harmônicas da corrente - início com a simulação em t=100s. 
À medida que a lâmpada tem sua temperatura elevada por decorrência da potência dissipada ao longo do tempo, o perfil de corrente evolui correspondendo à alteração da resistência do arco elétrico. Após o término da fase de aquecimento, o dispositivo assume um caráter de operação em regime permanente, sem alteração em sua temperatura de operação.

Na Figura 114 temos o estado da corrente através do dispositivo extraído no instante $\mathrm{t}=200$ s após o início da simulação, com a lâmpada em regime estável de operação, e na Figura 115 a representação do conteúdo harmônico da corrente do dispositivo. Cabe notar as pequenas alterações em relação às figuras da situação anterior, resultantes do aquecimento da lâmpada.

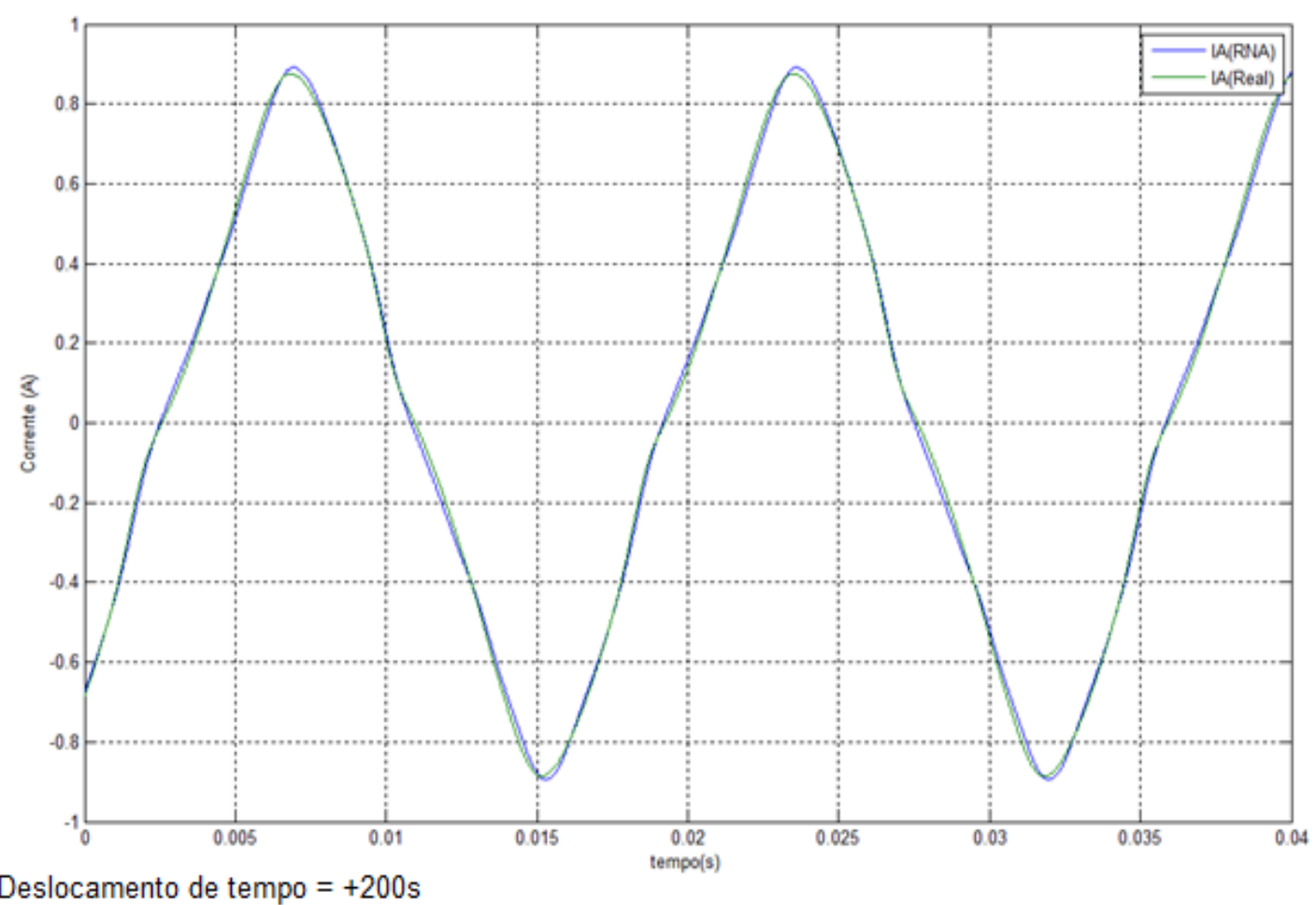

Figura 114 - Corrente na lâmpada de descarga - início com a simulação em t=200s.

A resposta do modelo a tensões de alimentação estáveis e inferiores à nominal também se mostrou satisfatória. Um exemplo desta situação é mostrado na Figura 116, onde o dispositivo encontra-se alimentado com tensão correspondente a $0,8 \mathrm{pu}$ 
(176V), classificada como alimentação crítica, e com temperatura estabilizada. O gráfico apresentado na Figura 117 traz a informação sobre as componentes harmônicas de corrente para esta situação.

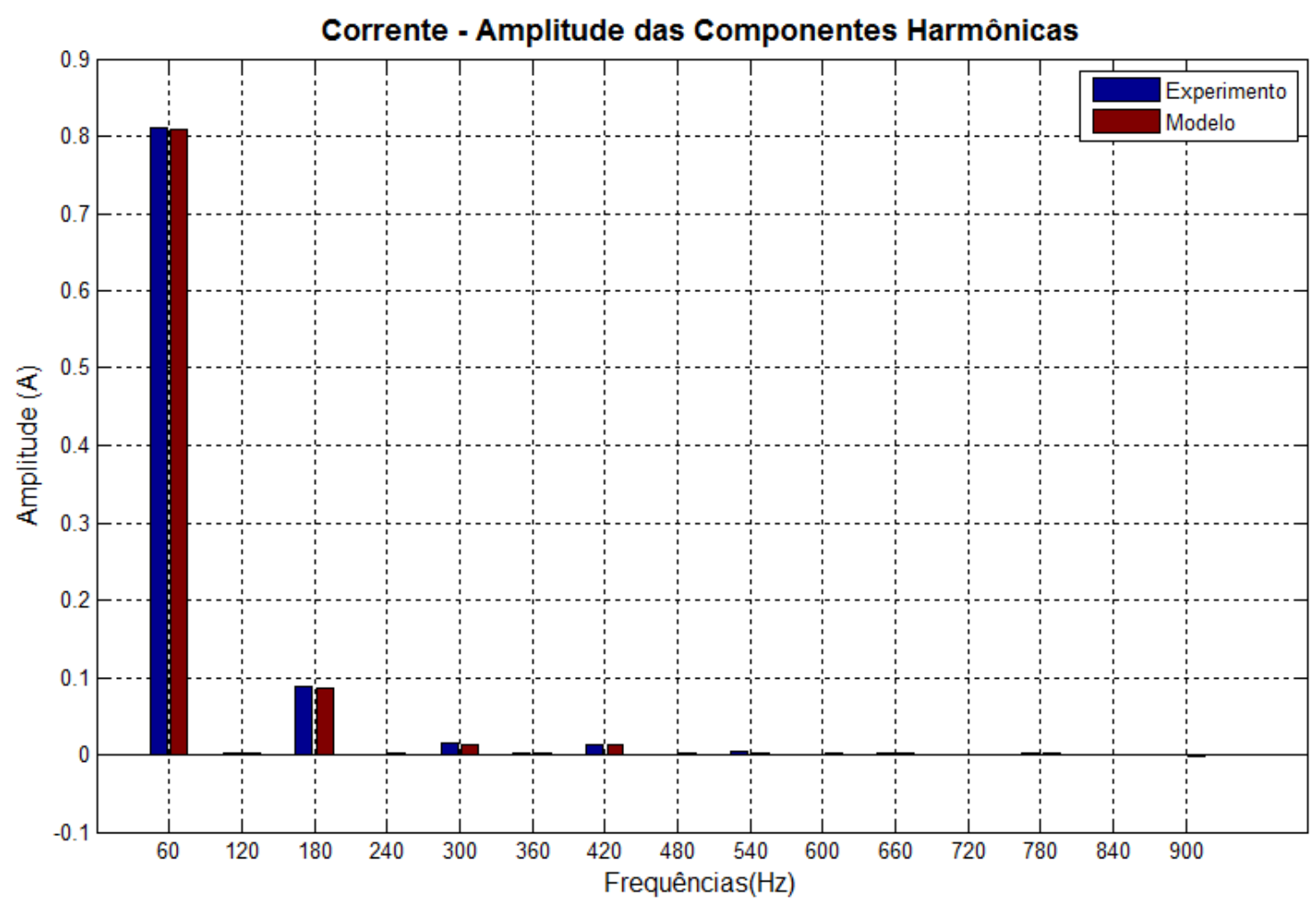

Figura 115 - Componentes harmônicas da corrente - início com a simulação em t=200s.

Apesar de serem apresentados poucos resultados, o modelo foi exaustivamente testado, com diversas situações de alimentação, e as respostas mostraramse satisfatórias em todos os casos experimentados, atestando assim sua eficácia na representação do dispositivo modelado.

A Tabela 10 apresenta a relação de ensaios preliminares que permitiu avaliar o desempenho e a eficácia do modelo implementado. A partir destes resultados, podemos concluir que a rede neural artificial responsável pela reprodução do conteúdo harmônico da corrente do dispositivo apresentou resultados satisfatórios com o treinamento efetuado, visto que os valores simulados apresentaram boa aproximação dos dados experimentais. 


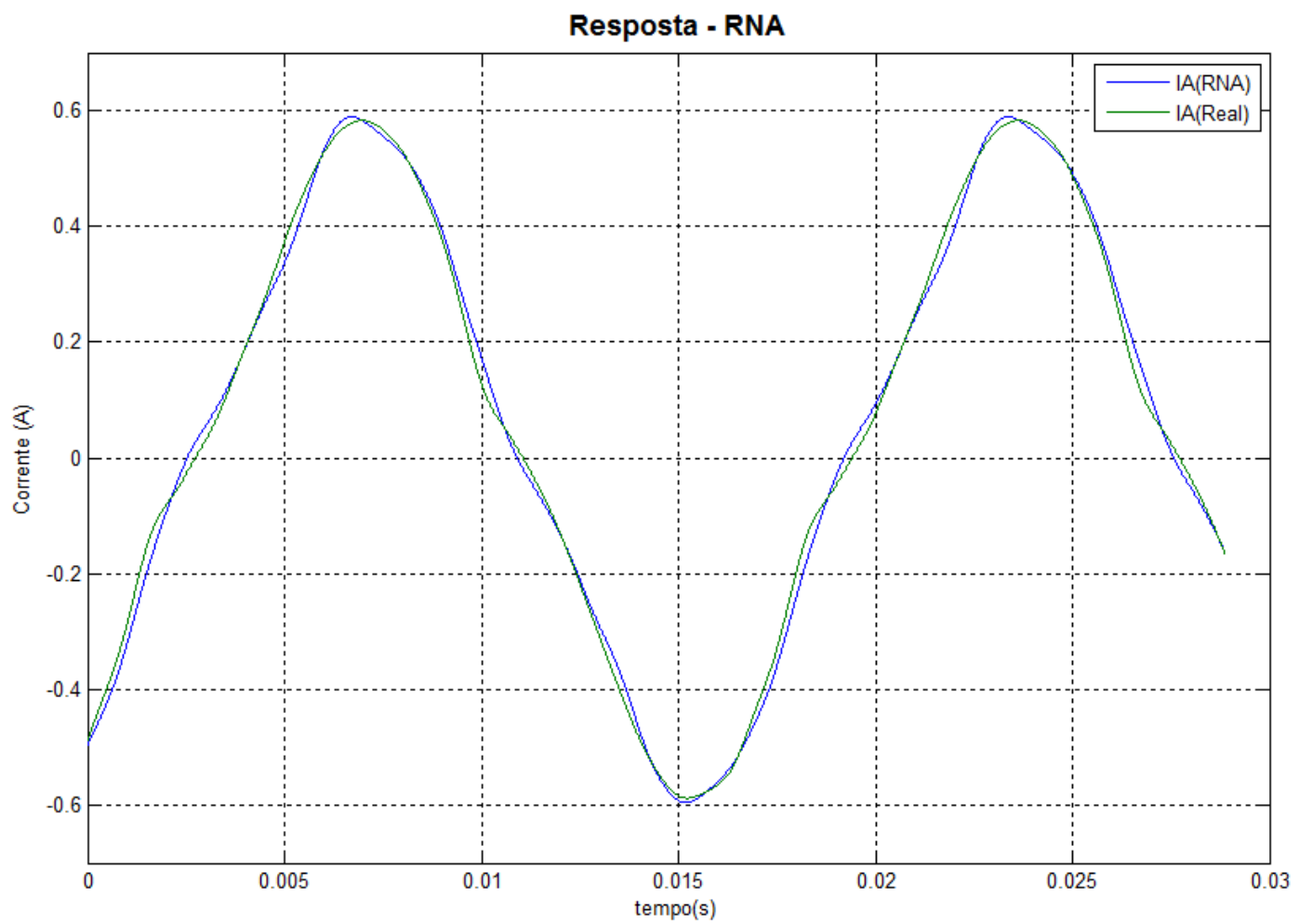

Figura 116 - Corrente na lâmpada de descarga - tensão de 0,8 pu (regime permanente).

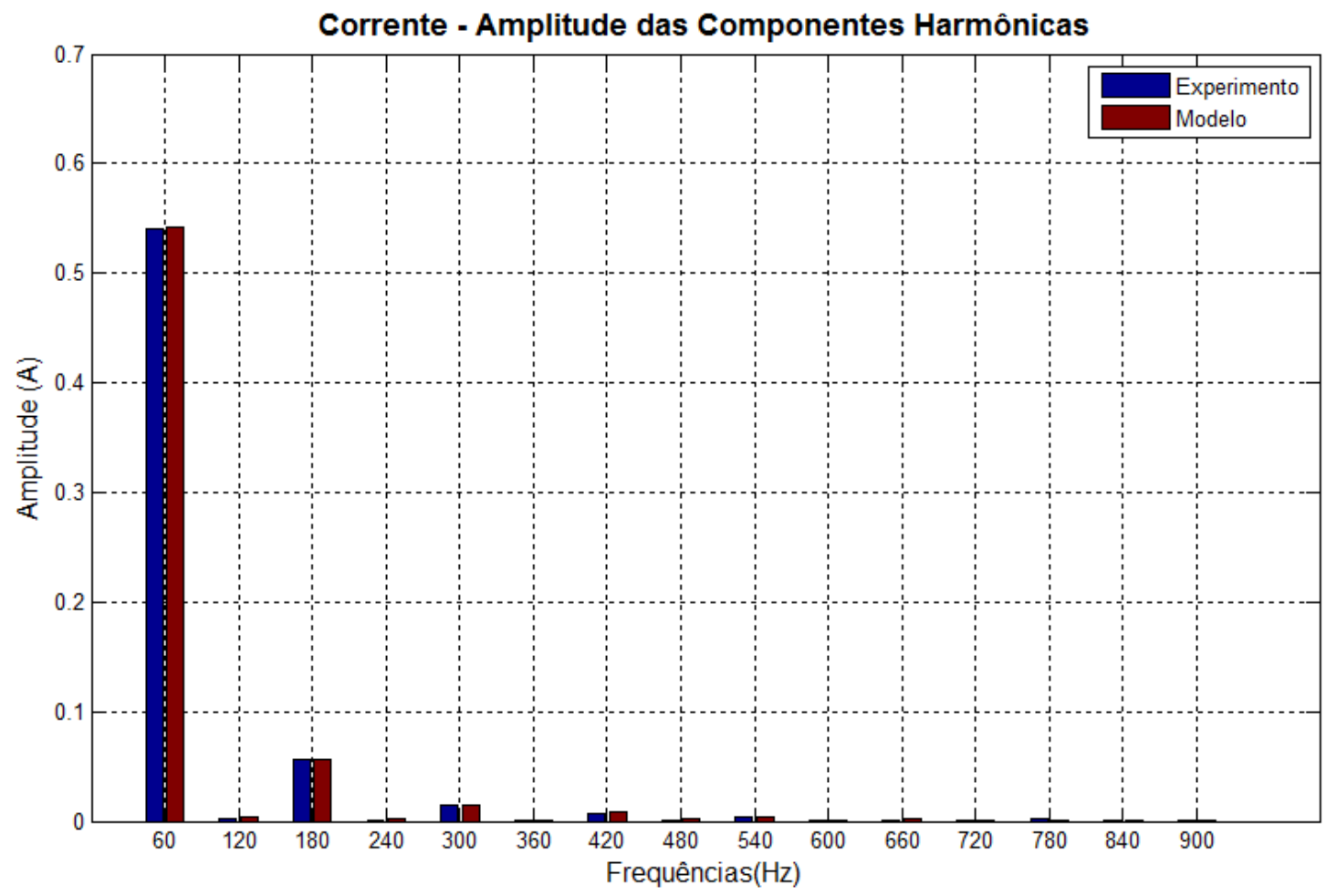

Figura 117 - Componentes harmônicas da corrente - tensão de 0,8 pu. 
Tabela 10 - Ensaios preliminares de validação do modelo

\begin{tabular}{|c|c|c|}
\hline \multicolumn{2}{|c|}{ Ensaios com alimentação em regime permanente } & Número de Ensaios \\
\hline \multirow{4}{*}{ Tensão de } & Nominal & 15 \\
\cline { 2 - 3 } Atendimento & Tensão Adequada & 10 \\
\cline { 2 - 3 } & Tensão Precária & 10 \\
\cline { 2 - 3 } & Tensão Crítica & 10 \\
\cline { 2 - 3 } & Subtensões & 25 \\
\cline { 2 - 3 } & Sobretensões & 20 \\
\hline
\end{tabular}

\subsubsection{Reprodução da característica termodinâmica}

A lâmpada de descarga pode ser representada através de sua característica termodinâmica, que serve como base para determinação do ponto de operação do dispositivo ao longo do tempo. Nesta representação, a temperatura e potência dissipada pelo conjunto lâmpada/reator são representados em função de condições iniciais de temperatura e tensão de alimentação do conjunto. O resultado é a reprodução do comportamento do dispositivo diante de situações operacionais de regime permanente e de regime transitório, em especial perante eventos relacionados à qualidade da energia elétrica.

O gráfico apresentado na Figura 118 mostra o comportamento termodinâmico da lâmpada no experimento durante a fase de aquecimento, partindo da temperatura ambiente, com base nos dados coletados pelo sistema de aquisição de dados.

O gráfico apresentado na Figura 119 representa o comportamento termodinâmico desempenhado pelo modelo neural a partir de uma alimentação estável igual ao valor nominal para o dispositivo, indicando a evolução de temperatura e de potência do conjunto ao longo do tempo.

O modelo de comportamento termodinâmico foi testado exaustivamente em variadas condições, mostrando-se eficiente na reprodução do comportamento da lâmpada modelada, para situações de operação de regime estável de alimentação. 


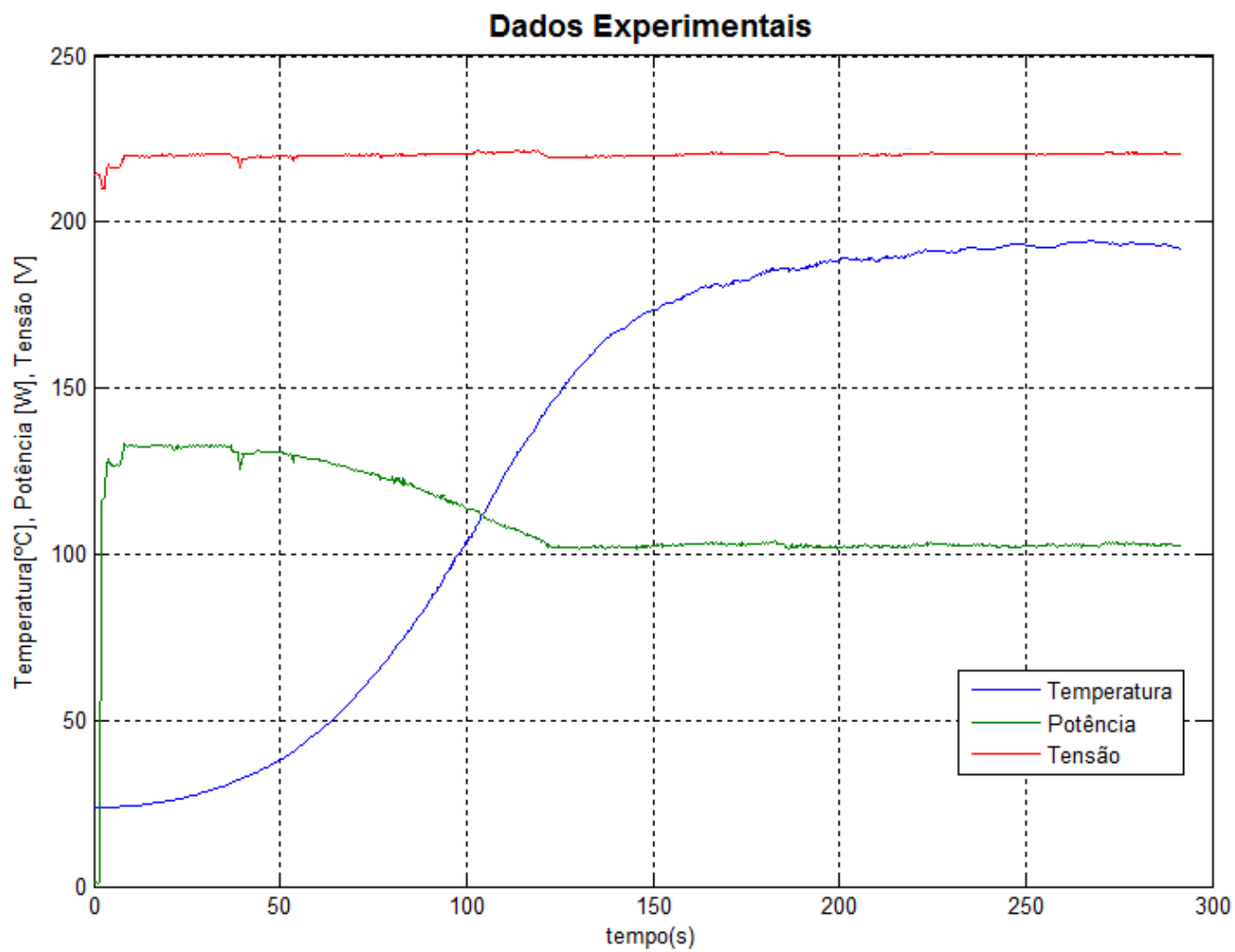

Figura 118 - Fase de aquecimento da lâmpada de descarga (Experimento).

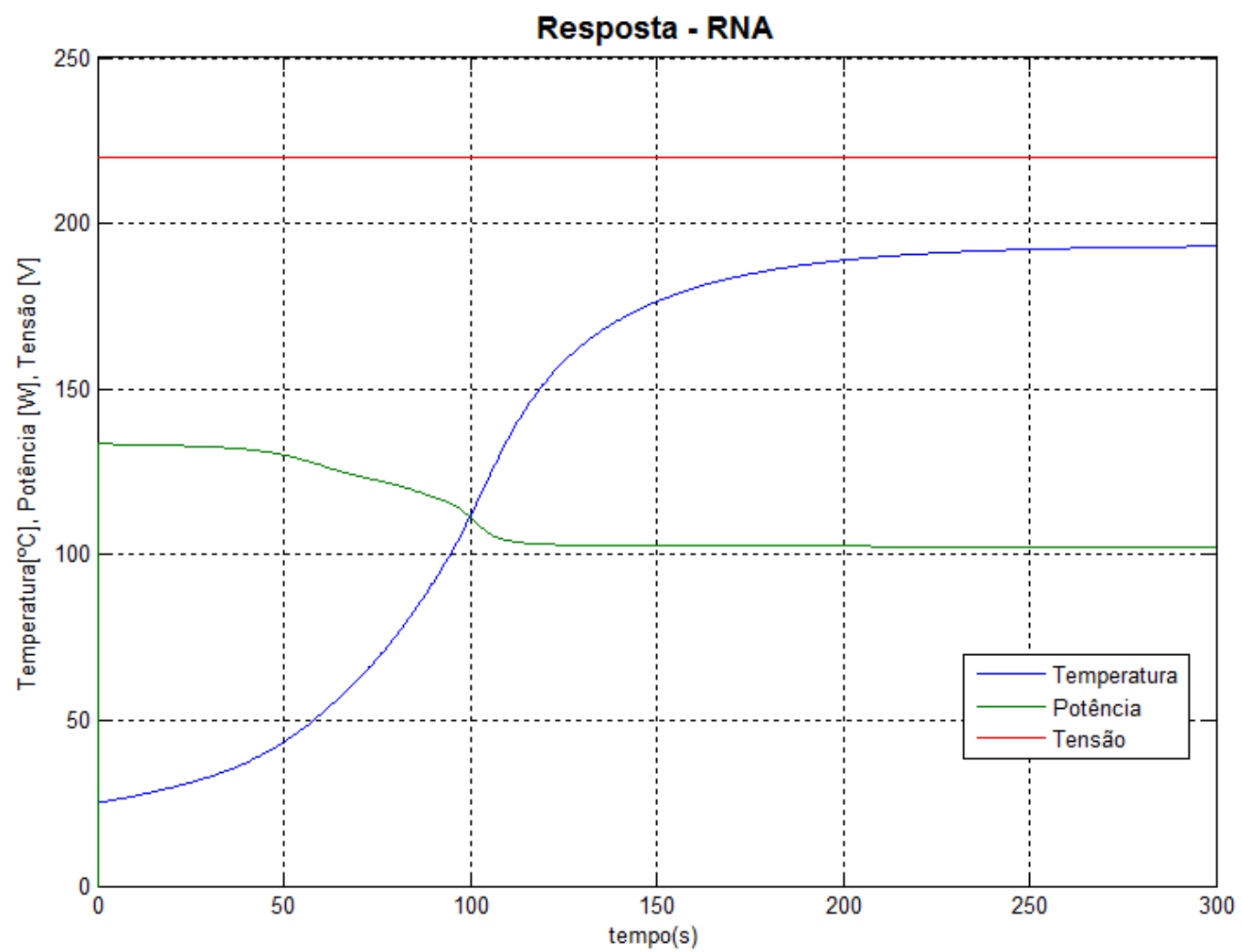

Figura 119 - Fase de aquecimento da lâmpada de descarga (RNA 1). 
Espera-se que o universo de situações empregado no treinamento da rede neural artificial RNA1 permita a esta rede uma reprodução abrangente do comportamento do dispositivo, não apenas em situações estáveis, mas também perante os eventos relacionados à qualidade da energia, e em especial aqueles que atingem o limite de estabilidade da lâmpada, provocando seu desligamento. Uma análise mais aprofundada desta situação será apresentada no próximo capítulo deste trabalho.

\subsection{Comparação de desempenho computacional}

Uma das vantagens aguardadas no desenvolvimento de um modelo baseado em redes neurais artificiais é um ganho no desempenho computacional das simulações realizadas, quando comparado com a modelagem matemática apresentada no capítulo cinco deste trabalho. Uma forma de se mensurar este acréscimo de desempenho tem por base a cronometragem dos tempos de simulação para situações operacionais idênticas.

Para efeito de comparação entre os dois modelos, foram realizadas simulações de situações idênticas empregando o modelo matemático implementado no software SIMULINK® e o modelo neural implementado no software MATLAB®. As tomadas de tempo foram realizadas através de coletas de variáveis do sistema referentes a temporização, e os cálculos das diferenças entre os tempos de início e término das simulações fornecem o tempo transcorrido em cada simulação.

As simulações empregando o modelo matemático construído e executado no SIMULINK ${ }^{\circledR}$ foram realizadas empregando-se o método de resolução de equações diferenciais ordinárias ode23t, baseado em integrações definidas por algoritmo trapezoidal com interpolador livre, com passo de integração variável, passo máximo igual a $10^{-5}$ segundos e passo mínimo igual a $10^{-9}$ segundos. Cabe salientar que o aumento do 
passo máximo de integração, empregado na tentativa de aumentar a velocidade da simulação, resultou em distorções que prejudicaram a representação do modelo.

As redes neurais artificiais foram treinadas com um conjunto de dados que contempla a maioria das situações de contorno admissíveis para a lâmpada modelada. Os resultados dos treinamentos, contudo, nem sempre apresentavam resultados correspondentes aos desejados, visto que as populações de treinamento e validação eram escolhidas aleatoriamente pelo conjunto de ferramentas de Redes Neurais Artificiais do $M A T L A B \circledR$. Por esta razão, os treinamentos foram efetuados por diversas vezes e os resultados analisados, até atingirem nível de representação aceitável para o propósito de modelagem. A partir deste treinamento satisfatório, o modelo foi constituído e as simulações passaram a ser realizadas com base na rede obtida.

O desempenho comparativo entre as simulações baseadas no modelo matemático e no modelo neural é mostrado na Tabela 11.

Nesta tabela estão apresentados os tempos médios, considerando três simulações realizadas por experimento, e com o microcomputador executando apenas o MATLAB ${ }^{\circledR}$. Notar que o ganho de desempenho no modelo neural é demonstrado nas simulações de longos períodos de operação, onde as RNAs substituem com vantagem o equacionamento matemático.

Convém salientar que o modelo matemático é executado através da ferramenta SIMULINK ${ }^{\circledR}$ do $M A T L A B \circledR$, e o modelo neural é executado através de um script desenvolvido para a plataforma $M A T L A B \circledR$.

Embora o tempo necessário ao treinamento das redes neurais artificiais atinjam em sua soma valores superiores aos necessários para simulação matemática, devemos lembrar que tais treinamentos são realizados apenas uma vez, e o resultado de tal treinamento pode ser aproveitado para todas as simulações desejadas. 
Tabela 11 - Comparativo de desempenho entre modelo matemático e modelo neural

\begin{tabular}{|c|c|c|}
\hline \multicolumn{3}{|c|}{$\begin{array}{c}\text { Desempenho Comparativo de Simulação - Modelo Matemático } \times \text { Modelo Neural } \\
\text { Hardware utilizado: Intel@ CORE } 2 \text { Quad 9550@2,83MHz; 4GB RAM } \\
\text { Sistema Operacional: Microsoft Windows } 7\end{array}$} \\
\hline \multirow{2}{*}{ Tarefa } & \multicolumn{2}{|c|}{ Tempo de Execução } \\
\hline & Modelo Matemático & Modelo Neural \\
\hline Treinamento - RNA Conteúdo Harmônico & - & $762 \mathrm{~s} *$ \\
\hline Treinamento - RNA Termodinâmica & - & $695 \mathrm{~s} *$ \\
\hline $\begin{array}{l}\text { Simulação termodinâmica regime permanente } \\
(\text { (t simulação }=300 \mathrm{~s})\end{array}$ & $1.421 \mathrm{~s}$ & $14 \mathrm{~s}$ \\
\hline $\begin{array}{l}\text { Simulação termodinâmica regime transitório } \\
\qquad(\mathrm{t} \text { simulação }=300 \mathrm{~s})\end{array}$ & $1.421 \mathrm{~s}$ & $14 \mathrm{~s}$ \\
\hline $\begin{array}{l}\text { Simulação harmônico regime permanente } \\
\text { (t simulação }=0,04 \mathrm{~s})\end{array}$ & $2,4 \mathrm{~s}$ & $2,2 \mathrm{~s}$ \\
\hline $\begin{array}{l}\text { Simulação harmônico regime transitório } \\
(\mathrm{t} \text { simulação }=0,04 \mathrm{~s})\end{array}$ & $2,4 \mathrm{~s}$ & $2,2 \mathrm{~s}$ \\
\hline $\begin{array}{l}\text { Simulação completa (harmônico + } \\
\text { termodinâmica); t simulação }=300 \mathrm{~s}\end{array}$ & $1.421 \mathrm{~s}$ & $29 \mathrm{~s}$ \\
\hline
\end{tabular}

*Treinamentos efetivamente empregados, com população adequada e resultados satisfatórios.

Pode-se notar que nas simulações de curta duração, onde os resultados pontuais das simulações são apresentados, a vantagem do modelo neural é pequena sobre o modelo matemático.

A partir destes resultados de desempenho, pode-se afirmar que o modelo neural proposto substitui o modelo matemático (descrito no capítulo cinco deste trabalho) na representação de um único conjunto lâmpada-reator, através da representação de suas características termodinâmicas e de composição harmônica de corrente em condições operacionais estáveis. A completa validação deste modelo proposto requer sua validação diante de distúrbios relacionados à qualidade da energia elétrica, que é o objeto de estudo do próximo capítulo deste trabalho.

Pelo comportamento apresentado em ensaios envolvendo um único conjunto de lâmpada e reator, podemos considerar que o esforço computacional exigido na 
simulação de conjuntos de lâmpadas poderia tornar inviável a aplicação do modelo matemático na avaliação das diversas variáveis de cada dispositivo, conforme a configuração adotada na simulação. Neste sentido, o modelo neural proposto se mostra mais adequado a este tipo de simulação computacional.

\subsection{Metodologia para obtenção do modelo neural}

Diante do modelo obtido e da capacidade de representação comprovada, torna-se possível descrever uma metodologia para a obtenção de modelos neurais de dispositivos elétricos, baseada nos procedimentos adotados para a lâmpada de descarga modelada. Esta metodologia é composta pelas fases a seguir descritas.

\subsubsection{Identificação das variáveis de operação}

Para o estabelecimento de um modelo neural, faz-se necessária a identificação das variáveis operacionais do dispositivo a ser modelado, e se possível a determinação dos limites destas variáveis para toda a faixa de operação do dispositivo.

\subsubsection{Determinação dos limites operacionais do dispositivos}

A partir de características operacionais e dados fornecidos por catálogos dos fabricantes, determina-se os limites absolutos de operação do dispositivo a ser modelado. Estes limites serão posteriormente utilizados para avaliação das características de operação do dispositivo.

\subsubsection{Montagem experimental e instrumentação}

Nesta fase da metodologia, uma montagem experimental deverá ser realizada de modo a permitir a instrumentação das variáveis de operação em toda sua faixa. O experimento deverá ainda permitir a captura e armazenamento dos dados com uma taxa 
amostral compatível com a taxa de variação das variáveis monitoradas, possibilitando assim a recomposição matemática da operação do dispositivo.

\subsubsection{Experimentos operacionais}

Esta etapa da metodologia deve contemplar tipos e quantidades de experimentos com o dispositivo capazes de colocá-lo em todas suas condições operacionais e seus limites de operação, tornando assim possível a identificação e reprodução destes limites por um modelo a ser implementado.

\subsubsection{Montagem da arquitetura e treinamento do modelo neural}

Nesta fase deve-se definir a arquitetura a ser utilizada para $o$ modelo e, a partir de criteriosa mineração dos dados obtidos na etapa experimental, realizar o treinamento das redes neurais desenvolvidas.

\subsubsection{Validação do modelo neural obtido}

Após a etapa de treinamento, deve-se proceder com a validação do modelo, que pode ser obtida através da aplicação de situações diversas das empregadas no treinamento das RNAs e verificação do desempenho obtido.

Um fluxograma contendo uma metodologia genérica para obtenção de modelos neurais é apresentado na Figura 120. 


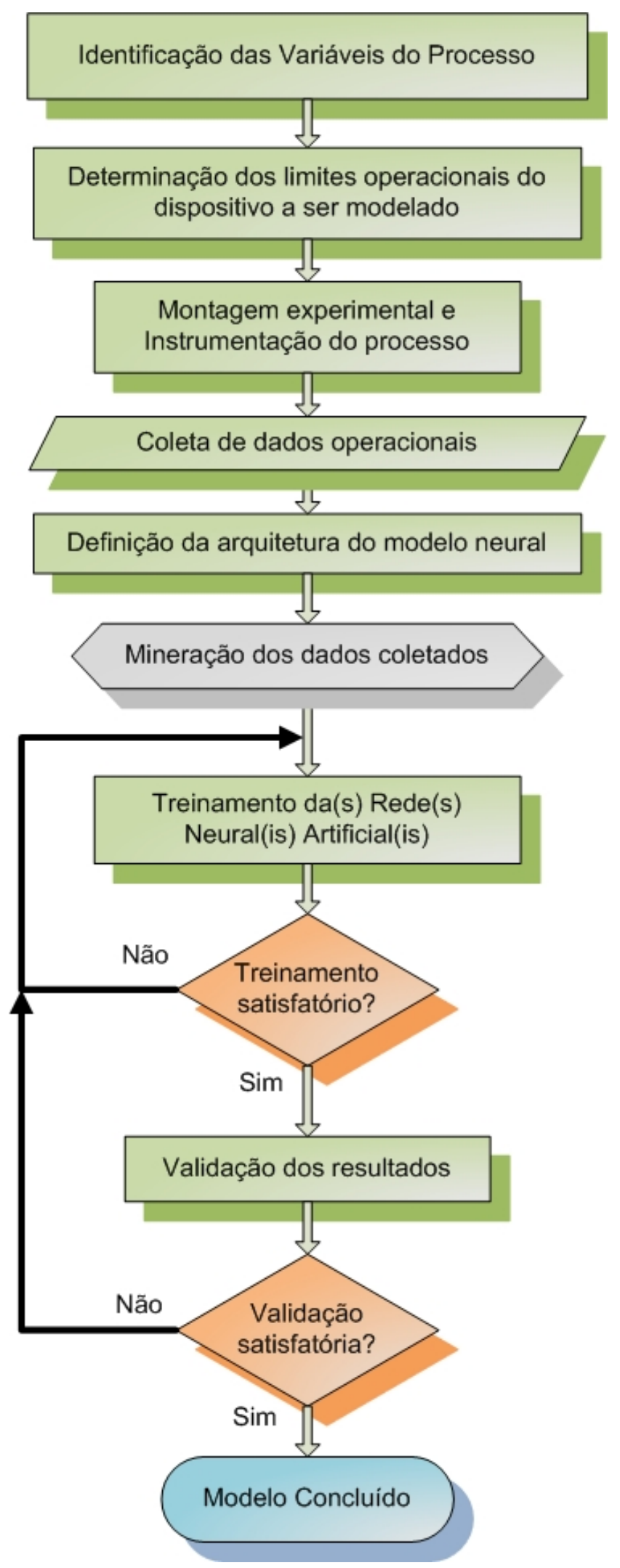

Figura 120 - Fluxograma - Metodologia para obtenção de modelos neurais. 


\section{ANÁLISE DE DESEMPENHO DO MODELO NEURAL DE LÂMPADA DE DESCARGA CONSIDERANDO PARÂMETROS DE QUALIDADE DA ENERGIA}

\subsection{Introdução}

A validação da metodologia de modelagem proposta só se torna completa após a avaliação do desempenho do modelo obtido perante eventos relacionados à qualidade da energia elétrica (QEE). Por se tratar de um elemento de características nãolineares do ponto de vista de carga elétrica, e com níveis de susceptibilidade a eventos de tensão que variam conforme a fase de operação em que o dispositivo se encontra, há a necessidade de avaliação do desempenho do modelo para diversas situações operacionais.

Serão apresentados os resultados das avaliações de desempenho do modelo a partir das seguintes condições:

a)Dispositivo em regime permanente de operação submetido a distúrbio de QEE; 
b)Dispositivo em regime transitório de operação submetido a distúrbio de QEE; e

c)Agrupamento de dispositivos e avaliação do desempenho do modelo.

\subsection{Desempenho do modelo em regime permanente de operação}

Considera-se regime permanente de operação aquele onde o dispositivo encontra-se com a temperatura estabilizada. O distúrbio de qualidade da energia ocorre, portanto, com o dispositivo fora de uma fase transitória. Em tese, esta fase de operação corresponde ao estágio onde o dispositivo é mais susceptível a distúrbios de qualidade da energia, por apresentar na maioria dos casos uma elevada temperatura de operação.

\subsubsection{Respostas do modelo a variações de tensão de longa duração}

Em regime permanente, a lâmpada de descarga apresenta susceptibilidade relativamente elevada a distúrbios relacionados a redução de tensão de alimentação. As reduções de tensão são toleradas dentro de certos limites, desde que não produzam significativo resfriamento da coluna de plasma a ponto de causar sua desestabilização.

A Figura 121 mostra o comportamento do experimento diante de um degrau permanente de tensão a $0,95 \mathrm{pu}$, considerado como tensão de fornecimento adequada, incidindo no instante $\mathrm{t}=250 \mathrm{~s}$ após o início de operação do dispositivo. Tal distúrbio não produziu o desligamento da lâmpada, e um comportamento idêntico foi obtido através da simulação com o modelo neural e é mostrado no gráfico da Figura 122. 


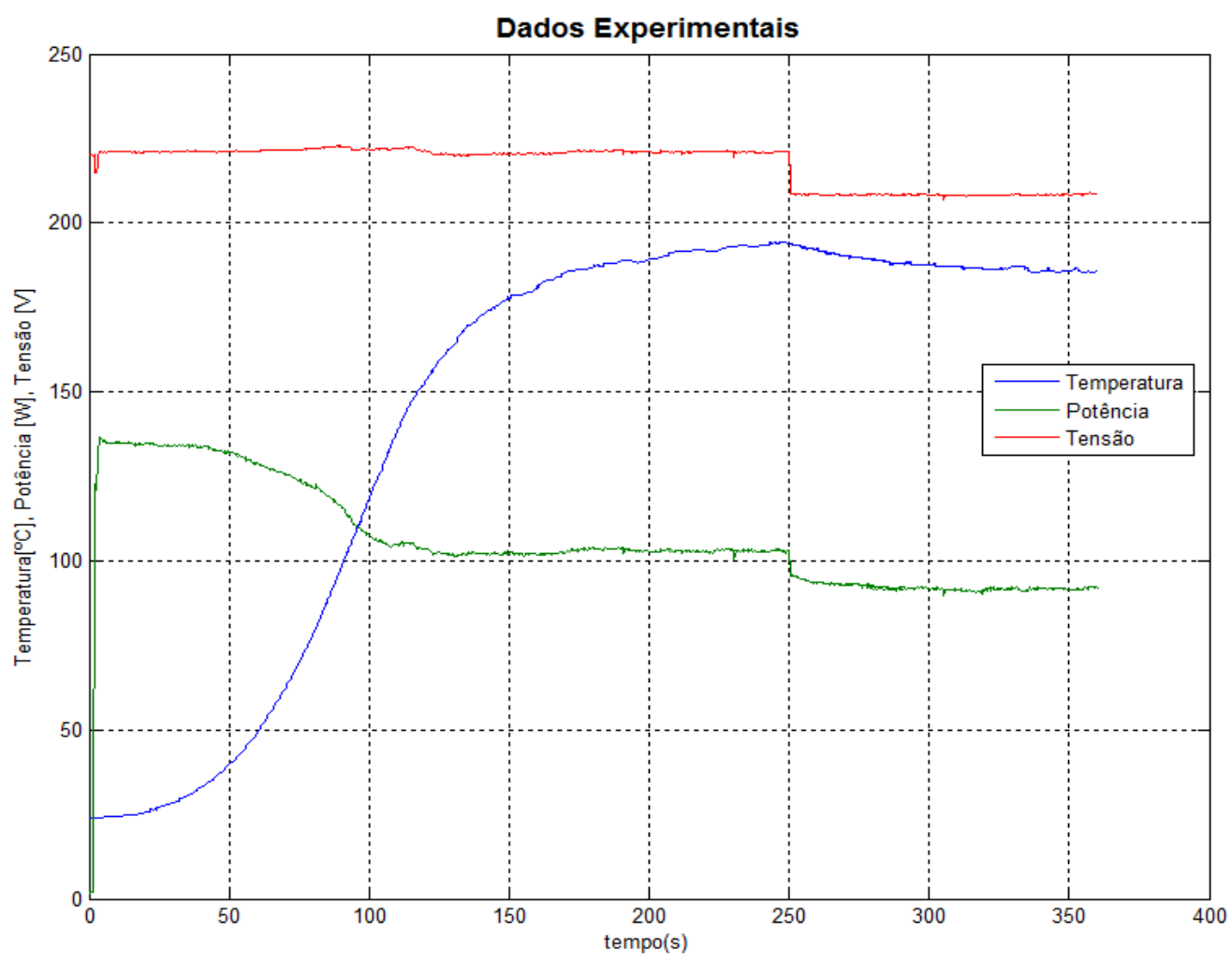

Figura 121 - Dados experimentais - degrau permanente de tensão a $0,95 p u$ em $t=250 s$.

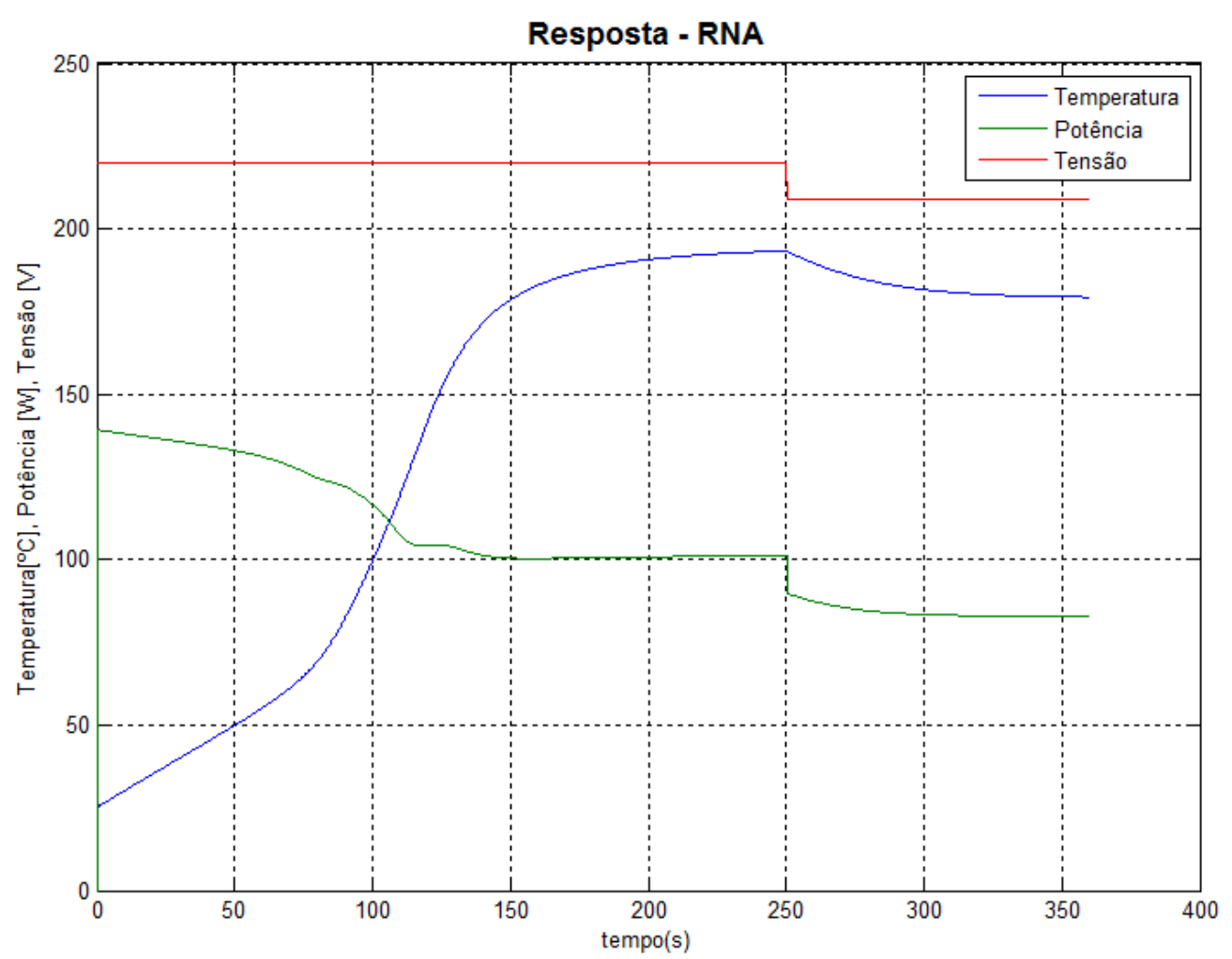

Figura 122 - Resposta do modelo - degrau permanente de tensão a $0,95 \mathrm{pu}$ em $\mathrm{t}=\mathbf{2 5 0 \mathrm { s }}$. 
A aplicação de um distúrbio mais severo, mas que ainda não produz extinção do arco, é mostrado no gráfico da Figura 123. Neste experimento, o conjunto é submetido a um afundamento a 0,90 pu aplicada de forma permanente. Nota-se a acomodação sofrida pela lâmpada, sem contudo apresentar seu apagamento.

A resposta do modelo ao afundamento a 0,90 pu aplicada em t=250s após o início da simulação é mostrado no gráfico presente na Figura 124, onde é possível avaliar o comportamento do modelo como bastante próximo ao apresentado pelo dispositivo real.

\subsubsection{Resposta do modelo a interrupções}

Para avaliação da resposta do modelo às interrupções, comparamos o modelo proposto com os experimentos realizados. A Figura 125 apresenta os dados experimentais de uma interrupção temporária aplicada no dispositivo em regime, com duração de 5 segundos. Deve ser observado o perfil de resfriamento do dispositivo, que se mantém mesmo após alguns segundos do restabelecimento do arco, devido à inércia térmica do conjunto.

A resposta obtida pelo modelo a uma interrupção temporária é apresentada na Figura 126. A simulação ocorre a partir de uma condição inicial de lâmpada em regime, estabelecida na rotina de simulação. O perfil de resfriamento e o perfil de potência após a incidência do evento correspondem aos perfis obtidos experimentalmente, comprovando a eficiência do modelo neste tipo de representação.

Pode ser observado que o modelo proposto permite uma satisfatória representação do comportamento da lâmpada de descarga quando submetida a uma interrupção de sua alimentação, reproduzindo com grande similaridade o comportamento termodinâmico do dispositivo. 


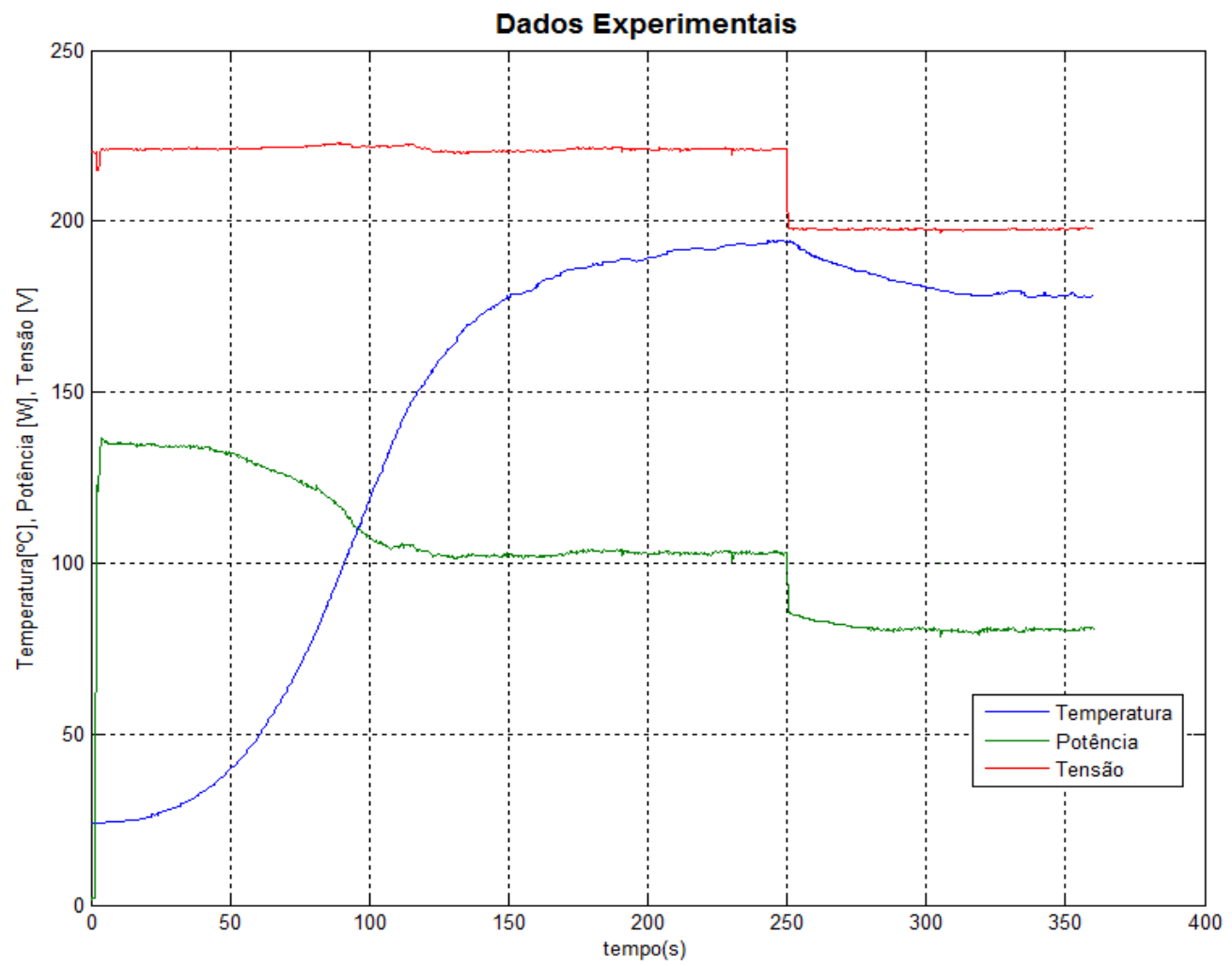

Figura 123 - Dados experimentais - afundamento a 0,9pu em $\mathrm{t}=250 \mathrm{~s}$.

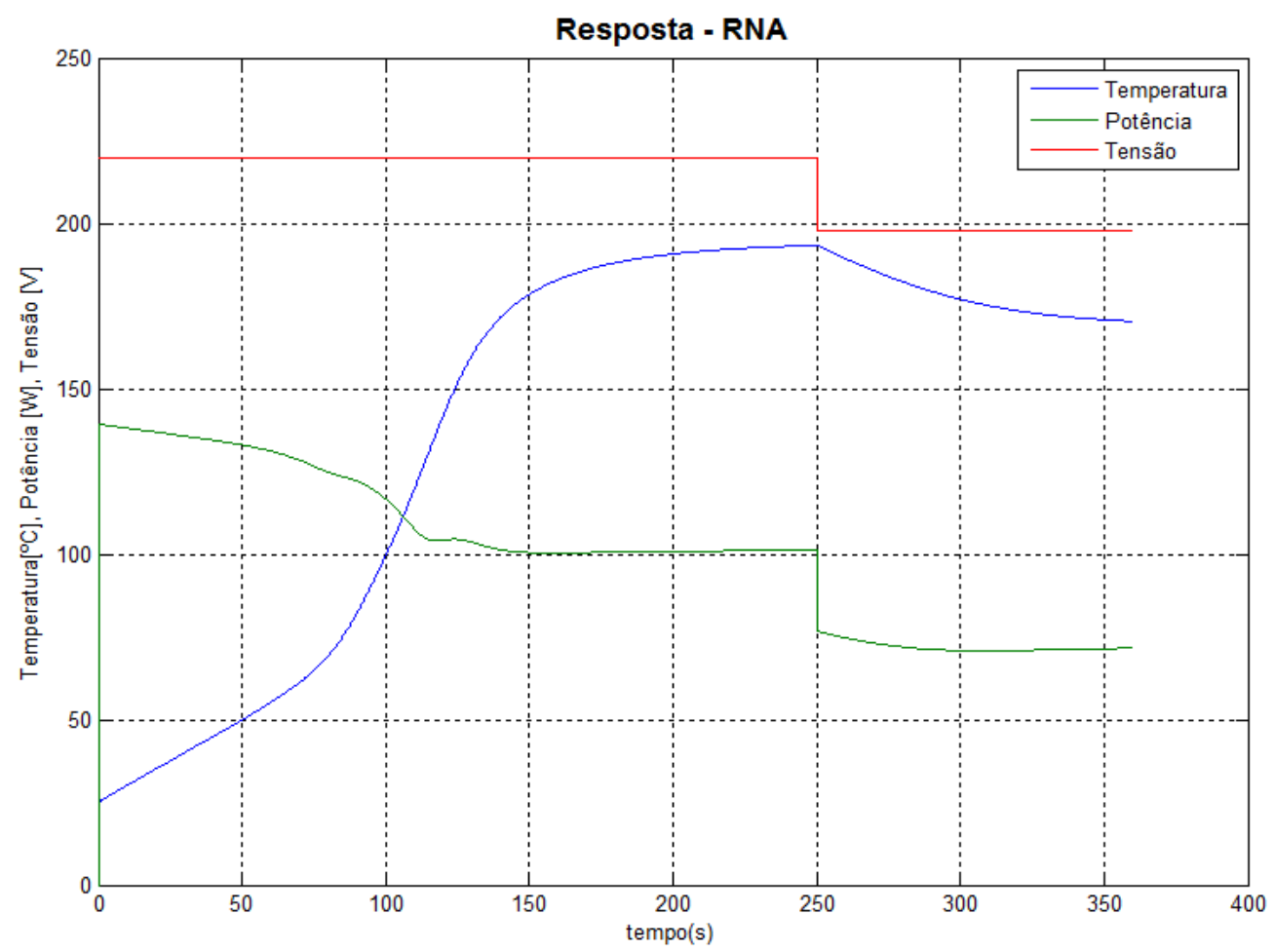

Figura 124 - Resposta do modelo - afundamento a 0,9pu em t=250s. 


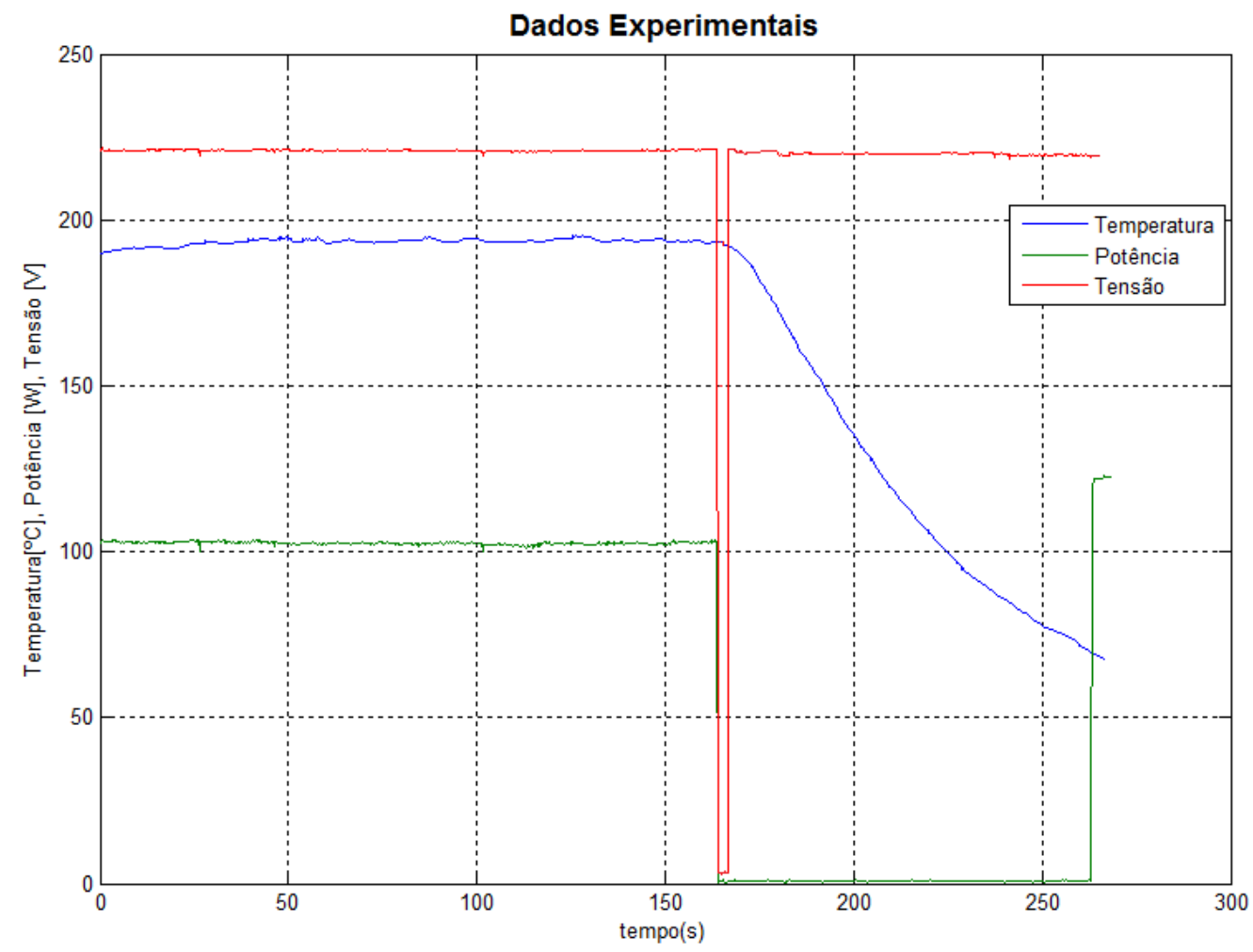

Figura 125 - Dados experimentais de uma interrupção temporária.

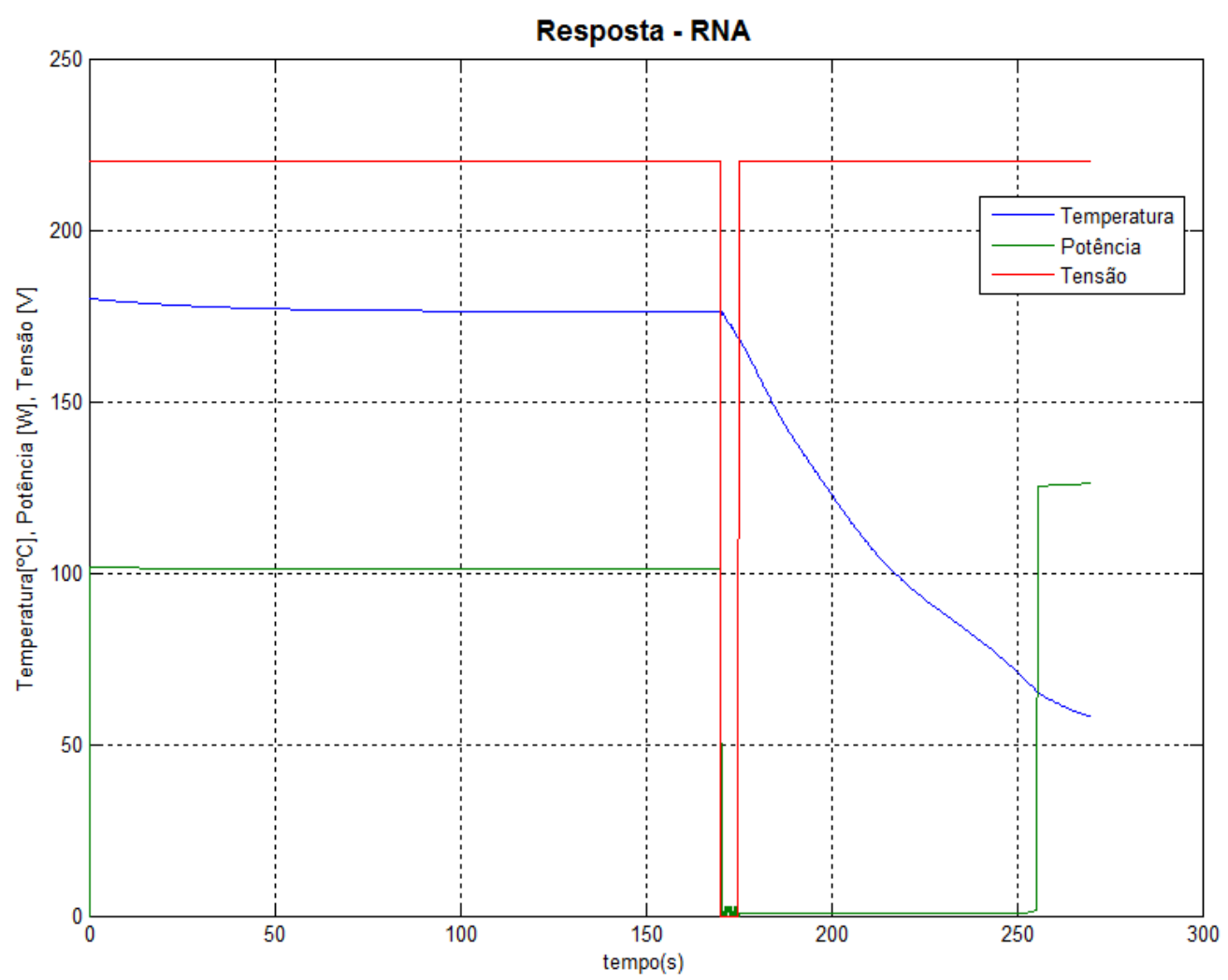

Figura 126 - Resposta do modelo a uma interrupção temporária de 5 segundos. 


\subsubsection{Resposta a variações de tensão de curta duração}

Os afundamentos, conforme anteriormente classificados, são eventos com duração limitada, e que produzem o deslocamento temporário do ponto de operação da lâmpada de descarga. Conforme a intensidade e duração, o afundamento pode produzir a extinção do arco e consequentemente o apagamento da lâmpada.

O gráfico da Figura 127 apresenta o experimento submetido a um afundamento temporário a 0,9 pu e duração de 20 segundos, incidindo em $\mathrm{t}=250 \mathrm{~s}$ após a partida da lâmpada, e na Figura 128 é apresentada a simulação do mesmo distúrbio, que não produziu desligamento da lâmpada.

Pela resposta apresentada, pode-se concluir que o modelo atende às necessidades de representação do dispositivo quando exposto a afundamentos e reduções de tensão em regime permanente de operação, tendo em vista as similaridades de comportamento entre os experimentos e as simulações demonstrada através dos gráficos apresentados.

As variações de tensão de curta duração aplicadas a lâmpadas de descarga apresentam efeitos diversos, dependendo de fatores como sua intensidade, duração e o instante em que ocorrem com relação ao estado de aquecimento da lâmpada. No caso de lâmpadas em estado permanente de operação, os fatores que limitam o estado de estabilidade da coluna de plasma são dependentes da variação de temperatura produzida no interior do tubo de descarga da lâmpada.

Em casos onde a intensidade do distúrbio produz excessivo resfriamento da coluna de plasma, o dispositivo sai de sua faixa operacional e o arco se extingue. Nestes casos, ocorre o resfriamento natural da lâmpada e, havendo condições de alimentação favoráveis, ao se atingir uma temperatura onde o arco consiga se restabelecer, a lâmpada apresentará reignição. 


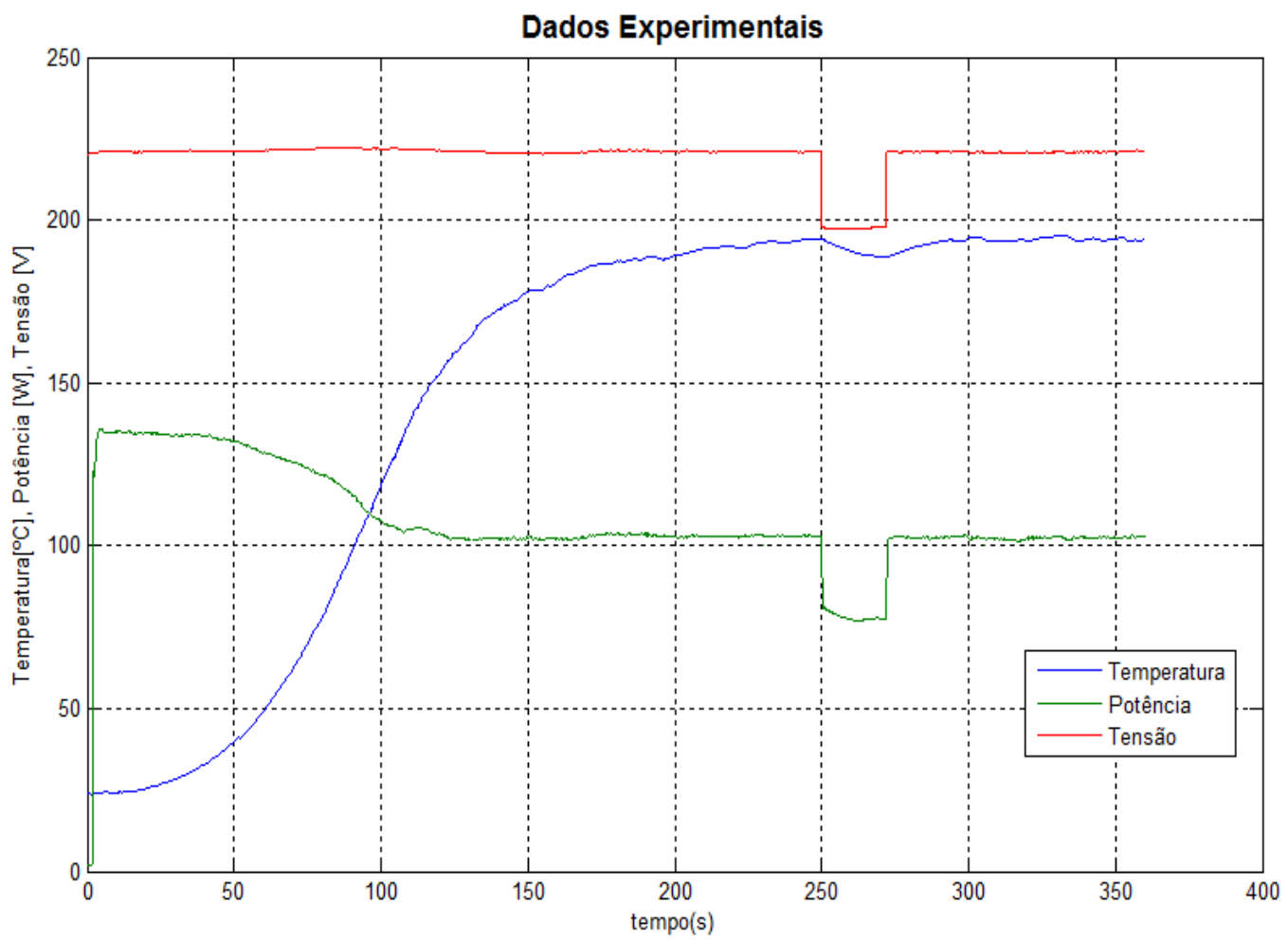

Figura 127 - Dados experimentais de um afundamento temporário a 0,9 pu em t=250s.

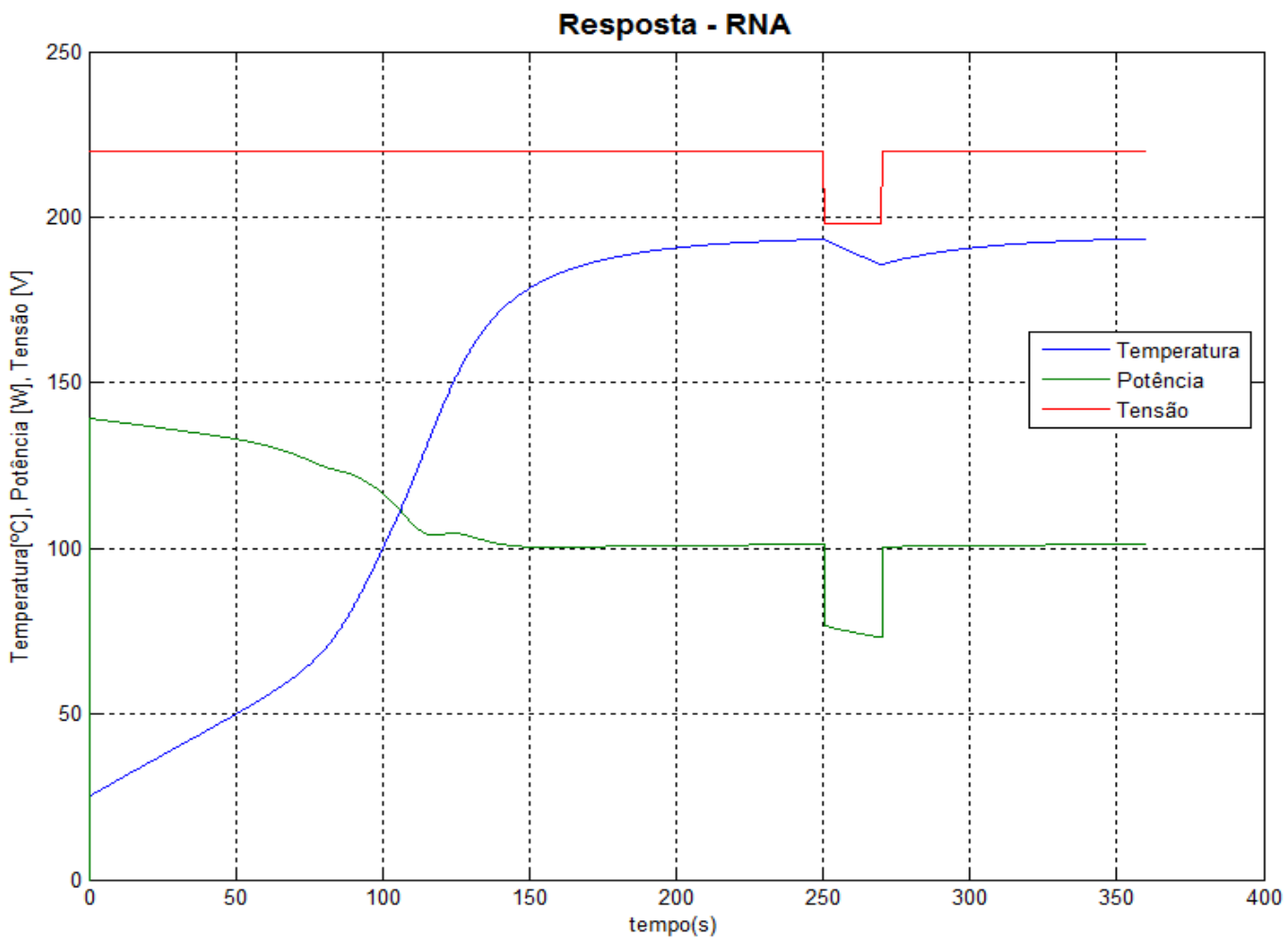

Figura 128 - Resposta do modelo a um afundamento temporário a 0,9pu. 
O gráfico apresentado na Figura 129 mostra uma situação onde um afundamento momentâneo a 0,8 pu produz o apagamento da lâmpada, e transcorrido o tempo de resfriamento, o dispositivo torna a acender.

O mesmo distúrbio simulado mostra a resposta do modelo neural da lâmpada conforme gráfico apresentado na Figura 130. Deve ser observado que os pontos de extinção e reignição do dispositivo nos gráficos guardam semelhança, o que nos permite concluir que o modelo proposto mostra-se eficaz, apresentando um desempenho compatível com o dispositivo real para o tipo de ensaio realizado. Deve-se notar que o modelo não representa a inércia térmica existente no dispositivo real, sem no entanto prejudicar o resultado final obtido pela simulação.

As comparações realizadas entre as simulações e os dados experimentais para o comportamento termodinâmico da lâmpada de descarga submetida a distúrbios relacionados à qualidade da energia elétrica durante sua fase estável de operação demonstram que o modelo proposto é adequado à representação do dispositivo, e isto se comprova pelos gráficos apresentados.

Pequenas diferenças no comportamento térmico demonstradas pelo modelo em determinadas situações são aceitáveis, visto que não descaracterizam o comportamento do dispositivo frente aos distúrbios ensaiados.

\subsection{Desempenho do modelo em fases de operação transitórias}

\subsubsection{Resposta a afundamentos durante a partida}

Durante a partida, a lâmpada de descarga apresenta potência e corrente diversos dos valores nominais do dispositivo manifestados após o período de estabilização, haja visto que as temperaturas e pressões no tubo de descarga encontram-se em fase de crescimento. 


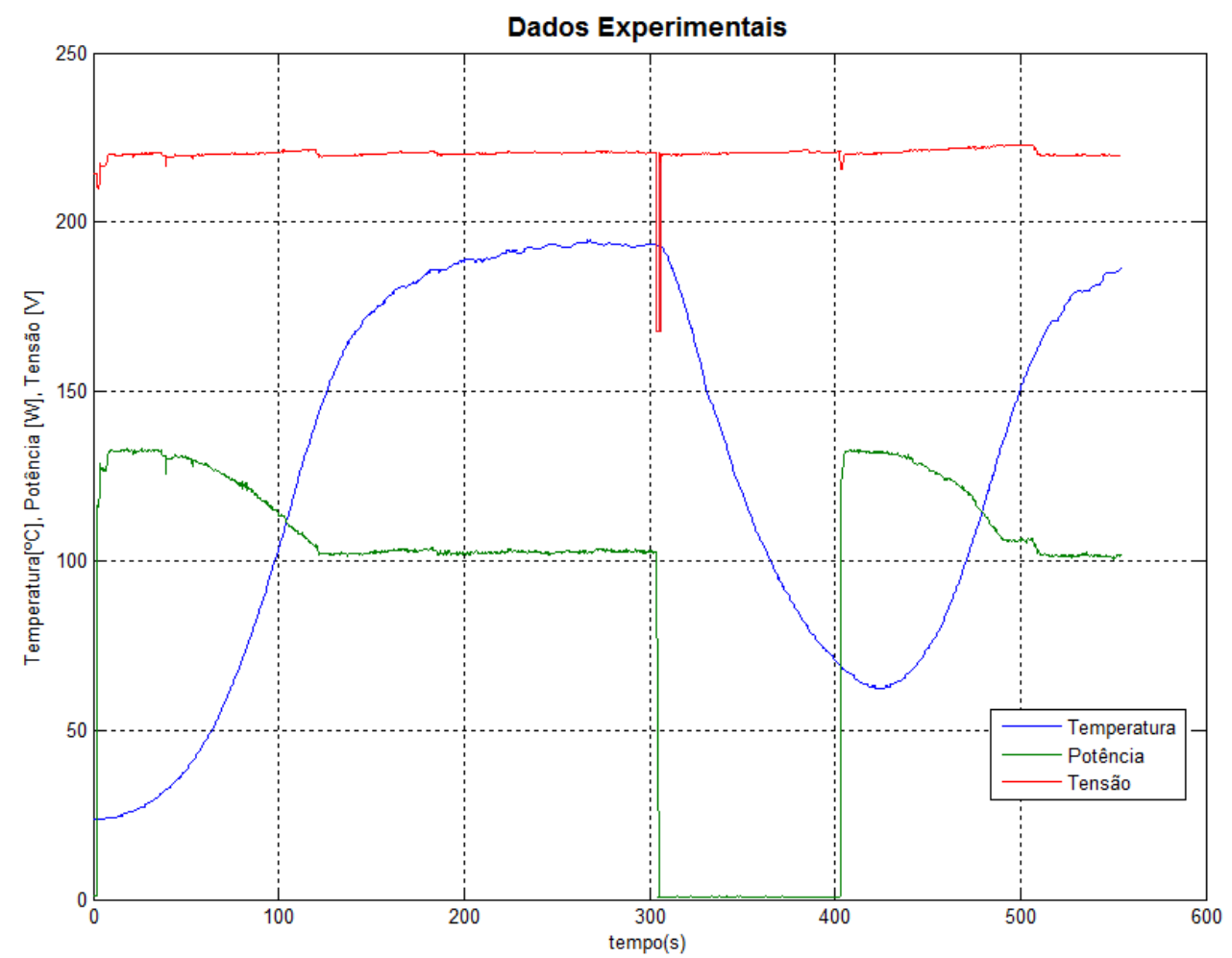

Figura 129 - Dados experimentais - redução de tensão de curta duração com extinção de arco.

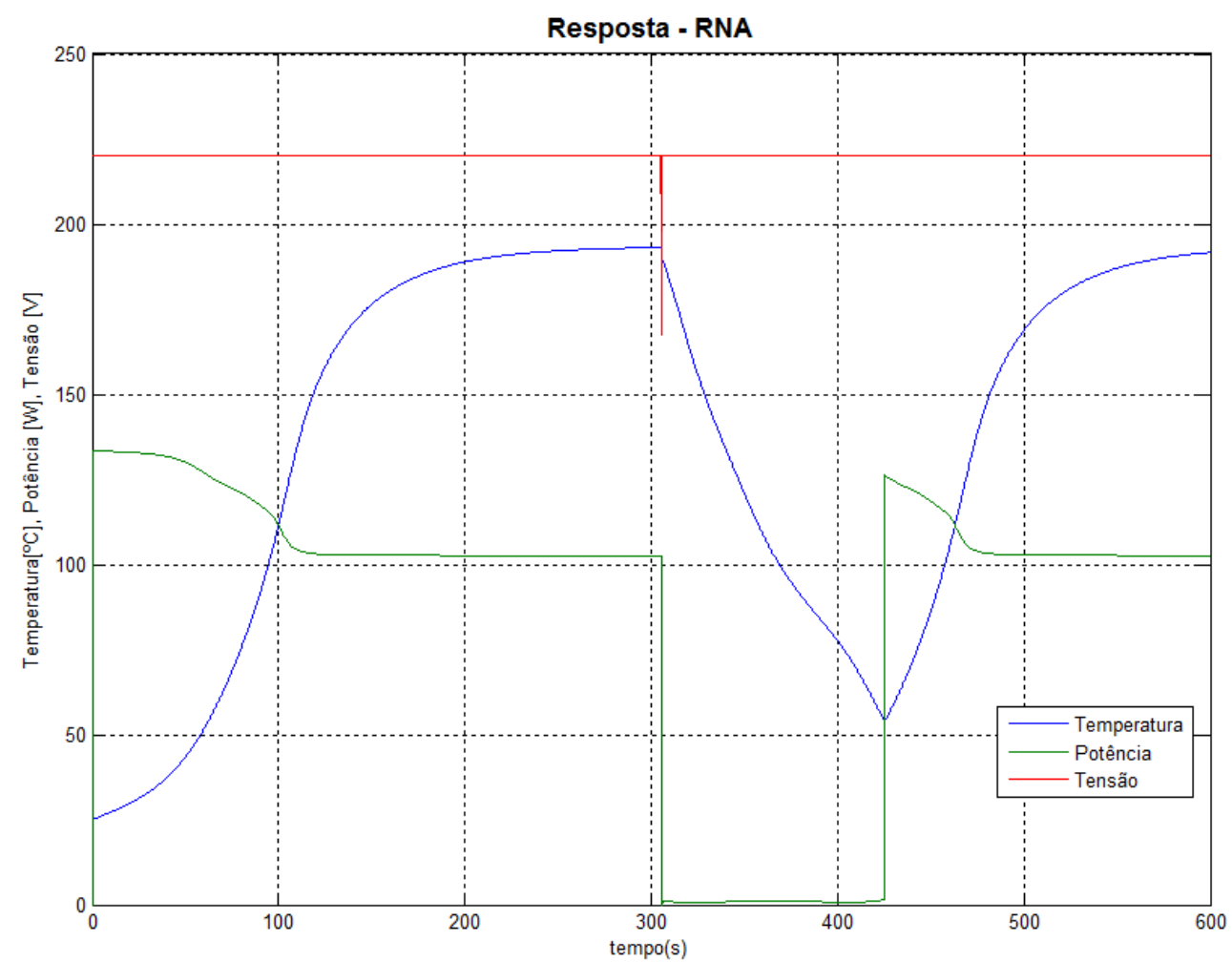

Figura 130 - Resposta do modelo - redução de tensão de curta duração com extinção de arco. 
Por esta razão, a resposta do dispositivo diante de eventos relacionados a QEE é também diferente daquela apresentada pela lâmpada já aquecida. Espera-se, portanto, que o modelo proposto permita a adequada representação do comportamento da lâmpada durante esta fase transitória, e isto comprovou-se através dos experimentos realizados, como exposto a seguir.

A captura das variáveis do experimento durante um afundamento temporário a 0,9 pu com duração de 20 segundos, incidindo no instante de tempo $\mathfrak{t}=50$ segundos após o início de funcionamento da lâmpada, é mostrada no gráfico presente na Figura 131. Deve ser observado que não ocorre extinção do arco durante e após o evento.

De forma a permitir a comparação de desempenho da simulação, a Figura 132 apresenta a resposta do modelo neural da lâmpada submetido a um afundamento temporário a $0,9 \mathrm{pu}$, ocorrido em sua fase de aquecimento. Deve ser observado que o dispositivo simulado, assim como o dispositivo real, não sofre apagamento, prosseguindo seu aquecimento normal após o restabelecimento da alimentação.

No gráfico da Figura 133 é mostrado o efeito de uma elevação temporária a 1,2 pu ocorrendo no experimento durante a fase de partida da lâmpada. Deve ser notado o aumento na taxa de variação de temperatura do dispositivo durante a elevação, e o retorno à condição normal de aquecimento após o restabelecimento da alimentação com o valor nominal de tensão. A resposta ao mesmo distúrbio apresentada pelo modelo neural da lâmpada de descarga é mostrada no gráfico da Figura 134, onde o comportamento do modelo se mostra bastante similar ao comportamento experimental. 


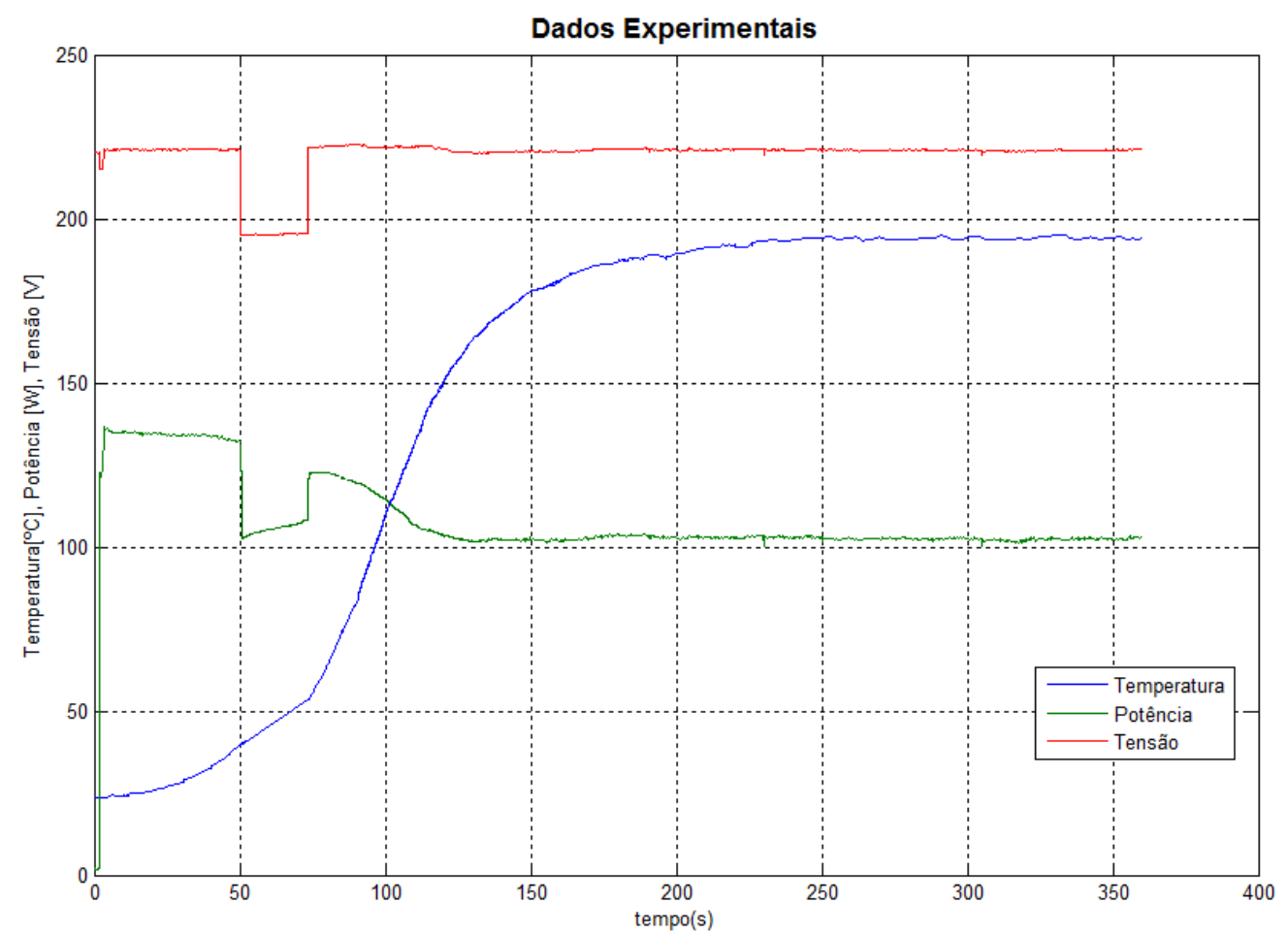

Figura 131 - Dados experimentais - afundamento temporário a 0,9 pu durante a partida.

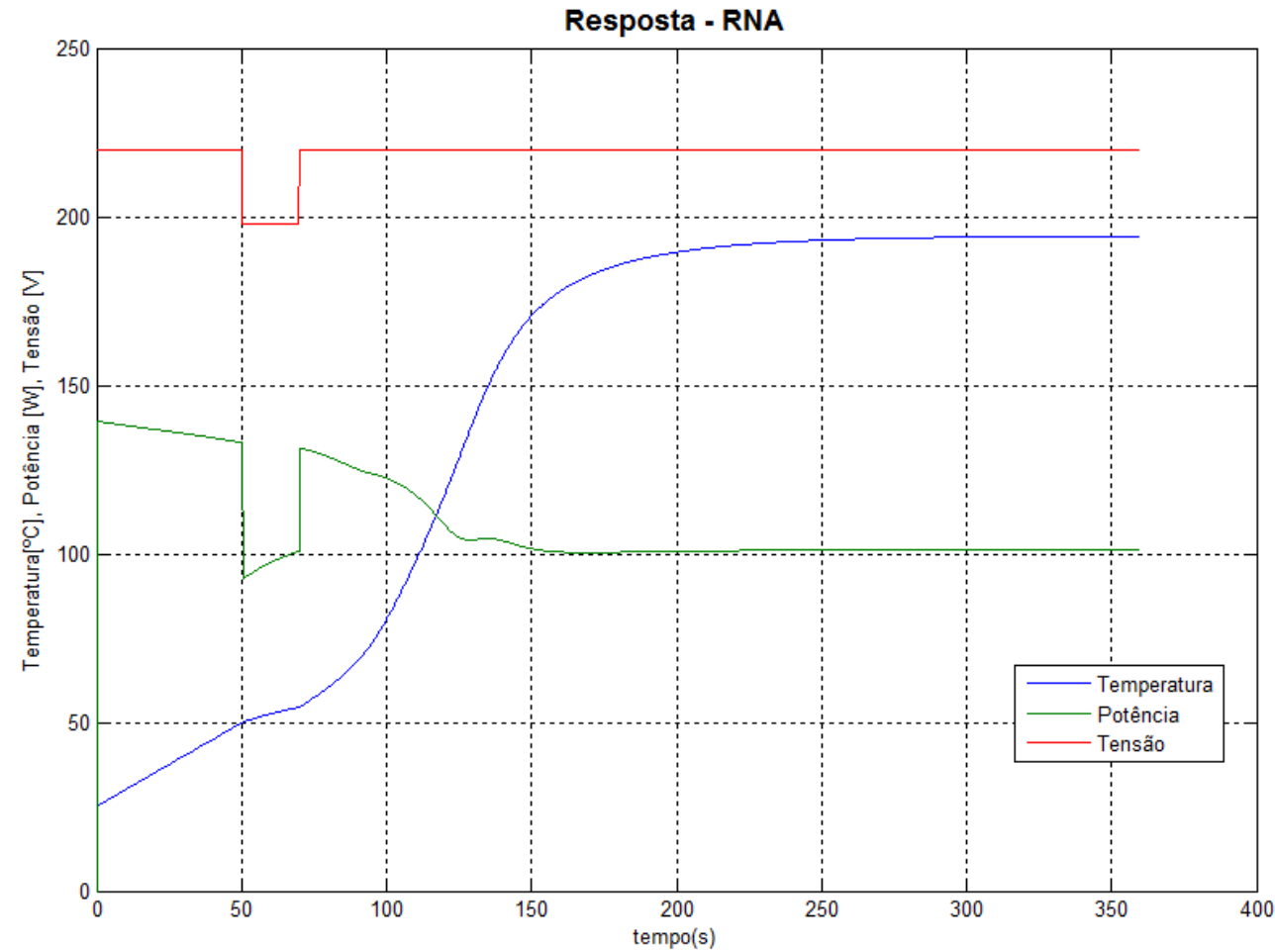

Figura 132 - Resposta do modelo a um afundamento temporário a 0,9 pu durante a partida. 


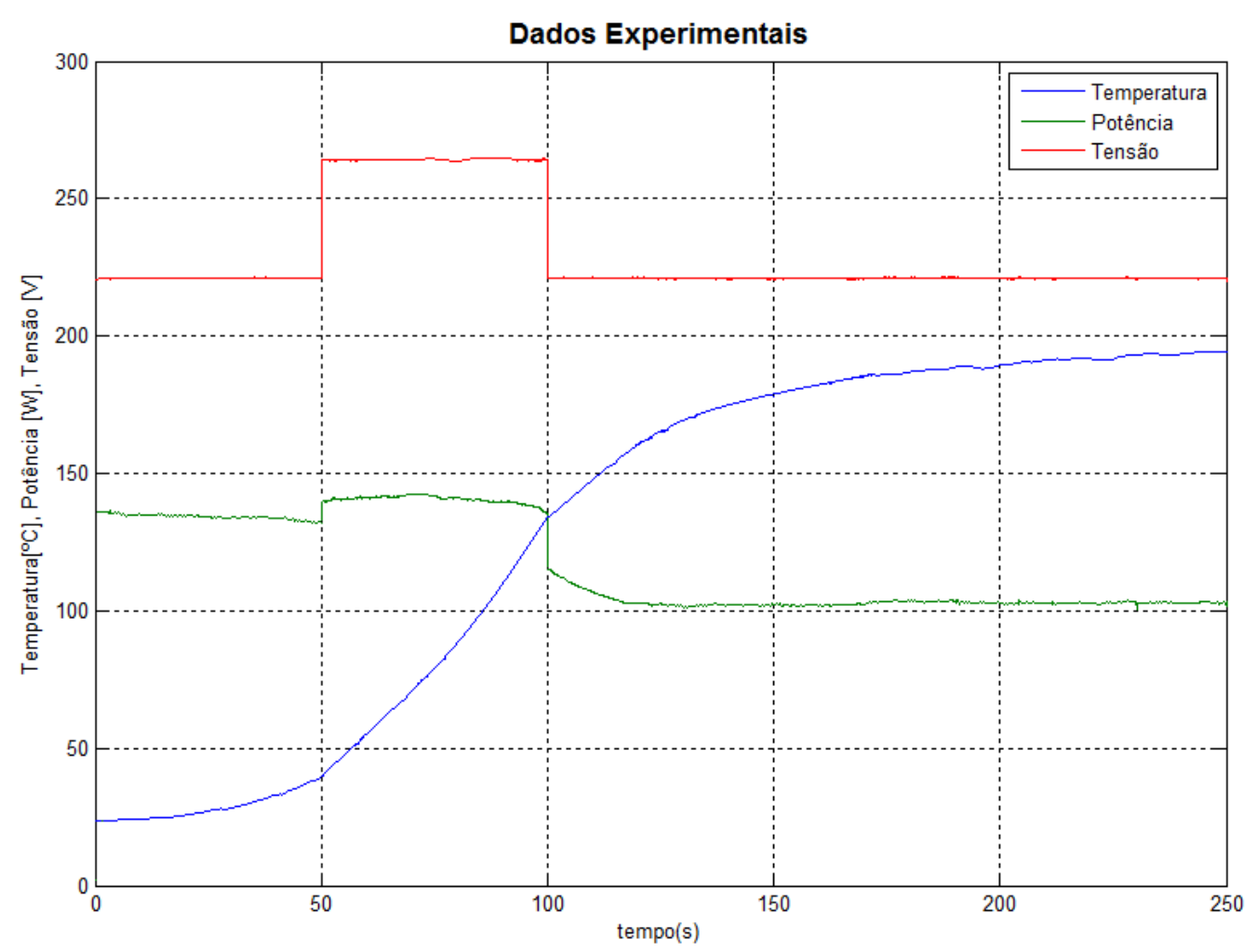

Figura 133 - Dados experimentais - elevação temporária a 1,2 pu durante a partida.

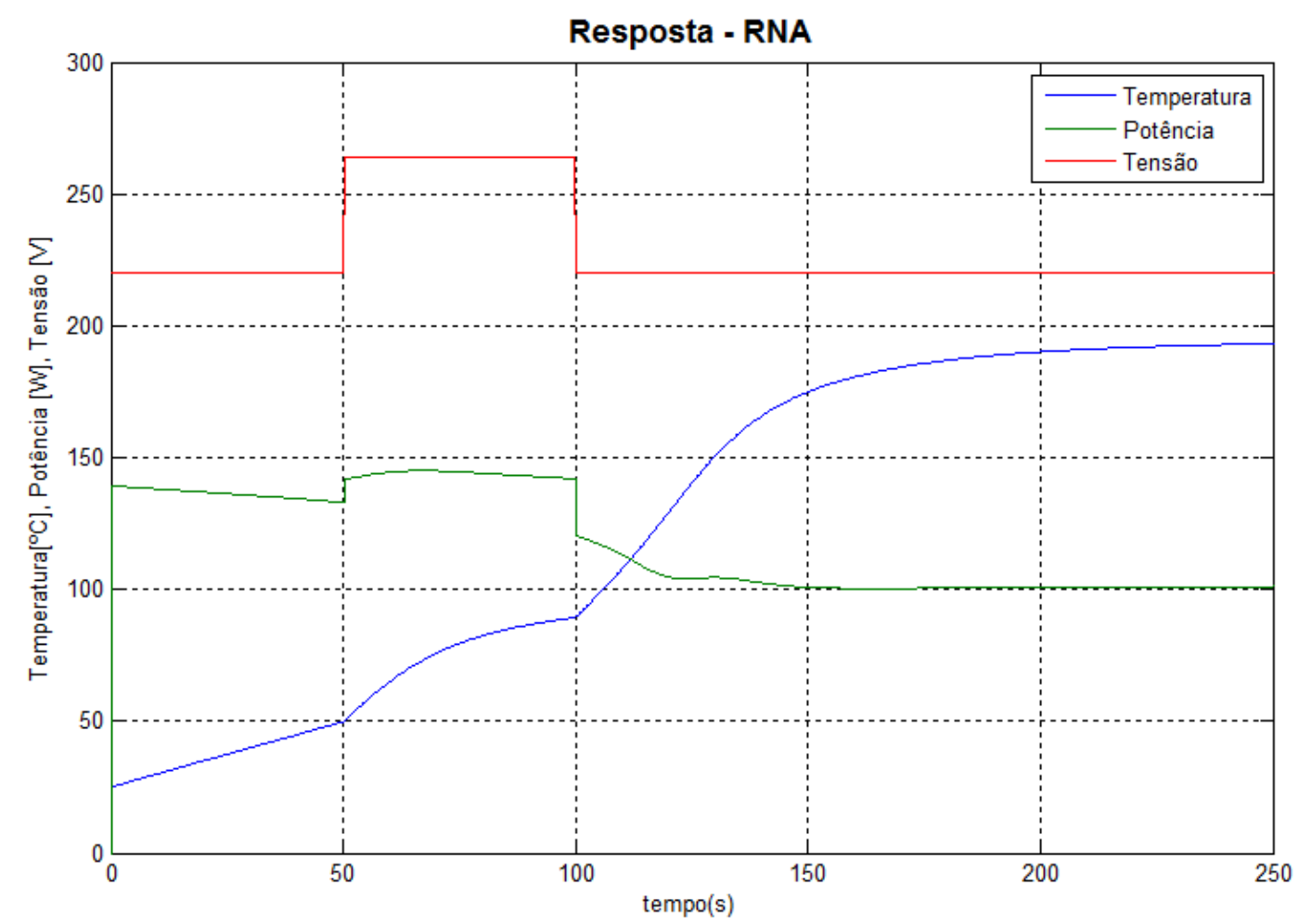

Figura 134 - Resposta do modelo a uma elevação temporária a 1,2pu durante a partida. 
Uma outra situação de distúrbio testada é apresentada na Figura 135. Neste gráfico, o experimento é submetido a um afundamento momentâneo a 0,1 pu durante o aquecimento da lâmpada, com incidência em $\mathrm{t}=25 \mathrm{~s}$ e duração de 1 segundo. Novamente, deve ser notado que a baixa susceptibilidade do dispositivo durante a fase de partida faz com que não ocorra o apagamento.

A resposta do modelo neural da lâmpada ao afundamento a 0,1 pu e 1 segundo de duração é apresentado no gráfico da Figura 136. A resposta do modelo é a mesma do dispositivo modelado, e verifica-se que não ocorre desvio do ponto de operação pelo fato da lâmpada encontrar-se em sua região de baixa susceptibilidade durante a fase de aquecimento. Deve ser observado que o dispositivo apresenta baixa susceptibilidade a variações de tensão que ocorram durante a partida, em sua fase inicial de aquecimento.

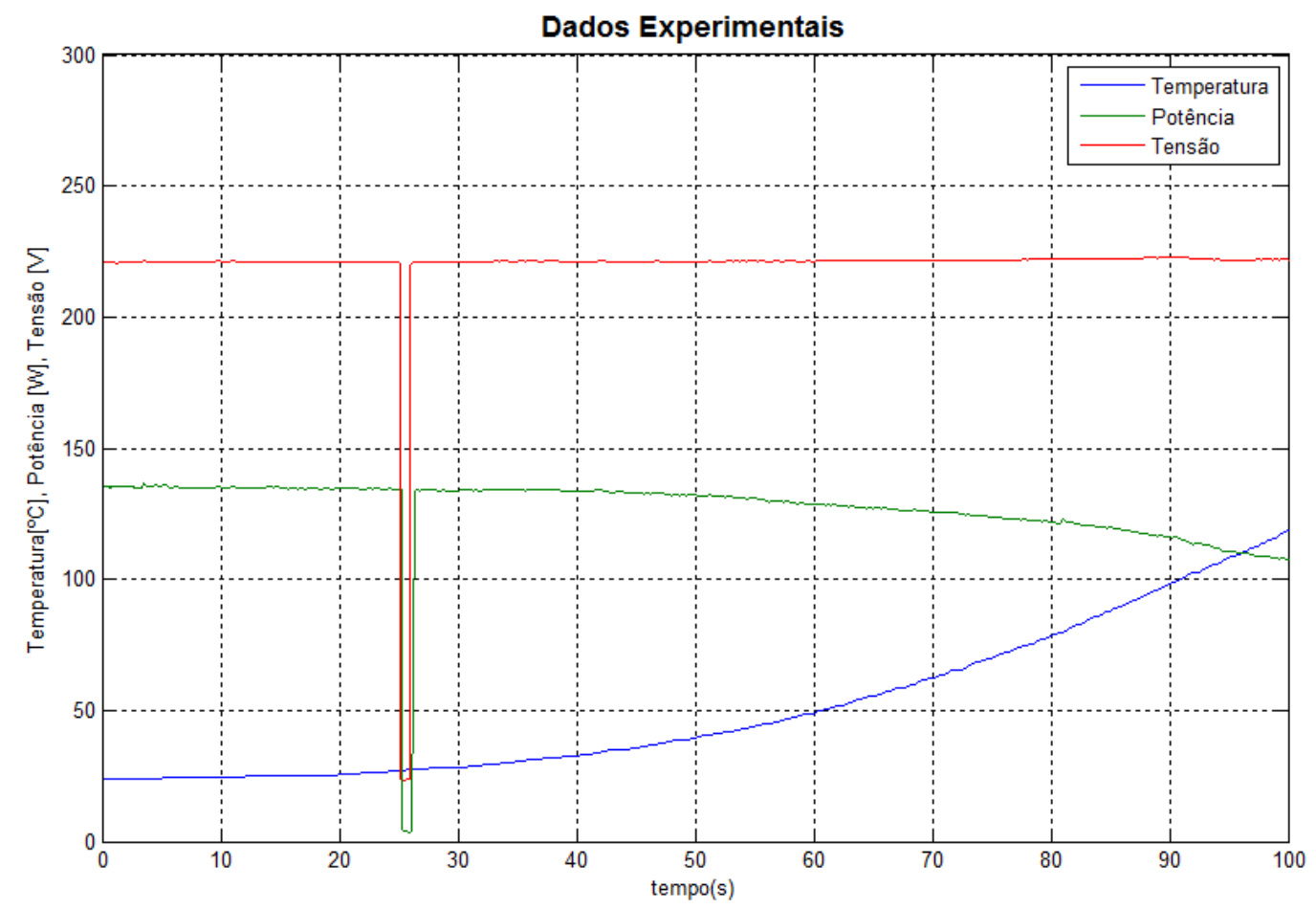

Figura 135 - Dados experimentais - afundamento momentâneo a 0,1 pu durante a partida. 


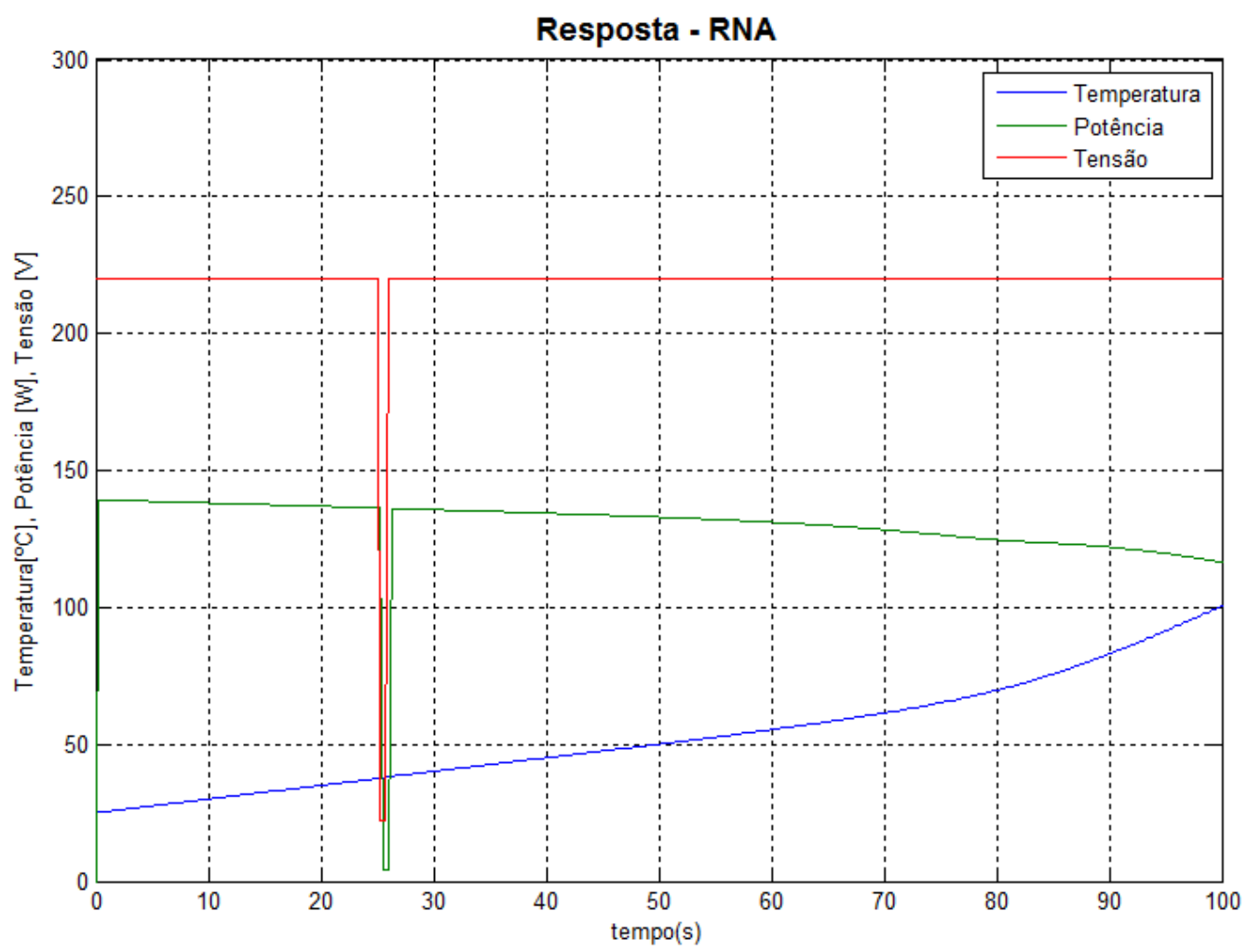

Figura 136 - Resposta do modelo a um afundamento momentâneo de 0,1pu durante a partida.

Conclui-se, portanto, que a representação do dispositivo demonstrada pelas simulações demonstra grande similaridade com o comportamento real da lâmpada de descarga quando submetida a distúrbios durante sua fase de aquecimento.

A Figura 137 apresenta o comportamento da montagem experimental submetida a um afundamento instantâneo a 0,1 pu, ocorrendo 50 segundos após o início de operação do dispositivo, com duração de 20 ciclos. Deve ser observado que não ocorre prejuízo a seu funcionamento. A resposta do modelo neural da lâmpada a este mesmo distúrbio de qualidade de energia está no gráfico mostrado à Figura 138. 


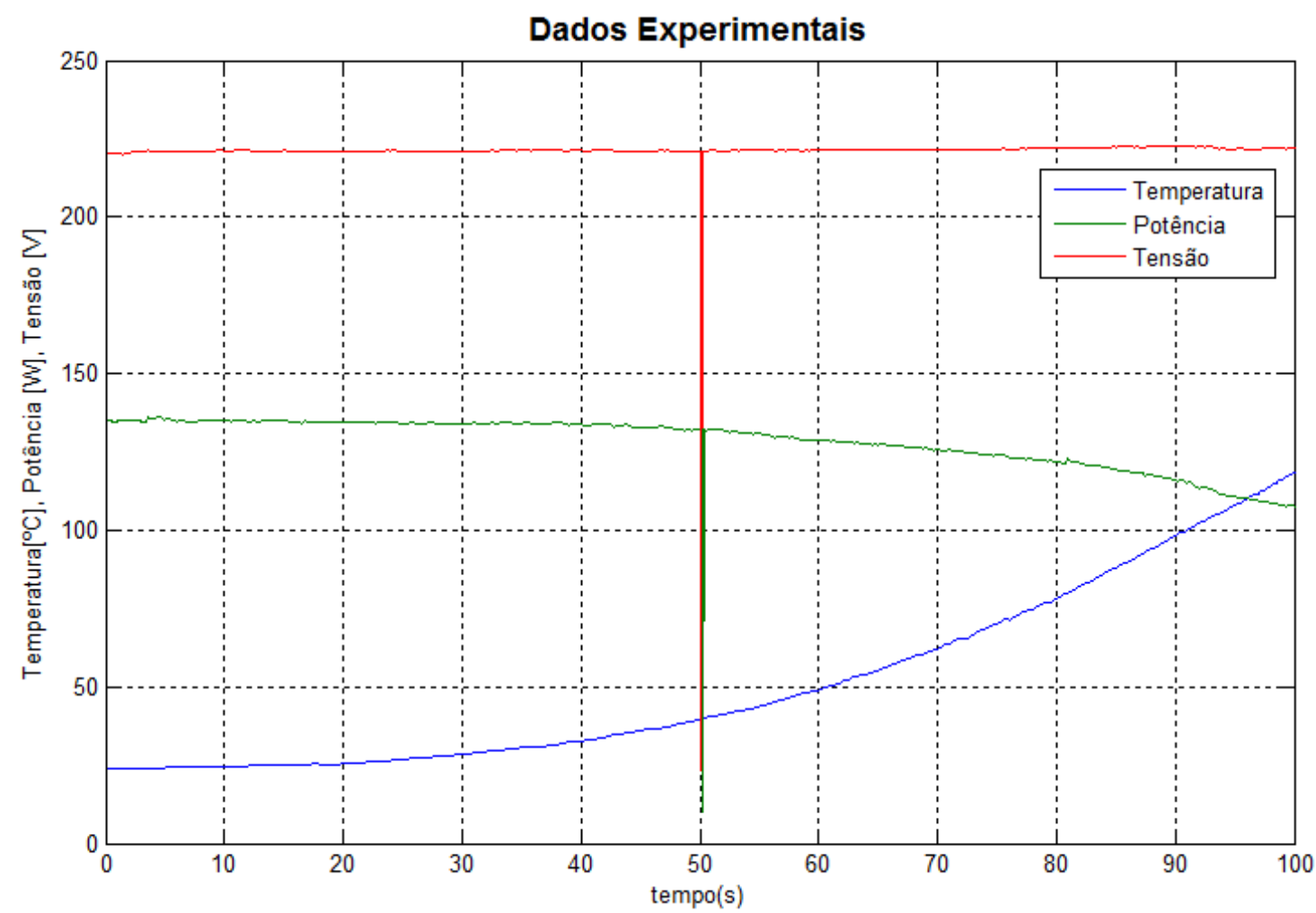

Figura 137 - Dados experimentais - afundamento instantâneo a 0,1 pu durante a partida.

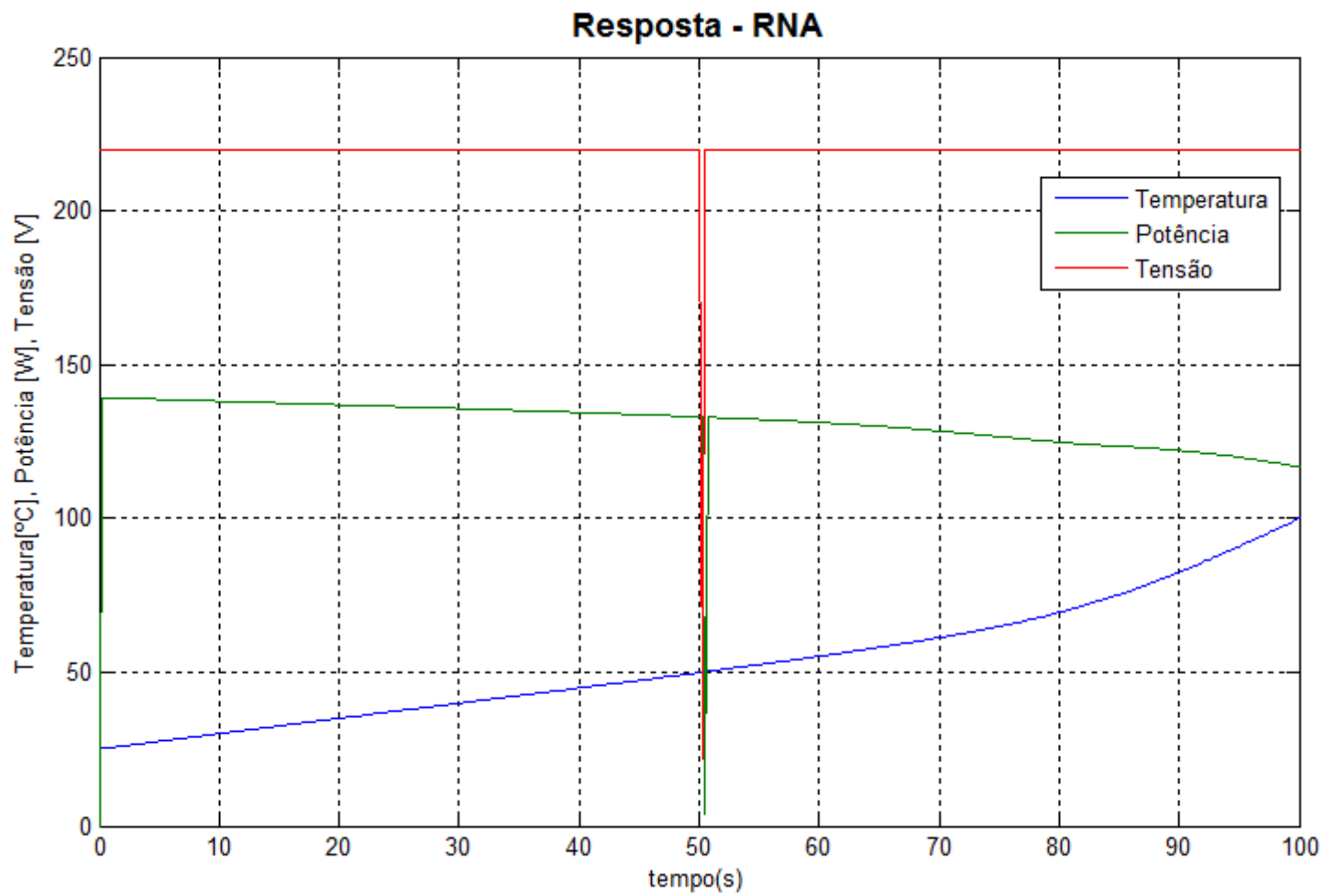

Figura 138 - Resposta do modelo a uma fundamento instantâneo a 0,1 pu durante a partida. 
O gráfico apresentado na Figura 139 representa a ocorrência de uma elevação instantânea a 1,35pu com duração de 20 ciclos ocorrendo durante a partida da lâmpada. Este valor foi adotado em virtude da limitação do gerador arbitrário de sinais, que tem sua saída limitada a 300V RMS. Novamente, não há alteração no comportamento operacional do componente em razão da alta inércia térmica e baixa susceptibilidade.

A resposta do modelo neural à aplicação de uma elevação instantânea a 1,35 pu incidindo em $\mathrm{t}=50$ s após a partida do dispositivo é mostrada no gráfico da Figura 140. Novamente, mostra-se a coerência entre a resposta do modelo e os dados experimentais com relação à resposta diante de eventos de qualidade da energia.

A ocorrência de variações de tensão de curta duração na partida da lâmpada não representa significativa alteração no ponto de operação do dispositivo, em decorrência de sua elevada inércia térmica, demonstrando portanto a baixa susceptibilidade do dispositivo nesta fase de operação.

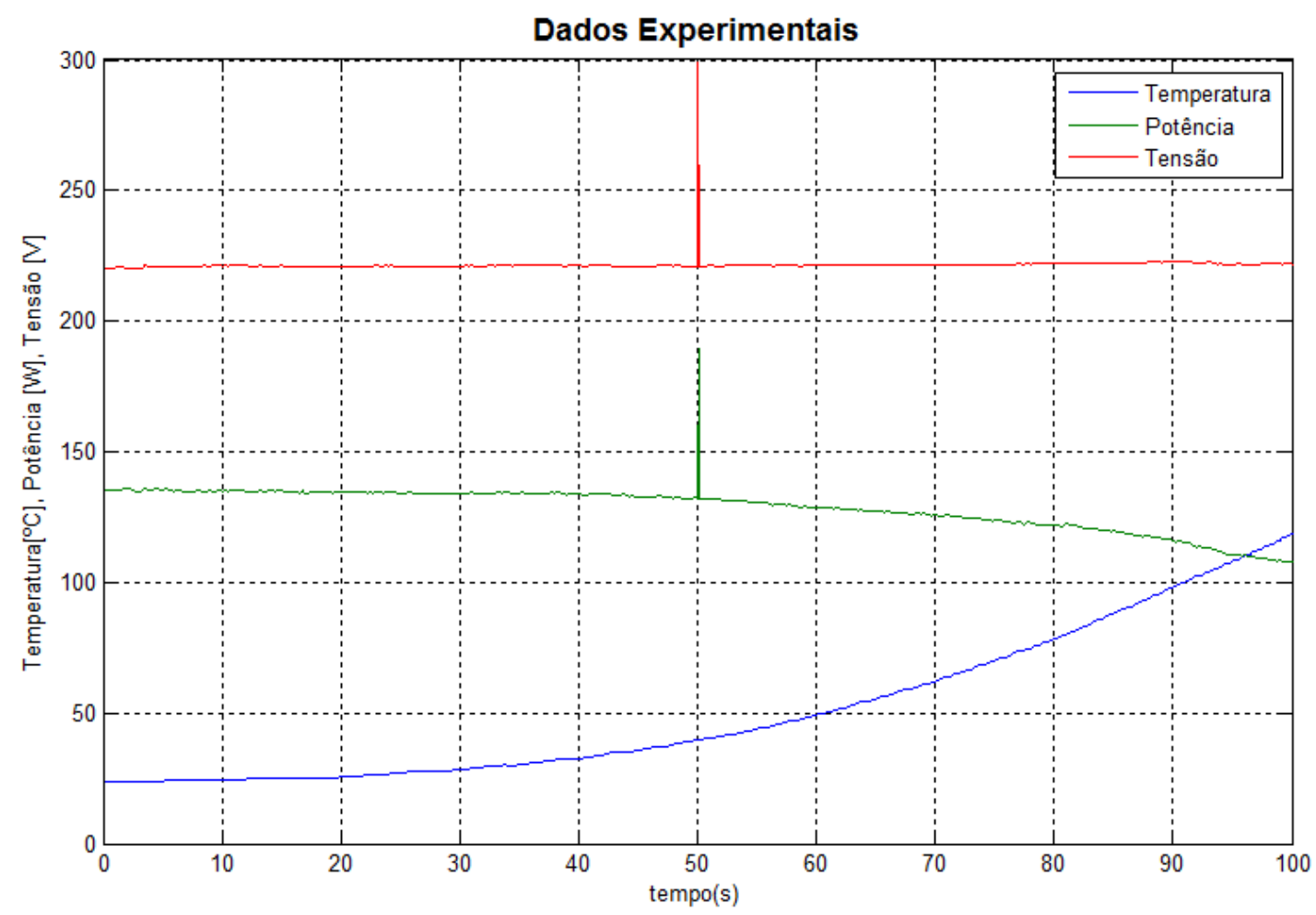

Figura 139 - Dados experimentais - elevação instantânea a 1,35 pu durante a partida. 


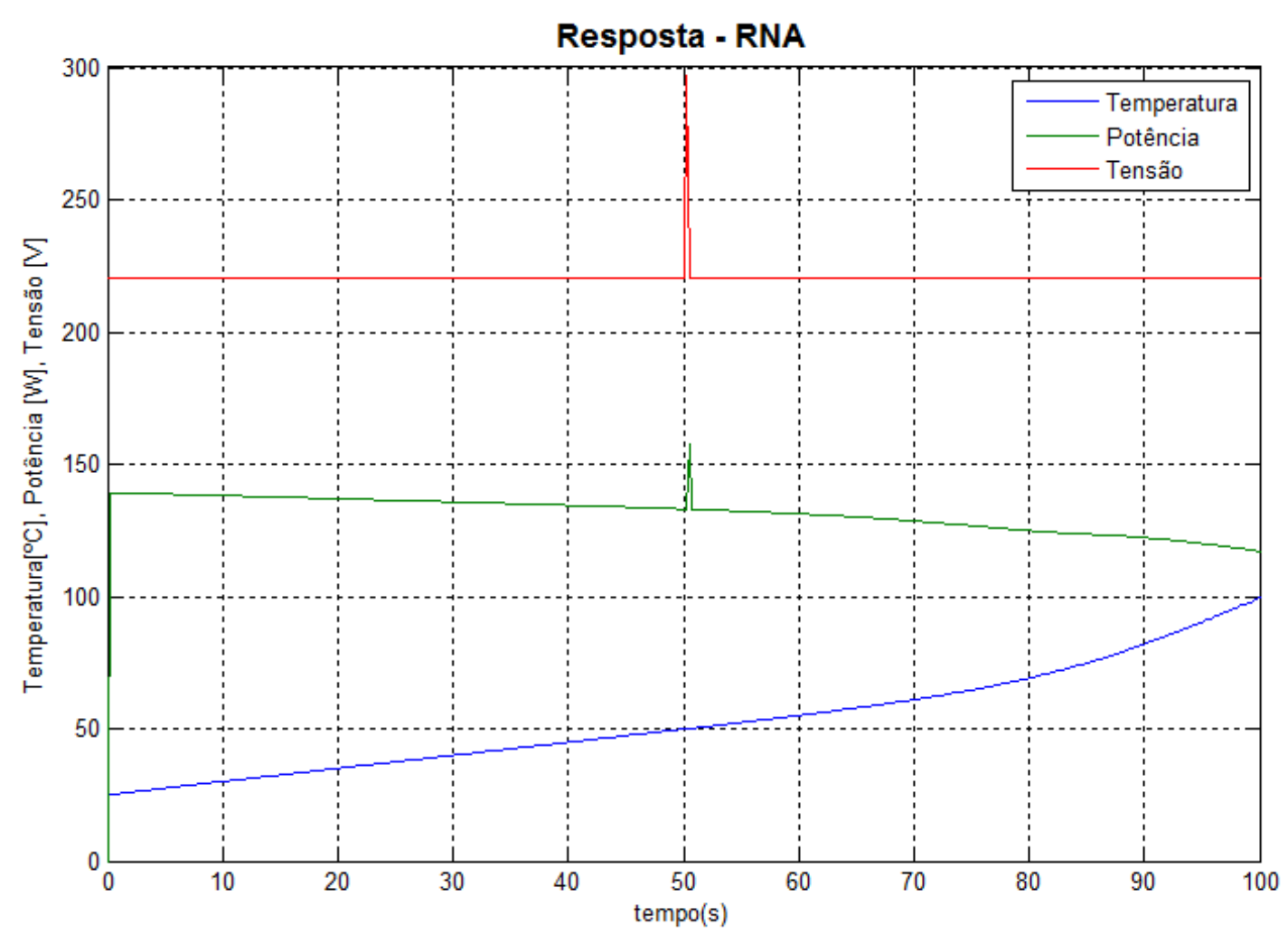

Figura 140 - Resposta do modelo a uma elevação instantânea a 1,35pu durante a partida.

À medida que a temperatura da lâmpada se aproxima de seu ponto de operação estável, os efeitos de susceptibilidade a variações de tensão se pronunciam e o dispositivo se torna mais vulnerável a distúrbios de alimentação relacionados a qualidade da energia.

Embora apenas alguns exemplos tenham sido ilustrados, outros experimentos foram comparados com as simulações, e todos apresentaram respostas compatíveis com o desempenho do elemento modelado. A Tabela 12 apresenta os tipos de ensaios de validação efetuados, abordando diversos fenômenos relacionados à qualidade da energia, que permitiram atestar a eficiência do modelo proposto. 
Tabela 12 - Eventos de Qualidade da Energia ensaiados

\begin{tabular}{|c|c|c|c|}
\hline \multicolumn{3}{|c|}{ Tipo de Evento de Qualidade da Energia } & Número de Ensaios \\
\hline \multirow{9}{*}{$\begin{array}{c}\text { Variações de } \\
\text { Tensão de Curta } \\
\text { Duração }\end{array}$} & \multirow{3}{*}{$\begin{array}{l}\text { Variação } \\
\text { Instantânea } \\
\text { de Tensão }\end{array}$} & $\begin{array}{l}\text { Interrupção Instantânea de } \\
\text { Tensão }\end{array}$ & 15 \\
\hline & & $\begin{array}{l}\text { Afundamento Instantâneo } \\
\text { de Tensão }\end{array}$ & 25 \\
\hline & & $\begin{array}{c}\text { Elevação Instantânea de } \\
\text { Tensão }\end{array}$ & 20 \\
\hline & \multirow{3}{*}{$\begin{array}{c}\text { Variação } \\
\text { Momentânea } \\
\text { de Tensão }\end{array}$} & $\begin{array}{l}\text { Interrupção Momentânea } \\
\text { de Tensão }\end{array}$ & 15 \\
\hline & & $\begin{array}{c}\text { Afundamento } \\
\text { Momentâneo de Tensão }\end{array}$ & 25 \\
\hline & & $\begin{array}{l}\text { Elevação Momentânea de } \\
\text { Tensão }\end{array}$ & 20 \\
\hline & \multirow{3}{*}{$\begin{array}{l}\text { Variação } \\
\text { Temporária } \\
\text { de Tensão }\end{array}$} & $\begin{array}{l}\text { Interrupção Temporária de } \\
\text { Tensão }\end{array}$ & 15 \\
\hline & & $\begin{array}{c}\text { Afundamento Temporário } \\
\text { de Tensão }\end{array}$ & 25 \\
\hline & & $\begin{array}{l}\text { Elevação Temporária de } \\
\text { Tensão }\end{array}$ & 20 \\
\hline \multirow{3}{*}{$\begin{array}{c}\text { Variações de } \\
\text { Tensão de Longa } \\
\text { Duração } \\
\end{array}$} & \multicolumn{2}{|r|}{ Interrupções } & 15 \\
\hline & \multirow{2}{*}{\multicolumn{2}{|c|}{$\begin{array}{c}\text { Subtensões } \\
\text { Sohretensões }\end{array}$}} & 25 \\
\hline & & & 20 \\
\hline
\end{tabular}

\subsection{Desempenho do modelo neural da lâmpada de descarga em agrupamento de}

\section{dispositivos}

Na avaliação de desempenho de agrupamentos de lâmpadas, tornase útil a avaliação da reprodução do conteúdo harmônico de corrente apresentado pelo conjunto quando inserido no sistema de distribuição. A distorção harmônica é evidenciada pelo surgimento de correntes de neutro em circuitos equilibrados, e pelo elevado conteúdo harmônico apresentado por estas correntes com o circuito em operação.

A presença de assimetrias nos agrupamentos evidencia o conteúdo harmônico da corrente de neutro (no caso de associações em Y).

Cabe salientar que os ensaios do modelo em agrupamentos de lâmpadas apresentados a seguir foram baseados nos treinamentos efetuados para uma única 
lâmpada, e as associações dos dispositivos foram realizadas através de procedimentos matemáticos, conforme o tipo de circuito elétrico adotado.

\subsubsection{Agrupamento em configuração monofásica}

O agrupamento de dispositivos em configuração monofásica mostra como resultado um valor de corrente que é a soma dos valores individuais de corrente dos dispositivos associados. Considerando as lâmpadas de descarga em condições idênticas de temperatura inicial e perfil de aquecimento, teremos como resultado da associação o produto dos efeitos individuais pelo número de elementos. Caso na associação haja algum elemento com condições iniciais diferenciadas, o resultado será a soma dos efeitos de cada elemento em seu ponto de operação.

O gráfico da Figura 141 mostra o comportamento de uma configuração experimental composta por três lâmpadas de vapor de mercúrio de $80 \mathrm{~W}$ associadas em paralelo, após atingirem o ponto de equilíbrio térmico, e alimentadas em tensão nominal de $220 \mathrm{~V}$.

É possível observar a grande similaridade apresentada pelos gráficos de corrente obtidos experimentalmente e por meio da simulação baseada em RNA, comprovando o elevado nível de representatividade do dispositivo conferido pelo modelo proposto.

Na Figura 142 é possível observar o conteúdo harmônico de corrente apresentado por esta associação, experimentalmente e através do modelo, evidenciando o desempenho satisfatório da modelagem obtida. 


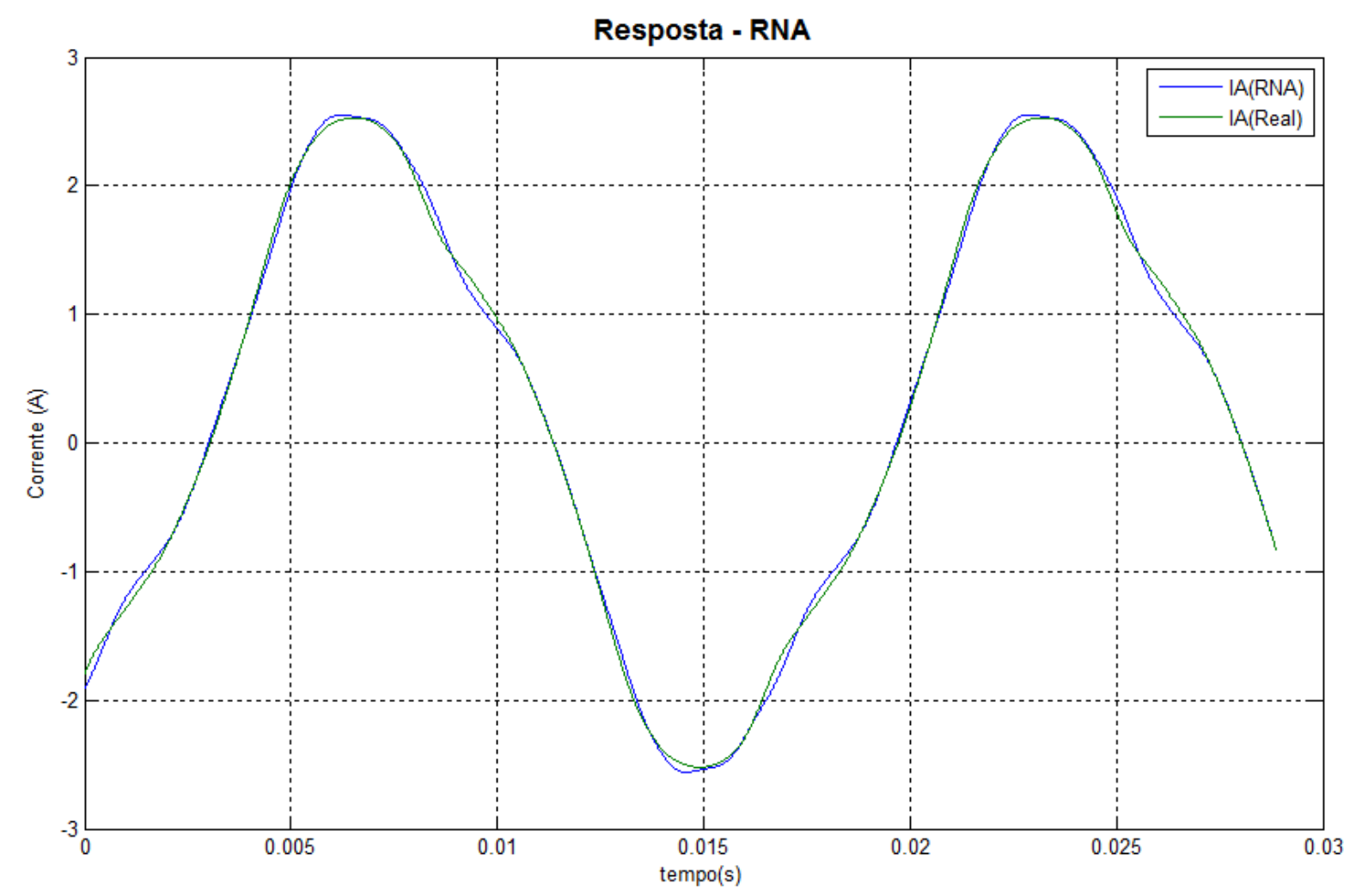

Figura 141 - Corrente de um conjunto de três lâmpadas em paralelo (alimentação monofásica).

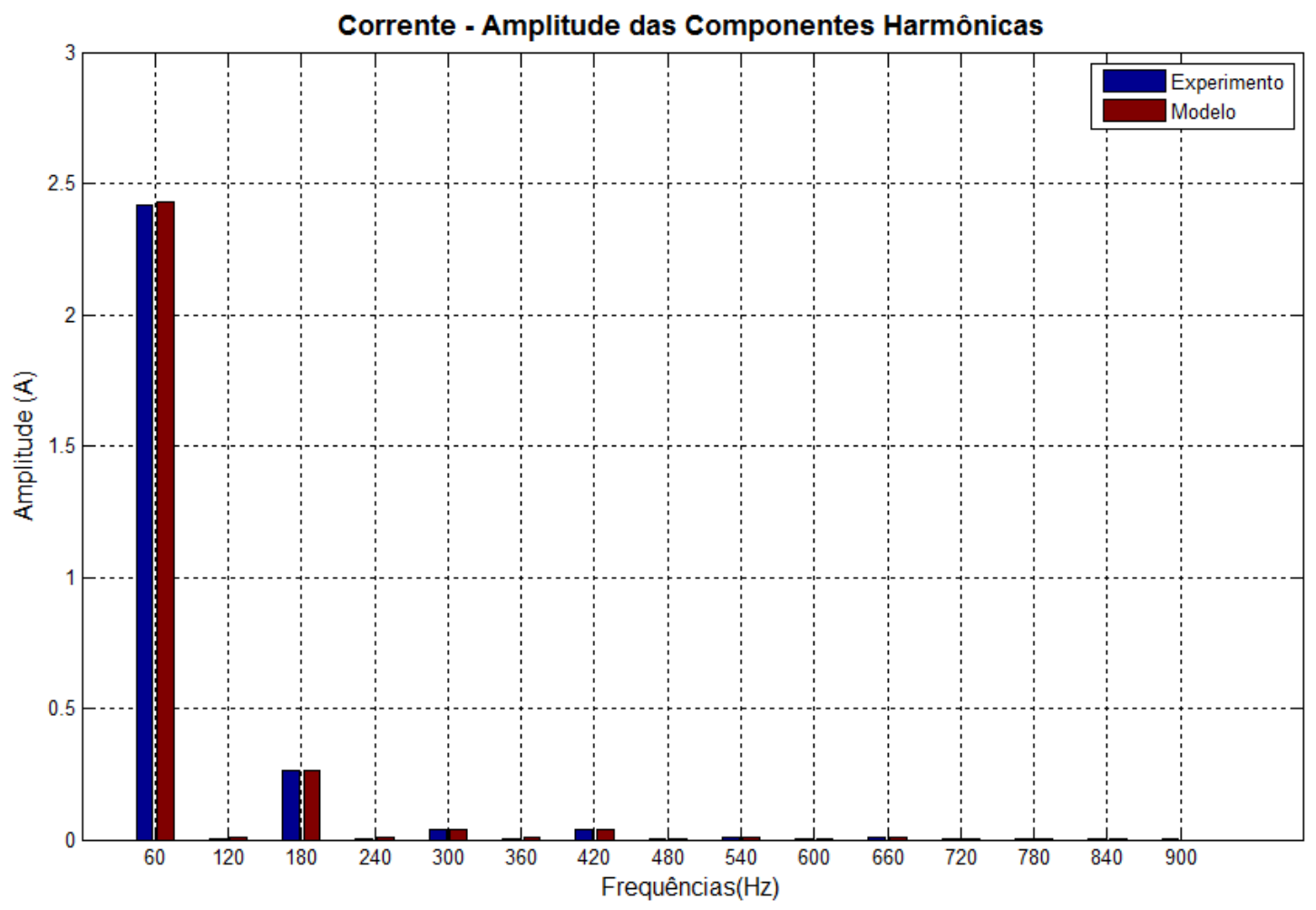

Figura 142 - Componentes harmônicas da corrente - conjunto de três lâmpadas em paralelo. 


\subsubsection{Agrupamento em Configuração trifásica}

O modelo neural proposto permite a simulação de conjuntos de lâmpadas em configuração trifásica, simétrica ou assimétrica, de modo a permitir a visualização das correntes de fase e neutro. Através de réplicas matemáticas do dispositivo real agrupadas nas configurações propostas, foi possível realizar a comparação entre correntes reais e correntes obtidas pela modelagem proposta.

O resultado de correntes correspondente a um agrupamento simétrico de lâmpadas é apresentado no gráfico da Figura 143. Neste exemplo, uma associação de três lâmpadas conectadas em configuração Y tem registradas as correntes de fase e neutro, após atingirem condição de estabilidade térmica. Novamente é possível atestar a semelhança entre as curvas experimentais e simuladas, que tornam evidente a boa resposta proporcionada pelo modelo neural implementado.

O conteúdo harmônico da corrente da Fase A da montagem é mostrado na Figura 144, onde se observa a similaridade entre a representação do modelo comparada com o dispositivo real.

Deve ser observado que a corrente de neutro da montagem apresenta conteúdo predominante em $3^{\mathrm{a}}$ harmônica, como mostrado na Figura 145, resultante da superposição de efeitos de distorção produzidos pela não-linearidade da lâmpada de descarga. 


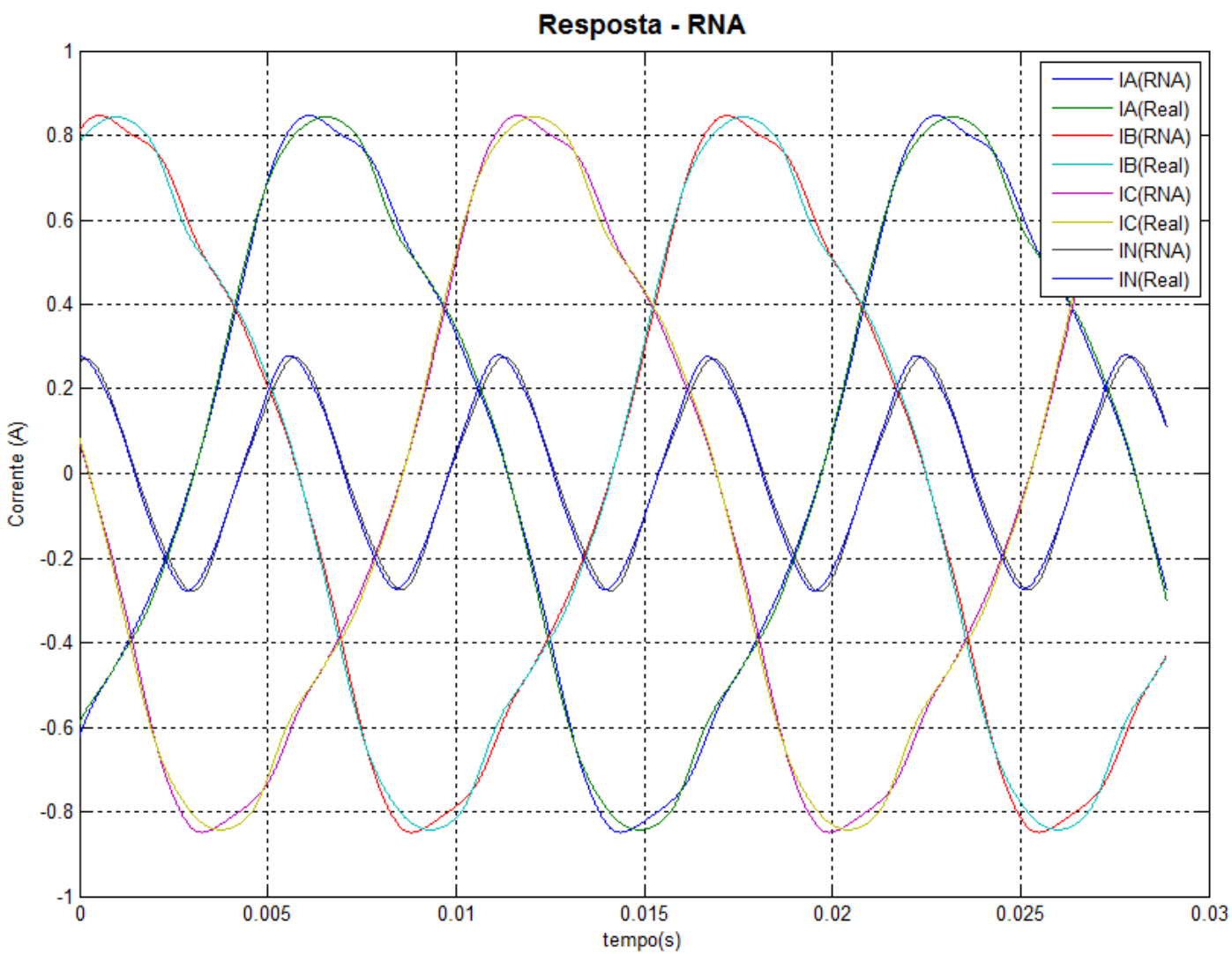

Figura 143 - Conjunto de três lâmpadas em configuração trifásica simétrica em Y (1+1+1).

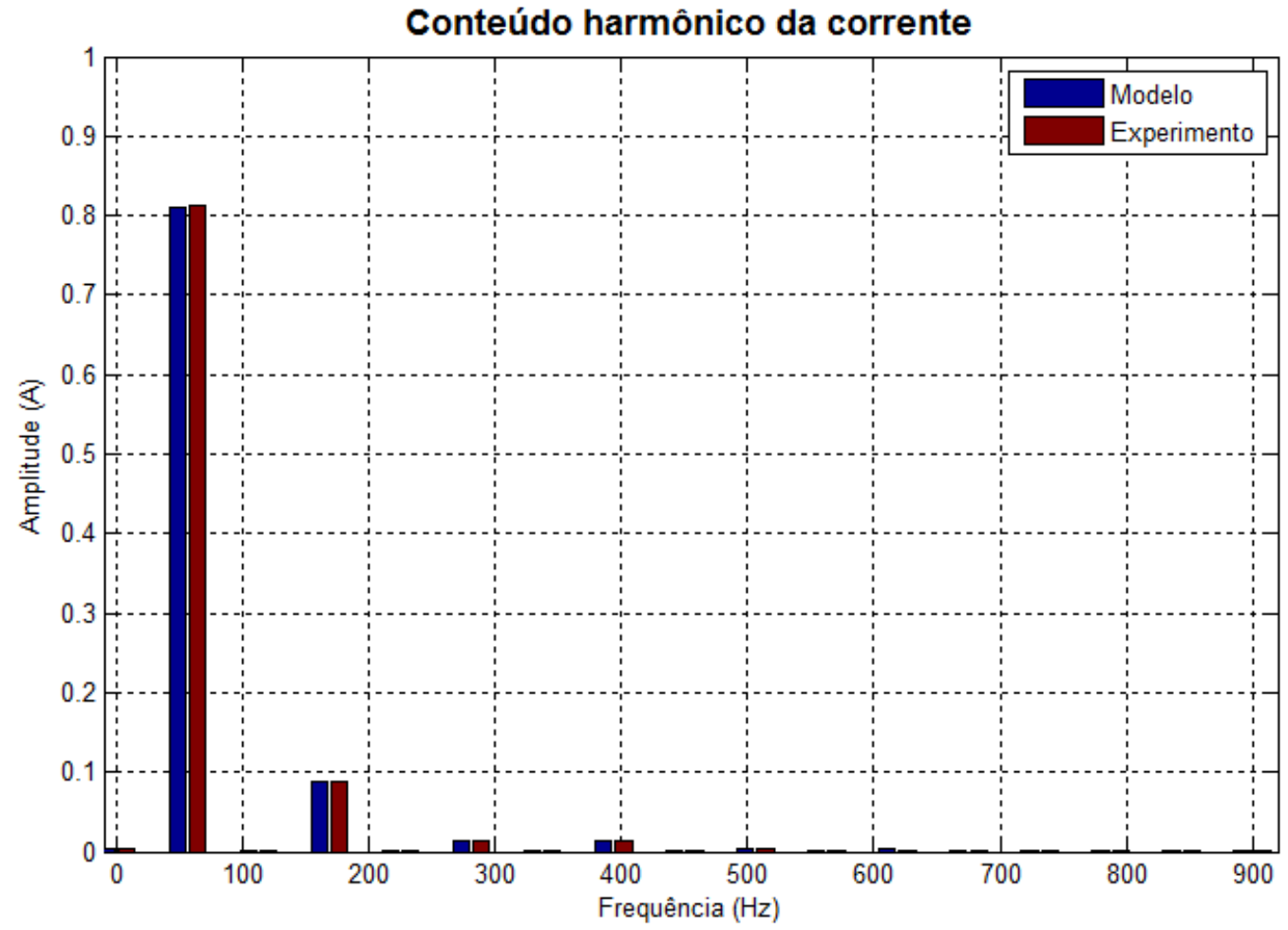

Figura 144 - Conteúdo harmônico da corrente - Fase A - três lâmpadas em Y. 


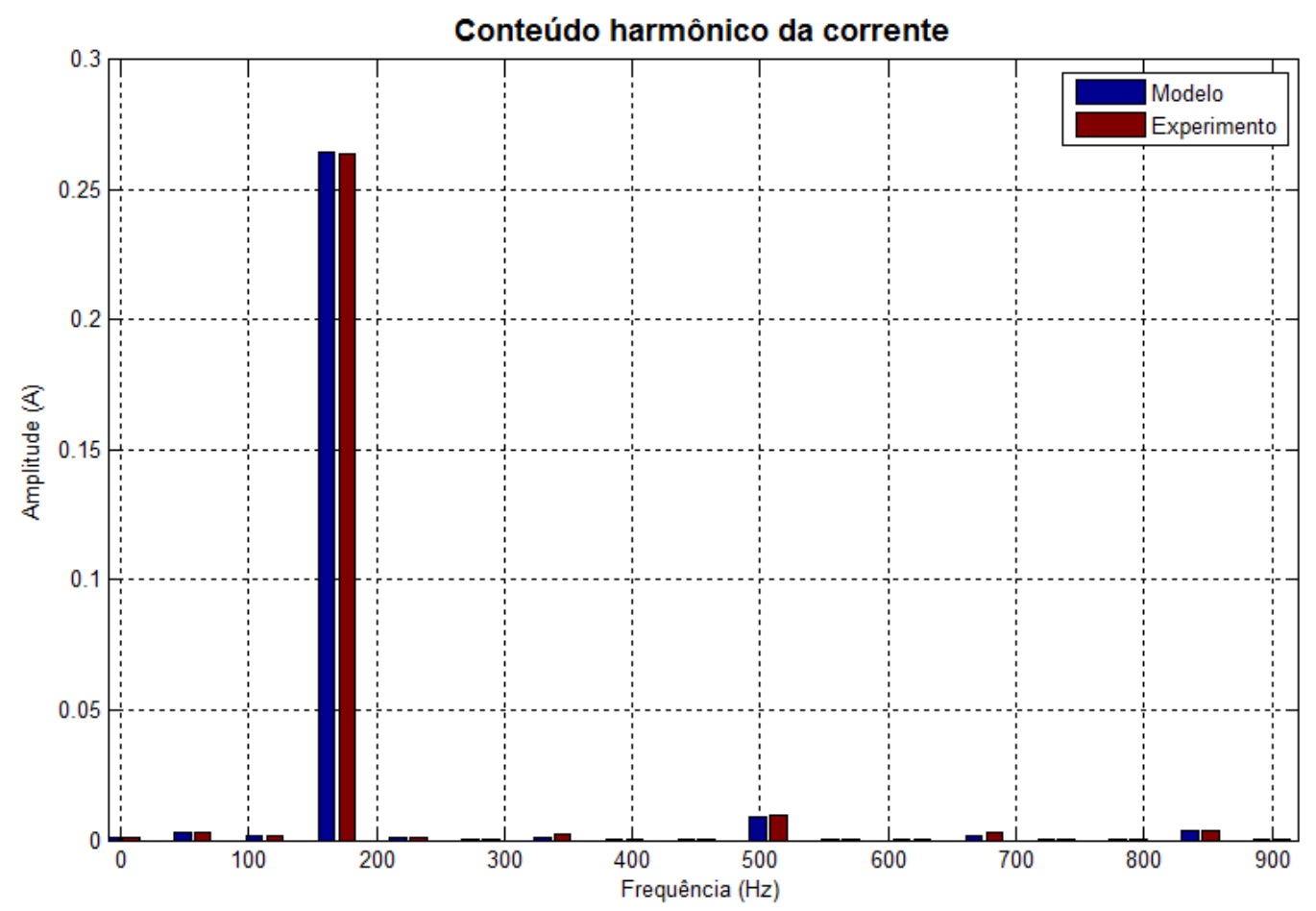

Figura 145 - Conteúdo harmônico da corrente de neutro - três lâmpadas em Y.

O arranjo de três lâmpadas conectados em $\Delta$ tem seu comportamento apresentado no gráfico da Figura 146, onde se verifica grande similaridade entre o comportamento do modelo e do experimento. A decomposição harmônica da corrente da Fase A desta configuração é apresentada no gráfico da Figura 147, e por analise dos resultados, cabe a observação de que a configuração em $\Delta$ apresenta menor proporção de conteúdo harmônico que a configuração em Y, resultante do efeito de superposição das componentes harmônicas homopolares do sistema trifásico.

O efeito de corrente harmônica presente no neutro das associações de dispositivos em Y se torna mais evidente nos casos de instalações onde há assimetria na quantidade de dispositivos instalados por fase. Um exemplo de configuração assimétrica de lâmpadas é mostrado na Figura 148, onde um arranjo de quatro lâmpadas conectadas em Y (duas na Fase A, uma na Fase B e uma na Fase C) contribuem na composição da corrente de neutro fortemente distorcida mostrada no gráfico, e que têm seu conteúdo harmônico 
apresentado na Figura 149. Pode ser observado que a composição da corrente de neutro apresenta conteúdo de corrente em frequência fundamental, resultante da assimetria da carga, e significativo conteúdo de corrente harmônica de $3^{\mathrm{a}}$ ordem, resultante da superposição de efeitos da associação de cargas não-lineares.

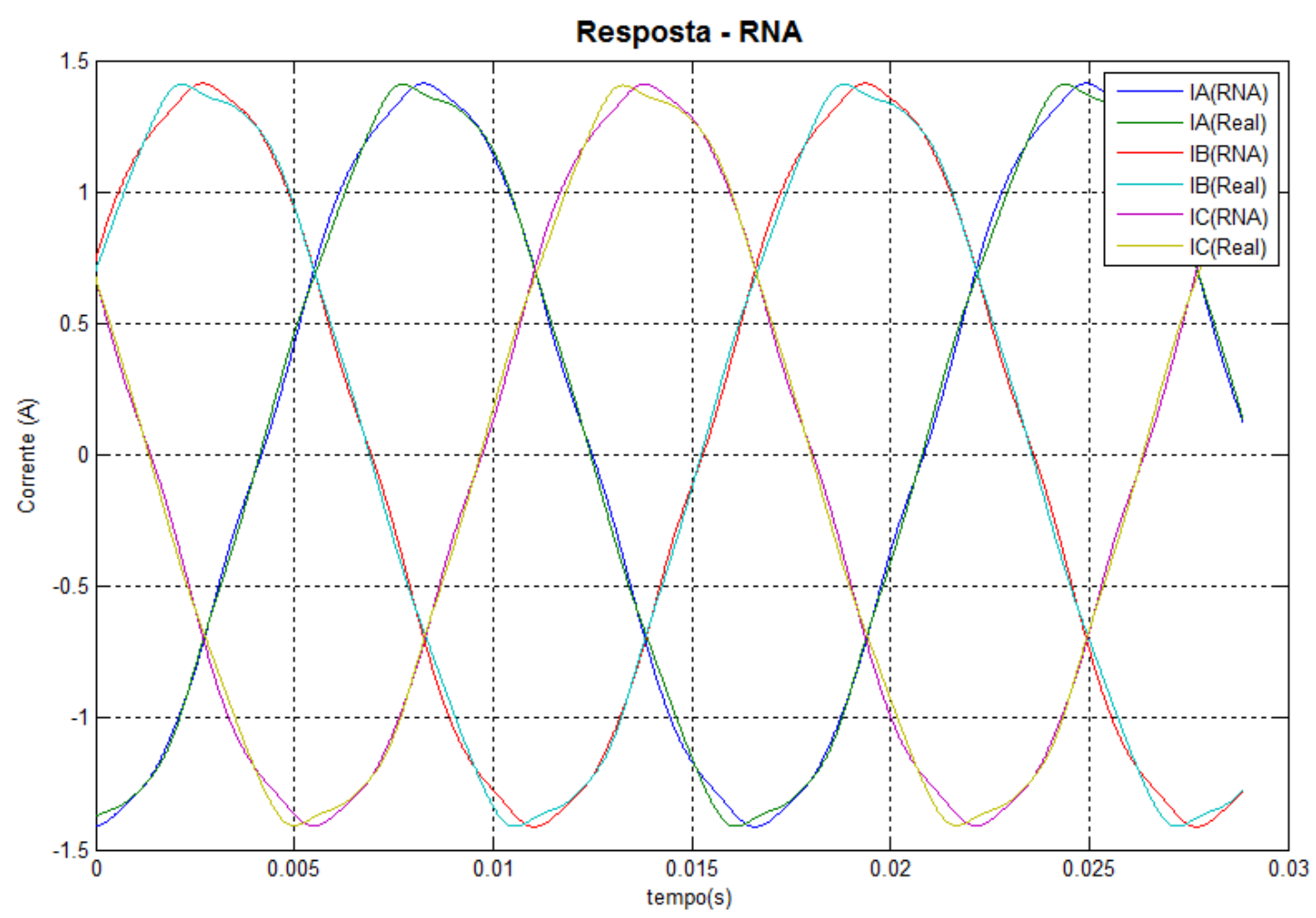

Figura 146 - Conjunto de três lâmpadas em configuração trifásica simétrica em $\Delta(1+1+1)$.

As quatro lâmpadas associadas em ligação $\Delta$, com duas lâmpadas entre as fases A e B, uma lâmpada entre as fases B e C e uma lâmpada entre as fases A e C, tem seu comportamento apresentado no gráfico presente na Figura 150. O comportamento mostra que a assimetria nos valores de corrente são compatíveis com a assimetria de carga introduzida no circuito.

A composição harmônica da corrente da Fase A para esta configuração é apresentada na Figura 151, onde é possível observar que o efeito da assimetria não introduziu significativa contaminação harmônica na corrente da associação. 


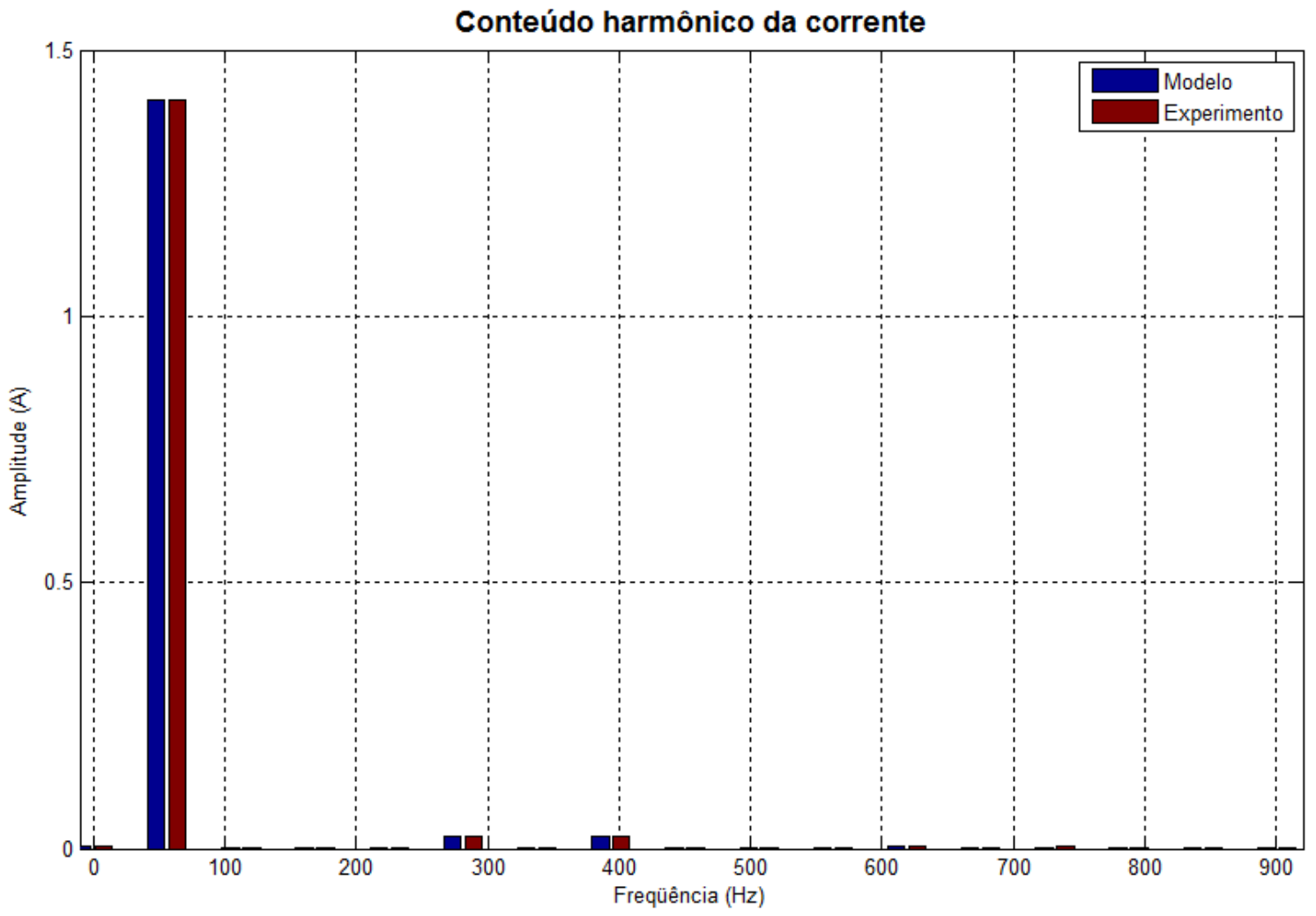

Figura 147 - Conteúdo harmônico da corrente - Fase A (Três lâmpadas em $\Delta$ ).

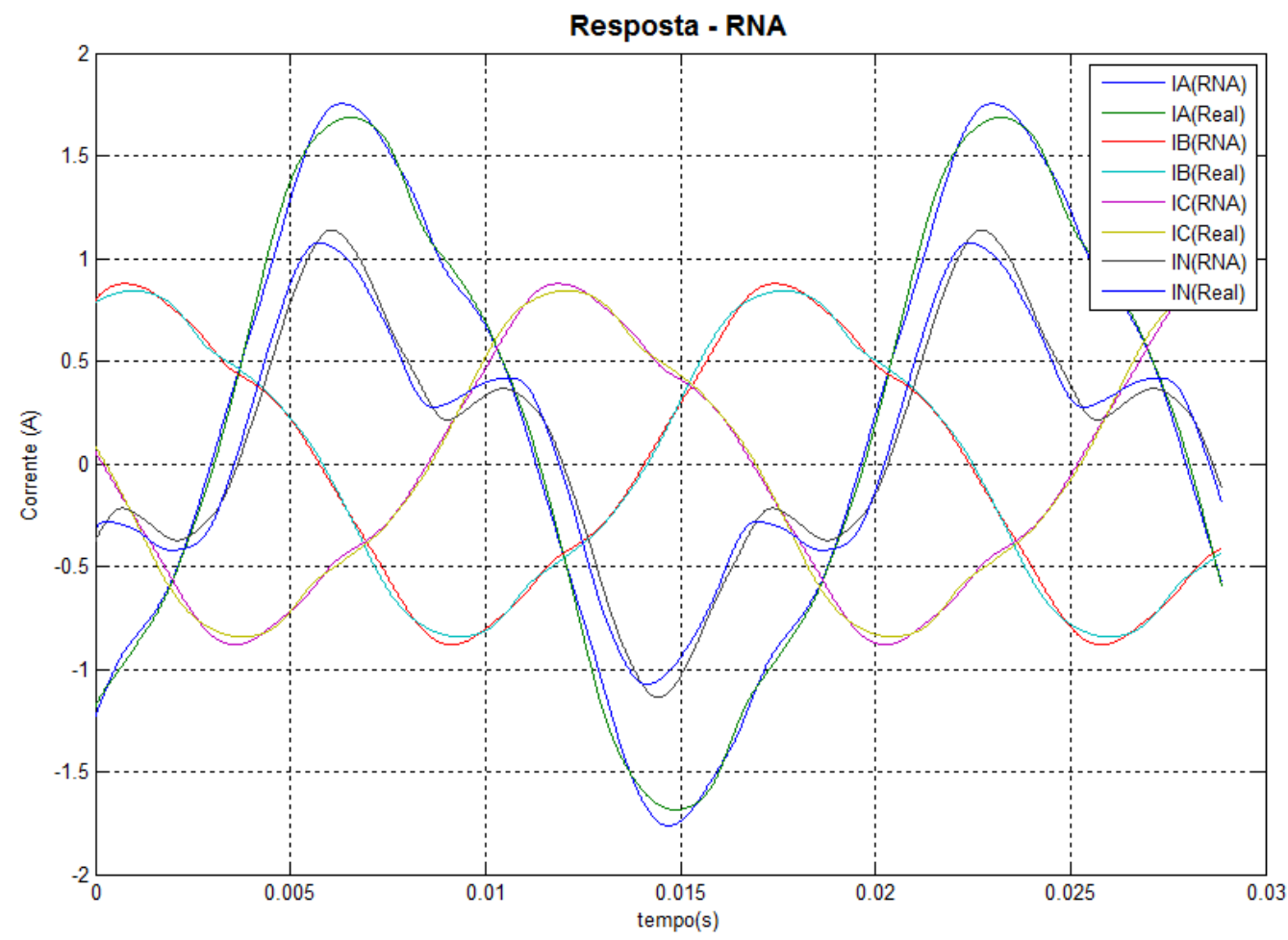

Figura 148 - Conjunto de quatro lâmpadas em configuração trifásica assimétrica em Y (2+1+1). 


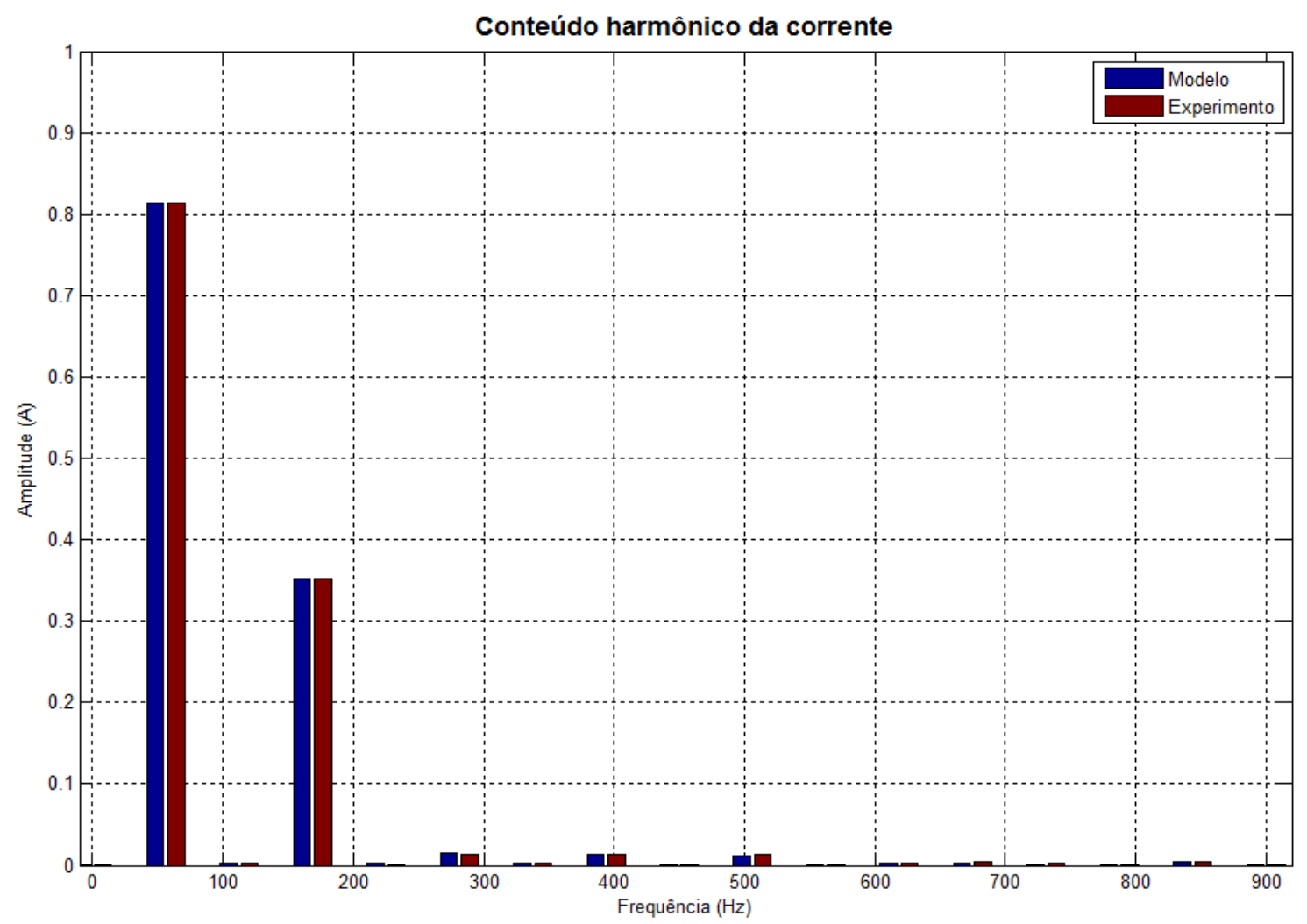

Figura 149 - Conteúdo harmônico da corrente de neutro - Quatro lâmpadas em Y.

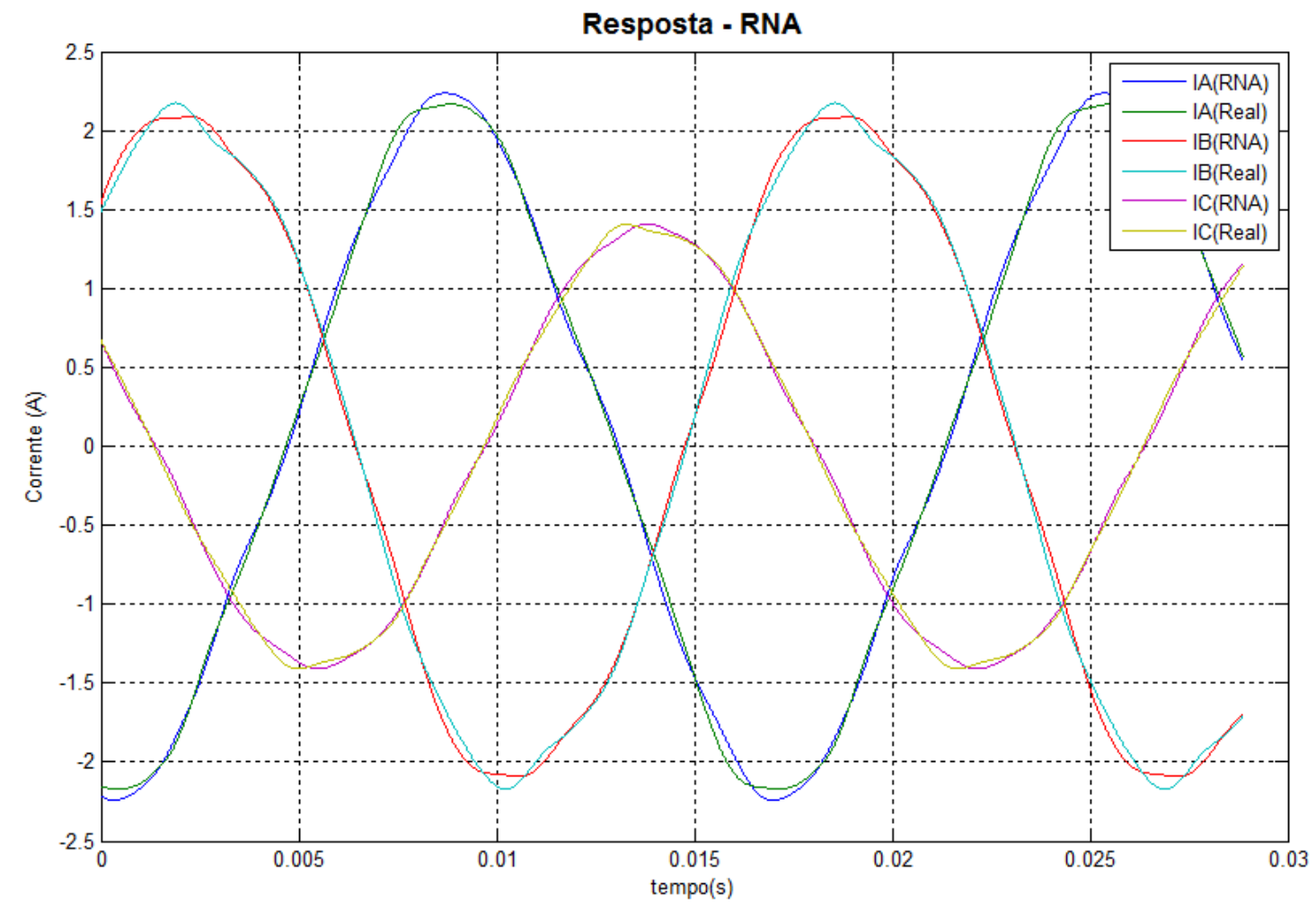

Figura 150 - Conjunto de quatro lâmpadas em configuração trifásica assimétrica em $\Delta(2+1+1)$. 


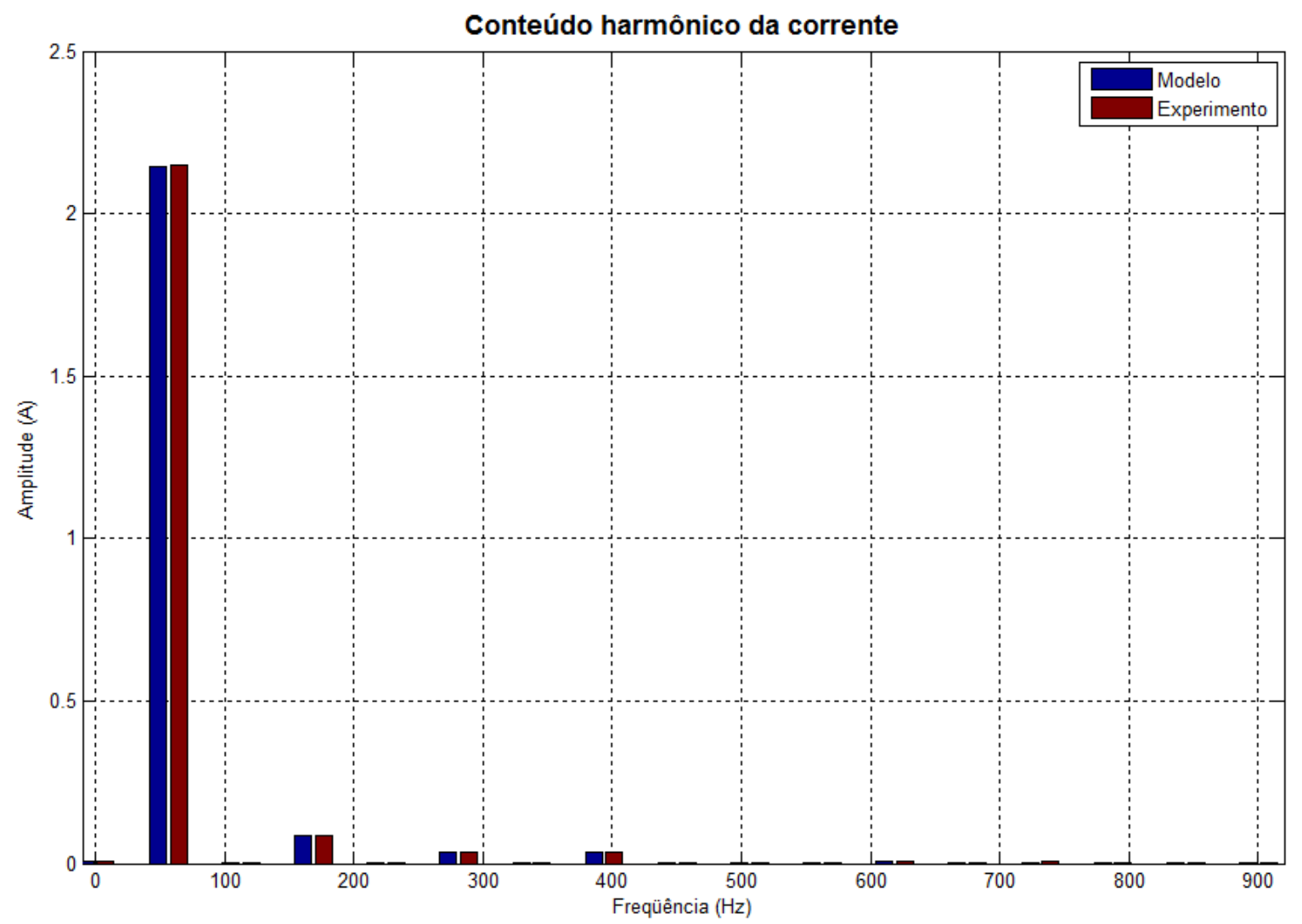

Figura 151 - Conteúdo harmônico da corrente - Fase A (Quatro lâmpadas em $\Delta$ ).

Como ferramenta de simulação de grandes conjuntos de lâmpadas,

o modelo foi ensaiado a partir de uma composição matemática correspondente ao produto dos resultados de lâmpadas modeladas individualmente, comparados igualmente a uma extrapolação dos resultados operacionais reais de lâmpadas de descarga.

Para ilustrar o desempenho deste método de ensaios proposto, algumas situações foram simuladas, e os resultados estão expostos no decorrer deste capítulo.

O resultado de uma associação simétrica de quarenta e cinco dispositivos distribuídos em quinze lâmpadas por fase e conectados em configuração Y é mostrado no gráfico da Figura 152. É possível notar a semelhança de comportamento entre o modelo e o dispositivo real, por comparação entre as curvas presentes no gráfico. 
Os efeitos de distorção harmônica apresentados na corrente de fase por esta configuração são mostrados pelo gráfico da Figura 153, e o aspecto da composição harmônica da corrente de neutro para o mesmo experimento é apresentado no gráfico da Figura 154. Observa-se novamente o conteúdo em $3^{\text {a }}$ harmônica presente na corrente de neutro das associações em Y originadas pela superposição de efeitos de distorção das cargas.

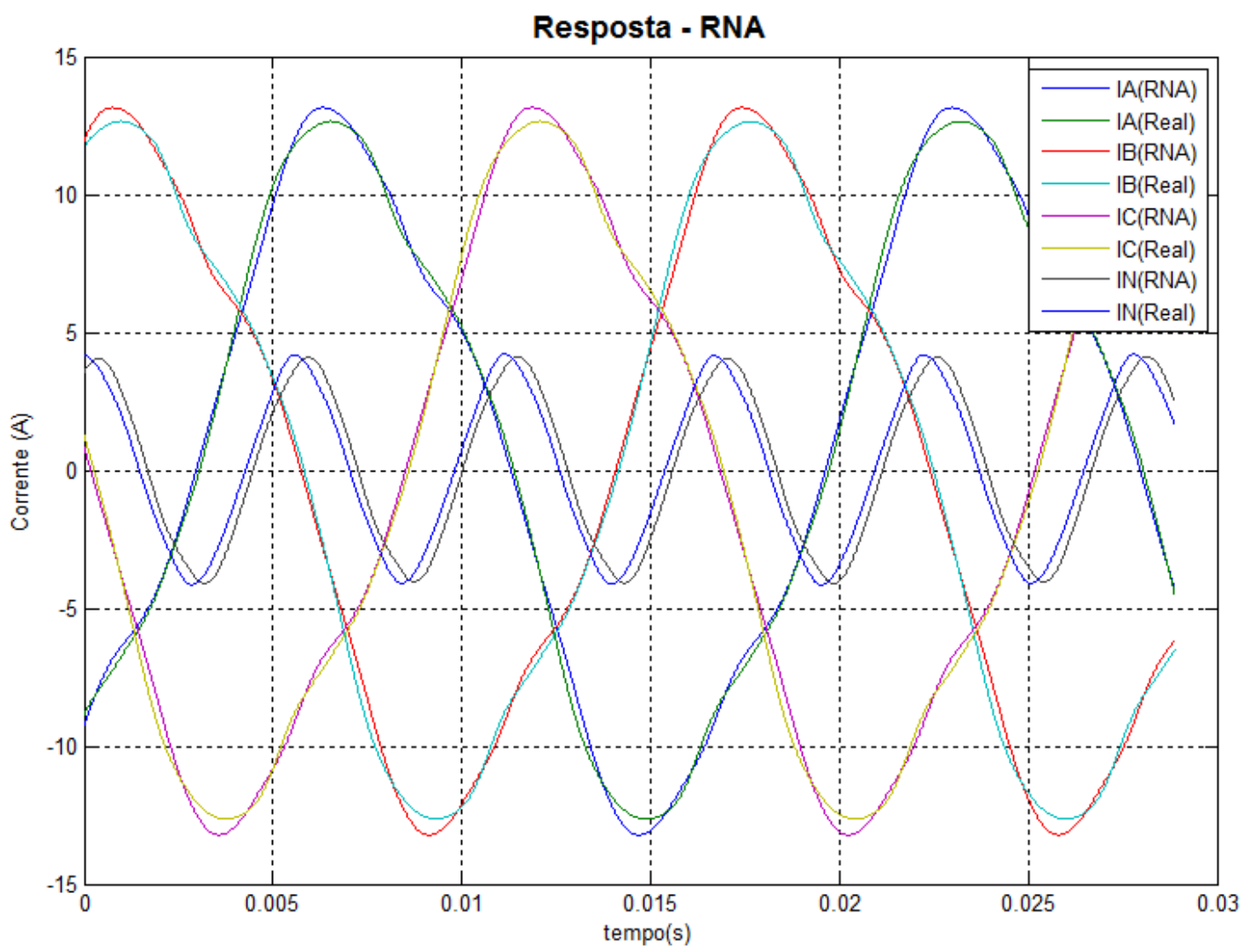

Figura 152 - Conjunto de quarenta e cinco lâmpadas em configuração trifásica simétrica em Y $(15+15+15)$.

A mesma configuração, quando submetida a uma alimentação com tensão reduzida a 0,8 pu e estabilizada termicamente, tem seu comportamento apresentado no gráfico da Figura 155. Para esta condição, a corrente de neutro tem seu conteúdo harmônico conforme o gráfico apresentado na Figura 156. 


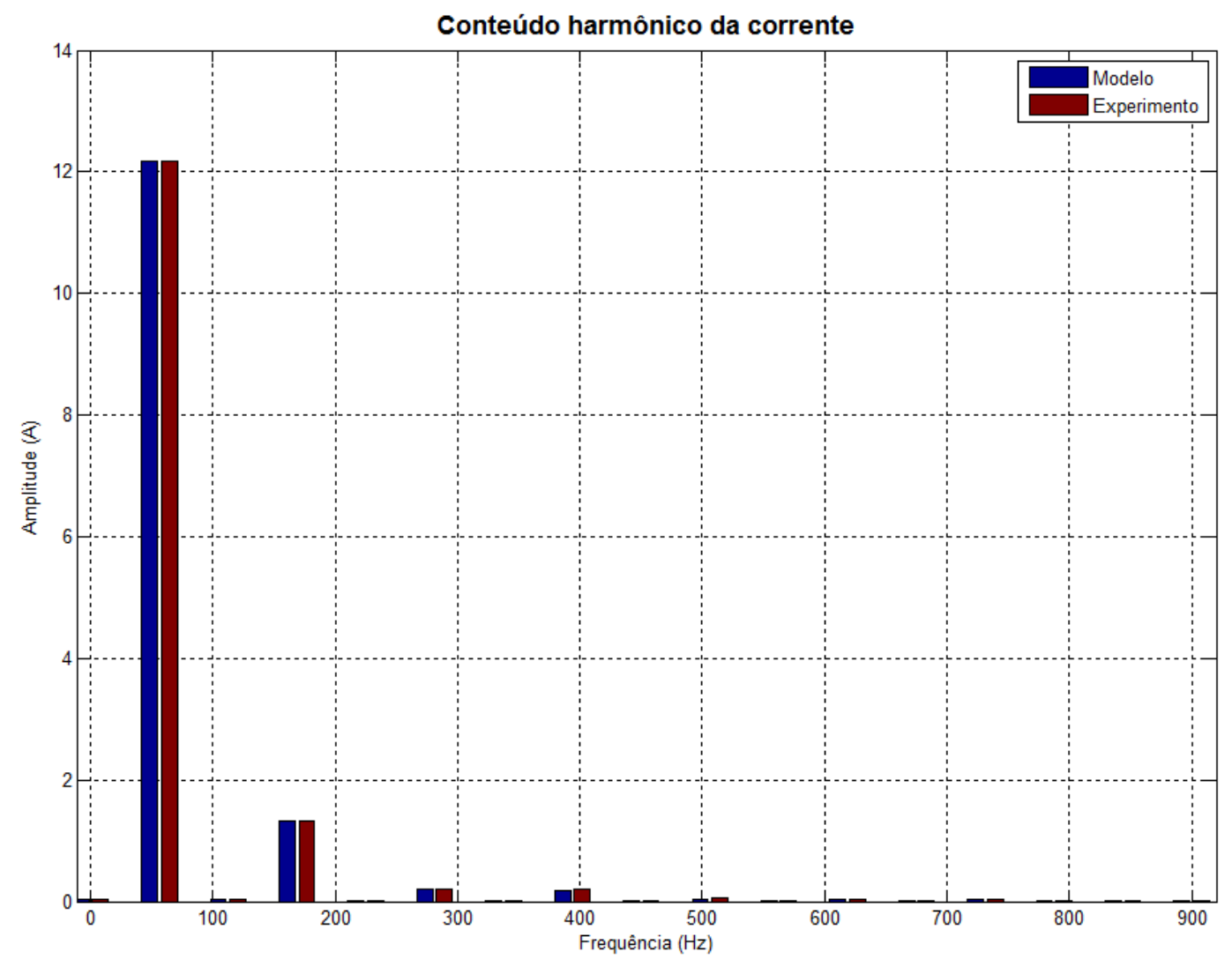

Figura 153 - Corrente da Fase A - Quarenta e cinco lâmpadas em Y simétrico (15+15+15).

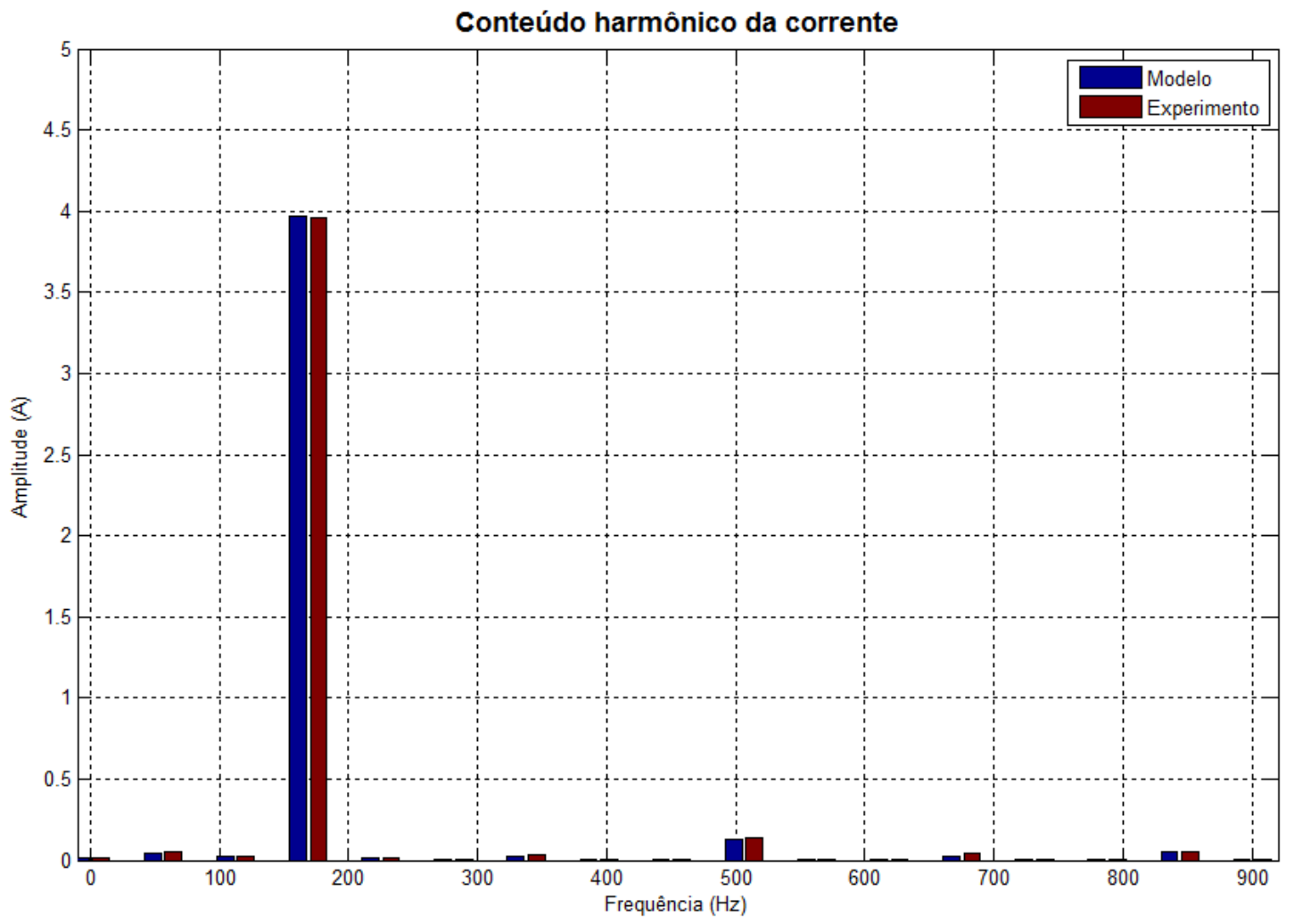

Figura 154 - Conteúdo harmônico da corrente de neutro - Quarenta e cinco lâmpadas em Y. 


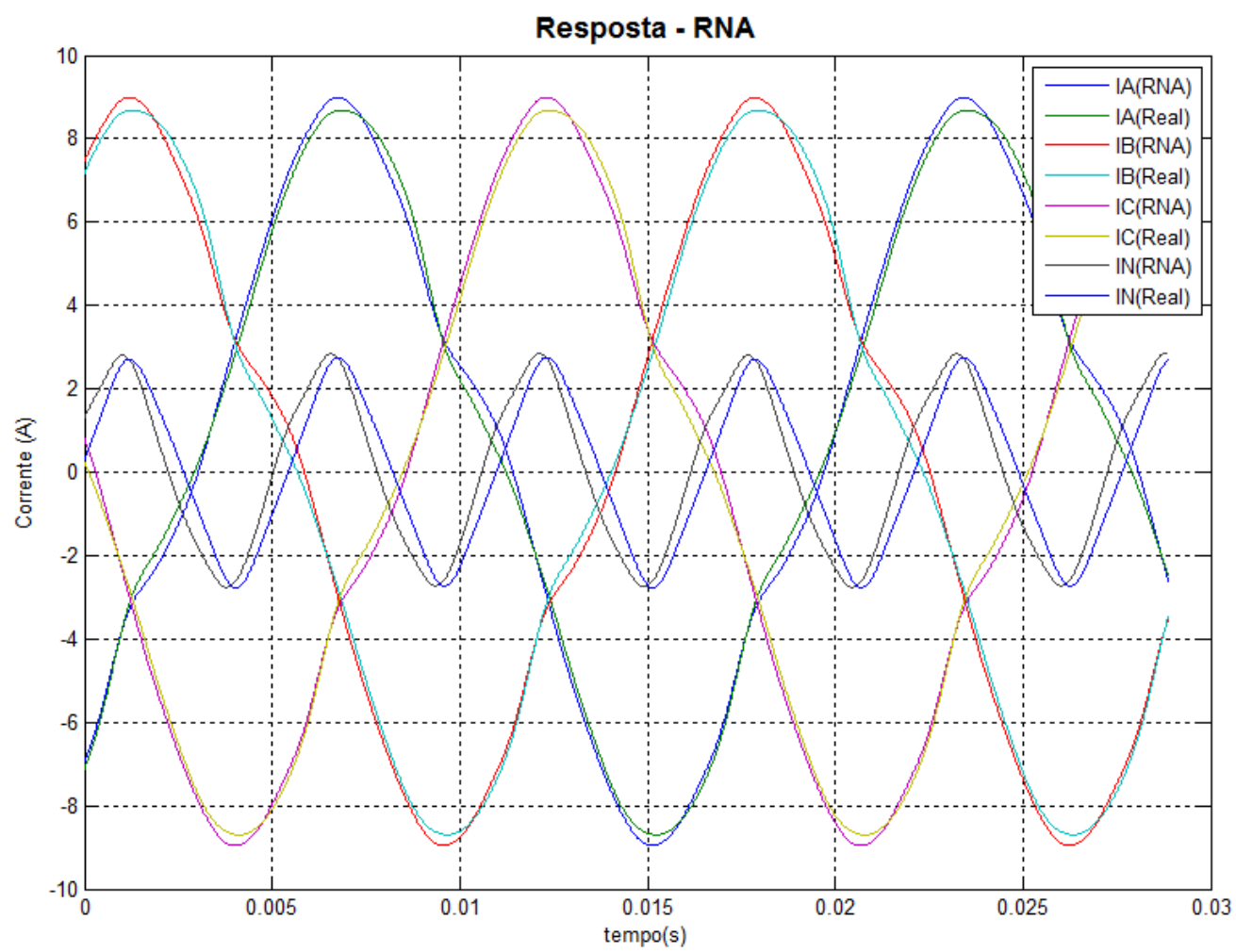

Figura 155 - Conjunto de quarenta e cinco lâmpadas em Y (15+15+15) - Alimentação em 0,8 pu.

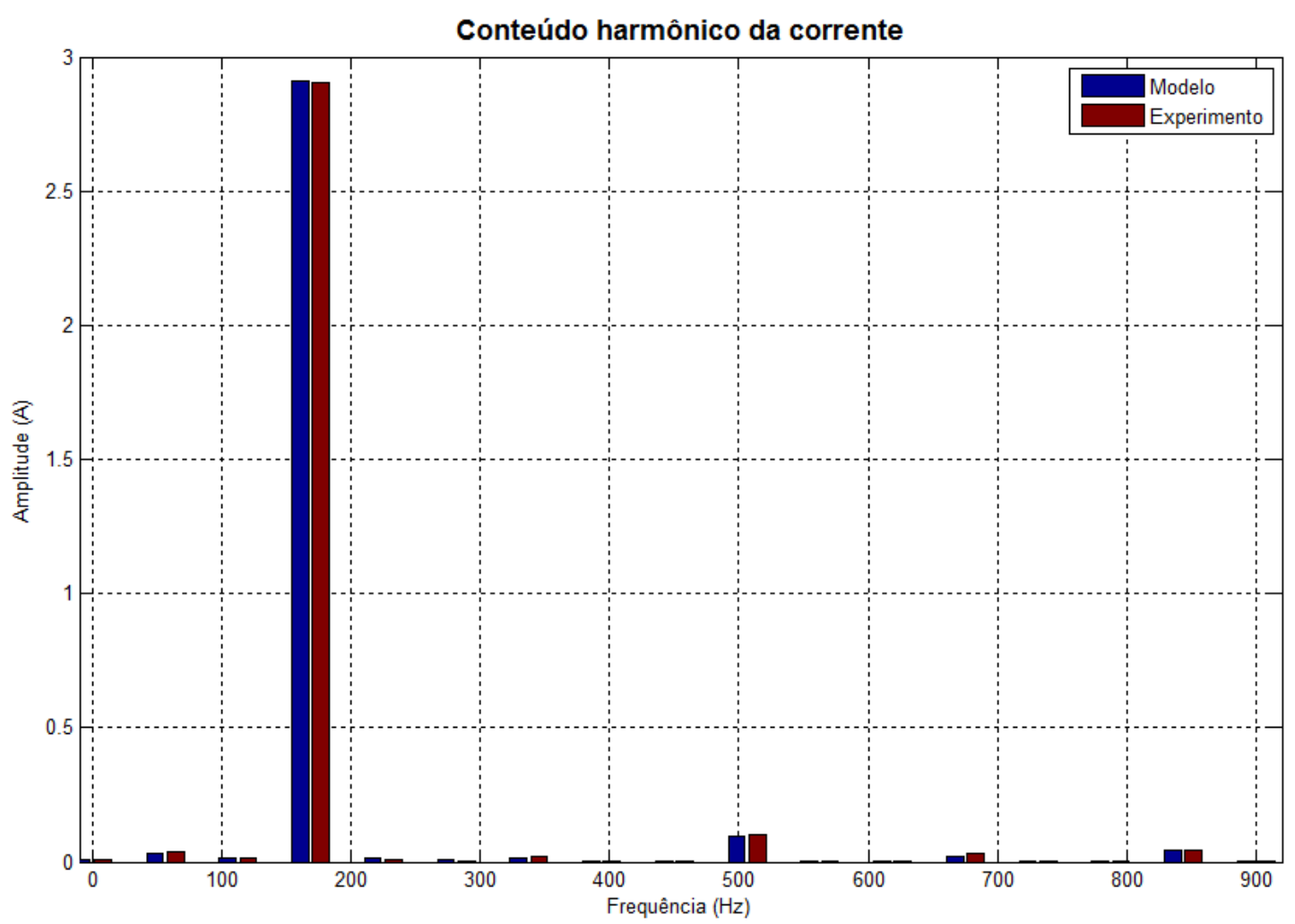

Figura 156 - Conteúdo harmônico corrente de neutro (quarenta e cinco lâmpadas em Y; 0,8pu). 
A presença de assimetrias de pequena ordem em associações de grandes quantidades de lâmpadas torna evidente o efeito da corrente de neutro nas associações conectadas em Y, com significativa presença de distorção harmônica, em especial de $3^{\mathrm{a}}$ e $5^{\mathrm{a}}$ ordem. Uma associação de quarenta lâmpadas apresentando assimetria em uma única fase (Fase A com quinze lâmpadas, Fase B com quinze lâmpadas e Fase C com dez lâmpadas), está representada no gráfico da Figura 157.

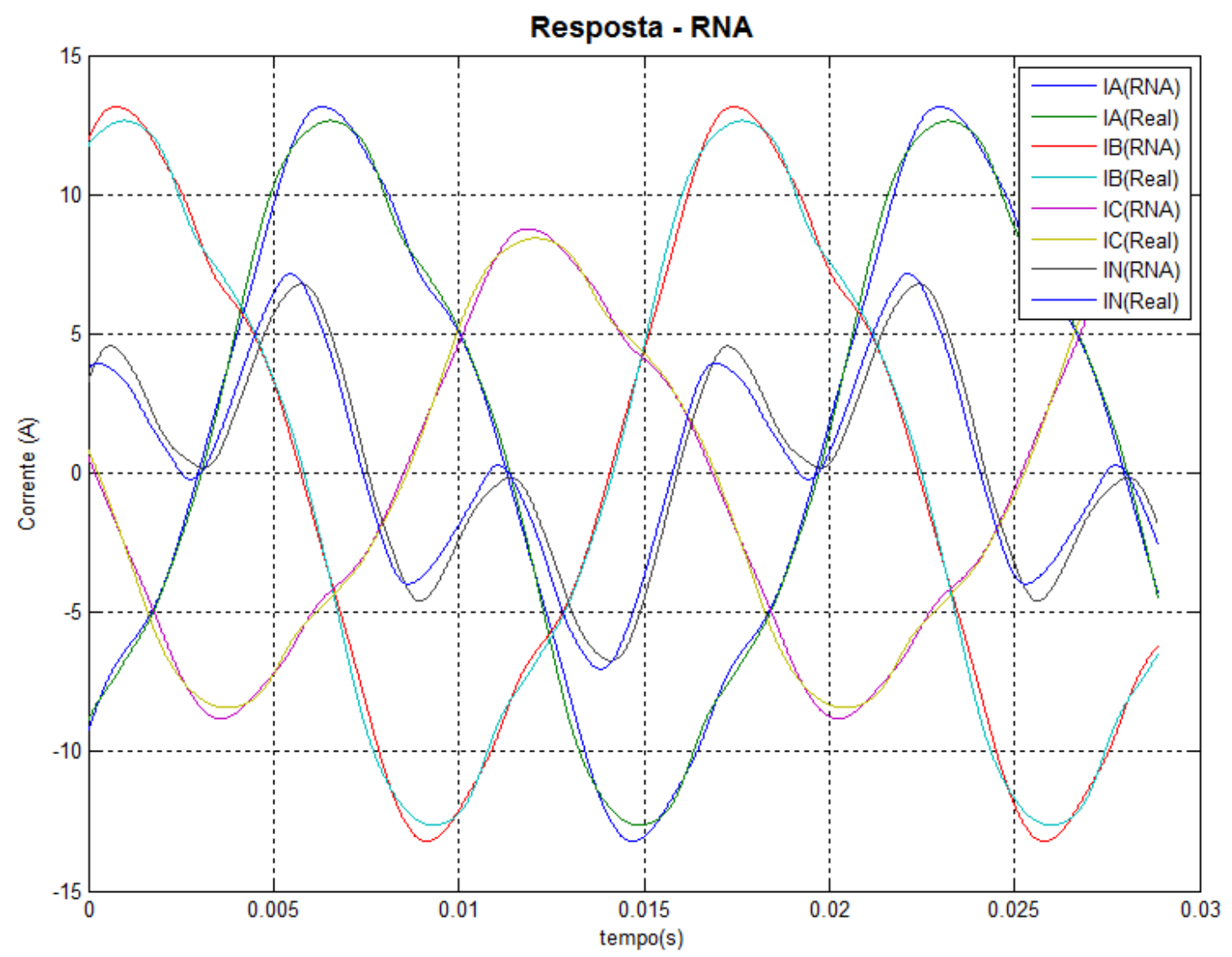

Figura 157 - Conjunto de quarenta lâmpadas em configuração trifásica assimétrica em Y (15+15+10).

A corrente de neutro para a configuração anteriormente apresentada é mostrada pelo gráfico de conteúdo harmônico apresentado na Figura 158. Notar o significativo conteúdo de $3^{\text {a }}$ harmônica e a presença de corrente de neutro com amplitude significativa na frequência fundamental, decorrente da assimetria da carga. 
Para esta mesma configuração assimétrica, com conexão entre dispositivos em $\Delta$ para quinze lâmpadas entre as fases A e B, dez lâmpadas entre as fases B e C e quinze lâmpadas entre as fases C e A, as correntes de linha assumem comportamento conforme o gráfico apresentado na Figura 159. A composição harmônica de corrente para a Fase A desta configuração pode ser observada na Figura 160.

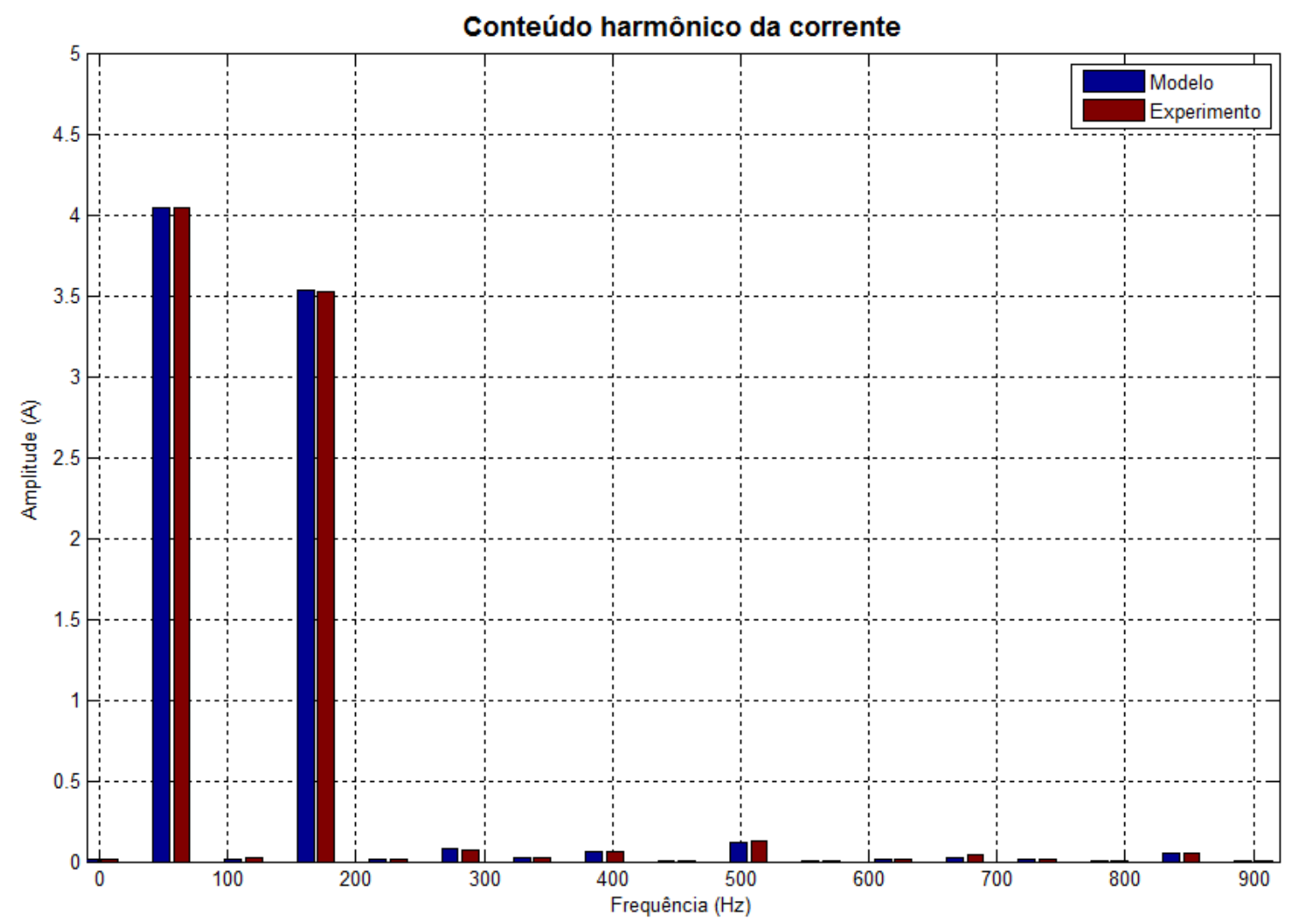

Figura 158 - Conteúdo harmônico corrente de neutro (quarenta lâmpadas em Y).

A Figura 161 apresenta a resposta do modelo neural de um conjunto de sessenta lâmpadas em configuração assimétrica trifásica em conexão Y, aquecidas à temperatura nominal, composto por dez lâmpadas entre fase A e neutro, vinte lâmpadas entre fase $\mathrm{B}$ e neutro e trinta lâmpadas entre fase $\mathrm{C}$ e neutro. Deve ser notada a composição da corrente de neutro, com forte conteúdo harmônico, conforme mostrado no gráfico de Figura 162, e apresentando amplitude com ordem de grandeza próxima à corrente da Fase A, originada pela assimetria do sistema. 


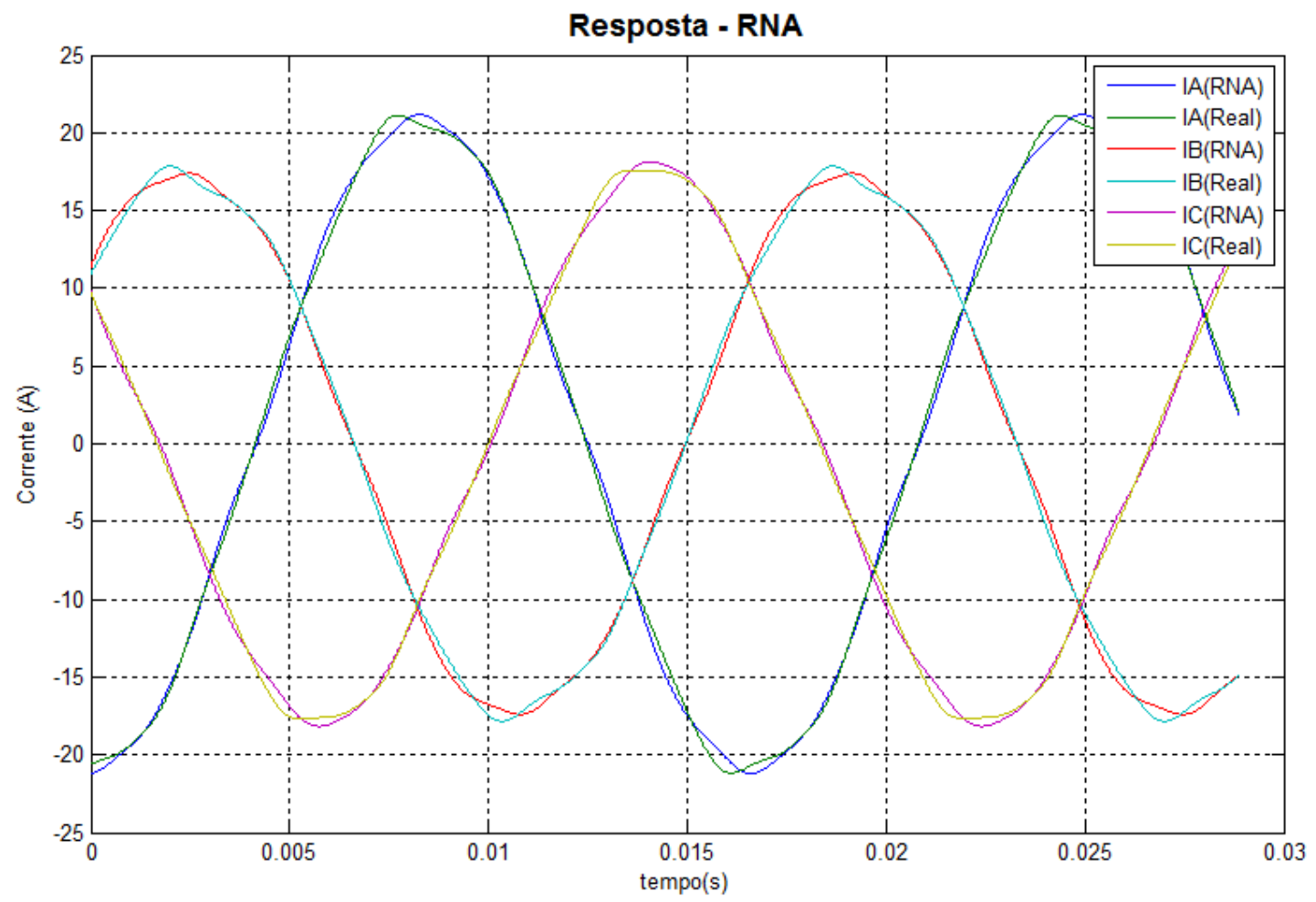

Figura 159 - Conjunto de quarenta lâmpadas em configuração trifásica assimétrica em $\Delta(15+15+10)$.

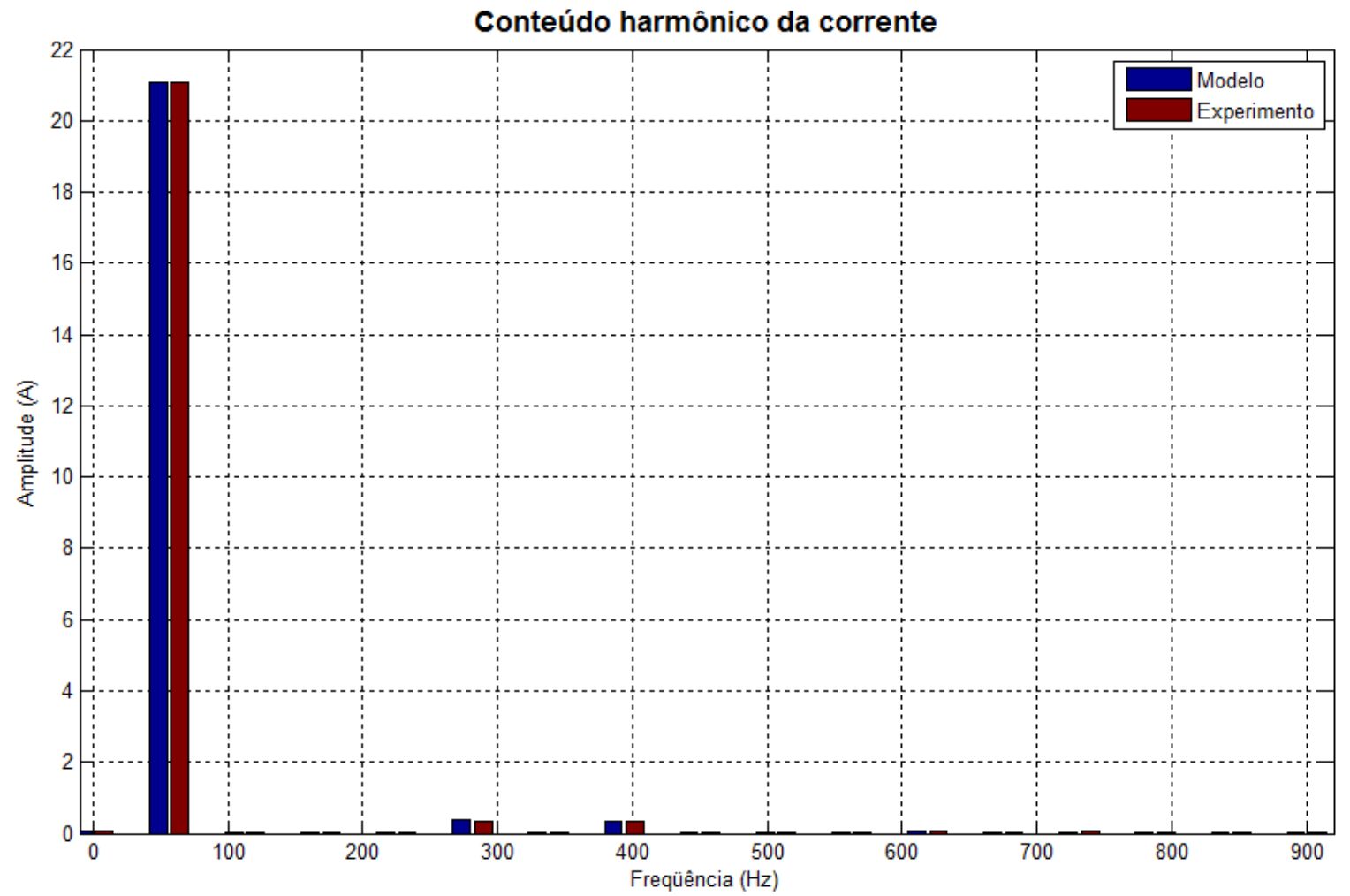

Figura 160 - Conteúdo harmônico da corrente - Fase A (Quarenta lâmpadas em $\Delta$ ). 


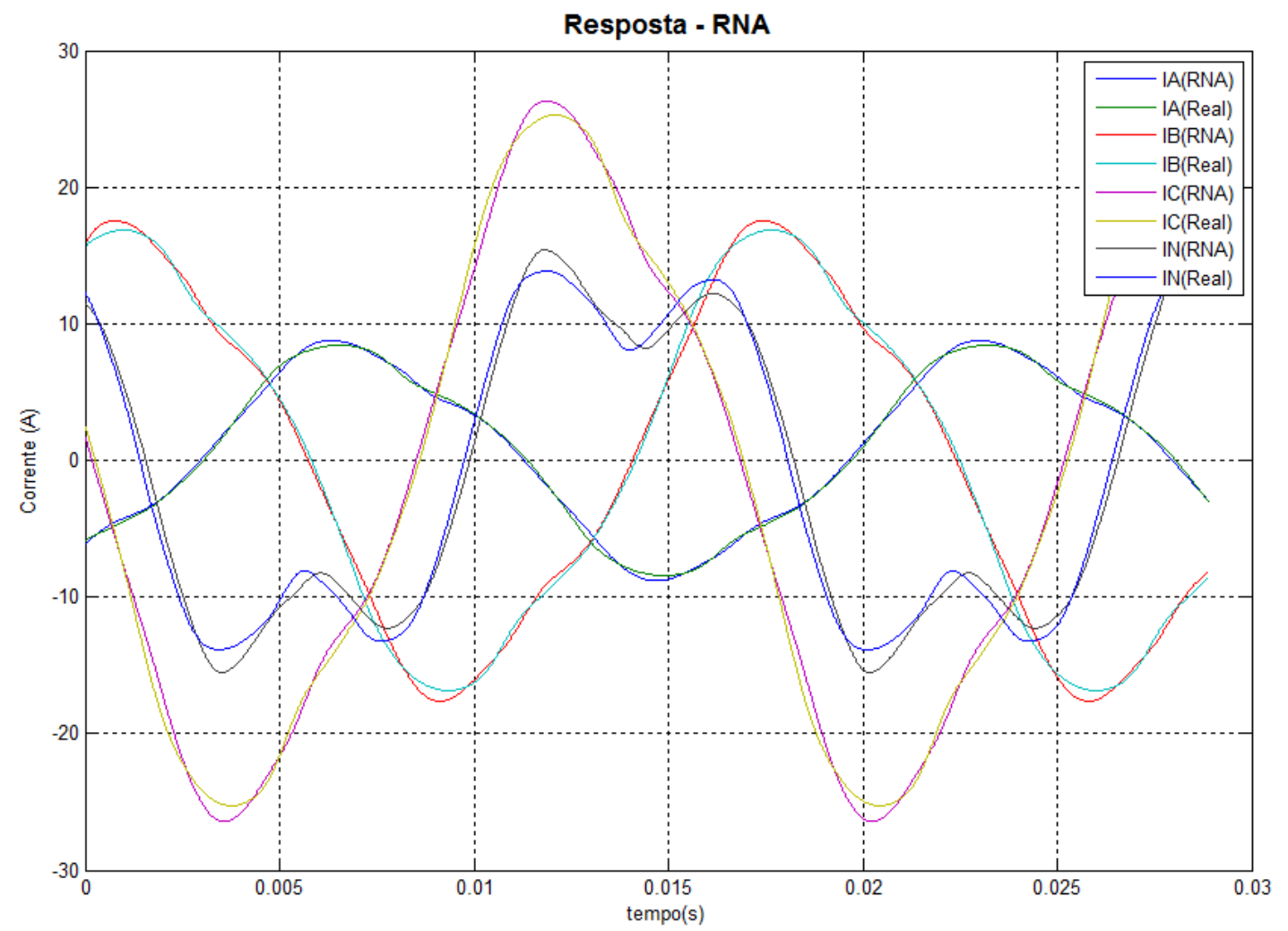

Figura 161 - Conjunto de sessenta lâmpadas em configuração trifásica assimétrica em Y $(10+20+30)$.

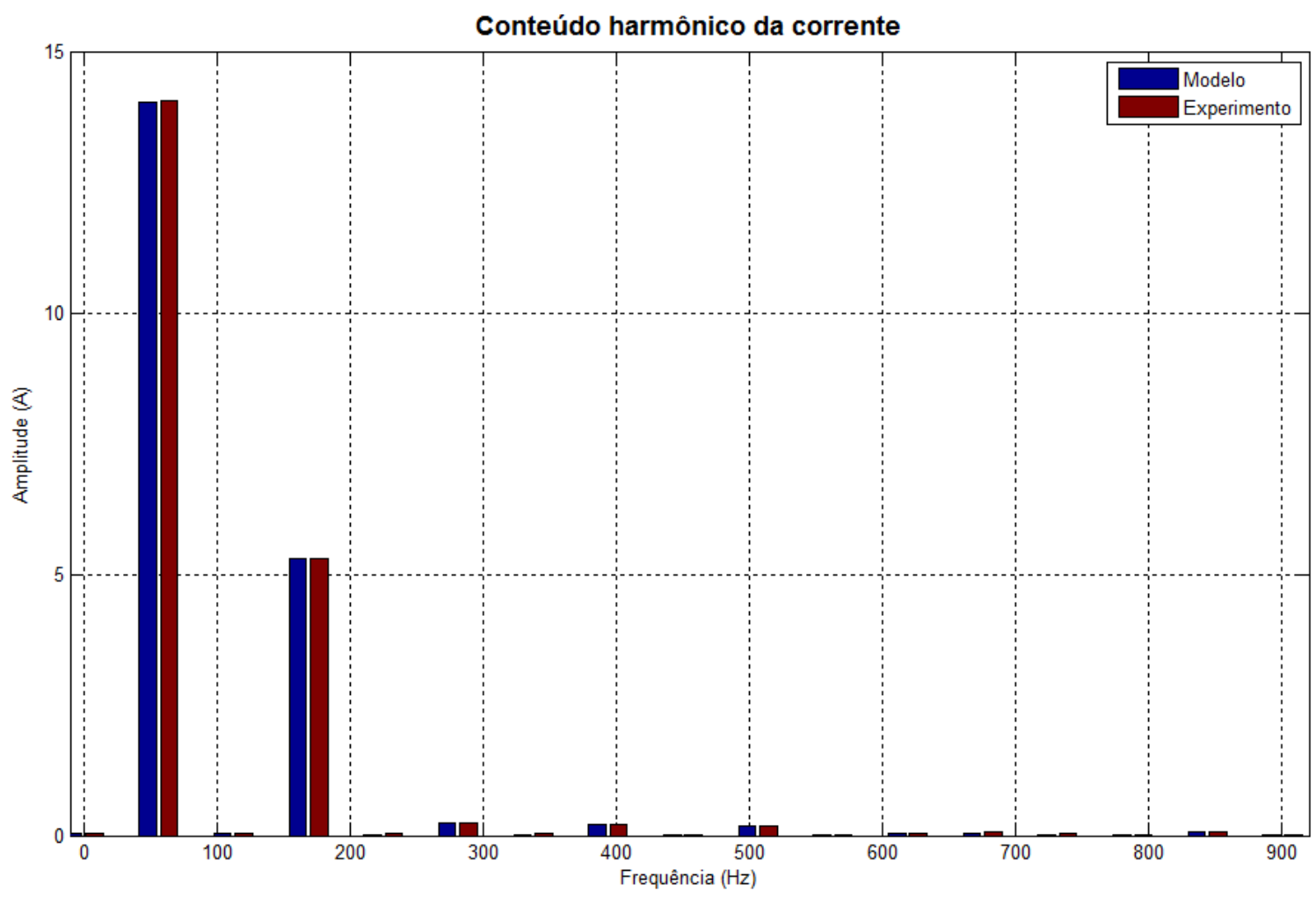

Figura 162 - Corrente de neutro - Sessenta lâmpadas em Y assimétrico (10+20+30). 
A configuração assimétrica proposta para um conjunto de sessenta lâmpadas, quando conectadas em $\Delta$, apresenta característica de corrente conforme o gráfico apresentado na Figura 163. Deve ser observada a distorção presente nas correntes de linha devido à não-linearidade da carga. $\mathrm{O}$ conteúdo harmônico da corrente da fase $\mathrm{B}$, que apresentou maior amplitude nesta configuração adotada, é exibido na Figura 164.

A Figura 165 representa um conjunto de noventa lâmpadas em regime normal de operação (temperatura nominal) e em configuração trifásica simétrica e conexão em Y. Cabe notar o elevado grau de correlação entre as curvas correspondentes à corrente real do dispositivo e a corrente obtida por simulação para a situação apresentada, e que pode ser evidenciado quando se compara a decomposição harmônica da corrente da Fase A da simulação e do dispositivo real, como mostrado no gráfico da Figura 166.

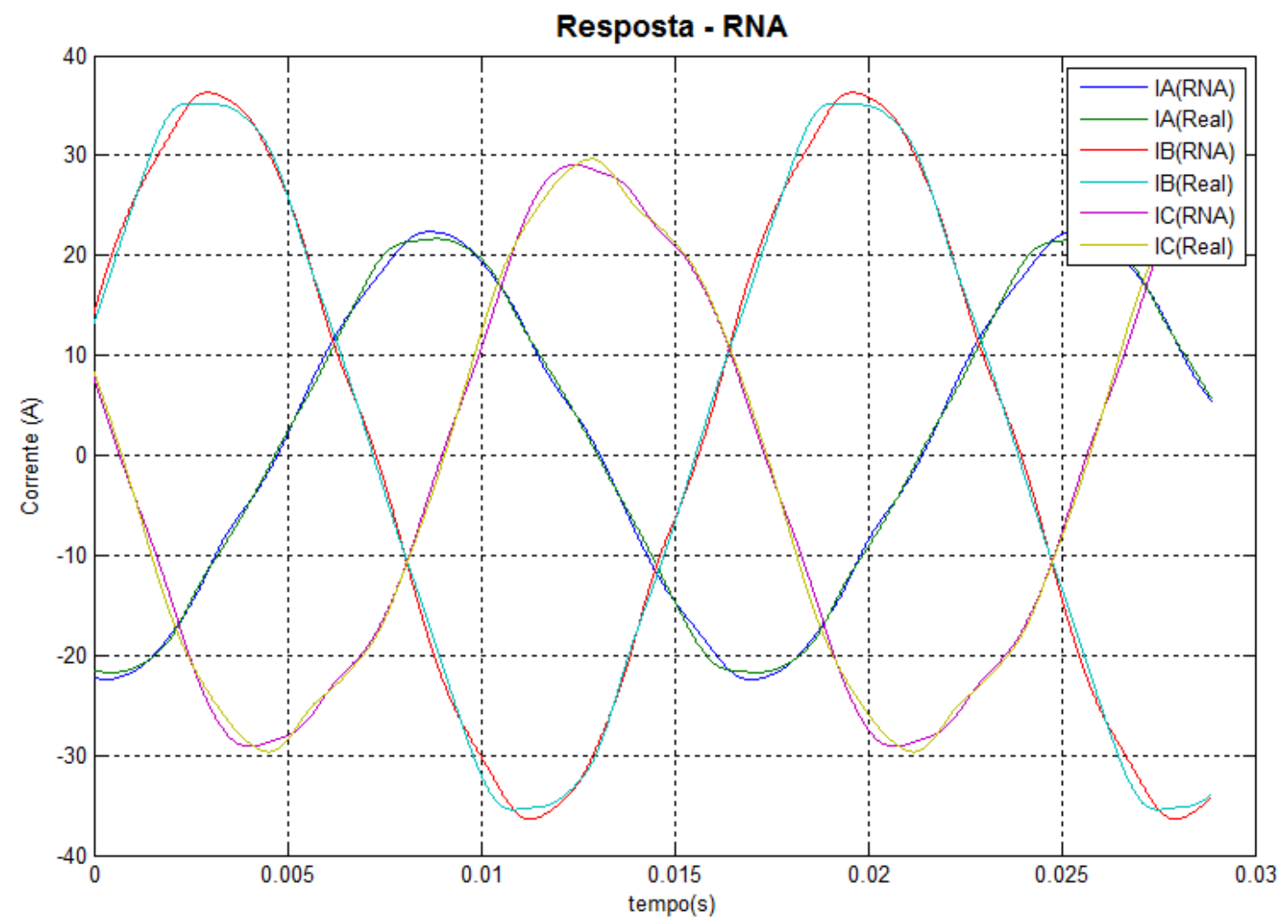

Figura 163 - Conjunto de sessenta lâmpadas em configuração trifásica assimétrica em $\Delta(10+20+30)$. 


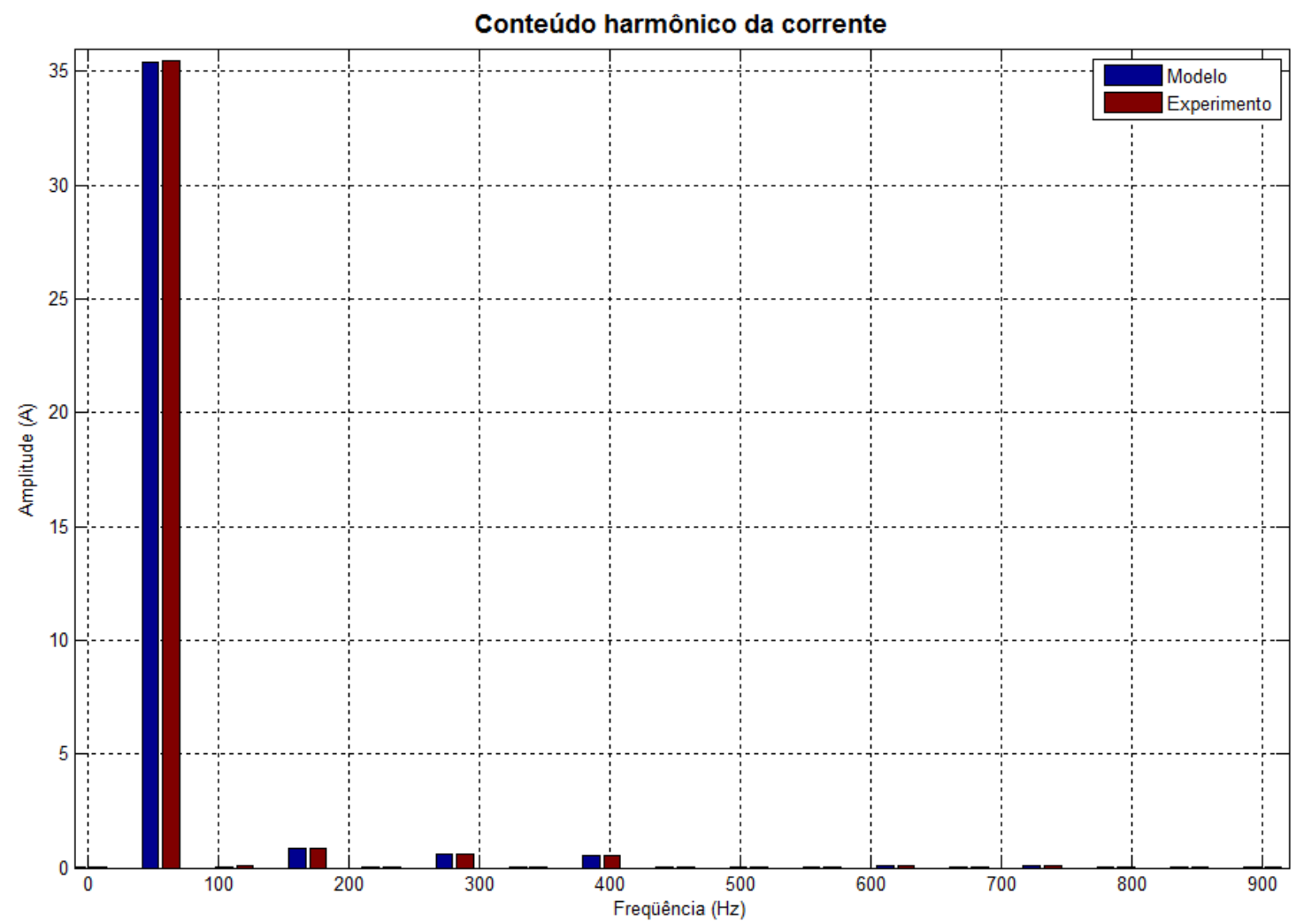

Figura 164 - Conteúdo harmônico da corrente - Fase B (sessenta lâmpadas em $\Delta$, assimétricas).

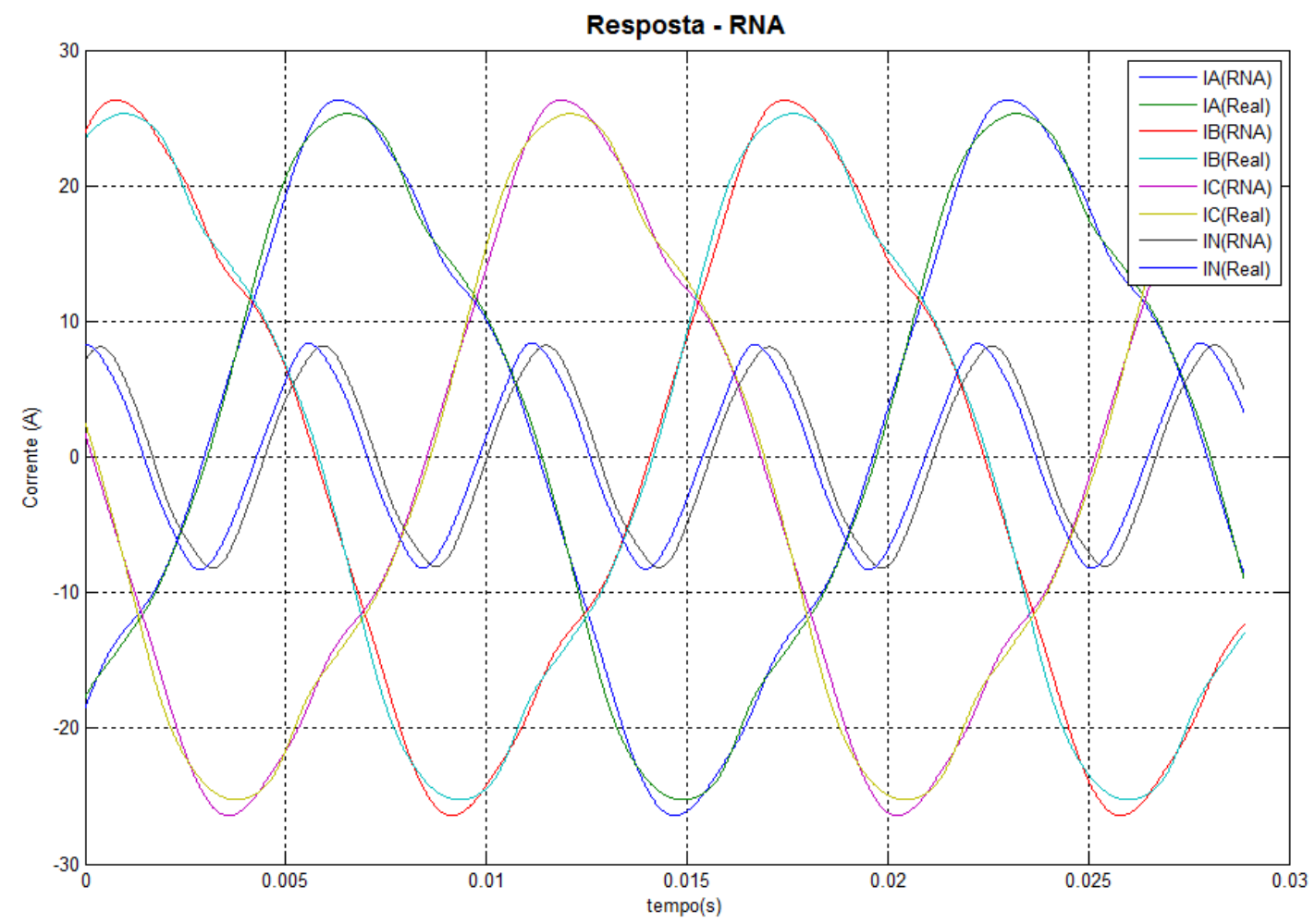

Figura 165 - Conjunto de noventa lâmpadas em configuração trifásica simétrica em Y (30+30+30). 
A presença de corrente de neutro com conteúdo em $3^{a}$ harmônica também é bastante evidenciada, como pode ser verificado no gráfico da Figura 167.

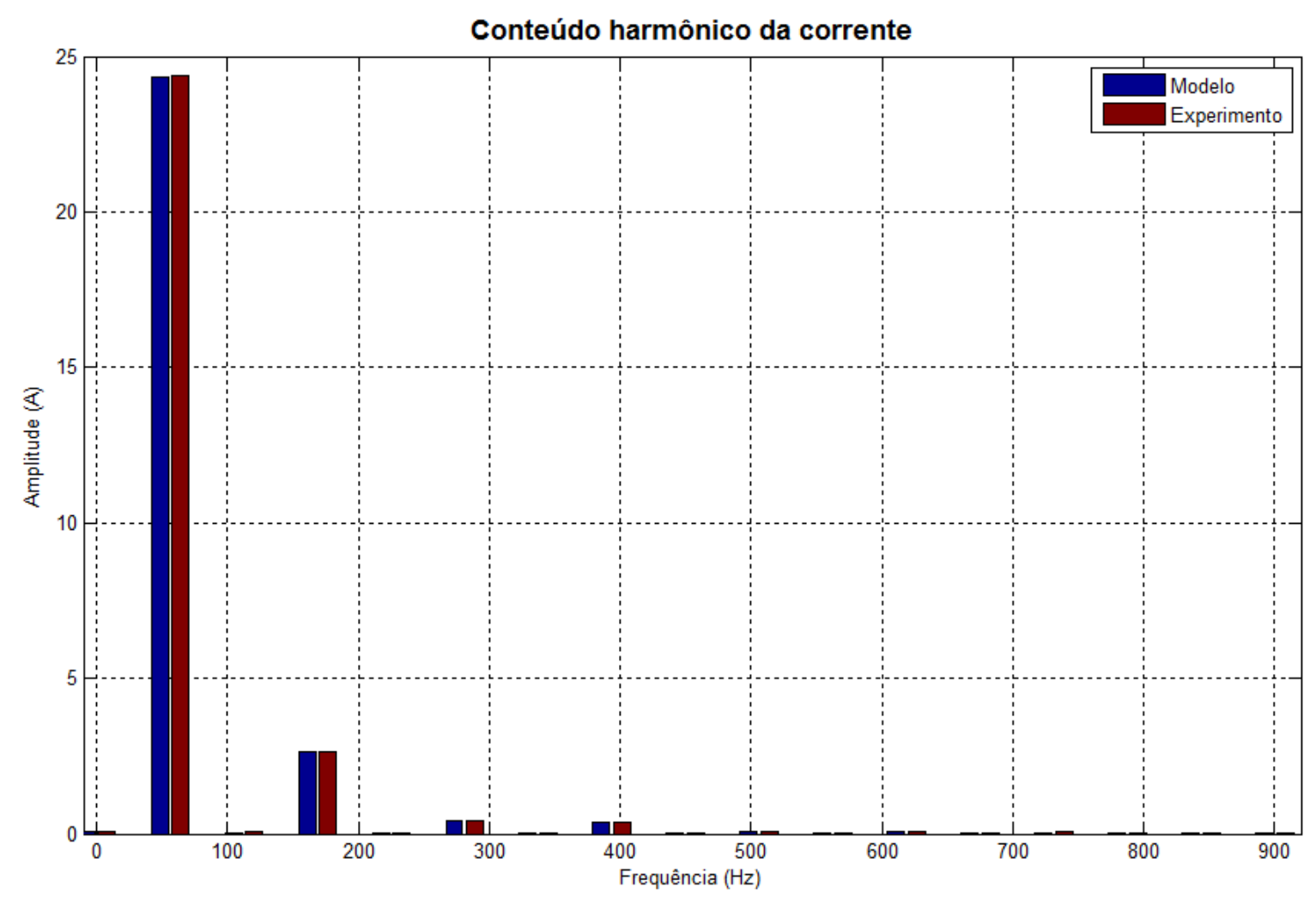

Figura 166 - Corrente da Fase A - Noventa lâmpadas em Y simétrico (30+30+30).

Para o mesmo agrupamento do exemplo anterior, com lâmpadas conectadas em configuração $\Delta$, as correntes assumem o aspecto mostrado no gráfico da Figura 168. Nota-se, através da observação do gráfico da Figura 169, a redução de proporção do conteúdo harmônico nas correntes de linha para esta configuração, embora ainda esteja presente conteúdo harmônico nas correntes de fase relativos aos dispositivos não-lineares do circuito.

No caso de configurações em Y incompleto, onde apenas duas fases são empregadas, o resultado evidencia a presença de corrente de neutro conforme o gráfico da Figura 170. Deve ser observado que a ausência de elementos associados à fase C faz com que o valor de corrente de neutro atinja ordem de grandeza similar às correntes de fase. 


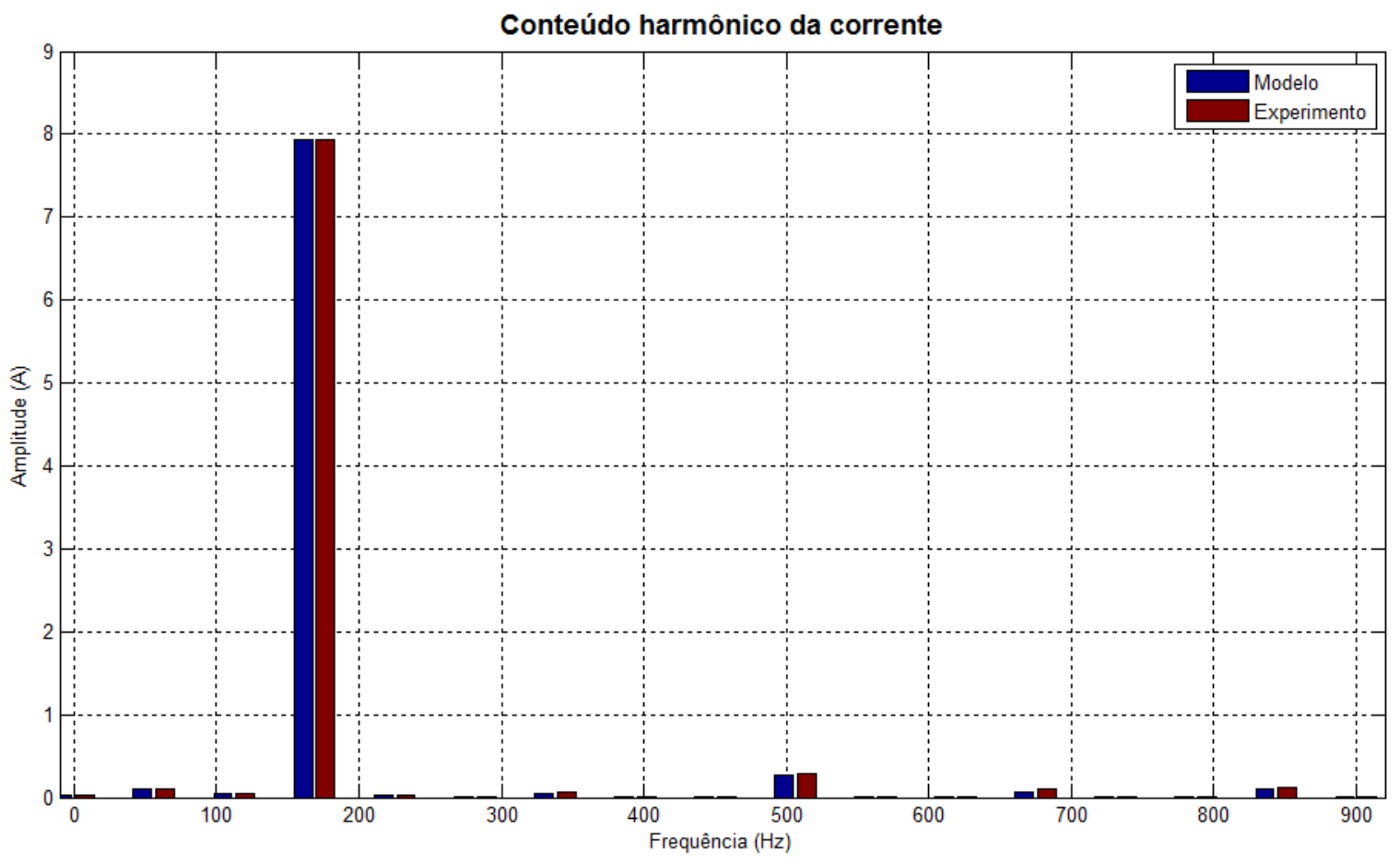

Figura 167 - Corrente de neutro - Noventa lâmpadas em Y simétrico $(30+30+30)$.

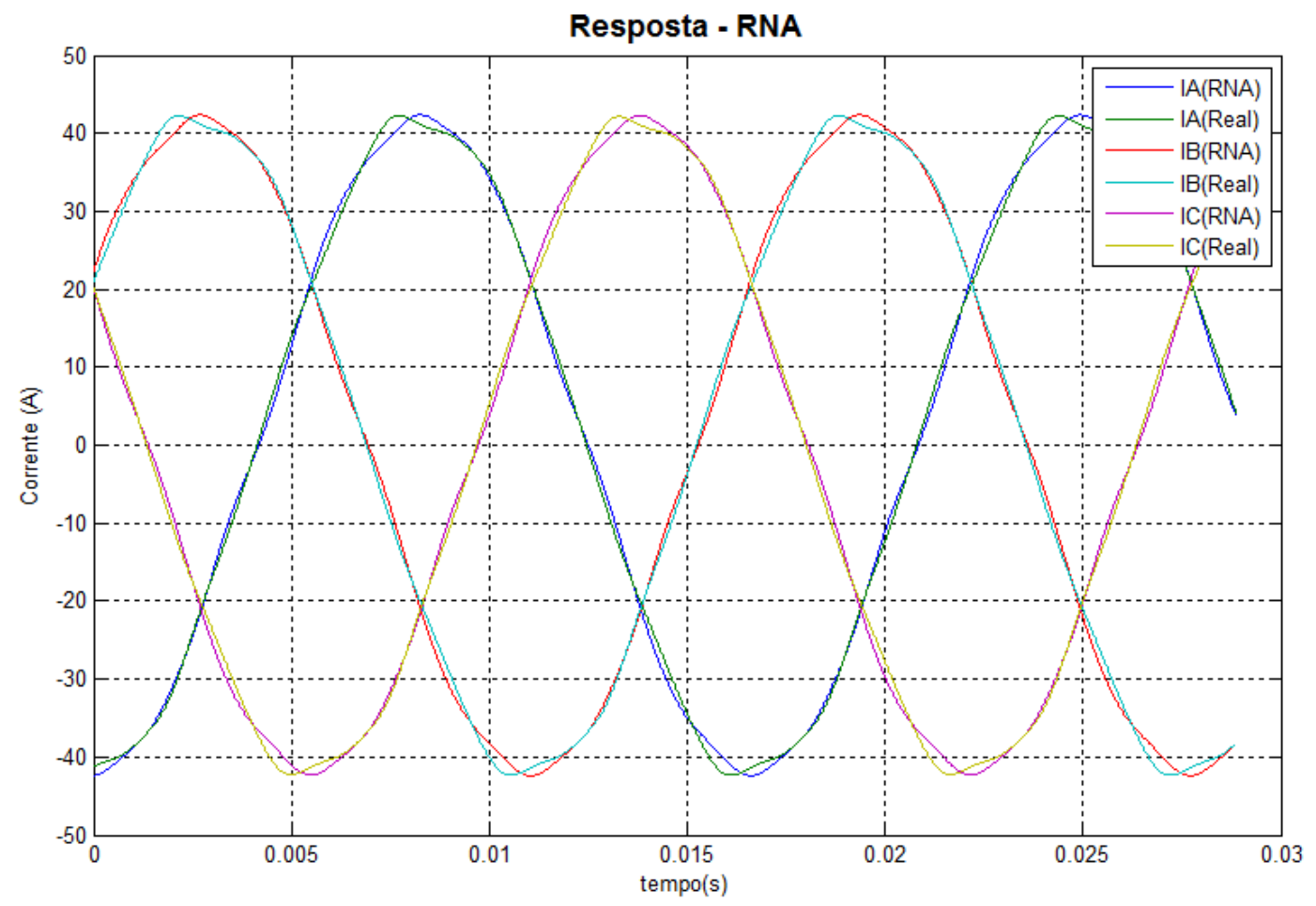

Figura 168 - Conjunto de noventa lâmpadas - configuração trifásica simétrica; conexão em $\Delta$. 


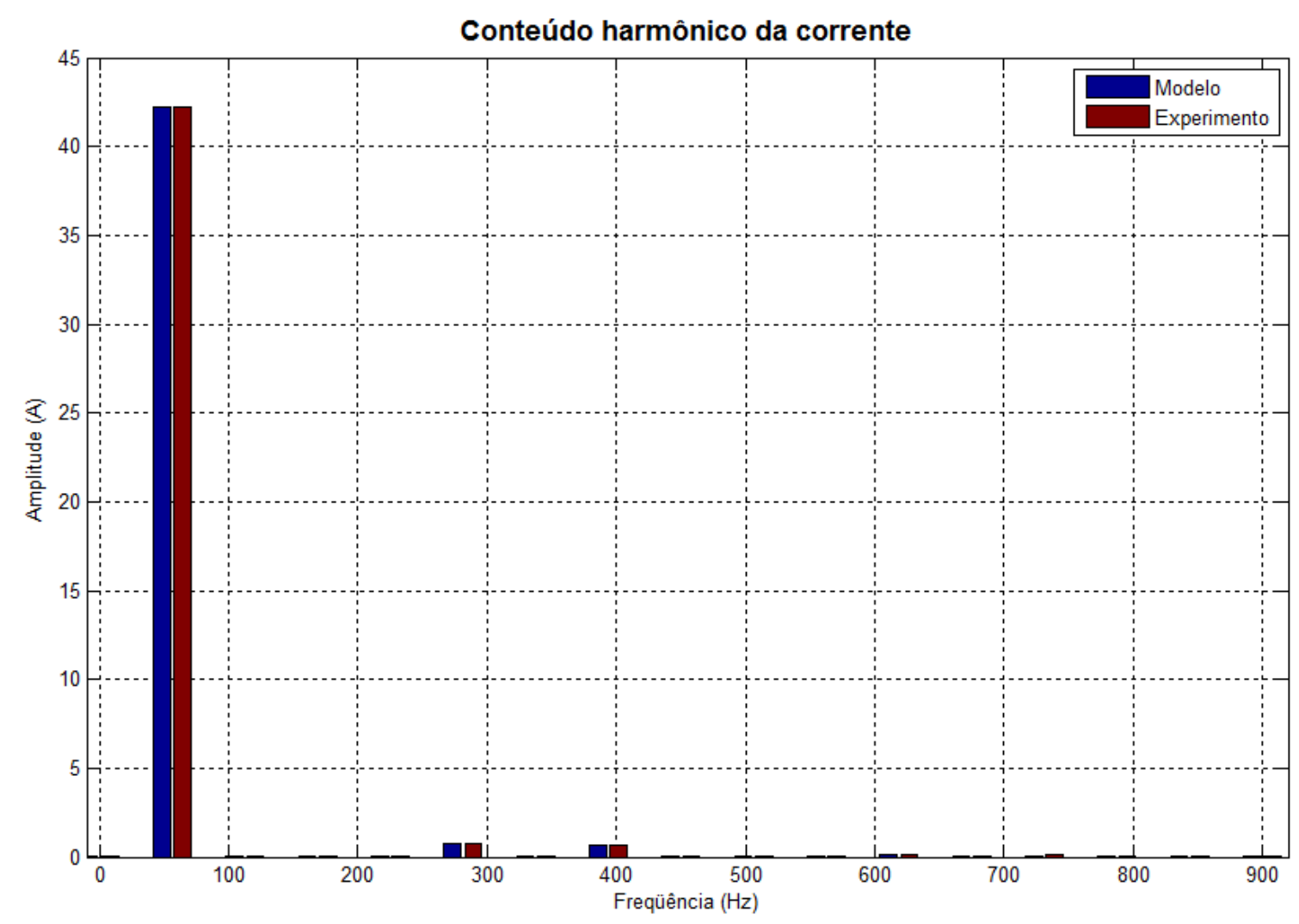

Figura 169 - Conteúdo harmônico da corrente - Fase A (noventa lâmpadas em $\Delta$, simétricas).

A decomposição em conteúdo harmônico da corrente de neutro resultante da configuração de duas lâmpadas em Y incompleto é mostrada na Figura 171, onde é possível verificar que a ordem de grandeza da componente fundamental é similar à corrente de fase de um sistema em Y simétrico, como o ilustrado na Figura 144.

Para duas lâmpadas conectadas em configuração $\Delta$ aberto (com uma lâmpada entre as fases A e B e outra lâmpada entre as fases A e C), o perfil das correntes de fase é apresentado no gráfico da Figura 172. Pode ser observado o considerável deslocamento de fase produzido pela assimetria da carga.

Nesta configuração, a corrente da fase que alimenta dois braços do triângulo tem seu comportamento harmônico apresentado no gráfico da Figura 173. Notase o espectro similar a outras associações de lâmpadas em $\Delta$, como o mostrado na Figura 147. 


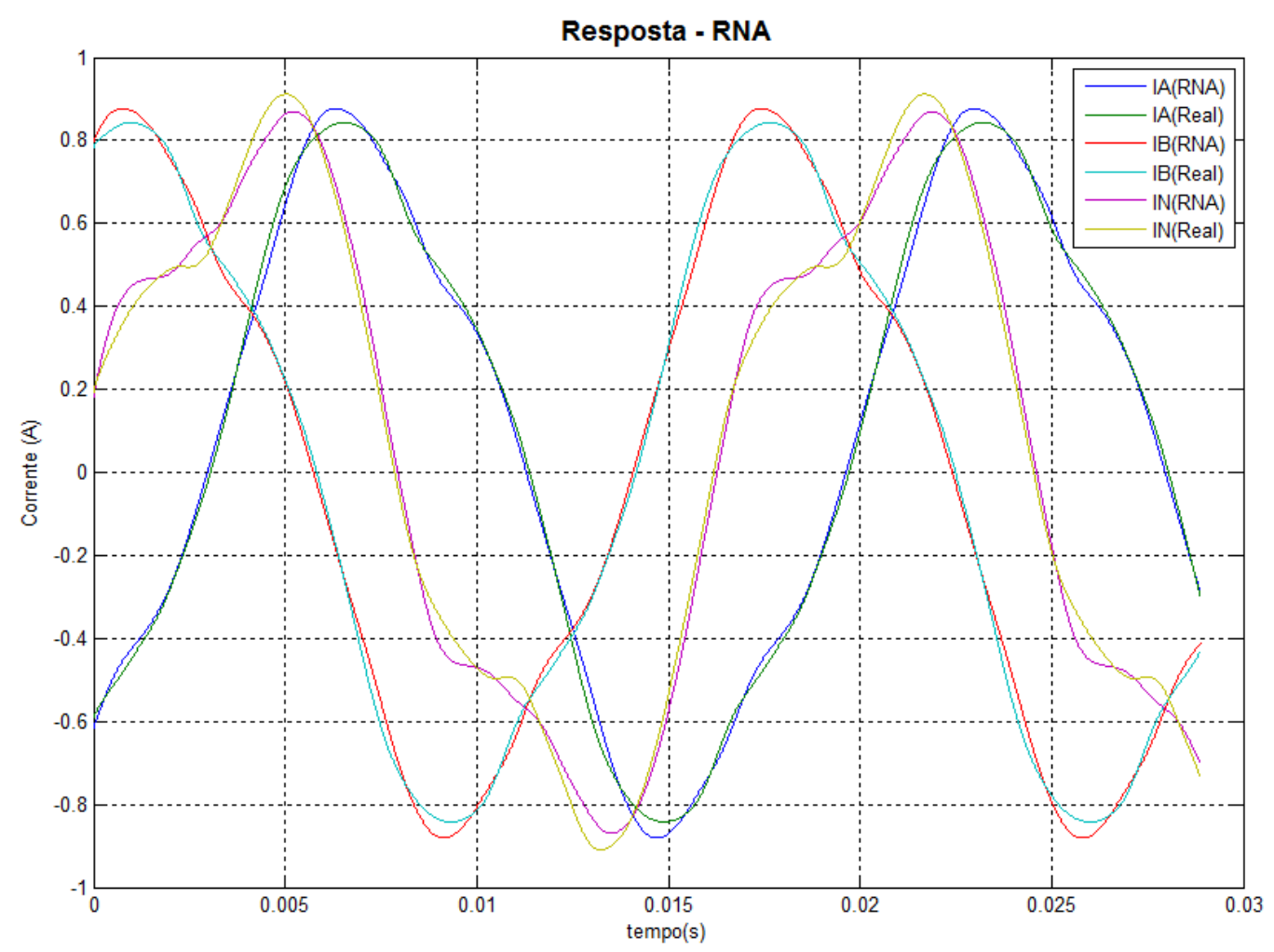

Figura 170 - Conjunto de duas lâmpadas em configuração Y entre duas fase e neutro (A-N e B-N).

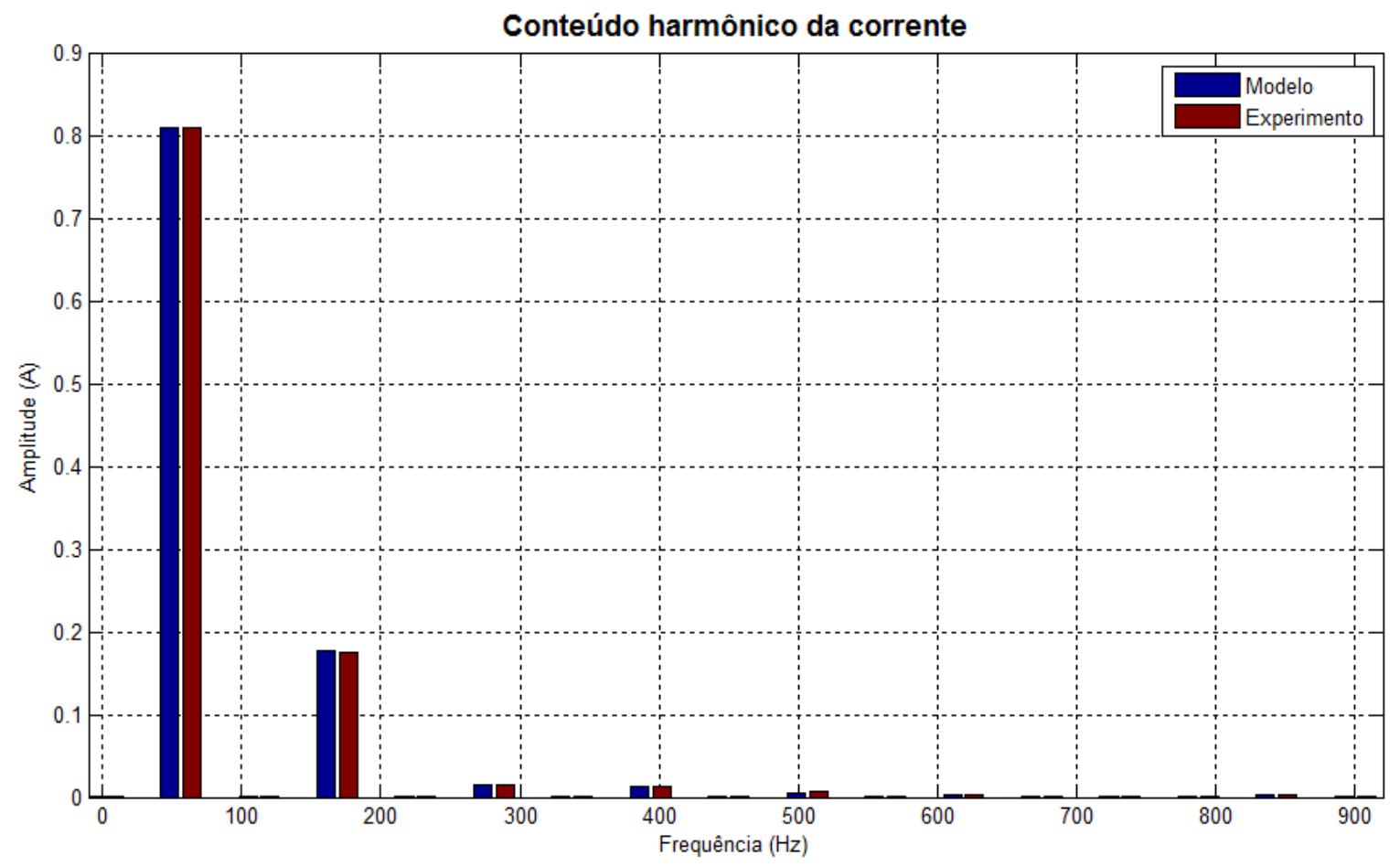

Figura 171 - Conteúdo harmônico da corrente de Neutro (duas lâmpadas, A-N e B-N). 


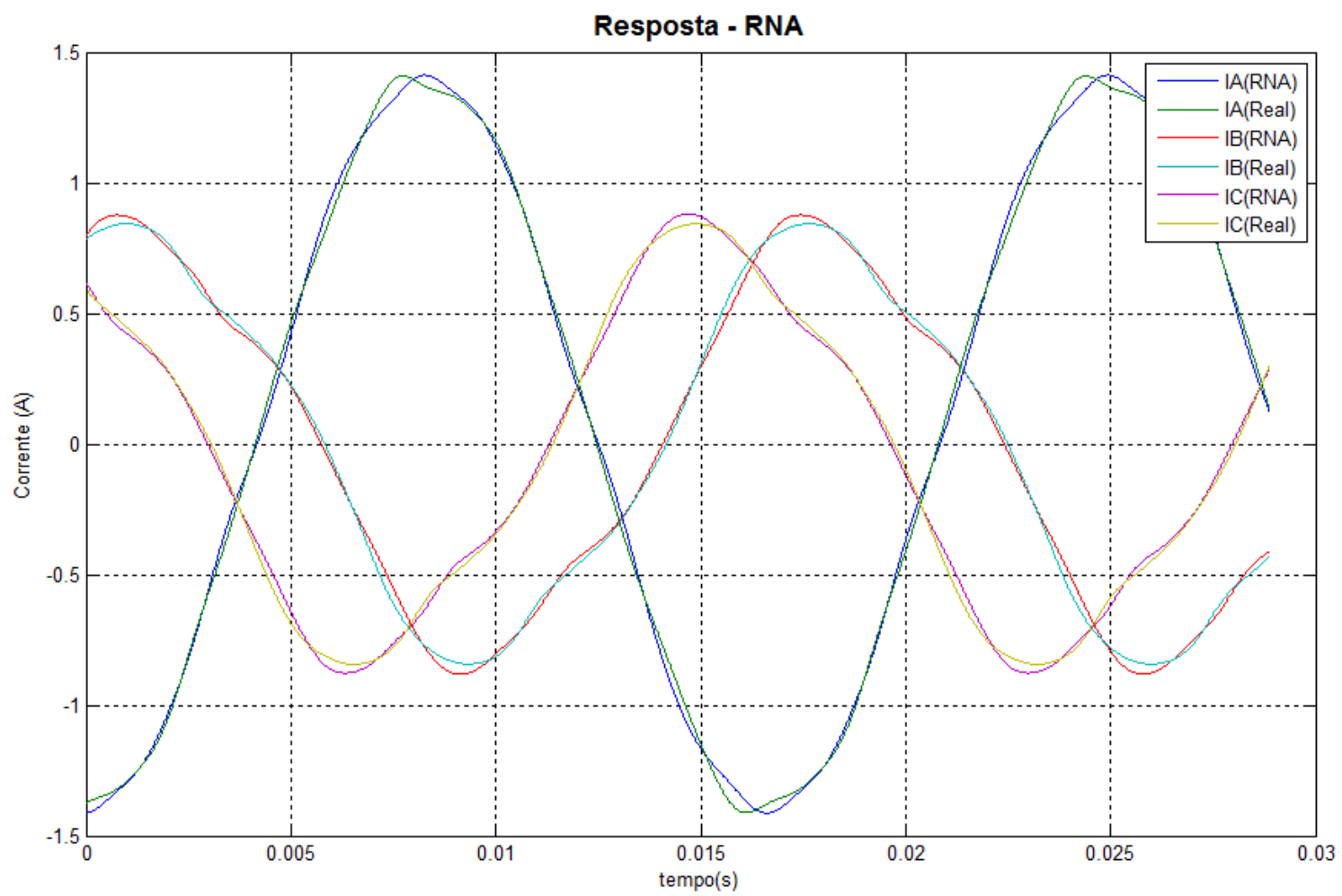

Figura 172 - Conjunto de duas lâmpadas em configuração $\Delta$ assimétrica entre fases (A-B e A-C).

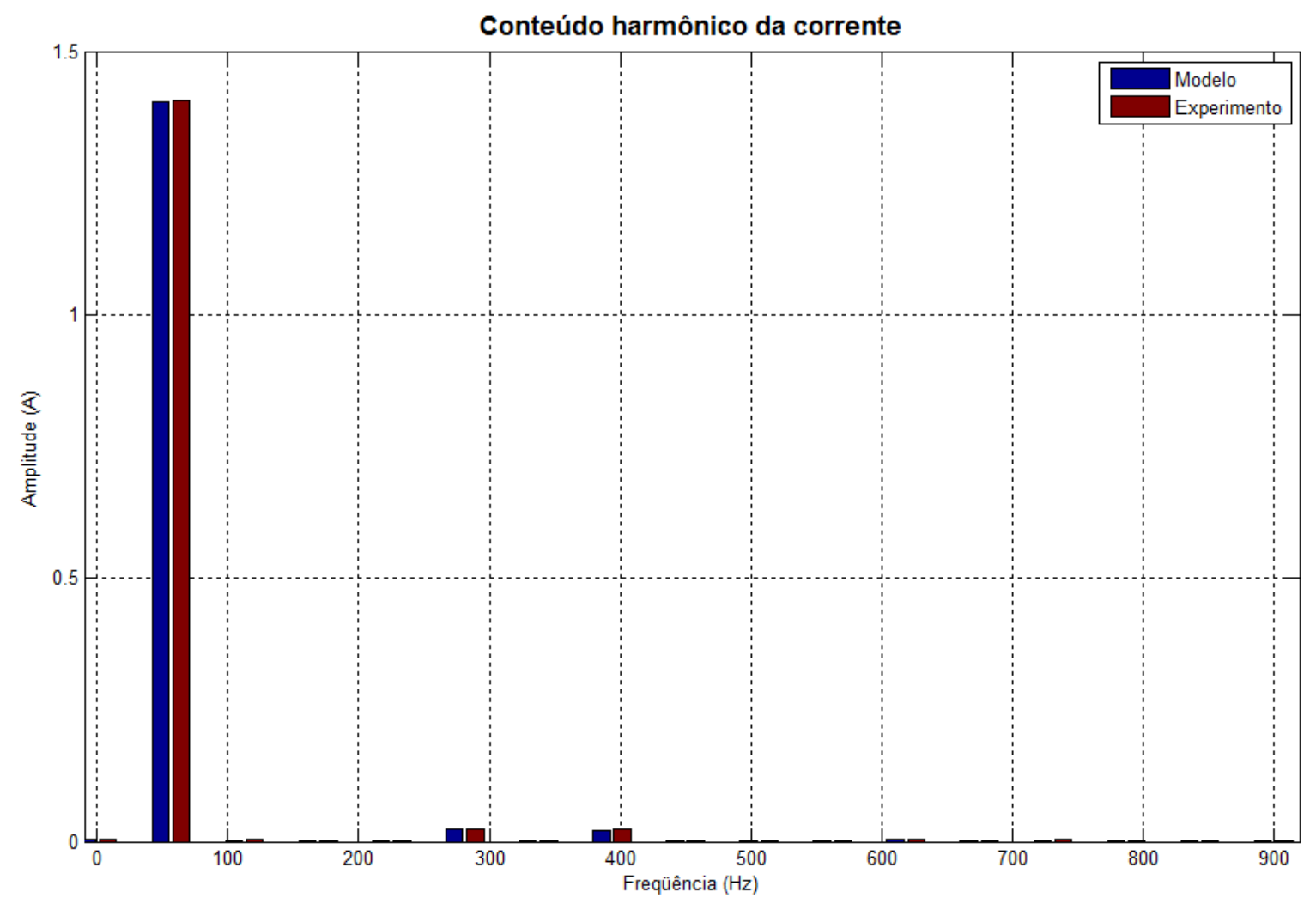

Figura 173 - Conteúdo harmônico da corrente - Fase A (duas lâmpadas, A-B e A-C). 
As fases que alimentam apenas um braço do triângulo incompleto apresentam conteúdo harmônico de corrente conforme o gráfico da Figura 174. Deve ser observado que a superposição de efeitos produz redução na amplitude da $3^{\text {a }}$ harmônica para esta configuração.

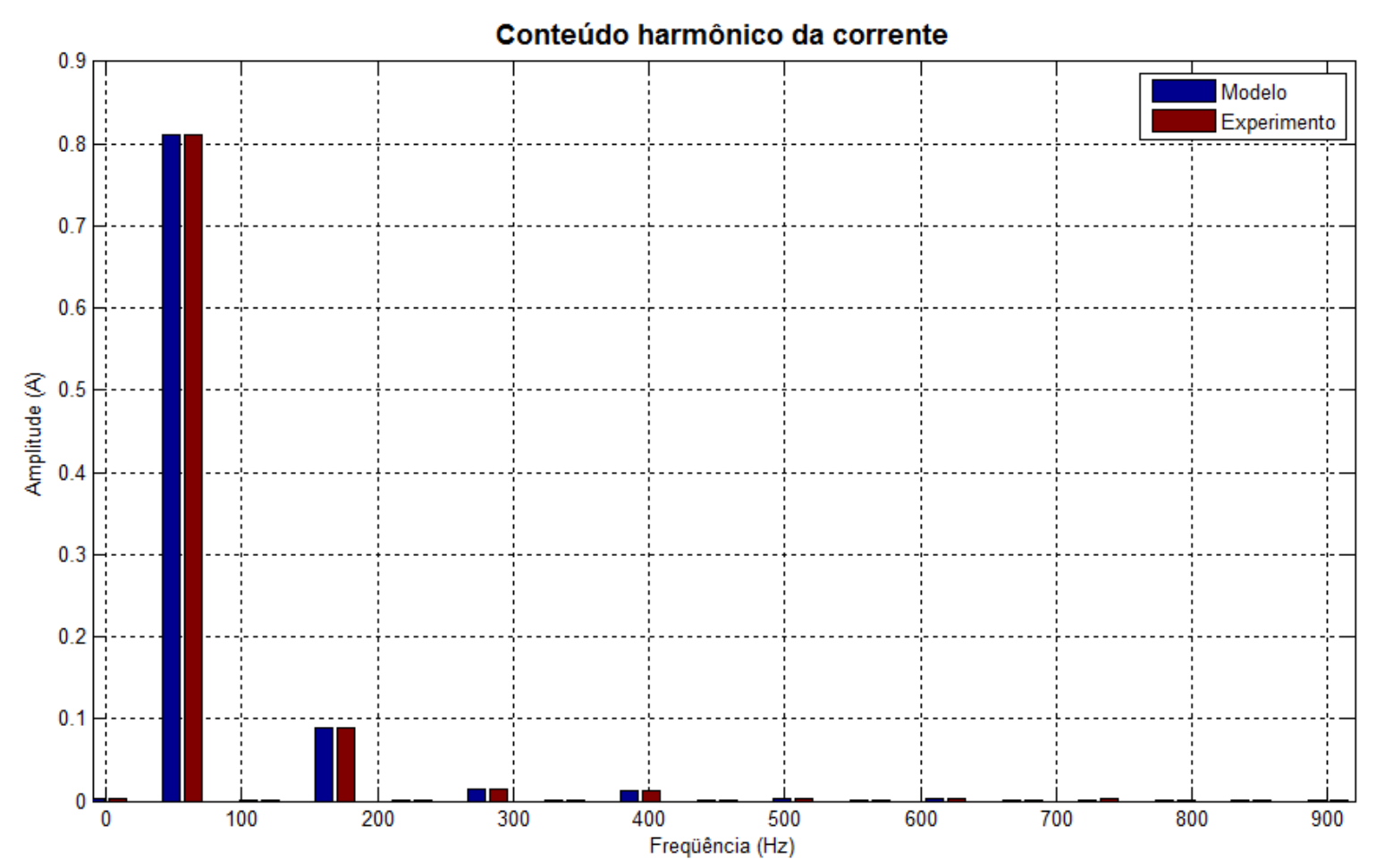

Figura 174 - Conteúdo harmônico da corrente - Fase B e Fase C (duas lâmpadas, A-B e A-C).

Diante dos resultados apresentados, pode-se concluir que o modelo proposto atinge o propósito de representar a lâmpada de descarga modelada em simulações de agrupamentos destes dispositivos.

Os gráficos mostrados apresentam um grande grau de correlação entre os valores obtidos por simulação através de RNAs das lâmpadas de descarga e os dados obtidos experimentalmente, reforçando a validação do trabalho, no sentido de apresentar uma alternativa à modelagem matemática de tais lâmpadas.

A principal vantagem apresentada pelo modelo neural proposto refere-se ao desempenho computacional, quando comparado com o processo de simulação 
adotado no caso do modelo matemático. Este avanço torna possível a simulação de uma grande quantidade de dispositivos associados simultaneamente, o que eventualmente tornaria inviável algumas simulações de longos períodos e de grande quantidade de elementos através de métodos matemáticos convencionais.

São várias as aplicações práticas do modelo obtido, mas podemos destacar as seguintes:

-A determinação do comportamento das correntes de neutro em sistemas de distribuição na presença de lâmpadas de descarga conectadas entre fase e neutro (configuração Y), e

-O estudo de carregamento harmônico de transformadores de distribuição empregados na alimentação dos sistemas de iluminação pública ou em instalações onde se encontrem presentes lâmpadas de descarga.

Nestas duas situações, a utilização do modelo proposto permitiria agilizar procedimentos de dimensionamento dos componentes elétricos da instalação, além de possibilitar simulações com nível de detalhamento significativo relacionado à estabilidade de funcionamento das lâmpadas e ao conteúdo harmônico de corrente introduzido por estes elementos. 


\section{CONCLUSÕES}

O presente trabalho apresentou a metodologia utilizada na obtenção de um modelo de lâmpada de descarga baseado em dados elétricos de desempenho do dispositivo, para aplicação em simulações de sistemas elétricos. Este modelo proposto visa preencher uma lacuna referente à descrição de lâmpadas de descarga no âmbito de simulações de sistemas de distribuição envolvendo distúrbios relacionados à qualidade da energia elétrica.

O emprego de ferramentas de simulação na avaliação de desempenho de sistemas de distribuição de energia elétrica tem se mostrado uma ferramenta bastante eficaz no planejamento e projeto destas instalações. Para que tais sistemas sejam completamente representados, torna-se interessante que cada elemento que o compõe possa ser descrito através de seu modelo, da forma mais fiel possível. 
A obtenção de um modelo de lâmpada de descarga capaz de representar as fases transitórias de operação e sua susceptibilidade aos efeitos da qualidade da energia constitui em importante ferramenta no estudo dos efeitos deste tipo de carga inseridos no sistema de distribuição em baixa tensão. A não-linearidade desta família de dispositivos, embora represente pequenos valores de potência harmônica em elementos isolados, tornam-se cargas poluidoras significativas para o sistema quando consideradas em sua total capacidade instalada.

A gama de distúrbios produzida por esses elementos é especialmente interessante quando se leva em consideração a resposta obtida durante transitórios de alimentação. A característica dinâmica do conteúdo harmônico pode levar inclusive a sobrecargas temporárias dos elementos do sistema de distribuição, ou ainda a falsa indicação de faltas que possam produzir interrupções indesejadas e desnecessárias.

Através de uma montagem experimental e de um sistema de aquisição de dados, os parâmetros de funcionamento do elemento a ser modelado foram armazenados, considerando diversas condições operacionais, e deste modo permitiram a composição de um banco de dados bastante abrangente com relação às características da lâmpada de descarga. Este banco de dados permitiu a avaliação do modelo matemático e posteriormente a obtenção dos parâmetros de treinamento da rede neural artificial que se destina a descrever o modelo proposto.

Em sua fase preliminar, a pesquisa teve foco em uma montagem experimental dotada de um sistema de condicionamento de sinais e de um sistema de aquisição de dados com capacidade de coleta, visualização e armazenamento de dados analógicos em tempo real. Com a interligação do sistema de instrumentação a uma placa de aquisição de dados, os valores das grandezas elétricas envolvidas na operação da 
lâmpada de descarga foram armazenados e o banco de dados obtido serviu como base para o ajuste e validação do modelo matemático empregado como referência.

Os dados coletados foram resultantes de diversos experimentos envolvendo formas diversificadas de alimentação a partir de fonte regulável, no caso dos experimentos relacionados a regime permanente de operação, e a partir de um gerador arbitrário de sinais configurado de forma a introduzir de forma controlada eventos relacionados à qualidade da energia elétrica, permitindo assim o estudo do comportamento do dispositivo em condições transitórias de operação.

A partir dos dados obtidos com o sistema de aquisição e utilizados na comparação com os resultados obtidos pelo modelo matemático, foi possível a realização do treinamento das redes neurais artificiais estruturadas de forma a representar a lâmpada de descarga, em seus aspectos termodinâmicos e elétricos, com o dispositivo operando em regime permanente também quando submetido a distúrbios de alimentação relacionados à qualidade da energia.

O modelo neural assim obtido foi submetido a condições de simulação que reproduziram os experimentos realizados, e os resultados obtidos foram comparados, de forma a permitir a avaliação de desempenho e a similaridade das respostas entre experimento e modelo. Foi observado que o grau de representatividade obtido pelo modelo permite seu emprego como elemento descritivo da classe de lâmpadas de descarga modelada.

Uma análise de desempenho computacional também tornou evidente o ganho obtido com o modelo neural de lâmpada de descarga em relação à simulação empregando o modelo matemático. Este aspecto é especialmente importante em casos onde a simulação envolve conjuntos de dispositivos associados entre si e conectados ao sistema de distribuição. 
As diferenças entre tempos de simulação observadas permitem concluir que o modelo proposto torna possível a execução de simulações em tempo bastante reduzido das situações que anteriormente consumiam considerável tempo quando simuladas através de um modelo matemático.

Salienta-se aqui a importância do modelo obtido com relação à facilidade e agilidade de simulação de grandes conjuntos de lâmpadas, em diversas configurações elétricas, demonstrando a utilidade da ferramenta obtida para o estudo de sistemas elétricos que contenham este tipo de carga em grande quantidade.

A precisão obtida pelo modelo implementado, comprovada pelos ensaios de validação realizados, confirmam sua utilidade como ferramenta computacional para a representação de lâmpadas de descarga inseridas em um sistema elétrico, com elevada capacidade de representar o comportamento deste tipo de dispositivo diante de eventos relacionados a qualidade da energia.

O resultado do estudo mostrou-se, portanto, como valiosa contribuição à representação das lâmpadas de descarga de alta intensidade através de sistemas computacionais, evidenciando a importância o uso das redes neurais artificiais aplicadas a processos de modelagem de dispositivos elétricos.

Como continuidade dos trabalhos aqui apresentados, podemos sugerir o estudo mais aprofundado do modelo com relação à alimentação em condições não-senoidais, que pode ser realizado partindo-se da metodologia proposta, mas com um aprimoramento das redes neurais artificiais empregadas através do treinamento adequado com condições de alimentação apresentando distorção harmônica em seu conteúdo.

Outra sugestão de continuidade da pesquisa seria o estabelecimento de procedimentos para obtenção de modelos de lâmpadas de descarga de outras naturezas, como as lâmpadas de vapor de sódio e as de multivapores metálicos, e o estudo do 
comportamento de um sistema composto por conjuntos de elementos de diferentes características operando frente a distúrbios de qualidade da energia elétrica.

Ainda como sugestão de continuidade das pesquisas, é possível a complementação dos resultados deste trabalho com as relações de desempenho luminotécnico apresentadas pelas lâmpadas, estando estas sujeitas a fenômenos perturbadores relacionados a qualidade de energia. 


\section{REFERÊNCIAS BIBLIOGRÁFICAS}

[1] BOWERS, B. Historical Review of Artificial Light Sources. IEE Proceedings, April 1980, Vol.127, Part A, No 3, p. 127-133.

[2] THE INSTITUTION OF ENGINEERING AND TECHNOLOGY - IET. IET Website. Apresenta informações sobre a história do IET e mantém arquivos relacionados à Engenharia Elétrica. Disponível em: <http://www.theiet.org>. Acesso em: 02 dezembro 2008 .

[3] BOWERS, B. New Lamps For Old: The Story Of Electric Lighting. IEE Review, Volume 41, Issue 6, 16 Nov. 1995, p. 239.

[4] MOREIRA, V. A. Iluminação Elétrica. 2a edição, Editora Edgard Blucher Ltda., SP, 2006.

[5] PHILIPS LIGHTING DIVISION (1986). Manual de Iluminação. 3a ed., Eindhoven, Holanda 
[6] MÄDER, U; HORN, P. A dynamic model for the electrical characteristics of fluorescent lamps. Conference Record of the 1992 IEEE Industry Applications Society Annual Meeting, Volume 2, 4-9 October 1992, p. 1928-1934.

[7] WU, T.-F.; HUNG, J.-C.; YU, T.-H. A PSpice model for fluorescent lamps operated at high frequencies. Proceedings of the 1995 IEEE IECON 21st International Conference on Industrial Electronics, Control, and Instrumentation, 1995. Volume 1, 6-10 November 1995, p. 359-364.

[8] SUN, N; HESTERMAN, B. PSpice high frequency dynamic fluorescent lamp model. Eleventh Annual Applied Power Electronics Conference and Exposition, 1996. APEC'96. Conference Proceedings 1996, Volume 2, 3-7 March 1996, p. 641-647.

[9] RIBARICH, T.J.; RIBARICH, J.J. A new high-frequency fluorescent lamp model. Conference Record of 1998 IEEE Industry Applications Conference, Thirty-Third IAS Annual Meeting, Volume 3, 12-15 October 1998, p. 2094-2098.

[10] WANG, L; KUO, S.C. Modeling of high-frequency fluorescent lamp using EMTP. PESC 98 Record, 29th Annual IEEE Power Electronics Specialists Conference, Volume 2, 17-22 May 1998, p. 1744-1748.

[11] MOO, C.S.; YEN, H.C.; HSIEH, Y.C.; LEE, C.R. A fluorescent lamp model for highfrequency electronic ballasts. Industry Applications Conference, 2000. Conference Record of the 2000 IEEE Industry Applications Conference, Volume 5, 8-12 October 2000, p. 3361-3366.

[12] EMANUEL, A.E.; ORR, J.A. An improved method of simulation of the arc voltagecurrent characteristic. Harmonics and Quality of Power, 2000. Ninth International Conference on Harmonics and Quality of Power Proceedings, Volume 1, 1-4 October 2000, p. 148-154.

[13] CERVI, M.; FORTES, E.C.; SEIDEL, A.R.; BISOGNO, F.E.; DO PRADO, R.N. Fluorescent lamp model employing tangent approximation. Conference Record of the 
2001 IEEE Industry Applications Conference, 2001. Thirty-Sixth IAS Annual Meeting, Volume 2, 30 September - 4 October 2001, p. 1249-1253.

[14] CERVI, M.; SEIDEL, A.R.; BISOGNO, F.E.; DO PRADO, R.N. Fluorescent lamp model based on the equivalent resistance variation. Conference Record of the 2002 IEEE Industry Applications Conference, 2002. 37th IAS Annual Meeting, Volume 1,13-18 October 2002, p. 680-684.

[15] CHEN, M.; QIAN, Z. A fluorescent lamp model based on its physical characteristics. PEDS 2003, The Fifth International Conference on Power Electronics and Drive Systems, Volume 2, 17-20 November 2003, p. 1132-1136.

[16] CARDOSO, H.H.; MARQUES, R.N.; BRAGA, H.A.C. Parameter estimation for a new Pspice fluorescent lamp model based on the exponential function. ISIE '03. 2003. IEEE International Symposium on Industrial Electronics, Volume 1, 9-11 June 2003, p. 500-505.

[17] PERDIGAO, M.; SARAIVA, E.S. MATLAB®-SIMULINK ${ }^{\circledR}$ implementation of the Mader-Horn fluorescent-lamp model: permissible range of the resistive lamp model.; IEEE ICIT '04. 2004 IEEE International Conference on Industrial Technology, Volume 1, 8-10 December 2004, p. 492-497.

[18] WAKABAYASHI, F.T.; DANTAS, F.D.; PINTO, J.O.P.; CANESIN, C.A. Fluorescent Lamp Model based on Equivalent Resistances, Considering the Effects of Dimming Operation. PESC '05. IEEE 36th Power Electronics Specialists Conference, 1616 June 2005, p.1136-1141.

[19] LOO, K. H. ; STONE, D.A.; TOZER, R.C.; DEVONSHIRE, R. A dynamic conductance model of fluorescent lamp for electronic ballast design simulation. IEEE Transactions on Power Electronics, Issue 5, Volume 20, September 2005, p. 1178-1185. 
[20] YAN, W; TAM, E.; HUI, S.Y. A Semi-Theoretical Fluorescent Lamp Model for Time-Domain Transient and Steady- State Simulations. IEEE Transactions on Power Electronics. Issue 6, Volume 22, November 2007, p.2106-2115.

[21] HOLlOWAY, A. J.; STONE, D. A.; TOZER, R. C. A hybrid, physical-behavioral fluorescent lamp model suitable for use in Spice and SIMULINK ${ }^{\circledR}$. 2007 European Conference on Power Electronics and Applications, 2-5 Sept. 2007, p. 1-9.

[22] ERENTURK, K. Dynamic Characterization of a UV Fluorescent Lamp, IEEE Transactions on Plasma Science, Issue 2, Part 2, Volume 36, April 2008, p. 519523.

[23] HERRICK, P. R. Mathematical Models for High-Intensity Discharge Lamps. IEEE Transactions on Industry Applications, Volume IA-16, Issue 5, September 1980, p. 648654.

[24] RIOS, S.; CASTANEDA, R.; VEAS, D. Harmonic distortion and power factor assessment in city street gas discharge lamps. IEEE Transactions on Power Delivery, Volume 11, Issue 2, April 1996, p. 1013-1020.

[25] MIELCZARSKI, W.; SZCZEPANIK, J.; LAWRANCE, W.B. Reduction of harmonic currents generated by discharge lamp systems. Generation, Transmission and Distribution IEE Proceedings, Volume 145, Issue 4, July 1998, p. 363-368.

[26] SHVARTSAS, M.; BEN-YAAKOV, S. A SPICE compatible model of high intensity discharge lamps. Power Electronics Specialists Conference, 1999. PESC 99. 30th Annual IEEE, Volume 2, 27 June-1 July 1999, p. 1037-1042.

[27] STAMBOUli, M.; CHARRADA, K.; COSTACHE, C.; DAMELINCOURT, J.-J. Modeling the warm-up phase of a high-pressure-lamps lighting network. IEEE Transactions on Plasma Science, Volume 27, Issue 3, June 1999, p.646-654. 
[28] YAN, W; HUI, S.Y.R.; CHUNG, H.; CAO, X.H. Genetic algorithm optimized highintensity-discharge lamp model. Electronics Letters, Volume 38, Issue 3, 31 January 2002, p.110-112.

[29] YAN, W.; HUI, S.Y.R. A universal PSpice model for HID lamps. Conference Record of the Industry Applications Conference, 2002. 37th IAS Annual Meeting, Volume 2, 13-18 October 2002, p. 1475-1482.

[30] ZOUIDI, A.; STAMBOULI, M.; CHAARI, A.; FNAIECH, F. Nonlinear continuous time modeling of a high pressure mercury vapor discharge lamp using feed forward backpropagation neural networks. IEEE International Conference on Industrial Technology, 2004. IEEE ICIT '04. 2004, Volume 2, 8-10 December 2004, p. 634-638

[31] ALONSO, J.M.; DALLA COSTA, M.A.; CARDESIN, J.; MARTIN-RAMOS, J.A.; GARCIA-GARCIA, J. Small-signal modeling of discharge lamps through step response and its application to low-frequency square-waveform electronic ballasts. Twenty-First Annual IEEE Applied Power Electronics Conference and Exposition, 2006. APEC '06. 1923 March 2006, p. 1021-1027.

[32] BLANCO, C.; ANTON, J.C.; ROBLES, A.; FERRERO, F.J.; CAMPO, J.C.; GONZALEZ, M.; ZISSIS, G. A Discharge Lamp Model Based on Lamp Dynamic Conductance. IEEE Transactions on Power Electronics, Part Special: Section on Lighting Applications, Volume 22, Issue 3, May 2007, p. 727-734

[33] MANANA, M.; ORTIZ, A.; RENEDO, C.; PEREZ, S.; DELGADO, F.; AZCONDO, F.J.; DIAZ, F.J.; BRANAS, C.; CASANUEVA, R. Comparison of flicker sensitivity in HPS lamps. IEEE International Symposium on Industrial Electronics, 2007. ISIE 2007. 4-7 June 2007, p. 3002-3007.

[34] FABELA, J.L.T.; PACHECO-SOTELO, J.O.; PACHECO, M.P.; BENITEZ-READ, J.S.; LOPEZ-CALLEJAS, R.; ZISSIS, G.; BHOSLE, S. Modeling the Voltage Drop Across the Cathode Sheath in HPS. IEEE Transactions on Plasma Science, Volume 35, Issue 4, Part 3, August 2007, p. 1104-1110. 
[35] ABDEL-GAWAD, A.F. Studying the impact of different lighting loads on both harmonics and power factor. 42nd International Universities Power Engineering Conference, 2007. UPEC 2007. 4-6 Sept. 2007, p. 109-114.

[36] DUGAN, R. C.; MCGRANAGHAN, M. F.; SANTOSO, S., BEATY, H. W. (2002). Electrical power systems quality. New York, McGraw-Hill.

[37] OLIVEIRA, J. C. Projeto SIDAQEE - Capítulo II - Qualidade da Energia Elétrica: Definição e Análise dos Itens de Qualidade. Uberlândia: Universidade Federal de Uberlândia.

[38] IEEE. Recommended Practice for Monitoring Electric Power Quality. IEEE,vi, 70 p. 1995.

[39] BOLLEN, M. H. J. Understanding power quality problems : voltage sags and interruptions. New York: IEEE Press, 543 p. 1999.

[40] ANEEL. AGÊNCIA NACIONAL DE ENERGIA ELÉTRICA: PRODIST Procedimentos de Distribuição de Energia Elétrica no Sistema Elétrico Nacional. Módulo 8 - Qualidade da Energia Elétrica. 70p. 01 Janeiro 2011. Disponível em: $<$ http://aneel.gov.br>. Acesso em: 09 Abril 2011.

[41] CALIFORNIA INSTRUMENTS. (2005). I Series/Ix Series AC power source user manual. Revision Z, November 2005. 340p. 2005.

[42] DOS SANTOS, A.L.; ROMARIZ, A.R.S.; DE CARVALHO, P.H.P. Neural model of electrical devices for circuit simulation. Proceedings of Microwave and Optoelectronics Conference, 1997, Volume 1, 1997, p. 253 - 258.

[43] ALIPPI, C.; PIURI, V.; Neural modeling of dynamic systems with non-measurable state variables. IEEE Transactions on Instrumentation and Measurement. Volume 48 , Issue 6, 1999, p. 1073 - 1080 
[44] GHOMI, M.; SAREM, Y.N.; KERMAJANI, H.R.; POSHTAN, J. Synchronous generator nonlinear model identification using wiener-neural model. Universities Power Engineering Conference, 2007, 2007, p. 236 - 241

[45] BERTHOUZE, L.; CHAVAND, F.; BARRET, C.; A camera neural model . IEEE International Conference on Systems, Man, and Cybernetics, 1996, Volume 3, 1996, p. $2124-2126$

[46] YIFAN GAO; CONG GU. A large signal elements' simulation of GaAs MESFET using neural network model. Proceedings of Computational Electromagnetics and Its Applications, 1999. (ICCEA '99), 1999, p. 593 - 596

[47] ABDEEN, M.; YAGOUB, M.C.E.. Nonlinear and Isothermal Neural-Based Modeling of the Dual Gate MESFET. Canadian Conference on Electrical and Computer Engineering, 2007. CCECE 2007., 2007 , p. 103 - 106

[48] MILOVANOVIC, BRATISLAV; STANKOVIC, ZORAN; MILIJIC, MARIJA. Hybrid Empirical-Neural Model of Microwave Slotted Patch Antennas. 8th Seminar on Neural Network Applications in Electrical Engineering, 2006. NEUREL 2006, 2006, p. $181-184$ 


\section{APÊNDICE A: UMA INTRODUÇÃO ÀS REDES NEURAIS ARTIFICIAIS}

\section{A.1.Aspectos gerais das Redes Neurais Artificiais}

O cérebro humano é considerado o mais fascinante processador biológico existente com capacidade de processamento paralelo, sendo composto por aproximadamente $10^{11}$ células neuronais. Todo o funcionamento, o comportamento e o raciocínio do organismo estão relacionados ao funcionamento dessas pequenas células. Os neurônios estão conectados uns aos outros através de sinapses e juntos formam uma grande rede chamada rede neural biológica.

Tal rede neural biológica é formada por uma teia extremamente complexa de neurônios. A comunicação entre os neurônios é realizada através de impulsos químicos e internamente aos neurônios através de impulsos elétricos. Quando impulsos químicos são recebidos, o neurônio os processa, e se o resultado do processamento for maior que um determinado limite de ativação, o mesmo dispara internamente um impulso 
elétrico que produz moléculas neurotransmissoras que fluem do corpo celular para o axônio, que por sua vez pode ou não estar conectado a um dendrito de outra célula. Essas moléculas neurotransmissoras geram impulsos químicos que são processados pelo neurônio seguinte.

A Figura a. 1 [A.1] apresenta o esboço de uma célula nervosa ou neurônio. Os seus principais componentes são:

a) Os dendritos, que têm por função receber os estímulos transmitidos pelos outros neurônios;

b) O corpo do neurônio, também chamado de soma, que é responsável por coletar e combinar informações vindas de outros neurônios;

c) O axônio, que é constituído de uma fibra tubular que pode alcançar até alguns metros, e é responsável por transmitir os estímulos para outras células.

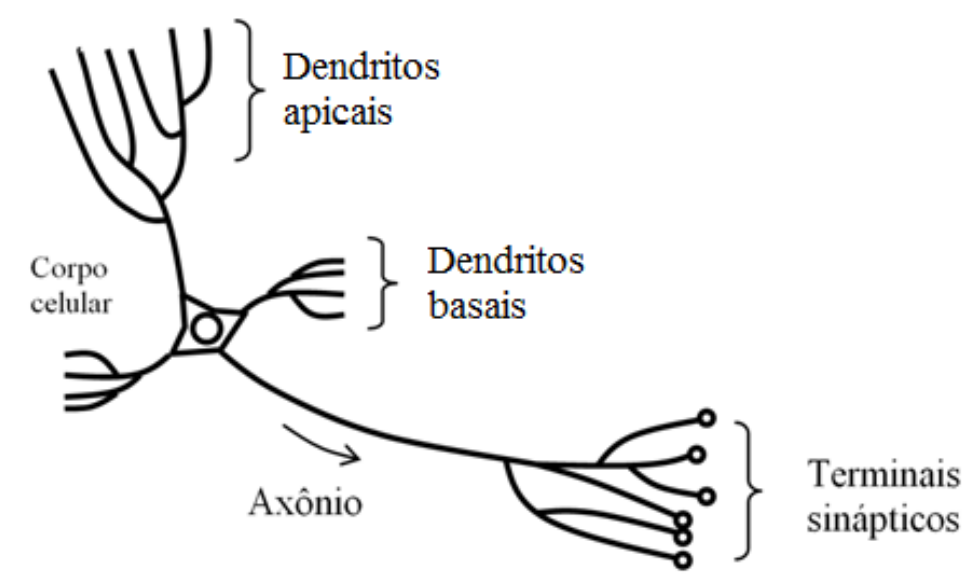

Figura a. 1 - Principais componentes do neurônio biológico [A.1].

Os primeiros trabalhos sobre a neurocomputação datam de 1943, em artigo publicado por McCulloch e Pitts apud McCulloch [A.2], em que sugeriam a construção de uma máquina baseada ou inspirada no cérebro humano. Muitos outros 
artigos e livros surgiram desde então, porém poucos resultados foram obtidos. Em 1949, Donald Hebb escreveu o livro intitulado "The Organization of Behavior", onde sustentava a idéia de que o condicionamento psicológico clássico está presente em qualquer parte dos animais, pelo fato de que essa é uma propriedade de neurônios individuais [A.1]. Suas idéias não eram completamente novas, mas Hebb foi o primeiro a propor uma lei de aprendizagem específica para as sinapses dos neurônios. Esse primeiro passo serviu de inspiração para que muitos outros pesquisadores perseguissem a mesma idéia.

O primeiro neurocomputador a obter sucesso (Mark I Perceptron) surgiu em 1957-1958, criado por Frank Rosenblatt. Devido a profundidade de seus estudos, suas contribuições técnicas e de sua maneira moderna de pensar, muitos o consideram como o fundador da neurocomputação na forma em que hoje se apresenta. Seu interesse inicial para a criação do Perceptron era o reconhecimento de padrões [A.3].

Após Rosenblatt, Bernard Widrow [A.4], desenvolveu um novo tipo de redes neurais chamado de ADALINE (abreviação de ADAptive LINear Element), e mais tarde propôs a sua generalização multidimensional, o MADALINE (Múltipla ADALINE). Essa rede era equipada com uma nova lei de aprendizado, conhecida como a "Regra Delta", que posteriormente foi generalizada para redes com modelos neurais mais elaborados [A.5].

Infelizmente, os anos seguintes foram marcados por um entusiasmo exagerado de muitos pesquisadores, que passaram a publicar vários materiais de divulgação que faziam uma previsão pouco confiável para a época, sobre máquinas tão poderosas como o cérebro humano e que surgiriam em um curto espaço de tempo. Em 1969, Minsky e Papert [A.6] publicaram o livro "Perceptrons - An Introduction to Computational Geometry", onde os autores argumentaram enfaticamente quanto às limitações básicas dos perceptrons isolados, a começar pela impossibilidade de se 
implementar regras lógicas tão simples como o ou-exclusivo. Historicamente, a publicação desse livro paralisou, a partir de 1970, as pesquisas na área de redes neurais.

Um período de pesquisa silenciosa seguiu-se durante o período de 1969 a 1982, quando poucos trabalhos foram publicadas em virtude dos fatos ocorridos anteriormente. No entanto, as pesquisas efetuadas neste período permitiram estabelecer novamente um campo concreto para o renascimento da área.

Na década de 1980, diversos pesquisadores publicaram inúmeras propostas para a exploração de desenvolvimentos em redes neurais, bem como suas aplicações. Esta retomada de interesse em redes neurais artificiais teve origem em diversos fatores, entre os quais ressaltam-se melhores conhecimentos da estrutura real do cérebro, disponibilidade de computadores com maior capacidade de cálculo e sobretudo o desenvolvimento de novos algoritmos de aprendizado. Nesse período, John Hopfield, renomado físico de reputação mundial, se interessou pela neurocomputação, e escreveu o clássico artigo "Neural network and physical systems with emergent collective computational abilities" [A.7], que percorreu o mundo conclamando grande número de cientistas a se unirem nessa nova área emergente. Outros pesquisadores também continuaram as pesquisas sobre o assunto, entre eles destacaram-se Teuvo Kohonen (Finlândia), Edoardo Caianiello (Itália), Stephen Grossberg e James Anderson (EUA) e Kunuhito Fukushima (Japão).

Apesar de um grande número de pesquisadores da área terem aderido à área de RNA pela influência de Hopfield, foi em 1986 que esse campo de pesquisa se expandiu com a publicação do livro Parallel Distributed Processing, de Rumelhart, Hinton e Willians [A.5], onde os autores desenvolveram o algoritmo de aprendizado backpropagation para as redes do tipo Perceptron com estruturas multicamadas. Paralelamente, os fundamentos teóricos foram melhorados, principalmente 
por Grossberg [A.8],[A.9], Hopfield [A.7] e Kohonen [A.10], que também contribuíram para o ressurgimento da área.

Desde então, as redes neurais artificiais vêm sendo aplicadas nas mais diversas áreas, tais como reconhecimento de padrões [A.11], processamento de imagens, sistemas de controle [A.12], robótica [A.13] e identificação de sistemas [A.14].

\section{A.2.O neurônio artificial}

As redes neurais artificiais (RNA) consistem em um método de solucionar problemas relacionados à engenharia e ciências por intermédio de algoritmos simples que simulam o cérebro humano, inclusive seu comportamento, ou seja, aprendendo, errando e fazendo descobertas. Além disso, RNA são técnicas computacionais que apresentam um modelo inspirado na estrutura neural de organismos inteligentes e que adquirem conhecimento através da experiência. Ao contrário do cérebro humano que contém muitos bilhões de neurônios, as redes neurais artificiais podem conter centenas ou milhares de unidades de processamento.

De uma forma geral, a operação de uma célula artificial da rede neural se resume em:

a) Sinais são apresentados à entrada;

b) Cada sinal é multiplicado por um peso sináptico que indica sua influência na saída da unidade;

c) A soma ponderada dos sinais é realizada para produzir um nível de atividade;

d) Se esse nível excede um limite de ativação (threshold) a unidade produz uma saída.

Da mesma forma que uma rede neural biológica é composta por bilhões de células nervosas, a rede neural artificial também é formada por unidades que nada mais são que pequenos módulos que simulam o funcionamento de um neurônio. 
Esses módulos devem funcionar de acordo com os elementos em que foram inspirados, recebendo e retransmitindo informações.

O modelo de neurônio mais simples e que engloba as principais características de uma rede neural biológica, paralelismo e alta conectividade, foi proposto por McCulloch e Pitts [A.2] e está ilustrado na Figura a. 2.

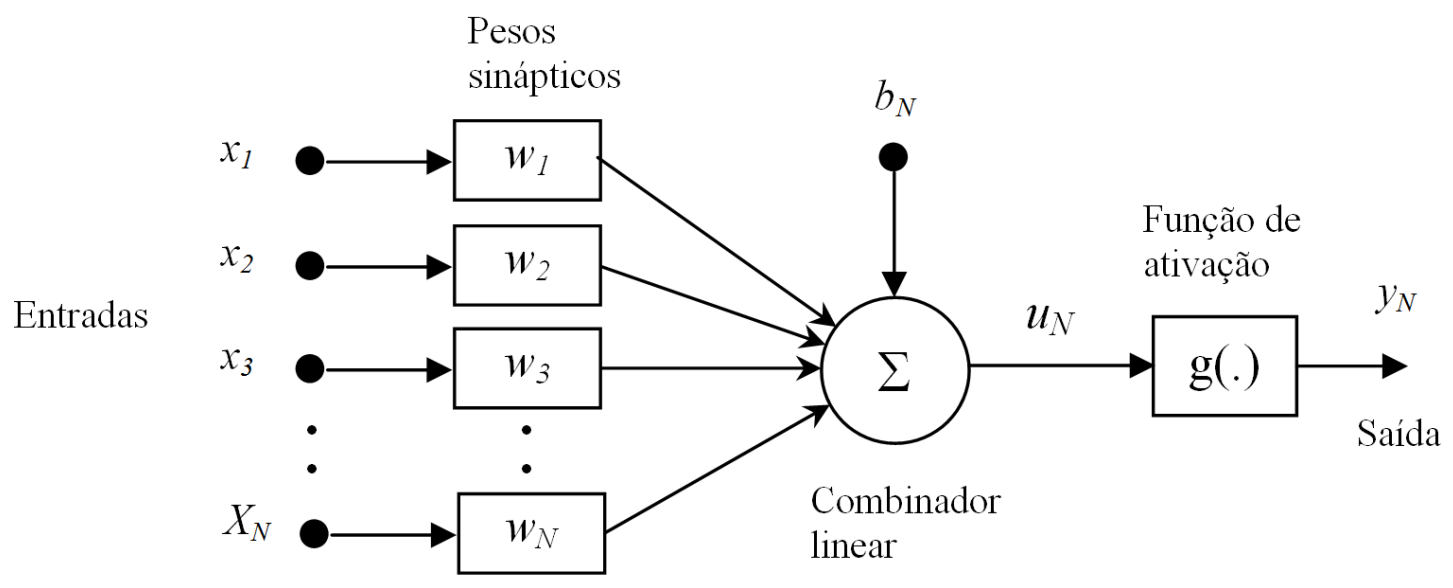

Figura a. 2 - Modelo geral do neurônio artificial [A.2].

O comportamento do neurônio artificial é definido pelas equações

(a.1) e (a.2) :

$$
\begin{gathered}
u=\sum_{i=1}^{N} w_{i} \cdot x_{i}+b \\
y=g(u)
\end{gathered}
$$

Onde:

$x_{1}, x_{2, \ldots} x_{N}$ são os sinais de entrada;

$w_{1}, w_{2}, \ldots w_{N}$ são os pesos ou conexões sinápticas;

$b_{N}$ é o limiar de ativação do neurônio;

$u_{N}$ é a saída do combinador linear;

$g(u)$ é a função de ativação (limita a saída do neurônio);

$y \quad$ é o sinal de saída do neurônio. 
As funções de ativação são escolhidas em função do problema que a rede esteja tratando. Do ponto de vista funcional, a função de ativação $g($.) processa o conjunto de entradas recebidas e o transforma em estado de ativação. Normalmente, o estado de ativação do neurônio pode assumir os seguintes valores binários $\left(\begin{array}{lll}0 & \text { e } & 1\end{array}\right)$, bipolares ( -1 e 1 ) e reais.

As funções de ativação mais típicas são:

a) Função degrau

Nesse tipo de ativação, mostrado na Figura a. 3, tem-se:

$$
g(u)=\left\{\begin{array}{lll}
1 & \text { se } & u \geq 0 \\
0 & \text { se } & u<0
\end{array}\right.
$$

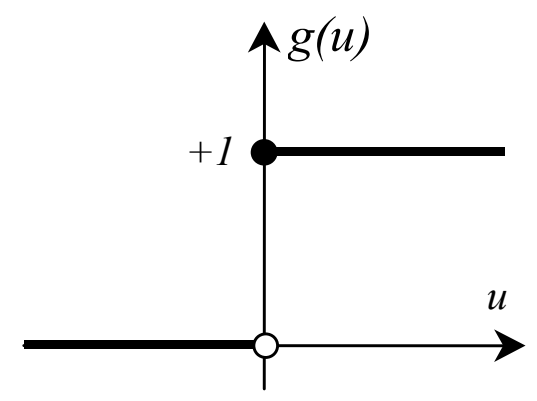

Figura a. 3 - Função Degrau [A.1].

A saída do neurônio assumirá o valor 1 se o nível de atividade interna total do neurônio for não-negativo, caso contrário a saída do neurônio assumirá o valor 0 .

b) Função degrau (bipolar)

Nesse tipo de ativação, mostrado na Figura a. 4, tem-se:

$$
g(u)=\left\{\begin{array}{ccc}
1 & \text { se } & u \geq 0 \\
-1 & \text { se } & u<0
\end{array}\right.
$$


A saída do neurônio assumirá o valor 1 se o nível de atividade interna total do neurônio for não-negativo, caso contrário, a saída do neurônio assumirá o valor -1 .

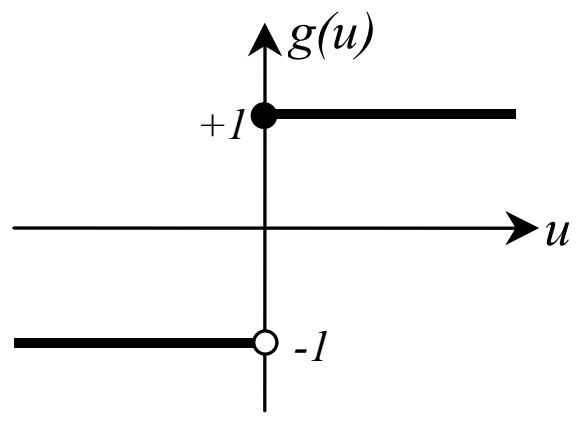

Figura a. 4 - Função Degrau (bipolar) [A.1].

c) Função rampa

Nesse tipo de ativação, mostrado na Figura a. 5, tem-se:

$$
g(u)=\left\{\begin{array}{ccc}
1 & \text { se } & u \geq a \\
u & \text { se } & -a<u<a \\
-1 & \text { se } & u \leq-a
\end{array}\right.
$$

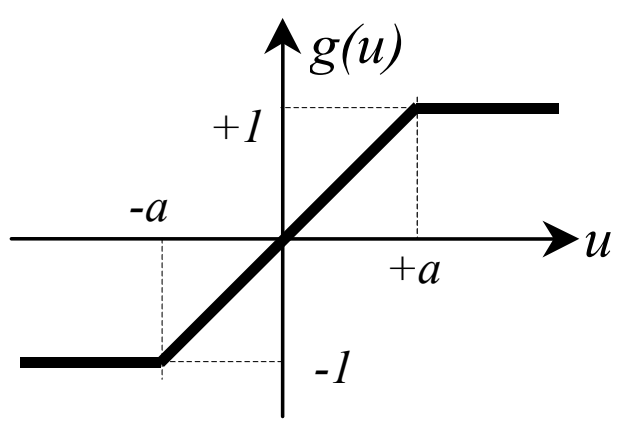

Figura a. 5 - Função Rampa [A.1].

Para essa função de ativação, a saída do neurônio pode assumir valores positivos e negativos no domínio de -1 a 1 , e no intervalo definido em $\{-a, a\}$, a saída assume o valor da função $g(u)=u$.

d) Função sigmóide 
Para a função sigmóide, ilustrada na Figura a. 6, tem-se:

$$
g(u)=\frac{1}{1+e^{(-\beta u)}}
$$

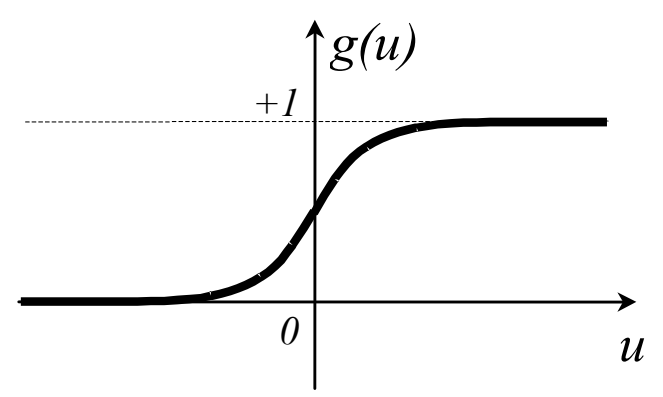

Figura a. 6 - Função Sigmóide [A.1].

Na função anterior, $\beta$ é o parâmetro que define a inclinação (ganho) da função sigmóide. Nesse tipo de função, a saída do neurônio assumirá valores reais entre 0 e 1.

e) Função tangente hiperbólica

Para a função do tipo tangente hiperbólica, ilustrada no gráfico da

Figura a. 7, tem-se:

$$
g(u)=\tanh (u)=\frac{1-e^{-u}}{1+e^{-u}}
$$

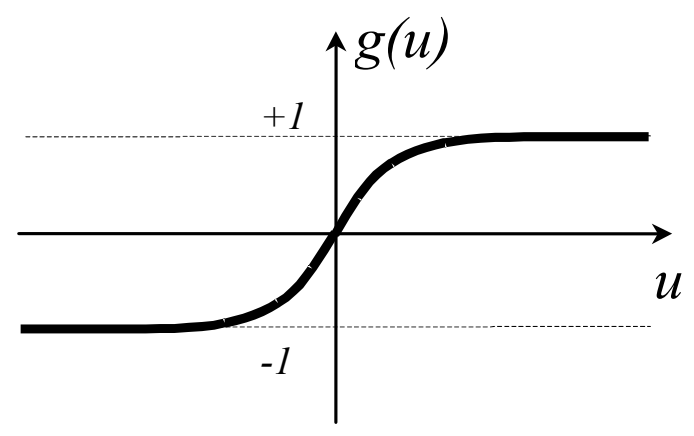

Figura a. 7 - Função tangente hiperbólica [A.1].

Para esta função de ativação, a saída do neurônio pode assumir valores reais (negativos e positivos) no domínio de -1 a 1 . 


\section{A.3.Topologia de redes neurais artificiais}

A forma pela qual os neurônios estão interligados está associado com algoritmo de aprendizagem para treinar a rede. Deve ser lembrado que uma RNA aprende através da experiência.

As arquiteturas neurais são tipicamente organizadas em camadas, com unidades que podem estar conectadas às unidades da camada posterior.

Conforme ilustrada na Figura a. 8, as camadas de uma rede neural são usualmente classificadas em três grupos:

a) Camada de Entrada: onde os padrões são apresentados à rede;

b) Camadas Intermediárias ou Escondidas: onde é feita a maior parte do processamento. Através das conexões ponderadas, essas camadas podem ser consideradas como extratoras de características;

c) Camada de Saída: onde o resultado final é concluído e apresentado.

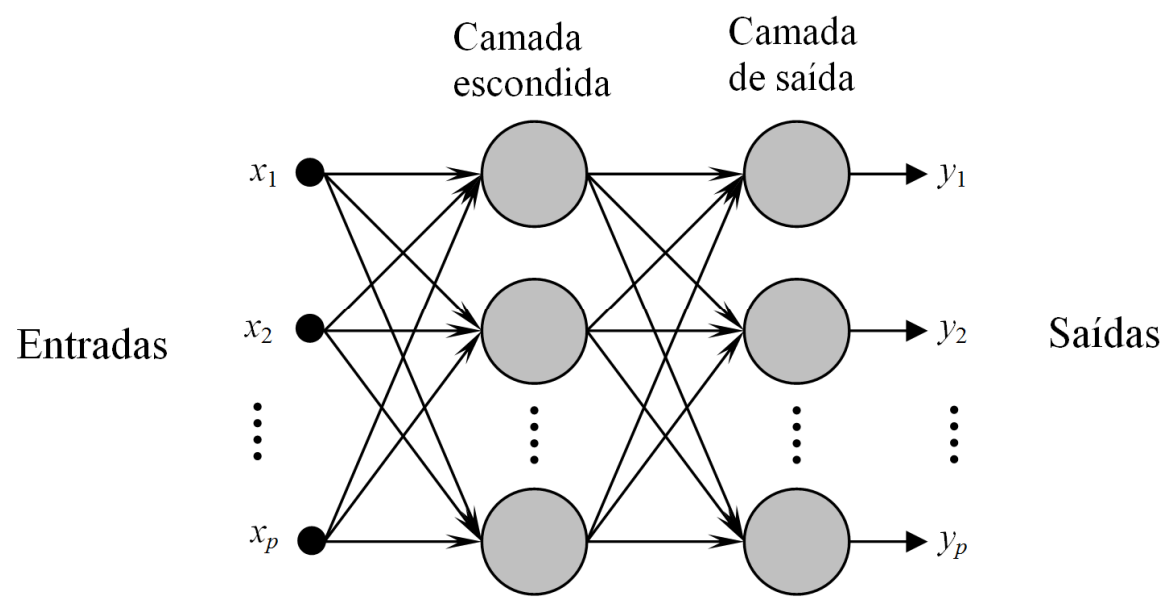

Figura a. 8 - Organização em camadas da redes neurais artificiais [A.1].

Redes neurais são também classificadas de acordo com a arquitetura (estrutura) em que foram implementadas, características de seus nós, regras de treinamento e tipos de modelos de neurônio empregados. Do ponto de vista topológico, 
Haykin [A.1] classifica as RNA em três classes de arquiteturas fundamentalmente distintas:

a) Redes alimentadas adiante com única camada (Feedforward - Camada Única)

São redes neurais com uma camada de entrada e uma única camada de neurônios que é a própria camada de saída (Figura a. 9). Suas principais aplicações são em memória associativas e no reconhecimento de padrões. Nesse tipo de redes, tem-se o modelo do Perceptron e o Adaline.

b) Redes alimentadas adiante com múltiplas camadas (Feedforward - Multicamadas)

Esse tipo de rede distingue da anterior pela presença de uma ou mais camadas escondidas de neurônios (Figura a. 10). Por exemplo, os neurônios que recebem sinais de excitação do meio externo estão na camada de entrada; os neurônios que estão na saída representam a camada de saída e os neurônios intermediários estão nas camadas escondidas.

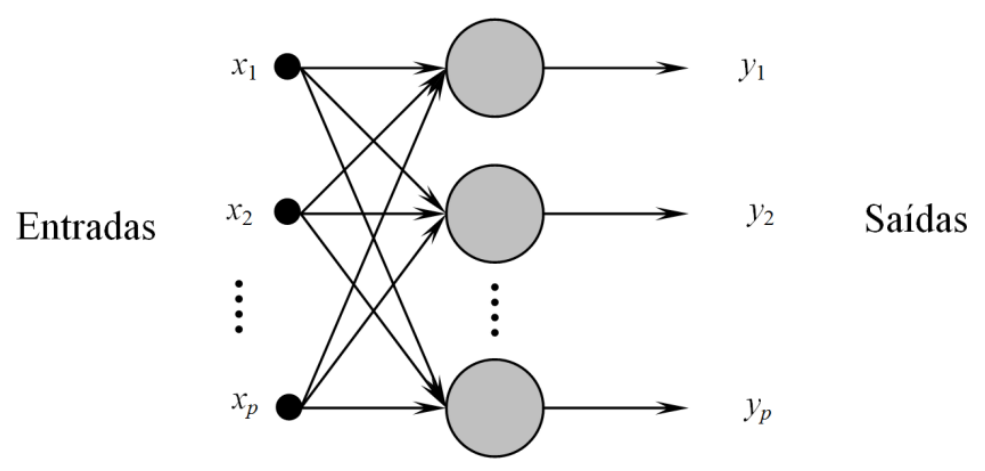

Figura a. 9 - Rede alimentada adiante com camada única [A.1].

As principais aplicações são em reconhecimento de padrões, aproximador universal de funções e em controle, como descrito em [A.14] e [A.15]. Nesse 
tipo de rede tem-se o Madaline, o Perceptron Multicamadas e o de Função Base Radial (RBF).

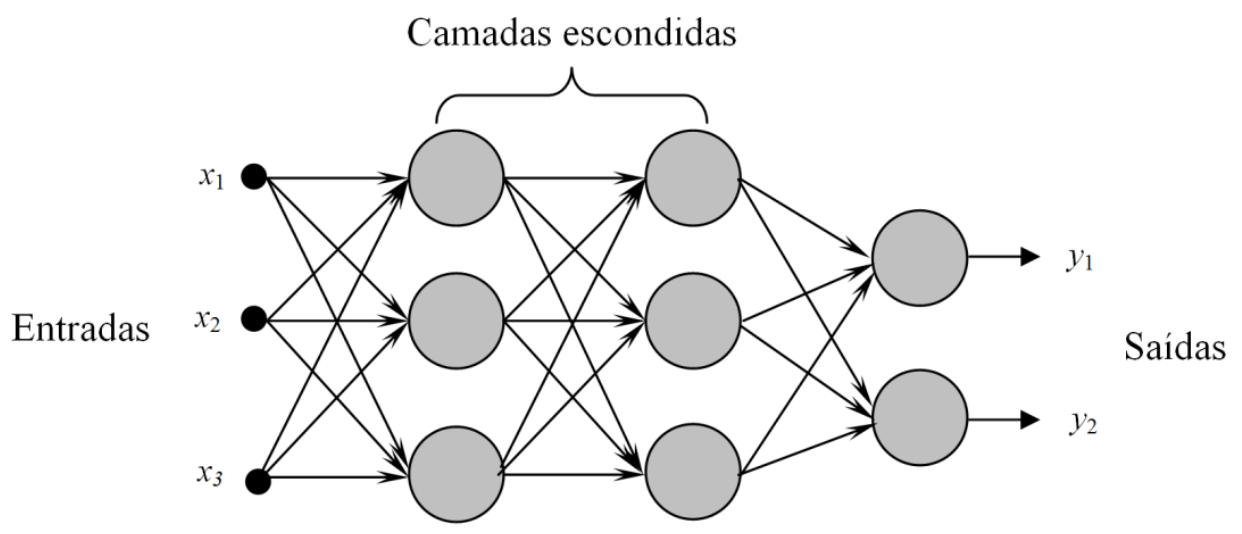

Figura a. 10 - Redes alimentadas adiante com múltiplas camadas [A.1].

c) Redes Recorrentes

Uma rede recorrente distingue-se de uma rede neural alimentada adiante por ter pelo menos um laço de realimentação entre neurônios de camadas diferentes (Figura a. 11). Suas principais aplicações são em sistemas dinâmicos, memórias associativas, previsão e estimação, otimização e no controle. Nesse tipo de rede tem-se o modelo de Hopfield e o Perceptron com realimentação.

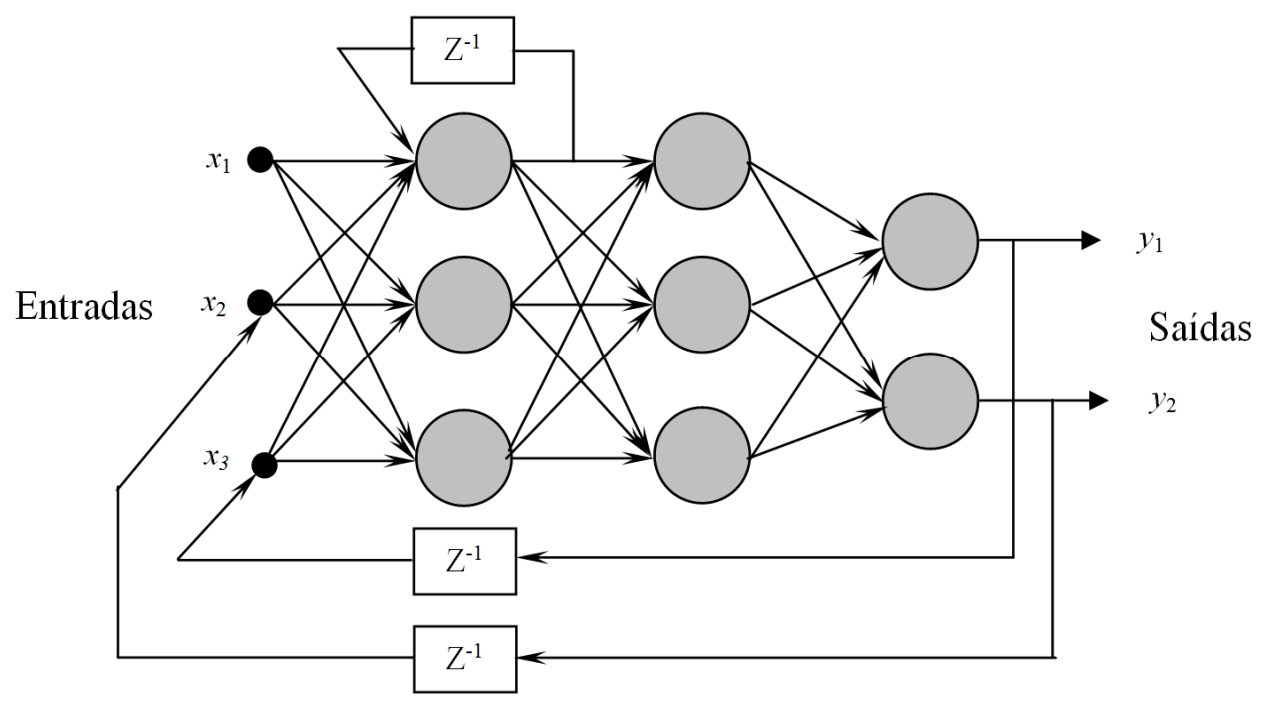

Figura a. 11- Exemplo de rede recorrente [A.1]. 
A rede neural passa por um processo de treinamento a partir dos casos reais conhecidos, adquirindo, a partir daí, a sistemática necessária para executar adequadamente o processo desejado dos dados fornecidos. Sendo assim, a rede neural é capaz de extrair regras básicas a partir de dados reais (conhecimento implícito), diferindo da computação convencional, onde é necessário um conjunto de regras rígidas pré-fixadas e algoritmos (conhecimento explícito).

\section{A.4. Treinamento das redes neurais artificiais}

\section{A.4.1.Aspectos gerais}

A propriedade mais importante das redes neurais é a habilidade de aprender a partir da "experiência". Esse processo de aprendizagem ou treinamento é realizado através de um processo iterativo (algoritmo de treinamento) no qual os pesos sinápticos são ajustados até que um conjunto de entradas produza um conjunto de saídas desejado [A.1].

Um algoritmo de treinamento consiste em um conjunto de regras bem definidas visando a solução de um problema de aprendizagem. Existem diversos tipos de algoritmos de aprendizagem, cada qual específico para uma determinada concepção arquitetural. Esses algoritmos diferem entre si principalmente pelo modo como os pesos são ajustados.

O treinamento das RNAs pode ser classificado em duas categorias

distintas:

a) Treinamento supervisionado

O aprendizado decorre do fornecimento de conjuntos de entrada associados aos respectivos conjuntos de saída. Dessa forma, quando um vetor de entrada é fornecido para a rede, essa calcula o vetor de saída que é comparada com o respectivo 
vetor de saída fornecido, produzindo, então, um erro. Esse erro é retropropagado na rede de forma a ajustar os pesos sinápticos e limiares de acordo com algum algoritmo que minimize esse erro.

Nessa categoria destacam-se as redes Perceptron [A.1], as redes de função de Base Radial (RBF) [56] e as redes Learning Vector Quantization (LVQ) [A.10].

b) Treinamento não supervisionado

Nesse processo de aprendizado, somente os conjuntos de entrada são fornecidos à rede, de forma que uma unidade de saída é treinada a fim de reconhecer grupos de padrões entre as entradas. $\mathrm{O}$ algoritmo de treinamento ajusta os pesos da rede de forma a produzir saídas relativas às particularidades estatísticas dos conjuntos de treinamento. A própria rede cria representações internas para codificar características de entradas e criar grupos (classes) automaticamente. As principais redes que utilizam essa categoria são as redes Counter-Propagation [A.16] e as redes de Kohonen [A.10].

O treinamento de uma rede neural artificial transcorre segundo um encadeamento definido de etapas, as quais são descritas a seguir.

1) Etapa 1: Escolha das variáveis de contorno

A primeira etapa envolve um estudo minucioso do problema a ser abordado identificando as variáveis que afetam o comportamento do processo. Deve ser verificada a viabilidade e o custo de cada variável a ter seus valores coletados para, então, efetuar a aquisição dos dados.

2) Etapa 2: Aquisição de dados

Essa etapa requer uma análise cuidadosa sobre o problema visando minimizar ambiguidades e erros nos dados. Além disso, os dados coletados devem ser significativos e cobrir amplamente o domínio do problema; não devem cobrir apenas as 
operações normais ou rotineiras, mas também as exceções e as condições nos limites do domínio do processo.

3) Etapa 3: Separação em conjuntos de treinamento e validação

Normalmente, os dados coletados devem ser separados em duas categorias: dados de treinamento, que serão utilizados no processo de treinamento da rede; e dados de validação, que serão utilizados para verificar o seu desempenho sob condições reais de utilização. Após a separação desses conjuntos, eles são geralmente colocados em ordem aleatória para prevenção de tendências associadas à ordem de apresentação dos dados. Pode ser necessário pré-processar esses dados, através de normalizações, escalonamentos e conversões de formato para torná-los mais apropriados ao treinamento da rede neural.

4) Etapa 4: Configuração da rede

Genericamente, a configuração da rede pode ser dividida em três etapas:

a) Seleção do paradigma neural apropriado à aplicação;

b) Determinação da topologia da rede a ser utilizada - o número de camadas, o número de unidades em cada camada e da função de ativação;

c) Determinação de parâmetros do algoritmo de treinamento e funções de ativação. Esse passo tem um grande impacto na performance do sistema resultante.

Deve ser observado que a tarefa de configuração da rede é mais uma arte do que uma ciência, significando que muitos dos fatores envolvidos na configuração são resultados da experiência particular de cada projetista. Entretanto, 
existem métodos heurísticos que melhoram significativamente o desempenho dos algoritmos de treinamento.

5) Etapa 5: Aprendizagem ou treinamento

Nessa etapa, seguindo o algoritmo de treinamento para o paradigma neural escolhido, serão ajustados os pesos das conexões sinápticas. Faz-se necessário nessa fase considerar alguns aspectos:

a) Iniciação dos pesos e limiares

Assumindo que não exista nenhuma informação prévia, os pesos e limiares iniciais devem originar-se de uma distribuição uniforme cuja média é zero e a variância é escolhida para que o desvio padrão dos campos locais induzidos dos neurônios recaia entre as partes linear e saturada da função de ativação sigmóide.

b) Critérios de parada do treinamento

Existem vários métodos para a determinação do momento em que o treinamento deve ser encerrado. Os critérios mais utilizados são:

a) encerrar o treinamento após $\mathrm{N}$ ciclos ou épocas de treinamento;

b) encerrar o treinamento após o erro quadrático médio ficar abaixo de um valor pré-estabelecido;

c) combinação dos métodos anteriores.

De uma forma geral, o treinamento deve ser encerrado quando a rede apresentar uma boa generalização, ou seja, diz-se que a rede generaliza bem quando o mapeamento entrada-saída computado pela rede for correto (ou aproximadamente correto) para os dados do conjunto de teste.

6) Etapa 6: Validação

Após o treinamento deve-se, de acordo com um certo critério, submeter a rede neural a um processo para a determinação do desempenho, utilizando o 
conjunto de dados para validação. Assim, é verificada se a rede neural tornou-se "bemtreinada", de modo que tenha aprendido o suficiente sobre o passado para generalizar o futuro.

Denomina-se ainda ciclo de aprendizado ou épocas de treinamento como sendo uma apresentação de todos os $N$ pares (entrada e saída) do conjunto de treinamento no processo de aprendizado. As correções dos pesos num ciclo podem ser executadas de dois modos. Pelo modo sequencial cuja correção dos pesos acontece a cada apresentação à rede de um exemplo do conjunto de treinamento. Cada correção de pesos baseia-se somente no erro do exemplo apresentado naquela iteração. Assim, em cada ciclo ocorrem $N$ ajustes dos pesos sinápticos. Um outro método para apresentação de dados de treinamento é no modo Lote (Batch), onde apenas uma correção é feita por época de treinamento. Todos os exemplos do conjunto de treinamento são apresentados à rede, seu erro médio é calculado e a partir desse erro fazem-se as correções dos pesos.

\section{A.4.2.Processos de treinamento das redes neurais perceptron multicamadas}

\section{a) Algoritmo backpropagation}

O treinamento supervisionado de Redes Neurais Artificiais do tipo Perceptron multicamadas (com uma única camada escondida) utilizado neste trabalho é baseado no algoritmo backpropagation proposto por Rumelhart et al. [A.5].

Durante o treinamento com o algoritmo backpropagation, a rede opera em uma sequência de dois passos:

1. Passo para a frente (propagação)

Um padrão de treinamento é apresentado à camada de entrada da rede. Realiza-se a computação, camada por camada, até que a resposta seja produzida pela camada de saída. 
2. Passo para trás (retropropagação)

A saída obtida é comparada à saída desejada para esse padrão particular. Se essa não estiver correta, o erro é calculado. O erro é então retropropagado a partir da camada de saída até a camada de entrada, e os pesos das conexões das unidades das camadas internas vão sendo modificados conforme o erro é retropropagado [A.1]. Esse processo é repetido para todos os vetores de entrada da rede até que o erro quadrático médio das saídas alcance um valor aceitável.

A derivação do algoritmo backpropagation, para redes Perceptron com uma única camada escondida é realizada conforme a notação apresentada na Figura a. 12.

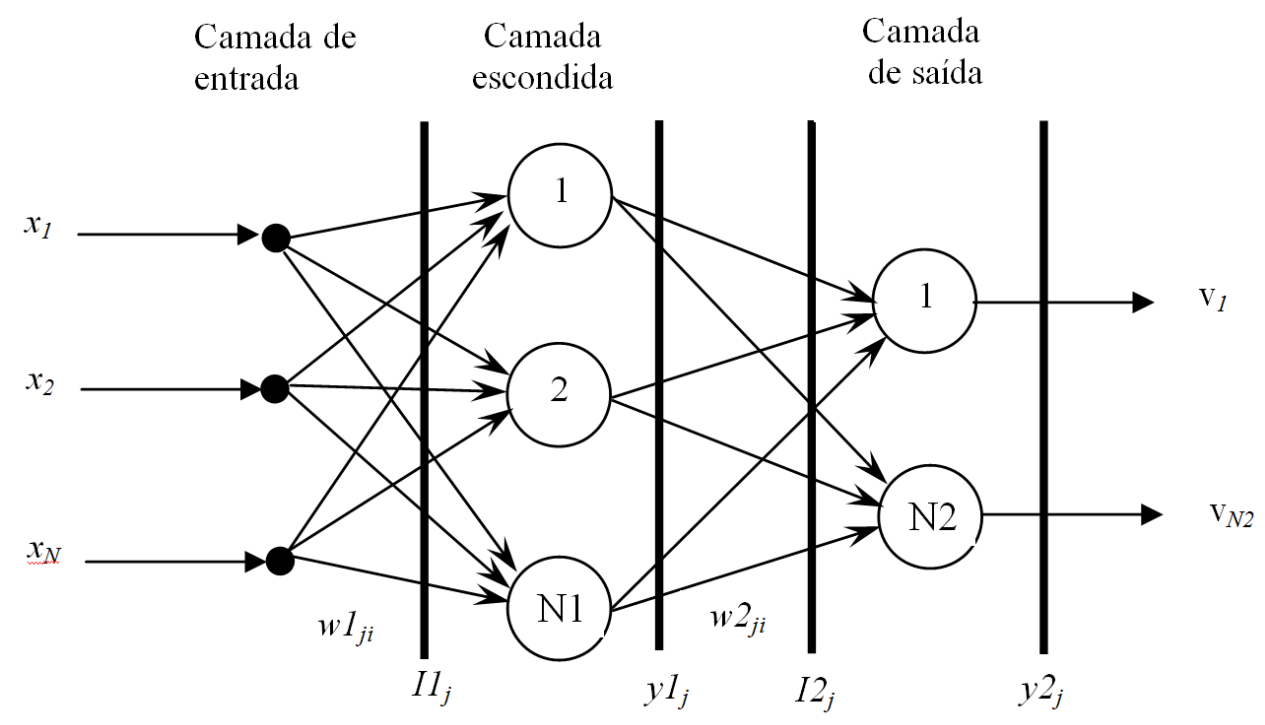

Figura a. 12 - Diagrama esquemático da rede "Perceptron" multicamadas [A.1].

A partir da estrutura apresentada na Figura a. 12, adota-se a seguinte convenção:

a) O parâmetro $N$ especifica o número de variáveis que constitui cada vetor de entrada;

b) O parâmetro N1 especifica a quantidade de neurônios utilizados na camada neural escondida; 
c) O parâmetro N2 especifica o número de variáveis que constitui cada vetor de saída, e também indica a quantidade de neurônios utilizados na camada neural de saída;

d) $\mathrm{O}$ vetor $x=\left[x_{1}, x_{2}, \ldots, x_{N}\right]^{T}$ denota o vetor de entrada da rede;

e) $\mathrm{O}$ vetor $y=\left[y_{1}, y_{2}, \ldots, y_{N}\right]^{T}$ denota o vetor de saída da rede;

f) O símbolo $w 1_{j i}$ fornece o valor do peso sináptico conectando o $j$-ésimo neurônio da camada (1) ao $i$-ésimo neurônio da camada (1-1);

g) $\mathrm{O}$ símbolo $I 1_{j}$ fornece o valor correspondente à entrada ponderada do $j$-ésimo neurônio da camada (1), ou seja:

$$
\begin{gathered}
I 1_{j}=\sum_{i=0}^{N} w 1_{j i} \cdot x_{i} ; j=1, \ldots, N 1 \\
I 2_{j}=\sum_{i=0}^{N} w 2_{j i} y 1_{i} ; j=1, \ldots, N 2
\end{gathered}
$$

O símbolo $y l_{j}$ fornece o valor correspondente à saída do $j$-ésimo neurônio da camada $(l)$, ou seja:

$$
\begin{gathered}
y 1_{j}=g\left(I 1_{j}\right) ; j=1, \ldots, N 2 \\
y 2_{j}=g\left(I 2_{j}\right) ; j=1, \ldots, N 2
\end{gathered}
$$

As funções erro quadrático $E(k)$ e erro quadrático médio $E_{M}$, as quais são utilizadas como critérios de desempenho e parada do processo de treinamento, são definidas por:

a) Erro quadrático

Essa função fornece o valor instantâneo da soma dos erros quadráticos (em relação ao $k$-ésimo padrão de treinamento) de todos os neurônios da camada de saída da rede, ou seja:

$$
E(k)=\frac{1}{2} \sum_{j=1}^{N 2}\left(d_{j}(k)-y 2_{j}(k)\right)^{2}
$$


onde $d_{j}(k)$ é o valor da saída desejada no neurônio $j$ em relação ao $k$-ésimo padrão de entrada.

b) Erro quadrático médio

$$
\text { O erro quadrático médio ou energia média do erro quadrático }
$$

médio é obtido a partir da soma dos erros quadráticos relativos a todos os padrões de entrada utilizados no conjunto de treinamento da rede, ou seja:

$$
E_{M}=\frac{1}{p} \sum_{k=1}^{p} E(k)
$$

onde o parâmetro $p$ especifica o número de padrões de treinamento ou a quantidade de vetores de entrada.

Para um dado conjunto de treinamento, $E_{M}$ representa a função de custo como uma medida de desempenho do aprendizado. Assim, o objetivo do processo de aprendizagem, utilizando o algoritmo backpropagation, consiste em ajustar as matrizes de pesos $\boldsymbol{W} \boldsymbol{1}$ e $\boldsymbol{W} \boldsymbol{2}$ da rede a fim de minimizar a função de custo $E_{M}$.

O processo de ajuste dos pesos é feito de forma elegante retropropangando-se os sinais de erro através da rede. Para uma rede Perceptron com uma única camada escondida, o processo pode ser dividido em duas fases como descrito a seguir:

\section{Fase 1: Ajuste dos pesos dos neurônios da camada de saída}

O ajuste dos pesos dos neurônios da camada de saída é feita a partir da minimização da função erro quadrático em relação aos pesos $w 2_{j i}$.

Utilizando a regra de diferenciação em cadeia, tem-se:

$$
\nabla E_{\left(w 2_{j i}\right)}=\frac{\partial E}{\partial w 2_{j i}}=\frac{\partial E}{\partial y 2_{j}} \cdot \frac{\partial y 2_{j}}{\partial I 2_{j}} \cdot \frac{\partial I 2_{j}}{\partial w 2_{j i}}
$$

onde: 


$$
\begin{gathered}
\frac{\partial I 2_{j}}{\partial w 2_{j i}}=y 1_{i} \\
\frac{\partial y 2_{j}}{\partial I 2_{j}}=g^{\prime}\left(I 2_{j}\right) \\
\frac{\partial E}{\partial y 2_{j}}=-\left(d_{j}-y 2_{j}\right)
\end{gathered}
$$

O símbolo $d_{j}$ indica a resposta desejada para o neurônio $j$ e $g^{\prime}($.$) a$ derivada da função de ativação associada ao neurônio. A derivada parcial $\partial E / \partial w 2_{j i}$ representa um "fator de sensibilidade", determinando a direção de busca no espaço de pesos, para o peso sináptico $w 2_{j i}$.

Substituindo as expressões (a.15), (a.16) e (a.17) na expressão

(a.14), obtém-se:

$$
\frac{\partial E}{\partial w 2_{j i}}=-\left(d_{j}-y 2_{j}\right) \cdot g^{\prime}\left(I 2_{j}\right) \cdot y 1_{i}
$$

O ajuste deverá ser feito na direção oposta ao gradiente a fim de minimizar a função erro quadrático, ou seja:

$$
\begin{gathered}
\Delta w 2_{j i}=-\eta \cdot \frac{\partial E}{\partial w 2_{j i}} \\
\Delta w 2_{j i}=-\eta \cdot \delta 2_{j} \cdot y 1_{i}
\end{gathered}
$$

ou ainda:

$$
w 2_{j i}(t+1)=w 2_{j i}(t)+\eta \cdot \delta 2_{j} \cdot y 1_{i}
$$

onde $\eta$ é uma constante que determina a taxa de aprendizagem (tamanho do passo em direção ao ponto de mínimo da função erro quadrático) do algoritmo backpropagation, e $\delta 2_{j}$ denota o gradiente local (o qual aponta para as modificações necessárias nos pesos sinápticos) sendo auto-definido por: 


$$
\delta 2_{j}=\left(d_{j}-y 2_{j}\right) \cdot g^{\prime} \cdot\left(I 2_{j}\right)
$$

Fase 2: Ajuste dos pesos dos neurônios da camada intermediária

$\mathrm{O}$ ajuste dos pesos dos neurônios da camada intermediária $\left(1^{\mathrm{a}}\right.$ camada neural) é feito normalmente a partir da função erro quadrático em relação aos pesos $w 1_{j i}$. Utilizando a regra de diferenciação em cadeia, tem-se:

$$
\nabla E_{\left(w 1_{j i}\right)}=\frac{\partial E}{\partial w 1_{j i}}=\frac{\partial E}{\partial y 1_{j}} \cdot \frac{\partial y 1_{j}}{\partial I 1_{j}} \cdot \frac{\partial I 1_{j}}{\partial w 1_{j i}}
$$

onde:

$$
\begin{gathered}
\frac{\partial I 1_{j}}{\partial w 1_{j i}}=x_{i} \\
\frac{\partial y 1_{j}}{\partial I 1_{j}}=g^{\prime}\left(I 1_{j}\right) \\
\frac{\partial E}{\partial y 1_{j}}=\sum_{k=1}^{N 2} \frac{\partial E}{\partial I 2_{k}} \cdot \frac{\partial I 2_{k}}{\partial y 1_{j}}=\sum_{k=1}^{N 2} \frac{\partial E}{\partial I 2_{k}} \cdot \frac{\partial\left(\sum_{k=1}^{N 2} w 2_{k j} \cdot y 1_{j}\right)}{\partial y 1_{j}}
\end{gathered}
$$

Inserindo o resultado da multiplicação de (a.16) por (a.17) em

(a.26), tem-se:

$$
\frac{\partial E}{\partial y 1_{j}}=-\sum_{k=1}^{N 2} \delta 2_{k} \cdot w 2_{k j}
$$

Substituindo (a.24), (a.25) e (a.27) em (a.23), tem-se:

$$
\frac{\partial E}{\partial w 1_{j}}=\left(-\sum_{k=1}^{N 2} \partial 2_{k} \cdot w 2_{k j}\right) \cdot g^{\prime}\left(I 1_{j}\right) \cdot x_{i}
$$

Novamente, o ajuste deve ser feito na direção oposta ao gradiente.

Dessa forma, a equação (a.28) torna-se:

$$
\Delta w 1_{j i}=-\eta \cdot \frac{\partial E}{\partial w 1_{j i}}
$$




$$
\Delta w 1_{j i}=-\eta \cdot \delta 1_{j} \cdot x_{i}
$$

ou ainda:

$$
w 1_{j i}(t+1)=w 1_{j i}(t)+\eta \cdot \delta 1_{j} \cdot x_{i}
$$

onde $\delta 1_{\mathrm{j}}$ denota o gradiente local e é auto-definido por:

$$
\delta 1_{j}=g^{\prime}\left(I 1_{j}\right) \cdot\left(\sum_{k=1}^{N 2} \delta 2_{k} \cdot w 2_{k j}\right)
$$

São aplicadas as Fases 1 e 2 deste processo sequencialmente, até erro quadrático médio da rede atingir valores aceitáveis, estipulados em função de cada aplicação específica.

\section{A.4.3.Algoritmo de Levenberg-Marquardt}

Como descrito no subitem a), o algoritmo backpropagation ajusta os valores das matrizes de pesos $\boldsymbol{W} 1$ e $\boldsymbol{W} 2$ em relação à direção oposta do gradiente da função erro quadrático. Entretanto, a utilização desse algoritmo na prática tende a convergir muito lentamente, exigindo assim um elevado esforço computacional. Para contornar esse problema várias técnicas de otimização têm sido incorporadas ao algoritmo "backpropagation" a fim de reduzir o seu tempo de convergência e diminuir o esforço computacional exigido pelo mesmo. Dentre as técnicas de otimização mais utilizadas para esse propósito destaca-se o algoritmo de Levenberg-Marquardt [A.17].

O algoritmo de Levenberg-Marquardt é uma técnica baseada no método dos mínimos quadrados para modelos não-lineares que pode ser incorporada ao algoritmo "backpropagation" a fim de aumentar a eficiência do processo de treinamento.

Nesse algoritmo, as funções erro quadrático e erro quadrático médio fornecidas respectivamente nas equações (a.12) e (a.13) podem ser expressas conjuntamente por: 


$$
\begin{gathered}
V=\frac{1}{2 p} \cdot \sum_{k=1}^{p} \sum_{j=1}^{N 2}\left[d_{j}(k)-y 2_{j}(k)\right]^{2} \\
V=\frac{1}{2 p} \sum_{k=1}^{p}(d(k)-y 2(k))^{T} \cdot(d(k)-y 2(k) \\
V=\frac{1}{2 p} \sum_{k=1}^{p} e^{T}(k) \cdot e(k)
\end{gathered}
$$

onde o termo $e(k)=d(k)-y 2(k)$ denota o vetor erro em relação ao

$k$-ésimo padrão de treinamento. Para um padrão $k$ específico o erro é dado por:

$$
V=\frac{1}{2} e^{T}(k) \cdot e(k)
$$

Dessa forma, enquanto o algoritmo backpropagation é um método de descida no gradiente da função erro quadrático, o algoritmo de Levenberg-Marquardt é uma aproximação do Método de Newton [A.18].

Nesse método a minimização de uma função $V(z)$ em relação a um vetor paramétrico $z$ é dada por:

$$
\Delta z=-\left[\nabla^{2} V(z)\right]^{-1} \cdot \nabla V(z)
$$

onde $\nabla^{2} V(z)$ denota a matriz Hessiana e $\nabla V(z)$ a matriz Jacobiana de $V(z)$. Assumindo-se que $V(z)$ é uma função que executa soma de funções quadráticas da forma:

$$
V(z)=\sum_{i=1}^{N} e_{i}^{2}(z)
$$

Então, a partir da equação anterior, pode ser mostrado que:

$$
\begin{gathered}
\nabla V(z)=J^{T}(z) \cdot e(z) \\
\nabla^{2} V(z)=J^{T}(z) \cdot J(z)+S(z)
\end{gathered}
$$

onde $J(z)$ é a matriz Jacobiana definida por: 


$$
J(z)=\left[\begin{array}{l}
\frac{\partial e_{1}(z)}{\partial z_{1}} \frac{\partial e_{1}(z)}{\partial z_{2}} \cdots \frac{\partial e_{1}(z)}{\partial z_{N}} \\
\frac{\partial e_{2}(z)}{\partial z_{1}} \frac{\partial e_{2}(z)}{\partial z_{2}} \cdots \frac{\partial e_{2}(z)}{\partial z_{N}} \\
\vdots \\
\frac{\partial e_{N}(z)}{\partial z_{1}} \frac{\partial e_{N}(z)}{\partial z_{2}} \cdots \frac{\partial e_{N}(z)}{\partial z_{N}}
\end{array}\right]
$$

e $S(z)$ é uma função dada por:

$$
S(z)=\sum_{i=1}^{N} e_{i}(z) \nabla^{2} e_{i}(z)
$$

Inserindo-se os resultados de (a.39) e (a.40) em (a.37) obtém-se a equação iterativa do método de Newton, ou seja:

$$
\nabla z=\left[J^{T}(z) \cdot J(z)+S(z)\right]^{-1} \cdot J^{T}(z) \cdot e(z)
$$

No algoritmo de Levenberg-Marquardt a equação (a.43) é modificada da seguinte forma:

$$
\left.\nabla z=\left[J^{T}(z) \cdot J(z)+\mu I\right)\right]^{-1} \cdot J^{T}(z) \cdot e(z)
$$

onde $I$ é a matriz identidade e $\mu$ é um parâmetro que ajusta a taxa de convergência do algoritmo de Levenberg-Marquardt.

Portanto a característica principal desse algoritmo é a computação da matriz Jacobiana. Para o processo de treinamento das redes neurais do tipo Perceptron multicamadas (PMC) ilustrada na Figura a. 12, a matriz Jacobiana (a.41) passa então a ser re-escrita em função dos pesos sinápticos da rede, ou seja:

$$
J(w)=[J(w 1) \mid J(w 2)]_{(p) x(N . N 1+N 1 . N 2)}
$$

onde: 


$$
w=[w 1 \mid w 2]=\left[\begin{array}{ccc}
w 1_{1,1} \ldots w 1_{1, N} & w 1_{2,1} \ldots w 1_{2, N} \ldots & w 1_{N 1,1} \ldots w 1_{N 1, N} \\
w 2_{1,1} \ldots w 2_{1, N 1} & w 2_{2,1} \ldots w 2_{2, N 1} \ldots & w 2_{N 2,1} \ldots w 2_{N 2, N 1}
\end{array}\right]_{(N . N 1+N 1 . N 2) x(1)}^{T}
$$

$$
\begin{aligned}
& J(w 1)=\left[\begin{array}{ccccc}
\frac{\partial e(1)}{\partial w 1_{1,1}} \ldots \frac{\partial e(1)}{\partial w 1_{1, N}} & \frac{\partial e(1)}{\partial w 1_{1,1}} \ldots \frac{\partial e(1)}{\partial w 1_{1, N}} & \ldots & \frac{\partial e(1)}{\partial w 1_{N 1,1}} \ldots \frac{\partial e(1)}{\partial w 1_{N 1, N}} \\
\frac{\partial e(2)}{\partial w 1_{1,1}} \ldots \frac{\partial e(2)}{\partial w 1_{1, N}} & \frac{\partial e(2)}{\partial w 1_{2,1}} \ldots \frac{\partial e(2)}{\partial w 1_{2, N}} & \ldots & \frac{\partial e(2)}{\partial w 1_{N 1,1}} \ldots \frac{\partial e(2)}{\partial w 1_{N 1, N}} \\
\vdots & \vdots & \vdots & \vdots \\
\frac{\partial e(p)}{\partial w 1_{1,1}} \ldots \frac{\partial e(p)}{\partial w 1_{1, N}} & \frac{\partial e(p)}{\partial w 1_{2,1}} \ldots \frac{\partial e(p)}{\partial w 1_{2, N}} & \ldots & \frac{\partial e(p)}{\partial w 1_{N 1,1}} \ldots \frac{\partial e(p)}{\partial w 1_{N 1, N}}
\end{array}\right]_{(p) x(N . N 1)} \\
& J(w 2)=\left[\begin{array}{cccccc}
\frac{\partial e(1)}{\partial w 2_{1,1}} \ldots \frac{\partial e(1)}{\partial w 2_{1, N}} & \frac{\partial e(1)}{\partial w 2_{1,1}} \ldots \frac{\partial e(1)}{\partial w 2_{1, N}} & \ldots & \frac{\partial e(1)}{\partial w 2_{N 2,1}} \ldots \frac{\partial e(1)}{\partial w 2_{N 2, N 1}} \\
\frac{\partial e(2)}{\partial w 2_{1,1}} \ldots \frac{\partial e(2)}{\partial w 2_{1, N}} & \frac{\partial e(2)}{\partial w 2_{2,1}} \ldots \frac{\partial e(2)}{\partial w 2_{2, N}} & \ldots & \frac{\partial e(2)}{\partial w 2_{N 2,1}} \ldots \frac{\partial e(2)}{\partial w 2_{N 2, N 1}} \\
\vdots & \vdots & \vdots & \vdots \\
\frac{\partial e(p)}{\partial w 2_{1,1}} \ldots \frac{\partial e(p)}{\partial w 2_{1, N}} & \frac{\partial e(p)}{\partial w 2_{2,1}} \ldots \frac{\partial e(p)}{\partial w 2_{2, N}} & \ldots & \frac{\partial e(p)}{\partial w 2_{N 2,1}} \ldots \frac{\partial e(p)}{\partial w 2_{N 2, N 1}}
\end{array}\right]_{(p) x(N 1 . N 2)}
\end{aligned}
$$

A partir da equação (a.46), a equação iterativa do método de Levenberg-Marquardt para o ajuste dos pesos da rede passa a ser definida por:

$$
\nabla z=\left[J^{T}(W) \cdot J(W)+\mu I\right]^{-1} \cdot J^{T}(W) \cdot e(W)
$$

onde $e(W)=\left[e_{1}(W) \cdot e_{2}(W) \ldots e_{p}(W)\right]_{(p) x(1)}^{T}$ é o vetor erro (em relação à matriz $\boldsymbol{W}$ ) referente aos $p$ padrões de treinamento.

Finalmente os elementos das matrizes $J(w 1)$ e $J($ w2) são obtidos sequencialmente a partir das Fases 1 e 2 do algoritmo backpropagation anteriormente apresentado. Com essas modificações comprova-se que o algoritmo de LevenbergMarquardt torna-se de 10 a 100 vezes mais rápido que o algoritmo backpropagation convencional. 


\section{A.4.4. Algoritmo de Levenberg regularizado}

Um dos problemas que ocorrem durante o treinamento de redes PMC é o fenômeno denominado overfitting. Quando ocorre o overfitting, o erro quadrático médio dos padrões de treinamento é muito pequeno, mas quando novos padrões são apresentados a rede, o erro relativo torna-se muito grande. Esse fato ocorre porque a rede memorizou apenas os padrões de treinamento, mas não conseguiu generalizar novas situações, ou seja, a rede funciona apenas como uma tabela que relaciona as entradas com as saídas. A Figura a. 13 ilustra o fenômeno. A curva representa o mapeamento não linear de entrada-saída resultante da aprendizagem dos pontos indicados como "dados de treinamento". O ponto marcado como "generalização" é visto como resultado da interpolação realizada pela rede.

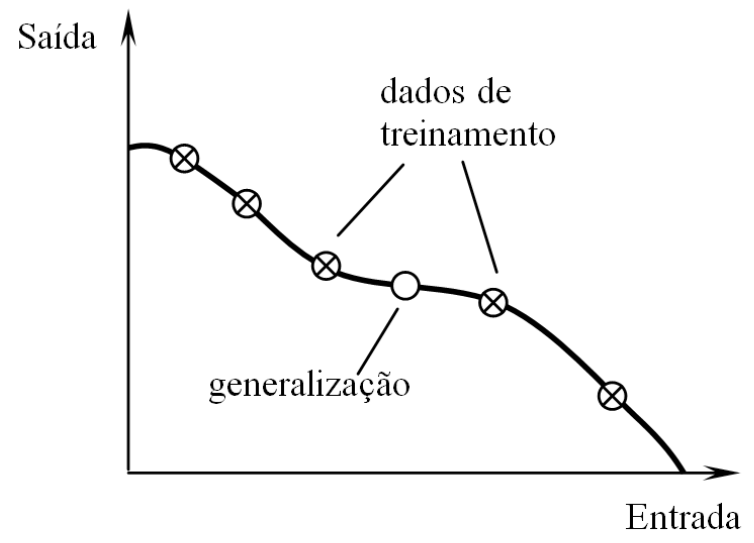

a)

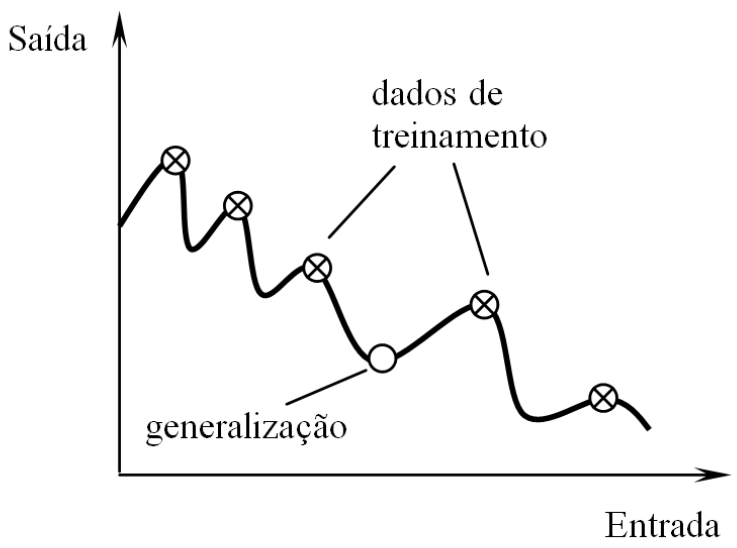

b)

Figura a. 13 - a) Dados ajustados adequadamente (boa generalização) ; b) Fenômeno do overfitting (generalização pobre) [A.1].

A generalização é influenciada por quatro fatores:

a) a disponibilidade de dados para treinamento da rede;

b) o nível de representatividade do processo pelos dados de treinamento;

c) a arquitetura da rede neural; e

d) a complexidade do problema em questão. 
Observa-se que não se tem controle sobre o último fator. Os outros três fatores são controláveis desse que se tenha acesso a aquisição dos dados e concepção da rede neural.

Nesse cenário, o problema do overfitting geralmente acontece quando a disponibilidade de dados no treinamento da rede é pequena. Um dos métodos para melhorar a generalização é o algoritmo de Levenberg regularizado, que consiste em modificar a função erro quadrático médio da rede. A partir da equação (a.36), tem-se:

$$
V=\frac{1}{2 p} \sum_{k=1}^{p} e^{T}(k) \cdot e(k)
$$

A generalização é melhorada se incluir na expressão (a.50) o erro quadrático médio dos pesos $\left(V_{\text {peso }}\right)$ que compõe a rede. Então a nova função erro quadrático regularizado $\left(V_{R E G}\right)$ é definida por:

$$
V_{R E G}=\gamma V+(1-\gamma) V_{\text {peso }}
$$

onde o parâmetro $\gamma$ especifica a taxa de desempenho e o termo $V_{\text {peso }}$

é definido por:

$$
V_{\text {peso }}=\frac{1}{q} \sum W_{j i}
$$

onde $W_{j i}$ são os pesos da rede e $q$ é a quantidade total de pesos que contém a rede.

Portanto, a utilização da equação (a.51) implica que os pesos da rede serão menores, e essa característica impõe à resposta da rede um comportamento mais suave e menos propenso ao fenômeno do overfitting. 


\section{REFERÊNCIAS BIBLIOGRÁFICAS - APÊNDICE A}

[A.1] HAYKIN, S. Neural Networks - A Comprehensive Foundation. 2nd edition, New Jersey: McMillan Inc.,1999. p.842.

[A.2] McCULLOCH, W. S., A logical calculus of ideas immanent in nervous activity. Bulletin of mathematical biophysics, v. 5, p. 115-113, 1943.

[A.3] ROSENBLATT, F. The Perceptron: A probabilistic model for information storage and organization in the brain. Psychological Review, v. 65, p. 386-408, 1958.

[A.4] WIDROW, B. Generalization and information storage in networks of adaline neurons. In M.C. Yovitz, G.T. Jacobi, and G.D. Goldstein, eds., Self-Organization systems, Washington DC: Sapartan Books, p. 435-461, 1962.

[A.5] RUMELHART, D.E., HINTON, G.E., WILliANS, R.J. Parallel Distributed Processing. Massachusetts: MIT Press, 1986.

[A.6] MINSKY, M.L., PAPERT, S.A. Perceptrons, Cambridge, MA: MIT Press, 1969.

[A.7] HOPFIELD, J.J. Neural network and physical systems with emergent collective computational abilities. In: PROCEEDINGS OF THE NATIONAL ACADEMY OF SCIENCE, USA, V. 81, , 1984. P.3088-3092.

[A.8] GROSSBERG, S. Adaptive pattern classification and universal recoding: I. Parallel development and coding of neural detectors. Biological Cybernetics, v. 23, p. 121-134, 1976.

[A.9] GROSSBERG, S. Adaptive pattern classification and universal recoding: II.Feedback, expectation, olfaction, illusions. Biological Cybernetics, v. 23, p. 187-202, 1976. 
[A.10] KOHONEN, T. Learning vector quantization for pattern recognition. Furland: Helsinnki University of Tecnology, 1986. (Technical Report TTK-F-A601).

[A.11] WIDROW, B., WALACH, E. Adaptive inverse control. New Jersey: Prentice Hall Inc., 1996.

[A.12] NARENDRA, K. S., Neural networks for Control: Theory and Practice. In: PROCEEDINGS OF IEEE, v. 84, n. 10, 1996. p.1385-1406.

[A.13] VAN DER SMAGT, P.P., KROSE J.A. A real-time learning robot controller. In: INTERNATIONAL CONFERENCE ON ARTIFICIAL NEURAL NETWORKS, Finland, 1991. p. 351-356.

[A.14] NARENDRA, K.S., PARTHASARATHY, K. Identification and control of dynamical systems using neural networks. IEEE Transactions on Neural Networks, v.1, p. 4-27, 1990.

[A.15] ANTSAKLIS, P. J. Neural Networks in Control Systems, IEEE Control Systems Magazine, v. 12, p. 8-10, 1992.

[A.16] HECHT_NIELSEN, R. Neurocomputing. Massachusetts: Addison Wesley, 1990.

[A.17] HAGAN, M.T., MENHAJ, M.B, Training feedforward networks with Marquardt algorithm. IEEE Transactions on Neural Networks, v. 5, p. 989-993, 1994.

[A.18] FORESSE, F.D., HAGAN, M.T. Gauss-Newton approximation to neural networks. In: INTERNATIONAL JOINT CONFERENCE ON NEURAL NETWORKS, 1997. p.1930-1935. 